\title{
International Law and Sexual Violence in Armed Conflicts
}




\title{
International Humanitarian Law Series
}

\author{
VOLUME 35
}

Editors-in-Chief

H.E. Judge Sir Christopher Greenwood

Professor Timothy L.H. McCormack

\author{
Editorial Advisory Board \\ Professor Georges Abi-Saab \\ H.E. Judge George H. Aldrich \\ Madame Justice Louise Arbour \\ Professor Ove Bring \\ Professor John Dugard \\ Professor Dr. Horst Fischer \\ Dr. Hans-Peter Gasser \\ H.E. Judge Geza Herczegh \\ Professor Frits Kalshoven \\ Professor Ruth Lapidoth \\ Professor Gabrielle Kirk McDonald \\ H.E. Judge Theodor Meron \\ Captain J. Ashley Roach \\ Professor Michael Schmitt \\ Professor Jiří Toman
}

The International Humanitarian Law Series is a series of monographs and edited volumes which aims to promote scholarly analysis and discussion of both the theory and practice of the international legal regulation of armed conflict.

The series explores substantive issues of International Humanitarian Law including,

- protection for victims of armed conflict and regulation of the means and methods of warfare

- questions of application of the various legal regimes for the conduct of armed conflict

- issues relating to the implementation of International Humanitarian Law obligations

- national and international approaches to the enforcement of the law and

- the interactions between International Humanitarian Law and other related areas of international law such as Human Rights, Refugee Law, Arms Control and Disarmament Law, and International Criminal Law. 


\section{International Law and Sexual Violence in Armed Conflicts}

by

Chile Eboe-Osuji

$\frac{\text { M A R T I N U S }}{\text { NIJU }}$

LEIDEN • BOSTON

2012 
B R I L L This is an open access title distributed under the terms of the CC-BY-NC License, O P E N which permits any non-commercial use, distribution, and reproduction in any medium, provided the original author(s) and source are credited.

An electronic version of this book is freely available, thanks to the support of libraries working with Knowledge Unlatched. More information about the initiative can be found at www.knowledgeunlatched.org.

Library of Congress Cataloging-in-Publication Data

Eboe-Osuji, Chile.

International law and sexual violence in armed confl icts / by Chile Eboe-Osuji.

p. cm. -- (International humanitarian law series ; 35)

Includes bibliographical references and index.

ISBN 978-90-04-20262-7 (hardback : alk. paper) -- ISBN 978-90-04-22722-4 (e-book) 1. Rape as a weapon of war. 2. War crimes. 3. War (International law) 4. Rape. 5. International criminal law. I. Title.

$\mathrm{KZ}_{7162 . \mathrm{E} 26} 2012$

341.6 '9--dc23

2012023807

ISSN 1389-6776

ISBN 9789004202627 (hardback)

ISBN 9789004227224 (e-book)

Copyright 2012 by Koninklijke Brill NV, Leiden, The Netherlands.

This work is published by Koninklijke Brill NV. Koninklijke Brill NV incorporates the imprints Brill, Brill Hes \& De Graaf, Brill Nijhoff, Brill Rodopi and Hotei Publishing.

Koninklijke Brill NV reserves the right to protect the publication against unauthorized use and to authorize dissemination by means of offprints, legitimate photocopies, microform editions, reprints, translations, and secondary information sources, such as abstracting and indexing services including databases. Requests for commercial re-use, use of parts of the publication, and/or translations must be addressed to Koninklijke Brill NV.

This book is printed on acid-free paper and produced in a sustainable manner. 
We note with sadness the passing of two esteemed members of our Editorial Advisory Board - Antonio Cassese (or January 1937 - 2I October 20II) and Leslie C Green (o6 November 1920 - 27 November 20II). Antonio and Leslie were outstanding scholars and enthusiastic supporters of the IHL Series and both will be sorely missed. 
Chile Eboe-0suji - 978-90-04-22722-4 Downloaded from Brill.com $04 / 26 / 2023$ 12:45:46PM via free access 
For

my mother Clara

my wife Shannon

my daughters Ula and Amara

my sisters Ada, Ego and Chika

and all the other women in my life:

that they may walk the Earth

and its farthest reaches

day and night

unafraid of violence from men. 
Chile Eboe-0suji - 978-90-04-22722-4 Downloaded from Brill.com $04 / 26 / 2023$ 12:45:46PM via free access 


\section{Table of Contents}

$\begin{array}{ll}\text { Acknowledgments } & \text { xiii }\end{array}$

Foreword $\quad x v$

Prologue 1

Introduction $\quad 11$

Chapter 1 Aetiology of Evil in Armed Conflicts 15

The Evil of War $\quad 15$

A General Review of Human Capacity for

$\begin{array}{ll}\text { The Situational Theory of Evil } & 18\end{array}$

Hanna Arendt 18

Zygmunt Bauman, Stanley Milgram and Philip Zimbardo 33

$\begin{array}{ll}\text { The Dispositional Theory of Evil } & 43\end{array}$

Daniel Goldhagen 43

C Fred Alford $\quad 45$

$\begin{array}{lr}\text { The Narcissistic Theory of Evil } & 50\end{array}$

The Eclectic Theory of Evil 53

Aetiology of Evil Viewed in the Context of the Law 60

Intent as Limiting the Theories of Aetiology of Evil 63

Uses in the Post-Conflict Quest for Justice and Reconciliation 64

Human Capacity for the Evil of Sexual Violence

in Armed Conflicts $\quad 65$

A Legislative Fact Amply Proved 68

Aetiology of the High Frequency of Sexual Violence during Armed Conflicts $\quad 72$

The Theory of Inevitability of Sexual Violence during Armed Conflicts 72

An Evolutionary Theory of Rape $\quad 75$

The Theory of Opportunism of Sexual Violence during Armed Conflicts 81

The Theory of Deliberate Policy of Sexual Violence during Armed Conflicts 83

Sexual Violence Traditionally Articulated as Policy 83

Sexual Violence Not Often Articulated as Policy-Systematic

Connivance or Condonation $\quad 86$

Conclusion 
Chapter 2 Superior Responsibility for the Rape of Women during Armed Conflicts

Introduction

The Law as It Should Be

The Law as It Is

$\begin{array}{lr}\text { The Requirement of Knowledge } & 101\end{array}$

Routes around the Difficulties of the Lex Lata 103

Joint Criminal Enterprise 104

Much Ado About Joint Criminal Enterprise 109

Ordering

121

Planning and Instigating $\quad 125$

Aiding and Abetting 126

Arguable Limits of Routes around the Difficulties of the Lex Lata 136

$\begin{array}{ll}\text { Superior Responsibility and the Duty to Punish } & 137\end{array}$

Conclusion

Chapter 3 Defining Rape in International Criminal Law: An Unsettled Tug of War?

Introduction

Primary Focus on the Violence of the Occasion

Reversion to Focus on Body Parts and Consent

Caught between Violence and Body Parts

Rape Law Reform in Domestic Jurisdictions

The Problems with Kunarac

Conclusion

Chapter 4 Rape as Genocide and Some Questions Arising

Rape as Genocide in Light of the Debate regarding Intent to Destroy the Group in Whole or in (Substantial) Part

Conclusion

Chapter 5 Armed Conflicts, Sexual Violence and the Mens Rea of the War Crime of Terrorism

Introduction

$\begin{array}{ll}\text { The Conventional Source of the War Crime of Terrorism } & 179 \\ \text { The Origins of the Jurisprudence of Specific Intent } & 181\end{array}$

Terrorism and the Mens Rea of Sexual Slavery

(a) The Primary Purpose of Spreading Terror and the Nature and Circumstances of the Acts

(b) The Multi-Purpose Approach

(c) A Holistic View of Attack: A Campaign of Terror 190

Terrorism and Specific Intent: a Matter of General Principle 193

A Purposive Analysis of Terrorism as War Crime

Subjective and Objective Examination of Primary Purpose of Attack 195

The Statute of Rome on the War Crime of Terrorism 199

Conclusion 
Chapter 6 Internal Armed Conflicts, Sexual Violence and 'Grave Breaches'

Introduction

Defining 'War Crimes'

'Serious Violations' and 'Grave Breaches' 206

Conclusion

Chapter 7 Forced Marriage-an International Crime?

The Judgment of the Special Court for Sierra Leone 222

A Proper Subject of International Criminal Law 224

A Recognised Crime in International law? 226

Evidential Problems of the SCSL Appeal's Chamber's Reasoning 229

Doctrinal Problems of the SCSL Appeal's Chamber's Reasoning 233

Forced Marriage and other Gender-oriented Crimes against Humanity 244

Forced Marriage versus Sexual Slavery 245

Forced Marriage versus Trafficking in Persons $\quad 252$

Conclusion

Chapter 8 Prosecution of Sexual Violence against Women in

Introductory: A Question of Choices? $\quad 257$

The Importance of Sexual Violence Prosecution 260

Post-Conflict Social (Re)Engineering as an Objective of the Prosecution Strategy 263

The Need to Avoid Double Victimisation of Women 268

$\begin{array}{ll}\text { Conclusion } & 269\end{array}$

Chapter 9 Reparation for Female Victims of Sexual Violence in Armed Conflicts 271

$\begin{array}{ll}\text { Introduction } & 271 \\ & \end{array}$

$\begin{array}{ll}\text { The Theoretical Bases for Reparation } & 275\end{array}$

(i) The Fault Basis for Reparation $\quad 278$

Regarding Chorzórw Case as a Reference for Reparation 279

Other Juristic Anchors for Reparation for Human Rights Violations 283

(ii) Fault resulting from Actions 288

(iii) Fault resulting from Omission 289

(a) Fault resulting from Omissions of State of Nationality in respect of State Agents 289

(b) Responsibility to Protect and National State's Omissions Regarding Rogue Agents of State and Non-State Actors 290

(c) National State's Omissions Regarding Non-State Actors 296

(d) Diplomatic Protection and National State's Omissions
Regarding Foreign States

Armed Conflicts and Diplomatic Protection 297

Diplomatic Protection as a Question of Duty on the National State 300

(e) The International Community and Fault resulting from
Omissions

(iv) A No-Fault Basis for Reparation 306

$\begin{array}{ll}\text { The Special Focus on Female Victims } & 312\end{array}$

$\begin{array}{ll}\text { Conclusion } & 314\end{array}$ 
xii Table of Contents

Epilogue

Summary of the Study

A Note of Optimism

Bibliography

Index

345 


\section{Acknowledgments}

This is the culmination of a dream hatched many years ago. The journey started in 1997, while practising law as a barrister doing criminal defence work in Toronto. I received an unexpected telephone call from Ms Louise Arbour, then Chief Prosecutor of the International Criminal Tribunals for both Rwanda and the former Yugoslavia. She had called to invite me to work for her as a prosecution counsel at the ICTR. Her offer was a unique opportunity to join what was then a very small group of lawyers from around the world who were engaged in a new experiment in Arusha, Tanzania and The Hague, charting the new course of modern international criminal law practice. There were no modern precedents then upon which to rely, other than material from Nuremberg and the Far East dating more than 50 years earlier. I had no doubt that the new career path would present fascinating avenues to reflect upon the practical problems of international criminal law from the perspective of legal scholarship. Indeed, opportunities for such reflections were amply afforded in my functions as prosecution counsel in the Office of the Prosecutor of the ICTR and, later, as senior legal officer in the Chambers of the ICTR, as well as head legal officer in the Appeals Chamber of the ICTR. Opportunities to consolidate such reflections were afforded during a twoyear break from 2005 to 2007 , when I returned to Canada and worked as counsel at the law firm of Borden Ladner Gervais LLP ('BLG') in Ottawa, during which I provided legal advice to some diplomatic missions whose countries had issues of interest to international criminal or humanitarian law. Perhaps, more importantly, I had the wonderful opportunity of teaching international criminal law as an adjunct professor of law at the University of Ottawa, Law Faculty. Unable to rid myself of the virus of international public service, I once more returned in 2007 to the practice of international criminal law, as senior prosecution appeals counsel at the Special Court for Sierra Leone.

Few journeys worth the while are ever undertaken successfully alone to the desired destination. The assistance to any successful mission comes in many forms - not always amenable to uniform measure of quantification, yet uniformly capable of appreciation as crucial in the achievement of purpose. In this connection, I must mention some persons to whom I owe much debt of gratitude. I remain ever conscious of the inevitable risk of omitting the mention of others who no less deserve such clear expressions of gratitude. 
I thank, first of all, my wife Shannon, who spared my life and marriage, while I spent what seemed like endless time to work on this project, in the face of the far more important task of raising our little children in need of parental attention. To our children, Ula, Chile Bis and Amara, who found it both inconvenient, yet adoringly forgivable, that daddy had to 'work on his computer all the time', rather than partake, as any half-decent father should do, in the far more wholesome endeavour of family fun time; never mind that daddy was mostly absent anyway, claiming to 'serve the course of humanity' in places thousands of miles away from home. I pray that they may continue to forgive in this way, even as they get older!

I thank David Scott QC at BLG, for his wonderful mentorship over the years. As his articling student many years ago (at Scott \& Aylen, as BLG-Ottawa was then known), he encouraged in me the temerity to dream that no achievement as a barrister was too much to contemplate, provided that an adequate measure of dignity and humility, as are his trade-marks as one of Canada's most distinguished advocates, was brought to bear. It is testament to these qualities of dignity and humility that David refuses to acknowledge that he had anything to do years later with that curious telephone call that I received from Ms Arbour in 1997 that launched my career in international criminal law. To Ms Arbour, I thank for an opportunity that was purely beyond the dreams that any young lawyer could dare to allow himself. I thank Dr Navi Pillay for her constant encouragement, in the early years and ever since, and for insisting that African lawyers have a place in the plane of authority to assist in the advancement of international criminal justice and the global human rights agenda.

I also thank my friends at BLG: they include George Hunter, Bruce CarrHarris, Marc Jolicoeur, Marc Babinski, Kirsten Crain, Kevin Nearing, David Sheriff-Scott and Gar Knutson, for their support and encouragement during my sojourn at BLG. I also thank Frank Walwyn of Weir Foulds in Toronto, for his brotherly support. I owe much gratitude to Roger S Clark, Stephen Rapp, Bill Schabas, Catherine McKinnon, Binaifer Nowrojee, Roman Boed, IBK Babajide, Segun Jegede, Alhagi Marong, Charles Jalloh, Alex Obote Odora, Don Webster, Christine Graham and Fred Harhoff, for allowing me to test with them some of the theories and insights that I now feel brave enough to advance on these pages. A special gratitude goes to Professor Harmen van der Wilt of the University of Amsterdam for supervising the doctoral dissertation that formed the basis of this book.

c e-o

Arusha, April $201 \mathrm{I}$ 


\section{Foreword}

The title of this book refers to sex crimes in a manner that is gender neutral, perhaps implicitly confirming a tendency of modern law to consider that 'gender crimes' may be committed by various permutations and combinations of offenders. But if there is any doubt in the title, the substance of the volume makes it abundantly clear that this is a book about victims who are women and perpetrators who are men. That, indeed, is the very unfortunate reality of such crimes in our modern world. It seems especially true in the context of armed conflict.

As Chile Eboe-Osuji convincingly demonstrates, women have been and have remained victims of these deliberate crimes from periods of great antiquity right to the present day. For instance, in a 2009 report released on I6 March 2010, the United States military reported a I6-percent increase in sexual assault complaints linked to its members (as victims or assailants) in war zones, primarily Iraq and Afghanistan. According to the report, 3,230 sexual assault complaints were filed with the United States military in 2009. And 87 per cent of these assaults involved female victims and male assailants. ${ }^{\mathrm{I}}$ What is significant about this should not be the debate regarding whether the statistics indicate an increase in the incidence of sexual violence within the organisation concerned (the United States Defence Department insists this is not necessarily so) or simply the effects of deliberate measures instituted to encourage greater reporting of incidents of sexual assaults (the Defence Department says this is more likely the case). The report reminds us that rape and similar crimes committed by soldiers against vulnerable women, who are generally non-combatants, is hardly a monopoly of the ragtag, undisciplined militias of the conflicts in Sierra Leone, Rwanda and the Balkans.

Others have already mapped the history of sexual violence in armed conflict, from the rape of the Sabine women by the founders of ancient Rome to the brutal attacks on German women by Soviet soldiers as the Third Reich crumbled. It is a theme in literature, and even in modern cinema. One of the great films of the Vietnam war, Casualties of War, vividly depicts the rape, abduction and murder of a peasant woman by American forces. The filmmaker, Brian De Palma, returned to the same theme in Redacted, the story of a rogue unit in Iraq that won the Venice Festival's Palme d'or.

I Elisabeth Bumiller, 'Sex Assault Reports Rise in Military', New York Times, I7 March 20Io. 
Often, this is treated as an ugly but unavoidable accompaniment of armed conflict. In the famous Yamashita case, Justice Murphy of the United States Supreme Court wrote: 'War breeds atrocities. From the earliest conflicts of recorded history to the global struggles of modern times, inhumanities, lust and pillage have been the inevitable by-products of man's resort to force and arms. ${ }^{2}$ It is true, of course, that war breeds much more than the dignified confrontation of professional soldiers. War itself, as the judges at Nuremberg insisted, 'is the supreme international crime differing only from other war crimes in that it contains within itself the accumulated evil of the whole'. But that is hardly to excuse it. As the International Committee of the Red Cross constantly reminds it, even war has laws.

Eboe-Osuji's contribution is not so much about documenting the phenomenon as it is about describing the very contemporary efforts to bring international criminal law to bear upon this scourge. The clear objective of these efforts is the reversal of a culture of impunity and condonation that is often cloaked by the view of these atrocities as 'inevitable by-products' of undesirable incidents bred by war. The pioneering work of the International Criminal Tribunal for Rwanda is described in this regard. So, too, are the efforts of the International Criminal Tribunal for the former Yugoslavia, the Special Court for Sierra Leone, the International Criminal Court, the Office of the High Commissioner for Human Rights, and the United Nations. But much, much more needs to be done, and in various ways.

When the international criminal tribunals first began prosecuting rape as a war crime, or as genocide or a crime against humanity, this was heralded as an important legal development. It is true, of course, that the applicable texts and definitions became more sophisticated. But it is inaccurate to suggest that rape had not previously been a crime, even when committed in armed conflict. There is evidence of this from the earliest codifications, such as the detailed text prepared by Francis Leiber and adopted for the Union armies by President Lincoln. It proscribed all 'wanton violence committed against persons in the invaded country' including 'all rape, wounding, maiming, or killing of such inhabitants', adding that these crimes were 'prohibited under the penalty of death'.

But as is the case with domestic criminal courts operating in peacetime, sexual crimes against women have often tended to elude justice. The prosecution of such crimes has been rendered difficult, at least historically, by archaic rules about evidence rooted in discriminatory stereotypes. At the domestic level, recent reforms have addressed many of these difficulties, often spurred by rulings of international human rights tribunals like the European Court of Human Rights or the United Nations Committee for the Elimination of Discrimination Against Women.

The international criminal tribunals, where Eboe-Osuji has spent much of his professional life, have highlighted and developed one particular aspect of this problem. The author's lengthy practical experience and extensive scholarship in this area stand him well to offer with authority, as he has done in this book, some

2 Justice Murphy in Yamashitav Styer, quoted as epigraph to chapter I of the present book. 
of the more innovative legal and policy solutions to the enduring problem of sexual violence against women during armed conflicts. Some of the solutions that he offers are capable of immediate application, while others will, at least, inspire more discussions and debates in this extremely important area of international law. I highly commend this important contribution to a growing field of study.

William A Schabas

Galway, May zоII 
Chile Eboe-0suji - 978-90-04-22722-4 Downloaded from Brill.com $04 / 26 / 2023$ 12:45:46PM via free access 


\section{Prologue}

Armed conflicts are the main domain of international criminal law. Sexual crimes against women are a scourge of armed conflicts.

The perennial problem of sexual crimes against women in armed conflicts strongly commands particular attention to the development of appropriate norms of international law - and appropriate review of existing ones-in such a deliberate manner as will assist in addressing the problem. The sole aim of the endeavour, of course, is to ensure that those responsible or complicit in sexual violations against women during armed conflicts are held accountable.

From virtually every international lawyer concerned with the problem-from the average judge sitting on the Bench of an international criminal court, to the average counsel appearing before them, to the average legal academic training future judges and counsel-there is no shortage of sympathy and good intentions. All would readily acknowledge the problem and profess a willingness to join in the quest for a solution. Yet, all too often, intellectual grooves hewn over a lifetime of professional thought habits are brought to bear, making it rather challenging to consider solutions that lie 'outside the box' of familiar methods. Occasionally, unspoken suspicion is raised as to whether those intellectual groves are always really free of the prejudicial dross that have influenced legal development over the years in ways that have generally contributed to law's failure to protect women fully from sexual violence even in peacetime. It is notable in this regard that not too long ago, Wigmore's venerable text on the law of evidence contained a legal endorsement of the Freudian theory suggesting that complaints of young women about sexual abuse tended to result from a projection of their own sexual fantasies. ${ }^{\mathrm{I}}$ Consequently, it was recommended in Wigmore on Evidence that every sexual assault complainant should undergo psychiatric assessment, in order to rule out fantasy. ${ }^{2}$ This Wigmorian endorsement falls squarely within the realms of the jury

I Sigmund Freud (rev Peter Gay), The Freud Reader [New York: W W Norton, 1989] p 439 .

2 As it was there contented: 'There is ... at least one situation in which chastity may have a direct connection with veracity, viz. when a woman or young girl testifies as complainant against a man charged with a sexual crime-rape, rape under age, seduction, assault. Modern psychiatrists have amply studied the behavior of errant young girls and women coming before the courts in all sorts of cases. Their psychic com- 
instructions from Sir Matthew Hale that guided the mindset of lawyers, judges and juries for very many years in the common law world; to the effect that rape is a crime easy to charge but difficult to defend, hence requiring the female complainant to be regarded with great caution. ${ }^{3}$

The question thus arises as to the extent to which a lifetime of professional thought habit conditioned by such legal reasoning might have continued to influence the intellectual reflexes of those who control or dominate the play in the arena of the courtroom that produces jurisprudence that fails to go the possible length that it can go in the direction of full protection of women from sexual violence during wars.

Ultimately, however, the reasons for lack of fuller protection are really not as important as is the query whether more could be done by way of law reform to offer a fuller protection from sexual violence during armed conflicts.

The research query the object of this study thus becomes this: Is it possible to develop, through the courtrooms of international law, such further or enhanced norms of international criminal law as may assist in combating impunity for those who commit sexual violence against women in armed conflicts, thereby contributing to deterrence against such violations in future and, hence, better protection to women?

Having delineated the research objective, it may be useful next to consider briefly the reasons for that objective. In other words, why should we strive for law reform in hopes of norms that may contribute in deterring sexual violence against women during armed conflicts, thereby leading to better and fuller protection for women?

The reasons for the quest span a spectrum of rationales-from the highly sophisticated articulation (in terms of integrity and dignity of the victim) to the prosaically practical (in terms of the ideal of safety and the ordinary pursuit of a

plexes are multifarious, distorted partly by inherent defects, partly by diseased derangements or abnormal instincts, partly by bad social environment, partly by temporary physiological or emotional conditions. One form taken by these complexes is that of contriving false charges of sexual offences by men. The unchaste (let us call it) mentality finds incidental but direct expression in the narration of imaginary sex incidents of which the narrator is the heroine or the victim. On the surface the narration is straightforward and convincing. The real victim, however, too often in such cases is the innocent man; for the respect and sympathy naturally felt by any tribunal for a wronged female helps to give easy credit to such a plausible tale. ... No judge should ever let a sex offense charge go to the jury unless the female complainant's social history and mental makeup have been examined and testified to by a qualified physician: John Wigmore (rev James Chadbourn), Evidence in Trials at Common Law [Boston: Little, Brown and Company, I970] §942a at p 737. [Emphasis received.]

3 See Matthew Hale, Pleas of the Crown, or, a methodical summary of the principal matters relating to that subject, vol I, [London: W. Shrewsbury, I694] p 635. See also Lynn Hecht Schafran, 'The Limits of Law Reform: What Really Happens in the Courtroom,' Shimon Shetreet, Women in Law (ed) [London: Kluwer International, I998] pp I7-I8. 
livelihood that all deserve in society). The entire gamut is identifiable in the rationales offered for rape law reform in the remarks of Senator Joseph R Biden Jr (as he then was), introducing a I993 US Senate Judiciary Committee report, appearing under the very erudite title of 'The Response to Rape: Detours on the Road to Equal Justice.' On that occasion, Senator Biden (the Committee Chairman) wrote as follows: 'The knowledge that society and its criminal justice system offer no real protection has the potential to victimize all women, forcing them to remain in abusive family situations, or to circumscribe their activities, to accept limitations on how they conduct their lives, because of fear. The stakes are high. If we do not succeed, we risk the faith of over half our citizens in the ability-and the willingness - of our criminal justice system to protect them. And, what is worse, we condemn future generations to accept not only the possibility of violence but the reality of lives too often limited by the fear of violence.'

From those great heights of eloquence, the good senator brought down his message to this: 'The purpose of this report is to help us recognize that violence against women is simply "violence."'5 This common sense conclusion is consistent with what another group of sexual violence law reform proponents have described as the need to protect women from a 'very destructive set of acts against human beings.' ${ }^{\prime}$

The same themes of freedom from fear, equal protection of the law, and safety from naked violence are equally reflected in the reasons offered in the report of a committee of the Parliamentary Assembly of the Council of Europe, as reasons for law reform efforts in Europe for increased protection of women against sexual violence. As they put it: 'Violence against women, in particular sexual violence, is a serious violation both of women's physical and psychological integrity and also of the right to freedom, safety and dignity enjoyed by all human beings.'

Although the foregoing rationales were offered in the context of sexual violence in the peacetime settings of the United States and Europe, the same rationales are equally applicable, with necessary variation, to the felt need of international law to offer greater protection to women against sexual violence during armed conflicts. In his report of 20 August 2009 to the Security Council, pursuant to Security Council resolution I820 (2008) of I9 June 2008 on sexual violence against women during armed conflict, the UN Secretary General noted that sexual vio-

4 United States Senate, Judiciary Committee, The Response to Rape: Detours on the Road to Equal Justice One Hundred Third Congress [Washington: US GPO, I993] p $\mathrm{v}$.

$5 \quad$ Ibid.

6 Jeanne Marsh, Alison Geist and Nathan Caplan, Rape and the Limits of Law Reform [Boston: Auburn House Publishing, 1982] p 5.

7 Parliamentary Assembly of the Council of Europe, 'Rape of women, including marital rape,' Report of the Committee on Equal Opportunities for Women and Men' dated I4 September 2009, Doc No I2OI3, p 5, para 2. 
lence is 'deeply dehumanizing, inflicts intense mental and physical trauma, and is often accompanied by fear, shame and stigma.'

At the personal level of the victim, some of the details of these physical and psychological traumas might include sexually transmitted infections, such as HIV and other ailments. ${ }^{9}$ Other probable physical problems associated with sexual violence include pelvic, lumbar and abdominal pain; vaginal discharge; vaginal itching; menstrual abnormalities; urinary symptoms (including incontinence); reproductive abnormalities such as infertility, premature labour and/or delivery, and miscarriages. ${ }^{\text {Io }}$ There are also special problems associated with pregnancy resulting from sexual violence. It has been observed in this regard that the management of pregnancy resulting from rape is always challenging in any society, even Western societies with advanced health care systems. ${ }^{\text {II }}$ The problem is more acute in economically challenged societies with traditionally higher maternal mortality rates and deaths per live births ratios. ${ }^{\mathrm{I2}}$ The acuteness of the problem is more drastic in relation to sexually violated 'young girls whose bodies are not mature enough for labour and delivery', as well as 'for women who have serious pelvic injuries and scarring from the physical damage often caused by gang rape ${ }^{\text {t3 }}$ (as is often the manner of sexual violence inflicted upon women during armed conflicts $^{\mathrm{I}}$ ), as well as by genital mutilation that is known to have been inflicted upon the victims in some cases. ${ }^{\mathrm{I}}$

Sexual violence takes a heavy psychological toll on women. Manifestations of the problem include 'sadness, anger, fear, anxiety, shame and misery as a result of the sexual assault. In many instances, these emotions appeared to be augmented by pregnancy resulting from rape and by spousal abandonment following the sexual assault.' ${ }^{16}$

Beyond the obvious debility represented by these physical and psychological traumas on their own merits, they also occasion heavy social encumbrances upon

8 United Nations, Report of the Secretary-General pursuant to Security Council resolution 1820 (2008) dated 20 August 2009, Doc No S/2009/362 (Reissued), para 4.

9 Harvard Humanitarian Initiative (with support from Oxfam of America), 'Now, the World is Without Me: an Investigation of Sexual Violence in Eastern Democratic Republic of Congo' dated April 2oro, pp 42-43.

Io Ibid, $\mathrm{p} 4 \mathrm{I}$.

II Ibid.

I2 See ibid.

I3 Ibid.

I4 Ibid, p 2. See also, United Nations, Report of the Secretary-General pursuant to Security Council resolution I820 (2008), supra, paras II, I4 and I6; and Libby Tata Arcel and Gorana Tocilj Simunkovic (eds), War Violence, Trauma and the Coping Process: Armed Conflict in Europe and the Survivor Response [Copenhagen: International Rehabilitation Council for Torture Victims, Denmark, 1998] p I95.

I5 Harvard Humanitarian Initiative (with support from Oxfam of America), 'Now, the World is Without Me,'supra, p 7 .

I6 Ibid, p 4I. 
the individual. In particular, these physical and psychological traumas have been known to impact negatively on the livelihoods of women in terms of their economic productivity and other social activities. ${ }^{17}$

It is further to be considered that sexual violence against women during armed conflicts presents the added dimension of other forms of cruelty beyond the violence itself. As noted in the UN Secretary General's report, 'In many instances, the sexual violence was particularly brutal both mentally and physically, and often accompanied by other heinous crimes. ${ }^{\mathrm{I} 8} \mathrm{~S}$ Some of the violence accompanying sexual violence has been known to include murder of the woman's husband, children or other male relatives. The emotional distress can be overwhelming, as many of the raped women were forced to watch helplessly, as their loved ones were tortured and killed. ${ }^{19}$

Even in those cases where the husbands were not killed, spousal abandonment has been known to occur, ${ }^{20}$ as the husband for whom the rape-surviving wife represented a constant reminder of his own inability to protect her. ${ }^{21}$

It is not unknown for the family home to be burnt down, as part of the criminal transaction accompanying the sexual violence during armed conflict; thus resulting in loss of the home and other personal valuables. 'Link these material losses to the potential for lost income after rape-related injury or the potential loss of the male head of household, and the magnitude of the resource extraction is further amplified. In fact, some families never recover from the financial hardships that result from these attacks. ${ }^{22}$

Sexual violence against women during armed conflict also has a special negative effect on children. First on the order of victimization are those children who are raped on account of their gender. Other forms of victimisation of children include their tendency to "[experience] sexual violence secondhand by witnessing the rape of their mothers and/or other family members. ${ }^{23}$ Another potent form

I7 Ibid, p 44. See also International Women's Tribune Centre, 'United Nations Security Council Resolution I820: a Preliminary Assessment of the Challenges and Opportunities', September 2009, p 7.

I8 United Nations, Report of the Secretary-General pursuant to Security Council resolution 1820 (2008), supra, para Io.

I9 Harvard Humanitarian Initiative (with support from Oxfam of America), 'Now, the World is Without Me,'supra, p 43.

20 Ibid.

2I As reported by Jocelyn Kelly, a researcher with the Harvard Humanitarian Initiative, the men that have survived these attacks on their families are extremely traumatised themselves: “They say: 'I can no longer look at my wife.' And every time they see this woman, they see someone they were not able to protect. They feel like failures and the only way they can deal with it is to reject their wife and start over": http://news. bbc.co.uk/2/hi/africa/8677637.stm.

22 Harvard Humanitarian Initiative (with support from Oxfam of America), 'Now, the World is Without Me,'supra, p 43.

Ibid, p 45. 
of victimisation of children through sexual violence is the social ostracism and rejection that the child born out of rape is made to endure in certain cultures by society, family or even mother-as the child is viewed, among other things, as belonging to the enemy, in some patriarchal societies. ${ }^{24}$ Children also experience the effects of family disintegration when the mother suffers spousal abandonment as a consequence of the rape. ${ }^{25}$ Finally, it goes without saying that the child suffers in circumstances where the mother (as the sole or main breadwinner) is reduced to a state of diminished productive capacity due to the physical or psychological effects of sexual violence.

Sexual violence against women during armed conflicts can have other palpable effects beyond the persons of the victim and her family members. These may include negative impact on 'durable peace, security and reconciliation, including post-conflict peacebuilding ${ }^{26}$ and development, ${ }^{27}$ as well as significant exacerbation of the conflict. ${ }^{28}$ This occurs particularly in terms of prolongation of 'conflict by creating a cycle of attack and counter-attack, especially when it is perpetrated on discriminatory grounds of, inter alia, race and religion' ${ }^{29}$ or ethnicity. Also particularly troubling, as a by-product of a culture of sexual violence against women during armed conflicts, is a trend towards maladjustment of social mores, in virtue of which sexual violence is accepted as 'normal' within the particular society. In the Secretary-General's report of 2009 , this phenomenon was noted as follows: 'When sexual violence is a feature of armed conflicts, there is often a corresponding increase in the incidence of rape and other forms of sexual violence among civilians. 30

Although indicating a need for further study to investigate a causal connection, the Secretary-General noted that 'all countries that are transitioning to peace from conflicts in which sexual violence was a defining feature indicate that rape and other forms of sexual violence are rife and major factors undermining early recovery and peacebuilding. ${ }^{3 \mathrm{I}}$ Studies published subsequently appear to bear out this causal connection, as case studies in Colombia ${ }^{32}$ and the Democratic Republic

24 Ibid, p 5. See also Arne Johan Vetlesen, Evil and Human Agency: Understanding Collective Evildoing [Cambridge: Cambridge University Press, 2005] pp 20I-202.

25 Harvard Humanitarian Initiative (with support from Oxfam of America), 'Now, the World is Without Me,' supra, p 45.

26 United Nations, Security Council resolution I820 (2008) dated I9 June 2008, Doc No S/Res/r820 (2008), p 2, 6th paragraph.

27 United Nations, Report of the Secretary-General pursuant to Security Council resolution I820 (2008), supra, para 6.

28 United Nations, Security Council resolution I820 (2008), supra, para I.

29 United Nations, Report of the Secretary-General pursuant to Security Council resolution 1820 (2008), supra, para 7.

$30 \quad$ Ibid.

3I Ibid, para 8.

32 Oxfam International, 'Sexual Violence in Colombia: Instrument of War' dated 9 September 2009, 2. 
of Congo ${ }^{33}$ have now confirmed. Indeed, in a late 2010 resolution, the Third Committee of the General Assembly affirmed that 'the persistence of armed conflicts in various parts of the world is a major impediment to the elimination of all forms of violence against women ....34 The African Union leadership has similarly noted as follows: 'Gender-based violence (GBV) and sexual-based violence (SBV) have deeper social roots, as they already exist in society and only exacerbated in war/conflict situations.' 35

These negative effects of sexual violence against women during armed conflicts fully recommend an inquiry into whether there is room for improvement of how lawyers and judges and policy makers could improve international law in hopes of improving protection of women from sexual violence during armed conflicts.

By way of methodology, this study will review key debates in the jurisprudence of international criminal tribunals that relate to sexual crimes, with a view to distilling from them serviceable solutions that are aimed at addressing the problem of sexual violence against women in armed conflicts in relevant respects.

In particular, discussions in the study will focus on the following issues, among others: definition and adjudication of rape in international law; sex crimes and genocide; sex crimes and 'grave breaches'; sex crimes and terrorism; the question of forced marriage as a crime against humanity; and, sex crimes and superior responsibility.

This study has not focussed in any dedicated way upon the wider framework of law reform, such as is capable of realisation through legislation in general, either by multilateral international efforts, or through transnational collaboration hinging on agreed upon domestic legislative or executive actions. A catalogue of such actions appears in Security Council resolution 1820 (2008). It envisages a multifaceted and wide-ranging approach, tasking various actors within their respective remits and competencies, to combat sexual violence against women during armed conflicts. Some of the recommended actions and their task bearers are as follows:

Parties to Armed Conflicts are required to take appropriate measures to protect women and girls, among other civilians, from all forms of sexual violence. These include, but are not limited to, enforcing military discipline for rank and file and upholding the principle of command responsibility; screening out of their ranks person with sexual violence histories; appropriate training of personnel against sexual violence; debunking myths that fuel the conduct; and evacuating persons under imminent threat of sexual violence. ${ }^{36}$ Parties are encouraged to facilitate the equal and full participation of women at decision-making levels during dis-

33 Harvard Humanitarian Initiative (with support from Oxfam of America), 'Now, the World is Without Me,' supra, pp 2 and 38-40.

34 UN General Assembly Third Committee resolution A/C.3/65/L.I7/Rev.2 (2010) dated 2 November 20Io, para Io.

35 African Union, 'African Union Gender Policy' (2008), p 26.

36 Security Council resolution 1820 (2008), supra, para 3. 
cussions dealing with conflict prevention and resolution, peace and security, and post-conflict peacebuilding. ${ }^{37}$

Member States of the United Nations are called upon to exclude sexual violence crimes from amnesty provisions in the context of conflict resolution processes; comply with their obligations to prosecute persons responsible for such crimes; ensure that all victims of sexual violence, particularly women and girls, have equal protection under the law and equal access to justice; strive to end impunity for such crimes as part of a comprehensive approach to seeking sustainable peace, justice, truth, and national reconciliation..$^{38}$

Troop and police contributing States (in consultation with the Secretary-General) are encouraged to consider steps they could take to heighten awareness and the responsiveness of their personnel participating in UN peacekeeping missions, in order, among other things, to prevent sexual violence against women and girls in armed conflicts and post-conflict situations, including deployment of a higher percentage of women as peacekeepers or police, whenever possible. ${ }^{39}$ Also troop and police contributing States are urged to take appropriate preventive actions, including pre-deployment and in-theatre awareness training, and other actions to ensure full accountability where their personnel commit sexual violence against women..$^{4}$

United Nations Security Council affirmed its intention, when establishing and renewing state-specific sanctions regimes, to take into account the appropriateness of targeted and graduated measures against parties to situations of armed conflict who commit sexual violence against women and girls in armed conflict. ${ }^{4 r}$

Secretary-General of the United Nations (in consultation with the Security Council, the Special Committee on Peacekeeping Operations and its Working Group and relevant States, as appropriate) is requested to develop and implement appropriate training programmes for all peacekeeping and humanitarian personnel deployed by the UN, in order to enable them better recognize, respond to, and prevent sexual violence during armed conflicts. ${ }^{42}$ As well, the Secretary-General is requested to continue and intensify efforts to implement the policy of zero tolerance for sexual exploitation and abuse in UN peacekeeping operations. ${ }^{43}$ The Secretary-General is also requested to develop effective guidelines and strate-

$\begin{array}{ll}37 & I b i d, \text { para I2. } \\ 38 & I b i d, \text { para } 4 . \\ 39 & I b i d, \text { para } 8 . \\ 40 & I b i d, \text { para } 7 \\ \text { 4I } & I b i d, \text { para } 5 . \\ 4^{2} & I b i d, \text { para } 6 . \\ 43 & I b i d, \text { para } 7 .\end{array}$


gies to enhance the ability of relevant UN peacekeeping operations, consistent with their mandates, to protect women and girls, among other civilians, from all forms of sexual violence and to systematically include in his written reports to the Council (in relation to conflict situations) his observations concerning the protection of women and girls and recommendations in that regard. ${ }^{44}$

The Secretary-General and relevant UN agencies are requested, among other things, to consult with women and women-led organisations as appropriate, and develop effective mechanisms for providing protection from sexual violence against women and girls, in particular, in and around UN managed refugee and internally displaced persons camps, as well as in all disarmament, demobilization, and reintegration processes, and in justice and security sector reform efforts assisted by the UN.45 The Secretary-General and his Special Envoys are urged to invite women to participate in discussions dealing with conflict prevention and resolution, peace and security, and post-conflict peacebuilding. ${ }^{6}$

The UN Peacebuilding Commission is encouraged to include in its advice and recommendations for post-conflict peacebuilding strategies, where appropriate, ways to address sexual violence committed during and in the aftermath of armed conflict, and in ensuring consultation and effective representation of women's civil society in countries. ${ }^{47}$

Regional and sub-regional bodies are urged to consider developing and implementing policies, activities, and advocacy for the benefit of women and girls who are victims of sexual violence in armed conflicts. ${ }^{4}$

All parties concerned, including financial institutions, UN Member States and the UN entities, are urged to support the development and strengthening of the capacities of national institutions, in particular of judicial and health systems, and of local civil society networks in order to provide sustainable assistance to victims of sexual violence in armed conflict and post-conflict situations. ${ }^{49}$

Indeed, it is important inquiry also to explore in detail how sexual violence in armed conflicts could be combated through all of these other avenues, jointly or severally. An omission to do so in the present endeavour is one that is fully acknowledged. But the omission is deliberate. For one thing, the preferred methodology enables sharper focus on reform through the courtrooms of international
$44 \quad$ Ibid, para 9.
45 Ibid, para Io.
46 Ibid, para I2.
47 Ibid, para II.
48 Ibid, para I4.
49 Ibid, para I3. 
law. There is also the further advantage that interstitial law reform is more easily and speedily achieved through the courtroom than through the other avenues of international law reform, such as international treaties and state practice.

Having stated the scope of the research inquiry, it is also important to acknowledge the limitations of the expectations intrigued by this research.

Invariably, this is a research effort in law reform - and, it needs to be stressed, law reform of the criminal law. No research inquiry geared towards law reform could possibly provide the perfect answer to a legal problem-let alone in the area of sexual violence. Such efforts necessarily have their limits. Some of those limits were illustratively evident in the lament appearing in the Report on Sexual Violence against Women in Armed Conflict, a report of the Committee on Equal Opportunities for Women and Men, Parliamentary Assembly of the Council of Europe. In that report, certain 'great ... legal advances' were noted. They included the adoption of the Statute of the International Criminal Court and the passing of UN Security Council resolution 1820 (2008), erasing 'any doubt as to whether or not sexual violence against women in times of armed conflict constitutes a war crime and a crime against humanity. ${ }^{50}$ Yet, the report contains the following lamentation: 'Unfortunately, as great as the legal advances have been, the setbacks on the ground have been terrible., ${ }^{51}$

It is for this reason that some commentators have, with sobering realism, tended to accept the symbolic impact of law reform efforts while remaining less ambitious about their instrumental impacts in every case. According to one commentator, "law reforms only rarely result in achievement of instrumental goals, and that their primary value rests in providing legitimacy and visibility to certain attitudes and values. These symbolic gains may be enough to satisfy some groups or may create the momentum required to achieve instrumental goals later.' ${ }^{52}$

Against this realistic background, the modest aims of the present study rest primarily in (a) helping to maintain visibility on a serious problem, and (b) making suggestions that may assist in providing the momentum needed to achieve later the instrumental objective of using international criminal law to protect women more fully. The eventual realisation of these humble aims would to this author be immensely satisfying indeed.

50 Parliamentary Assembly of the Council of Europe, Committee on Equal Opportunities, 'Report on Sexual Violence against Women in Armed Conflict, dated 15 May 2009, Doc No irgi6, p 5, para I.

5I Ibid, p 5, para 2.

52 Marsh et al, supra, p 5 . 


\section{Introduction}

'Those who value individual human life and dignity must recognise from whence they draw their strength, and if they are forced to make war they must do so with as much concern for innocent lives as humanly possible. They must not be tempted or antagonised into treading the treacherous and counterproductive path of atrocity.'

-Lt Col Dave Grossman

In the classical Greek drama, Lysistrata, ${ }^{\text {I }}$ Aristophanes employed high comedy to address the issue of women as peacemakers in armed conflicts that men conceive and inflict upon humanity. In that play, the irrepressible heroine, Lysistrata, sets out to mobilise the women of Athens, Sparta, Boeotia, and Corinth, in an effort to end the Peloponnesian War that disrupted life in Greece from 43I to 404 BC. ${ }^{2}$ Remarkably, the Lysistrata female-power movement encounters much resistance from the men-folk of Greece, who naturally consider it the height of 'impudence' and 'iniquity' for the women to concern themselves with 'the questions of war and peace'. In the end, and thanks to Lysistrata, a sex strike from the women of Greece is required to secure the capitulation of the men. The war is stopped. Peace is won. Or, so goes the fiction.

The failure of statesmen, in real life, to allow women the space they need to exercise their role as peacemakers has most assuredly remained a matter of great concern, for women in particular and civilization in general. But more horrifying, no doubt, is the eternal experience of women as victims of sexual violence, in the hands of men, in those armed conflicts that men start and humanity endures. The aim of this study, as stated in the Prologue, is to explore how international law can better protect women from evil in the shape of sexual violence during armed conflicts.

As the present effort is ultimately about a brand of evil-doing, it is proper to begin with a review of some of the theories frequently encountered in efforts to explain and understand the causes of evil-doing during armed conflicts. This discussion will begin in Chapter I with a review of the causes of evil, both from the wider perspective of evil generally and generically committed during armed conflicts. From that wider angle, the discussion will pan in to the more particular perspective of the evil of sexual violence committed during armed conflicts.

The purpose of this preliminary review directly recaptures in an obvious way the very aim of the study itself. That aim is best stated in the words of Professor Philip Zimbardo of Stanford University, famous for his Stanford Prison

I Aristophanes, Lysistrata (4IO BC) [anonymous translator]; available at http://drama. eserver.org/plays/classical/aristophanes/lysistrata.txt

2 See Lawrence Tritle, From Melos to My Lai: War and Survival [London: Routledge, 2000] p I3. 
Experiment of the early I970s (and more recently for his work on the Abu Ghraib prison abuses):

\begin{abstract}
Although it is often hard to read about evil up close and personal, we must understand its causes in order to contain and transform it through wise decisions and innovative communal actions. Indeed, in my view, there is no more urgent task that faces us today. ${ }^{3}$ [Emphasis added.]
\end{abstract}

Ultimately, the discussion in the following pages is conducted from the perspective of international law, by an international lawyer, primarily addressing fellow international lawyers and others who, from the perspective of other humanities, are interested in what international lawyers think and do. To that legal-oriented audience, the role of the law in 'transforming' evil-doing in armed conflicts may not be readily apparent as something within the proper zone of legal expertise. That particular exercise may be viewed, perhaps, as an endeavour that may more properly exercise the expertise of other branches of social engineering and their practitioners - sociologists, philosophers and psychologists like Philip Zimbardo. The aim here is not to engage in that particular debate. There is, however, little doubt that it is very much the business of the international lawyer, in his own province of social engineering, to understand the causes of the evil known as sexual violence in armed conflicts, in order to contain it through wise decisions and innovative actions in the arena of international law. Such containment is sorely and urgently needed, especially in a nascent field of international criminal law in which counsel and judges have continued to grapple with questions such as the extent of responsibility of superiors for sexual violence, among other evils, committed by subordinates during armed conflicts; how best to define rape in international law in order to provide the correct level of protection for women during armed conflicts; whether rape may correctly be viewed as an act of genocide and the extent of such a view; whether the evil of terrorism is sufficiently recognised as such when made manifest in the form of sexual violence during armed conflicts; whether sexual violence committed during internal armed conflicts may be recognised in international law as 'grave breaches' as they are when committed in international armed conflicts; and whether adequate response exists in international law against the brand of evil of sexual violence otherwise known as 'forced marriage'. In terms of the constituency of decision-makers for whom this discussion is relevant, the focus is not limited to the international lawyer formulating legislation or sitting on the bench as a judge in a particular case. The focus is equally on the lawyer who appears in a case as a prosecutor. It is hoped that these discussions might assist them, more so than has hitherto been the case, in making better decisions on how to prosecute the relevant case. For, as the saying goes, the soundness of a judgment from the bench is directly dependent on the quality of counsel appearing before her. In addition to judges and counsel, it is hoped that 
the present study will equally assist law teachers; as well as law students, who will make the legislators, judges and counsel of tomorrow.

The value of the discussions in this study lies chiefly in the practical dimensions of the issues studied. The aim is to integrate the theoretical into the practical, by reviewing and analysing problems identified in actual cases litigated before international criminal tribunals, against the background of old and new theories of the evil of sexual violence in armed conflicts. The exercise draws mostly on insights which the present author has gained from many years of practical experience in the courtrooms and chambers of international criminal law.

Chapter 2 examines the law relating to superior responsibility for the sexual assault committed by subordinates. The question is posed whether the constant feature of sexual violence in armed conflicts, explained by both policy and opportunism, on the part of warring parties and/or individual sexual predators, ought not to result in an enhanced degree of responsibility on superiors, such as would require proactive measures on their part, in order to prevent the perpetration of sexual violence by subordinates. Chapter 3 deals with the question of definition of rape in international criminal law. It examines the positions of two schools of judicial thought in international criminal law. The one school focuses on the law of rape in international law from the perspective of the violence of the circumstances of the armed conflicts in which the offences are usually committed: thus removing the inquiry from the conduct of a particular victim in terms of whether or not she consented to the sexual activity alleged as rape. This theory of rape in international law confronts another school of judicial thought that insists on the traditional forensic inquiry that requires showing, as part of the case for the Prosecution, that the victim did not consent to the sexual act at issue. The real consequences of the different views are examined, in terms of the deterrence of victims to participate in the criminal inquiry that would lead to enhanced protection. Chapter 4 involves a review of the theory of rape as an act of genocide, and some questions attending the development of the law in that regard. From this perspective, there is a re-examination of the debate relating to the mental element of the specific intent for genocide. Is it simply the intent to destroy a group in whole or in part, or is the intent more limited to the intent to destroy the group in whole or in substantial part? The consequences of either view are considered, especially from the angle of the ability to prevent the perpetration of rape as an act of genocide. In chapter 5 , recent developments are considered in the jurisprudence relating to terrorism as a war crime. In the chapter, the modern statutory basis of the war crime of terrorism is considered against the judicial reasoning that holds out terrorism as a crime of 'specific intent'. It is noted that in an extension of this reasoning, a Trial Chamber of the Special Court for Sierra Leone has held that the crimes of sexual slavery may not fit into the category of terrorism as a war crime. The aim of the chapter is largely to examine the correctness and limits of the proposition that terrorism is a crime of specific intent. In chapter 6 , the debate is revisited whether the notion of 'grave breaches' is one limited to international armed conflicts, to the exclusion of internal ones. Although the resulting principle is not unique to sexual violence, the debate is nevertheless re-examined against the particular background 
of sexual violence during war, noting that the resolution of the debate will have direct implications on the aspiration to contain sexual violence during armed conflicts: this is because just as many acts of sexual violence are committed in noninternational armed conflicts, if not more. And the question is considered whether sexual violence committed during internal armed conflicts is merely 'serious', but not 'grave' enough, simply because of the type of armed conflict involved. Chapter 7 engages the recent development in which attempts are being made to recognise forced marriage as a distinct crime in international law. The discussion involves the fundamental question regarding how norms of international law are established. The questions discussed include these: whether the creators of norms of international law have established a criminal norm against forced marriage, even when committed in the context of an armed conflict. In the absence of a norm so created, whether it is the place of international prosecutors and judges to fill the needed lacuna on their own. Are criminal norms created by prosecutors and judges, in the face of overarching need for such a norm, mere band-aids over gaping lacunae in need of proper correction by the international community? In other words, does the absence of such a specific crime suggest inadequate protection of women against the evil identified? In chapter 8 , it is suggested that prosecution of sexual violence committed during armed conflicts must form a cornerstone of justice and social reconstruction programmes in post-conflict societies. The aim of such efforts ought not be limited to the prevention of impunity for sexual predation as part of the system crimes forbidden by international criminal law. It must also include the object of re-engineering of societies whose values may have been corrupted partly by the criminal conducts that extended periods of armed conflicts tend to make possible. That being the case, it is recommended that post-conflict prosecution efforts must target all acts of sexual violence committed during an armed conflict; both in cases of direct connection of the crime to the armed conflict, as well as in cases of indirect connection, such as where the perpetrator took advantage of the distraction of the security forces (by the armed conflict) to commit a sexual crime that might otherwise have had no connection to the armed conflict. Such is the essence of the policy of zero-tolerance for sexual violence that currently pre-occupies the international community. And, finally, chapter 9 focuses attention on the need for continued attention on the question of reparation for victims of gross violation of human rights in armed conflicts in general, and of sexual violence in particular. The central message is that while it is necessary to insist upon fault-finding as the theortical basis for reparation, it is just as important also to develop alternative theories of reparation that depend on humanitarian considerations; as States and the international community may find it easier to subscribe to reparation schemes on that basis than on reparation schemes that may imply fault on their part. 


\section{Chapter 1}

\section{Aetiology of Evil in Armed Conflicts}

'War breeds atrocities. From the earliest conflicts of recorded history to the global struggles of modern times, inhumanities, lust and pillage have been the inevitable by-products of man's resort to force and arms.'

—Justice Murphy, Yamashita v Styer

\section{The Evil of War}

The average military professional may prefer to dispute the tendency of the general public to see war simply as 'episodes of mindless slaughter and wanton destruction'. The effects of war, however, must put beyond reasonable debate the proposition that wars and other manner of armed conflicts have proven, through the years, to be little more than morbid carnivals of variegated evils that make victims out of fellow human beings. That fact has now been recognised even by the legends of modern armed conflicts. General Norman Schwarzkopf of Desert Storm fame, for instance, reportedly remarked, 'War is a profanity because, let's face it, you've got two opposing sides trying to settle their differences by killing as many of each other as they can. ${ }^{2}$ In the same vein, Geoffrey Parker has observed that the 'business of the military in war is killing people and breaking things.' ${ }^{3}$ Beyond Robert McNamara's observation that more than 160 million lives were lost in wars during the $20^{\text {th }}$ Century, ${ }^{4}$ not counting the numbers maimed and wounded in body and mind, there is no denying that a host of what is generally accepted as evil conducts are unleashed with little or no compunction by human beings against their fellows during episodes of armed conflicts. In his lament of the 'monstrous cruelty of war' that does not limit its ravages to combatants only, J Glenn Gray (a World War II veteran) observed in his classic memoir The Warriors:

$[\mathrm{M}]$ odern wars are notorious for the destruction of nonparticipants and the razing of properties in lands that are accidentally in the path of combat armies and air forces. In World War II the number of civilians who lost their lives exceeded the number of soldiers killed in combat.... Through folly or fear, nearly

I David Chuter, War Crimes: Confronting Atrocity in the Modern World [Boulder, Colorado: Lynne Rienner, 2003] p 5.

2 Bob Woodward, The Commanders [New York: Simon \& Schuster, I99I] p 313.

3 Geoffrey Parker, 'Dynastic War: I494-1660' in Geoffrey Parker (ed), Cambridge Illustrated History of Warfare [Cambridge: Cambridge University Press, 1995] p I6r.

4 Robert S McNamara et al, Wilson's Ghost: Reducing the Risk of Conflict, Killing, and Catastrophe in the 2Ist Century [New York: Public Affairs, 200I], p xvi. 
every officer has exposed his own men to needless destruction at one time or another. Add to this the unnumbered acts of injustice so omnipresent in war, which may not result in death but inevitably bring pain and grief, and the impartial observer may wonder how the participants in such deeds could ever smile again and be free of care.

The sober fact appears to be that the great majority of veterans, not to speak of those who helped to put the weapons and ammunitions in their hands, are able to free themselves of responsibility with ease after the event, and frequently while they are performing it. Many a pilot or artilleryman who has destroyed untold numbers of terrified noncombatants has never felt any need for repentance or regret. Many a general who has won his laurels at a terrible cost in human life and suffering among friend and foe can endure the review of his career with great inner satisfaction. So are we made, we human creatures! 5

The sundry manner of this evil of life's ruination includes conducts viewed as 'necessary evil-authorised and promoted by responsible people in responsible command of their armed forces. Some of these 'unnumbered acts of injustice so omnipresent in war' are considered by some martial reactionaries as possessing 'sound military justification.' ${ }^{6}$ Also perpetrated with great regularity are conducts universally condemnable as aberrant, evidently unauthorised and unnecessary evil- perpetrated by insufficiently controlled 'rogue' fighters who had been trained, armed and mobilised by responsible people in responsible command of the relevant armed forces. Also accounting for a proportion of the evil committed during armed conflicts are criminal acts done by other persons subscribing to the prevailing mayhem of armed conflicts; or simply exploiting the presented opportunity, to commit crimes.

There is, however, one phenomenon that unites the various scenarios. Evil. These are all evil-whether authorised and necessary or illicit and gratuitous. Whether they are committed by regular professional troops or by amateur freebooters. And they are evil inflicted by humans upon human beings: in the order of 'man's inhumanity to man,' much worse than the virtual slave labour regime of Britain's industrial revolution era that Robert Burns lamented as that which 'makes countless thousands mourn.'

In view of the recurrence of these carnivals of evil which armed conflicts have visited upon humanity with unabated regularity since time immemorial, some notable inquiries have been made in the spheres of history, philosophy, psychology and sociology, all aimed at understanding why. In the following sections, some of the theories offered to explain human-inflicted evil during armed conflicts will

5 J Glenn Gray, The Warriors: Reflections on Men in Battle [New York: Harcourt, Brace, I959], pp I72§I73.

6 Chuter, ibid, p 5. See also Prosecutor v Fofana and Konderwa, dated 2 August 2007 [Trial Chamber, Special Court for Sierra Leone, Dissenting Opinion of Judge Thompson.]

7 Robert Burns, 'Man Was Made to Mourn' (A Dirge) (I784). 
be explored. As noted in the Introduction, the discussion will begin with a broad review of why human beings succumb to committing evil during armed conflicts: following that, we shall review some of the theories offered to explain the evil of sexual violence during armed conflicts.

The review is intended as an aid to a better understanding of how international law could more adequately serve its remit of containing (during an armed conflict) the general infliction of evil, as well as the infliction of the particular brand of evil done to women because of their gender. Before turning to the causes and explanations of the evil of sexual violence against women during armed conflicts, the review dwells at some length on the general typology of evil-doing found in armed conflicts. The reason is that an inquiry into the general brand of evil during armed conflicts affords a useful point of departure for the study of sexual violence as a particular sort of evil. It is not far-fetched to suggest, for instance, that a culture of conducts that permits the infliction of the general brand of evil may not be far removed from a culture of conducts that conditions perpetrators to commit - or moral accomplices to condone-sexual violence against women during an armed conflict. Thus, starting a review of the causes and explanations of the former may yield some useful insights into the nature of the latter. Will the official or military commander who superintended a homicidal enterprise with a personal moral detachment, simply because he had received the orders from his superiors, be readily seen to act differently if those orders were to permit sexual violence against the female victims of the homicidal enterprise? Will the sadist who tortured and killed his victims, and enjoyed doing so, be readily seen as a candidate of sudden epiphany of moral rectitude as regards sexual torture of a female victim?

As for the main object of this study-i.e. sexual violence against women committed during armed conflicts - it is readily appreciable that there is much work needed to be done in the area of international law, in spite of the existing rules within it, to fashion adequate responses to what is generally acknowledged to be a veritable scourge. It is felt that much inspiration will be drawn from a multidisciplinary appreciation of the nature of the evil for which such remedy is needed.

\section{A General Review of Human Capacity for Evil in Armed Conflicts}

Some of the explanations offered for the human capacity for evil during armed conflicts will be found in the writings of Hannah Arendt, Zygmunt Bauman, Stanley Milgram, C Fred Alford, Jean-Paul Sartre, Michael Ignatieff, J Glenn Gray, Arne Johan Vetlessen, and many other scholars. The knowledge gleaned from these writings include theories that may broadly be described as the situational theory, the dispositional theory, the theory of narcissism, and the eclectic theory of evil. We shall review them next. 


\section{The Situational Theory of Evil}

In the aetiology of mass atrocities one school of thought that has appeared irrepressible since the rg6os is the school that holds, controversially, that evil-doing, even in the order of genocide, is not explained by the dispositional propensity of particular men and women genetically wired in a special way to behave in a wicked way. This was a counter-think to an earlier school, appearing in the first decade after the Holocaust, which had concentrated hypotheses on the dispositional character of mass evil-doers. ${ }^{8}$ The controversy generated by the situational theorists stems mostly from the tendency of their theories, if accepted as truth, to apply to everyone. Some of the principals of this school of thought include Hanna Arendt, Zigmunt Bauman, Stanley Milgram and Philip Zimbardo. We shall review their hypotheses next.

\section{Hanna Arendt}

In Stephen Daldry's 2008 movie, The Reader, ${ }^{9}$ Hannah Schmitz (played by the Academy Award winner Kate Winslet) gives us a fictionalised glimpse into the banality of evil. The relevant scene is Schmitz's testimony, at her own trial as an SS camp guard complicit in the Holocaust. She explains in a very matter-of-fact way her motive for knowingly allowing 300 Jewish victims, under her and fellow guards' care, to die in an inferno at a church, during the death march that followed the evacuation of those victims from a concentration camp. The courtroom dialogue appears as follows:

Presiding Judge: Why didn't you unlock the doors?

Schmitz: Obviously. For the obvious reason. We couldn't.

Presiding Judge: Why couldn't you?

Schmitz: We were guards. Our job was to guard the prisoners. We couldn't just let them escape.

Presiding Judge: I see. If they escaped, you'd be blamed. You'd be charged. You might even be executed.

Schmitz: No.

8 See Christopher Browning, 'Introduction' in Leonard S Newman (ed), Understanding Genocide: The Social Psychology of the Holocaust [Oxford: Oxford University Press, 2002], p 3 .

9 This is a motion picture adaptation of the 1995 post-Holocaust novel of the same name by Berhnard Schlink translated into English by Carol Brown Janeway [Vintage Books, 1998]. 
Presiding Judge: Well, then?

Schmitz: If we'd opened the doors, there could have been chaos. How could we have restored order? ... We couldn't just let them escape. We couldn't. We were responsible for them. [Said with indignant emphasis; fist pounding the table.] ${ }^{\text {Io }}$

To Schmitz, then, her motivation for this atrocity was not even something as momentous as an external pressure to do evil by act or omission. It was simply a straight-forward and 'obvious' matter of doing one's job well. It did not matter that such a steadfast adherence to one's duties would result in misery and death to fellow human beings.

What is treated as a subtext in a sexually steamy fictional movie is a central subject of serious scholarship by renowned philosophers, in their attempt to explore evil. One such philosopher was Hannah Arendt. In the field of genocide research, Arendt is celebrated for her controversial early ig6os book Eichmann

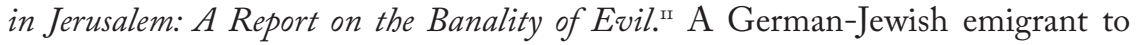
the United States, who had fled Germany during the Nazi persecution of Jews, Arendt felt an obligation to attend the trial of Adolf Eichmann in Jerusalem in 196I, as a freelance reporter for the New Yorker. Primed by the prevailing dispositional theories of evil, she had expected to observe the monstrosity of evil personified in Eichmann in the dock. She had hoped that the trial would aid her in an understanding of Eichmann's mind, and to enable her explore 'the totality of the moral collapse that the Nazis caused in respectable European society.' ${ }^{\text {I2 }}$ Instead, she was confronted by the pathos that she famously came to describe as the 'banality of evil'. By this, she meant that Eichmann was able to rise to the level of one of the worst criminals in history, in virtue of his personage as a faceless, uninspired and robotic bureaucrat who sat at his desk and did his job that was the extermination of European Jews.

In a view commonly shared by many other Holocaust scholars, Arendt opined that the Nazis had bureaucratised and legalised persecution of Jews and made the attendant levels of atrocity the new norm in Germany. The degree of perversion of the moral paradigm in Nazi Germany was such that evil lost the quality of that which confounded the mind; and the only phenomenon that held startling value was good. ${ }^{13}$ And good in those circumstances became a rare privilege experienced only by those with capacity for independent thought. ${ }^{14}$ According to

Io See The Reader (2008) directed by Stephen Daldry: starring Kate Winslet, Ralph Fines, David Kross; at video counter r:o9:05 to r:Ir:Io.

II Hannah Arendt, Eichmann in Jerusalem: A Report on the Banality of Evil [New York: Viking Press,1963].

I2 Ibid, Introduction by Amos Elon, p xii.

I3 According to Arendt: "[U]nder the conditions of the Third Reich only "exceptions" could be expected to react "normally," in so far as 'normal persons' are expected to realise the criminal nature of their acts: Arendt, supra, p 26.

I4 Ibid, p 295. Arendt's conclusion in this regard coincide with those made by Dave 
Arendt, Eichmann was lacking in such capacity. ${ }^{15}$ He was, in her view, a dull man that personified this banality of evil. ${ }^{16} \mathrm{He}$ was not a 'perverted sadist. ${ }^{17}$ Nor did he even hate his victims. ${ }^{\mathrm{I}}{ }^{8} \mathrm{He}$ was, among other things, a thought-deprived careerist doing his job in a system that had bureaucratised evil. To quote Arendt:

Except for an extraordinary diligence in looking out for his personal advancement, he had no motives at all.... He merely, to put the matter colloquially, never realised what he was doing. It was precisely this lack of imagination that enabled him to sit for months on end facing a German Jew who was conducting the police interrogation, pouring out his heart to the man and explaining again and again how it was that he reached only the rank of lieutenant colonel in the SS and that it had not been his fault that he was not promoted. ... He was not stupid. It was sheer thoughtlessness-something by no means identical to stupidity - that predisposed him to become one of the greatest criminals in that period.... That such remoteness from reality and such thoughtlessness can wreak more havoc than all the evil instincts taken together which, perhaps, are inherent in man - that was, in fact, the lesson one could learn [from Eichmann's trial] in Jerusalem. ${ }^{19}$ [Emphasis received.]

In the circumstances, argued Arendt, the efforts of the Prosecutor to portray Eichmann as a sadistic monster was not borne out by the reality of who Eichmann really was in the grand scheme of things. ${ }^{20}$

Arendt had attracted much criticism for these observations. ${ }^{21}$ Amos Elon, for instance, wondered if she had succumbed to the 'fallacy of physiognomy ... . She ought to have known better. Hitler would not have cut a better figure under the circumstances,' he chided. Elon considers that most tyrants and serial murderers, out of power, appear 'pathetic or ordinary, harmless, or even pitiful, as Saddam Hussein did coming out of his rat hole with an unkempt beard. ${ }^{22}$ Elon's commentary is certainly interesting, but not necessarily beyond factual dispute, if his point was to displace Arendt's observations of Eichmann and her attendant con-

Grossman many years later when he wrote: 'On rare occasions those who are commanded to execute human beings have the remarkable moral fibre necessary to stare directly into the face of the obedience-demanding authority and refuse to kill. These situations represent such a degree of moral courage that they sometimes become legendary': Dave Grossman, On Killing: The Psychological Cost of Learning to Kill in War and Society [New York: Little, Brown and Company, I995], p 224.

I5 Arendt, supra, pp 49, 287, etc.

I6 Ibid, pp 287-288.

I7 Ibid, p 276.

I8 Ibid, p 26.

I9 Ibid, pp 287-288.

$20 \quad$ Ibid, p 54 .

2I Arendt, supra, 'Introduction' by Amos Elon, generally.

22 Arendt, supra, 'Introduction' by Amos Elon, p xii. 
clusions. Saddam Hussein might have appeared pathetic, ordinary, harmless or pitiful at the point of his capture, as Eichmann, too, probably was at the point of his own capture. There was, however, nothing at all banal or uninspiring about Saddam Hussein at the comparative point that Arendt had observed Eichmanni.e. in the courtroom dock. Saddam Hussein had remained charismatic throughout, indulging regularly in displays of defiance towards the judges who were trying him; as well, even, as towards his executioners as he was being hanged. Similarly, other tyrants and strongmen on trial for genocide in contemporary memory did not all cut pitiful figures at their trials. Slobodan Milosevic, like Saddam Hussein, had proved irrepressibly defiant during his own trial, even refusing to accept counsel assigned to defend him, at the International Criminal Tribunal for the former Yugoslavia. And at the International Criminal Tribunal for Rwanda, Théoneste Bagosora, whom this author had assisted in prosecuting, never appeared a pathetic or pitiful figure. Similarly, Charles Taylor, another former strongman whom this author assisted in prosecuting, did not appear banal in his own trial. One is thus forced to question the correctness of Elon's attempts to extend to every evildoer, even the diabolically charismatic ones, Arendt's specific observations in relation to Eichmann. ${ }^{23}$

As noted earlier, Arendt was not alone in observing in an evil-doer the impersonal phenomenon she recorded about Eichmann. Some years ahead of the publication of Arendt's Eichmann in Jerusalem, another philosopher and a veteran of World War II had noted something similar. One particular episode which Gray observed appears in the story he tells as follows:

It happened in southern France shortly after our invasion. One day an attractive French girl appeared at our temporary headquarters and confessed that she had worked for a time with the local Gestapo and now feared the revenge of the Maquis. The French security officer with whom I was working interrogated her calmly at some length and soon found out that she had been in love with the Gestapo captain in charge of this district and had been persuaded to aid him on occasion in his repressive measures against the Resistance. Since our unit had to move on almost at once, the French officer wrote a report of his interrogation for the civil authorities of the liberated city—and closed it with his recommendation that the girl be shot! On the way to the city jail with the girl, he picked up

23 Another instance of that extension appears in the following observations of Elon: 'Before Arendt, others had emphasised the discrepancy between the personal mediocrity of monsters like Hitler or Stalin and the horrendous evil they unleashed on the world. Nearly everybody who attended the trials of mass killers after the war, some of them respected doctors and pharmacists, came away with the disconcerting impression that the killers looked pretty much like you and me. The Israeli court psychiatrist who examined Eichmann found him a "completely normal man, more normal, at any rate, than I am after examining him," the implication being that the coexistence of normality and bottomless cruelty explodes our ordinary conceptions and present the true enigma of the trial': Arendt, supra, Introduction by Amos Elon, $\mathrm{p} x \mathrm{v}$. 
some pictures of his wife and children, which he had had developed in a local photography shop during our brief stay. After showing them to me for my comment and approval, he carried them to the girl in the car ahead. Ignorant of the fate he had decreed for her (and which would almost certainly be carried out at once under conditions at that time), the girl admired the family snapshots and the two of them laughed and joked for many minutes. Passers-by might easily have mistaken them for lovers.

There was little savagery or blood lust in this French officer. He did not hate the girl, so far as I could tell, though he hated her deeds. He would, in fact, have been quite willing to sleep with her the night before ordering her execution. When I remonstrated with him about such callousness, he made clear to me that he regarded himself as an army officer in a quite different way from himself as a human being. The two personalities could succeed each other with lightning rapidity, as I was to see on numerous occasions. As a human being, he was capable of kindness, even gentleness, and within limits he was just and honest. In his capacity of functionary, he could be brutal beyond measure without ever losing his outward amiability and poise. I observed precisely the same qualities in the Fascist and Nazi politicians and police with whom it was my fate to deal.

After months of this sort of experience, I began to detect with a kind of horror that I was becoming inured to cruelty and not above practicing it myself on occasion. ${ }^{24}$

One readily sees striking similarities between Arendt's observations of the banality of evil in the character of Adolf Eichmann and Gray's first-hand observations of the predisposition of his French mate; complete with the same absence of hatred for the victims, and the same the capacity for great brutality as a functionary performing what he perceived as his duties. What is more, Gray himself admits that he, too, had found that after months of exposure to that sort of environment he was becoming accustomed to cruelty and not above perpetrating it himself.

Slightly ahead of Arendt's Eichmann in Jerusalem, Raul Hilberg had reached similar conclusions in his Holocaust magnum opus entitled Destruction of the European Jews. Hilberg, who like Gray was also a World War II veteran turned post-war scholar, had argued that the Holocaust was fundamentally an administrative and bureaucratic process. According to him, the 'bureaucrats who were drawn into the destruction process were not different in their moral makeup from the rest of the population. The German perpetrator was not a special kind of German. ... However one may wish to draw the line of active participation, the machinery of destruction was a remarkable cross-section of the German population.' ${ }^{25}$

Even more recently, the same phenomena were observed in the context of post-apartheid proceedings of the South African Truth and Reconciliation Commission. In a dispatch appearing in The New York Times, the reporter Susanne

24 Gray, supra, pp 7-9.

25 Raul Hilberg, The Destruction of the European Jerws (revised and definitive edition) [New York: Holmes and Meier, I985] vol 3, p IorI. 
Daley narrated how a torturer's testimony gave South Africa a new lesson in the banality of evil. Her report concerned the testimony of a South African police officer named Jeffrey Benzien, described as 'one of the many minor but effective functionaries who made apartheid work' for South Africa's white supremacist government. ${ }^{26}$ Benzien's torture specialty was the technique called the 'wet bag', a variant of 'water boarding'. The method involved covering the victim's head with a wet cloth and repeatedly bringing him 'to the terrifying brink of asphyxiation.' Confessions were thus extracted within a matter of minutes. But Benzien apparently had more techniques in his bag of torture tricks. For he did not deny his victims allegations, although he could not recall, that he applied electrodes to their noses, their genitals and their recta; he shoved a broomstick up the rectum of at least one of his victims; he hung his victims up on the window bars of their prison cells for hours with handcuffs; he inserted both thumbs into the nostrils of at least one of his victims and kept pulling until blood oozed out.

But Benzien was a family man who went home to his wife and children at the end of the 'work' day. And his 'job' was exactly what he saw himself as doinga true patriot good at his job. "I can sit here and tell you in all honesty that I was used by the then security branch", he said. "When it came down to getting the job done, I was the person who did it. Maybe I was too patriotic, too naive or anything else that you want to call it."'There, one clearly sees Arendt's banality of evil personified in Benzien, remarkably in the same manner as it does in Eichmann.

Given the manner of what Benzien did with his own hands, the description of 'sadist' will not be unanimously withheld from him. However, like Eichmann, he was very much a man recruited to do a job, saw what he was doing as such, took pride in doing that job, and brought creativity to bear. And, like Eichmann, he had no evident hatred towards his victims. It was nothing personal. It was all businesslike.

In 1999, two Frenchmen, Rony Brauman and Eyal Sivan, released an essay in celluloid on the Eichmann trial. They did this in their movie entitled The Specialist-Portrait of a Modern Criminal. The movie comprised entirely of the actual audiovisual footage of Eichmann's 350-hour (or over four-month) trial in I96I-compiled, arranged and edited down to a two-hour movie. The movie also features some special effects—-such as melodramatic sounds, photo-play with the actual pictures, as well as cutting down and splicing of sequences. But these special effects do not impair the authenticity of the footage employed.

One great accomplishment of Brauman and Sivan with The Specialist is their ability to have accurately presented the viewer with the perspective that Hannah Arendt had of the Eichmann trial proceedings, from her seat in the public gallery. The movie does not diminish, just as Arendt had not done, the truism of the Holocaust as a modern historical event that remains unrivalled in the grotesqueness of the evil and the criminality that it represents. But what quickly occurs to

26 Susanne Daley, 'Torturer's Testimony Gives South Africa a New Lesson in the Banality of Evil', New York Times, 9 November 1997. Available at <http://www.hartford-hwp.com/archives/37a/o4r.html> 
the viewer is the striking anti-climax between the grandeur of the evil and the criminality that the Holocaust represents versus the compelling ordinariness of the man put on trial, having deliberately been set up as the very personification of that evil and criminality in all their grotesqueness.

The movie opens with an excerpt of the opening statement of the AttorneyGeneral of Israel at the time, Gideon Hausner, leading the prosecution. He was a barrister of the more bombastic school of courtroom advocacy. In the movie, we see him commence the trial with the following descriptions of Eichmann: 'a destroyer of a people'; 'an enemy of mankind'; 'He committed atrocities so unspeakable that he who is guilty of such crimes no longer deserves being called human'; 'His crimes go beyond what we consider human. They go beyond what separates man from beast. ${ }^{27}$

Although it is not necessary to conduct genocide prosecutions with such big emotive descriptions of an accused, the foregoing descriptions are, nevertheless, arguably defensible, as a matter of logic and commonsense. They may permissibly apply to anyone guilty of complicity in a genocide. But, what proved more forensically questionable for $\mathrm{Mr}$ Hausner was his tactic of escalating this spirited description to the level of stereotyping Eichmann in the following way: 'He was born a human. But he lived like a beast in the jungle.' Now, this raised the expectations of the observer to expect to see palpable evidence that depicts the accused as the super- or sub-human monster that the prosecution so described.

In the Eichmann trial, that high expectation was quickly dashed. From the initial excitement roused by Mr Hausner's opening statement, the trial settled down to an inquiry_-sometimes painfully humdrum as these forensic inquiries tend to be-into questions such as (a) whether Eichmann was truly guilty of complicity in the Holocaust, as charged, given the nature of his functions, and the absence of evidence establishing beyond reasonable doubt that he actually killed anyone or knowingly ordered anyone to be killed ${ }^{28}$ (b) the technical details of his complicity, limited only to his functions as an SS lieutenant-colonel who, first, coordinated the emigration-turned-deportation programme, and later transportation of Jews to the death camps; and whether he was aware that certain death awaited the deportees at the receiving end of his work product; ;9 (c) whether he was only a subordinate executing orders that he received from his superiors to coordinate, at various times, the emigration of Jews, their deportation and their

27 R Brauman and E Sivan, The Specialist-Portrait of a Modern Criminal (1999) (a movie), video counter 00:03:30-00:04:13.

28 In fact, the Court acquitted Eichmann of the only allegation of direct perpetration of crime-i.e. that he had personally, with his servant Slawik, beaten a Jewish boy named Salomon to death in a cherry orchard at his home in Budapest (an allegation which Eichmann had abjured): The Eichmann Judgment, para Iı 8, available at <http:// www.nizkor.org/ftp.cgi/people/e/eichmann.adolf/transcripts/ftp.py?people/e/eichmann.adolf/transcripts/Judgment/Judgment-037>.

See for instance, The Specialist, supra, at oo:13:40, 00:21:40, etc. 
transportation to the concentration camps; $3^{3 \circ}$ (c) the significance of ligitimising crime by law or State practice or both, and the practical limits of the individual's freedom of will and conscience to opt out, in terms of the wholesome or mitigated culpability of the individual obligated to comply; ; $^{3^{\mathrm{T}}}$ (d) the complicity of some highly placed Jews themselves (serving in the Jewish Council or the Judenrat) in the realisation of the Holocaust committed against their own people; ${ }^{32}$ and, the

30 Not only did Eichmann hang on to this defence throughout his testimony, like a drowning man would hang on to a floating ball, but there were some corroborating evidence of this defence in the case for the prosecution. For instance, the former director of the Fund for Israel's Development, testified that during meetings at which members of the Jewish Council presented demands and grievances to Eichmann, he 'almost always said "I must ask my superiors"': ibid, oo:08:I2.

3I This question was surely engaged by Eichmann in his own defence: see, for instance, ibid, at or:39:35. Notably, Judge Halevi appeared to have recognised this idea in virtue of a proposition he had put Eichmann: 'At the time, it was very difficult ... for an individual to accept the consequences ... of refusing to obey orders': ibid. Indeed, at least one prosecution witness had given testimony which resonates in this theory of the case for the defence. For instance, Prosecution Witness Abraham Gordon, an inmate at Auschwitz who had lost his entire family during the Holocaust, had testified: (a) that there 'were Christians who tried to hide Jews. But were hanged': ibid at oo:20:40; and (b) that not all of the SS guards appeared to have been relishing the killing of Jews: 'The variety of their feelings was quite extensive, from one to another. Some [were] almost hysterical, some [were] close to nervous breakdown, some were just photographing the scene, and some were shooting and killing': ibid at oo:20:43. These engaged the question whether Eichmann had a choice but to obey orders, and whether he was among those who were deeply troubled by the extermination (as he claimed at trial) or whether he was one of those relishing its accomplishment (as the Prosecution urged the Court to hold). In the movie The Specialist, the viewer is presented with no evidence tending to show that he belonged to the latter camp. Much of what the viewer observes is his testimony to the effect that he was the trapped victim of circumstances from which he could not escape: see ibid at or:32:I2 et seq.

32 The testimony of $\mathrm{Mr}$ Freudiger (a former member of the Hungarian Jewish Council) was particularly telling in this regard. First, he made the disquieting admission that there was an understanding with the Nazis by which members of the Jewish Council and their close relatives would be spared from the ghettoisation programme: ibid at or:29:38. But it was his explanation of his failure to encourage Jews to flee that proved more unbearable for some of the survivors in the Courtroom's public gallery. According to him: 'By the time we knew, when we realised what Auschwitz was, the Jews from the east and the north-east of Hungary, 300,000 of them had already been deported. We informed them. They already knew what was in store for them. But what could we do? What could we do?': ibid or:30:04: This answer produced angry heckling from the public gallery. Requiring the Presiding Judge to intervene, by ordering the heckling man to be removed from the public gallery, in a bid to restore order in the Courtroom. In an evident attempt to improve upon this answer, the beleaguered Mr Freudiger painfully continued as follows: 'I beg your pardon, your Honour. With reference to what I said just now, before the incident, people 
distraction of that question from the central question of the guilt of the accused person who had been portrayed as a monster; (e) the possible complicity of the German Red Cross Society in the Holocaust; 33 and (f) the apportionment of blame to the victims for their fate, given the absence of mass resistance or revolt on their part, ${ }^{34}$ etc.

Against the foregoing background, one might find something instructive in the reaction of the Court to the protest of one witness, who had objected to any hint of blameworthiness arising from the question of why the would-be Nazi victims did not flee. The Presiding Judge (Moshe Landau) was thus prompted to admonish the Attorney-General for not conducting the case as he had set it up in his opening statement. Although the Court was later to, soothingly, describe the matter (in its Judgment) as 'a slight deviation here and there from the narrow path which the Court saw as its duty to set, 35 the following dialogue in the course of the trial remains interesting: ${ }^{36}$

Presiding Judge [addressing the Attorney-General]: Mr Hausner, we have just heard profoundly distressing matters related in the language of a poet. But ... with this testimony, we are getting away from the object of this trial. I'm sorry to have to say this at the end of this testimony.

Mr Hausner: No, it's a pity ...

now say that they were not told to flee. But $50 \%$ of those who fled were captured and killed. So we could have been reproached for telling them to flee. They were caught simply because they didn't have anywhere to flee to': ibid at or:30:48. This explanation instantly produced anther round of disruption in the public gallery. There was some snickering from the public gallery. One heckler shouted in anger, 'Him! Him! They reassured us to save their own families!' The Presiding Judge intervened again; he ordered the heckler to be removed; and he immediately adjourned the hearing.

33 Witness Gedalia Ben-Zvi, was one of the young, male Jews used as slave labourers to assist with the work of the concentration camp at Birkenau. He was forced to help in unloading train wagons of inmates upon their arrival at Birkenau. He had testified that when Jews were brought by train to the Birkenau concentration camp, 'There was always a vehicle marked with a Red Cross in case of possible incidents. In case someone resisted or went mad, became violent or had a fit. To prevent panic or disorder, they put them inside the [Red Cross] vehicle to calm them down. ... 'This was the same vehicle where the cans with the Zyklon B were loaded and later delivered to the gas chambers': $i b i d$, at or:08:44-01:09:15.

34 See $i b i d$, at or:16:09.

35 See The Eichmann Judgment, para 3 available at <http://www.nizkor.org/ftp.cgi/ people/e/eichmann.adolf/transcripts/ftp.py?people/e/eichmann.adolf/transcripts/ Judgment/Judgment-ooI>.

The Specialist, at or:16:26. 
Presiding Judge: The Court has a certain conception of what this trial should be. The prosecution must therefore conduct its [case] in accordance with what the Court says.

Mr Hausner: This is what we are doing, Your Honour.

Presiding Judge: I must state that the line of this trial is not being followed in the way it should be.

Mr Hausner: Maybe that's because you are not aware of all the elements ...

Presiding Judge: We heard your opening speech, which I believe outlines very well what you intend to demonstrate ....

It is not apparent what the Presiding Judge meant by his hint to the AttorneyGeneral when he said: 'I must state that the line of this trial is not being followed in the way it should be. ... We heard your opening speech, which I believe outlines very well what you intend to demonstrate.' Nevertheless, this should not preclude the struggle that the Attorney-General was experiencing in his task of actual demonstration, by the evidence, that Eichmann was the evil 'beast in the jungle' that the Attorney-General had described in his opening statement.

Particularly remarkable, as we see in The Specialist, is how empathetic and ordinary Eichmann actually appears during the course of the trial. Rather than appearing as a monster in a business suit, he is quite capable of being perceived credibly as the mild-mannered and quiet person that he describes himself to be ${ }^{37}$ an underdog that is being relentlessly badgered by a most pugnacious AttorneyGeneral (with a supporting battery of lawyers and police aides); while his Defence Counsel Dr Servatius sits quietly still, almost alone.

37 He had described himself as 'not brusque' in his manner of dealing with people; and that he simply obeyed orders and carried on quietly with his work: ibid, at or:35:05 et seq. Indeed, Eichmann's disposition in that regard was evidently on display during the trial. His attitude towards the court and counsel was always respectful and correct, even if his answers were unacceptably evasive when the questions appeared to zero in on his involvement in bad acts. There was never a hint of defiance in his attitude towards the judges, who represented authority in that Courtroom. Prominentlooking witnesses who were former members of the Jewish Council testified as to the respectful way that he treated them at their meetings during the Holocaust, when he was in office under the Nazi regime. The former director of the Fund for Israel's Development, for example, testified that Eichmann referred to him as 'Herr'; that when the Jewish Council went to him to present grievances and demands, Eichmann, 'from time to time' did something; and, that it was possible to reach an understanding with him: ibid, at o0:08:03-00:08:I6. Eichmann also came across as a great sympathiser for the cause of a Jewish homeland, and had cooperated with every effort to realise that objective: $i b i d$, at oo:14:36. 
There is, of course, a world of difference between optics and substance in a criminal trial. To look banal, ordinary or even empathetic is not the same as to be innocent of the charges proffered against the accused. It is important, therefore, to emphasis that none of the foregoing observations could possibly diminish the grandeur of the evil that was the Holocaust. Nor, for that matter, do they excuse from criminal responsibility those who make (even) banal contributions to evils great and small. It is perhaps helpful, in this regard, to keep in mind the classic dictum of the International Military Tribunal at Nuremberg in their judgement, rendered I5 $_{5}$ years ahead of the Eichmann trial, explaining the test of guilty participation in a joint criminal enterprise, even under dictatorial regimes. According to the Tribunal:

The argument that ... common planning cannot exist where there is complete dictatorship is unsound. A plan in the execution of which a number of persons participate is still a plan, even though conceived by only one of them; and those who execute the plan do not avoid responsibility by showing that they acted under the direction of the man who conceived it. Hitler could not make aggressive war by himself. He had to have the co-operation of statesmen, military leaders, diplomats, and business men. When they, with knowledge of his aims, gave him their co-operation, they made themselves parties to the plan he had initiated. They are not to be deemed innocent because Hitler made use of them, if they knew what they were doing. That they were assigned to their tasks by a dictator does not absolve them from responsibility for their acts. The relation of leader and follower does not preclude responsibility here any more than it does in the comparable tyranny of organised domestic crime..$^{38}$ [Emphasis added.]

The International Military Tribunal was speaking in the context of a common plan to wage aggressive war. There is, however, little doubt that the force of that reasoning fully applies to the question of participation of a bureaucrat, however lowly or banal, to a criminal enterprise to exterminate a people. It was thus wholly correct and appropriate that the District Court of Jerusalem rejected the argument that Eichmann's individual criminal responsibility was diminished by the guilt of others. As the Court reasoned:

In fact, it is not disputed that in all his activities the Accused always acted together with others, and this is how he was charged in the indictment. We shall not see the complete picture if we place the responsibility for the entire extermination campaign upon the Accused alone. Above him, there were the men at the top, beginning with Hitler himself-those who were the initiators of the Final Solution, and who gave the basic orders which guided the Accused; and alongside the Accused and his Section, many others were active, all of them determined to carry out the Fuehrer's order, each one of them in his own par-

38 The Göring Case (Judgment) I October 1946, I Trial of Major War Criminals before the International Military Tribunal at Nuremberg [Nuremberg, 1947] I7I at p 226. 
ticular field of action: The Ministries of the Interior and Justice, which laid the main formal groundwork for the persecution of the Jews, by drafting definitions which determined precisely who was a Jew, who was a descendant of mixed marriage and who was an Aryan, thereby setting up barriers which segregated the Jews from the rest of the population-by promulgating laws and regulations aimed at putting the Jews beyond the pale of the law; the Foreign Ministry, which laboured unceasingly to spread the poison of anti-Semitism all over the world, and to create conditions for the delivery of the Jews of other countries into German hands, in order to deport them to their slaughter; the Ministry of Finance and the Reichsbank, which took part in plundering the property of the victims; the Fuehrer's Chancellery, which was active in the introduction of the method of killing by gas; and also the German Army Command, which tainted itself by acting in partnership with the SS in the extermination of the Jews in the East, in Greece, and in other countries. Not only these, but all the authorities of the Reich and of the National Socialist Party, whose sphere of activity touched upon Jewish affairs - they all competed with one another to excel in furthering the common end-the complete extermination of the Jews, the enemies of the Reich, by every means in their power, efficiently and speedily.

But all this does not detract from the fact that the Accused's Section in the RSHA stood at the very centre of the Final Solution; and the guilt of the others does not lessen by one iota the personal guilt of the Accused. ${ }^{39}$ [Emphasis added.]

The two dicta set out above from both the International Military Tribunal and the Jerusalem District Court contain reasonable legal principles that properly frame the juridical picture of Eichmann as banal or ordinary. That is to say, his appearance as banal or ordinary is a red herring that was unfortunately introduced in the case by the Attorney-General himself when he set Eichmann up as a monster. His contrasting appearance as banal or ordinary has very little to do with the question of his guilt or innocence. In this connection, one must treat with care the reflections of Brauman and Sivan, in their mimeograph, In Praise of Disobedience, published as a companion to the movie The Specialist. According to them:

Our man is the type of person that power loves to have in its ranks. Certainly, with his generic model-employee look, his two pairs of horn-rimmed glasses, his slight stoop, his incipient baldness, he would never stand out in a crowd. Certainly, the behaviour of this excessively meticulous bureaucrat is more reminiscent of the world of Courteline than the world of Shakespeare. As for his imagination and his decision-making ability, experience has shown them to be in keeping with his appearance: he is not stupid, but he would not venture to take any initiative beyond the instructions he receives from his superiors-and even then, such instructions must be duly approved by those at the very top.

39 See The Eichmann Judgment, para 242 available at <http:/www.nizkor.org/ftp.cgi/ people/e/eichmann.adolf/transcripts/ftp.py?people/e/eichmann.adolf/transcripts/ Judgment/Judgment-o69>. 
It was definitely not for his charisma or his analytical abilities that he was hired and came to occupy, a few years later, a key position in the organisation he so admired. But this man had important qualities to offer his employers who saw them for what they were worth: a methodical organizer, a dedicated worker, he devoted himself to his job with tireless zeal and unfailing loyalty. He went even further: when he was assigned the task of processing an unfamiliar material which he knew only by name, he took it upon himself to study the specificities and properties of this new sector-and he did so at his own expense, for he was never able to get reimbursed for his pains. He even became a recognized specialist in this area and was asked to give lectures on the subject. Thus, the subaltern made his way up and found himself promoted, at the age of 32, to the post of Logistics and Operations Manager for all of Europe. And despite his ever-increasing workload and responsibilities, he remained undaunted. As long as his services were requested, he would put his talent and skills towards achieving the production goals of his company. And he proved, until the very end, to be extremely efficient.

For six years, from the height of his official position, he organised the collection, breakdown, evacuation and transportation to various destinations of the biological material under his responsibility. In doing so, he displayed great talent as a negotiator and organizer, never becoming discouraged by the innumerable material obstacles that stood in his way. Although the company strategy changed considerably during his career, he was able to adapt. Once the material was delivered, it underwent a 'special processing' of which he did not approve. But since he was not in charge of this part of the production chain - and he was very glad of this until the day he died-he felt it was not his place to judge. This engineer who worked for what was, in fact, a mass murder industry could not bear the sight of blood. He liked nothing more than paperwork, statistics, and seeing a job well done.

This man is the German SS Lieutenant-Colonel Adolf Eichmann, former head of Section IVB 4 of the 3rd Reich's Central Security Office. A 'specialist on the Jewish question', he was in charge of expelling Jews from the Reich from 1933 to 194I. From 194I to I945 he organised the European-wide deportation of Jews, as well as Poles, Slovenians and Gypsies, to the concentration and extermination camps. This 'emigration expert', chief logistician of the 'final solution to the Jewish problem' carried out his assignment with absolute loyalty until the very end. Captured in Buenos Aires by the Israeli Secret Service in 1960, he was tried in Jerusalem the following year and then hung.

In front of the Jerusalem court and the survivors of the death camps, the man whom the prosecutor presented as an incarnation of the devil had to answer for his role in the annihilation of several million people.... ${ }^{\circ}$

40 Éloge de la désobéssance: a propos d'«un spécialiste» Adolf Eichmann [Paris: Editions Le Pommier-Fayard, I999], excerpted in The Specialist, title II. 
As noted earlier, portraits of Eichmann painted in this way should not obscure his individual criminal responsibility in the Holocaust. Indeed, the painstaking process of justice, as was ultimately done in the case, does not readily preclude Eichmann from criminal responsibility for the part he played in the Holocaust. A review of the judgment provides ample rational basis for his conviction. The central theme in the judgment was that he knowingly participated in the extermination of Jews, by continuing to deport them to the concentration camps that he knew had been designed for that purpose..$^{4 \mathrm{I}}$ Referring to this role, the AttorneyGeneral had famously put the question thus to Eichmann in cross-examination: 'It didn't trouble you to be the big forwarding agent of death?' Eichmann's answer was notably: 'It troubled me greatly, more than anyone could imagine. I repeatedly went to my superior to request a transfer to other duties. ${ }^{42}$ But his explanation for continuing to act in that role is summed up in his response to Judge Halevi's question: 'One was living at a time where crime was legalised by the state. It was the responsibility of those who gave the orders.' ${ }^{43}$

It is ultimately immaterial that he might not have actually intended the extermination of his victims, when he was assisting that outcome. For this conclusion, it could suffice, of course, to leave things merely on the usual legal reasoning that an accomplice need not actually intend the crime but to knowingly lend substantial assistance. ${ }^{44}$ It needs to be said, however, that the luxury of the underlying technical inquiry into his intent (which could lead to reasonable doubt to the benefit of the accused) mocks the idea of justice, if that idea should also accommodate any concern for the victims who were killed in a genocide that the accused know-

4I See Eichmann Judgment paras I62 et seq available at <http://www.nizkor.org/ftp.cgi/ people/e/eichmann.adolf/transcripts/ftp.py?people/e/eichmann.adolf/transcripts/ Judgment/Judgment-052> et seq.

See The Specialist at video counter or:32:I2.

43 Ibid, or:39:35.

44 For instance, the ICTR Appeals Chamber has stated that, for an aider and abetter of an international crime, the 'corresponding intent, or mens rea, is indicated by the requirement that the act of participation be performed with knowledge that it will assist the principal in the commission of the criminal act:' Prosecutor $v$ Kayishema and Ruzindana (Judgment) I June 20oI, para I86. That is to say, the accused need not have actually intended the crime as such, as long as he knew that his actions would provide substantial assistance to the commission of the crime. See also Prosecutor v Tadić (Judgment), I5 July 1999, [ICTY Appeals Chamber], para 229(iv): 'In the case of aiding and abetting, the requisite mental element is knowledge that the acts performed by the aider and abettor assist the commission of a specific crime by the principal'; Prosecutor v Kajelijeli (Judgment) I December 2003, [ICTR Trial Chamber] para 768; Prosecutor v Semanza (Judgment) I5 May 2003 [ICTR Trial Chamber] para 388; Prosecutor v Bagilishema (Judgment) 7 June 200I [ICTR Trial Chamber] para 32; Prosecutor v Furundžija (Judgment) Io December 1998 [ICTY Trial Chamber] paras 236, 243 and 245; Prosecutor v Delalic E Ors (Judgment) 16 November 1998 [ICTY Trial Chamber] para 326; A Cassese, International Criminal Law (Oxford: Oxford University Press, 2003), I88. 
ingly assisted by his actions, although he may not have actually intended it. As his own life could not have been more objectively valuable than any one, let alone more, of the victims of that genocide, Eichmann should simply have done everything-including possibly mortally - to remove himself from assisting in that genocidal enterprise. To put it plainly, he could have resigned from his functions: if that were impossible, then he could have abandoned his post and gone into hiding: if that were impossible, he should have committed suicide, rather than help in the transportation of several Jews to their death - a fate he know as awaiting them as a direct product of his work.

Also as part of their reasoning in the case, the District Court correctly downplayed the distinction between the significance of Eichmann's role in overseeing the deportation of Jews to the concentration camps and the question of his responsibility for what happened to them there. As the Court put it:

Has the Accused's activity in the actual extermination operations, as distinct from his activities in rounding up Jews and deporting them to the places of extermination, been proved, and to what extent? In our view, this question is only of secondary importance, because the legal and moral responsibility of a person who delivers the victim to his death is, in our opinion, no less, and maybe even greater, than the liability of the one who does the victim to death..$^{45}$

Although the Court did go on to provide a forensic synthesis of the evidence tending to show the role of the accused in the actual extermination enterprise, it would have been sufficient, for purposes of criminal responsibility, that all that Eichmann had done was assist in the deportation and transportation of victims to the concentration camps. In this regard, it is notable that even Eichmann himself was not entirely convinced of his own innocence. He had admitted that although he did not, 'from the legal point of view', see himself as guilty of complicity in the extermination of millions of Jews, he did, in his conscience, see himself as guilty 'in human terms', because he was guilty of organising the deportations. ${ }^{4}$

There was no question therefore of Eichmann's innocence. The trouble with the Eichmann trial rather was that the prosecution made that elementary mistake of optically overstating their case in the opening statement, in terms of their description of Eichmann in the context of the evidence of the role that he played in the crime. The result of that miscalculation was the actual appearance of Eichmann, while on trial, as a fellow human being-and a particularly dull one: yet knowingly, even if unwillingly, participating in a horrendous joint criminal enterprise.

All told, the guilt of Eichmann is evident in a careful and painstaking collation and analysis of all the evidence in the case; and the resulting forensic com-

45 The Eichmann Judgment para I4I available at <http://www.nizkor.org/ftp.cgi/ people/e/eichmann.adolf/transcripts/ftp.py?people/e/eichmann.adolf/transcripts/ Judgment/Judgment-045>.

See The Specialist, supra, at or:55:55 et seq. 
position of a picture of his criminal responsibility, as was done in the judgment of the District Court of Jerusalem. As one commentator summed up the trial in ig62:

The trial of Adolf Eichmann can be described as a trial by documents and circumstantial evidence. The survivors of the holocaust gave a blood-curdling testimony of atrocities and sufferings in order to build up a general picture of the 'final solution' rather than establish the personal guilt of the accused. It was only against this background, and in the light of documentary evidence, that the sinister figure of the accused assumed realistic features as one of the executors of the 'final solution.' Bearing in mind the psychological climate and the place of the trial it is quite impossible to judge objectively whether or not the rules of evidence governing hearsay and relevance were infringed. The proceedings came very close to an English trial, but the nature of the crimes involved and the role filled by one particular person in the running of the machinery of extermination must by necessity invoke doubts which emerge in all marginal cases. Yet the dignity and restraint of the court and the desire to do justice which dominated all stages of the proceedings must be put on record because these are uncommon features of show trials. ${ }^{47}$

Eichmann's guilt does not then appear-certainly not in The Specialist-from grand statements made a priori to describe him as the Mephistopheles of the greatest modern evil known to humanity. It is in the sense that his guilt emerged rather from 'documents and circumstantial evidence' that it is eminently correct of Arendt to describe him as representing evil in its banal form.

\section{Zygmunt Bauman, Stanley Milgram and Philip Zimbardo}

Besides Arendt, other notable situational theorists of evil are Zygmunt Bauman, Stanley Milgram and Philip Zimbardo. In his book, Modernity and the Holocaust, Bauman offered the possibility of understanding the Holocaust as a by-product of modern society in which bureaucracy sapped a sense of personal responsibility out of its human operatives. Modernity achieves this feat by the simple process of roboticisation. Bauman is, in effect, warning of some of the great dangers that appear overlooked in modern society's preoccupation with 'rational, planned, scientifically informed, expert, efficiently managed, coordinated' way of life..$^{8}$ This preoccupation is characterised by the credo that modern institutions run most effectively when the sensory and mental attributes of the human being are kept at bay or eliminated altogether from the economic or bureaucratic process. The result is a certain pressure on human beings to operate and produce accordingly; failing which they are replaced by the very machines and computers which they have,

47 D Lasok, 'The Eichmann Trial', International and Comparative Law Quarterly [1962] vol II, 355 at $\mathrm{p} 372$.

48 Zygmunt Bauman, Modernity and the Holocaust [Ithaca, NY: Cornell University Press, 1989], p 89 . 
all along, been required to imitate. Bauman's central message is that the human race can pay a catastrophic price for this attitude to modernity. He points to the Holocaust as proof of the danger.

Reminiscent of Arendt's view of Eichmann as not a monster but a thoughtbereft bureaucrat doing his job, Bauman argued that the Holocaust needs to be understood as a product of modernity and not as a momentary relapse into barbarism. As he put it: 'The Holocaust was not an irrational outflow of the not-yetfully-eradicated residues of pre-modern barbarity. It was a legitimate resident in the house of modernity ...'. ${ }^{49}$ In other words, the Holocaust was the by-product of soul-numbing efficiency in the advances of technological and organisational accomplishments of a highly modernised and bureaucratised society that lays great store on discipline and efficiency, to the detriment of personal moral responsibility. Consequently, functionaries in those bureaucracies are capable of committing astonishing manner of evils, given the resulting mental distance between the person and his conduct/victim..$^{\circ}$

Bauman also implicates modernity in a deleterious process of social separation, where successfully created. The key to such a successful process involves the displacement of proximity which has a direct correlation to moral responsibility. 'Responsibility arises out of proximity of the other. Proximity means responsibility, and responsibility is proximity.'The process of defusing responsibility, which consequently results in the neutralisation of moral urge, necessarily involves the displacement/replacement of proximity with physical or psychic separation, resulting in social distance. Thus, erosion of proximity results in the silencing of responsibility. The void created by the absence of proximity may eventually be filled with resentment for the victim, if (s)he is successfully transformed as 'an Other' in the mind of the actor. According to Bauman, it was this process of social separation that made the Holocaust possible-involving thousands of killers and millions watching the carnage without protest. 'It was the technological and bureaucratic achievement of modern rational society that made such a separation possible. ${ }^{5}{ }^{1}$

Bauman recognised the patterns of the Holocaust, and he implicated modernity, in the now familiar pattern of evil-doing in which 'moral inhibitions against violent atrocities tend to be eroded once three conditions are met, singly or together; the violence is authorised (by official orders coming from the legally entitled quarters), actions are routinised (by rule-governed practices and exact specification of roles), and the victims of the violence are dehumanised (by ideological definitions and indoctrinations). ${ }^{52}$

Bauman's conclusions appear amply supported in a more recent study on another genre of actors performing lethal functions: executioners in the prisons of the southern states of the US. In that study, Osofsky, Bandura and Zimbardo

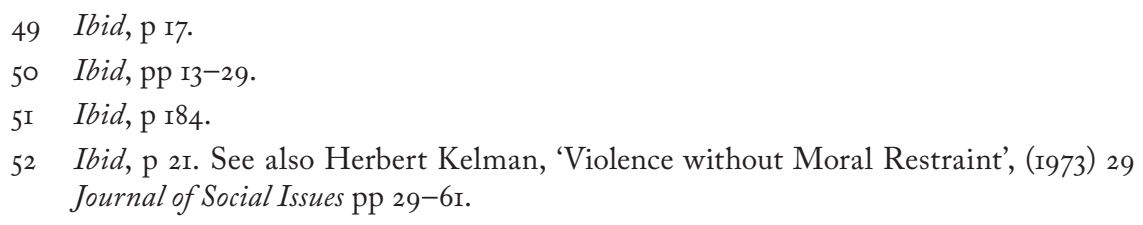


found that the executioners see themselves as doing society's work as in any other job in an institutional service facility. Their focus is not so much on the meaning of their activity, but on performing their functions efficiently. Their response is typically ' $[\mathrm{We}]$ had a job to do, that's what we did. Our job was to execute this man and we were going to do it in a professional manner. ${ }^{53}$ With the routinisation of the lethal activities into separate sub-functions, members of the execution teams shift their minds from the morality of their activity to the operational details and efficiency of their specific tasks. The process of routinisation also helped to achieve desensitisation: 'No matter what it is, it gets easier over time. The job just gets easier.' The element of routinisation helps to promote a sense of duty and professionalism on the part of the executioner who would then say, 'The process has become very routine and the next day is easy. ... It is a duty of my job that has to be done.' All this clearly points to a state of mind in which 'agentic responsibility' is displaced and diffused. ${ }^{54}$

Authoritative studies have also implicated the same factors as enabling soldiers to kill during armed conflicts. In his book On Killing, Lt Col Grossman posits that the demands of authority, ${ }^{55}$ routinisation, ${ }^{56}$ and dehumanisation ${ }^{57}$ are all implicated in the anatomy of killing and other atrocities committed by soldiers during warfare. Indeed, there is a haunting similarity between military ethos and the aspects of modern bureaucracy which Bauman implicates in the Holocaust. For instance, regarding modern bureaucracy, Bauman wrote: 'The first principle most obviously relevant to our query is that of organisational discipline; more precisely, the demand to obey commands of the superiors to the exclusion of all other stimuli for action, to put the devotion to the welfare of the organisation, as defined in the commands of the superiors, above all other devotions and commitments. ${ }^{5}$ Making virtually the same point, Lt Col Grossman writes: 'Someone who has not studied the matter would underestimate the influence of leadership in enabling killing on the battlefield, but those who have been there know better.'59

Bauman also identified the social distance created between the bureaucrat's action and the evil effect on the victim as correlative of the degree to which the victims have been made more psychologically or physically invisible to the perpetrator. Here, Bauman draws a direct link to the increase in human casualties during modern warfare.$^{60}$ In the fashion of Bette Midler, Grossman sings his agreement

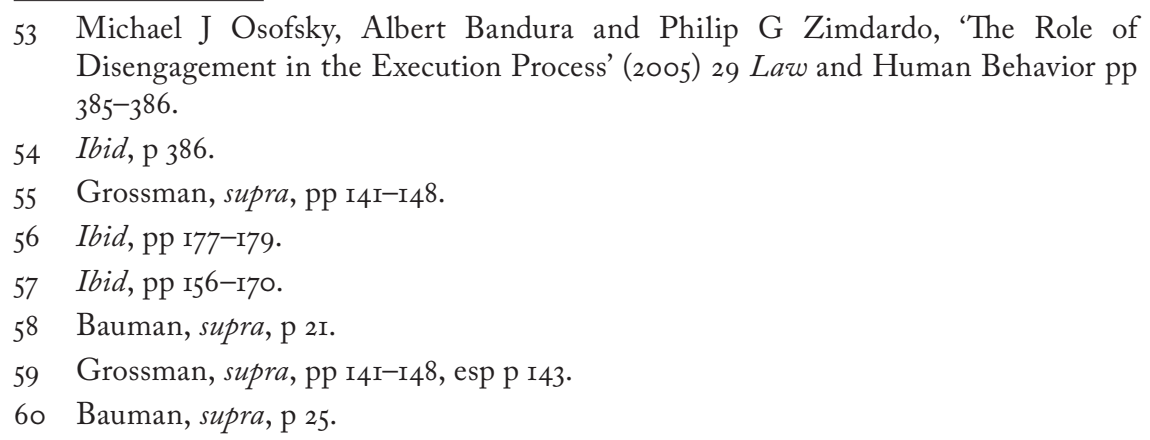


in the section he entitled: 'Killing and Physical Distance: From a Distance, You Don't Look Anything Like a Friend.' ${ }^{6 r}$ Part of this phenomenon of invisibility of the victim in modern warfare is achieved by the military through routinisation of the killing process. In this connection, Grossman writes: 'Traditional marksmanship training has been transformed into a combat simulator. ... [S]oldiers who have conducted this kind of simulator training "often report, after they have met a real life emergency, that they just carried out the correct drill and completed it before they realised that they were not in the simulator." Vietnam veterans have repeatedly reported similar experiences. ${ }^{\prime 2}$

Another way in which the invisibility of the victim is achieved, hence making evil capable of pervasive perpetration, as was seen in the Holocaust (and the Rwandan Genocide), was the tactic of removing the victim from the perpetrator's 'universe of obligation'. ${ }^{6}$ This universe delineates the perimeters of the social territory in which the perpetrator's moral urge is permitted sway. Hence, to 'render the humanity of victims invisible, one needs merely to evict them from the universe of obligation. ${ }^{64}$ In the Holocaust, this was achieved not only by depriving Jews of membership in the German nation, but also by associating them with other dehumanising objects, traits and notions: such as in the connection made between 'Jews and lice', by transforming the propaganda from the self-defence rhetoric of the 'Jewish question' to the Aryan rhetoric of 'self-cleansing' and 'political hygiene', 'the typhus-warning posters on the walls of the [Jewish] ghettos, and finally the commissioning of the chemicals for the last act from the Deutsche Gesellschaft für Schädlingsbekäpung — the German Fumigation Company. ${ }^{2} 5$

Although Bauman does not deal with the Rwandan Genocide and did not bring that event into his analysis in this regard, since his writing predated that Genocide, the similarity of the Jewish experience in Nazi Germany appears to have afforded a certain template for the Rwandan Genocide. For in the Rwandan Genocide, precisely the same brain-washing strategy was employed. Extremist Hutus first denied Tutsis membership in Rwandan nationality. Many Tutsis were literally forced into exile. As the exiles organised to return, first by negotiation and then by force, they and other Tutsis were generally branded as inyenzi (cockroaches), among other undesirable creatures, requiring a project of national fumigation or extermination.

Once more, Grossman concurs on the uses of the dehumanising propaganda in the killing enterprise during warfare: 'It is so much easier to kill someone if they

\footnotetext{
6I Grossman, supra, pp 97-137.

62 Ibid, pp I77-I78.

63 This was a term that Bauman borrowed from Helen Fein, defined as 'the circle of people with reciprocal obligations to protect each other whose bonds arise from their relation to a deity or sacred source of authority': Bauman, supra, p 26. See also Helen Fein, Accounting for Genocide: National Response and Jerwish Victimisation during the Holocaust [New York: Free Press, 1979] p 4.

64 Bauman, supra, p 27.

65 Loc cit.
} 
look distinctly different from you. If your propaganda machine can convince your soldiers that their opponents are not really human but are "inferior forms of life," then their natural resistance to killing their own species will be reduced. Often the enemy's humanity is denied by referring to him as a "gook," "Kraut," or "Nip." In Vietnam this process was assisted by the "body count" mentality, in which we referred to and thought of the enemy as numbers. One Vietnam vet told me that this permitted him to think that killing the NVA and VC was like "stepping on ants." 66

Indeed, this displacement of moral responsibility is the central thesis of Stanley Milgram's famous I96r study, which forms a theoretical pillar of Bauman's analysis. ${ }^{67}$ The basic design of Milgram's experiment is as follows. Two peopleone designated a 'teacher' the other a 'learner'-come to a psychology laboratory to take part in a study on memory and learning. The experimenter, a stark authority figure, explains that the study is concerned with the effects of punishment on learning. The 'learner' is conducted into a room, apparently seated on an electric chair. His arms strapped down to prevent excessive movement. An electrode is attached to his wrist. The experimenter explains that he will read a list of simple word pairs to the 'learner', to test his ability to remember the second word of a pair when the first word is read to him again. It is explained that whenever the 'learner' errs, the 'teacher' will deliver electric shocks to the 'learner' in increasing intensity. ${ }^{68}$

The real subject of the experiment is the unsuspecting 'teacher': both the 'learner' and the experimenter are accomplices in the ruse on the 'teacher'. The 'teacher' is seated before an impressive electric shock generator, as he watches the 'learner' being strapped into place in the 'electric chair'. The instrument panel in front of the 'teacher' consists of 30 lever switches, each clearly labelled with voltage designation ranging from 15 to 450 volts. The lever switches are arranged in groups progressively marked as: 'Slight Shock', 'Moderate Shock', 'Strong Shock', 'Very Strong Shock', 'Intense Shock', 'Extreme Intense Shock', 'Danger' and 'Severe Shock.' ${ }^{\prime 9}$

The purpose of the experiment is to see how far the subject - the 'teacher'will proceed in the progression of shocks, to a victim screaming in agony, before refusing to comply with the experimenter's instructions to continue inflicting the pain..$^{\circ}$ In Milgram's original experiment at Yale University, 26 out of the 40 subjects (i.e. approximately 60 percent) administered the highest shocks on the

\footnotetext{
66 Grossman, supra, p i6ı.

67 Stanley Milgram, 'Behavioral Study of Obedience', (I96r) 67 Journal of Abnormal Social Psychology pp 371-8; and Stanley Milgram, Obedience to Authority [New York: Harper \& Row, 1974].

68 Milgram, Obedience to Authority, supra, p 3.

69 Milgram, Obedience to Authority, supra, p 20, 28-29.

$70 \quad$ Ibid, p 3 .
} 
generator, upon the experimenter's instructions. ${ }^{71}$ Some subjects were noted to have continued, upon instructions, to deliver the 450-volt shocks even when there was no further response from the 'learner', suggesting that he was either dead or unconscious.

The first experiment involved Yale undergraduates as subjects. But the results were similar in subsequent experiments, involving people from every stratum of society in New Haven, Connecticut. Indeed, higher levels of obedience were observed in experiments repeated in Princeton; as they were in Germany, Italy, South Africa and Australia. One scientist in Munich found an obedience level of 85 percent. In the control experiment, different results were recorded when the subject was left with complete discretion as to the escalation of the shock levels. The great majority of the subjects delivered very low shocks at levels that were usually harmless. ${ }^{72}$

The primary lesson of the Milgram experiment is this. Ordinary people, simply doing their jobs, and without any particular hostility animating them, 'can become agents in a terrible destructive process' ${ }^{73}$ Furthermore, even when the harmful effects of what they consider their 'work' become quite clear, relatively few people have the courage needed to resist authority when they are asked to carry out actions that are incompatible with basic standards of morality, or, it might be added, their own personal sense of morality. ${ }^{74}$ As Milgram concluded:

With numbing regularity good people were seen to knuckle under the demands of authority and perform actions that were callous and severe. Men who are in everyday life responsible and decent were seduced by the trappings of authority, by the control of their perceptions, and by the uncritical acceptance of the experimenter's definition of the situation, into performing harsh acts. ${ }^{75}$

In an interview with Morley Safer of CBS News 6o Minutes, Milgram said as follows:

Safer: Are you suggesting that-that it could happen here?

Milgram: I would say, on the basis of having observed a thousand people in the experiment and having my own intuition shaped and informed by these experiments, that if a system of death camps were set up in the United States of the sort

7I Ibid, pp 5 and 33 .

72 Stanley Milgram, 'The Perils of Obedience', Harper's Magazine [1974] at <http:// home.swebell.net/revscat/perilsOfObedience.html>

73 Milgram, Obedience to Authority, supra, p 6.

74 Loc cit. See also Milgram, 'The Perils of Obedience', supra.

75 Stanley Milgram, 'Some Conditions of Obedience and Disobedience to Authority', (I965) I8(I) Human Relations, 57 at 74. 
we had seen in Nazi Germany, one would be able to find sufficient personnel for those camps in any medium-sized American town. ${ }^{76}$

Another conclusion which Bauman and Milgram before him drew from that experiment is that the presence of an authority figure who commanded the perpetration of evil, thus displacing the perpetrator's sense of responsibility for his conduct, made it easier for the average bureaucrat to commit disturbing acts of evil once ordered to do so. Succumbing to the impulsion of obedience, the perpetrator sees himself as a mere instrument or agent for carrying out another person's wishes: hence absolving himself of personal responsibility for his own actions. ${ }^{77}$ But, according to Milgram, morality does not disappear altogether. Rather, "it acquires a radically different focus: the subordinate person feels shame or pride depending on how adequately he has performed the actions called for by authority. ${ }^{2}{ }^{8}$

Direct links have been made between the Milgram experiment and the Holocaust. ${ }^{79}$ In his own study of the implementation of the Nazi Final Solution in Poland, Christopher Browning characterised one particular incident of massacre of I,500 Jews in the Polish village of Józefów by the German Reserve Police Battalion Ior constituting 'graphic confirmation' of many of Milgram's insights. ${ }^{80}$ He further observed that, as in the Milgram experiment, "without direct surveillance, many policemen did not comply with orders when not directly supervised; they mitigated their behaviour when they could do so without personal risk but were unable to refuse participation in the battalion's killing operations openly.' ${ }^{\text {r }}$

An important element in the theory of evil advanced by Bauman and Milgram is the role of division of labour. Milgram's experiments led him to conclude that any intervening force or event placed or appearing between the subject and the action-on-victim dampens moral strain on the subject. In Milgram's summation, this is described as the fragmentation of responsibility that results from the professionalised and depersonalised modern society. ${ }^{82}$ Accepting John Lachs's characterisation of the same idea as 'mediation of action', ${ }^{83}$ Bauman wrote in terms of

76 CBS News, Sixty Minutes, 3I March 1979, excerpted in Thomas Blass (ed), Obedience to Authority: Current Perspectives on the Milgram Paradigm [Mahwah, NJ: Lawrence Erlbaum Associates, 2000], pp 35-36.

77 Milgram, Obedience to Authority, supra, pp 7-8. See also Bauman, supra, p 22.

78 Milgram, Obedience to Authority, supra, p 8. Milgram, 'The Perils of Obedience', supra.

79 Milgram, Obedience to Authority, supra, pp I-2 and 5-6.

8o Christopher Browning, Ordinary Men: Reserve Police Battalion IOI and the Final Solution in Poland [New York: Harper Perennial, 1993], see generally pp I72-I89, especially at pp I74.

8I Ibid, p I76.

82 Milgram, Obedience to Authority, supra, pp Io-II. See also Arne Johan Vetlesen, Evil and Human Agency: Understanding Collective Evildoing [Cambridge: University Press, 2005], p I8.

83 See John Lachs, Responsibility of the Individual in Modern Society [Brighton: 
one's action being performed for one by someone else, by an intermediate person, who stands between one and his action, thereby making it impossible for one to experience directly the action and its consequences. ${ }^{84}$ Indeed, as the actual footages of Eichmann under cross-examination reveals in the movie The Specialist, Eichmann did not feel any personal responsibility for his role as the 'great forwarding agent of death', although he knew that those he was deporting to the concentration camps were being exterminated at their points of destination. 'I had orders', he declared, 'Whether people were killed or not, orders had to be executed in accordance with administrative procedure. ${ }^{85}$ In a dialogue with Judge Halevi, Eichmann elaborated as follows: ${ }^{86}$

Judge Helevi: Did you never experience ... a conflict ... what one could call a conflict of conscience? Between your duty and your conscience?

Eichmann: One could call it a state of being split ...

Judge Halevi: Being split?

Eichmann: A conscious split state, where one could flee from one side to the other.

Judge Halevi: It was necessary to abandon one's personal conscience?

Eichmann: Yes, one could say that. Because one could not control or regulate it oneself.

Judge Halevi: Except if one accepted the personal consequences.

Eichmann: One could have said: "I refuse to do this." But I don't know what would have happened then.

Harvester, I98I], pp I2-I3, 58 .

84 Bauman, supra, p 24. See also Vetlesen, supra, pp I8-I9. Other theorists have described the same phenomenon: 'Responsibility can be diffused in three ways, by division of labor in which each of the subdivided tasks seem harmless in themselves, by group decision-making which absolves any individual from feeling personally responsible, and also by engaging in collective action which provides some degree of personal anonymity while minimizing individual accountability: Osofsky et al, p 373, citing H C Kelman, and V L Hamilton, Crimes of obedience: Toward a social psychology of authority and responsibility [New Haven, CT: Yale University Press, I989] and P G Zimbardo, 'The psychology of evil: situationist perspective on recruiting good people to engage in anti-social acts', (1995) in Research in Social Psychology, pp I25-I33.

85 The Specialist, supra, at oo:22:18.

86 Ibid, at or:37:21 et seq. 
Judge Halevi: If there had been more civil courage, things would have been different. Don't you think so?

Eichmann: Of course, if this civil courage had been hierarchically organised.

Judge Halevi: Then it wasn't fate ... an inevitable fate?

Eichmann: It's a question of human behaviour. That's how it happened, it was wartime, everyone thought: "It's useless to fight against it ... it's only a drop in the ocean, what use is it? There's no point in it, it will do neither good nor harm." It was also connected with the times, I think, with the era, with ideological education, rigid discipline, and all that kind of thing.

Judge Halevi: At the time, it was very difficult ... for an individual to accept the consequences ... of refusing to obey orders.

Eichmann: One was living at a time where crime was legalised by the state. It was the responsibility of those who gave the orders. [Emphasis added.]

Notably, during his trial, Eichmann testified that he was at the Wannsee Conference where methods of 'killing' and 'extermination' were discussed in blunt terms, 'without circumlocution'. He testified that 'prominent figures of the Reich' spoke at the Conference. They included Secretaries of State. He was to prepare the minutes of the conference. He was told by his superiors Heydrich and Müller on what the minutes should say, and to be excluded from the minutes were the discussions about the methods of extermination. At the end of it, they enjoyed a celebratory glass or two or three of Cognac. Although he realised the horror of the extermination plot discussed at Wannsee Conference, he ffelt satisfied as to [his] personal self-examination.' He felt 'the kind of satisfaction Pontius Pilate must have felt because [he] felt devoid of any guilt.' As he saw it, 'The Popes had given their orders. I had to obey. I kept this in mind throughout the following years .... ${ }^{87}$

The elemental relationship with Arendt's conclusions continues unabated. Evidently, there is no profound difference between Bauman's theory and that of Arendt. Indeed, the contrary is the case. The chief difference would be that Bauman, being a sociologist, simply gave a sociological rendition to the phenomenon which Arendt had articulated from a perspective of contemporary philosophy. Milgram himself drew a direct link to Arendt's analysis of the actions and personage of Eichmann. According to him, the experiment contradicted the popular expectation that those who would shock the victim at the most severe levels came only from the sadistic fringes of society. Indeed, contends Milgram, the experiment 'is highly reminiscent of the issue that arose in connection with Hannah Arendt's I963 book, Eichmann in Jerusalem. ${ }^{88}$ It is recalled that Bauman

87 See The Specialist, supra, at video counter or:00:53-or:01:05.

88 Milgram, 'The Perils of Obedience,' supra. 
had founded elements of his own conclusions on Milgram's experiment and conclusions. ${ }^{89}$ Decades later, in December 2008, it was reported that the Milgram experiment was repeated by Jerry Burger at Santa Clara University in California. The conclusions remained the same as in the original Milgram experiment. ${ }^{\circ}$

A related experiment was the Stanford Prison Experiment conducted in I97I by Philip Zimbardo. As with Milgram's experiment, Zimbardo's was designed to test the idea that inherent personality traits were responsible for evil behaviour. Zimbardo's chosen setting was a prison environment, in which prison guards exercised power, authority and control over prisoners. Participants were recruited and told that they would participate in a two-week 'prison simulation.' Of the 70 respondents, Zimbardo and his team selected the 24 male students of Stanford University who were deemed to be among the most psychologically stable and healthy. The simulated prison was in the basement of Stanford's Psychology Department, which had been converted into a mock jail. Zimbardo played the role of prison superintendant. The participants were provided the usual prison paraphernalia: the 'guards' were fitted in khaki uniforms, reflective sunglasses to prevent eye contact, and armed with wooden batons; the 'prisoners' were fitted in loosefitting smocks with no underwear, and stocking caps, to simulate shaven heads. Chains around the ankles reminded the 'prisoners' of their roles as such. Physical abuse was forbidden of the 'guards'; but they were otherwise permitted to be creative in their methods of generating in the prisoners 'feelings of boredom, a sense of fear to some degree, ... a notion of arbitrariness that their life is totally controlled by' the prison guards and by the system. The objective was to create a sense of powerlessness in the prisoners. The participants who had been chosen to play the part of prisoners were 'arrested' at their homes and 'charged' with armed robbery. The local Palo Alto police department assisted Zimbardo with the arrests and conducted full booking procedures on the prisoners, which included fingerprinting and taking mug shots. They were transported to the mock prison where they were strip-searched and given their new identities. The first day of the experiment was relatively uneventful. But by the second day, the experiment had begun to take on a life of its own. The 'guards' had settled into their roles and increasingly became abusive in sadistic ways. The prisoners initially attempted to rebel, but were quickly put down by the guards. The 'prisoners' evidently started resigning themselves to their powerlessness and the humiliating treatment to which they were being subjected.

A false rumour spread that one of the prisoners, who asked to leave the experiment, would lead companions to free the rest of the prisoners. The guards were forced to dismantle the prison and move the inmates to another secure location. When no breakout attempt occurred, the guards were angry about having to rebuild the prison, so they took out their feelings on the prisoners. ${ }^{9 \mathrm{I}}$ Several

\footnotetext{
89 Bauman, supra, pp I5I-I68.

90 See 'People "still willing to torture", BBC News, I9 December 2008. See <www. news.bbc.co.uk/2/hi/health/7791278.stm>.

9I 'Stanford Prison Experiment', Wikipedia Free Encyclopedia available at <en.wikipedia.org/wiki/Stanford_prison_experiment>.
} 
of the guards became progressively abusive. The abuses suffered by the 'prisoners' included verbal insults, sleep deprivation, simulated homosexual abuses. Zimbardo was compelled to terminate the experiment early when Christina Maslach, a former graduate student of his who was now his girlfriend, objected to the appalling conditions of the prison after she was introduced to the experiment to conduct interviews. Zimbardo noted that of more than 50 outsiders who had seen the prison, Maslach was the only one who questioned its morality. After only six days of a planned two weeks' duration, the Stanford Prison experiment was shut down..$^{22}$ Although the experiment was criticised as unethical by Ms Maslach (whom Zimbardo later married) and by many in the academic circles, Zimbardo (who also accepted the charges of ethical challenges to the experiment) insisted that it demonstrated the thesis advanced by Milgram that evil is capable of explanation by situational attributes, rather than the innate predisposition of the perpetrators. According to Zimbardo:

The Stanford prison experiment is but one of a host of studies in psychology that reveal the extent to which our behaviour can be transformed from its usual set point to deviate in unimaginable ways, even to readily accepting a dehumanized conception of others, as "animals", and to accepting spurious rationales for why pain will be good for them.... [A]s a great deal of social-psychological research before and since has confirmed, we humans exaggerate the extent to which our actions are voluntary and rationally chosen - or, put differently, we all understate the power of the situation. ${ }^{93}$

In the wake of Abu Ghraib prison abuse, the Stanford Prison Experiment has received renewed interest and has been cited, including in the report authored by James R Schlesinger, the former US Secretary of Defence, as holding important lessons that the US military ought to have learned in the management of prisoners of war. ${ }^{94}$

\section{The Dispositional Theory of Evil}

\section{Daniel Goldhagen}

Diametrically opposed to the axis of Arendt-Bauman-Milgram-Zimbardo common theories of evil as situational is the view that evil is very much a product of the perpetrator's personal predisposition. Daniel Goldhagen is a particularly high profile figure in this camp. In his book Hitler's Willing Executioners: Ordinary Germans and the Holocaust, he delivered a furnace blast of opinion against ordinary

92 Philip Zimbardo, 'Revisiting the Stanford Prison Experiment: a Lesson in the Power of Situation', Chronicle of Higher Education, 30 March 2007 available at <www. lucifereffect.org/about_reviews_chronicle.htm>. 
Germans. In his view, tens of thousands of ordinary Germans willingly participated in the Holocaust because of centuries old anti-Jewish conditioning that was particularly virulent in Germany more than anywhere else in Europe. As he put it: 'Genocide was immanent in the conversation of German society. It was immanent in its language and emotion. It was immanent in the structure of cognition.'95 According to him, the Nazi regime merely removed the restraint that had hitherto prevented the German citizenry from indulging in the 'eliminationist antiSemitism' to which they had been in thrall much earlier than the Nazi regime. ${ }^{96}$ The point appears quite stridently in his assertion that a 'demonological antiSemitism, of the virulent racial variety, was the common structure of the perpetrators' cognition and of the German society in general. The German perpetrators ... were assenting mass executioners, men and women who, true to their own eliminationist antisemitic beliefs, faithful to their cultural antisemitic credo, considered the slaughter to be just.' ${ }^{97}$

It would have been arguable that Goldhagen belongs in the camp of situational theorists, considering that social pollution of the mind through negative stereotyping of a people should qualify as an environmental, rather than dispositional, flaw. However, Goldhagen's conclusions were partly shaped by his view of the Holocaust as often accompanied by sadism: 'gratuitous cruelty, such as beating, mocking, torturing Jews' and there was no other use in the enterprise for such gratuitous cruelty other than the 'satisfaction and pleasure of the perpetrators. ${ }^{98}$

Goldhagen's book has attracted a fair amount of criticism, ${ }^{99}$ some of them just as scorching ${ }^{\mathrm{IOO}}$ as his own commentary had been of the ordinary German living in Third Reich Germany. But a fuller discussion of the criticisms of his work is outside the limit of the present study, given the ad bominem focus of Goldhagen's work.

95 Daniel Jonah Goldhagen, Hitler's Willing Executioners: Ordinary Germans and the Holocaust [New York: Vintage Books, I997], p 449.

96 Ibid, Part VI generally.

97 Ibid, pp 392-393.

98 Ibid, pp I7, I88, 228, 256, 259, 386, 388, 389, 400, 457 and 480. See also Norman Finkelstein, 'Daniel Jonah Goldhagen's "Crazy" Thesis: A Critique of Hitler's Willing Executioners', (1997) New Left Review vol a Issue 224, p 68.

99 See for instance, Leonard Newman, 'What is Social-Psychological Account of Perpetrator Behaviour? The Person versus the Situation in Goldhage's Hitler's Willing Executioners' in Leonard Newman and Ralph Erber (ed), Understanding Genocide: The Social Psychology of the Holocaust [New York: Oxford University Press, 2002] p 43 et seq. See also Daniel Jonah Goldhagen, 'A Reply to My Critics', The Nerw Republic 23 December 1996.

Ioo See Finkelstein, supra, p 39 et seq. 


\section{Fred Alford}

Of greater interest in the present study is the work of C Fred Alford, another dispositional theorist whose conclusion rests on sadism. His theory is less parochial than Goldhagen's limited focus on Germans. Alford conducted a psychological study on the meaning of evil at the Patuxent Institution - a maximum security prison in Maryland, USA, with an emphasis on the psychotherapeutic treatment of dangerous criminal offenders. His study involved interviews with prisoners over a I4-month period. His findings and conclusions are published in his book What Evil Means to Us. ${ }^{\text {ror }}$

According to Alford, sadism is the route to understanding the evil of mass atrocities such as genocide. In this regard, he notably returns to the Milgram experiment. ${ }^{102}$ But he disputes Milgram's conclusions that the experiment has nothing to do with sadism but all about obedience-'man's potential for slavish groupishness. ${ }^{\text {'03 }}$ Alford observes that the motion picture of Milgram's experiment reveals that a 'grotesque nervous laughter, the giggling fits at the shock generator' is a common reaction noticeable in the subjects of the experiments delivering the shocks. He contends that, contrary to Milgram's unsubstantiated dismissal of the idea, the giggling fits suggest 'embarrassed pleasure at being given permission to inflict great pain and suffering on an innocent vulnerable man.' ${ }^{104}$ According to Alford,'permission' in this sense does not mean the comforting licence: 'Go ahead. It's okay.' It is rather a situation that protects the evil-doers from their own sadism while allowing them to express it. In Alford's words:

That is what they want, that is what they do, and that is what they get pleasure from-embarrassed pleasure, guilty pleasure, but it is still pleasure. ${ }^{105} \ldots$ In this light we should consider whether much of what passes as the result of leaders' orders is actually leaders granting permission to their followers to do what they want to do anyway but are too guilty or embarrassed to know it. Could it be the psychological function of leaders to provide plausible psychological deniability to their followers, as well as to shelter them from the consequences of their desires? ${ }^{\text {ro6 }}$

Alford defines sadism as 'the joy of having taken control of the experience of victimhood by inflicting [the victimhood] upon another.' And, it is ultimately about control ${ }^{107}$ - the control of the senses of vulnerability, anxiety, pain, suffer-

IoI C Fred Alford, What Evil Means to Us [Ithaca, NY: Cornell University Press, I997].

IO2 Ibid, p 25.

IO3 Ibid, p 26.

IO4 Loc cit.

I05 Loc cit.

Io6 Ibid, p 27.

IO7 Ibid, p 28. 
ing and dread. The perpetrator conceives of these human encumbrances as reified burdens capable of both exorcism out of oneself and projection onto a fellow human within whom the perpetrator can control and manipulate the burdens at will. With these existential burdens thus controlled and manipulated in someone else, the perpetrator feels a sense of relief from their weight. Enacting the scenario from the perspective of the perpetrator and his attitude towards his victim, another commentator has recast Alford's hypothesis in this way:

$[N]$ ow that I have seen to it that all you feel is pain, all you are is suffering, I myself am (no longer, or — anyway — right now, as long as I make this last) nothing of the sort: by forcing you to be A, I liberate myself from everything to do with being A; that is, I effectively, psychically, make myself not-A. You are the one who suffers, who has the origin of mortality in you; you are the very embodiment of vulnerability to suffering. By stark contrast, I, being the one who makes you suffer, exhibit my vitality, my capacity to negate mortality: me subject, you object; me alive, you sensing life dwindle; me controlling the whole process, you being controlled by it to the point of losing control over yourself altogether: you eventually merge with your pain, your body-in-pain, whereas I am wholly mind over body, activity over passivity, life over death ... ${ }^{\text {I08 }}$. [Emphasis received.]

Unlike his kindred theorists who view killing as the primary means of the control and manipulation indicated above, ${ }^{109}$ Alford's primary concern is not with killing but 'with the thousand ways evil aims to sacrifice the soul of another. 'Iro This will undoubtedly include the evil of sexual violence.

As Vetlesen correctly interprets Alford's hypothesis, the mindset at issue is something more than intentional or deliberate infliction of evil upon another. It is the seizure of the perpetrator's life force by a raptorial tenacity to inflict evil upon another human being. ${ }^{\text {III }}$ And it is the very fact of the victim's humanity that makes him or her suitable to the perpetrator as the proper receptacle of the existential burdens which the perpetrator desires to control and manipulate in that alter receptacle, in order to achieve relief for himself; hence the proper recipient of the evil (thus inflicted). ${ }^{12}$

Vetlesen criticises Alford's theory for perceived exclusive locus in the dispositional attribution, to the exclusion of the situational attribution, of behaviour. That is to say, Alford singularly focused on the individual perpetrator as an autonomous fountain of evil, ruling out his environment as alternative explanation for

Io8 Vetlesen, supra, pp III-II2.

Io9 Otto Rank, for instance, opined that the 'death fear of the ego is lessened by the killing, the sacrifice, of the other; through the death of the other, one buys oneself free from the penalty, of being killed': Otto Rank, Will Therapy and Truth and Reality, I vol d [New York: Knopf, 1945] p г30. See also Alford, supra, p io.

iı Alford, supra, p io.

III See Vetlesen, supra, p Io9.

II2 See ibid, p пाо. 
his behaviour. ${ }^{\mathrm{Ir} 3}$ Indeed, Alford's prose in parts of What Evil Means to Us may lend his work to legitimate criticism of exclusive focus on sadism as the only explanation for evil. This is especially the case when he stakes his theory against those of Milgram and Zimbardo. ${ }^{\text {II }}$

Another flaw in Alford's theory is its tendency for over-generalisation in an apparent bid to simplify an understanding of evil. One notes the following passage, for example:

Pleasure in evil may be complex, about the pleasure in avoiding one's fate, and the joy that stems from the illusion of inflicting the fate on others. It is complex, but it is simple — something Milgram and Zimbardo have forgotten. Augustine holds that evil is chaos and confusion, whatever keeps us from seeing clearly. Let us mitigate evil by not eliminating the simplest and clearest explanation of evil of all. People like to hurt one another, obtaining great pleasure and satisfaction from doing so.' ${ }^{\text {II5 }}$ [Emphasis added.]

A related motivation for this generalisation appears to be terror in Alford's mind resulting from an inability to pin evil down in a specific location. This terror appears in the following passage:

It is too easy, separating the person from the act in a way that suggests that evil just happens. Evil, or at least a particular type of evil, happens because people do it. Where else could it come from? These people need not be totally or unredeemably evil, but separating the act from the person can only make evil even more terrifying, as we no longer know where it is located. ${ }^{\text {Ir6 }}$

It is well nigh impossible to hope to persuade everyone that such a view holds universal application to all 'people', as implicated in Alford's charge: 'People like to hurt one another, obtaining great pleasure and satisfaction from doing so.' Alford's challenge in this regard comes not only in the form of emotional resistance of some of his audience to the idea that everyone is a sadist at heart, but also in the overwhelming evidence and hypotheses tending to support the situational attribution theories. Notable among these studies are the findings reported by

II3 See Vetlesen, supra, pp I29-130.

II4 One notes, for instance, the following passage about the predisposition of executioners: 'The state's executioner follows public procedures to exact revenge; the man with the electric chair in his basement is a freelance predator. One subjects his sadism to the demands of the state; the other takes his sadism freelance. It is the difference between the subjects in the Milgram experiment and the criminal; it is the difference between civilization and chaos. But it is not the difference between sadism and obedience. Nor is it necessarily a difference in basic psychology': Alford, What Evil Means to Us, supra, p 30.

II5 Alford, What Evil Means to Us, supra, p 31.

II6 Ibid, p 33 . 
S L A Marshall in his book Men Against Fire: The Problem of Battle Command in Future War. Marshall was a Brigadier-General and US combat historian. He was commissioned to examine the firing rates among American GIs during World War II. He and his team of historians conducted extensive individual and group interviews of US soldiers immediately following close combat with Japanese and German forces. He startled the military world by reporting that only about 15 percent of soldiers - and no more that 25 percent in the most aggressive combat units - had been willing to fire their weapons at the enemy during combats. This was the case whether the battle in question was for just one day or spread over three days. ${ }^{\text {II7 }}$ And when the enemy troops grew careless and offered themselves as targets, the GIs were often known to say to themselves: 'Let 'em go; we'll get 'em some other time. ${ }^{\text {Ir8 }}$ All these led Marshall reasonably to believe that the 'average and healthy individual ... still has such an inner and usually unrealised resistance towards killing a fellow man that he will not of his own volition take life if it is possible to turn away from that responsibility. ${ }^{\text {II9 }}$ Other notable modern military historians and military psychologists concur with this conclusion. ${ }^{120} \mathrm{With}$ proper conditioning, however, as appears now to have been a central focus in military trainings since Marshall's findings, the rate of fire has increased, ${ }^{\text {I2I }}$ no doubt partly explaining why the $20^{\text {th }}$ century has 'produced a bloodbath of war and destruction that dwarfed earlier periods, as approximately r6o million human beings were killed in violent conflict[s]. , $22^{2}$

Marshall had attributed the low rate of fire he observed during WWII to dispersion of troops in modern combat, as opposed to earlier wars in which troops amassed together in close formation during battle, and were thus able to observe each other's effectiveness during fire fights. Although there have been some controversy about Marshall's research methodology, ${ }^{\mathrm{I} 23}$ it is still noteworthy that subsequent researches conducted into earlier wars suggested no higher rates of fire. ${ }^{124}$ Until this finding, it had been assumed, consistent with Alford's view no doubt,

II7 S L A Marshall in his book Men Against Fire: The Problem of Battle Command in Future Wars [New York: William Morrow, 1947] pp 56-57.

II8 Ibid, p 79 .

II9 Loc cit.

I20 See Dave Grossman, supra, pp xiv and 2-4. See also Gwynne Dyer, War: the Lethal Custom, revised edition [New York: Carroll \& Graf, 2004] p 57.

I2I See Grossman, supra, pp xv-xvi, 4, I3, I8, I77-I79; and Dyer, supra, pp 3I-62. With the new kind of training evident in the Korean War of 1951, Marshall found that 50 percent of the soldiers were indeed firing the weapons and in some cases, everyone was firing: Peter Watson, War on the Mind: the Military Uses and Abuses of Psychology [London: Hutchinson, 1978] p 45.

I22 See Robert S McNamara and James G Blight, Wilson's Ghost: Reducing the Risk of Conflict, Killing and Catastrophe in the 2Ist Century [New York: Public Affairs, 200I] $\mathrm{p}$ xvii.

I23 See Grossman, supra, p xv.

I24 See Grossman, supra, pp I6-28; and Dyer, supra, p 57. 
that the average soldier would readily kill in battle, especially if he had been ordered to do so and if he understood that his own life depended on it.

All this is not to obliterate all value from Alford's sadistic theory of evil. It is, however, hardly an improvement in the cause of his anxiety to accept wholly Alford's theory of evil as the 'simplest and clearest explanation of evil of all', if his aim is to resolve the opposite dilemma of "chaos and confusion [that according to Augustine] keeps us from seeing clearly.' Nor is it less terrifying, as Alford worries, to embrace - in evident desperation - a single theory of evil, such as the commonality of the latent trait of sadism, to the exclusion of a different explanation in the appropriate case. Far better, it would seem, to accept that evil is capable of explanation in some instances by situational attributes, as are Alford's dispositional theory of sadism. Hence, it is possible to recognise the usefulness of Alford's theory as affording explanation for some instances of evil-doing, while situational factors might explain evil in other instances. ${ }^{\mathrm{I} 25}$

But there is an ironic twist, ultimately, to Alford's disagreement with the situational theorists. It is that at long last, his theory arrives at the same destination, albeit using a different route. The common ground is that perpetrators of evil are no different from the average person. This conclusion becomes inescapable on the basis of Milgram's findings that over 60 percent of the subjects of his experiments were prepared to apply, upon instruction, the maximum electric shocks to the victims. Alford's own conclusion extends the distribution of the propensity for evil even further: for according to him, everyone is a sadist.

Even more useful, perhaps, within the paradigm of understanding evil, in order to facilitate appropriate decisions, is the need to recognise what ought to be an obvious interplay between Alford's dispositional attribution of evil with the dispositional theories championed by the likes of Arendt, Bauman, Milgram and Zimbardo. If people are indeed sadists at heart, but could go through life without acting it out in the manner that would produce a Holocaust, a Rwanda, a Mai Lai or an Abu Ghraib, then it should be something of critical interest to a decision maker whether a situation has been created in which the sadistic forces of human nature have been unleashed or encouraged to control the conduct of a given perpetrator. The range of evil's expressions which the decision maker must contemplate and capture in the bid to fashion adequate responses may have to include, inter alia, 'strong forces of moral distance, social distance, cultural distance, group absolution, close proximity, and obedience-demanding authority' all of which may operate severally or jointly to compel the perpetrator to commit—or participate in - the evil act. ${ }^{\mathrm{I} 2} 6 \mathrm{We}$ will return to this interplay later in our discussion of the usefulness of these theories of evil in the province of the law.

I25 Indeed, it is possible to allow for that possibility in Alford's theory; for before concluding that 'People like to hurt one another, obtaining great pleasure and satisfaction from doing so', he had expressed the view that Milgram's and Zimbardo's experiments must not be taken as explaining every instance of evil: see, for instance, Alford, What Evil Means to Us, pp 26, 27 and 29.

See Grossman, supra, p 209. 


\section{The Narcissistic Theory of Evil}

Jean-Paul Sartre offers another theory of appreciation of mass evil. Using the framework of genocide, he argues that there is no society that is protected by its structure from committing mass evil, such as genocide. According to him, every case of such mass evil 'is a product of history and bears the stamp of the society which has given birth to it. 'riz7 Sartre's historical frame of reference was the wars of aggression employed by colonial powers to subjugate their colonies both in order to gain the foreign territory and to stave off wars of liberation. Since the period of colonialism, he observes, 'there has been countless acts of genocide outside Europe', perpetrated by European powers. ${ }^{128}$ Some of these wars reflected authoritarian political structures, while others were the product of internal structures of capitalist democracies. Colonial empires, he contended, resulted from the need to export imperial products and capitals. The colonies at the receiving end were acquired by acts of aggression. It was not necessary to use overwhelming force to achieve the initial conquest, in view of the disproportionately superior military might of the colonial power. Only expeditionary forces were required to achieve victory. However, since the naked aggression aroused deep hatred for the colonial occupation, the imperial forces would resort to terror-in the form of 'perpetual massacres' - to maintain their authority. And according to Sartre, 'these massacres were genocidal in character .... ${ }^{\mathrm{r} 29}$ When, later, the colonised peoples became emboldened to fight for independence, the imperial responses were total and thorough torture and genocide- it was no

I27 Jean-Paul Sartre, 'On Genocide', in Richard Falk, et al (ed), Crimes of War: A Legal, Political-Documentary, and Psychological Inquiry into the Responsibility of Leaders, Citizens, and Soldiers for Criminal Acts in Wars [New York: Random House, 1971], supra, 534.

I28 Sartre, supra, p 535. This observation is not uniquely Sartre's. Arendt had made similar observations. Commenting on the nature of the crime on which Eichmann stood trial, Arendt observed as follows: '[T] he concept of genocide, introduced explicitly to cover a crime unknown before, although applicable up to a point is not fully adequate, for the simple reason that massacres of whole peoples are not unprecedented. They were the order of the day in antiquity, and centuries of colonization and imperialism provide plenty of examples of more or less successful attempts of that sort': Arendt, Eichmann in Jerusalem, supra, 288. Berkeley noted that the worst genocide recorded in African history was committed by the Belgians who killed between five and Io million people in the Congo between 1885 and I912: Bill Berkeley, The Graves Are Not Yet Full: Race, Tribe and Power in the Heart of Africa [New York: Perseus Publishing, 200I] p 9. See also Adam Hochschild, King Leopold's Ghost: A Story of Greed, Terror and Heroism in Colonial Africa [New York: Houghton Mifflin, 1999] generally, especially at p 28r; Sven Lindqvist, "Exterminate All the Brutes": One Man's Odyssey into the Heart of Darkness and the Origins of European Genocide [New York: New Press, 1996]; A Dirk Moses and Dan Stone (eds), Colonialism and Genocide [New York: Routledge, 2006]; and A Dirk Moses (ed), Empire, Colony, Genocide: Conquest, Occupation and Subaltern Resistance in World History [New York: Bergham Books, 2008].

Ibid, pp 535-536. 
longer a question of intimidating the populace, but rather of physically liquidating it. 'ro The colonial powers only gave up and conceded independence upon realising the futile, uneconomical and wasteful nature of protracted conflict. ${ }^{\mathrm{I} 3 \mathrm{I}}$ In the absence of such 'infrastructural contradictions', it was not unusual to see imperial powers employ the strategy of absolute genocide-either precipitously or by degrees- to deal with the wars of liberation confronting them..$^{132}$

Michael Ignatieff, for his part, updated this narcissistic theory of mass evil to the post-imperial era. His argument, however, is not identically founded upon the same premise, as Sartre's, that the evil of mass atrocity resulting from imperialism was the product of internal structures of capitalist democracies. Ignatieff's argument, rather, is that the evil of mass atrocity, enacted in acts and omissions that imperialism produced, resulted from the 'moral disgust' that ensued from the futile expectations of colonial powers to experience boundless gratitude from the colonised peoples. But what Ignatieff's hypothesis shares with Sartre's is the posit of frustration of (neo)imperialism's self-regard as the point of descent into resultant large-scale atrocity.

In his thoroughly engaging essay The Seductiveness of Moral Disgust, Ignatieff takes the moral of Joseph Conrad's Heart of Darkness as his point of departure. Conrad's character Kurtz personifies the spirit of imperialism and the resulting genocidal evil about which Sartre had written. As Ignatieff puts it:

The ferocious rapacity of Kurtz's search for ivory is ennobled in his own eyes by his plans to bring civilization to the savages. In the end, of course, this idea redeems nothing at all. When Marlow finds Kurtz, at the final bend of the river, all there is to show of Kurtz's civilizing mission is a row of native heads stuck on spikes and the tattered remains of Kurtz's concluding report to the International Society for the Suppression of Savage Customs, on the final page of which the delirious Kurtz had scribbled, 'Exterminate all the Brutes!' ${ }^{\mathrm{r} 33}$

Ignatieff's theory of moral disgust takes straight aim at atrocities committed by modern day peace-keeping forces, led by Western Powers including under the aegis of even the United Nations. With three UN-sanctioned missions since I989 on his mind-the Kurdish, the Somali and the Bosnian missions (the US led invasion of Iraq had not yet occurred when he wrote)-Ignatieff demonstrates how the allures of narcissistic good intentions are soon overtaken by the seductions of moral disgust. In his words:

The three key rescue missions undertaken since 1989-the Kurdish, Somali, and Bosnian operations - were understood as noble attempts to give substance to that

I30 Ibid, p 537 .

I3I Loc cit.

$\mathrm{I} 32$ Ibid, p 538.

I33 Michael Ignatieff, 'The Seductiveness of Moral Disgust', (I995) 62 Social Research 77. 
formless yet blameless entity 'the international conscience.' Yet Conradian continuities continue to haunt these operations: the ironic interplay between noble intentions and bloody results, between fantasies of omnipotent benevolence and impotent practice, between initial self-regard and eventual self-disgust. Conrad himself could hardly have imagined a more terrible image of these ironies than the spectacle, on all our television screens, of the UN soldiers, mostly Pakistani, firing upon Somali crowds and killing the women and children they were mandated to protect. When Conrad encapsulated imperial impotence in the image of the gunboat in Heart of Darkness, moored off the African shore, lobbing useless shells into the unanswering jungle, the contemporary imagination leaps to the image of NATO warplanes lobbing shells into abandoned Serbian artillery dugouts. Past and present meet in a shared image of the futility of great power. ${ }^{\mathrm{I} 4}$

Ignatieff directly contends that there was 'a strong element of narcissism buried inside the more obvious motivations' of Western powers to intervene. Those Western-led interventions were motivated as much by the need to salve the West's image of itself as the bastion of civilisation as by the aspiration to protect humanity from misery. ${ }^{\mathrm{I} 5}$ Tragically, therefore, the ghost of Kurtz haunts these humanitarian interventions.

Ignatieff does not argue, of course, that the remedy against the seduction of moral disgust is the disavowal of humanitarian interventions, out of concern for criticisms of narcissistic interloping. As he takes care to point out, 'Conrad's scepticism did not deny that there were universal decencies, sometimes though not always of European origin. ${ }^{{ }^{1} 36}$ Ignatieff's point rather is the recognition that the West is not an omnipotent force with unlimited power to do good; and that it often allows unconscionable means and motives to tarnish its own decent aspirations. The result often is lack of serious commitment to worthy ends ${ }^{137}$ - halfmeasures of cure that permit the transformation of initial good intentions into evil results, even in criminal proportions. ${ }^{138}$

Surely, Ignatieff's theory of moral disgust may not always explain the commission of the sort of evil under contemplation. Is Kurtz's predisposition for evil merely explained by his moral disgust, stemming from his lack of total commitment to his professed mission 'to bring civilisation to the savages'? Or is he a virulent vector of hate, whose prejudice did not preclude a programme of pogrom at the slightest excuse? Why would it be too difficult to conceive of an image of Kurtz in the hood of the Ku Klux Klan? Are the conducts of those UN soldiers and civilian staff on peace-keeping missions who rape and sexually exploit their

\footnotetext{
I34 Ignatieff, supra, p 78.

I35 Ibid, p 8o.

I36 Ibid, p 8I.

I37 Ibid, pp 8I-82.

I38 Ibid, p 86.
} 
wards — even under-aged boys and girls ${ }^{\mathrm{r} 39}$ — readily explained by their own moral disgust? The answers to these questions can respectively run as follows: not necessarily_possibly—it should not be-no.

Yet, as far as it goes, Ignatieff's theory of moral disgust does carry much purchase. Although he does not refer to it in his essay, his theory is thoroughly validated in the failure of the UN to stop the Rwandan genocide in I994, even with forces of the United Nations Assistance Mission in Rwanda (UNAMIR) on the ground. There was always the question of how seriously committed the UN had been in its peace-keeping mission in Rwanda just before and during the genocide. ${ }^{140}$ And the imagery of Kurtz, symbolising Ignatieff's theory of the seduction of moral disgust, finds no better enactment than in Belgium's withdrawal of its troops- the vertebral force of UNAMIR - from the UN peace-keeping mission in Rwanda. This was followed by Belgium's spiteful lobbying for total UN withdrawal. All of this happened at the very height of the Rwandan genocide. And the reason for that quintessential show of moral disgust was that just $I$ o Belgian soldiers were killed in Rwanda by the same forces that were killing, in a genodical orgy, hundreds of thousands of the innocent Rwandans that the UNAMIR were supposed to protect.

\section{The Eclectic Theory of Evil}

Another theory of evil that must be noted is that advocated by Arne Johan Vetlesen. His central thesis involves a critique of the severalty of explanations of evil variously offered by Arendt, Bauman, Milgram, and Alford as insufficient to explain collective evil in every case, such as the Holocaust, genocide and ethnic cleansing. His 2005 book, Evil and Human Agency-Understanding Collective Evildoing, is no bed-side reading for the distracted mind, but it has, for good reason, been wellreceived as an important contribution to the discourse on comparative theories of extreme malevolence.

He begins his discussion with what he admitted to be a commonsensical and minimalist definition of evil as the "[intentional infliction] of pain and suffering on another human being, against her will, and causing serious and foreseeable pain to her. ${ }^{{ } 4 \mathrm{I}} \mathrm{It}$ is indeed an interesting definition of evil. One could readily see how some

I39 In August 2000, for example, Staff Sergeant Frank Ronghi, 36, of the elite 82nd Airborne Division of the US Army, was sentenced to life imprisonment for sodomizing and murdering a Kosovar Albanian girl, Merita Sabiu, II, the Kosovo peacekeeping mission: Wenona Giles et al (eds), Sites of Violence: Gender and Conflict Zones [Berkeley, California: University of California Press, 2004] pp I2-I3.

I4O See generally, United Nations, Report of the Independent Inquiry into the Actions of the United Nations during the 1994 Genocide in Rwanda, dated I6 December 1999, Doc No S/1999/r257. See also Organisation of African Unity, 'The Preventable Genocide', the report of the International Panel of Eminent Persons to Investigate the 1994 Genocide in Rwanda, dated 7 July 2000.

I4I Arne Johan Vetlesen, Evil and Human Agency: Understanding Collective Evildoing [Cambridge: University Press, 2005] p 2. 
might view it as overly simplistic. What are the types of pain and suffering that are accepted as evil? Surely criminal conducts such as rape, murder, extermination and genocide would qualify. But what about state-sanctioned executions of convicted murderers; the imposition of prison sentences - for life or term of years-upon convicted persons; the termination of a romantic relationship characterised by a deeply unrequited love from the jilted; a parent's forcible confinement of a teenaged drug addict into a drug rehabilitation facility? Surely, all these would qualify as intentional infliction of pain and suffering on another human being, against her will, causing pain and suffering. But are they necessarily evil?

Nevertheless, with its shortcomings kept in mind, Vetlesen's definition of evil is serviceable within its remit. It certainly captures both the necessary evil authorised and promoted by those in responsible command of the relevant armed forces, as well as the aberrant, evidently unauthorised and gratuitous evil, perpetrated by the insufficiently controlled rogue fighters trained, armed and mobilised by those in responsible command of the relevant armed forces.

What commends Veltesen's book, however, is not his definition of evil, but rather his critique of other theories of evil and then his offering up of a new approach to the appreciation of evil. It is possible, though, to say that Vetlesen may have made too much out of the flaws he perceived in the works of Arendt, Bauman and Milgram. In their common situational theory of evil, none of these authors ever professed to be expounding a universal formula for the comprehension of evil and its human agency. Milgram, for instance, had clearly explained that the chief lesson of his experiments was that ordinary people 'can become agents in a terrible destructive process' [emphasis added]. He and his adherents must then not be understood as claiming that all agents of terrible destructive processes are ordinary people of the banal kind. Indeed, Milgram, was careful to report that left to their own discretion and personal codes of morality, the average subject of his experiment did not deliver the level of shock that simulated the evil conduct.

Similarly, Arendt's commentary was limited to her observation of a single man on trial. Although she did observe that Eichmann 'and the nature of his acts as well as the trial itself raise problems of a general nature, ${ }^{\text {'I } 42}$ she never claimed that Eichmann's predisposition explained the actions and mentality of other actors in the horrid enterprise of the Holocaust. Given her commentary on the levels of participation of other actors, chiefly Hitler, ${ }^{\mathrm{I} 43}$ Arendt must be given some credit for recognising that Eichmann - the banal and uninspired bureaucrat, devoid of hate and imagination-would not readily displace the obvious dynamism and charisma of Hitler ${ }^{\mathrm{I} 44}$ the ideologue and architect-in-chief of the Holocaust, ${ }^{\mathrm{I} 45}$ who institutionalised evil in Eichmann's Germany, to the level that bureaucrats saw genocide as their moribund duty to execute. It would be wrong then to foist

\footnotetext{
I42 Arendt, supra, p 287 .

I43 See for instance ibid, pp 93-94, I35, I39-I40, I44, I48, I49, I5O, I53, 267, 273 and 283.

I44 Arendt, supra, p 37.

I45 See ibid, pp 153 and 283 .
} 
upon Arendt the speculation that she would have described Adolf Hitler and his particular brand of evil as 'banal', were he in the dock in Jerusalem instead of Adolf Eichmann. Indeed, she realised that 'Eichmann was not Iago and not Macbeth .... ${ }^{\mathrm{I} 4^{6}}$ She may then not be fairly taken to have supposed that either Iago or Macbeth was Eichmann.

It is to be noted that Arendt never claimed a loftier purpose for her book. In her own words she wrote as follows:

[T] he book itself dealt with a sadly limited subject. The report of a trial can discuss only the matters which were treated in the course of the trial, or which in the interests of justice should have been treated.... This book, then, does not deal with the history of the greatest disaster that ever befell the Jewish people ... nor is it, finally and the least of all, a theoretical treatise on the nature of evil. The focus of every trial is upon the person of the defendant, a man of flesh and blood with individual history, with an always unique set of qualities, peculiarities, behaviour patterns, and circumstances. ${ }^{\text {I47 }}$

It is against that limited province that Arendt's pronouncements on the banality of evil must then be understood.

One of Vetlesen's quarrels with Bauman involves the charge that Milgram's experiments, upon which Bauman relies, 'are poorly suited to throw light on the behavioural mechanisms which-supposedly-were operative to such disastrous effects in the case of the Nazi extermination of the Jews. ${ }^{{ }^{\prime} 48}$ This charge is anchored on the essential distinction that, in Milgram's experiment, the victim was notionally anonymous - in the sense of not known to the subject (the 'teacher'). In the Holocaust, on the other hand, the victim had, in bad faith, been over-familiarised to the genocidaire, through the mechanism of Nazi propaganda that dehumanised Jews. It is this negative propaganda, argues Vetlesen, and not the anonymity of the victims (as in Milgram's experiment) that made the Holocaust easy for the perpetrators.

Vetlesen is surely right to draw a causal link between the virulent anti-Jewish propaganda and the Holocaust. A similar link notoriously existed between an anti-Tutsi propaganda and the Rwandan genocide. ${ }^{\text {I9 }}$ Other psychological studies

I46 Arendt, supra, p 37 .

I47 Ibid, p 285.

I48 Vetlesen, supra, p 25.

I49 In the Akayesu case, a Trial Chamber of the International Criminal for Rwanda found that there had been a 'psychological preparation of the population to attack the Tutsi, which preparation was masterminded by some news media with the RTLM [Radio-télévision libre des milles collines] at the forefront': Prosecutor v Akayesu (Judgment) 2 September 1998 [ICTR Trial Chamber] para I26. Similarly, in the Media case, the ICTR noted 'the striking indifference to these massacres evident in the broadcast, and the dehumanisation of the victims': Prosecutor $v$ Nabimana et al (Judgment) 3 December 2003 [ICTR Trial Chamber] para 4I6. Note, however, that 
have led to similar conclusions. ${ }^{50} \mathrm{It}$ is, however, interesting to note that judges of the Appeals Chamber of the International Criminal Tribunal for Rwanda are not persuaded that propaganda alone must necessarily explain every killing during a genocide. In their reasoning, notwithstanding the presence of an anti-group propaganda somewhere along the continuum of time, it is possible for other factors to be responsible for the commission of a genocide against the group. According to this reasoning, 'the longer the lapse of time between a broadcast and the killing of a person, the greater the possibility that other events might be the real cause of such killing and that the broadcast might not have substantially contributed to it.' ${ }^{\prime}{ }^{1}$

The Appeals Chamber is not to be understood, of course, as denying a causal link between negative propaganda and a genocide against a group. The Appeals Chamber's pronouncement merely stresses the need for evidence of causal link between propaganda and the resulting genocide, rather than an exclusive reliance upon the mere presumption that it did. It merely refuses to accept one theory of causation. That is to say, a negative propaganda may or may not contribute to the genocide. But, the more specific the evidence of the causal link, the greater the likelihood of persuasion beyond reasonable doubt that the propaganda resulted in the genocide. In the absence of such evidence, a court of law is not likely to convict upon the mere possibility of a particular cause, where other causes are also possible.

Without precise evidence of the temporal proximity of particular items of the anti-Jewish propaganda and occurrences of specific killings during the genocide, the reasoning of the ICTR Appeals Chamber would then subtract from Vetlesen's protest against the value of the Milgram experiments in helping to illuminate the Holocaust. That is to say, both Milgram's experiment and anti-Jewish propaganda can help in an understanding of the Holocaust. If one applied the Appeals Chamber's reasoning to Vetlesen's observations, the result would be that propa-

the Appeals Chamber of the ICTR was not prepared (in the same Media case) to assume a causal link between the propaganda and the genocide. It required precise evidence of that link: see Prosecutor $v$ Nabimana et al (Judgment) 28 November 2007 [ICTR Appeals Chamber] paras 503-519.

I50 Having reviewed a number of disengagement mechanisms that enable people to do harm to others, Osofsky et al observed as follows: 'The final set of disengagement mechanisms operates at the locus of the recipients or objects of detrimental acts through dehumanisation and attribution of blame. Self-censure for injurious conduct can be disengaged or blunted by divesting people of human qualities, or by attributing demonic and bestial qualities to them ... . Blaming the recipients of injurious treatment for bringing suffering on themselves also serves self-exonerating purposes. In this process of "blaming the victim," perpetrators see themselves as driven to injurious conduct by compelling circumstances or the foe's appalling inhumanities rather than by their personal decisions': Osofsky, Bandura and Zimdardo, supra, p 373.

Prosecutor v Nabimana et al (Judgment), supra, [ICTR Appeals Chamber] para 513. 
ganda alone may not explain the Holocaust. Hence, Bauman's and Milgram's theories retain their original force.

Equally unconvincing is another of Vetlesen's criticisms of the Milgram experiment as poorly suited to explain the Holocaust. Taking aim at Milgram's hypothesis that obedience to authority can explain evil-doing, Vetlesen's attempt at refutation is that obedience in those circumstances does not simply result from the subject's view of himself as a mere 'instrument of carrying out another person's wishes.' But that 'such obedience carries a strong ideological component; it comes from "accepting the fundamental ideas that guide that authority and wishing to help realise them in practice." To drive home his point, Vetlesen insists that it must be realised that "both the authority and those who obey it "share the same prejudices, the same view of the world, the same fundamental perception of reality." ${ }^{152}$ This may be a criticism taken much too far. It is accepted that there will be subjects who obey their superiors out of shared prejudice and outlook on life. But that will not always be the case. As Milgram's control experiments indicated, only a minority of the subjects continued to apply the electric shocks past the perceived point of severe pain, when they were left to their own discretion. A great majority did not. ${ }^{\mathrm{I53}}$ Browning makes the same observation in the context of the massacre of Jews in the Polish village of Józefów by Reserve Police Battalion IOI. ${ }^{154}$ Since the majority of subjects in Milgram's experiment had applied the high voltage shocks when ordered to do so, and since 'many policemen did not comply with the orders [to massacre Jews in Józefów] when not directly supervised', it becomes difficult to sustain the case that those who did must necessarily share the order-giver's outlook on life.

Another notable criticism from Vetlesen is his ultimate categorical rejection of Bauman's warning against the dangers of modernism. As Vetlesen put it: 'I conclude that Bauman is wrong to think that the modern bureaucratic institution is pregnant with the sort of immorality exhibited in the Holocaust. Only by hijacking pre-existing bureaucratic structures, by altering and exploiting them ruthlessly for their own highly ideological objectives, could the Nazis turn the German state apparatus into a smooth vehicle of mass destruction.'555 Vetlesen's attempted dismissal of Bauman is intrinsically self-contradictory. The contradiction appears in the very passage quoted above, among others of his conclusions. ${ }^{\mathrm{I} 5}$

I52 Vetlesen, supra, pp 25-26.

I53 Stanley Milgram, 'The Perils of Obedience', Harper's Magazine [I974] at <http:// home.swebell.net/revscat/perilsOfObedience.html>

I54 Browning, supra, pp I75-176.

I55 Vetlesen, supra, p 50.

I56 One also notes Vetlesen's criticism of C Fred Alford's theory of individual sadistic bent as being too focused on the individual at the risk of ignoring environmental influences upon evil-doing. In Vetlesen's own words: 'Alford risks eternalising evil inasmuch as he views it sub specie aeternitatis, as a feature of the human condition as such, thereby ignoring the structural and situational conditions of specific instances of evil (especially collective evil) where in-group pressure and the request for obedi- 
It lies in Vetlesen's quarrel with the suggestion that the modern bureaucratic institution is 'pregnant' with the sort of malignancy that leads to evil at the scale of the Holocaust. Yet, he contends that Nazis were able to hijack and manipulate 'preexisting bureaucratic structures', and were thus able to deploy the grotesque evil now known as the Holocaust. But this, in fact, makes Bauman's very point. How were the Nazi's able to hijack and manipulate German bureaucracy and achieve their evil ends in such catastrophic proportions had the 'pre-existing' bureaucratic institutions not been 'pregnant' with a potential towards such manipulation? It is the proneness of modern bureaucratic institutions to such wicked manipulations that is the very danger that Bauman warns about. ${ }^{157}$ The dispute may indeed relate to the degree of modern bureaucracy's pregnancy with evil potentials, but Bauman is certainly right to sound his warning. In the end, it is hard to quarrel with Bauman's central thesis that it is modernity that enabled the Einsatzgruppen to kill, by shooting, approximately I.5m Jews, before Himmler ordered their killing methods to be replaced by the more efficient and impersonal methods of the death camps; it is modernity that enabled those more efficient and less messy methods, the gas chambers and crematoria, to be built at Auschwitz, Belsen, Dachau, etc, in order to maximize the macabre productivity of the Holocaust enterprise against European Jewry; it is modernity that enabled US military pilots to fly great distances and drop atomic bombs on Hiroshima and Nagasaki from great heights and without a view of the innocent humanity being decimated below; it is modernity that vectored to many Rwandan Hutu peasants, through small transistor radios, the infectious genocidal propaganda that their Tutsi neighbours were repulsive 'cockroaches' and cruel demons deserving of extermination. Thus, Bauman is not so easily to be dismissed in his ultimate thesis that modernity offers patterns in which 'we can hope to uncover the possibility so dramatically revealed in the times of the Holocaust. ${ }^{3}{ }^{8}$

Vetlesen's method of dwelling upon a criticism of his forerunners before offering his own theory of evil is no doubt a legitimate method of scholarly disputation. It is, however, fraught with the danger of appearing more concerned with the flaws he perceived in those earlier works than offering his own. The average reader in a hurry in a high-paced world may then not tarry long enough to get

ence, control, and predictability often necessitate a neutralisation of the individualexistential twist to partaking in evil that Alford takes as his principal focus': ibid, $\mathrm{p}$ I4I. The environmental conditions of which Vetlesen writes as also accounting for evil surely include the environmental expressions of modernity, such as is found in modern bureaucratic institutions of the sort that resulted in the widespread realisation of the Holocaust.

I57 To be noted in this regard is Bauman's declaration that the 'truth is that every "ingredient" of the Holocaust-all those things that render it possible-was normal; "normal" not in the sense of the familiar ... but in the sense of being fully in keeping with everything we know about civilization, its guiding spirit, its priorities, its immanent vision of the world': Bauman, supra, p 8. [Emphasis added.]

I58 Bauman, supra, p I9. 
to the real point of Vetlesen's otherwise valuable book: which really is that evil is better appreciated from the multi-dimensional perspectives of the personalities and characters, the prevailing circumstances and the structure of the society concerned. That is to say, the impetus for evil, just as with its human agents, comes in different guises. Vetlesen's approach in this regard is captured in the following quotes:

Due to the heterogeneous nature of the phenomenon-evildoing-different theoretical approaches are called for, one illuminating what another ignores. ${ }^{159} \ldots$ $[\mathrm{E}]$ vil is such a manifold and heterogeneous phenomenon in social life as to frustrate various theoretical attempts ... to let one 'form' or one feature speak for all. Indeed, even such established category of collective evil as genocide may come in many-quite distinct-forms. ${ }^{160}$

In The Graves Are Not Yet Full, dealing with the Rwandan Genocide of r994, Bill Berkeley, too, aptly captured the essence of the inquiry into evil through his question about the participation of François in the killings: 'What malignant blend of bigotry and fear, coercion or cowardice, history, politics, poverty and ignorance, envy, opportunism, unquestioning obedience, peer pressure perhaps-what brought out the shark in this man? ${ }^{\text {'6r }}$ Berkeley is quite right to seek to capture such a variegated 'blend' of factors that may result in a genocide: except that there need not be a blend; for these factors may jointly or severally account for a genocide. This multi-dimensional approach to the appreciation of evil would then comfortably accommodate the observations of Arendt, Milgram, Bauman, Zimbardo, Sartre, Ignatieff, Alford, Hilberg, Goldhagen and others. Vetlesen's real criticism of his forerunners then becomes - and quite correctly- that it is neither possible nor helpful to approach the comprehension of evil during armed conflicts from a mono-causal perspective. There is no silver thread that explains all manner of evil which human beings have proven capable of inflicting upon one another, especially during armed conflicts. ${ }^{\mathrm{I} 2}$ As will be seen below, this eclectic approach is entirely consistent with criminal law's primary concern with the question of responsibility for the evils forbidden in its own realm.

Beyond Vetlesen's multi-dimensional aetiology of evil, he does offer other very solid views of his own - notably in chapter four - that aid in an understanding of collective evil. Among his notable observations is the identification of similarities between ethnic-cleansing in the former Yugoslavia and the Holocaust, in the manner of the perpetrators' claim of victimhood and self-defence to jus-

I59 Vetlesen, supra, p I4I.

I60 Ibid, p I42.

I6I Bill Berkeley, supra, p 3. Similarly, Dirk Moses has observed: 'Genocide is to be explained as the outcome of complex processes rather than ascribable solely to the evil intentions of wicked men': A Dirk Moses (ed), Empire, Colony, Genocide: Conquest, Occupation and Subaltern Resistance in World History, supra, p 7 .

I62 Vetlesen, supra, p 42. 
tify their atrocities, citing ancient wrongs and present dangers from internal and external enemies. Serviceable here would be the Nazi grievance about the defeat of Germany in World War I and the humiliation of the Treaty of Versailles and the targeting of German Jews as internal enemies forever scheming to take over the German economy. The scenario is compared to the historical grievance of Serbs about their defeat in the battle of Kosovo Polje in 1389 and their paranoia that their heritage is in danger in the hands of Muslims who would mix and outnumber genuine Slavic peoples. ${ }^{163}$

Although Vetlesen does not address the Rwandan Genocide in specific terms, his observations in this regard bear clear and direct application to that Genocide. Similar tactics were employed during the Rwandan Genocide. Hutu extremists regularly cited the ancient domination of the Rwandan society by the Tutsi, which domination was ended by the 1959 violent social overthrow of the Tutsi hegemony, (popularly referred to in Rwanda as the 'I959 Revolution'), which drove a huge number of Tutsis into exile. ${ }^{164}$ The refusal of repatriation rights to exiled Tutsis eventually led to a civil war in 1991, launched by the Rwandan Patriotic Front, the military wing of the exile movement. ${ }^{165}$ The incidence of the ongoing civil war at the time, coupled with the traditional suspicion on the part of the Hutu, afforded fertile soil for anti-Tutsi propaganda, before and during the Genocide. In this propaganda, a constant theme of reference was the ancient domination of the Hutu by the Tutsi and the allegation that the objective of the civil war (in which the country was embroiled in 1994) was a reversal of the socio-political gains of the 1959 Revolution - and even the extermination of the Hutu who had been put on the driving seat of all aspects of the Rwandan society. ${ }^{\mathrm{I} 66}$

Hence, Vetlesen is amply borne out in his observation that all cases of genocide in the twentieth century have been typically cast as a matter of 'self-defence' by the perpetrator groups. 'To the extent that aggression is exhibited, it is presented in the propaganda as but a mirror of the aggression once performed-or now about to be unleashed-by the chosen targeted group. ${ }^{\text {'67 }}$

\section{Aetiology of Evil Viewed in the Context of the Law}

Evil's explanations by Vetlesen, Arendt, Sartre, Ignatieff, Milgram, Bauman, Alford, etc, were offered in the realms of philosophy, sociology and psychology. Quite clearly the theories in question have considerable value in the province of those disciplines as social sciences. But the question inevitably arises: what purchase do these theories have for decision making in international law? It is the answer to that question that gives these theories their proper context within the

I63 Vetlesen, supra, pp I49- I51.

I64 See Prosecutor v Akayesu, supra, para 89 et seq.

I65 Ibid, para 95 et seq.

I66 Ibid, paras 99--оoо, I03 and IIo.

I67 Vetlesen, supra, pp I50-I5I. 
province of the law. As noted earlier, the task of 'transforming' evil may not be as obvious a matter for the law as is clearly the case with the task of 'containing' evil. In the more obvious task of containing evil, the theories of aetiology of evil as propounded in the fields of philosophy, sociology and psychology are very important as influences that fertilise the right sort of decisions urgently needed in international law to achieve the needed containment.

Happily, whether by coincidence of the law's affinity (as a member of the humanities) or by deliberate design, international law in its responses to evildoing appears more favourably disposed towards the recognition of these theories of evil-doing in their various shapes and guises. This conclusion is borne out by, among other things, the legislative and jurisprudential features of international criminal law. First, modern legislation in international criminal law casts the net of criminal responsibility sufficiently wide to capture as many actors as might have engaged in the criminal conduct substantively proscribed. The point was well captured by Jeremy Horder when he wrote: 'while there is some pattern to the way in which the criminal law shapes conditions of culpability, no single theory of culpability unifies that pattern to the exclusion of all others. ${ }^{\text {' } 68}$ In that view, Horder amply captures the way of international criminal law. For instance, article 6(I) of the Statute of the International Criminal Tribunal for Rwanda provides as follows: 'A person who planned, instigated, ordered, committed or otherwise aided and abetted in the planning, preparation or execution [of genocide, crime against humanity or war crime] shall be responsible for the crime. 'T69 That legislative language would permit no impunity for the directing mind, the commanding voice, the executing hand or agent; or even for the adherent latecomer who joined the criminal enterprise from the fringe. This dragnet of criminal responsibility allows no excuses for Arendt's Eichmann, Milgram's 'teacher' and apartheid's Benzien, who might have been uninspired state employees proficiently carrying out their ghoulish jobs within 'a businesslike and strictly impersonal framework,' 170 with no apparent hatred toward their victims. It would also capture the genocidal archetypes of Kurtz and the sort of imperial soldier (and their superiors) depicted by Ignatieff and Sartre in their narcissistic theories of evil; as would it capture Alford's sadist.

To underscore the legislative intent to cast wide the net of criminal responsibility, modern legislators of instruments of international law made sure to preclude in specific terms certain defences. One such precluded defence is that of respondeat superior. A classic statement of this preclusion may be found in article 6(4) of the Statute of the International Criminal Tribunal for Rwanda which provides: 'The fact that an accused acted pursuant to an order of a government or of a superior shall not relieve him or her of criminal responsibility, but may be

I68 Jeremy Horder, 'Criminal Culpability: the Possibility of a General Theory', (May 1993) i2 Law and Philosophy p 193, at 194.

I69 See also article $7(\mathrm{I})$ of the Statute of the International Criminal Tribunal for the former Yugoslavia.

I70 See Bauman, supra, p 20. 
considered in mitigation of punishment if the International Tribunal for Rwanda determines that justice so requires.' Similar provisions abound in the Statute of the International Criminal Tribunal for the former Yugoslavia ${ }^{\text {T7x }}$ and the Statute of the International Criminal Court. ${ }^{172}$

Similarly, judicial pronouncements on the subject of responsibility in international criminal law have also been careful to maintain and supplement the wide dragnet of criminal responsibility originally cast by the legislator. Those judicial pronouncements include, but are not limited to, those on the principle of joint criminal enterprise, ${ }^{173}$ on the defence of duress, ${ }^{174}$ on the place of policy as an ele-

I7I Article 7(4).

I72 Article 33 .

I73 There are three forms of joint criminal enterprises-the basic form, the systemic form and the extended form. The basic form of JCE entails a situation in which there is a meeting of the minds on the part confederates in a crime to commit that crime, although each of them play a separate part in it. The systemic form relates to an organised system of criminal activity. As with the basic form, it may involve decentralisation of roles on the parts of those involved. The difference, however, is that there is no requirement of a meeting of minds as to the crime in the systemic form; but there is a requirement of knowledge of the existence of the system of criminal activity on the part of each member of the system. The classic example of a systemic JCE is the Nazi concentration camps. Criminal responsibility arising from the extended form of JCE involves a risk-based conception of criminal responsibility. Here, the accused is held criminally responsibility for a crime which other confederates commit outside the strict confines of the common purpose of the confederates in the crime, but which was a natural and foreseeable consequence of the common criminal purpose. See Prosecutor v Tadić(Judgment) I5 July 1999 paras 195-226 [ICTY Appeals Chamber]; Prosecutor v Ntakirutimana (Judgment) i3 December 2004 paras 463-465 [ICTR Appeals Chamber]; Prosecutor v Vasiljević (Judgment) 25 February 2004, paras 96-99 [ICTY Appeals Chamber].

I74 According to the pronounements of judges of the ad hoc international criminal tribunals, duress does not afford a complete defence to a charge: Prosecutor v Erdemović (Judgment) 7 October 1997 para I9 [ICTY Appeals Chamber] together with Joint Separate Opinion of Judge McDonald and Judge Vohrah paras 55, 66, 72, 75 and 88. It is to be noted, however, that duress is not excluded as a complete defence under the Statute of the ICC. According to article $3 \mathrm{I}(\mathrm{I})(\mathrm{d})$, 'In addition to other grounds for excluding criminal responsibility provided for in this Statute, a person shall not be criminally responsible if, at the time of that person's conduct: ... The conduct which is alleged to constitute a crime within the jurisdiction of the Court has been caused by duress resulting from a threat of imminent death or of continuing or imminent serious bodily harm against that person or another person, and the person acts necessarily and reasonably to avoid this threat, provided that the person does not intend to cause a greater harm than the one sought to be avoided. Such a threat may either be: (i) Made by other persons; or (ii) Constituted by other circumstances beyond that person's control.' 
ment of crime against humanity, ${ }^{175}$ on the notion of aiding and abetting, ${ }^{176}$ on the encouraging presence during a crime, ${ }^{177}$ etc.

Closer then to what obtains in the realms of the law is Vetlesen's eclectic theory of evil which correctly affords equal opportunity for the recognition of all manner of impulses to commit collective atrocity. Hence, the law is once more seen in kinship with the other humanities as a system of complementary disciplines working together to forge and continually improve a post-Hobbesian social life.

\section{Intent as Limiting the Theories of Aetiology of Evil}

Notwithstanding the foregoing, it is, however, proper to offer a needed proviso to the law's receptivity to the influences of the other humanities. It is notable that philosophy, sociology and psychology do often shine a bright light on the dark path of human life along which the law travels, in order to give it bearing along the way. But the law does not always follow that illumined path to its furthest reaches. There is a certain sense in which such is the case as regards the theories of evil previously reviewed. The law-more precisely, criminal law-does not always accord pride of place to the higher questions of morality in relation to criminal responsibility. Criminal law rather is primarily concerned with the intent of the perpetrator-not his morality. Morality is to be contrasted with intent, in that the former is concerned with the perpetrator's sense of qualms, so to speak. Intent deals rather with the extent to which the perpetrator's consciousness-not his conscience-directly or indirectly occasioned the forbidden outcome in question. In that sense, intent, for purposes of criminal law may be defined as the existence of consciousness of the mind in correlative proximity to the foreseeable results of

I75 Notably, judges of the ad hoc tribunals have held that to constitute a crime against humanity, the conduct in question need not result from a preexisting criminal plan or policy: Prosecutor v Kordić and Čerkez (Judgment) I7 December 2004 [ICTY Appeals Chamber] para 98. See also Prosecutor v Blaškić (Judgment) 29 July 2004 [ICTY Appeals Chamber] para ı2o. However, 'attack directed against any civilian population', has been defined in article $7(2)$ (a) of the ICC Statute, for purposes of crimes against humanity, to mean 'a course of conduct involving the multiple commission of acts referred to in paragraph I against any civilian population, pursuant to or in furtherance of a State or organizational policy to commit such attack.'

I76 An accused will have aided and abetted a crime if his actions gave practical assistance, encouragement or support, such as had a substantial effect on the commission of the crime: Kayishema and Ruzindana (Judgment) I June 200I [ICTR Appeals Chamber] para 186. See also Prosecutor v Tadić, supra, para 229 and Prosecutor v Blaškić, supra, paras 46-48.

I77 Presence at the scene of crime may amount to aiding and abetting a crime, if such presence had the effect of significantly encouraging the perpetrators to commit the crime in question: Prosecutor v Kajelijeli (Judgment) I December 2003 [ICTR Trial Chamber] para 769. See also Prosecutor v Vasiljević (Judgment) 29 November 2002 [ICTY Trial Chamber] para 70. 
one's action..$^{17}$ By 'correlative proximity' is meant a proximity in which there is a connection between or among the proximate things.

For purposes of culpability then, the law tends not to agonise much over the questions whether Eichmann's sense of qualms was dead or in deep coma at the time of his actions; nor with whether Bauman's villain had inserted the widest physical or psychic separation between his own action and its outcome. Neither is the law concerned with the degree to which Kurtz' sense of qualm had been provoked into auto-mutiny characterised by a sudden attack against its very own moorings. Those are considerations that go to the conscience of the perpetratorhis sense of qualms or this morality - they do not speak to the existence of consciousness as to the results of his actions.

\section{Uses in the Post-Conflict Quest for Justice and Reconciliation}

Ultimately, it is possible-indeed commendable - to look, from another angle, behind the construct of criminal responsibility, in search of profitable juristic uses of the theories of evil prevailing in the other humanities. The situational explanation of evil is particularly notable in this regard. It helps to resolve the dilemma often expressed in the wishes of the international community when they establish tribunals to prosecute mass atrocities committed in given societies. Those wishes often engage an apparent tension between punishing the perpetrators of the crime while permitting lasting reconciliation within the societies involved. ${ }^{179}$ Often, tension is perceived between the two goals. The situational theory of evil articulated by Arendt, Bauman, Milgram, Zimbardo and others points the way to doing both.

Their explanations of mass atrocities assist in fuller rationalisation of some of the law's responses to evil-doing. In particular, it helps to rationalise the idea of criminal responsibility as spelled out in modern international criminal law instruments, such as in articles 6(I) of ICTR Statute and article 7(I) of ICTY Statute reviewed above. As noted in those provisions, criminal responsibility is attributed to those who plan, order, instigate, actually commit, or otherwise aid and abet the crimes proscribed substantively in those Statutes. Of particular note in this regard is the value of the Arendt-Bauman-Milgram theory, in relation to the doctrine

I78 This definition affords a sufficient basis for understanding the meaning of intent, notwithstanding that intent in criminal law has often been perceived as a notion too elusive to define satisfactorily. See Glanville Williams, Textbook of Criminal Law [London: Stevens \& Sons, 1978] p 51.

I79 For instance, in resolution 955 of 1994, introducing the ICTR Statute, the Security Council concurrently expressed a determination to 'to put an end to such crimes and to take effective measures to bring to justice the persons who are responsible for them', and a conviction 'that in the particular circumstances of Rwanda, the prosecution of persons responsible for serious violations of international humanitarian law would enable this aim to be achieved and would contribute to the process of national reconciliation and to the restoration and maintenance of peace': United Nations, Resolution 955 adopted by the Security Council at its 3454th meeting on 8 November 1994, Doc No S/RES/955 (1994) of 8 November 1994. 
of joint criminal enterprise, which typically involves different people contributing different components of activity towards the commission of a crime. Hence, this dragnet of responsibility will capture everyone implicated in the circumstances that explain collective evil-doing according to the postulations of Arendt, Beauman and Milgram.

At the same time, the Arendt-Bauman-Milgram theory assists the spirit of post-conflict reconciliation by pointing out that the evil done was not necessarily borne out of personal hatred; and that given the 'right' conditions, the average person is capable of doing the same thing. Hence, a new interpretation attends a familiar biblical injunction: 'You may cast the first stone of revenge if you are sure that you will not do the same thing in similar conditions.' This then cuts out the primary tasks of post-conflict efforts as two-fold: (a) commit all efforts towards forgiveness and healing, rather than expend collective social energy on suspicion and mutual distrust; and (b) make every effort to guard against those 'right' or 'similar' conditions that made the evil possible for the average perpetrator. Taken to extremes, this might prove too simplistic and unrealistic. But it provides a useful starting point for national reconciliation in post conflict societies.

\section{Human Capacity for the Evil of Sexual Violence in Armed Conflicts}

Moving now from the wider perspective of evil, as a general phenomenon, during armed conflict, we will next turn our attention to the narrower dimension of the aetiology of the evil of sexual violence during armed conflicts. In the following section, it will be found that within the wider macro-inquiries into the human capacity for evil during armed conflicts snugly fits the narrower inquiry into the prevalence of sexual violence during armed conflicts.

It is no longer a matter for reasonable debate that a high frequency of sexual violence during armed conflicts is very much an integral part of the wider and regular waves of armed conflicts. This has led one commentator to observe that the 'pervasiveness and carnivalesque nature of rape in wartime often gives the impression that military practices are inextricably entwined with sexual violence. ${ }^{\text {' } 80}$ The manner of sexual violence during armed conflicts include, but is not limited to, gang-rapes of women, even in their homes and in front of their family members; detention of women and their repeated rapes in detention centres or military barracks and billets for extended periods; systematic rape of women in forced 'mar-

I80 Joanna Bourke, Rape: Sex, Violence, History [Berkeley, CA: Shoemaker \& Hoard, 2007] p 359. Lt Col Dave Grossman makes a similar observation: 'The linkage between sex and killing becomes unpleasantly apparent when we enter the realm of warfare. Many societies have long recognized the existence of this twisted region in which battle, like sex, is a milestone in adolescent masculinity. Yet the sexual aspects of killing continue beyond the region in which both are thought to be rites of manhood and into the area in which killing becomes like sex and sex like killing: Grossman, supra, pp $\mathrm{I} 35^{-1} 36$. 
riages'; women being kept in captivity for purposes of forced labour (including such lethal activities as mine-sweeping) and forced sex; sexual mutilation and torture prior to being killed or being left to die from their injuries; other forms of sex-oriented humiliation. ${ }^{\mathrm{I} 8 \mathrm{r}}$

This link between war and violence against women on grounds of their sex has led some icons of feminism to assert a sinister nexus to the wider pattern of anti-woman sexism in society. As Susan Brownmiller observed:

War provides men with the perfect psychologic backdrop to give vent to their contempt for women. The very maleness of the military-the brute power of weaponry exclusive to their hands, the spiritual bonding of men at arms, the manly discipline of orders given and orders obeyed, the simple logic of the hierarchical command-confirms for men what they long suspect, that women are peripheral, irrelevant to the world that counts, passive spectators to the action in the centre ring. ${ }^{182}$

But this allegation does not come exclusively from famous feminists. Indeed, Brownmiller's central thesis of the misogynistic subtexts of war in terms of sexual violence finds striking resonance in Lt Col Dave Grossman's observations as follows:

Women have also been defiled, debased, and dehumanised for the aggrandisement of others. Throughout history women have been probably the greatest single group of victims of this empowerment process [the bonding among military officers and their soldiers]. Rape is a very important part of the process of dominating and dehumanising an enemy; and this process of mutual empowering and bonding at the expense of others is exactly what occurs during gang rapes. In war, empowerment and bonding through such gang rapes often occur on a national level.... The thing to understand here is that the gang rapes and gang or cult killings in times of peace and war are not "senseless violence." They are instead powerful acts of group bonding and criminal enabling that, quite often, have a hidden purpose of promoting the wealth, power, or vanity of a specific leader or cause ... at the expense of the innocent. ${ }^{183}$

Brownmiller and Grossman thus arrive at the same interpretation of the evidence of sexual violence against women during armed conflicts. Here, one observes that Brownmiller's language of 'psychologic backdrop' can equally address what Grossman saw as 'not "senseless violence"; and the phenomenon that Brownmiller

I8I United Nations, 'Systematic Rape, Sexual Slavery and Slavery like Practices during Armed Conflict': Final report submitted by Ms Gay J McDougall, Special Rapporteur, Doc E/CN.4/Sub.2/1998/13 of 22 June 1998, para Io.

I82 Susan Brownmiller, Against Our Will: Men, Women and Rape [New York: Simon \& Schuster, 1975], p 32 .

I83 Grossman, supra, pp 210-2II. 
described as a band of brothers enjoying prime, exclusive male action in the centre ring becomes interchangeable with Grossman's conception of aggrandisement of leaders and peers in the promotion of wealth, power or vanity of a specific leader or cause.

Madeline Morris arrives very much at similar conclusions in her conception of the military as a 'primary group' akin to the family. ${ }^{184}$ She observes, notably, that ' $[\mathrm{h}]$ eightened rape incidence is associated with certain primary groups. ${ }^{185}$ This is explained at least in part by the groups' social norms-and these 'invariably include gender and sexual norms. ${ }^{9} 86$ The sexual norms of some primary groups are conducive to rape. ${ }^{187}$ The underlying attitudes in this regard include attitudes towards masculinity, sexuality and women. ${ }^{188}$ Certain attitudes toward masculinity, in particular, "have been found to be related to heightened levels of rape propensity.' ${ }^{89}$ According to Morris:

Standards of masculinity that emphasize dominance, assertiveness, aggressiveness, independence, self-sufficiency, and willingness to take risks, and that reject characteristics such as compassion, understanding, and sensitivity have been found to be correlated with rape propensity. Several different measures for this construct of masculinity have been used in the studies that have identified this correlation. These measures include "negative masculinity," meaning a posture of self-assertion and self-protection unalloyed with communion or concern with others; "hypermasculinity," meaning stereotypic masculinity and interpersonal opportunism; and nonfeminine "sex-typing," meaning personality or sex role constructs with minimal stereotypically feminine characteristics such as sensitivity or gentleness. ${ }^{190}$

Morris's point is that there is a correlation between a heightened predisposition toward machismo and sexual violence. A similar point had been made earlier Donald Mosher and Ronald Anderson. In their own conclusion:

The socialisation of the macho man, if it does not directly produce a rapist, appears to produce calloused sex attitudes toward women and rape and proclivities toward forceful and exploitative tactics to gain sexual access to reluctant women. The socialisation of the hypermasculine male may script him to overvalue a definition of masculinity as tough and unfeeling, violent and exploitative

I84 Madeline Morris, 'By Force of Arms: Rape, War, and Military Culture' (I996) 45 Duke Law Journal 65I at 691-692 and 698.

I85 Ibid, p 698.

I86 Ibid, p 699 .

I87 Ibid, p 700.

I88 Ibid, p 70I.

I89 Ibid.

I90 Ibid. 
of women, and as seeking the excitement of risking danger. This personality constellation, in conjuction with a history of aggressive behaviour that elicits increasing levels of positive affect and decreasing levels of negative affect, may provide the disinhibition that transforms the rape fantasy into a brutal reality. ${ }^{191}$

Morris observes that these rape-conducive norms are present in military culture, although some militaries, are making efforts towards change. ${ }^{192}$ Hence, Brownmiller's interpretation is not to be regarded, marginalised or dismissed as a mere feminist interpretation of the matter at stake.

\section{A Legislative Fact Amply Proved}

It might help at this juncture to consider briefly a disturbing pattern of evidence. The worrying trend is adequately captured by the phrase military 'rape differential' during armed conflict - a phrase employed by Morris in her comparative study of rapes and other crimes among US military personnel during periods of peace and armed conflicts. Her research 'indicates that the peacetime rates of rape by American military personnel are actually lower (controlling for age and gender) than civilian rates. However, the data also indicate that peacetime military rape rates are diminished from civilian rates far less than are military rates of other violent crimes. A similar phenomenon is also reflected in the wartime data collected: Military rape rates in the combat theatre studied climbed to several times civilian rates, while military rates of other violent crime were roughly equivalent to civilian rates. Thus, in both the wartime and the peacetime contexts studied, a rape differential exists: The ratio of military rape rates to civilian rape rates is substantially larger than the ratio of military rates to civilian rates of other violent crime.' ${ }^{193}$ Although her study focused on US military personnel, Morris anticipated that her observations are generalisable, in part at least, to the armed forces of other countries. ${ }^{194}$ Available literature and other studies on the subject amply bear her out. Besides the numerous synthesised accounts of the problem, ${ }^{195}$ there is, assuredly, an over-abundance of authoritative evidence to establish the legislative fact of sexual violence against women as a constant feature of armed conflicts all through history, all over the world and in all cultures. Some of the more topical examples, in recent times, are the findings made in the Report of the International Commission

I9I Donald Mosher and Ronald Anderson, 'Macho Personality, Sexual Aggression, and Reactions to Guided Imagery of Realistic Rape,' (1986) 20 Journal of Research in Personality 77 at p 9I.

192 Morris, supra, pp 706 st seq.

I93 Ibid, p 653 .

I94 Ibid, at $\mathrm{p} 659$.

I95 See for example Brownmiller, supra, pp 3I-I39; Christine Chinkin, 'Rape and Sexual Abuse of Women in International Law' (I994) 5 European Journal of International Law. 
of Inquiry on Darfur ${ }^{196}$ and the 2008 Amnesty International Report. ${ }^{197}$ Other evidence of this phenomenon would include those recounted next. In his Report to the Security Council on the Protection of Civilians in Armed Conflict, the UN Secretary-General observed as follows:

Complex emergencies have a different impact on women and men. While men account for the largest numbers of combatants, women and children are disproportionately represented among civilians affected by conflict. This usually leads to dramatic increases in the number of children and women heads of households, leading to abrupt changes in their roles and increases in their workloads. The breakdown of the social fabric and the disintegration of families during times of armed conflict often leave women and girls especially vulnerable to gender-based violence and sexual exploitation, including rape and forced prostitution. ... ${ }^{198}$

In the Vienna Declaration and Programme of Action of 1993, the World Conference on Human Rights expressed its dismay at massive violations of human rights especially in the form of genocide, "ethnic cleansing" and systematic rape of women in war situations, creating mass exodus of refugees and displaced persons.' ${ }^{99}$ Although the declaration of the World Conference on Human Rights was motivated by the conflict in the former Yugoslavia, it is consistent with other findings recognising a pattern of violence against women, notably sexual violence, as a frequent feature of armed conflicts elsewhere. ${ }^{200}$

I96 See generally United Nations, 'Report of the International Commission of Inquiry on Darfur to the Secretary-General of the United Nations', pursuant to Security Council Resolution 1564 of 18 September 2004, dated 25January 2005 (transmitted to the Security Council under the cover of the Secretary-General's letter of I February 2005) Doc S/2005/6o.

I97 Amnesty International, 'The State of the World's Human Rights (2008),' AI Index: POL Io/oor/2008, pp 4, 7, 8, 9, 5I, 54, 70, 7I, 80, 8I, 87, 90, 9I, II2, I27, I29, I44, I45, I6o, I62, I63, 205, 221, 236, 27I, 308.

I98 United Nations, 'Report of the Secretary-General to the Security Council on the Protection of Civilians in Armed Conflict,' Doc S/r999/957 of 8 September I999, para I8. See also United Nations, 'Report of the Secretary-General to the Security Council on the Protection of Civilians in Armed Conflict,' Doc S/2002/1300 of 26 November 2002, para 31 .

I99 UNGA/CONF.157/23 of I2 July I993, para 28.

200 United Nations, Review and Appraisal of the Implementation of the Beijing Platform for Action': Report of the Secretary-General, Doc E/CN.6/20oo/PC/2 of I9 January 2000, para 328; United Nations, 'Report of the United Nations Development Fund for Women on the Elimination of Violence against Women': Note by the Secretary-General, Doc E/CN.6/2004/8-E/CN.4/2004/II7 of I9 January 2004, paras 6 and I7; United Nations, 'Women's Equal Participation in Conflict Prevention, Management and Conflict Resolution and in Post-Conflict Peace-Building: Report of the Secretary-General, Doc E/CN.6/2004/1o of 22 December 2003, para I9; United Nations, 'Systematic Rape, Sexual Slavery and 
Judicial findings also exist in respect of this phenomenon. The International Criminal Tribunal for Rwanda, the International Criminal Tribunal for the former Yugoslavia, the Special Court for Sierra Leone, among other international criminal courts, have found conclusively in many cases that acts of sexual violence were committed against women as part of the cataclysmic events that led to the establishment of those international tribunals in their respective domains. A sampling of the relevant judgments of these international courts are Akayesu, ${ }^{201}$ Musema, ${ }^{202}$ Semanza, ${ }^{203}$ Kajelijeli, ${ }^{204}$ Gacumbitsi ${ }^{205}$ and Mubimana ${ }^{206}$ at the ICTR; Celebicí, ${ }^{207}$ Furund žija, ${ }^{208}$ and Kunarac ${ }^{209}$ at the ICTY; Brima at the Special Court for Sierra Leone. ${ }^{210}$

It might also be noted that in his memoir, War as I Knew It, General George Patton recalled a discussion he had with the Grand Vizier of Morocco during World War II. As the General put it: 'I then told him that, in spite of my most diligent efforts, there would unquestionably be some raping, and that I should like to have the details as early as possible so that the offenders could be properly hanged. ${ }^{2 ⿰ I}$ It is noted that not only did the General acknowledge rape of women as an incidence of war, but that this is 'unquestionably' the case.

Slavery like Practices during Armed Conflict': Report of the High Commissioner for Human Rights, Doc E/CN.4/Sub.2/2000/20 of 27 June 200o, generally, especially para 20; United Nations, 'Systematic Rape, Sexual Slavery and Slavery like Practices during Armed Conflict': Final report submitted by Ms Gay J McDougall, Special Rapporteur Doc E/CN.4/Sub.2/1998/13 of 22 June 1998, paras 7 and 9; United Nations, 'Review of Reports, Studies and Other Documentation for the Preparatory Committee and the World Conference,' Doc A/CONF.189/PC.3/5 of 27 July 200I, paras 4, I4, I5, 29 and II7 et seq; UNICEF, 'Armed Conflict', SOURCE: http://www.unicef.org/protection/index_armedconflict.html; Council of Europe (Parliamentary Assembly), Resolution I2I2 (2000): Rape in Armed Conflict, para 7.

20I Prosecutorv Akayesu, supra.

202 Prosecutorv Musema (Judgment and Sentence) 27January 2000 [ICTR Trial Chamber]. The conviction for rape was reversed on appeal on grounds of insufficient evidence of the personal involvement of the accused in the rape: Musema v Prosecutor (Judgment) i6 November 200I [ICTR Appeals Chamber].

203 Prosecutorv Semanza (Judgment and Sentence) I5 May 2003 [ICTR Trial Chamber].

204 Prosecutorv Kajelijeli, supra.

205 Prosecutorv Gacumbitsi (Judgment and Sentence) I7 June 2004 [ICTR Trial Chamber].

206 Prosecutorv Mubimana (Judgment and Sentence) 28 April 2005 [ICTR Trial Chamber].

207 Prosecutor v Delalić \& Ors (Judgment) I6 November 1998 [ICTY Trial Chamber].

208 Prosecutor v Furundžija (Judgment) ro December 1998 [ICTY Trial Chamber].

209 Prosecutor v Kunarac E Ors (Judgment) 22 February 2001 [ICTY Trial Chamber].

210 Prosecutor v Brima E Ors (Judgment) 20 June 2007 [SCSL Trial Chamber II]; and Prosecutor v Brima E Ors (Judgment) 22 February 2008, reasons issued on 3 March 2008 [SCSL Appeals Chamber].

2II George S Patton Jr, War as I Knew It (with an Introduction by Rick Atkinson) [Boston \& New York: Houghton Mifflin Company, 1995] pp 23-24. 
This fact of sexual violence during war, as a fact of life for women caught up in armed conflicts, is also virtually dramatised in another classic play on the military exploits of a legendary soldier of a much earlier period. In Shakespeare's Henry $V$, the warrior king unleashes a torrent of threats to the inhabitants and mayor of Harfleur, in order to achieve the surrender of the city. King Henry thunders thus: 'And the flesh'd soldier, rough and hard of heart,/ In liberty of bloody hand shall range/ With conscience wide as hell, mowing like grass/ Your fresh-fair virgins .../ .../ What is't to me, when you yourselves are cause,/ If your pure maidens fall into the hand/ Of hot and forcing violation?'212

We are not told in the play that these threats are carried out in the end. But in this fearsome speech, King Henry, like General Patton centuries later, is clearly noting the propensity of soldiers not only to wreak death and destruction in their path, but to commit sexual violence against women as part of the universal mayhem unleashed by war. Against this, Henry warns the inhabitants of Harfleur that the only barrier standing between them and such tribulation is his ability to rein in his men-a condition better achieved by converting the prevailing lull in battle into a permanent armistice if there is a surrender of the city before he releases the pandemonium of war again. But what was rendered as an averted fate for the inhabitants of Harfleur in a drama had been a non-fiction for the inhabitants of Cremona. In what appears as one of the earliest accounts of atrocities in armed conflicts, Cornelius Tacitus recounts the horror of the Second Battle of Cremona in October 69 AD. As Tacitus described the events:

$[F]$ orty thousand soldiers burst into the town with a yet larger crowd of servants and sutlers, even more depraved than the soldiers in their readiness for cruelty and lust. Without any respect for age or for authority they added rape to murder and murder to rape. Aged men and decrepit old women, who were worthless as booty, were hustled off to make sport for them. If some grown girl or a handsome youth fell into their clutches, they would be torn to pieces in the struggle for possession, while the plunderers were left to cut each other's throats. Whoever carried off money or any of the solid gold offerings in the temples was liable to be cut to pieces, if he met another stronger than himself. Some disdaining easy finds, hunted for hidden hoards, and dug out buried treasure, flogging and torturing the householders. They held torches in their hands and, having once secured their prize, would fling them wantonly into an empty house or some dismantled temple. Composed as the army was of citizens, allies, and foreign troops, differing widely in language and customs, the objects of the soldiers' greed differed also. But while their views of what was right might vary, they all agreed in thinking nothing wrong. ${ }^{213}$

2I2 Shakespeare, Henry V, Act 3, Scene 3, II-36.

213 Cornelius Tacitus, The Histories vol 2, translated by W Hamilton Fyfe [Oxford: Clarendon Press, I9I2] pp 4I-42. 
As with men's resistance to the exercise of women's peacemaking role during conflicts (seen in Lysistrata), men's subjection of women to sexual violence during conflict has remained a matter of grave concern in the annals of armed conflicts.

\section{Aetiology of the High Frequency of Sexual Violence during Armed Conflicts}

In addition to inquiries into explanations for the prevalence of evil during armed conflicts as a general inquiry, there have also been inquiries into the reasons for the prevalence and recurrence of sexual violence during armed conflicts. Some of the reasons discerned from research suggest that the prevalence of sexual violence during armed conflicts may be broadly explained as follows: that the sexual violence during armed conflicts is an automatic feature of the process; sexual violence is a crime of opportunity during wars; and that sexual violence can be a crime of deliberate policy.

\section{The Theory of Inevitability of Sexual Violence during Armed Conflicts}

Part of the explanations offered for the prevalence of sexual violence during armed conflicts is that armed conflicts do mysterious things to the psyche of male fighters, causing them to inflict sexual violence upon women. As noted earlier, in spite of his most diligent efforts, General Patton conceded that 'there would unquestionably be some raping' during World War II. ${ }^{214}$ The explanation is offered in comments such as, 'You can't stimulate and let loose the animal in man and then expect to be able to cage it up again at a moment's notice' ${ }^{215}$ or that war triggers 'the force in buman nature which may make a soldier of any nationality bayonet an old man or rape a woman. ${ }^{216}$ [Emphasis added.] Anthropological views exist to the effect that it is possible to predict the rate of sexual violence in a given society by reviewing their propensity for war. ${ }^{217}$

J Glenn Gray observes that war 'offers [soldiers] an opportunity to return to nature and to look upon every member of the opposite sex as a possible conquest, to be wooed or forced. ${ }^{218}$ According to him, there is 'enough of a rapist in every man to give him insight into the grossest manifestations of sexual passion. Hence, it is presumptuous of any of us to scorn the practitioners of this lowest kind of passion as beings with whom we have no kinship. ${ }^{219}$ In his view, sex thus 'wooed

2 I4 Patton, supra, p 23.

215 Bourke, supra, p 365, quoting an unnamed World War I colonel reported in the book by two military chaplains of the same war: Rev T W Pym and Rev Godfrey Gordon, Papers from Picardy by Two Chaplains [London: Constable, 1917] pp 29-30.

216 Bourke, supra, p 365, quoting the observations of Pym and Gordon, supra, p 30.

2I7 Bourke, supra, p 359; citing Don Grubin, 'Sexual Offending: A Cross-Cultural Comparison', (I992) iii Annual Review of Sex Research, pp 208-209.

218 Gray, supra, p 63.

2I9 Ibid, p 66. Gray's theory here is very reminiscent of the view expressed at an ear- 
or forced' ${ }^{220}$ is 'intimately associated with the impersonal violence of war. ${ }^{221}$ Gray's ruminations on the subject take him scouring the realms of Greek mythology for serviceable analogy. In Gray's hypothesis, there is an inevitable attraction between Ares and Aphrodite - the god of war and goddess of love, respectively-that explains why men rape. According to him, '[c] opulation under such circumstances is an act of aggression' in which 'the girl is the victim and her conquest the victor's triumph. Preliminary resistance on her part always increases his satisfaction, since victory is more intoxicating the harder the winning may be. ${ }^{222}$

To make good his plea against scorn for the perpetrators of sexual predation, Gray contends that what is at play here is not animalistic behaviour but quite the opposite:

It seems hardly necessary to remark that such degradation is not possible for other than the human species. The animal cannot transform his mate into an object because it does not regard itself as a subject. A human being who thus deserts his humanity does not become like an animal, but, in the expressive German term, an Untier (an "unanimal"), in an exact sense, a creature without parallel in nature. ${ }^{223}$

It would have been possible to suggest that, according to this view, the man who rapes during war might be viewed as even worse than an animal. But that would be the wrong interpretation of Grey's view, given his earlier rebuke of those inclined to dissociate themselves from the martial rapist.

Gray's views, thus presented, require closer examination. For they compel a dissenting view. It is granted that, in terms of biological equipment, man is predisposed towards the sexual atavism of which Gray wrote. This is considering his possession of the phallus, the testosterone that powers its system, and a natural endowment of superior brute strength, as compared to woman. However, when a strong sexual desire is excited at actionable levels, what must separate behaviour of the modern man from the baser animal instinct-or worse- to take what can be taken immediately in satisfaction of a strong desire becomes the highly valued, civilised qualities of self-control and discipline. Hence, it is not correct of Gray to discourage scorn on those who succumb to the base animal instinct, the expression of which results in physical and emotional harm-'evil' as we know it- to

lier period by the Dutch criminologist Willem Adriaan Bonger who, insisting that every man is a brute at his birth, wrote that "[e]very normally constituted man would be born a rapist if the sexual appetite could find no other means of satisfaction': W A Bonger, Criminality and Economic Conditions, translated by Henry P Horton [Boston, I916], pp 612 and 617-620. See also, Bourke, supra, 97.

220 Gray, supra, p 63.

22I Ibid, p 66.

222 Loc cit.

223 Ibid, p 67. 
others, just because the average human male is able to say, 'But for the grace of God, there go I.'

Glenn Gray was not the average soldier. He was a doctor of philosophy when he was serving as an intelligence officer during World War II, having received his $\mathrm{PhD}$ from Columbia on the same day that he received his draft papers. One could see how his subtle soul would endeavour hard in good faith to cling to affinity with his coarser comrades-at-arms who abused the idea of sex in their language and behaviour. Gray's bona fides, however, comes uncomfortably close to sophistry when he objects to the likening to an animal someone who has abandoned his humanity and behaved like an animal. His objection is merely grounded upon the fact that the human being in question is quite capable of exhibiting, at convenient moments, the cherished traits that are beyond the capacity of mere animals. But this objection is unpersuasive. The point is not to say with any degree of seriousness that the human being is an animal, for that would diminish his culpable mind. The point rather is that in failing to bring to bear the faculties of control and discipline against his sexual urge in any carnal intercourse with a non-consenting woman, he did allow himself to behave like an animal; thus, deserving of scorn. Interestingly, even Gray found it hard to remain consistent with his own objection. For, on the very next page, in his effort to liken war to sexual predation, Gray could not avoid describing the predatory male warrior as a 'dangerous beast of prey' outside of his humanity:

It would be folly, I believe, to minimise the similarity between war and this gross form of love. Observations of others and being honest about our own sensations must convince us that sexual passion in isolation and the lust for battle are closely akin. Such sexual passion and war have been married from the beginning, and there is no cause to speak of an illicit relationship. To be sure, the sexual partner is not actually destroyed in the encounter, merely overthrown. And the psychological aftereffects of sexual lust are different from those of battle lusts. These differences, however, do not alter the fact that the passions have a common source and affect their victims in the same way while they are in their grip. We should not forget, either, that sometimes the consequences are not different, after all. Sexual lust often leads to murder, and in wartime, particularly, the same person often suffers rape and murder. Both reveal man as a berserker, outside of his humanity, a dangerous beast of prey. ${ }^{224}$ [Emphasis added.]

Thus, any level of scorn is perfectly deserving of the man who stepped 'outside his humanity' to behave like 'a dangerous beast of prey' resulting in the evil of rape, let alone compounded by the murder, of his victim.

While the seriousness of the subject matter under discussion does not commend reference to Fantasia as a guiding authority, it is still possible to question Gray's resort to Greek mythology, even at the level of the myth in question. Here, the case is easily made that Gray's analogy to the legend of Ares and Aphrodite is

224 Ibid, p 68. 
quite simply flawed. Aphrodite was the swinging goddess of pleasure-'a champion seducer in her own right ${ }^{225}$ - who fornicated with practically half the gods on Mount Olympus, ${ }^{226}$ and mortal men, too; ${ }^{227}$ although she was married (albeit unhappily) to Hephaitos the crippled god of blacksmiths. Granted, the most famous of her lovers was Ares the warrior god, her one true love, whom she also drove to distraction with jealousy. It must then follow that her copulations with Ares were consensual on her part. She had an affair with him. Such consensual relationships between human soldiers of our own world and age are not unheard of-some women do feel attraction to male soldiers, even on the 'enemy' side. Even Gray recognises this in his compelling reflections. ${ }^{228}$ But what the story of Ares and Aphrodite may not readily bear out or legitimise in addition is the proposition that it is - or should be-an understandable norm, in terms of the natural order of things, that soldiers will rape women who say 'No' to sexual advances by soldiers.

On a more serious note, the theory that sexual violence is an 'inevitable' part of armed conflicts must not be permitted a foothold in the consciousness of the modern society, if the objective is to excuse or mitigate its essence and nature as evil. There is much more that can be said to discredit the proposition. It suffices, however, to point out that while there is a very high incidence of sexual violence during armed conflicts, not all soldiers rape-indeed there is no evidence to suggest that a majority of them do. That alone is enough to rebut the hypothesis of inevitability of sexual violence during armed conflicts.

\section{An Evolutionary Theory of Rape}

J Glenn Gray's hypothesis that there is 'enough of a rapist in every man to give him insight into the grossest manifestations of sexual passion' has recently been given scientific validation. In their book, A Natural History of Rape: Biological Bases of Sexual Coercion, ${ }^{229}$ Randy Thornhill (a professor of biology at the University of New Mexico) and Craig Palmer (a professor of anthropology at the University of Colorado), offer a quite bold explanation of the phenomenon of rape, from the perspective of evolutionary psychology. According to them, the phenomenon of rape of women in modern society is ultimately a matter of sex differences between men and women, and the resultant different adaptations over many thousands of generations past.

225 Brownmiller, supra, p 283.

226 See, for instance, Aaron J Atsma, Theoi Project: Greek Mythologies, 'Aphrodite Loves I' at <www.theoi.com/Olympios/AphroditeLoves.html>

227 See Aaron J Atsma, Theoi Project: Greek Mythologies, 'Aphrodite Loves 2' at <www.theoi.com/Olympios/AphroditeLoves2.html>

228 See Gray, supra, pp 6I-62 and 74-78.

229 R Thornhill and C T Palmer, A Natural History of Rape: Biological Bases of Sexual Coersion [Cambridge, Mass: MIT Press, 200o.] 
An understanding of this theory begins perhaps with an understanding of the same Darwinian theory of natural selection that readily explains, as with most aspects of modern life, the differences in the morphology of men and women in the first place. The authors naturally invoke the authority of the renowned biologist, Theodosius Dobzhansky's dictum: 'Nothing in biology makes sense except in light of evolution. ${ }^{230}$ For instance, cite Thornhill and Palmer, the modern woman has functional breasts, compared to man, out of her evolved need to nurse her babies. Modern man has a stronger upper body out of his evolved need for physical competition with other men for sexual mate(s), and the physical protection of his mate(s) and offspring from other men and threats.

Thornhill and Palmer argue that although these evolutionary explanations of the physical differences indicated above are largely uncontroversial, what is not readily understood is that the differences also involve evolved behavioural differences between the sexes. The functional breasts, for instance, resulted from the predisposition of ancestral mothers to place their babies against the breasts and permit suckling. And the stronger upper body in men resulted from the development of the relevant muscles, due to the actions of pushing and shoving and grabbing, such as were entailed in the physical competition. Additionally, the evolution of these behavioural patterns implies both cognitive and emotional psychological adaptations that guided those behaviours. It is not scientifically tenable, then, to acknowledge the physical adaptation in these sex differences without acknowledging the attendant adaptation in behavioural and psychological differences. ${ }^{23^{2}}$

Those are some of the points of departure for the evolutionary theory of rape. According to Thornhill and Palmer, '[e]volutionary theory applies to rape, as it does to other areas of human affairs, on both logical and evidential grounds. There is no legitimate scientific reason not to apply evolutionary or ultimate hypotheses to rape. The only scientific question concerns how to apply theoretical biology to a particular aspect of human endeavours. Evolutionary history would be applicable to human rape even if it were explicable only as a trait that exists as a result of evolutionarily novel circumstances faced by modern humans. And if such were the case, one would still want to know why men's psychological adaptations are designed in a way that yields rape behaviour in the novel circumstances. ${ }^{2{ }^{232}}$

The evolutionary theory of rape, as thus offered, rests on either of two competing and alternative hypotheses: rape as an evolutionary adaptation or rape as an evolutionary by-product of another evolutionary adaptation. ${ }^{233}$ Thornhill and Palmer variously favour the competing hypotheses, and do not agree with each other that the evidence conclusively supports the one over the other. More studies, they concede, will be required to determine which of the two hypotheses more

230 Ibid, p 55. See also T Dobzhansky, et al, Evolution [San Francisco: W H Freeman, 1977].

23I Ibid, p 32.

232 Randy Thornhill and Craig T Palmer, ibid, p 55.

233 Ibid, pp 59-6o. 
accurately explains the phenomenon of rape in human society. ${ }^{234}$ What they do jointly insist upon is that 'the ultimate causes of rape are clearly to be found in the distinctive evolution of male and female sexuality. The evidence demonstrates that rape has evolved as a response to the evolved psychological mechanisms regulating female sexuality, which enabled women to discriminate among potential sex partners.' ${ }^{235}$

The adaptation hypothesis is all about reproductive success and the primordial contest among men to prevail in it. Rape 'may be an adaptation that was directly favoured by selection because it increased male reproductive success by way of increasing mate number. That is, there may be psychological mechanisms designed specifically to influence males to rape in ways that would have produced a net reproductive benefit in the past. ${ }^{236}$

The basic framework of the evolutionary theory of rape, particularly from the perspective of adaptation, is that men must compete among themselves, in order to be selected by the more discriminating women. The ability to prevail in this competition determines the relative reproductive success of men. There are many factors that determine which men are more successful in this competition to be chosen by women. They include resource control, social status, symmetry of physical features, genetic quality, etc. But victory in this competition to be chosen by women is not the only way to gain sexual access to females. And this is where rape enters the calculation. By raping, the men are able to circumvent the female choice. ${ }^{237}$ Rape was thus an evolutionary strategy adapted to overcome obstacles to individual reproductive success. This male dilemma is explained as follows:

In ancestral populations of many species, including humans, the difficulty of obtaining the parental investment of a choosy member of the other sex was a prominent obstacle to reproductive success for individuals of the sex with the lesser parental investment. That is, the difficulty of gaining sexual access to choosy females was a major obstacle to reproductive success for males. Owing to the significance of this obstacle throughout evolutionary history, there would have been strong and effective selection pressures favouring traits in males that increased their access to mates. ${ }^{238}$

In their alternative hypothesis, the by-product hypothesis, Thornhill and Palmer contend that rape 'may only be a product of other psychological adaptations, especially those that function to produce the sexual desires of males for multiple partners without commitment. In this case, there would not be any psychological

234 Ibid, p 6r.

235 Ibid, $\mathrm{p} 84$.

236 Ibid, p 60.

237 Ibid, p 52.

238 Ibid, p 53. 
mechanism designed specifically to influence males to rape in ways that would have produced a net reproductive benefit in the past. ${ }^{239}$

The legendary American criminal lawyer, Clarence Darrow, had ventured a congruent supposition many years ago. According to him:

Nature, in her determination to preserve the species, has planted sex hunger very deep in the constitution of man. The fact that it is necessary for the preservation of life, and that Nature is always eliminating those whose sex hunger is not strong enough to preserve the race, has overweighted man and perhaps all animal life with this hunger. At least it has endowed many men with instincts too powerful for the conventions and the laws that hedge him about. ${ }^{240}$

Darrow's hypothesising ostensibly received a more sophisticated scientific treatment in the work of Thornhill and Palmer. Upon its publication in 2000, $A$ Natural History of Rape promptly provoked an avalanche of controversy, with critics $^{241}$ and supporters ${ }^{242}$ aligned on both sides. The criticism provoked by Thornhill and Palmer is entirely understandable. Quite apart from the scientific merits of the theory, in view of the hypotheses offered and the evidence supporting them, the deterministic flavour of the evolutionary theory would offend some important constituencies that have tirelessly engaged in social engineering against rape. Two particular reasons for their resentment will be as follows. First, it undercuts, in a very direct way, the feminist-inspired argument that rape has little to do with sex but everything to do with men's strategic domination, power and control over women. Thornhill and Palmer make no apology for this concern. Indeed, they flatly dismiss, as mere ideology, the theory of rape as a strategy calculated to dominate women. ${ }^{243}$ It is beyond the scope of the present work to engage in an assessment of the validity of the claim of either side to this particular debate. As the chief aim of the present work is to explore the possibility of diminishing the incidence of sexual violence in armed conflicts - whatever its cause(s) - using the avenue of international law, it is eminently possible to explore that possibility, without engaging in the assessment of the relative merits of the debate as to whether or not sexual violence is an instrument of domination of women by men.

239 Ibid, p 60.

240 C S Darrow, Crime: Its Cause and Treatment [New York: Kaplan Publishing, 2009; originally published: New York: Thomas Y Crowell, I922], 77. See also Bourke, supra, p 99.

24I See, for instance, C B Travis (ed), Evolution, Gender and Rape [Cambridge, Mass: MIT Press, 2003].

242 See, for instance, T K Shackelford and G J LeBlanc, 'Courageous, Compassionate and Scholarly: An Evolutionary Analysis of Rape and Male Sexual Coercion' in The Journal of Sex Research vol 38 No I (200I), pp 8I-83.

243 See Thornhill and Palmer, supra, generally at chapters 5 and 6. 
The second cause for concern is the feared danger that the evolutionary theory of rape would provide a new legal defence to rapists, ${ }^{244}$ by giving legal legitimacy to the 'boys-will-be-boys' aphorism. Thornhill and Palmer do defend themselves against this concern. According to them, the concern is born out of what they dismiss as the twin concepts of 'naturalistic fallacy' and 'myth of genetic determinism', which they protest as corrupted understandings or representations of evolutionary theories. Genetic determinism is the assumption that behaviour is fixed by genes and cannot be altered except by altering the genes in question; ${ }^{245}$ while naturalistic fallacy is the view that every offensive behaviour is pardonable or tolerable if it is attributable to nature. Thornhill and Palmer do not accept these views. ${ }^{246}$ For instance, while they do not propose a specific programme for 'increasing the cost associated with rape; [they] simply suggest that social engineers who wish to get realistic about rape [should] pursue a programme of punishment that is informed by what is known about evolution. ${ }^{247}$ In the end, they left it to society to decide appropriate punishment for rape. As they put it:

\begin{abstract}
Voters must decide what is suitable punishment for rape. Science has nothing to say about what is right or wrong in the ethical sense. Biology provides understanding, not justification, of human behaviour. Biological knowledge is useful to a democratic society to the extent that it can be used to achieve goals that people decide are appropriate. ${ }^{248}$
\end{abstract}

In fairness to Thornhill and Palmer, criminal law forbids much that is generally understood as conducts or impulses attributable to human nature or evolutionary conditioning. Homicide, for example, is not always excused by the fact that it was the instinct of self-preservation that caused the accused to kill the victim. Nor does the natural heat of passion provide adequate defence for the cuckold who murdered his wife or her lover.

In order to succeed as a defence, the evolutionary theory of rape would need to be juridically received within the realms of the defence of necessity; in the sense of the existence of an extreme pressure of circumstances that overwhelmed the will to resist the conduct in question. The difficulty of clearing this hurdle is perhaps illustrated by the fact that the defence of necessity was denied to defendants who were charged with possession of marijuana for purposes of pain management, on grounds that the choice facing the defendants was not (a) absence of pain upon consumption of marijuana or (b) severe pain without consumption of marijuana. Given the availability of other pain management medication, the

244 See, for instance, M Kimmel, 'An Unnatural History of Rape,' in C B Travis (ed), Evolution, Gender and Rape [Cambridge, Mass: MIT Press, 2003], 22I at p 232.

245 See Thornhill and Palmer, supra, pp iı--irr.

246 Ibid, pp ro7-IIо.

247 Ibid, p 165.

248 Ibid, p 199. 
defendants' choice rather was (a) absence of pain but presence of minimal sideeffects upon consumption of marijuana or (b) absence of pain but presence of severe side-effects if marijuana was not consumed. In the circumstance, held the court, the defence of necessity was not available. ${ }^{249}$

It will thus be extremely hard to find the existence of an extreme pressure of circumstances that could reasonably be accepted as capable of overwhelming the will of a man to resist raping a woman, out of either an evolutionary impulse to have casual sex (according to the 'by-product' hypothesis of the evolutionary theory of rape) or reproductive sex (according to the 'adaptation' hypothesis). Hence, the criticism of Thornhill and Palmer may not be as troubling as first appears.

What then is the relevance of the evolutionary theory of rape to international criminal law? Some have argued that the logical connection is weak at best. One critic expressed this view in the following way:

The human sociobiological approach to war rape attests to logical difficulties of defining rape under all circumstances as related to reproductive success. The military leaders in charge of organized rape as an 'entitlement' for the soldiers are not concerned with the result of rapes, in terms of increasing the population under their control. ${ }^{250}$

This misses the point of the evolutionary theory of rape. An evolved trait is not a trait developed by an individual at the conscious level, but one that is shared among the species over hundreds of thousands of generations, with the individual having little choice in the matter. According to evolutionary theorists, women evolved, not chose, to have breasts. So, too, does the typical man have little choice in his possession of stronger upper body, compared to the average woman. Similarly, the evolved psychological predisposition is not a cognitive trait that drives the choice of the individual at all times. ${ }^{25 \mathrm{r}}$ Hence, Thornhill and Palmer's theory is not easily defeated by the fact that the military superior or subordinate implicated in war time rape may not have consciously made a decision to spread, increase or perpetuate his own gene pool in virtue of the conduct.

For my purposes, I find the evolutionary theory of rape as one that may not be easily ignored in any meaningful enterprise to construct a wholesome doctrine of superior responsibility for war-time rapes. It plays into the range of explanation for why sexual violence is committed so rampantly during wars. The evolutionary theory of rape commends close attention to Glenn Gray's observation that war 'offers [soldiers] an opportunity to return to nature and look upon every member

249 Quayle and Others v R; Attorney-General's Reference (No 2 of 2004) [2005] EWCA Crim I4I5 [Court of Appeal of England and Wales.]

250 E Tobach and R Reed, 'Understanding Rape', in C B Travis (ed), Evolution, Gender and Rape, supra, I05 at $\mathrm{p}$ I30.

25I See S Kanazawa and M Still, 'Why Men Commit Crimes (And Why They Desist)', Sociological Theory I8.3 (November 2000), p 440. 
of the opposite sex as a possible conquest, to be wooed or forced.'This is a view not to be dismissed lightly. The evolutionary theory of rape, from this perspective, does not exclude any of the other social-science based theories. As will be seen in Chapter 2, the evolutionary theory of rape should heighten, rather than diminish, the duty upon military hierarchies to put efficient systems in place to prevent rapes during war, having trained, armed and deployed men whom they ought to have known or suspected as having evolved to rape women at any available opportunity. Failure to put such systems in place should result in criminal responsibility on the part of superiors for the resulting rapes.

\section{The Theory of Opportunism of Sexual Violence during Armed Conflicts}

Another dominant explanation of the prevalence of sexual violence during armed conflicts is opportunism on the part of the individual soldier. The theory of individualistic opportunism proceeds, for its part, from the more modest premise that sexual violence is a crime of opportunity that is frequently committed, during conflict, by arms-bearing men, indulging their libidos, under the cover of the chaotic circumstances of armed conflict. As Brownmiller put the point, 'the original impulse to rape does not need a sophisticated political motivation beyond a general disregard for the bodily integrity of women. ${ }^{252}$ Such prosaic explanations for sexual violence are borne out in the following excerpt in a $\mathrm{BBC}$ report about sexual violence in the Congolese armed conflict:

[Emmanuel] fought with the CNDP [Congrès national pour la défense du people] rebel group. $[\mathrm{He}]$ says that they raped to show their anger with the authorities for neglecting them:

'Soldiers or rebels usually rape because we stay in isolated places and we don't get our pay - even if it can come, it doesn't come on time.

'After living for a long time in the forest, you don't see women and so if one woman shows up then all of us, we profit. ${ }^{253}$

This manner of sexual predation is not limited to rebel groups. For the same BBC report presents a similar scenario on the part of government troops.

A former government soldier who is serving 20 years in Goma Central Prison says he attacked the first woman he came across after sneaking away from his post:

'I asked her to help me. I had this urge to have sex. She didn't want to have sex with me. But I forced her. I felt that if I didn't have sex then I would get sick.

252 Brownmiller, supra, p 37.

253 <http://news.bbc.co.uk/2/hi/africa/8677637.stm>. 
'She left without crying but as she was leaving she said she would denounce me. I regret it now because I am in prison. ${ }^{2} 54$

The power of military weapons of violence at their disposal, and, the superiority of their natural physical prowess or the specialised combat training they would have received enable these male military sexual predators to realize this carnal opportunity more easily. ${ }^{255}$ The opportunity itself is afforded when the fighting men are brought in close proximity with the civilian population. ${ }^{256}$

Consistent with the theory of opportunism is the fact that the typology of victimisation is not limited to women on the opposing side of the gulf of belligerency or women in occupied territories. Women of the own-side also do fall victims. It has been suggested, notably, that one-third of US female military personnel suffer sexual violence in the hands of their male comrades, even in theatres of war abroad. ${ }^{257}$

The theory of opportunism is further enhanced by the victimisation of neutral females, such as aid workers and humanitarian personnel. That is to say, female personnel of the United Nations and those of NGOs do also fall victims to the crime. For instance, in its Resolution of 2003 , on safety and security of humanitarian personnel and protection of United Nations personnel, the UN General Assembly expressed grave concerns 'at the acts of violence in many parts of the world against humanitarian personnel and the United Nations and its associated personnel, in particular, deliberate attacks, which are in violation of international humanitarian law as well as other international law that may be applicable, $\ldots .{ }^{25^{8}}$ Following that expression of concern came a strong condemnation of 'acts of murder and other forms of violence, rape and sexual assault, intimidation, armed robbery, abduction, hostage-taking, kidnapping, harassment and illegal arrest and detention to which those participating in humanitarian operations are increasingly exposed, as well as attacks on humanitarian convoys and acts of destruction and looting of their property. ${ }^{259}$

254 Ibid.

255 See United Nations, Report of the Secretary-General to the Security Council on the Protection of Civilians in Armed Conflict, supra.

256 See Bourke, supra, p 359 .

257 See Col Ann Wright (rtd), 'Sexual Assault in the Military: a DoD Cover-Up?', Common Dreams at www.commondreams.org/archive/2008/08/04/10786/; Jeffrey Smith, 'Sexual Assaults in Army on Rise', Washington Post at <www.washingtonpost.com/wp-dyn/articles/Aro959-2004Jun2.html>; Michele Norris, 'Reported Cases of Sexual Assault in Military Rise', National Public Radio at www.npr.org/ templates/story/story.php?storyId=15005484; Gloria Hillard, 'Scars of War Run Deep for Female Vets', National Public Radio at <www.npr.org/templates/story/ story.php?storyId=I5005484\#I492I2I4; 'Sexual Assault in Military "jaw dropping”, CNN at www.edition.cnn.com/2008/US/o7/3i/military.sexabuse/>.

258 Doc A/58/L.47 of 16 December 2003.

259 Ibid. 
That these acts of sexual violence are not limited to such conducts committed against enemy females underscores the rampancy of these acts. All this evidence begs the question (the subject of this study) of how well international law is laid down and construed to protect women - or contain the evil of sexual violenceduring armed conflicts.

\section{The Theory of Deliberate Policy of Sexual Violence during Armed Conflicts}

In addition to the theories of inevitability and opportunism of sexual violence during armed conflicts, is the far more sinister theory of policy as explaining the rampancy of sexual violence during armed conflicts. It has now been widely recognized that sexual violence during armed conflicts often results from a motive of deliberate policy. In the following section, a review will be conducted of the practices traditionally articulated as policy oriented sexual violence, as well as other policies not so often articulated clearly as such.

\section{Sexual Violence Traditionally Articulated as Policy}

A number of explanations have been offered to explain the incidence of sexual violence as a tactical weapon in armed conflicts. First, Radhika Coomaraswamy (formerly UN Special Rapporteur on Violence against Women) has observed that in many societies sexual violence is seen as a crime of honour committed against the victim's community and not the victim as such. ${ }^{260}$ It is thus a factor of humiliation to rape the womenfolk of the enemy State, ethnic group, community or faction. One poignant story related by Coomaraswamy involves an event that occurred during the India-Pakistan partition riots. It concerned the fate of a wealthy Hindu man and his family. He had six daughters. One day, his Muslim neighbours, with whom he had hitherto good relations, came to him. They asked him to give his daughters in marriage to their sons, for the sake of continued good relations and the safety of his family. In seeming agreement, he kept nodding as they spoke. That evening, he assembled all his family together and decapitated each of them with his sword-thirteen people in all. He then lit their funeral pyre and climbed onto the roof of his house and cried, 'Bring on the marriage parties ...'; following which he committed suicide. ${ }^{26 \mathrm{I}}$ To the man, it was evidently an act of humiliation worse than death to live to see his beautiful daughters in sexual relations with people he considered as unworthy or as his enemies.

Second, this humiliation theory has an added angle, if sexual violence is conceived or perceived as an act of domination of the enemy. In her classic work, Against our Will: Men, Women and Rape, Brownmiller explores the effect of rape as

260 Radhika Coomaraswamy, 'A Question of Honour: Women, Ethnicity and Armed Conflict' (1999) mimeograph. Available at <http://www.sacw.net/Wmov/ RCoomaraswamyOnHonour.html>

26I Ibid, citing $\mathrm{K}$ Bhasin and $\mathrm{R}$ Menon, Borders and Boundaries: Women in India's Partition [New Brunswick, N J: Rutgers University Press, I998] p 48. 
a sexual coup de grace that 'destroys all remaining illusions of power and property for the men of the defeated side. ${ }^{262}$ As such, sexual violence against the women of the group becomes the final act of emasculation and ultimate abasement of the men who are supposed to protect the women of their group. Hence, to violate the women is also to rape the souls of their men; in veritable 'devastations of the soul', as Hillis put it. ${ }^{263}$

Third, in a phenomenon recorded during the conflict in the former Yugoslavia, Bosnian women were held captive by Serbs and repeatedly raped and forcibly impregnated. They were then kept in captivity until a point past a period of possible safe abortion, and then released. ${ }^{264}$ Some commentators have found absurd the sense behind the thinking that the population of a group could be negatively affected by the fact of outsiders forcibly impregnating the women of the group. Vetlesen, for instance, registered his scepticism in the following words:

Unfortunately, as observed by Allen and other commentators who have been in contact with the rape victims, one of the most tragic results of this policy is that the victims, if they survive, often do so believing the Serb illogic. At some level, they begin to subscribe to the very reasoning that seeks to erase their cultural identity: they are convinced that the pregnancy they carry will result in the birth of a Chetnik, a Serb, a child who will bear none of his mother's characteristics. It is as though the things told them by their rapists have borne fruit, have become a self-fulfilling prophecy—namely, that the raped woman would in future give birth to a Serb child. ${ }^{265}$

Although charitably disposed towards the victims, the trouble with observations such as the foregoing is that their evident good intensions might get undone by an instinctual resistance to the very same paternalism that Vetlesen himself has eschewed elsewhere in his book. ${ }^{266}$ The apparent incredulity being decried might be readily explained by the shared cultural codes of the concerned groups. In a society in which the lineage of a child follows the biological father, such acts of sexual violence were clearly intended to force women to bear children that genetically belong to their enemies. Evidently, this was considered to be the case not only by the Serbian assailants but also by their Bosnian victims of the transgression in question. ${ }^{267}$ If this transgression reveals how they have arranged the codes that ordinarily guide their ways of life, then their continued interpretation and

262 Brownmiller, supra, 38.

263 Newell Dwight Hillis, German Atrocities: Their Nature and Philosophy [New York: Fleming H Revell, I918] p 26. See also Brownmiller, supra, p 45 together with pp $38-40$.

264 Coomaraswamy, supra. See also Vetlesen, supra, pp I99-200.

265 See Vetlesen, supra, pp 20I-202.

266 Ibid, p 29.

267 Ibid, pp 20I-202. 
application of those codes may not be so easily abjured, even in the abhorrent circumstances under consideration. An alternative explanation for the systematic forced impregnation might, of course, be the added factor of the enemy's determination to brand humiliation, in an enduring way, into the social fabric and psyche of the subjugated group.

Fourth, another manner in which sexual violence gets used as a policy during armed conflicts is in the manner of an instrument of terror during armed conflicts. In this sense, it is used to intimidate belligerent opponents away from where they are not wanted, or to terrorise them into capitulation. In the context of some US soldiers aberrantly using raping and killing as a method of dissuading guerrilla fighters from American soldiers during the Vietnam war, particularly in the context of the My Lai, one US officer in 1969 described it as an 'effective tactic.' According to him, 'If you scare people enough they will keep away from you': although he did not say that he approved of it. ${ }^{268}$ During the conflict in the former Yugoslavia, Serbian forces did find a particular use for this tactic, as a method of ethnic cleansing. Bosnian women were raped in the presence of their relatives and communities, in order to force them to flee from their villages and towns and never to return. ${ }^{269}$ In a much earlier armed conflict, in 1746, King George's troops led by the Duke of Cumberland effectively employed sundry brands of terror, including the rape of women, to tame Scottish Highlanders who 'showed no enthusiasm for surrendering' following the Battle of Culloden. ${ }^{270}$

Lt Col Grossman, a retired psychology professor at West Point, puts the matter quite simply thus: 'There is a simple, horrifying, and obvious value in atrocity.'275 According to him, one of the most obvious and blatant benefits of atrocity is that it "quite simply scares the hell out of people. The raw horror and savagery of those who murder and abuse cause people to flee, hide, and defend themselves feebly, and often their victims respond with mute passivity.' And this process, found to work well for criminals and outcasts, can work even better when institutionalized as policy by revolutionary organizations, armies, and governments. ${ }^{272}$ As will be seen in Chapter 5 , sexual violence was a particular instrument of terror during the Sierra Leonean civil war.

Fifth, policy is also implicated when rape is used as an instrument of torture during interrogation. In one such incident reported by Coomaraswamy, in her former capacity as the UN Special Rappoteur for Violence against Women, she recounted the story of ' $N$ ' of East Timor. Indonesian soldiers had taken her from her home to a military post. They began interrogating her about the whereabouts of her husband. On the I6th day, they began to use force. They undressed her. One of them raped her, while the others watched and laughed. When they

268 Bourke, supra, p 362.

269 See Vetlesen, supra, pp 197-198.

270 Brownmiller, supra, p 38.

27I Grossman, supra, p 208.

272 Ibid, p 207. 
were done raping her, they applied electric shocks to her ears, nose, breasts and vagina. ${ }^{273}$ Bourke also captures the theme of targeting the sexual organs of victims as a method of torture employed by some American interrogators in Vietnam. According to an unnamed member of the ist Air Calvary Division in Vietnam, 'If you are looking for information, you seek out the most sensitive areas of their body. If you are out in the field, you basically want to degrade them more. And attacking their sexual organs would be more degrading than their arms or legs. ${ }^{274}$ Although the story recounted was given in the context of interrogation of men, it is clear that sexual assault on women was very much a part of the arsenal of interrogation methods employed by some troops during the Vietnam War. As Bourke's research revealed:

According to one veteran from Vietnam, infantry training for Marine Corps included a class on interrogating POWs and villagers about 'where they hide things. They stress over and over that a woman has more available places to hide things like maps or anything than a male. So it took about twenty minutes to cover where to search a male suspect, and about an hour on a female.'275

Still on the methods of interrogation, it was reported by some Vietnam veterans that their search methods of the women included the practice of male soldiers, in some instances, using 'their penises to probe the women to make sure they didn't have anything hidden anywhere; and this was raping but it was done as searching. ${ }^{276}$ Furthermore, some American soldiers had threatened rapes of their female detainees under interrogation, sometimes using the occasional black interrogator as the bogeyman potential rapist, in hopes that the female victims would provide the needed information in order to avoid being raped by the black interrogator. ${ }^{277}$

\section{Sexual Violence Not Often Articulated as Policy-Systematic Connivance or Condonation}

Although not often articulated in terms of policy, systematic connivance or condonation, by military or political hierarchy, of sexual violence are other emanations of sexual violence that eminently deserve clear categorisation as policy during war. Systematic condonation of sexual violence occurs when the military or political hierarchy systematically turns a blind eye to its troops' commission of sexual violence or systematically avoid prosecution, notwithstanding legal proscrip-

273 Coomaraswamy, supra. See also United Nations-Special Rapporteur for Violence against Women, 'Report on Mission to Indonesia and East Timor' (1999) Doc No E/CN.4/1999/68/Add.3.

274 Bourke, supra, p 362.

275 Ibid, p 367.

276 Ibid, pp 367-368.

277 Ibid, p 368. 
tions against sexual violence. Such attitudes from the hierarchy certainly have the effect of encouraging impunity in soldiers who would rape women during war. Systematic connivance in sexual violence means tacit encouragement of troops to commit sexual violence. It is sufficiently bad, and no less evil, that condonation or connivance occurs at all, and not at a systematic level: but the presence of such attitudes in systematic patterns is what converts the evil to one of policy. In Rape, Sex, Violence, History, for instance, Bourke retells the story related by one Ed Murphy, a rifleman in the infamous i98th Infantry Brigade, Americal Division. He is reported as recalling that his platoon leader was a morally upright Mormon minister when he arrived in Vietnam. However, the platoon leader quickly ended up 'condoning everything that was going on because it was part of a policy.... He would condone rapes. Not that he would do them, but he would just turn his head to them because who was he in a mass military policy. ${ }^{2} 78$

Systematic connivance or condonation is evident in the following suggestions of behaviours and attitudes found in the antecedents of certain militaries, notably the American military. First, it appears to be part of military orthodoxy that rape is a safety-valve for 'pent-up aggressive feelings' or resentment induced by war; and, despite official proclamations to the contrary, that it is 'more satisfactory' to have fighters express such pent-up feelings in the manner of 'forcible rape against a conquered people than to turn the same feelings towards their officers. ${ }^{279}$ Theories offered to explain these pent-up feelings would include the obsession of men-at-arms with thoughts of women and sex, or the negativity that encumbers the average fighter's mind.

The obsession theory is clearly articulated by Gray. Part of that articulation appears as follows:

Anyone entering military service for the first time can only be astonished by soldiers' concentration upon the subject of women and, more especially, upon the sexual act. The most common word in the mouths of American soldiers has been the vulgar expression for sexual intercourse. This word does duty as adjective, adverb, verb, noun, and in any other form it can possibly be used, however inappropriate or ridiculous in application. Many soldiers seem hardly able to utter a sentence without using it at least once. Apparently they derive a vague satisfaction by invoking the word itself, habitual and thoughtless as its employment becomes. It must serve to recall fleeting memories or fond desires. At all events, its overuse indicates clearly a predominant interest for nearly all military men in wartime. ${ }^{280}$

Evidently, the soldiers' obsession with thoughts of women and the sexual act is not limited to merely mindless vocalisation of the 'f' word and all its derivatives

278 Ibid, p 369.

279 Ibid, p 365.

280 Gray, supra, p 6r. 
at every available opportunity. The oral fixation with the word is equally matched by an obsessive compulsive predisposition toward the act itself at every available opportunity - if not with the consent of the women concerned, then by force. As Gray observes: 'If we are honest, most of us who were civilian soldiers in recent wars will confess that we spent incomparably more time in service of Eros during our military careers than ever before or again in our lives. When we were in uniform almost any girl who was faintly attractive had an erotic appeal to us. ${ }^{281}$ In soldiers fighting a war, an 'unmistakable similarity' has been observed between 'eating and drinking, a devouring of the woman as object. Even the appetite seemed to recur with the same regularity as do hunger and thirst. To these soldiers it did not matter who the woman was they used to satisfy themselves. ${ }^{282}$ Doubtless, all this thirst and hunger for women and sex must be slaked and assuaged somehow. And herein enters the idea of government-issue brothels, intended to limit rapes as well as to 'insure efficiency of soldiering'. ${ }^{283}$ Needless to say, however, that the high frequency of rapes during armed conflicts attests to the inadequacy of military brothels to limit rapes practically or conceptually. Rapes are not practically limited, since straight-forward rapes continue to occur at high rates. And rapes are not conceptually limited, as some of the 'comfort women' working in those brothels are often victims of sexual exploitation ${ }^{284}$ or pragmatic decoys who volunteer

\footnotetext{
28I Loc cit.

282 Ibid, p 65.

283 Loc cit.

284 In The Warriors, Gray recalls watching hungry Italian women and children during World War II, 'standing in February rains, holding crude cans with wire handles to collect leftover food from our mess.' Generous GIs were all to glad to oblige. But that must not have been enough, as the story implied that scavenging the military garbage was resorted to in supplement to donation of the leftovers. Eventually, however, "higher headquarters soon put out stern orders that all garbage was to be buried forthwith. Then began the hideous spectacle of unwilling soldiers forced to push back the women and children while garbage cans of food were dumped in freshly dug pits.... More than once we saw the despairing children and women break through the lines and scrabble in the rain and mud to rescue dirty pieces of food before the soldiers could seize them and push them away': Gray, supra, pp 6-7. It is obviously in conditions such as these that these women and children will succumb to sexual exploitation. Stories of sexual exploitation in those circumstances no doubt obtained in earlier wars, but an excellent recent chronicle of it is revealed in stories from the recent war in the Democratic Republic of Congo in which, in addition to more blatant forms of sexual violence, even some UN peacekeepers were known to give women and young girls as little as a cup of milk, a few eggs, peanut butter or one dollar in exchange for sex. See, for instance, Susan Notar, 'Peacekeepers as Perpetrators: Sexual Exploitation and Abuse of Women and Children in the Democratic Republic of the Congo' (2006) I4:2 Journal of Gender, Social Policy and Law $4 \mathrm{I} 3$ at $\mathrm{p} 4 \mathrm{I} 7$.
} 
their own bodies to serve as 'fire-breakers' between the soldiers' obsessive sexual preoccupations and the more vulnerable females in the victim population. ${ }^{285}$

The psyche of negativity that explains the pent-up feeling of soldiers (which is considered as better channelled against the bodies of women than at the soldiers' military commanders) apparently rests on the bedrock of what Grossman terms the 'Wind of Hate.' This is in the nature of the resentment on a slow boil inside the soldier for being forced into a situation of conflict: of enduring the military system's reversal of his natural resistance to kill fellow human beings: of being put in situations in which other human beings, particularly the enemy population, regard him with contempt; hateful expressions from helpless geriatric citizens, women and children of the enemy population would include passive aggressive displays of contempt, and the able-bodied members of the enemy population would desire to kill him: of being put in a situation in which he must endure a constant feeling of insecurity to his own life. ${ }^{286}$ To that stewing cauldron one might add other factors of hate which the soldier must feel, such as 'the marching orders and manipulations of a military headquarters'; ${ }^{287}$ frustration born of the tension between expectation and futility in the quest for victory in the given war such as was the case in Vietnam and Iraq; ${ }^{288}$ loss of freedom to do as he pleases, including terminate at will his involvement in the armed conflict, even when not a conscript; deployment away from loved ones, etc. The pathetic circumstances of soldiers have been aptly summarised by John Mueller as follows:

They must be able to live with and to commit intense violence, and they must also be able to endure long intervals - months at least, often years — of various kinds of deprivations. Among the problems: lice, maggots, leaches, and other vermin; debilitating and very often fatal battles with dysentery and other diseases; the absence of women; terrible, even inedible, food; germ-ridden water; stale cigarettes; bone-deep fatigue; syphilitic prostitutes; watered or even poisonous liquor; sleep deprivation; family separation and homesickness; absence of privacy; constant and often brutal and pointless harassment or physical abuse by superiors and by an incoherent system; exposure to extremes of weather; masturbatory fantasies that become decreasingly stimulating; boredom that can become cosmic, overwhelming, stupefying — an emotion, though only rarely remarked upon, that is far more common in war than the rush that comes with combat. ${ }^{289}$

285 See Bourke, supra, p 358.

286 Grosmann, supra, pp 76-82.

287 See Gray, supra, p 74 .

288 See, for instance, Tritle, supra, pp 3-4. In this regard, it was quite telling that President Barack Obama generated sustained applause from US marines at Camp Lejeune, North Carolina, when he announced there on 27 February 2009: 'Let me say this as plainly as I can. By August 3I, 20IO, our combat mission in Iraq will end': CNN, 'Obama: U S to withdraw most Iraq troops by August 20I0' at <www.cnn. com/2009/POLITICS/o2/27/obama.troops/index.html>

289 John Mueller, The Remnants of War [Ithaca: Cornell University Press, 2004] p 8. 
This simmering resentment that must result from the foregoing has a potential to implode into loss of morale or explode into mutiny ${ }^{290}$ or both. The military hierarchy is thus put in the unenviable position of electing what they might view as the lesser of two evils: loss of morale/mutiny versus 'some raping' ${ }^{291}$ as an outlet for the resentment. Indeed, Zimbardo's Stanford Prison Experiments did capture this instinct of the perpetrators to let out their resentment and frustrations on those over whom they exercise power and authority; as was evident in the incident where the 'guards' were forced by a rumour of imminent 'prison escape' to dismantle the prison and move the 'prisoners' to a safer location, only to realise later that the rumour had been false. They later took out their frustrations on the 'prisoners.'

Presumably, Grossman's 'Wind of Hate' theory is equally capable of embracing situations in which the armed fighter confronts the silent, yet searing, contempt that is often present in the eyes, attitudes and demeanours of unarmed and helpless civilians whose territory has come under domination or occupation-the passive resistance of the spirit of the violently dominated and or oppressed. In some cases, especially in modern wars, the occupying forces may make efforts to 'win hearts and minds' of the dominated. The alternative course is to break that resistant spirit-or even sheer frustration from the temerity of its mere existence. This alternative course might lead the armed fighter(s) to commit atrocities against unarmed civilians.

Second, there is an acceptance that rape may be necessary for effective combat performance. ${ }^{292}$ In addition to a felt need to allow raping as an escape valve for pent up feelings of resentment, a view of rape as necessary for combat performance also appears in the sense that a prize for victory in war becomes the licence to rape. Thus, fighting to secure women became equivalent to fighting to secure food in primitive societies. ${ }^{293}$ According to the Old Testament of the Bible, Hebrew men were permitted to keep female war captives as slaves and concubines. ${ }^{294}$ These

290 Soldiers everywhere are reminded of the deadly force of mutiny by February 2009 mutiny of the Bangladeshi Border Rifles which claimed the lives of at least I3O of their officers, including the Major-General who commanded them: see <http:// en.wikipedia.org/wiki/2009_Bangladesh_Rifles_revolt>

29I The phrase 'some raping' is arguably a parapraxis on the part of General Patton as he recounted his discussion with the Grand Vizier of Morocco whom Patton told that 'in spite of my most diligent efforts, there would unquestionably be some raping, and that I should like to have some details as early as possible so that the offenders could be properly hanged': Patton, supra, pp 23-24. Of greater interest in this regard is the attitude reported in Bourke's book that when sexual violence does occur 'the brass would say, "Well, look, cool it for a little while ... at least let it happen with little more time in between." But we were never discouraged.' This led Bourke to the sensible conclusion that military authorities officially disapproved of rape and pillage, but turned a blind eye to such antics: Bourke, supra, p 366.

292 Loc cit.

293 Brownmiller, supra, p 33.

294 The licence appears as follows in the Bible: 'As for the women, the children, the livestock and everything else in the city, you may take these as plunder for yourselves. 
historical roots and biblical precedent might explain why some modern day soldiers may still condone, or connive at, sexual violence by their troops. As will be seen later in Chapter 7 below, some fighting forces have formally adopted as a form of policy the practice of 'forced marriage' of women captured during war. It is reported that the subplot of German-Russian conflict within World War II saw evidence of this manner of mass rape of women. Soviet soldiers attacking Germany were reportedly told that German women were theirs by right. It is estimated that, in consequence, millions of rapes occurred, resulting in an estimate of a hundred thousand births in Berlin alone, after the war. ${ }^{295}$ An excellent recent example of this was the system of 'bush wives' formally and blatantly adopted by rebel forces during the Sierra Leone civil war of the $1990{ }^{296} \mathrm{~A}$ further explanation might relate back to the not-too-distant past when women were regarded as mere property. As property, then, they were treated as spoils of war in the same way that other chattels captured in war would have been treated. ${ }^{297}$ Directly correlative to the prize theory of rape, is the practice of using the licence to rape as inducement to future recruits. For instance, there is evidence tending to show that the prospect of sexual violence was held out as 'an inducement to encourage Marines to volunteer for Vietnam. ${ }^{298}$

And you may use the plunder the Lord your God gives you from your enemies': Deuteronomy 20:I4. In the same vein, the author of that thought continues: 'When you go to war against your enemies and the Lord your God delivers them into your hands and you take captives, if you notice among the captives a beautiful woman and are attracted to her, you may take her as your wife. Bring her into your home and have her shave her head, trim her nails and put aside the clothes she was wearing when captured. After she has lived in your house and mourned her father and mother for a full month, then you may go to her and be her husband and she shall be your wife. If you are not pleased with her, let her go wherever she wishes. You must not sell her or treat her as a slave, since you have dishonoured her': Deuteronomy 2I:IO-I4. See also Brownmiller, supra, p 33.

295 See Grossman, supra, p 2II.

296 During the Sierra Leone civil war, the regime of 'forced marriage' was indeed highly organized by the rebels under a hierarchy coordinated by Santigie Bobor Kanu, the third defendant, who was a high-ranking member of the rebel forces. A woman known as 'Mammy Queen' assisted Kanu in the administration of the forced marriage system. The system included the following: written disciplinary orders issued by Kanu to regulate the conduct of the abducted women; upon the abduction of women following a military operation, subordinate commanders were required to 'sign for' the abducted women; either party to the 'forced marriage' was required to notify Kanu of any problem between them, Kanu would in turn refer the matter to the 'Mammy Queen'; if the 'wife' was adjudged guilty of misbehaviour, Kanu would order the imposition of a corporal punishment against her or a period of detention in a rice storage box. See Prosecutor v Brima, Kamara and Kanu (Judgment) 20 June 2007 [SCSL Trial Chamber], paras 233, 523-526. See also Prosecutor v Brima, Kamara and Kanu (Judgment) 3 March 2008 [SCSL Appeals Chamber] paras 190-I9I.

297 Brownmiller, supra, p 35.

298 Bourke, supra, p 367. 
Yet another manner in which sexual assault may be viewed as necessary for effective combat performance is derived from the combat ruthlessness of fighters who have crossed the Rubicon of morality, as it were. These are fighters who, like Dr Faustus, have made a pact with the Devil for the power of the feeling and perception of deadly effectiveness in battle. This derives from the phenomenon which Grossman describes as 'killing empowerment'. ${ }^{299}$ This source of empowerment comes from the moment when the perpetrator, faced with the stark choice between committing the atrocity or refraining, makes the choice that leads him to resolve within himself that he is justified in committing the atrocity. Grossman outlines the resolution of this dissonance in the following way:

The soldier who does kill must overcome that part of him that says that he is a murderer of women and children, a foul beast who has done the unforgiveable. He must deny the guilt within him, and he must assure himself that the world is not mad, that his victims are less than animals, that they are evil vermin, and that what his nation and leaders have told him to do is right.

He must believe that not only is this atrocity right, but that it is proof that he is morally, socially, and culturally superior to those whom he has killed. It is the ultimate act of denial of their humanity. It is the ultimate act of affirmation of his superiority. And the killer must violently suppress any dissonant thought that he has done anything wrong. Further, he must violently attack anyone or anything that would threaten his beliefs. His mental health is totally invested in believing that what he has done is good and right.

It is the blood of his victims that binds and empowers him to even greater heights of killing and slaughter. ${ }^{300}$ [Emphases received.]

Although the references in this explanation relate to killing, there is no doubt that it applies with greater force to the evil of sexual violence, especially when sanctioned in any way as policy.

Third, sexual violence against women has also been identified as a form of social glue that aids in the bonding process of esprit de corps of men-at-arms. ${ }^{301}$ It is said to be commonly found in scientific studies that the "bonds combat soldiers form with one another are stronger than the bonds most men have with their wives. ${ }^{302}$ And among men who are thus so intensely bonded together, 'there is a powerful process of peer pressure in which the individual cares so deeply about his comrades and what they think about him that he would rather die than let them down. ${ }^{303}$ Thus, it is extremely difficult for a man who is so bonded to break away and openly refuse to participate in what the group is doing, 'even if it is killing

299 Grossman, supra, pp 208-210.

300 Ibid, pp 209-210.

3 I Ibid, pp 2IO-2II.

$302 \mathrm{Ibid}, \mathrm{p}$ I49.

303 Ibid, p 150. 
innocent women' ${ }^{304}$ or, of course, committing sexual assault against them. One sees an illustration of precisely this phenomenon in Chimamanda Ngozi Adichie's novel Half of a Yellow Sun, an epic set in the Biafran civil war. In one incident, the lovable character Ugwu, now a conscript in the Biafran army, ultimately succumbs to the pressure to participate in the gang rape of a female victim, though he initially resists. These theories of deep bonding among men-at-arms are not lost in significance to the concept of systematic condonation of, or connivance in, sexual violence committed by one or more of them. Of particular significance is the view of the bonding as involving deep caring of the individual for his comrades at a level that may be stronger than the bond with his own wife. In some legal systems, spouses are not compellable witnesses against one another, in recognition of the need to preserve the bond of marriage between them. A similar instinct, expressed as 'group absolution', ${ }^{305}$ would readily explain why some militaries find it easier to condone systematically the atrocity of sexual violence committed by their troops.

A direct effect of all this, which shores up the perception of policy by participants and observers alike, is that soldiers were encouraged to not fear punishment for sexual violence ${ }^{306}$ and to consider sexual violence as 'authorised transgression'..$^{307}$

References to the conduct of some renegade American soldiers in Vietnam, are by no means intended to denigrate that military establishment or to encourage smugness on the part of other nations' soldiers. It rather strikes a chilling note on the issue of sexual violence against women during armed conflicts in the modern age. If the American military-with a reputation as some of the finest, the most professional and the most disciplined in the world - could number among it troops who are so frequently implicated in the evil of sexual violence during armed conflicts in the modern age, a most cautious eye must then be kept on the average fighter in less disciplined and professional militaries. It thus heightens the urgent need for increased vigilance and legal responses to the evil under consideration.

From these reviews one finds the reasons for sexual violence during armed conflicts fitting snugly within the pattern of the wider pathogen of evil during armed conflicts. That is to say: as with the wider pathogen of evils, the cocktail of sexual violence during armed conflicts includes conducts accepted as necessary evil authorised and promoted by those in responsible command of the relevant armed forces (such as in the case of sexual violence as incidents of policy); as well as conducts (such as opportunistic acts of sexual violence) viewed as aberrant and evidently unauthorised and unnecessary evil perpetrated by insufficiently controlled rogue fighters trained, armed and mobilised by those in responsible command of the relevant armed forces.

In view of the need to understand evil in order to design adequate response for it, very careful consideration must then be given to the need to review the

304 Ibid, p 225.

305 Ibid, p r5I.

$306 \mathrm{Ibid}, \mathrm{p} 368$.

307 Ibid, p 366, quoting Mikhail Bakhtin, Rabelais and His World (translated by Helen Iswolsky) [Bloomington: Indian University Press, I985]. 
development of international criminal law in the area of jurisprudence relating to sexual violence. Of particular note in this connection is responsibility of the superior for sexual crimes committed by subordinates, as considered in Chapter 2 below. The need for this careful consideration is particularly critical given the new theory of connivance and condonation identified and articulated above.

\section{Conclusion}

In view of the foregoing, the question remains: how well has international law acquitted itself in the task of containing the evil of sexual violence, thus affording better protection for women caught up in armed conflicts?

From the outset, the point may be made that despite the constancy of the problem, there remains a yawning gap between the mischief and the responses to it in international law. To be clear, the charge here is not that international law does not prohibit sexual violence. Quite the contrary, there is an impressive body of formal prohibition'. ${ }^{308}$ But the lesson to be drawn from the unabated regularity of sexual violence in armed conflicts is that there remains much to do on the part of those who make and apply international law, in order to address the problem from the perspective of prevention or containment.

Since the I990s, however, there has been renewed interest in the subject, chiefly due to the efforts of women in international law. The catalyst-nay, opportunity for this renewed interest has principally been afforded by the work of the modern generation of international criminal courts. ${ }^{309}$ Their jurisprudence and constitutive instruments have afforded an opportunity for continued exploration of ways of making international law more responsive to the need for greater protection of women during armed conflicts. The present study is but one modest instance of such continued exploration.

This study will presently engage a review and analysis of recent developments in international criminal law from the perspective of sexual violence against

308 Chinkin, supra. See also Theodor Meron, 'Rape as a Crime under International Humanitarian Law' (1993) 87 American Journal of International Law 424. Some of the provisions regarding rape are as follows: the obligation of special respect and protection for women, especially regarding rape and kindred abuses [art 27 of the I949 Geneva Convention Relative to the Protection of Civilian Persons in Time of War and art 76 of the 1977 Additional Protocol I to the Geneva Conventions]; rape and kindred offences as forbidden acts and war crimes [art 8(2)(b)(xxii) and art 8(2) (e)(vi) of the International Criminal Court Statute (international armed conflicts), art $4(\mathrm{e})$ of the ICTR Statute, and art 4(2)(e) of the 1977 Additional Protocol II to the Geneva Convention]; rape and kindred offences as crimes against humanity, when committed as part of a widespread or systematic attack against a civilian population $[\operatorname{art} 7(\mathrm{I})(\mathrm{g})$ of the ICC Statute, art $3(\mathrm{~g})$ of the ICTR Statute, and art $5(\mathrm{~g})$ of the ICTY Statute.]

309 See Susana SáCouto, 'Advances and Missed Opportunities in the International Prosecution of Gender-based Crimes' (2007) I5 Michigan State Journal of International Law 137 at I39. 
women during armed conflicts, with the view to improving the ability of international law to protect women within the framework of modern international law.

Available literature, much of which have been reviewed in this discussion, canvasses a multitude of theories that seek to explain the reign of evil during armed conflicts-either from the perspective of general deviltry during armed conflicts or as a matter of sexual violence against women as a particular brand of evil prevalent in war. The understanding of evil that is facilitated by these theories will assist the framers of legal policy in the shaping of appropriate legal norms. It will also aid judges in the fashioning of appropriate sentences following convictions. But beyond all those positive values for these theories lies an elementary call. It is that international law must afford better protection for women against sexual violence during armed conflicts, notwithstanding the reasons for the violence. In order to achieve the required optimum scheme of protection, there is need for careful consideration of not only relevant aspects of substantive legal principles, but also procedural rules. The deficiencies discussed in this study include absence of rules; missed opportunities to adapt existing rules at all or sufficiently or to give them the desired scope; over-enthusiasm to stretch existing rules in ways that exacerbate the more fundamental problem of a lacuna in need of rectification by the international community. 
Chile Eboe-0suji - 978-90-04-22722-4 Downloaded from Brill.com $04 / 26 / 2023$ 12:45:46PM via free access 


\section{Chapter 2}

\section{Superior Responsibility for the Rape of Women during Armed Conflicts}

'Power without responsibility: the prerogative of the harlot throughout the ages.'

—Rudyard Kipling.

\section{Introduction}

As observed above, the constancy of the evil of sexual violence during armed conflicts is not explained by the uniform failure of international law to proscribe such conducts. For, there is indeed an 'impressive body of formal prohibition'. The punitive potentials of international law in this respect is, perhaps, best illustrated by the rather unusual case of Pauline Nyiramasuhuko, the Rwandan genocide-era Minister of Family and Women's Development. She was convicted by an ICTR Trial Chamber, on 24 June 201 , for crimes including rapes of her fellow women. Notably, that conviction hinged upon the theory of superior responsibility in respect of those rapes - committed by her male Interahamwe subordinates. ${ }^{2}$ The problem rather is that compared to the unabated regularity of sexual violence in armed conflicts, there remains a gap between the problem and the norms needed to address it in a manner that could better protect women against the identified vice. In this regard, one area of solutions that requires a second look is the area of superior responsibility for rapes committed by subordinates.

The purpose of this chapter is to consider that question. The discussions here will entail a review of the current state of international law and what more could be done to address the identified problem.

I Chinkin, supra. See also Meron, supra. As has already been observed, the proscriptions against rape include: the obligation of special respect and protection for women, especially regarding rape and kindred abuses [art 27 of the 1949 Geneva Convention Relative to the Protection of Civilian Persons in Time of War and art 76 of the 1977 Additional Protocol I to the Geneva Conventions]; rape and related offences as forbidden acts and war crimes $[$ art $8(2)(\mathrm{b})(\mathrm{xxii})$ and art $8(2)(\mathrm{e})(\mathrm{vi})$ of the International Criminal Court Statute (international armed conflicts), art 4 (e) of the ICTR Statute, and art 4(2)(e) of the 1977 Additional Protocol II to the Geneva Convention]; rape and related offences as crimes against humanity, when committed as part of a widespread or systemic attack against a civilian population [art $7(\mathrm{I})(\mathrm{g})$ of the ICC Statute, art $3(\mathrm{~g})$ of the ICTR Statute, and art $5(\mathrm{~g})$ of the ICTY Statute.]

2 Prosecutor $v$ Nyiramasubuko et al (Judgment and Sentence) delivered on 24 June $201 \mathrm{I}$ [ICTR Trial Chamber]. 


\section{The Law as It Should Be}

Given the overabundant evidence of the rape of women throughout the history of armed conflicts, there seems little doubt that the following simple proposition must by now be a reasonable one in the mind of the average reasonably informed person: women are always at risk of rape during periods of armed conflicts. If that be the case, that reality ought to follow the law into the mix of what is considered in assessing the responsibility of superiors whose subordinates have committed rape.

In this connection, the motive for such rapes need not derive from the deliberate policy of a party to the conflict in question; although the range of policy theories canvassed in Chapter $\mathrm{I}$ is wide and varied enough to implicate the average superior in the sexual violence committed by the subordinate. It should be sufficient that there is a general apprehension in the average mind that some armsbearing men, even purely on a frolic of their own, might exploit the opportunity ${ }^{3}$ of war (or other forms of armed conflict) to rape vulnerable women. The test should perhaps be this: would the average person habour a primal fear for the sexual-oriented safety of a female relative or friend, upon, say, receiving news that she had been confronted by a band of armed men, in an environment of armed conflict?

The historical frequency warranting the reasonableness of this general apprehension makes no distinction as to the reasons for the feared rape. In other words, the historical instances where rapes had been used as a weapon of war do combine with the instances where they had resulted from criminal opportunism, an evolutionary conditioning of men, etc, to raise this general apprehension in the average mind.

The question then arises: what does this mean within the context of the responsibility of a superior for the rapes committed by his men in times of conflict? The answer is this. There should be a resulting legal duty of due diligence on the superior that is more exacting than what currently obtains. This enhanced duty of due diligence will require the superior to take reasonable measures at all times - even before imminent danger of the risk arises - to prevent his armed men from committing acts of sexual violence against women during armed conflicts. It is not enough that the offender is 'properly hanged' after the fact, as General Patton would have it. For obvious reasons, it is far better for all that the rapes are prevented in the first place and that the hangings are avoided, than to hang someone after they have already raped.

This standard of protection in international law no doubt finds support in the following clarion call in a resolution of the Parliamentary Assembly of the Council of Europe: ' $[\mathrm{I}] \mathrm{n}$ view of the number of rapes in armed conflicts ... better legal protection of women is more necessary than ever, ... such protection must

3 United Nations, Basic Security in the Field-Staff Safety, Health, and Welfare: a CD-ROM Course <http://www.christie.ab.ca/htmlsite/webBSITF.htm>. See also United Nations, Security Awareness: An Aide-Mémoire (1995), p I6. 
apply in all circumstances.'4 It is submitted that one way through which such better protection may be achieved would be to consider the responsibility of the superior for failing to take reasonable measures at all times to prevent an obvious danger. That responsibility is sufficiently compelling in view of the theories which would attribute the rampancy of sexual violence during armed conflicts to individualistic opportunism, inevitability or evolution. And the responsibility is even more compelling given theories of policy, including condonation or connivance, as explaining the rampancy of sexual violence during armed conflicts.

\section{The Law as It Is}

Regrettably, however, international criminal law as it is, does not, as will be seen shortly, require a superior to put in place at all times such reasonable measures as will ensure that subordinates do not commit sexual violence against women.

The similarly worded Statutes of the International Criminal Tribunals for Rwanda and for the former Yugoslavia, for example, do not permit a superior to escape criminal responsibility for the crimes of a subordinate. But this is the case only if the superior "knew or had reason to know that the subordinate was about to commit such acts or had done so and the superior failed to take the necessary and reasonable measures to prevent such acts or to punish the perpetrators thereof.' ${ }^{5}$ This provision was undoubtedly inspired by article 86(2) of Protocol Additional to the Geneva Conventions of I2 August 1949 (Protocol I) which provides as follows:

The fact that a breach of the Conventions or of this Protocol was committed by a subordinate does not absolve his superiors from penal or disciplinary responsibility, as the case may be, if they knew, or had information which should have enabled them to conclude in the circumstances at the time, that he was committing or was going to commit such a breach and if they did not take all feasible measures within their power to prevent or repress the breach.

Article 28 of the Rome Statute introduces new twists to the regime of superior responsibility. To begin with, the article separates superior responsibility into military-type and non-military-type hierarchies. For both types, there is criminal responsibility accruing to the superior who failed to take all necessary and reasonable measures within his or her power to prevent foreseeable crimes of subordinates or repress those in progress. And for both types of superiors, the test of foreseeability is limited by the same undesirable language of immediacy: that the subordinates 'were committing or about to commit such crimes.' But the critical twist appears in the different treatment given to the two types of superiors. For the military-type superior, the duty to take all necessary and reasonable measures to prevent or repress arises if (s)he knew or owing to the circumstances prevailing at the time, ought to have known, that the crimes were about to be committed or

4 Council of Europe (Parliamentary Assembly), Resolution I2I2 of 2000, supra, para 7.

5 Art 6(3) of the ICTR Statute; art 7(3) of the ICTY Statute. 
were being committed. And for the non-military-type superior, responsibility is further limited in that the duty to prevent or repress crimes arises if (s)he knew or consciously disregarded information which clearly indicated that the subordinates were committing crimes or about to commit them.

It is within statutory frameworks such as these that the responsibility of a superior for the rapes committed by subordinates is currently assessed. And it is fairly apparent that, within these statutory frameworks, the criminal responsibility of the superior for rapes committed by his subordinates does not depend on the general risk of rape to which women are exposed during armed conflicts. In other words, there is no general duty upon a superior at all times to prevent his subordinates from committing sexual violence against women.

The language of relevant instruments of international law, as typified by the ICTR, the ICTY and the ICC Statutes, do clearly indicate that the earliest point at which the superior's duty to prevent the sexual violence (hence his criminal responsibility for failing so to prevent) is engaged only when the subordinate is 'about to commit' the act, and extends to when he is 'committing it'. This requires an immediate connection between the particular subordinate(s) at the particular time and the particular rape committed. As an ICTY Trial Chamber noted in the case of Kordic E Čerkez:

The duty to prevent should be understood as resting on a superior at any stage before the commission of a subordinate crime if he acquires knowledge that such a crime is being prepared or planned, or when he has reasonable grounds to suspect subordinate crimes. ${ }^{6}$ [Emphases added.]

Prior to the Rome Statute, the clearest legal statement on the point was that contained in Article 6 of the Draft Code of Crimes against the Peace and Security of Mankind, adopted by the International Law Commission at its forty-eighth session. It states as follows:

The fact that a crime against the peace and security of mankind was committed by a subordinate does not relieve his superiors of criminal responsibility, if they knew or had reason to know, in the circumstances at the time, that the subordinate was committing or was going to commit such a crime and if they did not take all necessary measures within their power to prevent or repress the crime. ${ }^{7}$ [Emphases added.]

It is thus amply clear that the superior's responsibility for sexual violence against women is not engaged until a time immediately before the crime.

6 Prosecutor v Kordić \& Čerkez (Judgment) 26 February 20oI [ICTY Trial Chamber], para 445 .

7 Yearbook of the International Law Commission (1996), Vol II, Part Two, Report of the Commission to the General Assembly on the Work of its Forty-eighth Session (A/51/10), p 25. 


\section{The Requirement of Knowledge}

It is undoubtedly this requirement of immediate connection between the particular subordinates at the particular time and the particular rape that has generated the extensive jurisprudence at the ad hoc Tribunals on the subject of knowledgeactual or constructive - of the superior and the difficulties regarding its proof. ${ }^{8}$ It has also been a central focus of much commentary.9 According to this line of jurisprudence, the requirement of knowledge is satisfied only if information was available to [the superior] which would have put him on notice of offences committed by subordinates.' ${ }^{\mathrm{I}} \textrm{ }$

8 See Kai Ambos, 'Superior Responsibility' in Antonio Cassese et al (eds), The Rome Statute of the International Criminal Court: A Commentary [London: Oxford University Press, 2002] Vol I, 823 at $\mathrm{p} 834$.

9 For instance, see generally, Guénaël Mettraux, The Law of Command Responsibility [Oxford: Oxford University Press, 2009]; Ilias Bantekas, 'The Contemporary Law of Superior Responsibility' (1999) 93 American Journal of International Law p 573; Nicole Laviolette, 'Commanding Rape: Sexual Violence, Command Responsibility, and the Prosecution of Superiors by the International Criminal Tribunals for the Former Yugoslavia and Rwanda' (I998) 36 Canadian Yearbook of International Law 93; Timothy Wu and Yong-Sung (Johnathan) Kang, 'Criminal Liability for the Actions of Subordinates-the Doctrine of Command Responsibility and Its Analogues in United States Law' (1997) 38 Harvard International Law Journal 272; Jia Bing Bing, 'The Doctrine of Command Responsibility: Current Problems', (2000) 3 Yearbook of International Humanitarian Law I3I; Mirjan Damaška, 'The Shadow Side of Command Responsibility' (200I) 49 Am J Comp L 455; William Schabas, 'Mens Rea and the International Criminal Tribunal for the Former Yugoslavia', (2003) 37 New England Law Review Ior5; Jia Bing Bing, 'Doctrine of Command Responsibility Revisited' (2004) 3 Chinese Journal of International Law I; Arthur O'Reilly, 'Command Responsibility: A Call to Realign the Doctrine with Principles' (2004-2005) 20 American University International Law Review 71; Allison Danner and Jenny Martinez, 'Guilty Associations: Joint Criminal Enterprise, Command Responsibility, and the Development of International Criminal Law' (2005) 93 California Law Review 75; Beatrice Bonafé, 'Finding a Proper Role for Command Responsibility', (2007) 5 Journal of International Criminal Justice 599; Chantal Meloni, 'Command Responsibility: Mode of Liability for the Crimes of Subordinates or Separate Offence of the Superior?' (2007) 5 Journal of International Criminal Justice 619; Volker Nerlich, Superior Responsibility under Article 28 ICC Statute: For What Exactly is the Superior Held Responsible?'(2007) 5 Journal of International Criminal Justice 665; Jenny Martinez, 'Understanding Mens Rea in Command Responsibility: From Yamashita to Blaškić and Beyond' (2007) 5 Journal of International Criminal Justice 628; Yaël Ronen, 'Superior Responsibility of Civilians for International Crimes Committed in Civilian Settings' (2010) 43 Vanderbilt Journal of Transnational Law 313; and Nicholas Tsagourias, 'Command Responsibility and the Principle of Individual Criminal Responsibility: a Critical Analysis of International Jurisprudence' in C Eboe-Osuji, Protecting Humanity [Leyden: Martinus Nijhoff: 20I0] 817.

See Prosecutor v Delalić (Judgment) 20 February 200I para 24I [ICTY Appeals 
Quite naturally, knowledge, in these circumstances, is an active notion whose ability to assist in the protection of women is relative, largely depending upon the dynamics of the situation at hand. This makes the duty of protection as vulnerable as the inherent limitations of those dynamics. For these reasons, this scheme of legal duty becomes deficient in my view. ${ }^{\text {II }}$

Considering that current authoritative legal statements tend to require this immediate connection between the particular subordinate(s) at the particular time and the particular rape committed, it might seem rather tenuous, at present, to anchor the responsibility of the superior upon the more desirable scheme of a larger theory of foreseeability discussed earlier. ${ }^{12}$

This apparent deficiency in international law has been brought home in some of the judgments of the ICTR. Although in Akayesu, ${ }^{13}$ an ICTR Trial Chamber had found the accused guilty of rape of particular Tusti women, it is clear that the conviction was based on the fact that the Accused had been heard clearly encouraging and ordering assailants to rape Tutsi women. ${ }^{\text {I4 }}$ In instances where there had been no clear words from the accused implying a grant to subordinates of the licence to rape, the Chamber had been reluctant to find him criminally responsible for any ensuing rape. The following pronouncement in the Akayesu case illustrates this reluctance:

In considering the role of the Accused in the sexual violence which took place and the extent of his direct knowledge of incidents of sexual violence, the Chamber

Chamber]. See also Delalić, supra, para 383-393 [Trial Chamber].

II Possibly worse still, in regard to rape, is the provision of the ICC Statute with respect to the responsibility of a civilian superior. While the responsibility of a military commander arises where " $t$ ] hat military commander or person [effectively acting like a military commander] either knew or, owing to the circumstances at the time, should have known that the forces were committing or about to commit such crimes', the responsibility of a civilian superior must meet a higher threshold. His criminal responsibility arises only when he 'either knew, or consciously disregarded information which clearly indicated, that the subordinates were committing or about to commit such crimes.' Though unlikely, it is not clear that this higher threshold will not avail a civilian superior who is a leader of a band of militia, such as the Interahamwe of the Rwandan Genocide fame, who had been actively involved in attacks against civilians, although it is also probable that he would be treated as a 'person acting effectively in the position of a military commander'. As the ICC Statute now stands, such a leader may only be criminally responsible for rape, only if he knew or deliberately disregarded information clearly showing that a rape was being committed or was about to be committed.

I2 See discussion under the subheading 'The Law as It Should Be.'

I3 Prosecutorv Akayesu, supra, paras 422, 452, 706 and 73-733.

I4 He had been heard saying to the assailants, 'Never ask me again what a Tutsi woman tastes like;' and 'you should first of all make sure that you sleep with this girl' referring to a Tutsi woman whom he had ordered his subordinates to kill. Akayesu, supra, paras 422 and 452 . 
has taken into account only evidence which is direct and unequivocal. Witness $\mathrm{H}$ testified that the Accused was present during the rape of Tutsi women outside the compound of the bureau communal, but as she could not confirm that he was aware that the rapes were taking place, the Chamber discounts this testimony in its assessment of the evidence. Witness PP recalled the Accused directing the Interahamwe to take Alexia and her two nieces to Kinihira, saying "Don't you know where killings take place, where the others have been killed?" The three women were raped before they were killed, but the statement of the Accused does not refer to sexual violence and there is no evidence that the Accused was present at Kinihira. For this reason, the Chamber also discounts this testimony in its assessment of the evidence. ${ }^{15}$ [Emphases added.]

Similarly, in Kajelijeli, another Trial Chamber found that the accused had ordered assailants to exterminate Tutsis, ${ }^{16}$ but declined to find the accused guilty of the rapes of Tutsi women committed as part of that order to exterminate. This was because the accused had not ordered the assailants to commit the collateral crime of rape. As the Chamber put it:

[...] After careful consideration of the evidence presented at trial the Chamber is convinced that Witness GDT was raped by members of the Interahamwe on 7 April 1994 in Susa secteur, Kinigi Commune. It is not in contention that the Accused was not present at the scene of the rape of GDT. The Chamber finds, by a majority, Judge Ramaroson dissenting, that the Prosecution did not prove that the Accused issued a specific order to rape or sexually assault Tutsi women in Susa secteur, Kinigi Commune on that day. ${ }^{17}$

Had international law required the superior to put in place at all times reasonable measures to prevent subordinates from raping women, the issue in Akayesu and Kajelijeli would have been whether the Accused had put those measures in place when they ordered the killing of Tutsis in an armed conflagration of the type in which assailants are known typically to commit rape. That they did not actually order or instigate the rapes would have been immaterial to their criminal responsibility.

\section{Routes around the Difficulties of the Lex Lata}

Problematic though it is, the deficiency in the law noted here ${ }^{\mathrm{I} 8}$ is not altogether an impossible obstacle to overcome, especially at the ad hoc Tribunals. One pos-

\footnotetext{
I5 Akayesu, supra, para 451.

I6 Prosecutor v Kajelijeli, supra, para 907; see also paras 823, 825, 833, 836, 842, 856, 897, 899, 904, 905 .

I7 Ibid, para 681. See also paras 682, 683, 920, 923, 924, 936-938.

I8 Specifically, the deficiency resulting from the 'committing or about to commit' requirement.
} 
sible route around the problem will be to follow the jurisprudence of the ad hoc Tribunals in their interpretation and application of article 6(I) of the ICTR Statute and article 7(I) of the ICTY Statute. In this connection, a close look needs to be taken at the case law relating to joint criminal enterprise and ordering which are modes of responsibility covered within those provisions. Whether the law develops similarly in the relatively uncharted terrains of 'instigating' and 'aiding and abetting' remains to be seen.

Before we examine these concepts, it must be noted, however, that the assistance they offer are not perfect; for they depend on the imagination of counsel (on both sides) and the judges, as well as on the prevailing wind of jurisprudence at any particular time.

\section{Joint Criminal Enterprise}

The most obvious mode of criminal responsibility is commission, as provided for under article 6(I) of the ICTR Statute and article 7(I) of the ICTY Statute. But that concept has been expansively construed at the ad hoc Tribunals, to hold accused persons criminally responsible in ways not appearing so obvious at first. This is notably so under the doctrine of joint or common criminal enterprise. The doctrine has been pronounced upon in a number of cases reaching the Appeals Chamber of the ICTY. ${ }^{19}$ The notion was originally discussed by that Chamber in Prosecutor $v$ Tadic (Judgment). ${ }^{20}$ For present purposes, the gist of the discussion, aptly captured by Judge Hunt in a subsequent case, is as follows: ${ }^{2 \mathrm{~T}}$

6. The Appeals Chamber held that the notion of a joint criminal enterprise "as a form of accomplice liability" was firmly established in customary international law, and that it was available ("albeit implicitly") under the Tribunal's Statute. The Appeals Chamber identified three "distinct categories of collective criminality" as being encompassed within the concept of joint criminal enterprise, [fn23] although it subsequently suggested that the second category was in many respects similar to the first, and that it was really a variant of the first category. [fn25] The three categories were as follows:

I9 See Prosecutor v Tadić (Judgment) I5 July I999 [ICTY Appeals Chamber], para 185 et seq; Prosecutor v Furundžija (Judgment) 2I July 2000 [ICTY Appeals Chamber], paras II5-I20; Prosecutor v Delalic E Ors, supra, [ICTY Appeals Chamber], paras 343, 365-366; and Prosecutor v Milutinović, Šainović \& Ojdanić (Decision on Dragoljub Ojdanić's Motion Challenging Jurisdiction-Joint Criminal Enterprise) 2I May 2003 [ICTY Appeals Chamber].

20 Prosecutor v Tadić (Judgment) datedi5 July 1999 [ICTY Appeals Chamber]. See also Kai Ambos, 'Joint Criminal Enterprise and Command Responsibility' (2007) 5 Journal of International Criminal Justice 159.

2I See Separate Opinion of Judge David Hunt in Prosecutor v Milutinović, Śainović E Ojdanić (Decision on Dragoljub Ojdanic's Motion Challenging Jurisdiction-Joint Criminal Enterprise) 2I May 2003 [ICTY Appeals Chamber]. 
Category $\mathrm{r}$ : All of the participants in the joint criminal enterprise, acting pursuant to a common design, possessed the same criminal intention. The example is given of a plan formulated by the participants in the joint criminal enterprise to kill where, although each of the participants in the plan may carry out a different role, each of them has an intent to kill.

Category 2: All of the participants in the joint criminal enterprise were members of military or administrative groups acting pursuant to a concerted plan, where the person charged held a position of authority within the hierarchy; although he did not physically execute any of the crimes charged, he actively participated in enforcing the plan by aiding and abetting the other participants in the joint criminal enterprise who did execute them. The example given is of a concentration camp, in which the prisoners are killed or otherwise mistreated pursuant to the joint criminal enterprise. Category 3: All of the participants were parties to a common design to pursue one course of conduct, where one of the persons carrying out the agreed object of that design also commits a crime which, whilst outside the "common design", was nevertheless a natural and foreseeable consequence of executing "that common purpose". The example is given of a common (shared) intention on the part of a group to remove forcibly members of one ethnicity from their town, village or region (labelled "ethnic cleansing"), with the consequence that, in the course of doing so, one or more of the victims is shot and killed.

Although described in an earlier decision as a form of 'accomplice liability', ${ }^{22}$ the ICTY Appeals Chamber has subsequently clarified that joint criminal enterprise is a form of 'commission' pursuant to article 7(r) of the ICTY Statute, and not a matter of aiding and abetting. ${ }^{23}$ Clearly, all these categories are relevant to the

22 At paragraph 220 of the Tadic judgment, the ICTY Appeals Chamber put the point as follows: 'In sum, the Appeals Chamber holds the view that the notion of common design as a form of accomplice liability is firmly established in customary international law and in addition is upheld, albeit implicitly, in the Statute of the International Tribunal.' [Emphasis added.] See also paragraph 223 where the Appeals Chamber concluded that 'the mode of accomplice liability under discussion is well-established in international law and is distinct from aiding and abetting.'

23 See Prosecutor v Milutinović, Šainović É Ojdanić (Decision on Dragoljub Ojdanić's Motion Challenging Jurisdiction-Joint Criminal Enterprise), supra, [ICTY Appeals Chamber], paras I9 and 20. See also Prosecutor v Stakić (Judgment) 3I July 2003 (ICTY Trial Chamber II), para 432. This clarification is entirely consistent with the statements of the Appeals Chamber even in paragraphs 192 and 229 of their Tadic judgment. At paragraph 192, the Appeals Chamber said as follows:

Under these circumstances, to hold criminally liable as a perpetrator only the person who materially performs the criminal act would disregard the role as co-perpetrators of all those who in some way made it possible for the perpetrator physically to carry out that criminal act. At the same time, depending upon the circumstances, to hold the latter liable only as aiders and abettors might understate the degree of their criminal responsibility. 
notion of criminal responsibility for an accused in the position of a superior. In other words, if the superior is linked to his subordinates in a transactional relationship that qualifies as a joint criminal enterprise, he runs a high risk of criminal responsibility for the rapes committed by the subordinates. In view of this relationship between the notions of joint criminal enterprise and superior responsibility, Kai Ambos, aiming to avoid confusion, usefully discusses the need to keep in mind the distinct elements of the two concepts whenever they operate to govern the conduct of the same accused in relation to the same situation. In particular, he points out that the notion of joint criminal enterprise requires some form of contribution to the criminal enterprise by persons 'normally belong[ing] to the same hierarchical level and operate[ing] in a coordinated, horizontal way'; while the notion of superior responsibility hinges adequately upon the fault of criminal omission as the culpable conduct in a vertical hierarchical relationship of superior and subordinate. ${ }^{24}$ Some care is needed in the appreciation of Ambos's point, particularly as regards the factor of relationship in the respective constructs of joint criminal enterprise and superior responsibility. His thesis does not negate for all purposes the presence of a hierarchical relationship in a joint criminal enterprise. Nor does he, for all purposes, insist upon the existence of a coordinate or horizontal relationship in a joint criminal enterprise. His point is best understood as emphasising what is a compulsory element in the notion of superior responsibility such as necessarily sets it apart from joint criminal enterprise. Thus, the absence of a superior-subordinate hierarchy will negate a finding of superior responsibil-

And at paragraph 229, the Appeals Chamber said as follows:

In light of the preceding propositions it is now appropriate to distinguish between acting in pursuance of a common purpose or design to commit a crime, and aiding and abetting.

(i) The aider and abettor is always an accessory to a crime perpetrated by another person, the principal.

(ii) In the case of aiding and abetting no proof is required of the existence of a common concerted plan, let alone of the pre-existence of such a plan. No plan or agreement is required: indeed, the principal may not even know about the accomplice's contribution.

(iii) The aider and abettor carries out acts specifically directed to assist, encourage or lend moral support to the perpetration of a certain specific crime (murder, extermination, rape, torture, wanton destruction of civilian property, etc.), and this support has a substantial effect upon the perpetration of the crime. By contrast, in the case of acting in pursuance of a common purpose or design, it is sufficient for the participant to perform acts that in some way are directed to the furthering of the common plan or purpose.

(iv) In the case of aiding and abetting, the requisite mental element is knowledge that the acts performed by the aider and abettor assist the commission of a specific crime by the principal. By contrast, in the case of common purpose or design more is required (i.e., either intent to perpetrate the crime or intent to pursue the common criminal design plus foresight that those crimes outside the criminal common purpose were likely to be committed), as stated above.

24 Ambos, 'Joint Criminal Enterprise and Command Responsibility', supra, generally, especially at pp I80. 
ity: the presence of such a relationship, on the other hand, is unnecessary in a joint criminal enterprise-but does not negate it. An accused, in a superior position, who makes a positive contribution in a joint criminal enterprise that includes his own subordinates will thus become a co-perpetrator to the crime, ${ }^{25}$ with an enhanced moral fault, rather than someone guilty merely in virtue of omission.

Category 3 or the extended form of joint criminal enterprise is of special relevance in this discussion. No doubt, in determining whether the rape committed by the subordinate was a 'natural and foreseeable consequence' of executing another crime which was the object of the common enterprise, such that the superior will be held criminally responsible, the judge in the case will take into account the generalised risk of rape which the context of armed conflicts presents. It is, however, for the prosecutor to make that case.

While the ICTR and ICTY Statutes are silent on the concept of joint criminal enterprise, the ICC Statute does provide for it. Where the silence of the ICTR and ICTY Statutes on the subject had enabled the judges to construe its existence and scope within the notion of 'commit', the ICC Statute goes some way in prescribing the boundaries of the concept, thus limiting judicial ability to extend its reach by way of interpretation. In these regards, article $25(3)$ of the ICC Statute provides as follows:

3. In accordance with this Statute, a person shall be criminally responsible and liable for punishment for a crime within the jurisdiction of the Court if that person:

(a) Commits such a crime, whether as an individual, jointly with another or through another person, regardless of whether that other person is criminally responsible;

(b) Orders, solicits or induces the commission of such a crime which in fact occurs or is attempted;

(c) For the purpose of facilitating the commission of such a crime, aids, abets or otherwise assists in its commission or its attempted commission, including providing the means for its commission;

(d) In any other way contributes to the commission or attempted commission of such a crime by a group of persons acting with a common purpose. Such contribution shall be intentional and shall either:

(i) Be made with the aim of furthering the criminal activity or criminal purpose of the group, where such activity or purpose involves the commission of a crime within the jurisdiction of the Court; or

(ii) Be made in the knowledge of the intention of the group to commit the crime; 
While Categories I and 2 of the concept of joint criminal enterprise at the ad hoc Tribunals adequately fit within the general scheme of article $25(3)(d)$ of the ICC Statute, Category 3 appears a more difficult proposition. This is for the simple reason that while the essence of Category 3 is that the resulting crime was a 'natural and foreseeable consequence' of executing the group's common purpose, article $25(3)(d)$ of the ICC Statute appears on its face to require a settled intention to make some contribution to the resulting crime - and not just to the common purpose of the group. This makes it more difficult to impute to the accused a crime to which he had not intended to contribute, though the crime be a natural and foreseeable consequence of a joint criminal enterprise.

Conversely, however, it is possible to interpret article $25(3)(d)$ to the same effect as Category $3 .{ }^{26}$ This might be achieved by decoupling the mens rea of the 'contribution' from the mens rea of the actual perpetrators of the resulting 'criminal activity'. In this connection, an analogy may be drawn from the jurisprudence relating to the mens rea of an accomplice, ${ }^{27}$ in which it is settled that the mens rea of the accomplice need only be to do the actual thing that amounted to assistance; he need not have wished the crime per se. ${ }^{28}$ The analogy then is to the effect that the intention to do that which is seen as contribution to the crime [under article $25(3)(d)$ of the Rome Statute] may be treated in the same way, for purposes of mens rea, as the intention to do that which is seen as the assistance to the crime [under the jurisprudence of the ad hoc Tribunals].

From this springboard, it becomes easy to achieve a Category 3-type joint criminal enterprise, especially if it is appreciated, first, that it is sufficient that the contribution ' $[\mathrm{b}] \mathrm{e}$ made in the knowledge of the intention of the group to commit the crime'; and secondly, that the ICC Statute has left open the content of what may constitute 'contribution', hence, planning, conspiring, giving moral support, etc, are all candidates to what may constitute 'contribution'.

Alternatively, the same result may be achieved, perhaps with greater difficulty, by proceeding in the following cumulative way. By undertaking the same decoupling exercise indicated above. By stressing that the contribution need only satisfy the alternatives of furthering either the 'criminal activity' or the 'criminal purpose of the group'. By stressing that the fault element in the contribution is that 'such activity or purpose' 'involves the commission of a crime' within the jurisdic-

26 Although not specifically addressing the different types of joint criminal enterprise developed by the ICTY and ICTR judges, Schabas considers it 'plausible' that the ICC judges will be strongly influenced by the jurisprudence of the ad hoc Tribunals on the subject: William Schabas, Introduction to the International Criminal Court, 2nd edn [Cambridge, Cambridge University Press, 2004] at p I04.

27 Which is, in any event, very directly relevant to the concept of joint criminal enterprise, since a confederate in crime is an accomplice: see Schabas, supra, pp Io3 and IO4.

28 See Chile Eboe-Osuji, “Complicity in Genocide” versus "Aiding and Abetting Genocide: Construing the Difference in the Statutes of the ICTY and ICTR' (2005) 3 Journal of International Criminal Justice 56 at 63 . 
tion of the ICC. Here, the construction will turn on the significance of the word 'involves', with the following two possible jurisprudential results, inasmuch as it relates to the common purpose: (A) It is possible to take the view that 'involves', in this context, calls for no more than a subjective appraisal of the properties of the common purpose. For example, where the common purpose was to kill members of an ethnic group, men and women, the plan to kill does not involve rape of the women, if no one said anything about raping the women of the group as part of the business of killing them; and, (B) The alternative view is that the term 'involves' calls for an objective evaluation of the common purpose, including taking into account any foreseeable risk of the resulting crime, in the process of executing the common purpose. Thus, in the preceding example, one might reasonably (fore)see how it is that rape of the women might result, since the chances are great that a genocidal thug might see no objection to raping a woman who, at any rate, was to be extra-judicially killed. Clearly, the latter approach, a perfectly reasonable one to follow, will include within the scope of article $25(3)(\mathrm{d})$ of the ICC Statute the same results as seen in Category 3 of the concept of joint criminal enterprise as developed by the judges of ICTY and ICTR.

The problem with these constructions is that they rely on an analogy drawn to the jurisprudence of the ad hoc Tribunals. Objection might be taken against them for this reason, based on the fact that the ICC Statute might be taken as eschewing criminal liability by analogy. ${ }^{29}$ However, the aversion towards analogy might be correctly taken as relating only to 'definition' of substantive crimes and not to modes of attribution. Still, it could be argued that any mode of attribution that results in the imposition of a criminal liability that might not otherwise have resulted is equivalent to imposing liability for a substantive crime deduced only from a definition of a crime that has been extended by analogy. On the other hand, the sin of creation of a crime by analogy is that the deduced crime was hitherto unknown to law, while the analogy to existing jurisprudence does not suffer from the same legal flaw.

\section{Much Ado About Joint Criminal Enterprise}

The doctrine of joint criminal enterprise has not been free from controversy. ${ }^{30}$ The version of the doctrine attracting the most vigorous criticism is the extended form.

29 Specifically, article $22(2)$ provides: 'The definition of a crime shall be strictly construed and shall not be extended by analogy. In case of ambiguity, the definition shall be interpreted in favour of the person being investigated, prosecuted or convicted.'

30 See, for instance, Danner and Martinez, supra; Jens Ohlin, 'Three Conceptual Problems with the Doctrine of Joint Criminal Enterprise' (2007) 5 Journal of International Criminal Justice 69; Mark Osiel, 'The Banality of Good: Aligning Incentives against Mass Atrocity', (2005) I05 Columbia Law Review I751; Harmen van der Wilt, 'Joint Criminal Enterprise: Possibilities and Limitations' (2007) 5 Journal of International Criminal Justice 9r; Harmen van der Wilt, 'The Continuous Quest for 
Allison Danner and Jenny Martinez have described it as the 'most far-reaching aspect' of a 'wide-ranging form of liability, ${ }^{3 \mathrm{I}}$ lending support to the indignant declarations of other critics such as that '[s] uccessive rulings of the ICTY Appeals Chamber have allowed this doctrine to get wildly out of hand. ${ }^{32}$ I shall next discuss these criticisms.

The usual form of complaint is that the extended form of the doctrine unduly leans toward culpability built upon the sentiment of 'guilt by association'. The basis of this assessment is the doctrine's mainstay of aggregate or collective criminal responsibility rather than individual criminal responsibility. ${ }^{33}$ A particularly dramatic form of these criticisms appears in the extremely tough essay by Danner and Martinez tellingly entitled 'Guilty Associations: Joint Criminal Enterprise, Command Responsibility, and the Development of International Criminal Law.' In that piece, the following ominous warning was sounded:

Joint criminal enterprise provides an example of an international criminal doctrine where certain aspects of the human rights and transitional justice influences in international criminal law are in danger of overpowering the restraining force of the criminal law tradition. As currently formulated, the doctrine has the potential to stretch criminal liability to a point where the legitimacy of international criminal law will be threatened-thereby undermining not only the criminal law aims, but also the human rights and transitional justice goals of international criminal law. 34

Actually invoking 'doom' in this connection, they went on to pronounce as follows: 'Over-expansive doctrines, unbridled prosecutorial discretion, and unpersuasive judicial decision-making may still doom international criminal adjudication. ${ }^{35}$

But it may well be, upon close examination, that such levels of hyperbole really do overstated the merits of the criticism. This is especially so when the complaints are said to have been inspired by 'the criminal law tradition. ${ }^{36}$ In this regard, it must be said that although the idea of joint criminal enterprise is, as much else, a new concept in the administration of international criminal justice, given its ori-

Proper Modes of Criminal Responsibility' (2009) 7 Journal of International Criminal Justice 307; Harmen van der Wilt, 'Joint Criminal enterprise and functional perpetration' in André Nollkaemper and Harmen van der Wilt, (eds), System Criminality in International Law [Cambridge: Cambridge University Press, 2009] $\mathrm{I}_{5} 8$.

3I Danner and Martinez, supra, pp Io8 and I42.

32 John Laughland, 'Conspiracy, joint criminal enterprise and command responsibility in international criminal law' available at <www.heritagetpirdefense.org/papers/ John_laughland_Conspiracy_joint_criminal_enterprise_and_command_responsibility.pdf> $\mathrm{p} 2$.

33 Ohlin, supra, at p 70.

34 Danner and Martinez, supra, p I32.

35 Ibid, $\mathrm{p}$ I43.

$36 \quad$ Ibid, $\mathrm{p} \mathrm{I} 32$. 
gins in the I999 judgement of the ICTY Appeals Chamber in Prosecutor v Tadic, 37 the doctrine itself is a very familiar one to criminal lawyers from the common law tradition..$^{8}$ In $R v$ Powell, Lord Hutton observed that there is ' $a$ strong line of authority that participation in a joint criminal enterprise with foresight or contemplation of an act as a possible incident of that enterprise is sufficient to impose criminal liability for that act carried out by another participant in the enterprise. ${ }^{39}$ [Emphasis added.] Notably, in $R v$ Rabman, Lord Rodger of Earlsferry starkly illustrated the relevant common law principle in the following way: 'Suppose that, knowing what $\mathrm{A}$ is like and that he tends to carry a gun, $\mathrm{B}$ contemplates that $\mathrm{A}$ may take a gun and use it in the course of the attack on the victim. Then, even if $\mathrm{B}$ is vehemently opposed to the use of a gun and tries to dissuade A from carrying one, nevertheless, if, being aware of the risk, B takes part in the joint assault, he will be guilty of murder if A shoots the victim.' ${ }^{\circ}$ And in Clayton $v R$, the High Court of Australia explained the relevant principle of culpability in this way: " $[T]$ he criminal culpability lies in the continued participation in the joint enterprise with the necessary foresight ... . That the participant does not wish or intend that the victim be killed is of no greater significance than the observation that the person committing the assault need not wish or intend that result, yet be guilty of the crime of murder.'4 ${ }^{\mathrm{I}}$ [Emphasis received.]

Clearly, the principle being discussed by the House of Lords in Powell and Rahman, and the High Court of Australia in Clayton, is not at all different from the formulation of the extended form of joint criminal enterprise in international criminal law. In the Privy Council case of Chan Wing-Siu v R, Sir Robin Cooke had referred to it as the 'wider principle' of joint criminal enterprise, ${ }^{42}$ in contrast to the version of the doctrine described by Lord Hoffman, in Brown E' Isaac $v$ The

37 See Prosecutor v Tadić (Judgment) I5 July 1999 [ICTY Appeals Chamber], para I85 et seq.

38 See Johns v $R$ (1980) I43 CLR ro8 [High Court of Australia]; Chan Wing-Siu v $R$ [1985] AC r68 [Privy Council]; Hui Chi-Ming v $R$ [1992] 94 Cr App R 236 [Privy Council]; McAuliffe $v R$ (1995) I30 ALR 26 [High Court of Australia]; $R$ v Powell and English [1999] AC I, [1998] I Cr App R 26r [House of Lords]; $R$ v Rahman and Ors [2008] UKHL 45 [House of Lords]; Clayton $v R$ [2006] HCA 58 [High Court of Australia]; Gillard $v R$ (2003) 219 CLR I [High Court of Australia]; $R v$ Tomkins [I985] 2 NZLR 253 [New Zealand Court of Appeal]; $R v$ Hyde [199I] I QB I34 [Court of Appeal of England and Wales]; $R v$ Uddin [1999] i Cr App Rep 319 [Court of Appeal of England and Wales]. See also Alan Reed, 'Joint Participation in Criminal Activity' (1996) 60 Journal of Criminal Law 310; and A P Simester, 'The Mental Element in Complicity', (2006) I22 Law Quarterly Review 578.

$39 R$ v Powell, supra, $\mathrm{p} 2 \mathrm{I}$.

$40 \quad R v$ Rabman, supra, para 36.

4I Clayton v R, supra, para I7. See also Chan Wing-Siu v R, supra, at I75, where Sir Robin Cooke indicated that the 'criminal culpability lies in participating in the venture with that foresight'. 
State, at the Privy Council, as the 'plain vanilla version' 43 or the 'paradigm case' 44 of the doctrine. The 'plain vanilla' version is equivalent to the version described in Tadic as Category I of joint criminal enterprise.

In $R v$ Powell, Lord Hutton indicated that under the wider or extended principle of joint criminal enterprise, 'the scope of the common purpose is to be determined by what was contemplated by the parties sharing that purpose.' In context, the term 'contemplated' is synonymous with 'realised' or 'foresaw'.45 The accused is spared from liability only if the secondary crime committed by another member of the joint criminal enterprise is 'fundamentally different', in the sense of not being reasonably foreseen. ${ }^{46}$ The secondary crime would thus be seen as outside the scope of the joint criminal enterprise and the accused would not be guilty of the secondary crime.

Another critic, Jens Ohlin, more moderately accepts that the problems he perceives with joint criminal enterprise in international criminal law 'do not implicate the essential core of the doctrine.' ${ }^{47}$ But, he proposes a programme of reform - preferably by way of amendment to article 25 of the Rome Statute-with the view to ensuring that intentionality, foreseeability and culpability, as essential factors in the administration of criminal justice, are sufficiently reflected in the analysis and application of the doctrine of joint criminal enterprise. In that regard, the reform efforts he proposes will respectively correct the following deficiencies that he had identified as dangers in the current application of the doctrine: (a) the mistaken attribution of criminal liability to members of the joint criminal enterprise who might have made unintentional contribution towards the criminal purpose of the enterprise or those whose moral burden went no further than mere awareness of the criminal purpose, (2) the imposition of criminal liability for the foreseeable acts of one's co-conspirators, without differentiation between the penalisation of the primary perpetrator and the participant who merely ought to have foreseen the criminal act of the primary perpetrator; and (3) the 'mistaken claim that all members of a joint enterprise are equally culpable for the actions of its members. ${ }^{\prime}{ }^{8}$

It is submitted that while the concerns triggered by the extended form of joint criminal enterprise in both its doctrinal formulation and application are well intended and healthy efforts in improving international criminal justice as a relatively new human endeavour, there is no grave danger that the doctrine will turn

43 Brown E Isaac $v$ The State [2003] UKPC io [Privy Council], para i3. See also $R v$ Rabman, supra, paras 9, 33 and 52.

44 Brown E Isaac v The State, supra, para 8.

$45 R v$ Rabman, supra, para II.

$46 R v$ Powell, supra, pp I7 and 28. See also $R v$ Rahman, supra, generally; and Steve Forster, 'Joint Enterprise Liability', Criminal Law and Justice Weekly (8 August 2009) available at <www.criminallawandjustice.co.uk/index.php?/Analysis/joint-enterprise-liability.html>

47 Ohlin, supra, p 89.

48 Ibid, pp 89-90. 
into the Frankenstein's monster that some critics, such as Danner and Martinez, postulate as possessing nearby potential to eventually destroy the very essence of justice and the cause of human rights and the general legitimacy of international criminal law. It is notable, in this regard, that the Clayton litigation at the Australian High Court engaged efforts of domestic critics of the doctrine of joint criminal enterprise urging the Court to reconsider the doctrine. But the Court flatly declined the urge. The Court stated the primary reason for declining in the following way: 'contrary to the applicants' central submission, it is not demonstrated that the application of the principles [of joint criminal enterprise] has led to any miscarriage of justice in this case or, more generally, has occasioned injustice in the application of the law of homicide. The applicants pointed to no decided case said to reveal the alleged injustice. Rather, for the most part, the argument was advanced in a wholly abstract form.' ${ }^{4}$ The same is true of critics of the doctrine of joint criminal enterprise in international law.

In particular, experience would suggest that international judges have been very responsible in the way they have applied the doctrine. In contrast to Danner and Martinez, Harmen van der Wilt identifies on the part of ICTY judges, a 'restrictive approach' towards the doctrine. A development that he 'considered an honourable effort to save the ICTY from relapsing into the earlier errors of the Nuremberg Tribunal. ${ }^{\circ}$ The ICTR judges, for their part, rarely base convictions on the doctrine, even when the Prosecution had pleaded it. ${ }^{5 \mathrm{I}}$ Hence, actual experience does not bear out the fear that international judges perceive 'all members of a joint enterprise [as] equally culpable for the actions of its members. ${ }^{52}$ The reality rather is that international judges have, for the most part, tended to approach their tasks with a heightened sense of consciousness of the degrees of culpability appropriate in the assessment of the individual criminal responsibility of persons prosecuted before them..$^{53}$ It is that consciousness in the gradation of culpability that explains,

49 Ibid, para 15.

50 Van der Wilt, supra, p roo. Contrast this with the assessment of Danner and Martinez that 'when faced with decisions about how to limit the potential scope of JCE, international judges have almost invariably elected the most expansive interpretation of the doctrine': Danner and Martinez, supra, p I42.

5I In Prosecutor $v$ Zigiranyirazo, for example, the Trial Chamber founded a conviction on a theory of joint criminal enterprise, among other things: Prosecutor $v$ Zigiranyirazo (Judgment) dated I8 December 2008 [ICTR Trial Chamber]. But on appeal, the Appeals Chamber reversed the conviction and acquitted him altogether: Zigiranyirazo $v$ Prosecutor (Judgment) dated I6 November 2009 [ICTR Appeals Chamber].

52 Ohlin, supra, pp 89-9o.

53 As someone who has both prosecuted cases as senior trial counsel and senior appellate counsel respectively at the International Criminal Tribunal for Rwanda and the Special Court for Sierra Leone, as well as assisted judges in a different senior advisory capacity in the drafting of judgments in both the Trial Chambers and the Appeals Chamber at the ICTR, this author is in a position to observe how keenly aware judges are-sometimes frustratingly so-of their responsibility to ensure that an accused person receives a sentence that is appropriate to his grade of culpability. 
at least in part, the phenomenon of sentencing trend that Mark Harmon and Fergal Gaylor lament as 'ordinary sentences for extraordinary crimes'. ${ }^{54}$ They noted how light the sentences handed down at the ICTY appear in comparison to those handed down at the ICTR, for instance. ${ }^{55}$ According to the comparative statistical snapshot they provided:

At the International Criminal Tribunal for Rwanda (ICTR), 37\% of those convicted have received a life sentence. At the ICTY, just one person (I.8\% of those convicted) has received a life sentence.

A closer look at the sentencing practices of the ICTY and the ICTR reveals a considerable discrepancy in the length of sentences meted out. Of the 57 persons convicted at the ICTY, 20 persons $(35 \%)$ have received sentences of less than Io years. 28 persons (49\%) have received sentences of Io-20 years. Only nine persons ( $16 \%$ ) have received sentences above 20 years, of whom just one, as mentioned, received a life sentence. Of the 27 persons convicted at the ICTR, three persons (II\%) have received sentences of less than Io years. Five persons (I9\%) have received sentences of $10-20$ years. I9 persons (70\%) have received sentences above 20 years, of whom to received life sentences. ${ }^{5}$

Against that comparative background, they posed the question: 'Why are persons convicted of extraordinary crimes at the ICTY sentenced to such ordinary sentences? Why are many ICTY sentences, whether following a trial or a guilty plea, so much lower than those at Nuremberg, Tokyo and Arusha? ${ }^{27}$... How appallingly awful must a campaign of murder, rape and expulsion be to merit life sentences?' Harmon and Gaylor partly answered their own questions when they acknowledged that there is 'no doubt that the other courts each dealt with a graver set of crimes than the ICTY: the number of victims, of all ethnicities, murdered or criminally mistreated in Yugoslavia in the I99os was of a much lesser magnitude than those in the Nazi- or Japanese-occupied zones in the Second World War, or in Rwanda in 1994. ${ }^{5_{8}}$ But they remain unconvinced that such difference in the magnitude of the crimes should be more than 'of limited relevance to sentencing. ${ }^{59}$

A further answer, perhaps, is possible. The disparate trend of sentencing that they identified may have, it is submitted, a direct correlation with the higher frequency of use of the doctrine of joint criminal enterprise in prosecutions at the

\footnotetext{
54 Mark Harmon and Fergal Gaylnor, 'Ordinary Sentences for Extraordinary Crimes' (2007) 5 Journal of International Criminal Justice 683.

55 Ibid, pp 684-686.

56 Ibid, pp 684-685.

$57 \quad$ Ibid, pp 685-686.

$58 \quad$ Ibid, p 686.

59 Ibid.
} 
ICTY than is the case at the ICTR. ${ }^{60}$ At the ICTR, the sentences are heavier because there is heavier reliance on evidence of direct involvement of the accused persons in the commission of the offences, thus making joint criminal enterprise less necessary for convictions. ${ }^{6 r}$ In the result, the judges at ICTR have been more confident in imposing heavier sentences, reflecting that direct involvement of the accused in the commission of the offences. Notably, Harmon and Gaylor acknowledged in a footnote that reliance on joint criminal enterprise is one of the factors that could affect sentencing. ${ }^{62}$ What was missing in their analysis was the significance of that reality in explaining the disparity of sentences between the ICTR and the ICTY.

The point therefore is that it is an exaggerated criticism to suggest that the doctrine of joint criminal enterprise poses a grave risk of misleading judges of international courts into a 'mistaken claim that all members of a joint enterprise are equally culpable for the actions of its members. ${ }^{6} 3$ The reality lies more likely in the opposite direction.

Regarding the charge that the doctrine of joint criminal enterprise entails 'guilt by association', it needs to be boldly said at once that there is nothing essentially wrong with the idea of 'guilt by association'. What is wrong rather is guilt by association alone. But the doctrine of joint criminal enterprise, properly understood, does not entail guilt by association alone. I shall discuss such proper understanding next.

In this connection, it is possible to observe that so much of the criticism alleging 'guilt by association' reveals a tendency either to miss the significance of the adjective criminal in 'joint criminal enterprise' or to project a dangerously relaxed view of the role of criminal law in the ordering of society, by adopting a tunnel vision of the notion of individual culpability. Ohlin errs on the first count-when he illustrates his motivating worry by the fear that 'merchants providing mere background services should not be charged with the crimes of their customers.' ${ }_{4}$ [Emphasis added.] And Danner and Martinez are guilty of the latter error in their

6o See Allison Danner, 'Joint Criminal Enterprise' in Cherif Bassiouni, International Criminal Law 3rd edn [Leyden: Martinus Nijhoff, 2008] vol III, p 483. The experience of the present author is a case in point. In the prosecution of the Semanza case, in which this author appeared as senior prosecution counsel, joint criminal enterprise was pleaded in the indictment, as a mode of liability. However, in light of the ample evidence of the direct involvement of the accused in the crimes-including direct evidence of genocidal intent on his part-it was deemed unnecessary to emphasise joint criminal enterprise as a mode of responsibility in the case.

6I In Rwamakuba, for instance, the Prosecution withdrew their case of joint criminal enterprise and relied instead on a direct responsibility of André Rwamakuba: Prosecutor v Rwamakuba (Judgment) 20 September 2006 [ICTR Trial Chamber] paras $2 \mathrm{I}-23$.

62 Harmon and Gaylor, supra, footnote iI7.

63 Ohlin, supra, pp 89-9o.

64 Ohlin, supra, p 89. 
conceptualization of the notion of individual culpability, as bearing a near exclusive 'focus on individual wrongdoing as a necessary prerequisite to the imposition of criminal punishment. ${ }^{65}$ But such a view of the notion of individual culpability strangely ignores the gaseous effects of particular wrongdoings beyond their own immediate compartments. In this connection, one must note Van der Wilt's wholly useful caution against 'a one-sided emphasis on personal guilt' such as 'may obscure the collective dimension of system criminality.' ${ }^{66}$ Van der Wilt's caution is consistent with the following explanation of joint criminal explanation offered by Lord Bingham of Conrnhill in Rahman: 'In the ordinary way a defendant is criminally liable for offences which he personally is shown to have committed. But, even leaving aside crimes such as riot, violent disorder or conspiracy where the involvement of multiple actors is an ingredient of the offence, it is notorious that many, perhaps most, crimes are not committed single-handed. Others may be involved, directly or indirectly, in the commission of a crime although they are not the primary offenders. Any coherent criminal law must develop a theory of accessory liability which will embrace those whose responsibility merits conviction and punishment even though they are not the primary offenders. ${ }^{\prime} 7$ [Emphasis added.]

In my view, a correct understanding of the doctrine of joint criminal enterprise lies in a distinct appreciation that there is jural significance in the idea of a difference between a joint enterprise that is criminal by definition, and a joint venture that is perfectly legitimate. That is to say, a distinction needs to be made between a legitimate purpose in which a partner commits a crime, and a criminal purpose in which a confederate commits a different crime. $\mathrm{A}$ and $\mathrm{B}$ are not in the same league of social conduct if $\mathrm{A}$ is accused of rape-on a theory of joint criminal enterprise - on grounds that he had embarked upon robbery of an undergraduate female hostel in the middle of the night, with a gang including young men he knew to be rape ex-convicts, one of whom ended up raping one of the victims. B, for his part, is a kitchen utensils dealer in the business of selling extremely sharp Wüsthof meat-cleavers, one of which was used by his mentally unstable partner to murder a customer. A clearly had embarked upon a joint criminal enterprise (the midnight robbery) and $\mathrm{B}$ had been involved in a purely legitimate business enterprise (selling kitchenware, including extremely sharp meat-cleavers). The assessment of the liabilities of A and B for the foreseeable conducts of their partners will take off from different places on the scale of social acceptability of the underlying

65 Danner and Martinez, supra, p 82.

66 Van der Wilt, supra, p Io8. He also usefully reminds us that 'criminal law derives its existence from the legal and moral authority of states to protect society and its members against anti-social and disruptive behaviour, and it focuses on individual responsibility and guilt': ibid, p 9r. Connecting these two observations from Van der Wilt, a third proposition becomes that the protective work of criminal law could not be done effectively by way of strict compartmentalisation that prevents it from permitting or giving penal significance to the existence of the jural link of foreseeability between two crimes.

67 Rahman, supra, para 7 . 
activities, in the sense that $\mathrm{A}$ had been involved in a criminal undertaking to begin with, and B had not been.

The principle of public policy reflected in the mental element requirement of the extended form of joint criminal enterprise is equally reflected in the mental element requirement of culpable homicide. In murder, the mental element ranges from premeditation, at the higher end, down to 'wicked and corrupt disregard of the lives and safety of others. ${ }^{68}$ Particularly notable is the tainting role of illegality in characterising a conduct as criminal. Notably, a person is guilty of murder, if death is caused by means of an act done in the prosecution of an unlawful purpose, which act is of such nature as to be likely to endanger human life; ... In [that] case it is immaterial that the offender did not intend to hurt any person.' ${ }^{69}$ [Emphasis added.] It is no doubt the prevalence of principles of criminal law like these that led Gerhard Werle and Florian Jessberger correctly to observe that in the realms of domestic and international law, 'under the concepts of recklessness or dolus eventualis, the perpetrator's awareness merely of the risk that a particular consequence may occur is generally sufficient to establish criminal responsibility. ${ }^{\circ}$

Approached differently, it may be possible to understand the issues better if they are viewed from the perspective of a certain tension between two interests: the interest of a subject in pursuing a primary purpose versus the interest of the policy maker in stopping him. In the ordering of society, using the criminal law, ${ }^{7 \mathrm{~T}}$ policy makers have a proper function in aiming to discourage unlawful undertakings or participation in primary criminal enterprises that entail the foreseeable risk of certain secondary crimes. The subject, on the other hand, has no right to engage in such unlawful undertakings or primary criminal enterprises. Hence, the dictates of morality, public policy and criminal law do combine to require the subject to abandon such unlawful undertakings or primary criminal enterprises. In persisting, he assumes the risk of the foreseeable secondary crime. The resulting legal order is appreciably different from a situation in which the subject has the right to engage in the pursuit of a purely legitimate enterprise by way of a joint venture, though there is a foreseeable risk that an associate in the undertaking may engage in a secondary activity that is criminal. As the subject has a perfectly legitimate interest or right in pursuing the joint venture, there is no requirement on him to abandon it on account of the risk of an associate's foreseeable secondary activity that is criminal. The attendant concern of morality, public policy and criminal law, in the second scenario, becomes the question of the subject's contribution to the secondary activity that is a crime- assessed at the level of that activity —or his duty (to the extent that it exists) to prevent or punish its occurrence.

68 See Prosecutor v Delalić \& Ors (Judgment) I6 November 1998 [Trial Chamber] para 434.

69 See Section 316 of the Nigerian Criminal Code and s 302 of the Criminal Code of Queensland, Australia (I899). See also s 229(c) of the Canadian Criminal Code, and §210.2(I)(b) of the US Model Penal Code.

70 Gerhard Werle and Florian Jessberger, Principles of International Criminal Law [The Hague: T M C Asser Press, 2005], para 307.

7I See Van der Wilt, supra, p 9I. 
Ohlin recommends a reform of the law of joint criminal enterprise in the terms of requiring a 'substantial and indispensable' contribution to the criminal enterprise. ${ }^{72}$ Danner and Martinez, for their part, insist that the continuing legitimacy of the doctrine of joint criminal enterprise depends upon a reform of the law in a manner that requires 'substantial contribution. ${ }^{73}$

It is important to observe that the ICTY Appeals Chamber has clearly rejected the idea of requiring substantial contribution as an element of joint criminal enterprise. ${ }^{74}$ Given the suggestion that the doctrine entails guilt by association alone, the remaining question becomes whether there is a need to reform the doctrine in order to emphasise positive contribution, hence addressing the criticism of guilt by association alone? I see no need for any such reform. For a correct understanding of the doctrine reveals - as already existing in it - the element of positive contribution, at the levels necessary for the philosophical or public policy rationale of the doctrine. That rationale has already been explained above, as a proper function of public policy. And the element of positive contribution already exists, if the public policy objective of the doctrine is deterrence against the commission of crimes - reasonably foreseen - from the springboard of a different crime. Since the secondary crime is necessarily connected to the springboard crime by the jural link of foreseeability, it becomes legitimate to gauge the accused's contribution not only at the level of the secondary crime, but also at the level of the springboard crime. Such contributions would include material assistance provided to the primary perpetrator in the commission of the springboard crime, as well as psychic boost or fortification for the springboard crime from which platform the primary perpetrator achieved impetus to commit the secondary crime. Recognition of psychic boost as positive contribution to crimes is a legal tradition that calls for no extended discourse here. ${ }^{75}$ Given, therefore, that the secondary crime is con-

72 Ohlin, supra, p 89.

73 Danner and Martinez, supra, pp I50-I5I.

74 Prosecutor v Kvockka and Ors (Judgment) 28 February 2005 [ICTY Appeals Chamber] para 97 and Io4.

75 In this regard, one must note Van der Wilt's correct observation that '[g]roup crimes are committed by virtue of a common effort in which each and every contribution counts, as each member is fortified and feels comforted by the presence of the others': Van der Wilt, supra, p I07. But I disagree with his assessment that '[w]e are largely left in the dark as to the requisite mens rea and actus reus standards' ( $\mathrm{p}$ roo); and with his claim that the 'basic problem' with the doctrine of joint criminal enterprise is that 'mens rea and actus reus attach to the common purpose instead of the crimes themselves' (p Ior). To the extent that there exists a jural link of foreseeability that connects the secondary crime to the springboard crime, one may not easily say that the mens rea and actus reus attaches only to the common purpose (read the springboard crime). Nor do I agree with his suggestion that the doctrine of joint criminal enterprise is necessarily 'predicated on at least a silent understanding' among or between 'partners in crime' (pp 92 and 102). As regards the extended form of joint criminal enterprise, which is the most controversial form, the doctrine is not so much predicated on a silent understanding of partners in crime, as it is on the mental fault of assumption 
nected to the springboard crime by the jural link of foreseeability; and, where the accused positively contributed to the springboard crime; it becomes irrelevant, for purposes of his culpability in the secondary crime, that he had even discouraged it while still contributing to the springboard crime. That is the essence of the observation of Lord Rodger of Earlesferry discussed above, when he wrote that where the secondary crime was foreseeable to the accused as possibly incidental to the springboard crime forming the common purpose, the responsibility of the accused for the secondary crime is engaged even if he was 'vehemently opposed' to it, as long as he had persisted in pursuing the springboard crime. Lord Lane CJ had made a similar observation in $R v H y d e$. In that case, he explained the principle in terms of the psychic boost that the accused, with foresight of the secondary crime, gave the primary perpetrator in the commission of the springboard crime. According to Lord Lane:

If $\mathrm{B}$ realises (without agreeing to such conduct being used) that A may kill or intentionally inflict serious injury, but nevertheless continues to participate with $A$ in the venture, that will amount to a sufficient mental element for $B$ to be guilty of murder if $\mathrm{A}$, with the requisite intent, kills in the course of the venture. As Professor Smith points out, B has in those circumstances lent himself to the enterprise and by so doing he has given assistance and encouragement to $\mathrm{A}$ in carrying out an enterprise which $\mathrm{B}$ realises may involve murder. ${ }^{76}$

The extended or wider version of the joint criminal enterprise is thus a principle of public policy. It entails the moral or legal fault of criminal recklessness in the dogged pursuit of a criminal activity that the accused had no right to pursue. It is an entirely sound principle. In the circumstances, it is incorrect to suggest that the doctrine of joint criminal enterprise entails imposing punishment "where the

of a foreseeable risk of the secondary crime (being the mens rea) on an insistent pursuit of the risky primary crime that afforded the springboard for the secondary crime, thereby supplying the actus reus of the secondary crime. In $R v$ Hyde, Lord Lane $\mathrm{CJ}$ had explained the mental element or mens rea in the following way: 'If B realises (without agreeing to such conduct being used) that A may kill or intentionally inflict serious injury, but nevertheless continues to participate with $\mathrm{A}$ in the venture, that will amount to a sufficient mental element for B to be guilty of murder if A, with the requisite intent, kills in the course of the venture' [emphasis added]: $R v$ Hyde, supra, p I39. See also Brown E Isaac $v$ The Estate, supra, para 8. It is the same mental element that the ICTY Appeals Chamber had explained as follows: 'What is required is a state of mind in which a person, although he did not intend to bring about a certain result, was aware that the actions of the group were most likely to lead to that result but nevertheless willingly took that risk. In other words, the so-called dolus eventualis is required (also called "advertent recklessness" in some national legal systems)' [emphasis added]: Tadić (Judgment), supra, para 220 [ICTY Appeals Chamber].

$76 R$ v Hyde, supra, p i39. See also $R$ v Powell, supra, pp 25-26, par Lord Hutton; McAuliffe v R, supra, 30 . 
person is not blameworthy'77 or 'basing guilt on association alone. '78 ${ }^{8}$ The better view is that once the moral and public policy premises of the doctrine of joint criminal enterprise are correctly understood, it will become clear that there is nothing wrong at all in punishing the sort of 'guilty associations' that the doctrine implicates. Quite the contrary, it is the proper function of criminal law to do that.

All this is not, of course, to dismiss entirely the call for reform. Law reforms are a necessary part of the life of the law in any jurisdiction. Even in common law jurisdictions, with a longer experience in the use of the doctrine of joint criminal enterprise, there is continuing pressure for a reform of the doctrine. ${ }^{79}$ While incremental reform is made, it is important not to overhype the criticisms about the danger inherent in the doctrine. The matter of greater importance lies, it is submitted, in the need always to keep in mind that the doctrine of joint criminal enterprise serves an essential purpose in the administration of international criminal justice. That essential purpose is what Cassese and his associates have correctly described as 'ensuring that individual culpability is not obscured in the fog of collective criminality' thus resulting in the 'evasion of accountability. ${ }^{80}$ Hence, joint criminal enterprise remains a useful tool through which a superior, in appropriate cases, could be held responsible for rapes committed by his subordinates.

The difference between an enterprise that is criminal in its purpose (in the pursuit of which a foreseeable secondary crime is committed) and an undertaking that is purely legitimate (but in pursuit of which a foreseeable crime is committed) brings us to the judgment of the Appeals Chamber of the Special Court for Sierra Leone in the $R U F$ case. ${ }^{8 \mathrm{r}}$ The SCSL Appeals Chamber found that the doctrine of joint criminal enterprise applied to that case. That joint criminal enterprise was anchored by the necessary common criminal purpose. And the common criminal purpose consisted of (a) the objective of gaining and exercising political power and control over the territory of Sierra Leone, especially the diamond mining areas; and (b) a programme of criminal conducts as the means of achieving that objective. $^{82}$

Notably, the Appeals Chamber employed a progressive sequence of legal analysis to arrive at this conclusion. That analysis began with considering the objective of gaining power and exercising control over the territory of Sierra Leone, particularly the diamond mining areas. The Appeals Chamber concurred with the Trial Chamber in finding that objective as non-criminal. But that non-criminal

77 Danner and Martinez, supra, $\mathrm{p} 83$.

78 Ibid, p 85 .

79 See, for instance, Clayton $v$ R, supra.

80 Antonio Cassese and the Board of Editors of the Journal of International Criminal Justice, Amicus Curiae Brief filed before the Extraordinary Chamber in the Courts of Cambodia in Case No oor/18-07-2007-ECCC/OCIJ (PTC 02) dated 27 October 2008, para 20.

8I Prosecutor v Sesay, Kallon and Gbao (Judgment) 26 October 2009 [SCSL Appeals Chamber].

82 Ibid, para 305 . 
objective transformed into a criminal purpose once the commission of crimes became the intended means for the achievement of the objective. ${ }^{{ }_{3}}$ At that level of abstraction, it is hard to argue with that legal proposition-i.e. what may be a perfectly legitimate objective will become a criminal activity once it is corrupted by criminal means. But the analysis becomes more interesting when one considers what the Appeals Chamber considered to be the criminal means that corrupted the objective in the $R U F$ Case. Those crimes were acts of violence against the civilian population, with the aim of spreading extreme fear in the civilian population, with the view to dominating and controlling them-essentially through acts and conducts intended to terrorise the civilian population into submission. ${ }^{84}$

This is certainly an important dimension in the law of joint criminal enterprise. In the era of protection of human rights, the future application of the underlying principle will certainly not be limited to the facts of the RUF Case, which involved seizure of political power by way of a military coup and the violent conduct of the military junta to subjugate the population. It should not take a quantum leap to apply the principle, thus enunciated, to the conduct of even initially duly elected politicians who would seek to perpetuate themselves in political office, by using violence and terror to suppress opposition or the population seeking a change of regime.

In the $R U F$ Case, however, it might also have been possible-even quickerto resolve the character of the objective as a common criminal purpose by limiting or focusing the analysis on the actual military coup per se. In the scenarios of violent change of power through violent military coups, it is possible to use the analogy of burglary and robbery (the classic cases involving the doctrine of joint criminal enterprise in national jurisdictions). That is to say, violent military coups involve the pursuit of political power just like burglary or robbery typically involves the quest for property acquisition. Yet, robbery or burglary has been viewed by the Courts as the primary criminal enterprise that afforded the springboard for the secondary crime. It is possible also to view military coups as criminal enterprises. The criminal character of violent military coups would derive severally from the domestic laws of every State, as violent military coups are proscribed by the criminal laws of States. The combined effect of those several domestic criminal laws would arguably anchor a norm of international law, by virtue of general principles of law recognised by modern States..$^{85}$

\section{Ordering}

Another way in which the case law has made it possible for a superior to be held criminally responsible for rapes committed by his subordinates is by extending the

83 Ibid, para 300.

84 Ibid, paras $30 \mathrm{I}-302$.

85 See Chile Eboe-Osuji and Angela Nworgu, 'Nigeria's Jurisdiction to Prosecute Johnny Paul Koroma for War Crimes Committed in Sierra Leone' in C Eboe-Osuji, Protecting Humanity [Leyden: Martinus Nijhoff: 2010] 839 at p 843. 
criminal consequences of 'ordering', as was done by the ICTY Appeals Chamber in Prosecutor v Blaškić:

The Appeals Chamber ... holds that a person who orders an act or omission with the awareness of the substantial likelihood that a crime will be committed in the execution of that order, has the requisite mens rea for establishing liability under Article 7 (I) pursuant to ordering. Ordering with such awareness has to be regarded as accepting that crime. ${ }^{86}$ [Emphases added.]

Of note in Blaškic is the significance of the Appeals Chamber's pronouncements as to when 'mere possibility', as opposed to 'substantial likelihood', of the collateral crime may attract criminal responsibility upon a superior. Having stated, as noted above, that there will be criminal responsibility on him that orders something to be done with awareness of a substantial likelibood of a crime being committed in the execution of the order, the Appeals Chamber reiterated the existing jurisprudence in which mere possibility, and not substantial likelihood, of a collateral crime is seen as sufficient to attract criminal responsibility for the crime on the part of a member of a joint criminal enterprise. Recalling its reasoning in an earlier judgment, ${ }^{87}$ the Appeals Chamber said as follows:

In relation to the responsibility for a crime other than that which was part of the common design, the lower standard of foreseeability — that is, an awareness that such a crime was a possible consequence of the execution of the enterprise-was applied by the Appeals Chamber. However, the extended form of joint criminal enterprise is a situation where the actor already possesses the intent to participate and further the common criminal purpose of a group. Hence, criminal responsibility may be imposed upon an actor for a crime falling outside the originally contemplated enterprise, even where he only knew that the perpetration of such a crime was merely a possible consequence, rather than substantially likely to occur, and nevertheless participated in the enterprise. ${ }^{88}$

It follows then that a superior ordering his subordinates to commit a crime, as opposed to a legitimate deed, will bear criminal responsibility for any collateral crime which was a possible consequence of the crime ordered. This conclusion flows from the stated doctrine of common enterprise. Hence, where a superior orders one or more to commit a crime, that crime becomes a joint criminal enterprise which the superior shares with the subordinates who would execute the criminal order. Although it is typically not stated in this way, it is still obvious that if criminal responsibility for a collateral crime will ordinarily be visited upon

\footnotetext{
86 Prosecutor v Blaškić (Judgment), supra, [ICTY Appeals Chamber] para 42.

87 Prosecutor v Vasiljević (Judgment) 25 February 2004 [ICTY Appeals Chamber] para IoI, quoting Prosecutor v Tadić (Judgment) I5 July I999 [ICTY Appeals Judgment] para 228.
}

Blaškic, supra, para 33 . 
a member of a common criminal enterprise (with an awareness of the mere possibility that such a crime may be committed in the course of carrying out the joint criminal purpose), it must follow that a superior who ordered a crime will equally be liable for the commission of a collateral crime, where there was a mere possibility that the collateral crime may be committed.

The extension of the criminal consequences of 'ordering', as was done in Blaškic, is a perfectly sensible result as far as it goes. And the significance of this legal development to the responsibility of a superior for rapes committed by subordinates is all too apparent. But it only goes as far as visiting such criminal responsibility on a superior for positively stimulating a crime. It is submitted that the same legal template will not fit considerations of responsibility for omission (without more) to prevent the crime. In the latter scenario, the responsibility needs to arise where the mere possibility is reasonably foreseeable, but the superior failed to take preventive measures proportionate to the foreseeable risk. And, as will be shown below, this is aptly considered as part of 'aiding and abetting'. Of course, the degree of culpability will be reflected in the sentencing of the superior upon conviction.

Unlike joint criminal enterprise, no attempt was made in the ICC Statute to circumscribe the conceptual boundaries of 'ordering'. Hence, there are no apparent limitations on the possibility that future ICC jurisprudence may extend the consequences of 'ordering' along the Blaškić lines noted above.

Before moving on, it might be necessary to consider the value of article 30 of the ICC Statute to the development of the law according to the Blaškic jurisprudence thus far reviewed. The jurisprudence according to the ICTY Appeals Chamber in Blaškić, as it permits criminal liability upon a member of a joint criminal enterprise, on grounds of mere possibility of risk, requires a careful look at article 30 of the ICC Statute, which articulates a certain view of mens rea. Article 30 of the ICC Statute provides as follows:

I. Unless otherwise provided, a person shall be criminally responsible and liable for punishment for a crime within the jurisdiction of the Court only if the material elements are committed with intent and knowledge.

2. For the purposes of this article, a person has intent where:

(a) In relation to conduct, that person means to engage in the conduct;

(b) In relation to a consequence, that person means to cause that consequence or is aware that it will occur in the ordinary course of events.

3. For the purposes of this article, "knowledge" means awareness that a circumstance exists or a consequence will occur in the ordinary course of events. "Know" and "knowingly" shall be construed accordingly.

As Werle and Jessberger rightly observed, article 30 'establishes a standard of mens rea that is apparently stricter than the one applied by both domestic and international courts. There, under the concepts of recklessness or dolus eventualis, the perpetrator's awareness merely of the risk that a particular consequence may occur 
is generally sufficient to establish criminal responsibility.' ${ }^{\prime 9}$ A question thus arises as to this provision's provenance and rationale. Werle and Jessberger raised this query appropriately in the following way: "[W] hy should the standard of mens rea under the ICC Statute be stricter than the standard applied by the Yugoslavia or the Rwanda Tribunals or national courts in prosecuting crimes under international law?'9o

In pondering an appropriate answer to this question, it is important to consider that, in view of its legislative history, it would be a mistake to exaggerate the value of this provision as either a product or a reflection of rational legislative drafting inspired by accurate distillation of either customary international law or general principles of criminal law accepted in modern states. To put it plainly, this provision appears mostly to be a product of diplomatic compromise, the culmination of a very intense and sustained disagreement (over earlier drafts of the article) during the negotiations of the draft ICC Statute in Rome. As Professor Roger Clark observed, significantly in a commentary on the drafting of article 30, "[d]rafting by consensus, the norm in both exercises, the Statute and the Elements, leads sometimes to awkward compromises. An adamant minority can carry the day.' ${ }^{91}$ Notably, article 30 reportedly came from a proposal suggested by the Canadian delegation. ${ }^{92}$ This is certainly interesting, given that mens rea in Canadian criminal law is not, even for crimes against humanity, so easily reduced to such simple formulae as (a) 'a person shall be criminally responsible and liable for punishment for [genocide, crimes against humanity and war crimes] only if the material elements are committed with intent and knowledge' and (b) "knowledge" means awareness that a circumstance exists or a consequence will occur in the ordinary course of events'. ${ }^{93}$ Noting also that this apparently might not accu-

89 Werle and Jessberger, supra, para $30 \%$.

90 Ibid.

9I Roger S Clark, 'The Mental Element in International Criminal Law: the Rome Statute of the International Criminal Court and the Elements of Offences,' (200I) I2 Criminal Law Forum 29I at p 295. The attendant compromises include the feature "that assorted "theoretical" issues, the resolution of which some of the players see as a matter of life and death, will simply be finessed. Another feature is that some issues, intractable during the negotiations, will ultimately be postponed for another day, either by silence or by creative obfuscation': ibid, p 317.

92 Per Saland, in Roy S Lee (ed), The International Criminal Court, The Making of the Rome Statute [The Hague: Kluwer Law International, I999], p I89 at 205. See also Werle and Jessberger, supra, footnote 70 to para 301.

93 In $R v$ Finta, for instance, the Supreme Court of Canada held that although awareness of circumstances of criminality of his actions is required to be established on the part of a person accused of war crimes and crimes against humanity, such awareness will be sufficiently proved by way of wilful blindness on the part of the accused: 'The mental element required to be proven to constitute a crime against humanity is that the accused was aware of or wilfully blind to facts or circumstances which would bring his or her acts within the definition of a crime against humanity. However it would not be necessary to establish that the accused knew that his 
rately reflect the understanding of mens rea in the continental European legal system, ${ }^{94}$ one then wonders what study and experience would have prompted the Canadian delegation to come up with this proposal during the heat of such an intense and sustained disagreement?

How this provision is eventually interpreted and applied at the ICC remains to be seen. Happily, however, there is an escape route from the strictures of the provision. This is chiefly afforded by an appropriate construction of the prefatory proviso: 'unless otherwise provided'. In this connection, Werle and Jessberger are correct in observing that not only does this proviso permit a way out of the apparent strict requirements of article 30,95 but it also permits reliance upon doctrines of mens rea developed under customary international law (such as in the jurisprudence of the ICTR and ICTY), as well as upon the mens rea doctrines comprised in the general principles of law recognized by modern nations..$^{96}$ This solution could reconcile article 30 of the ICC Statute with the mens rea elements found within the doctrine of joint criminal enterprise. ${ }^{97}$ Thus, the Blaškic jurisprudence, which permits criminal liability upon a member of a joint criminal enterprise, on grounds of mere possibility of risk, may not, after all, be that inconsistent with article 30 of the ICC Statute.

\section{Planning and Instigating}

Having discussed 'ordering' as it did in the Blaškić case, the Appeals Chamber declined to discuss 'planning' and 'instigating' as modes of criminal responsibility, since those modes of responsibility were not subject of the appeal under consideration in that case. It is submitted, however, that there is no reason to expect that any analysis of 'planning' and 'instigating' will produce a legal result that is markedly different from those of 'ordering', and of 'joint criminal enterprise' as a mode of 'committing.'

Besides, noting that 'planning' a crime which would be committed by others very much involves a conspiracy (of the planner and the perpetrators) to commit

or her actions were inhumane. For example, if the jury was satisfied that Finta was aware of the conditions within the boxcars, that would be sufficient to convict him of crimes against humanity even though he did not know that his actions in loading the people into those boxcars were inhumane. [9]Similarly for war crimes the Crown would have to establish that the accused knew or was aware of facts that brought his or her action within the definition of war crimes, or was wilfully blind to those facts. It would not be necessary to prove that the accused actually knew that his or her acts constituted war crimes. Those then are the requisite elements of the offence and the mental element required to establish it': $R v$ Finta [1994] I SCR 70I at 82 I.

94 See generally Werle and Jessberger, supra, especially para 307.

95 Ibid, para 303.

96 Ibid, para 3 I4.

97 Cf: Clark, supra, at p 301. 
the crime, there may be no denying a place here for the principle of law according to which declarations and acts of one member of a conspiracy, made in pursuance of the object of the conspiracy, before the consummation of the object of the conspiracy, is attributed to all the members of the conspiracy. ${ }^{98}$ The rationale for this rule derives from the doctrine of agency which underlies the idea of people combining in pursuit of a common enterprise. According to this doctrine, the actions and declarations of one member bind all, as they are agents of one another. ${ }^{99}$ This is especially so if it is reasonably foreseeable that the collateral crime, such as rape, may be committed in the course of committing the one planned or instigated. Hence, the superior who plans or instigates a crime will most likely be liable for both the crime expressly intended and any rape which was reasonably foreseeable in the circumstances.

In the ICC Statute, neither 'planning' nor 'instigating' appears as part of the language of the provisions on criminal responsibility. Nevertheless, the same import as instigating clearly is present in the language of article 25(3) in general, with particular regard to the notion of inducing a crime. ${ }^{100}$ And there is nothing in that language which limits the possibility of the future case law of the Court extending the consequences of inducing a crime.

The notion of planning a crime is also clearly envisaged within the notion of joint criminal enterprise appearing, as discussed above, in article $25(3)$ (a) and (d). To that extent, the apparent limitations already noted as regards joint criminal enterprise within the ICC Statute will, accordingly, encumber the extension of responsibility for planning.

\section{Aiding and Abetting}

Apart from the types of positive acts described above, a superior may also incur criminal responsibility under article 6(I) of the ICTR Statute by the not-so-obvious route of dereliction of duty. ${ }^{\text {Ior }}$ This will come under the rubric of aiding and abetting in the planning, preparation or execution of the crime(s). It is notable in this

98 Phipson on Evidence [London: Sweet \& Maxwell, 1990] pp 659-66o; Richard May, Criminal Evidence, 3rd edn [London: Sweet \& Maxwell, 1995] p 216; Roger Salhany, The Practical Guide to Evidence in Criminal Cases, 5th edn [Toronto: Carswell, 1997] pp 276-277; Don Stuart, Canadian Criminal Law, 3rd edn [Toronto: Carswell, 1995] p 628 .

$99 R$ v Carter (1982), 1982 CarswellNB I3 para 8; [1982] г SCR 938, 3г CR (3d) 97, 67 CCC (2d) 568, I37 DLR (3d) 387 [Supreme Court of Canada]; Stuart, supra, p 628.

Ioo See article $25(3)$ (b).

IOI In this connection, it is submitted that Judge Güney's analysis of superior responsibility as part of the analysis under art 6(I) of the ICTR Statute is truer to the general structure of the statute than is the prevailing view of separating superior responsibility from art 6(I) analysis. See Separate and Dissenting Opinion of Judge Güney in Prosecutor v Bagilishema (Judgment), supra, para 5 et seq [ICTR Trial Chamber]. See also Mettraux, Law of Command Responsibility, supra, p 40; Bantekas, supra, pp 585-586; Wu and Kang, supra, 272, 276 and 286. 
regard that some domestic criminal legislation have clearly situated the superior's duty to prevent crimes within the conception of accomplice liability ${ }^{\mathrm{IO2}}$ - the functional equivalent of 'aiding and abetting' under article 6(I) of the ICTR Statute. In this connection, there is great merit in Ilias Bantekas's articulation of the juristic rationale for the doctrine of superior responsibility in international criminal law. As he very sensibly put it, superior responsibility is 'a form of complicity through omission. Since accomplices and principals are held equally liable, failure of commanders to discharge their binding obligation entails their responsibility for the underlying crimes committed by their subordinates. ${ }^{\text {'о3 }}$

In international law, the extent of the superior's duty to prevent the commission of a crime, however, will depend on whether the accused was a superior in a military-type versus a non-military-type hierarchy. As is evident from the relevant provisions of the Statute of Rome, ${ }^{\text {104 }}$ different considerations do apply to these two types of leadership structures, for purposes of criminal responsibility for the crimes actually committed by the subordinates.

For the military-type hierarchy, different considerations apply, obviously as a result of occupational hazards of soldiery. It is notable in this regard that the circumstances in which the superiors and subordinates are brought together are such that put the subordinate in a position of ability or privilege to 'commit' the crime. A soldier is trained to inflict injury and damage and armed to do so, and perhaps deployed to a given place, by a State (or a rebel movement) for purposes of doing so. There are at least two theories of hazard here, either or both of which should trigger criminal responsibility. First, the fact of this training and provision (and deployment) would constitute the assistance to the subordinate which enabled him to commit the crime in question. These potentially meet the positive requirements of aiding and abetting, as that would clearly be the case where such training, provision or deployment was done for criminal purposes and not for the legitimate purposes of an armed conflict. What separates soldiery from banditry is the ethos of discipline and control or restraint, in conformity with the law. Absent this ethos, a soldier becomes a rogue, and his derivative conduct becomes potentially criminal. And, secondly, if one believed the situational theorists of evil seen in Chapter I above, these circumstances of training, provision for or deployment

IO2 One such legislation is the Model Penal Code of the United States which provides as follows in $\$ 2.06(3)$ (a)(iii):

A person is an accomplice of another person in the commission of an offense if:

(a) with the purpose of promoting or facilitating the commission of the offense, he

(i) solicits such other person to commit it, or

(ii) aids or agrees or attempts to aid such other person in planning or committing it, or

(iii) having a legal duty to prevent the commission of the offense, fails to make proper effort so to do;...

I03 Bantekas, supra, 577 .

IO4 See article 28. 
of soldiers will constitute an alteration ${ }^{\text {ros }}$ to the natural, social order in a manner that is potentially dangerous, if not properly controlled. The reasoning here is not entirely different from that which holds owners and handlers of naturally dangerous animals strictly liable for any harm done to others by such dangerous animals. It is for these reasons that one is compelled to disagree with Bantekas when he observes that the 'crux of the issue is that because of their aura of authority, military and civilian superiors are entrusted with far-reaching duties and must especially ensure their troops' compliance with the laws of war.' ${ }^{106}$ The individual criminal responsibility of a superior rests more reliably upon a firmament of facilitation or causation as reasoned above. The superior's 'aura of authority' offers a rather weak support for criminal responsibility.

Undoubtedly, the analogy to strict liability in respect of owners of dangerous animals is bound to attract the traditional concerns that the aversion to strict liability has attracted to the doctrine of superior responsibility. ${ }^{107}$ But, the reasoning espoused here with respect to superior responsibility in armed conflicts does not even go as far as to advocate strict liability similar to that governing the liability of owners of dangerous animals. This is because belligerents in an armed conflict are not animals, let alone naturally dangerous ones. Subordinate soldiers are human beings with the distinguishing faculties of intellect and moral empathy.

These faculties of human intellect and empathy that subordinates possess will necessarily bind with credible, purposive measures that superiors put in place at all times and maintain regularly, with the effect that women are afforded the desired better protection from sexual violence during armed conflicts. The fault on the part of the superiors therefore becomes the failure to put those credible measures in place at all times or to maintain them regularly. Their fault is not that they were merely superiors, perhaps with 'aura of authority', over errant subordinates. Understood from this perspective, it becomes clear that the legal regime here advocated is something distinctly removed from a regime of strict liability. It is a regime of due diligence, made necessary by the historical prevalence of sexual violence against women during armed conflicts. In the circumstances, Justice Murphy's worries, expressed in Yamashita, ${ }^{108}$ are laid to rest. That is to say, no future US President or his chiefs of staff or military advisers, as Justice Murphy had feared, ${ }^{\text {rog }}$ would be held individually criminally responsible for the sexual violence by rogue troops in the field, where there is evidence that those superiors had put in place and regularly maintained credible measures to ensure that military

I05 See Dyer, supra, pp 3I to 62; Marshall, supra, pp 56-57 and 79; Grossman, supra, pp IO-II, I8-28 and I78-I79; and Watson, supra, p 45.

Io6 Bantekas, supra, 576-577.

Io7 Strict liability has been a constant source of worry for some judges and commentators, as regards the doctrine of superior responsibility. See, for instance, Danner and Martinez, supra, I24, I25, I27, I28, I39, I47; Wu and Kang, supra, 279 et seq, Bantekas, supra, 577 and 586.

Io8 In re Yamashita 327 US I (1946).

Io9 See Yamashita, supra, p 28. 
personnel under their command do not commit sexual violence against women during armed conflicts.

Still, there is a need for proper control and discipline, despite these faculties of intellect and empathy possessed by subordinates. For, human experience has shown that there will always be instances of anti-social behaviours among human beings. And, soldiers have particularly been known to rape women during armed conflicts. In this connection, the theory of inevitability of sexual violence during armed conflicts ought to increase, rather than diminish, the criminal responsibility of superiors, by requiring them to take reasonable steps to control those whom they train, arm and deploy in a manner that results inevitably in sexual violence to women. The case for greater control, tending towards the regime of strict liability, much like that warranted by ferae naturae, also becomes tempting if Alford's theory of universal human trait towards sadism is allowed pride of place.

On either theory-i.e. strict liability or not-the resulting conditions are such that if the soldiers are not properly controlled, it is reasonable to foresee that they may cause harm beyond what is warranted by military necessity. They may rape women - and they do. It becomes necessary then to impose on those who command such subordinates a duty to exercise such control so as to prevent the subordinates from abusing this position of ability or privilege (to inflict harm and destruction) into which they have been placed. The liability, however, is not strict since it can be avoided where the conditions are such as to show that the commander took reasonable steps in the circumstances to prevent the crime or punish the culprits, as is, for instance provided for under article 6(3) of the ICTR Statute.

These considerations did clearly actuate the Yamashita judgment. General Tomoyuki Yamashita was both the commander of the I4th Division of the Japanese Imperial Army as well as the Governor of the Philippines during World War II. Towards the end of the war, troops under his command committed numerous atrocities against the civilian population of the Philippines. Following the unconditional surrender of Japan to the United States, General Yamashita surrendered to the US forces in the Philippines. He was indicted before a US military commission for war crimes, upon the allegation that troops under his command had deliberately planned to massacre and exterminate a large portion of the civilian population of Batangas Province which resulted in the killing and/or mistreatment of over 25,000 civilians. As his defence, he argued that he did not personally commit the crimes. He was convicted by the US Military Commission. The Supreme Court of the Commonwealth of the Philippines denied his writ of habeas corpus. He appealed to the US Supreme Court. Responding to his defence of non-perpetration of the crimes in question, the majority of Supreme Court reasoned that the defence overlooked the fact that the 'gist of the charge is an unlawful breach of duty by the petitioner as an army commander to control the operations of the members of his command by "permitting them to commit" the extensive and widespread atrocities specified' in the indictment. In the view of the Supreme Court, the 'question then is whether the Law of War imposes on an army commander a duty to take such appropriate measures as are within his powers to control the troops under his command for the prevention of the speci- 
fied acts which are violations of the Law of War and which are likely to attend the occupation of hostile territory by uncontrolled soldiery, and whether he may be charged with personal responsibility for his failure to take such measures when violations result.' Having reviewed a range of international instruments applicable at the time, ${ }^{\text {IIO }}$ the majority of the Supreme Court held as follows:

\begin{abstract}
It is evident that the conduct of military operations by troops whose excesses are unrestrained by the orders or efforts of their commander would almost certainly result in violations which it is the purpose of the Law of War to prevent. Its purpose to protect civilian populations and prisoners of war from brutality would largely be defeated if the commander of an invading army could with impunity neglect to take reasonable measures for their protection. Hence the Law of war presupposes that its violation is to be avoided through the control of the operations of war by commanders who are to some extent responsible for their subordinates. ${ }^{\text {III }}$
\end{abstract}

According to the Supreme Court, the duty imposed by international law in the circumstances was 'an affirmative duty to take such measures as were within his power and appropriate in the circumstances to protect prisoners of war and the civilian population.' ${ }^{\mathrm{II} 2}$

The commander's failure in this duty to control his troops will no doubt justify the characterization made in Yamashita that the commander had in a sense 'permitted' his troops to commit the crimes. This characterisation is made more compelling by two sets of factors at least; first, if one considers, as I have suggested earlier, the elements of training, arming and deploying the troops, thereby assisting them into the position that enabled them to commit the crime. And, secondly, if one considers the policy theories reviewed in Chapter I as explaining the prevalence of sexual violence during war. This includes especially, but is not limited to, the theory of systematic condonation or connivance and their motivations.

From the day it was delivered by the US Supreme Court, the Yamashita judgment promptly acquired the status of an obligatory punching bag on the thoroughfare of spirited criticism. The milder forms of these criticisms are couched in terms such as that Yamashita's conviction was 'based on negligence or, per-

IIo These include the Annex to the Fourth Hague Convention of 1907, respecting the laws and customs of war on land (article I); the Tenth Hague Convention, relating to bombardment by naval vessels (article I9), which provides that commanders-inchief of the belligerent vessels 'must see that the above Articles are properly carried out'; the Geneva Red Cross Convention of 1929 for the amelioration of the condition of the wounded and sick in armies in the field (article 26), makes it 'the duty of the commanders-in-chief of the belligerent armies to provide for the details of execution of the foregoing articles, (of the Convention) as well as for unforeseen cases'; and, the Annex of the Fourth Hague Convention (article 43).

III Yamashita, supra, p I5.

II2 Ibid, p I6. 
haps, even strict liability. ${ }^{\mathrm{Ir}}$ But the criticism is equally susceptible of more colourfully rendition. One of those was understandably deployed by Yamashita's defence counsel when he submitted at first instance that his client was 'charged not with having done something or having failed to do something, but solely having been someone. For the gravamen of the charge is that the Accused was the commander of the Japanese forces, and by virtue of that fact alone, is guilty of every crime committed by every soldier assigned to his command.' ${ }^{\mathrm{II} 4}$ More remarkably, this criticism found sympathy in the dissenting opinion of US Supreme Court Justice Murphy. For, in his own view, General Yamashita 'was not charged with personally participating in the acts of atrocity or with ordering or condoning their commission. Not even knowledge of these crimes was attributed to him. ... No one in a position of command in an army, from sergeant to general, can escape those implications. Indeed, the fate of some future President of the United States and his chiefs of staff and military advisers may well have been sealed by this decision. 'II

Many legal academic commentators have also not viewed Yamashita with great favour. ${ }^{\mathrm{II} 6}$ These criticisms are not without merit, in light of the particular fact pattern in the Yamashita case. Particularly noteworthy in this regard is the fact that his control over his troops had been disrupted by the military efficiency of the US offensive against his troops. He had been forced to order an evacuation. He then split his troops into three divisions. He ceded command over two of those divisions and retained command over only one. His evacuation order was not carried out. He was left isolated in a remote mountainous region; unable to communicate with his headquarters and the other two commanders. Notwithstanding this loss of actual and effective control, he was convicted upon the theory that he could not avoid criminal responsibility by delegating his command. In these circumstances, one is sympathetic to complaints such as that '[i]t strains the mind to consider the possibility of upholding criminal responsibility in cases where both de facto control is missing and de jure command was already ceded for military purposes and not for the purpose of escaping criminal responsibility. 'II7

Particularly worrying was the refusal of the Majority of the Supreme Court to appraise the facts at play in the case. As the Majority expressed itself: 'We do not here appraise the evidence on which petitioner was convicted. We do not consider

II3 See Martinez, supra, p 64I.

II4 See Wu and Kang, supra, footnote I7.

II5 Yamashita, supra, p 28, See also Wu and Kang, ibid, footnote I7.

ir6 See Danner and Martinez, supra, p I24; Damaška, supra, at p 48r; Cherif Bassiouni, 'From Versailles to Rwanda in Seventy-Five Years: The Need to Establish a Permanent International Criminal Court,' (1997) io Harvard Human Rights Journal II, at pp 36-37. A more sympathetic treatment of the case is seen in William Parks, 'Command Responsibility for War Crimes' (1973) 62 Military Law Review I, at pp 22 et seq.

II7 Bantekas, supra, p 585. See also Laurie Barber, 'Yamashita Trial Revisited' (I998) I WaiMilHist (available at www.waikato.ac.nz/wfass/subjects/history/waimilhist/1998/ yamashita.htm) 
what measures, if any, petitioner took to prevent the commission, by the troops under his command, of the plain violations of the law of war detailed in the bill of particulars, or whether such measures as he may have taken were appropriate and sufficient to discharge the duty imposed upon him. These are questions within the peculiar competence of the military officers composing the commission and were for it to decide. ${ }^{\mathrm{II} 8}$ The majority of the Supreme Court was quite happy to defer all those considerations to the senior soldiers who composed the military commission that tried Yamashita at first instance. According to the Supreme Court: 'It is plain that the charge on which petitioner was tried charged him with a breach of his duty to control the operations of the members of his command, by permitting them to commit the specified atrocities. This was enough to require the commission to hear evidence tending to establish the culpable failure of petitioner to perform the duty imposed on him by the law of war and to pass upon its sufficiency to establish guilt.' ${ }^{\text {II9 }}$

This is surely a most peculiar application of the all too familiar doctrine of judicial deference in appellate adjudication. It is one thing for an appellate court to decline to appraise the forensic strength of evidence tendered before the trial court, in terms of the credibility - especially when founded on demeanour-of witnesses whom the appellate court did not observe testify. This handicap usually compels appellate courts to defer to the trial judges on questions of appraisal of credibility of witnesses. There is therefore nothing strange about the Supreme Court declining to 'appraise the evidence on which petitioner was convicted', if they meant that they had declined to consider the testimonial credibility of the evidence in the case. But it is a different matter altogether for an appellate court to decline to assess whether the established presence or absence of facts in a case is sufficient for purposes of answering the central legal question engaged in the case. In Yamashita, that central question was whether General Yamashita had breached the duty on him to prevent the atrocities committed by his troops. It was therefore very strange that the Supreme Court refused to 'consider what measures, if any, petitioner took to prevent the commission, by the troops under his command, of the plain violations of the law of war detailed in the bill of particulars, or whether such measures as he may have taken were appropriate and sufficient to discharge the duty imposed upon him.' For, those considerations engage-what is necessarily a mixed question of law and fact-the central question in the case. In Yamashita, that question was whether Yamashita breached the duty on him to prevent the atrocities committed by troops under his command. That the Majority of the Supreme Court had avoided that question fully justifies the scepticism with which their judgment continues to be greeted in the Yamashita case.

But these shortcomings in the Yamashita case do not diminish the notion of duty articulated in the judgment, as the foundation of the doctrine of superior responsibility. For, as even Justice Murphy conceded, 'No one denies that inaction

II8 Yamashita, supra, p I7.

II9 Ibid. 
or negligence may give rise to liability, civil or criminal. ${ }^{\text {'20 }}{ }^{2} \mathrm{He}$ also pointed out that his criticism of the majority judgment 'is not to say that enemy commanders may escape punishment for clear and unlawful failures to prevent atrocities. ${ }^{\text {I2I }}$ Hence, the Yamashita criticisms are predominantly directed at the application of the duty to prevent atrocities in the particular context of that case. ${ }^{122}$

While the full extent of the criminal responsibility of civilian leaders is not as clear in international law ${ }^{\mathrm{I} 23}$ outside of the ICC Statute, ${ }^{\mathrm{I} 24}$ there is some clarity as regards the criminal responsibility of civilian leaders who direct and control the functions of government. This view emerges from an examination of the judgment of the International Military Tribunal for the Far East in the Tokyo case. Though speaking in relation to duties owed to prisoners of war and the civilian population, the pronouncement should be of some value in the assessment of the extent of criminal responsibility of both military and civilian leaders in other contexts as well. According to the Tribunal:

Prisoners taken in war and civilian internees are in the power of the Government which captures them. This was not always the case. For the last two centuries, however, this position has been recognised and the customary law to this effect was formally embodied in the Hague Convention No IV in I907 and repeated in the Geneva Prisoner of War Convention of 1929. Responsibility for the care of prisoners of war and of civilian internees (all of whom we will refer to as 'prisoners') rests therefore with the Government having them in possession. This responsibility is not limited to the duty of mere maintenance but extends to the

I20 Yamashita, supra, p 39.

I2I Ibid, p 40. A repeated gravamen of Justice Murphy's criticism was his perception of the absence of lack of precedent in international law for the charge against General Yamashita. Notably, his view that Yamashita's conviction violated the rule requiring that 'punishment should be based upon charges fairly drawn in light of established rules of international law and recognized concepts of justice:' ibid, p 40. He had earlier lamented: 'Nothing in all history or in international law, at least as far as I am aware, justifies such a charge against a fallen commander of a defeated force. To use the very inefficiency and disorganization created by the victorious forces as the primary basis for condemning officers of the defeated armies bears no resemblance to justice or to military reality': ibid, p 35. Leslie Green is not at all persuaded that Justice Murphy's historical knowledge of international law was encyclopaedic enough to warrant such a pronouncement. As Green put it: 'While there may be something to be said for Murphy's comments on the effectiveness of the American campaigns and their consequent disruption of Yamashita's lines of communication, it is submitted that his knowledge of the history of command responsibility is not as complete as he implied': Leslie Green, 'War Crimes, Crimes against Humanity and Command Responsibility' (1997) 50 Naval War College Review 26, at p 35.

I22 Parks, supra, at p 35-36. See also Green, 'War Crimes, Crimes against Humanity and Command Responsibility', supra, $\mathrm{p} 33$.

I23 Prosecutor v Delalic, supra, para 240 [ICTY Appeals Chamber].

I24 See article $28($ b). 
prevention of mistreatment. In particular, acts of inhumanity to prisoners which are forbidden by the customary law of nations as well as by conventions are to be prevented by the Government having responsibility for the prisoners.

In the discharge of these duties to prisoners Governments must have resort to persons. Indeed the Governments responsible, in this sense, are those persons who direct and control functions of Government. In this case and in the above regard we are concerned with the members of the Japanese Cabinet. The duty to prisoners is not a meaningless obligation cast upon a political abstraction. It is a specific duty to be performed in the first case by those who constitute the Government. In the multitude of duties and tasks involved in modern government there is of necessity an elaborate system of sub-division and delegation of duties. In the case of the duty of Governments to prisoners held by them in time of war those persons who constitute the Government have the principal and continuing responsibility for their prisoners, even though they delegate the duties of maintenance and protection to others. ${ }^{\mathrm{I} 25}$

Given that civilian leaders who control the functions of Government are as responsible as military commanders, if not more so in democratic States, for enlisting, training, arming and deploying soldiers, it is right to make them share with military commanders the same responsibility, all reasonable qualifications made, that arises from the occupational hazards of soldiery discussed earlier.

The duty of the superior is further delineated with greater clarity in the judgment in the Tokyo case. Using the ratio of the system of humane treatment of prisoners of war, the IMT held that the duty comprised not only the establishment of a system of protection for protected persons, but also the ensuring of its continued and efficient operation: 'It is the duty of all those on whom responsibility rests to secure proper treatment of prisoners and to prevent their ill-treatment by establishing and securing the continuous and efficient working of a system appropriate for these purposes.'Those upon whom the duty rests would be in breach of it if 'they fail to establish such a system' of protection; or having established it, 'they fail to secure its continued and efficient working.'The duty to establish and secure continued operation of the system of protection comprises within it a duty of constant vigilance to ensure that the system is continually affording the desired level of protection. As the Tribunal put it, every obligor 'has a duty to ascertain that the system is working and if he neglects to do so he is responsible'. The obligor 'does not discharge his duty by merely instituting an appropriate system and thereafter neglecting to learn of its application. An Army Commander or a Minister of War, for example, must be at the same pains to ensure obedience to his orders in

I25 Bernard V A Röling and C F Rüter (eds), The Tokyo Judgment [Amsterdam: APAUniversity Press Amsterdam BV, i977] p 29. See also Gabrielle Kirk McDonald and Olivia Swaak-Goldman (eds), Substantive and Procedural Aspects of International Criminal Law: The Experience of International and National Courts, vol II part 2 [The Hague: Kluwer, 200o] p 768. 
this respect as he would in respect of other orders he has issued on matters of the first importance.'

Even where the proper system is put in place and efficient monitoring of continued operation is met, the obligor may still be criminally responsible for violations committed within the system if the superior bearing the duty (i) had knowledge that such crimes were being committed, and having such knowledge he failed to take such steps as were within his power to prevent the commission of such crimes in the future, or (ii) was at fault in having failed to acquire knowledge that the crimes were being committed within the system of protection. According to the Tribunal:

If such a person had, or should, but for negligence or supineness, have had such knowledge he is not excused for inaction if his Office required or permitted him to take any action to prevent such crimes. On the other hand it is not enough for the exculpation of a person, otherwise responsible, for him to show that he accepted assurances from others more directly associated with the control of the prisoners if having regard to the position of those others, to the frequency of reports of such crimes, or to any other circumstances he should have been put upon further enquiry as to whether those assurances were true or untrue. That crimes are notorious, numerous and widespread as to time and place are matters to be considered in imputing knowledge.

A civilian or military member of cabinet that is collectively responsible for the system of protection will be individually responsible and does not escape responsibility, if he continues to stay in that government, after gaining knowledge of the violations, he omitted or failed to secure corrective measures. In the words of the Tribunal:

A member of a Cabinet which collectively, as one of the principal organs of the Government, is responsible for the care of prisoners is not absolved from responsibility if, having knowledge of the commission of the crimes in the sense already discussed, and omitting or failing to secure the taking of measures to prevent the commission of such crimes in the future, he elects to continue as a member of the Cabinet. This is the position even though the Department of which he has the charge is not directly concerned with the care of prisoners. A Cabinet member may resign. If he has knowledge of ill-treatment of prisoners, is powerless to prevent future ill-treatment, but elects to remain in the Cabinet thereby continuing to participate in its collective responsibility for protection of prisoners he willingly assumes responsibility for any ill-treatment in the future.

The Tribunal recognised that military or civilian members of a military hierarchy, in the personage of military commanders and civilian ministers of defence can, by order, secure proper treatment and prevent ill-treatment of prisoners. And if 'crimes are committed against prisoners under their control, of the likely occurrence of which they had, or should have had knowledge in advance, they 
are responsible for those crimes. If, for example, it be shown that within the units under his command conventional war crimes have been committed of which he knew or should have known, a commander who takes no adequate steps to prevent the occurrence of such crimes in the future will be responsible for such future crimes.'

Beyond these higher-level officials, the duty to resign does not extend to civil servants. Nevertheless, where their duties include administration of the system of protection, they have a duty to take steps within their powers to prevent or correct abuses, if they have knowledge of the occurrence of such abuses. 'Departmental Officials having knowledge of ill-treatment of prisoners are not responsible by reason of their failure to resign; but if their functions included the administration of the system of protection of prisoners and if they had or should have had knowledge of crimes and did nothing effective, to the extent of their powers, to prevent their occurrence in the future then they are responsible for such future crimes. ${ }^{126}$

Now, insofar as the point of the Yamashita and Tokyo judgments on this matter is that there exists in the superior an affirmative duty to take such measures as are within his power and appropriate in the circumstances to protect those at their mercy, it becomes clear that this duty envisages that the superior must always have in place reasonable measures to prevent his subordinates from committing sexual violence. This is because such crimes have traditionally been committed by arms bearing men during armed conflicts. In this regard, it should be no defence that there was no contemporaneous evidence seen by the superior foreboding that the subordinates were 'about to commit' or 'committing' rape.

But for one obstacle, the foregoing analysis should work as well within the construct of 'aids, abets, or otherwise assist' in the commission or attempted commission of an offence, as provided for in article 25(c) of the ICC Statute. The obstacle in question is that article 25 (c) requires that the assistance of the aider and abettor must have been rendered for the 'purpose of facilitating the commission of such a crime'.

\section{Arguable Limits of Routes around the Difficulties of the Lex Lata}

Apart from those already indicated in the foregoing review, there are other possible limitations to the routes around the difficulties created for a better protection of women from rape, in virtue of the requirement of 'committing or about to commit.'

For one thing, the doctrine of joint criminal enterprise discussed above, the extension of 'ordering' as done in Blaškic, as well as any eventual development of the concepts of planning, instigating and aiding and abetting as explained above, are arguably judge-made. Hence, they may not override the express language of 'committing or about to commit.' In other words, the judicial interpretation of ordering, for instance, to include 'substantial likelihood' of a collateral crime in the theory of

I26 Röling, supra, pp 29-3i; McDonald, supra, p 769. 
criminal responsibility, being judge-made law, ought not negate the defence which the legislator has expressly afforded a superior to the effect that he is criminally responsible for the crimes of the subordinate only when he knew or ought to have known that the subordinate was 'committing' a crime or was 'about to commit a crime.'There is apparent force in this argument especially given the jurisprudence of the ICTY Appeals Chamber which has stated in clear terms that liability under article $7(\mathrm{I})$ of the ICTY Statute is distinct and separate from liability under article $7(3)$.

On deeper reflection, however, it is possible to overcome this argument. In this connection, there is a need to focus on the actus reus of the superior in the relevant analysis. When this is done, it becomes clear that the modes of responsibility, such as in article 6(I) of the ICTR Statute, which have ensnared the superior, involve some positive stimulus from the superior in question. This is clear from joint criminal enterprise, ordering, planning and instigating. While this is not always as clear from 'aiding and abetting', the story is still the same: there is some positive stimulus which raises his conduct from that of a mere bystander to that of a participant in crime. As shown earlier, he has done something jointly or severally to put the subordinate in the position to commit the crime-i.e. enlist, train, equip and mobilise - thence arises his duty to control their actions. In contrast, the 'committing or about to commit' defence remains a valid defence for those superiors who could not be said to have provided such a positive stimulus in any way. They may then not be held responsible, in the current state of international law, for failing to take measures at large to prevent rapes given the general knowledge that women are always at risk of rape during armed conflict.

\section{Superior Responsibility and the Duty to Punish}

The foregoing discussion has a special significance to a superior's duty to prevent the commission of a crime. A related duty is the duty to punish a subordinate who committed a crime that was not-or could not be-prevented.

In many instruments of international law, the two duties are often stated together in the same clause. ${ }^{\mathrm{I} 7}$ Yet, the duty to punish is different from the duty to prevent. The duty to punish does not supplant the duty to prevent. That is to say, even where it is amply discharged, the duty to punish would not absolve from responsibility the superior who had failed in his duty to prevent the commission

I27 For instance, article 6(3) of the ICTR Statute provides as follows: 'The fact that any of the acts referred to in Articles 2 to 4 of the present Statute was committed by a subordinate does not relieve his or her superior of criminal responsibility if he or she knew or had reason to know that the subordinate was about to commit such acts or had done so and the superior failed to take the necessary and reasonable measures to prevent such acts or to punish the perpetrators thereof.' [Emphasis added.] Article 7(3) of the ICTY Statute contains a similar provision. 
of the crime which the superior knew or ought to have known was being committed or about to be committed..$^{128}$

The duty to punish, in a sense, underscores the character of superior responsibility as a jural concept in the nature of dereliction of duty. In Hadžihasanović, both the Trial Chamber ${ }^{\mathrm{r} 29}$ and the Appeals Chamber ${ }^{\mathrm{r} 30}$ of the ICTY made it plain that the superior's responsibility is something sui generis. It arises from responsibility for a certain omission on the part of the superior. According to this line of jurisprudence, superior responsibility is not equivalent to vicarious responsibility, in virtue of which the superior is subrogated in punishment for the subordinate's criminal conduct.

Although it is my view, as a matter of lex ferenda, that the doctrine of superior responsibility should attract direct criminal responsibility upon the superior who failed to control rogue subordinates, given the superior's implication in training, arming, and deploying the subordinates, it is possible to note, first, that this theory of responsibility would obviously not encumber a superior who was never in a position to control the subordinate at the time of the offence, such as a superior who had not been put into command at the time of the crime. Secondly, the lex ferenda view under consideration remains just that in the meantime. The lex lata, according to the jurisprudence of the ICTY Appeals Chamber, is that superior responsibility is something sui generis.

Interestingly, the full import of this line of jurisprudence was thrown into a state of flux in virtue of a division of opinion among the five ICTY appellate judges who decided an interlocutory appeal in Hadżihasanović. The debate concerned whether there is a duty upon a superior to punish a subordinate for a crime committed prior to the superior's assumption of command.

In a very narrow split (3:2) the ICTY Appeals Chamber judges disagreed. In the ensuing debate, Judge Shahabuddeen and Judge Hunt, writing separately, articulated the minority view; while the majority opinion was written by Judge Meron (also representing the views of Judge Pocar and Judge Güney).

The majority held that a superior is under no duty to punish a subordinate who committed a crime prior to the superior's assumption of command. The majority opinion is essentially based upon the reasoning that there is no evidence of prac-

I28 Prosecutorv Aleksovski (Judgment) dated 24 March 2000 [ICTY Appeals Chamber] paras 72 and 76; Prosecutor v Delalić et al (Judgment) dated 20 February 200 IICTY Appeals Chamber] paras 192, 193, and 198; Prosecutor v Blaškić (Judgment) dated 3 March 2000 [ICTY Trial Chamber] para 336; Prosecutorv Kordic E Čerkez (Judgment) dated 26 February 200I [ICTY Trial Chamber] paras 444-446.

I29 See Prosecutor v Hadžihasanović (Judgment) dated I5 March 2006 [ICTY Trial Chamber] paras $73^{-75}$.

I30 See Prosecutor v Hadžihasanović (Judgment) dated 28 April 2008 [ICTY Appeals Chamber] para 39. See also Prosecutor v Krnojelac (Judgment) dated I7 September 2003[ICTY Appeals Chamber] para I7I; and Prosecutor v Halilović (Judgment) dated I6 November 2005 [ICTY Trial Chamber] para 78. 
tice coupled by opinio juris supporting such a duty in a superior. ${ }^{\mathrm{I3}}$ According to them, criminal responsibility can be imposed only if the crime charged was clearly established under customary law at the time the events in issue occurred. Any doubt in this regard would, they contended, negate the imposition of criminal responsibility, out of 'full respect for the principle of legality'..$^{32}$

The minority disagreed. To them, the correct approach is not to look for evidence of practice coupled with opinio juris, to the effect that a superior has a duty to punish a subordinate who committed a crime prior to the superior's assumption of command. The better approach rather is to identify the existence of a principle of customary international law, and then seek to interpret that principle in terms of its applicability to the factual question at hand. And this task must be undertaken with the object and purpose of the particular principle always kept in view. Applying this method, the established principle of customary international law is that a superior operates under a duty to punish a subordinate for a consummated crime; and the factual question is whether this duty also encumbers a superior who came into command after the commission of the crime.

The minority were of the view that this factual question must be answered in the affirmative. As already indicated, the essence of their position is generally anchored upon the canon of interpretation that requires to be taken into account the object and purpose of the relevant rule or provision, as dictated by the Vienna Convention on the Law of Treaties of 1969. ${ }^{133}$ According to Judge Shahabuddeen, 'the object and purpose of the provisions [relating to the duty to punish] would include the avoidance of future crimes by the subordinates of a new commander arising from seeming encouragement through inaction by him over crimes committed by the same subordinates before he assumed duty but of which he knows or had reason to know. ${ }^{134}$ The aim is to make certain that 'there is always someone who will have responsibility for ensuring that the commission of war crimes by a subordinate will not go unpunished'; considering that reports of 'the commission of the crime might never have reached the previous commander and he might therefore have never been in a position to exercise power to punish the subordinate for it; the reports might only be received by the new commander. Responsible command, from which flows the concept of command responsibility, vests the new commander

I3I Prosecutor v Hadžihasanovic (Decision on the Interlocutory Appeal Challenging Jurisdiction in relation to Command Responsibility) dated I6 July 2003 [ICTY Appeals Chamber] paras 45 and 53 .

I32 Ibid, para 5 I.

I33 Prosecutor v Hadžihasanovic (Decision on the Interlocutory Appeal Challenging Jurisdiction in relation to Command Responsibility), supra, [ICTY Appeals Chamber, Partial Dissenting of Judge Shahabuddeen] paras ir et seq. See also the Separate and Partially Dissenting Opinion of Judge Hunt, paras 22-26.

I34 Hadžihasanović (Decision on the Interlocutory Appeal Challenging Jurisdiction in relation to Command Responsibility), supra, Partial Dissenting of Judge Shahabuddeen, para 12. 
with power to punish the subordinate for the crime so disclosed. 'י 355 Judge Hunt was generally of a similar view, although he had expressed himself differently. ${ }^{\mathrm{r} 36}$

It appears that the concerns underlying the majority view stems from their being viscerally haunted by the lurking ghost of vicarious liability, which imputes unto someone else the jural consequences of the act of another. Seen in this way, a commander becomes liable for, say, the war crime of torture, committed by a subordinate. Notably, this appears to be the view of superior responsibility that the drafters of the Statute of the International Criminal Court had taken of superior responsibility. For according to them, where the prescribed conditions are met, ${ }^{137}$ the superior 'shall be criminally responsible for crimes within the jurisdiction of the Court committed by forces under his or her effective command and control, or effective authority and control as the case may be, as a result of his or her failure to exercise control properly over such forces'. ${ }^{13^{8}}$ It is, perhaps, telling that the majority in the Hadžihasanovic interlocutory appeal cited article 28 of the ICC Statute as their first example of statement of norms tending to negate the imposition on a superior a duty to punish a subordinate who committed an offence prior to the assumption of command.

If, as the majority in the Hadžihasanovic interlocutory appeal did, superior responsibility is always to be viewed from the prism of article 28 of the ICC Statute-i.e. as imposing a form of vicarious criminal responsibility upon a superior for the acts of his subordinate-the concerns of the majority in the Hadžihasanović interlocutory appeal would be fully justified. For it would offend elementary principles of criminal justice to impute onto someone responsibility for a crime committed when he was not in a position of the relevant relationship with the actual perpetrator.

However, those concerns evaporate if, as is indicated in the jurisprudence of ICTY, the nature of superior responsibility is viewed within a sui generis framework, entailing a type of assessorial responsibility in the nature of dereliction of duty. ${ }^{139}$ That duty entails a failure on the part of the superior to do something else

I35 Ibid, para 24 .

I36 See the Separate and Partially Dissenting Opinion of Judge Hunt, paras 22-26.

I37 For instance, 'where: (i) that military commander or person either knew or, owing to the circumstances at the time, should have known that the forces were committing or about to commit such crimes; and (ii) that military commander or person failed to take all necessary and reasonable measures within his or her power to prevent or repress their commission or to submit the matter to the competent authorities for investigation and prosecution.' See article 28 (a) of the ICC Statute. See also article 28(b) where a differently worded provision is made regarding the responsibility of a superior other than a military commander.

I38 See article 28 of the ICC Statute.

I39 See Prosecutor v Hadžihasanović (Judgment), supra, [ICTY Trial Chamber] paras 73-75; Prosecutor v Hadžihasanović (Judgment), supra, [ICTY Appeals Chamber] para 39; Prosecutor v Krnojelac (Judgment), supra, [ICTY Appeals Chamber] para I7I; and Prosecutor v Halilović (Judgment), supra, [ICTY Trial Chamber] para 78. 
entailing a renunciation of the crime, so that it is either not committed (the duty to prevent) or, once committed, the perpetrator does not enjoy impunity (the duty to punish).

If it is accepted that the duty to punish is about the prevention of impunity, as opposed to vicarious criminal responsibility derived from a subordinate's criminal conduct, why should it then matter that the superior had not yet assumed the command position when the crime was committed?

Recalling a point of jurisprudence noted at the beginning of this section, it would seem that the answer to this question would expose a scenario in which the superior in command at the time of the offence would be burdened by two types of duty (to prevent an imminent or immediate crime or both, and to punish consummated crimes); while his successor would bear the burden of only one duty (to punish consummated crimes). There is therefore no injustice done to the latter kind of superior, as there is a distinction made between him and his predecessor. There is, on the other hand, injustice done to victims and to society if there were no obligation on a succeeding superior to prevent impunity, by requiring him to punish a consummated crime whenever the crime or its perpetrator is discovered.

The reasoning of the minority in the Hadzihasanovic interlocutory appeal is therefore more appealing than that of majority. On the whole, it is difficult to resist a view of the position of the majority as curiously mechanical. This is particularly so for a number of reasons. The first thing one notices in this regard is the failure of the majority to invite-and their refusal to accept at the urging of the minority - the 'object and purpose' canon in their analysis. That is to say, not once in their reasoning did the majority make reference to this canon. What is more, they categorically rejected the reasoning of the minority, as it is generally anchored on that canon.

Indeed, the improbability of the position of the majority appears in relief in the realms of impunity for sexual crimes against women committed during armed conflicts. This is the case, given the theory (already explored) that it might be in the interest of some armed forces to condone or cover-up crimes of sexual violence that their members commit against women. Clearly, this concern is not assisted by the fact that a superior enjoys a licence to ignore the fact that one or more members of his troops had committed sexual violence against women, prior to his assumption of command.

In this regard, one notes that in the judgment on the merits in Hadzi ihasanovici.e. the final appeal-the Appeals Chamber stressed that 'a superior's failure to punish a crime of which he has actual knowledge is likely to be understood by his subordinates at least as acceptance, if not encouragement, of such conduct with the effect of increasing the risk of new crimes being committed. ' ${ }^{\mathrm{I} 40}$ If the object of the dictum is that a superior's permission of impunity in respect of a consummated crime has a minimum value of likely appearance to subordinates as condonation of the given crime, thus increasing the risk of future crimes of that nature,

I40 See Prosecutor v Hadžihasanović (Judgment), supra, [ICTY Appeals Chamber] para 30. 
then there is no reason why this should be a matter of concern only in respect of a superior under whose command the crime was committed. This message of condonation, as a result of failure to punish, is no less a concern in respect of a superior who came into command only after the crime had been committed.

It must of course be noted that the employment of the phrase 'actual knowledge' by the Appeals Chamber is something of moment. It is not clear whether by employing that phrase the Appeals Chamber meant to limit the contemplated knowledge to that which the superior gained in consequence of his own direct observation of the underlying facts - as opposed to knowledge that the superior had gained by way of received credible evidence. It is submitted that any such limitation of the idea of knowledge will, as a matter of principle, be wholly unrealistic, even for purposes of assessing whether a message of condonation of the crime had been sent by the superior. It will impermissibly exclude from desirable blame the upper military hierarchy, who are rarely in the theatre of actual military operations so as to observe a crime being committed. As a practical matter, it might, in view of the majority in the Hadžihasanovic interlocutory appeal, also exclude from blame a superior who subsequently came into his command, following his own direct observation of the crime when he had not yet come into command.

Another reason that the position of the majority comes across as curiously mechanical is the rather low obligation which the duty to punish may really entail. The superior's imposition of disciplinary measures may, given the circumstances, be sufficient to satisfy the duty. ${ }^{\mathrm{I} I}$ So, too, may the reporting of the matter to appropriate investigative or prosecutorial authorities be sufficient to discharge the duty to punish. ${ }^{142}$ It is therefore surprising that the majority in the Hadzihasanovic interlocutory appeal appear to be suggesting that a superior has no duty to undertake even these minimal actions in respect of crimes committed prior to his assumption of command. Finally, time may not be of the essence in relation to the superior's duty to punish the rogue subordinate for the subsequently discovered crime, such as makes the duty to punish an unjust imposition on the current superior. That is to say, given that no statute of limitation applies to war crimes, the current superior may generally be able to take his time in punishing the subordinate for the past crime. What is unjust to victims and society is that he does not punish at all.

Still, the division of opinion in the Hadžibasanovic interlocutory appeal has a minimum value of identifying an area in which international criminal law is in need of improvement for purposes of affording women better protection during armed conflicts. In this connection, it is important for the loophole identified in virtue of the position of the majority to be closed-through appropriate legislation or by way of jurisprudence - so that it is beyond question that a superior is clearly placed under an obligation to punish a subordinate who had committed sexual violence against women, prior to the assumption of a superior's command.

I4I See Prosecutor v Hadžihasanović (Judgment), supra, [ICTY Appeals Chamber] para 33 .

I42 See Prosecutor v Hadžihasanović (Judgment), supra, [ICTY Trial Chamber] para I73. 


\section{Conclusion}

In its bid to protect women from rapes during armed conflicts, international law leans on both subordinates and their superiors. While the proscription against rape is more definitive in relation to the subordinate with a tendency to rape, there remains an undesirable gap on the superior's flank. That gap mostly results from the legal duty which requires the superior to prevent rapes only when the subordinate is about to commit it or is actually doing so. This leaves the superior the defence that he did not know nor ought he have known, given the circumstances then prevailing, that the rapist subordinate was 'committing' or 'about to commit' rape.

In view of the frequency of rape as a constant occurrence in armed conflicts throughout history, it is submitted that it is reasonable to impose upon superiors a duty to take all reasonable measures to prevent rapes, notwithstanding that there might not yet be an immediate danger of rape in the particular circumstances. But the present state of international law does not impose such a duty beyond the immediate timing of the crime.

Although it may still be possible in some cases to limit the effects of this deficiency in the law, the present solutions remain unsatisfactory, since they largely depend on judicial interpretations which may vary from judge to judge and from time to time. Furthermore, even this ability to cover the gap by way of judicial interpretation is more difficult with the ICC Statute where the provisions have gone into such details as do not always leave the judges much room to manœuvre.

Ultimately, what is required to permit the foreseeability of sexual violence in armed conflicts as a factor in the assessment of criminal responsibility of the superior is to recognise the limitations which the existing texts of relevant instruments of international law pose. These limitations necessarily call for normative correction of international law, with the view to covering the legal lacuna under consideration here. One method of achieving this is by fostering a regime of due diligence that enhances the duty on superiors to put measures in place at all times, and maintain them regularly, with the view to preventing subordinates from committing sexual violence against women during armed conflicts.

The question does naturally arise as to whether the regime of due diligence advocated here is also not applicable and relevant to all or other types of violations during armed conflict. The answer is that they may be so to varying degrees, depending on the violation contemplated. However, the regime is particularly suited and uniquely necessary to sexual violence against women during armed conflict. This is for the simple reason of obvious foreseeability of that particular brand of violations during armed conflict. Few other types of violations during armed conflict share the same attraction and frequency of occurrence during armed conflicts. As has been noted earlier, the phenomenon was serviceably described as military 'rape differential, ${ }^{143}$ by Madeline Morris in her study that compared the rates of sexual violence between military men and civilian men during periods

I43 Morris, 'By Force of Arms: Rape, War, and Military Culture', supra, p 653. 
of peace and of armed conflicts. As discussed, she found in particular that the peacetime rates of rape by American military personnel are actually lower than civilian rates, taking age and gender into account. Her study also suggested that that peacetime military rape rates are diminished from civilian rates far less than are military rates of other violent crime. In the contrasting context of armed conflicts, her study suggested that military rape rates climbed to several times civilian rates, while military rates of other violent crime were roughly equivalent to civilian rates. Morris's study thus provides specific confirmation of what has become general knowledge, or assumed as a matter of common sense, in great abundance of literature on the subject. It thus sets sexual violence against women during armed conflicts as a crime that is unique in comparison to other crimes that are committed during armed conflicts. That uniqueness supplies ample justification for singling out sexual violence against women for the special regime of due diligence in which superiors are required to put in place at all times measures aimed at preventing their troops from committing such crimes-and to maintain such measures regularly to ensure their continuing effectiveness. A related consideration is the fact of specific foreseeability of the crime. The frequency of sexual violence against women during armed conflicts makes it so specifically foreseeable that it can be easily singled out and be more manageably subjected to the special measures which superiors are required to put in place at all times and maintain regularly.

In the next chapter, we will examine legal developments in the area of definition of rape, from the perspective of containment of the evil that is sexual violence during armed conflicts. 


\section{Chapter 3}

\section{Defining Rape in International Criminal Law: An Unsettled Tug of War?}

\section{Introduction}

In the project of legal containment of the evil of sexual violence in armed conflicts, one angle in need of urgent attention is that of definition of rape. It is an area fraught not only with the substantive issues of the elements of the crime to be proved in specific litigation, but also issues of the procedural sequencing of acts in the play of litigation, with incidental consequences pertaining to questions of fairness of the treatment of the victims in the litigation process. The relevance of the issue to adequate legal responses to the evil of sexual violence is engaged when victims of sexual violence, motivated by reasonable apprehension of unfair treatment, refuse to participate in the litigation process. The result is that perpetrators may enjoy impunity.

There is no statutory definition of rape in international law. The result is that the rape jurisprudence of the ad hoc Tribunals, from Akayesu and Celebici to Mubimana through Furundžija and Kunarac, reveals an apparent jostling of positions among the judges, on the definition of 'rape'. What appears in the debate is a divergence of views on the objective of criminalising rape in international lawnotably referred to in Akayesu as 'the central elements of the crime of rape'. 'Yet, tarry a while and one realises that the debate might be ultimately academic, for it is possible to agree that within the omnibus of aims of international law (in criminalising rape) there is room for the various views. The strict packaging of the one view to the exclusion of all others is neither plausible nor, it is submitted, desirable.

\section{Primary Focus on the Violence of the Occasion}

Akayesu was the first case in which the judges of the ad hoc Tribunals had to grapple with both the issue of rape and the absence of its definition in international law. Having then to devise a definition, an ICTR Trial Chamber offered the following definition of rape: 'a physical invasion of a sexual nature, committed on a person under circumstances which are coercive. ${ }^{2}$ In arriving at this definition, the Trial Chamber took the view that proscription of aggression of a sexual nature was

I Akayesu, supra, para 687 [Trial Chamber].

$2 \quad$ Ibid, paras 598 and 688. 
the central objective of international law in criminalising rape. Hence, the judges declined to follow what they saw as 'a mechanical description of objects and body parts' which constituted the traditional view in many national jurisdictions. In the words of the Chamber:

The Tribunal considers that rape is a form of aggression and that the central elements of the crime of rape cannot be captured in a mechanical description of objects and body parts. The Tribunal also notes the cultural sensitivities involved in public discussion of intimate matters and recalls the painful reluctance and inability of witnesses to disclose graphic anatomical details of sexual violence they endured. ${ }^{3}$

Throughout its discussion, the Chamber remained distinctly focused on the violence of the circumstances rather than the carnality of it, even insisting that '[s] exual violence is not limited to physical invasion of the human body and may include acts which do not involve penetration or even physical contact.'

Next came Čelebicí. In it, an ICTY Trial Chamber agreed with both the Akayesu definition as well as its expression of violence as the central reason of international law in proscribing rape.

\section{Reversion to Focus on Body Parts and Consent}

But Furundžija struck a departure. The facts in Furundžija involved not only the procurement of one male prisoner of war to vaginally rape the female victim, but also the subjection of the female victim to perform fellatio on the male prisoner of war. The ICTY Trial Chamber found both acts to qualify as rape. In their analysis, the Furundzija judges first noted the definition of rape stated in the Akayesu and the Celebici $i$ cases, but with admirable show of judicial diplomacy, directly ignored it, formulating a different definition. They did this though the Chamber had appeared to have reached the same conclusion, as in Akayesu, that punishment of aggression was the objective of the law of rape. ${ }^{5}$

As with Akayesu, the Furundzija Chamber found that there was no definition of rape in international law. In those circumstances, the Chamber felt compelled to conduct a survey of how rape had been defined in domestic jurisdictions; a process evidently also undertaken in Akayesu but with the markedly different result that while the Akayesu judges chose not to follow what they saw, the Furundzija judges did precisely the opposite. Having done so, the Furundzija Chamber offered a definition of rape that depends on coitus. As they put it:

\footnotetext{
$3 \quad$ Ibid, para 687.

$4 \quad$ Ibid, para 688.

5 Furundžija, supra, paras I75, I80 [Trial Chamber]. It is to be noted, however, that as regards their eventual extension of the description of rape to forcible oral sex, the Chamber appeared to have based their analysis on the motivation of international law in preventing 'outrages upon personal dignity': see para I83.
} 
[T]he Trial Chamber finds that the following may be accepted as the objective elements of rape:

(i) the sexual penetration, however slight:

(a) of the vagina or anus of the victim by the penis of the perpetrator or any other object used by the perpetrator; or

(b) of the mouth of the victim by the penis of the perpetrator;

(ii) by coercion or force or threat of force against the victim or a third person. ${ }^{6}$

For their part, the judges in the subsequent case of Kunarac largely followed the Furundzija approach, ${ }^{7}$ but expanded it only as regards the 'other factors which would render an act of sexual penetration non-consensual or non-voluntary on the part of the victim,'besides the factors of 'coercion or force or threat of force against the victim or a third person' indicated in Furundžija. ${ }^{8}$

In explaining their line of reasoning, the judges in Kunarac made it clear that they understood the 'sexual autonomy' of the victim as the 'true' objective of the law against rape. ${ }^{9}$ In this analysis, they focused primarily on the criminal situation as one of 'sexual act', involving 'sexual penetration' to which the victim did not give consent or was put in a position of 'inability to resist'. ${ }^{\text {Io }}$

One notable curiosity of the suggested reason for the Furundzija-Kunarac departure from Akayesu was the principle of specificity in criminal law. The muted suggestion is that Akayesu had taken the rape definition beyond what is specifically settled by a review of the domestic laws of nations, as general principles of law recognised by modern nations, given that there was no definition of rape in international law. But the irony of this suggestion is that the Furundžija-Kunarac judges themselves also proceeded to extend the definition of rape to include forced 'oral penetration', 'I when their own survey shows domestic laws to be united, in their definition of 'rape', only as far as forcible penetration of the vagina or anus. ${ }^{\text {I2 }}$

$6 \quad$ Furundžija, supra, para 185 [Trial Chamber].

7 So did the ICTR judges who decided the Semanza and Kajelijeli cases.

8 Kunarac, supra, para 438 [Trial Chamber], emphasis in original.

$9 \quad$ Ibid, paras 440 and $44 \mathrm{I}$.

Io See paras 438 to 460 .

II See Furundžija, supra, paras I82 and I84. Although the Chamber's analysis in this respect started in paragraph 183 with a reference to 'forced penetration of the mouth by the male sexual organ', there is no doubt that the analysis would also contemplate coerced cunnilingus.

I2 Ibid, para 18r. As noted by the Chamber in paragraph I82: 'A major discrepancy may, however, be discerned in the criminalisation of forced oral penetration: some States treat it as sexual assault, while it is categorised as rape in other States.' 


\section{Caught between Violence and Body Parts}

The ICTR Trial judges who decided the Musema and the Niyitegeka cases followed the Akayesu definition, ${ }^{13}$ while their colleagues who decided the Semanza, the Kajelijeli and the Kamubanda cases preferred the Furundžija-Kunarac definition. ${ }^{14}$ For their part, the Gacumbitsi Chamber made the first attempt to reconcile the two schools of thought, while obviously limiting itself to the facts of the case before it, the Chamber stated as follows:

The Chamber is of the opinion that any penetration of the victim's vagina by the rapist with his genitals or with any object constitutes rape, although the definition of rape under Article $3(\mathrm{~g})$ of the Statute [fn] is not limited to such acts alone. In the case at bench, the Chamber has already found that Witness TAQ was raped at the same time as seven other Tutsi women and girls; that the rapists either penetrated each victim's vagina with their genitals or inserted sticks into them; that Witness TAO's wife was raped, with the rapist penetrating the victim's vagina with his genitals; that Witness TAS was raped in a similar manner, as well as Witness TAP and her mother. The Chamber finds that all these acts fall within the definition of rape. ${ }^{15}$

The Gacumbitsi Trial Chamber had referred to Kunarac in a footnote. This provokes the temptation to think that by saying that the definition of rape is not limited to 'penetration of the victim's vagina by the rapist with his genitals or with any object', the Chamber might have had in mind only anal and oral penetration, which are also recognised as rape in Kunarac as the only other acts of rape other than vaginal penetration. Given, however, that the Chamber had also referred to Akayesu, it suggests that the Chamber meant to recognise the larger scope of rape as comprised in the Akayesu definition.

In the Mubimana case, another attempt was made to marry the two schools of thought, although the Chamber ended up on the side of the Akayesu definition. ${ }^{\text {.6 }}$ The Chamber began the effort by suggesting that the Furundżija and Kunarac

I3 Musema, supra, paras 229, 907, 933 and 936; Prosecutor v Niyitegeka (Judgment and Sentence) I6 May 2003 [ICTR Trial Chamber], para 456. It is noteworthy, perhaps, that although the Niyitegeka Bench was composed of Judge Navanethem Pillay (presiding) and two other judges, Musema was decided by the same three judges (Laity Kama, Lennart Aspegren, and Navanethem Pillay) who had decided Akayesu. In Musema, the Chamber reiterated the definition they offered in Akayesu, having considered the departure from that definition as was made in Furundžija: see Musema, supra, paras 220-229.

I4 See Semanza, supra, paras 344-346; Kajelijeli, supra, paras 910-915; and, Prosecutor $v$ Kamuhanda (Judgment and Sentence) 22 January 2003, paras 705-710 [ICTR Trial Chamber].

I5 Gacumbitsi, supra, para 32I.

I6 Mubimana, supra, paras 551. 
jurisprudence did not necessarily set out to depart from the Akayesu definition, but had 'tacitly accepted' it. ${ }^{17}$ This proposition is highly debatable, in my view. For one thing, the Furundzija-Kunarac jurisprudence was quite clear in saying that the definition of rape must be governed by what was viewed as the rule of 'specificity' ${ }^{\mathrm{I} 8}$ : an obvious suggestion that the Akayesu definition was overly broad. Nevertheless, the conclusion in Mubimana that the Furundžija-Kunarac fits within the Akayesu definition $^{19}$ is entirely accurate; for while the Furundžija-Kunarac school focused on the proscription of sex without consent, with coercive circumstances being recognised as vitiating consent, Akayesu had focused just on the concept of aggression or violence. Of course, the reverse is not necessarily true: the Akayesu definition does not necessarily fit within the Furundżija-Kunarac construct of rape. In other words, while every scenario envisaged as rape in the Furundžija-Kunarac definition would also qualify as rape in the Akayesu definition, not every scenario envisaged as rape in Akayesu would qualify as such in the Furundžija-Kunarac construct. The significance of this difference will be discussed below. ${ }^{20}$

\section{Rape Law Reform in Domestic Jurisdictions}

It is opportune, perhaps, to review at this point a certain related development seen in some domestic jurisdictions in the last few decades, in the legal and philosophical discourse on the subject of rape. This development has as a central element the debate on whether to view rape primarily as an act of sex or an act of violence. ${ }^{21}$ This debate is captured in the following quote:

Among the conceptual questions to be asked about rape ... is whether it is an instance of sex, violence, or both. Assuming that rape is some kind of sexual intercourse (an assumption that may well deserve to be questioned), [fn] should it be conceived as forced sex, violent sex, coerced sex, compelled sex, nonconsensual

I7 Ibid, paras 54I and 549 .

I8 In this connection, one must note the following remark in Furundžija following the Chamber's note of how rape had been defined in Akayesu and Čelebici

This Trial Chamber notes that no elements other than those emphasised may be drawn from international treaty or customary law, nor is resort to general principles of international criminal law or to general principles of international law of any avail. The Trial Chamber therefore considers that, to arrive at an accurate definition of rape based on the criminal law principle of specificity (Bestimmtheitgrundsatz, also referred to by the maxim "nullum crimen sine lege stricta"), it is necessary to look for principles of criminal law common to the major legal systems of the world. These principles may be derived, with all due caution, from national laws.

I9 Mubimana, supra, paras $55^{\circ}$ and $55^{1}$.

20 See discussion under the subtitle 'The Problems with Kunarac'.

2I See Chinkin, supra, at note I3. 
sex, pressured sex, exploited sex, involuntary sex, expropriated sex, objectified sex, unwanted sex, nonmutual sex, or bad sex? ?2 $^{22}$

It is not my aim here to weigh in on either side of this debate, for the issue might well be close to moot in international criminal law, given, as will be demonstrated later, that violence is the dominant context of rapes in armed conflicts - armed conflicts being typically the raison d'etre of international criminal law. ${ }^{23}$ It might do, nevertheless, to point out that the modern view, increasingly gaining ground in some domestic jurisdictions, is that rape is centrally a crime of violence and domination and not just a crime of sex without consent. 'On this account, the failure to distinguish rape from sex derives from a sexist point of view that fails to encompass the perspective of the victim for whom rape is a violent-rather than a sexual-act.' ${ }^{24}$ This represents an important shift, even if ever subtle to some, from the traditional view of rape as a crime of sex without consent. To those who hold the modern view, it is improper for the traditional view to focus the inquiry in rape trials on the conduct of the victim, which is necessarily the case where the inquiry is to find out whether or not sex was had with her without her consent. According to Burgess-Jackson:

Whether the language in question is "by force," "against her will," "without her consent," or some combination of the three, the focus of rape law and practice has been on the victim's mental state and behavior. [fn] This fact about the law of rape has struck many reformers, liberal and radical alike, as misplaced, unjust, and intolerable, and has led to the enactment of statutes that eliminate nonconsent as an element of the offense. ${ }^{25}$

Since the traditional inquiry has focused on the conduct of the victim- to see whether or not she gave consent to the sexual activity-victims have often found it difficult to submit themselves to such inquiries by reporting the rapes: as a result, many a rape has gone unpunished. ${ }^{26}$

Many domestic jurisdictions have now reformed their rape law in line with this modern view. Canada is one notable national jurisdiction which has done so. As Brenda Baker observed:

22 Keith Burgess-Jackson, 'Introduction' in K Burgess-Jackson (ed), A Most Detestable Crime: New Philosophical Essays on Rape [New York: Oxford University Press, 1999] p 4. Emphasis received.

23 See discussion of the 'Sex $\rightarrow$ Consent $\rightarrow$ Force Inquiry' below.

24 Jeffery Gauthier, 'Consent, Coercion and Sexual Autonomy' in Burgess-Jackson (ed), A Most Detestable Crime: New Philosophical Essays on Rape, supra, p 71.

25 Burgess-Jackson, 'A History of Rape Law' in Burgess-Jackson (ed), A Most Detestable Crime: New Philosophical Essays on Rape, supra, p 2I.

26 David P Bryden and Sonja Lengnick, 'Rape in the Criminal Justice System' (1997) 87 Journal of Criminal Law and Criminology $1 \mathrm{I} 94$ et seq. 
In 1983 , Canada replaced its rape law with the offense of sexual assault. The sexual assault law took the form of a multitiered offense recognizing different severities of sexual violation, incorporating sexual assault, sexual assault with a weapon, threats to a third party or causing bodily harm, and aggravated sexual assault. The new classification was designed both to respect gender neutrality as required by the Canadian Charter of Rights and Freedoms [fn] and to emphasize that sexual aggression against women and other persons should be viewed as a crime of violence and domination rather than one of sexual passion. It acknowledged feminist arguments that rape is not about sex but about power. ${ }^{27}$

This Canadian law reform effort followed a similar effort in the American state of Michigan. According to one commentator:

\begin{abstract}
Michigan's reform statute, for example, which became effective in April 1975,[fn] emphasizes the force or coercion used by the rapist, not the resistance (or lack thereof) of the victim.[fn] This, it is claimed, brings rape in line with other violent felonies. No prosecutor has to prove beyond a reasonable doubt that a robbery victim did not consent to the taking of his or her money or that a murder victim did not consent to being killed; so why should a prosecutor in a rape case have to prove that the rape victim did not consent? So goes the argument. This development goes to the core of the legal understanding of rape and has therefore generated heated controversy. Much has been written about the Michigan experiment in particular. ${ }^{28}$
\end{abstract}

There is still much debate as to whether the reform efforts in national jurisdictions have produced the intended results. ${ }^{29}$

\title{
The Problems with Kunarac
}

Returning now to the judicial debate at the ad hoc Tribunals, a few comparative remarks are here warranted. First, the allusion to Canadian rape law in the

27 Brenda M Baker, 'Understanding Consent in Sexual Assault' in Burgess-Jackson (ed), A Most Detestable Crime: New Philosophical Essays on Rape, supra, p 49. See also Sheila McIntyre et al, 'Tracking and Resisting Backlash against Equality Gains in Sexual Offence Law' (2000) 20 Canadian Woman Studies 72.

28 Burgess-Jackson, 'A History of Rape Law' in Burgess-Jackson (ed), A Most Detestable Crime: New Philosophical Essays on Rape, supra, р 21. Emphasis in original.

29 See generally Elizabeth Sheehy, 'Legal Responses to Violence against Women in Canada' (1999) I9 Canadian Woman Studies 62; Bryden and Lengnick, supra; Margaret Denike, 'Sexual Violence and "Fundamental Justice": On the Failure of Equality Reforms to Criminal Proceedings' (2000) 20 Canadian Woman Studies 15I et seq; Vivian Berger, 'Rape Law Reform at the Millennium: Remarks on Professor Bryden's Non-Millennial Approach' (2000) Buffalo Criminal Law Review 513. 
Kunarac judgment appears misleading as to the true state of the law in Canada..$^{\circ}$ The allusion suggests that Canadian law is still operating under the traditional view, being the view favoured by the judges in the Kunarac case. Second, there are other national jurisdictions apart from Canada that now adhere to the modern view. They include Italy, ${ }^{3 \mathrm{I}}$ apart from many states within the USA, besides Michigan..$^{32}$ The discussion in Kunarac did not indicate that. Third, it is evident that the Akayesu analysis leans towards the modern view.

Regarding the objective of the law, however, there is no reason to suppose that the different views cannot be accommodated within the compass of international law. What is more important is the need to develop international criminal law in a manner that produces deterrence from international crimes and to do justice to victims. To achieve this aim, it must be acknowledged that there is no one 'true' answer to the problem, as was suggested in the Kunarac case. Surely, to subject someone to an unwanted contact of a sexual nature in an aggressive manner (the point of Akayesu) is to violate the person's sexual autonomy (the point of Kunarac).

The Akayesu judges had done as much service to the advancement of international law in the way they defined rape, as did the Furundžija judges in extending to forcible oral sex the tag of rape. To develop international law in this way is precisely what is implied in article $38(\mathrm{I})(\mathrm{d})$ of the Statute of the International Court of Justice when it indicates judicial decisions as a subsidiary means for the determination of rules of law. In my opinion, the value of article $38(\mathrm{I})(\mathrm{d})$ is that where all of the primary sources of law (treaties, customary international law and general principles of law) do not lend suitable assistance to the legal question at hand, the judges must then decide the case as best they can bearing in mind what

30 The troubling part of the Kunarac judgment includes mentioning Canada in the context of a dense review of national jurisdictions that have retained the element of 'sexual penetration' in their rape laws (which is no longer an element of Canadian law of sexual assault), and then saying as follow:

453. In most common law systems, it is the absence of the victim's free and genuine consent to sexual penetration which is the defining characteristic of rape..$^{[\mathrm{f}]}$ The English common law defined rape as sexual intercourse with a woman without her consent. ${ }^{[\mathrm{fn}]}$ In 1976 rape was also defined by statute. Under the provision in force at the time relevant to these proceedings, a man committed rape where "(a) he has unlawful sexual intercourse with a woman who at the time of the intercourse does not consent to it; and (b) at that time he knows that she does not consent to the intercourse or he is reckless as to whether she consents to it ...". ${ }^{[\mathrm{fn}]}$ Force or threat or fear of force need not be proven; however where apparent consent is induced by such factors it is not real consent. ${ }^{[\mathrm{fn}]}$ Similar definitions apply in other Commonwealth countries including Canada, ${ }^{[\mathrm{fn}]}$ New Zealand ${ }^{[\mathrm{fn}]}$ and Australia. ${ }^{[\mathrm{fn}]}$

3I See generally Amy Jo Everhart, 'Predicting the Effect of Italy's Long-Awaited Rape Law Reform in "The Land of Machismo"' (1998) 3I Vanderbilt Journal of Transnational Law 671.

32 See generally Ronet Bachman and Raymond Paternoster, 'A Contemporary Look at the Effects of Rape Law Reform: How Far Have We Really Come? (I993) 84 Journal of Criminal Law and Criminology 554. 
they understand to be the mischief which international law had set out to address in particular circumstances. That is precisely what the Akayesu judges were doing, and properly so as will become presently apparent, when they were defining rape in international criminal law.

Finally, as regards practical consequences of the different approaches, as opposed to the objectives of international criminal law of rape, it is easy to see much that is weak in the heavy reliance in Kunarac on what was identified there as the preponderant theme in domestic jurisdictions. The theme in question is the sex $\rightarrow$ consent $\rightarrow$ force inquiry. 33

To appreciate the difficulties with the sex $\rightarrow$ consent $\rightarrow$ force inquiry in international criminal law, one must recall the famous counsel of Judge McNair (as he then was) in the International Status of South West Africa Case ${ }^{34}$ advising against the wholesale uploading of the principles of domestic law. According to McNair:

What is the duty of an international tribunal when confronted with a new legal institution the object and terminology of which are reminiscent of the rules and institutions of private law? To what extent is it useful or necessary to examine what may at first sight appear to be relevant analogies in private law systems and draw help and inspiration from them? International law has recruited and continues to recruit many of its rules and institutions from private systems of law. Article 38 (I) (c) of the Statute of the Court bears witness that this process is still active, and it will be noted that this article authorizes the Court to 'apply .... (c) the general principles of law recognized by civilized nations.' The way in which international law borrows from this source is not by means of importing private law institutions 'lock, stock and barrel', ready-made and fully equipped with a set of rules. It would be difficult to reconcile such a process with the application of 'the general principles of law'. In my opinion, the true view of the duty of international tribunals in this matter is to regard any features or terminology which are reminiscent of the rules and institutions of private law as an indication of policy and principles rather than as directly importing these rules and institutions. ${ }^{35}$

In no area of international law is this caution more fitting than in the area of rape as an international crime. While the circumstances of the inquiries in domestic law situations might make the inquiry into consent more appropriate (such as date rape and acquaintance rape, for instance), the very nature of the circumstances in which rape occurs in the context of international law makes inquiry into consent almost wholly out of place..$^{36}$ In international criminal law, judges will typically, if not exclusively, deal with rape in any of the following circumstances:

33 Prosecutor v Kunarac (Judgment) of I2 June 2002 [ICTY Appeals Chamber] para I29.

34 Case concerning International Status of South West Africa (1950) ICJ ${ }_{22} 8$.

35 Ibid, at p I48.

36 See Kunarac, supra, para I30 [ICTY Appeals Chamber]. 
- $\quad$ rape as genocide

- rape as a crime against humanity, or

- $\quad$ rape as a war crime.

Rape as an act of genocide is predicated on the special intent to destroy a group in whole or in part, the victim of rape being part of the group targeted for such destruction. Rape as a crime against humanity is predicated on the rape being part of a widespread or systematic attack against a civilian population, with the victim being raped as part of that attack. And rape as a war crime is predicated on the existence of an armed conflict (internal or international), during which the victim was raped. As reiterated in Mubimana, this makes general violence, force or coercive circumstance a constant feature of the rape narrative in international criminal trials. ${ }^{37}$ In these circumstances, it becomes almost hapless to import into the inquiry tenets of domestic law that were designed to try to ensure that a complainant had not merely changed her mind after the fact of a consensual 'sexual activity', often involving a lecherous employer, colleague, suitor, or other acquaintance. This is the major flaw in Kunarac, given its heavy reliance on domestic law.

In defence of Kunarac, however, it must be acknowledged that the Chamber did recognise that force and coercion do negate consent. But this does not make things right in the Kunarac analysis. It is rather, in a way, the nub of the matter. It will reduce the administration of justice into a mere academic or mechanical exercise where in every case the judges insist that the prosecutor must go through a checklist of proof in the following order:

$\begin{array}{ll}\text { Step 1: } & \text { Sex } \\ & + \\ \text { Step 2: } & \text { Absence of Consent } \\ & + \\ \text { [Step 3: } & \left.\text { Presence of Force }{ }^{*}\right] \\ & = \\ & \text { Rape }\end{array}$

First Scenario * Reference to 'force' here includes real force, threat of use of force or other coercive circum-
stance.

In international criminal law, the requirement of Step 2 above is entirely academic. The only value it may serve, when made routine as Kunarac would have it, is routinely to hold out the prospect of forensic embarrassment to every victim who is a witness in a rape trial, even though there may not be any question that she might have been raped as part of a plot to destroy her in a genocide, as was the case in Rwanda.

37 Mubimana, supra, para 546. See also Chinkin, supra, at note I3. 
In my view, it is amply sufficient, in a rape trial before an international criminal court, to require the case for the prosecution to comprise no more than:

Step 1: $\quad$ Sex

Step 2: $\quad \begin{aligned} & + \\ & \quad \text { Presence of Force }\end{aligned}$

$=$

Rape Second Scenario

Furthermore, the proof of force should be deemed as discharged if established at the overarching level of, say, a war in progress. More precisely, 'force' in this equation is synonymous with 'coercive circumstances', if you will. ${ }^{38}$

At this stage, it must be made clear that what I am advancing here is not a theory of complete abolition of the consent inquiry from rape trials in international criminal law, as might have been advocated in some quarters in North America in the context of rape trials under domestic law. As will be seen presently, there may yet be a place for that inquiry in the interest of justice, however improbable that might be.

As noted earlier, the first scenario does focus attention on the victim, at times unduly so, while the second does not. On the face of it, the ends of justice may be served in both scenarios. In real terms, however, to the extent that the victim's conduct is also the subject of the inquiry, justice may not be done if the victim elects not to submit herself to that inquiry, which results in the abortion of the trial. In this connection, it needs to be said with maximum emphasis that justice is not well served in a system of rape inquiry that needlessly turns attention to the conduct of the victim in such a central way. ${ }^{39}$ She is not on trial. Conversely, there is

38 In this connection, one must note the concern of the Appeals Chamber saying as follows: 'A narrow focus on force or threat of force could permit perpetrators to evade liability for sexual activity to which the other party had not consented by taking advantage of coercive circumstances without relying on physical force.' [Kunarac, supra, para I29 [ICTY Appeals Chamber]]. With respect, this concern might not have arisen if the notion of 'force' is taken, as it should, to include the presence of coercive circumstances, such as that which exists in the typical context of the events that give rise to the rape cases tried before international criminal courts. It is submitted that this is what the Akayesu Trial Chamber was driving at; and that is where the Akayesu Trial Chamber's aim meets the analysis and analogy made by the Kunarac Appeals Chamber in paragraphs I3I to I32 of their judgment.

39 Much of what makes the consent inquiry, nay the traditional view, particularly suspect is its ancient link to Sir Matthew Hale's now much criticised jury caution that 'it must be remembered, that [rape] is an accusation easily to be made and hard to be proved, and harder to be defended by the party accused, tho never so innocent.' Matthew Hale, Pleas of the Crown, or, a methodical summary of the principal matters relating to that subject, vol I, [London: W. Shrewsbury, 1694 ] p 635. See also William Blackstone, Commentaries on the Laws of England, vol 4 [Oxford: Clarendon Press, I765-69] pp 2I4-I5; Burgess-Jackson, supra, p I8. While reasonable people may disa- 
no injustice in a system of rape inquiry that requires the prosecutor to prove only the presence of force on the part of the perpetrator. This does not negate the right of the accused to full answer and defence, which might include rebuttal as to the presence of force in the particular sexual relation. And such a rebuttal of force may entail the proof of consent.

This nuance is important in international criminal law in the following practical way. Removing the requirement (on the prosecutor) to prove non-consent will meet the practical needs of international criminal justice as indicated above and, by the way, has a potential to shorten the trials. On the other hand, the very benefit of eliminating this a priori inquiry into the conduct of the victim also portends the side-effect that a prosecutor may improperly prosecute an innocent man with whom the 'victim' had consensual sex. If the prosecutor is not required to call the 'victim' or ask her about consent, then that story of consent may entirely escape the inquiry, certainly so during the case for the prosecution. But this is not an argument to require the prosecutor routinely to call the 'victim' as part of the case for the prosecution in every case, notwithstanding that consent might not be a real issue. It is, rather, an argument to leave the defendant to raise consent as part of his case. ${ }^{40}$ Where such consent is raised, then it falls on the Prosecution to disprove it as part of the case for the Prosecution, as with other cases of affirmative defences such as alibi and diminished mental capacity. Noting that article 67(I)(i) of the ICC Statute forbids imposing on the Defendant 'any reversal of the burden of proof or any onus of rebuttal', it bears stressing that there is an appreciable difference between establishing a proposition as a question of burden and raising it. Although, as the law of alibi tells us, ${ }^{4 \mathrm{I}}$ there needs to be evidence of the proposition raised, before it can pass the required juristic muster, it is still possible that all that the evidence does is raise-rather than establish - the proposition in question beyond a mere assertion.

The value of this manner of proceeding before international criminal courts is that as it eliminates the routine of proof of non-consent as part of the case for the

gree on the reasonableness of that caution per se, what is done in the name of it is quite another matter. Specifically, complainants should not be put on trial in rape trials any more so than any other complainant in another case.

40 This suggestion must not be taken as supporting any school of thought that might be understood to be advocating that the burden of proof in a rape case should entirely shift from the prosecution to the defence. [See Edward Greer, 'The Truth Behind Legal Dominance Feminism's “Two Percent False Rape Claim” Figure' (2000) 33 Loyola of Los Angeles Law Review 947 at 948.] Rather, the specific context of international criminal law perfectly accommodates the view that consent should be an affirmative defence, a view already expressed by such feminist writers as Catherine MacKinnon: see Greer, supra, p 963 at footnote 79.

$4 \mathrm{I}$ For instance, the Supreme Court of Nigeria has explained that the 'onus' on the Defendant is to 'adduce evidence which sufficiently contains the particulars of the alibi': Ukwunnenyi E' Anor v The State, (1989) 7 NILR 7. See also Nwosisi v The State (1976) 6 SC rog [Supreme Court of Nigeria.] 
prosecution, it also ensures that the soldier who genuinely had a love affair with an enemy in an occupied village is not punished for that love affair.

Happily, however, the Appeals Chamber of the ICTR has now recognised the forgoing dilemma in its judgment in the Gacumbitsi Case. In that judgment, the ICTY Appeals Chamber refused to depart from the view expressed in Kunarac that proof of lack of consent of the victim will remain an element of rape to be proved by the prosecution beyond a reasonable doubt. ${ }^{42}$ Nevertheless, the ICTR Appeals Chamber has clarified that the prosecution will be able to prove absence of consent by establishing the presence of coercive circumstances. As the Appeals Chamber put it:

The Prosecution can prove non-consent beyond reasonable doubt by proving the existence of coercive circumstances under which meaningful consent is not possible. As with every element of any offence, the Trial Chamber will consider all of the relevant and admissible evidence in determining whether, under the circumstances of the case, it is appropriate to conclude that non-consent is proven beyond reasonable doubt. But it is not necessary, as a legal matter, for the Prosecution to introduce evidence concerning the words or conduct of the victim or the victim's relationship to the perpetrator. Nor need it introduce evidence of force. Rather, the Trial Chamber is free to infer non-consent from the background circumstances, such as an ongoing genocide campaign or the detention of the victim. [fn] Indeed, the Trial Chamber did so in this case. ${ }^{43}$

Although the foregoing decision is to be applauded, it might have been better for the Appeals Chamber to override the flawed jurisprudential analysis in Kunarac which failed to recognise organically that there is no place for the consent inquiry as a necessary consideration in the case for the prosecution in a case involving rape as an act of genocide.

\section{Conclusion}

In the effort to achieve a holistic legal framework aimed at containing the evil of sexual violence during armed conflicts, a proper definition of rape in international criminal law must play a part. The part envisaged here will include procedural legal developments which will not permit perpetrators of sexual violence during armed conflicts to enjoy impunity. Such impunity may occur if victims of sexual violence during armed conflicts are induced to refrain from participating in rape trials due to an unhealthy focus on their conducts. This may result from a definition of rape that unwittingly puts the victims on trial, by routinely focusing on whether or not they gave consent to the sexual acts. A definition of rape which concentrates on the coercive circumstances of the occasion is more likely to achieve the

42 Prosecutor v Gacumbitsi (Judgment) dated 7 July 2006, Case No ICTR-200I-64-A [ICTR Appeals Chamber] para I54.

Ibid, para 155 . 
I58 Chapter 3

ends of containment of sexual violence than is one which routinely requires the Prosecution to prove that the victim did not give consent to the sexual act.

In the next chapter, we will examine the question of rape as an act of genocide, and whether there are some resulting questions that will have a bearing on the need to contain the evil of sexual violence during armed conflicts. 


\section{Chapter 4}

\section{Rape as Genocide and Some Questions Arising}

\section{Introduction}

In the constant chronicle of evil during armed conflicts, over-saturated with incidents of sexual violence, genocides account for a significant proportion of these crimes against women. In Chapter I, we saw how rape was a chosen policy instrument of 'ethnic cleansing' employed by Serbian forces during the Bosnian war. In the report Shattered Lives: Sexual Violence during the Rwandan Genocide and its Aftermath, ${ }^{\mathrm{I}}$ Binaifer Nowrojee painted a convincing portrait of the prevalence of rapes during the Rwandan Genocide of I994.

While the legal response to sexual violence committed amidst genocide is by no means perfect, it is possible to recognise some progress. In this connection, it is to be noted that one of the most significant developments in the jurisprudence of modern international criminal law is the determination of the International Criminal Tribunal for Rwanda, in the Akayesu case, that rape can be an act of genocide. ${ }^{2}$ The striking value of that conclusion lies in the fact that none of the leading instruments of international criminal law, being the primary sources of the law of genocide, mentions rape specifically as an act of genocide.

The reasoning that rape can be an act of genocide has not, however, agitated much disagreement. The general acceptance of the reasoning is not explained by considerations of political correctness, but because the deductive reasoning deployed by the ICTR Trial Chamber in the Akayesu case is simply unassailable. Here is how.

Article II of the Genocide Convention of 1948 defines genocide as follows:

In the present Convention, genocide means any of the following acts committed with intent to destroy, in whole or in part, a national, ethnical, racial or religious group, as such:

(a) Killing members of the group;

(b) Causing serious bodily or mental harm to members of the group;

I Human Rights Watch, Shattered Lives: Sexual Violence during the Rwandan Genocide and its Aftermath [New York: Human Rights Watch, 1997].

2 Prosecutor $v$ Akayesu, supra, [ICTR Trial Chamber] paras 73I-734. 
(c) Deliberately inflicting on the group conditions of life calculated to bring about its physical destruction in whole or in part;

(d) Imposing measures intended to prevent births within the group;

(e) Forcibly transferring children of the group to another group.

The foregoing definition contains the complete elements of the crime of genocide, in terms of both the acti rei and the mens rea. This provision has now been incorporated directly and repeatedly into the leading modern instruments on the subject of international criminal law, such as the Statutes of the International Criminal Tribunal for Rwanda, ${ }^{3}$ the International Criminal Tribunal for the former Yugoslavia ${ }^{4}$ and the International Criminal Court. ${ }^{5}$

As is apparent from the definition of genocide, there are five categories of act $i$ rei for the crime. For purposes of clarity, I repeat them below:

i. killing members of the group;

ii. causing serious bodily or mental harm to members of the group;

iii. deliberately inflicting on the group conditions of life calculated to bring about its physical destruction in whole or in part;

iv. imposing measures intended to prevent births within the group; and

v. forcibly transferring children of the group to another group.

This list was intended to be exhaustive and not illustrative of the acts of genocide. ${ }^{6}$ Nevertheless, they are, for the most part, categories of acts; and within those categories much may fit. This is so, given that within each of the listed items, except for the first (killing) and last (forcible transfer of children), there is a host of different actions the perpetration of which may reasonably fit within the listed categories as an act of genocide. And this is particularly so for the second item on the list of acti rei-i.e. 'causing serious bodily or mental harm to members of the group'. It is thus that rape can, without much debate, be seen as an act of genocide. And it is thus that the ICTR convicted Jean Paul Akayesu of rape as an act of genocide, although rape itself does not specifically appear on the list of acti rei of genocide.

In early 2009, another Trial Chamber of the ICTR attempted to extend the notion of rape as an act of genocide even further to include less aggressive forms of sexual assaults. In the Rukundo case, ${ }^{7}$ the accused, who was a Catholic priest and a military chaplain, was charged, among other things, with sexually assaulting $\mathrm{CCH}$, a female victim. $\mathrm{CCH}$ and her family were Tutsis. During the Rwandan

3 See art 2(2) of the ICTR Statute.

4 See art $4(2)$ of the ICTY Statute.

5 See art 6 of the ICC Statute. See also art I7 of the I996 ILC Draft Code of Crimes against Peace and Security of Mankind.

6 William Schabas, Genocide in International Law [Cambridge: Cambridge University Press, 2000] p 73 .

7 Prosecutor v Rukundo (Judgment) 29 February 2009 [ICTR Trial Chamber]. 
Genocide she and her family fled to the sanctuary of a Catholic seminary. In the course of the events, the seminary was surrounded by genocidal Interahamwe militia threatening to attack and kill the refugees, including $\mathrm{CCH}$ and members of her family. Armed with lists of alleged saboteurs from among the refugees, soldiers allied with the Interahamwe would enter the seminary from time to time, and abduct refugees in bus-loads to undisclosed locations where they were killed.

Upon seeing the familiar accused who was armed, in military uniform and had military escort, $\mathrm{CCH}$ pleaded with him to save her and her family. The accused denied the request. Instead, with apparent menace, the accused told $\mathrm{CCH}$ that her family were saboteurs and would be killed. Still hoping to obtain a change of heart from the accused, $\mathrm{CCH}$ assisted the accused with carrying his personal effects into a nearby room. Once inside the room, the accused locked her in, put his firearm down on a nearby table, and demanded sexual intercourse with her. When she refused, the accused initially attempted to use force, but soon gave up the effort when she resisted. He thus limited himself to rubbing his groin against her until he ejaculated. He then left. According to $\mathrm{CCH}$, the accused had not even attempted to touch her vagina during the whole encounter.

Having found that the accused haboured genocidal mens rea by telling $\mathrm{CCH}$ that she and her family would be killed, the Chamber had to determine whether it could be said that the conduct of the accused had occasioned serious mental harm to $\mathrm{CCH}$. The Prosecution had not lead evidence of such mental harm and did not even, during her testimony, ask $\mathrm{CCH}$ any question tending to elicit evidence of mental harm. The majority of the Chamber noted these short-comings in the case for the Prosecution. Nevertheless, the majority were prepared to infer serious mental harm from the highly charged and oppressive circumstances in which the event occurred.

The key to this inference is the ability to look beyond just the sexual act in question. It is particularly important to keep in view the highly charged and oppressive circumstances which merged into the assault on her mind, of which the outward sexual character of the experience she endured formed a part. Those circumstances include the following. Members of her ethnic group were being massacred in a genocidal bloodbath. She and her family, fearing death in this way, sought refuge in a religious institution. Upon seeing a familiar person of authority, i.e. the Accused, she allowed herself a flicker of hope from lurking doom and requested protection for herself and her family. Her hope was doubly dashed when, not only did the Accused refuse her the protection she had requested, but he distinctly directed her mind to a specific threat - that her family in particular was to be killed by reason of alleged association with the 'Inyenzi. He was bearing a firearm. Still keeping hope alive, she sought to ingratiate herself to him by assisting him to carry his effects into a nearby room. While in the room, he locked her in, put his firearm down nearby and proceeded to physically manhandle her in a sexual way. Granted, for reasons best known to him, he did not attempt forcible 
penetration. Nevertheless, his actions, under the circumstances, were enough to cause serious mental harm: penetration would only have made matters worse. ${ }^{8}$

There is little question that the reasoning of the majority of the Trial Chamber in the Rukundo case will generate some controversy, as has been signalled by the fact that the third judge in the case dissented from the majority view on the point. In Judge Park's dissent, he reasoned that the level of the physical act done by the accused did not rise to the usual level of sexual violence seen in previous cases of rape as genocide. And he worried that the Rukundo case may have the effect of contemplating conviction as genocide every act of sexual assault committed with the genocidal intent. Judge Park's point is that genocidal intent alone does not make a genocide; it is necessary for the Prosecution to also prove the actus reus of the crime, which in this case includes proof of serious mental harm, which the Prosecution did not establish.

On appeal, the majority of the Appeals Chamber (Judge Pocar dissenting) overturned the Trial Chamber's reasoning that Rukondo's sexual assault upon $\mathrm{CCH}$ amounted to genocide. In this connection, the Appeals Chamber reasoned that the circumstances did not necessarily lend themselves to an interpretation that would lead to the finding of genocidal intent on the part of Rukundo. The Appeals Chamber's point of departure was their quarrel that '[c]entral to the Trial Chamber's finding of genocidal intent was Rukondo's assertion that Witness CCH's family had to be killed because one of her relatives was "Inyenzi".'9 Given the real prospect that the majority of the Appeals Chamber was wrong, it is important immediately to note that the Appeals Chamber did not question the Trial Chamber's factual finding that Rukundo had asserted that 'Witness CCH's family had to be killed because one of her relatives was assisting the "Inyenzi".' [Emphasis added.] Indeed, the Trial Chamber's actual finding which was not questioned by the Appeals Chamber was that CCH's 'entire family had to be killed for assisting the Inyenzi. .o As part of their reasoning, the Appeals Chamber recalled that 'inferences drawn from circumstantial evidence must be the only reasonable inferences available. 'II In the particular context of Rukundo's conduct, the majority of the Appeals Chamber considered that genocidal intent was not the only reasonable inference to be drawn from Rukundo's assertion. According to the majority of the Appeals Chamber 'Rukundo's language can plausibly be interpreted as expressing anger that a former friend was affiliated with the "Inyenzi", without signifying a personal desire to destroy Tutsis. ${ }^{\text {I2 }}$ Further more, the majority considered that the alternative interpretation of the circumstances that they

\footnotetext{
8 Prosecutorv Rukundo (Judgment), supra, paras 386-389.

9 Rukundo v Prosecutor (Judgment) dated 20 October 2oio [ICTR Appeals Chamber] para 235 .

Io Prosecutorv Rukundo (Judgment), supra, [ICTR Trial Chamber] para 575.

II Ibid.

I2 Ibid.
} 
have offered 'is supported by the fact that Rukundo's statement did not frighten Witness $\mathrm{CCH}$...'. ${ }^{\text {r3 }}$

With respect, the majority of the Appeals Chamber was plainly wrong in this interpretation. It is recalled, first, that what drives the persuasiveness of an inference is the notion of reasonableness. The alternative interpretation suggested by the Appeals Chamber is not at all persuasive in the prevailing circumstances. Those circumstances are these. At the time of the events, Tutsis in Rwanda were being killed in a genocide. This was a matter of common knowledge. It is also a matter of common knowledge that a central part of the Rwandan genocide narrative was the branding of the Tutsi victims as either "Inyenzi" who posed an existential threat to the Hutu majority thus deserving extermination, or accomplices to the "Inyenzi" who deserved a similar extermination fate. ${ }^{\mathrm{I4}}$ Secondly, Rukundo was a chaplain and a soldier in an army whose troops at all material times-and particularly at the Seminary - were apparently acting in concert with the Interahamwe in an anti-Tutsi genocide at the seminary where the events under review took place. In particular, Tutsis at that seminary were being rounded up by soldiers and bussed off to their deaths. Thirdly, $\mathrm{CCH}$ requested Rukundo the military chaplain to intervene and save her and her family from the same fate that other Tutsis were facing at the Seminary. It was in that context that Rukundo asserted, instead, that CCH's family ' $h a d$ to be killed because one of her relatives was assisting the "Inyenzi". Without entering into inquiry as to whom Rukundo contemplated as 'had to' kill CCH's family, it is reasonable to infer, at a minimum, that Rukundo's assertion indicated approval with the ongoing programme of killing

I3 Ibid.

I4 See generally Nabimana $\mathcal{E}^{2}$ ors v Prosecutor (Judgment) dated 28 November 2007 [ICTR Appeals Chamber], especially at paras 739, where the Appeals Chamber observed as follows: 'The Appeals Chamber would begin by pointing out that the broadcasts must be considered as a whole and placed in their particular context. Thus, even though the terms Inyenzi and Inkotanyi may have various meanings in various contexts (as with many words in every language), the Appeals Chamber is of the opinion that it was reasonable for the Trial Chamber to conclude that these expressions could in certain cases be taken to refer to the Tutsi population as a whole.' See also, ibid, paras 756 to $758,767,768$, and 77 I. Indeed, in their very own judgment in the Rukundo case, the Appeals Chamber held as follows on a relatied question: 'The Appeals Chamber also finds that it was reasonable for the Trial Chamber to consider that Rukundo's reference to the Rudahunga family as Inyenzi referred to the fact that they were Tutsi': Rukundo v Prosecutor (Judgment), supra, [ICTR Appeals Chamber], para 64. Similarly of note is the case of Prosecutor $v$ Ruggiu (Judgment and Sentence) dated I June 2000, where the Trial Chamber noted as follows: "The accused acknowledges that the widespread use of the term "Inyenzi" conferred the de facto meaning of "persons to be killed". Within the context of the civil war in 1994, the term "Inyenzi" became synonymous with the term "Tutsi". The accused acknowledges that the word "Inyenzi", as used in a socio-political context, came to designate the Tutsis as "persons to be killed": [ICTR Trial Chamber], para 44(iii). See also Mugesera $v$ Canada (Minister of Citizenship and Immigration), [2005] ${ }_{2}$ SCR roo, ${ }_{2005} \mathrm{SCC}_{40}$ [Supreme Court of Canada] paras 55, 76, 78 and 93. 
Tutsis alleged to be related to the "Inyenzi". Notably, the Appeals Chamber found that acts of genocide against Tutsis were taking place at the seminary and that the perpetrators were acting in knowledge of a generalized attack against Tutsis throughout Rwanda and the particular region in which the seminary was located. ${ }^{15}$ That Rukundo made the declaration under consideration against the background of awareness of this widespread attack and killing of Tutsis in Rwanda is sufficient to justify as reasonable the finding of genocidal intent on his mind. It thus becomes a flight of intellect to the higher planes of the fanciful to reason, as the Appeals Chamber majority had done, that Rukundo's declaration might reasonably be seen as 'expressing anger that a former friend was affiliated with the "Inyenzi", without signifying a personal desire to destroy Tutsis.'

Just as strange is the extended reasoning of the majority of the Appeals Chamber that their negation of genocidal intent on the part of Rukundo is supported by their finding that 'Rukundo's statement did not frighten Witness CCH .... It is possible to limit the import of this reasoning by accepting that it was merely an appendage of thought intended only to bolster the main frame of the majority's reasoning. Still, the appearance of such cogitative noise in the jurisprudence of an appellate court can cause confusion in unforeseen circumstances in the future. It is therefore necessary immediately to draw attention to the flaws in that reasoning. One major flaw in that reasoning is the suggestion that for the assessment of genocidal intent on the part of an accused the decision maker should consider the effect of the accused's conduct or utterances on the mind of the victims of an alleged genocide. The flaw in that reasoning is immediately evident in the scenario where the victim was not in a position to witness or appreciate the conduct or utterance in question, such as where the victim was not present at the time of the conduct or utterance, or where the victim could not, due to sensual, mental or experiential limitations, understand the import of the conduct or utterance in question. It becomes strange then to suggest that utterances and conducts which do not register in the consciousness of victims such as threatens them may not convey an intent on the part of the authors of such utterances and conducts.

A more persuasive reasoning is that found in Judge Pocar's dissenting opinion. According to him: '[T] he proper focus should have been on what Rukundo's words conveyed about his intention. In this respect, they clearly conveyed Rukundo's knowledge that his victim was Tutsi and that she and other members of her family should be killed for this reason alone. This is compelling evidence that Rukundo possessed genocidal intent at the time of the assault, which occurred moments later, in particular when coupled with the serious nature of his crime and the campaign of massive violence directed against Tutsis in the area in which he was found to have participated. ${ }^{16}$

I5 Rukundo v Prosecutor (Judgment), supra, [ICTR Appeals Chamber], paras I77 and I82.

I6 Rukundo v Prosecutor (Judgment) dated 20 October 2010 [ICTR Appeals Chamber], Dissenting Opinion of Judge Pocar, para 3. 
One particular difficulty in the reasoning of the Appeals Chamber's majority is the suggestion that Rukundo's genocidal intent had evaporated by the time he sexually assaulted CCH. Notably, the Appeals Chamber had found that Rukundo had possessed genocidal intent in relation to some of the acts for which he was convicted of genocide-some of which occurred in the same seminary where he sexually assaulted $\mathrm{CCH} .{ }^{\mathrm{r}}$

It was this dilemma, perhaps, that had led the Appeals Chamber's majority to pursue a subsidiary reasoning for rejecting the Trial Chamber's finding that Rukundo possessed genocidal intent as regards the sexual assault on $\mathrm{CCH}$. According to this subsidiary reasoning, Rukundo's sexual assault upon $\mathrm{CCH}$ 'was qualitatively different from the other acts of genocide perpetrated by Rukundo.' According to the Appeals Chamber majority, the qualitative difference lay in the fact that the other acts of genocide were associated with 'systematic, repeated searches for Tutsis on the basis of identity cards or lists, and the subsequent killing or assault of those individuals removed', thus warranting the finding of genocidal intent; while Rukundo's sexual assault on $\mathrm{CCH}$ had been 'unplanned and spontaneous. ${ }^{18}$

In this connection, one must note the distinguishing element of systematic and repeated occurrence in the Akayesu case regarding sexual assault in the form of rape. For Akayesu's conviction revealed a systematic and repeated pattern of conduct - involving his instigation or ordering — or failure to prevent-rapes and other sexual violence against Tutsi women. ${ }^{19}$ Nevertheless, questions linger about the correctness of the Appeals Chamber's majority reasoning in Rukundo about the 'qualitative difference' between his sexual assault on $\mathrm{CCH}$ and his other acts accepted as genocide. What puts that reasoning into question is that the issue of CCH's sexual assault engaged the genocidal act of inflicting mental suffering on members of a group protected by the Genocide Convention. The Appeals Chamber did not question the Trial Chamber's factual finding that sexual assault against $\mathrm{CCH}$ had occasioned mental suffering on her. One common denominator that this conduct shares with other genocidal acts of Rukundo is the likelihood of mental suffering that those acts would also have occasioned on members of the protected group with whom $\mathrm{CCH}$ shares ethnic affinity. This shared incident of mental suffering thus limits the persuasiveness of the reasoning that Rukundo's sexual assault on $\mathrm{CCH}$ is qualitatively different from Rukundo's other acts of genocide.

Notwithstanding that the judgment of the majority of the Rukundo Trial Chamber was overruled by a majority of the Appeals Chamber, the Trial Chamber's judgment was, in principle, sensible decision-making by an international criminal court, in view of the need to address the evil of sexual violence

I7 Rukundov Prosecutor (Judgment), supra, [ICTR Appeals Chamber], paras 6I-64 and I7I-I82.

I8 Ibid, para 236 .

I9 See Prosecutor v Akayesu (Judgment), supra, [ICTR Trial Chamber], paras 4I6-438 and 449-452. 
in context. The context which the majority recognised was the very context of extreme fear and terror which gave the victim's experience a palpable psychic quality of an enduring nature. This factor of extreme fear and terror is adequately brought out by Grossman in his 'Wind of Hate' imagery. First, he attempts to explain the phenomenon at issue by focusing on the experiences of soldiers fighting a war. He explains that the potential for death and injury is an important ingredient in the complex mixture of circumstances that makes combat so stressful, but it is not the major cause of stress in either daily life or in combat. To him, 'facing aggression and hatred in our fellow citizens is an experience of an entirely different magnitude. ${ }^{20}$

Although Grossman was writing about the experience of soldiers, it is clear, as will be seen presently, that his thesis is not limited to the experiences of soldiers. His analysis is indeed readily applicable to the sexual assault victim in the Rukundo case. She clearly did face that petrifying aggression and hatred in her fellow citizens-the general inferno of her fellow citizens killing members of her ethnic group throughout Rwanda; the Interahamwe militia surrounding their place of refuge, threatening to attack and kill them; and the real-life, Kafkaesque nightmare of her one hope of survival — the accused — not only refusing to rescue her and her family, but looking her straight in the eye and telling her that she and her family would be killed.

Relating this 'Wind of Hate' to the matter of sexual assault, Grossman writes that the 'ultimate fear and horror in most modern lives is to be raped or beaten, to be physically degraded in front of our loved ones, to have our family harmed and the sanctity of our homes invaded by aggressive and hateful intruders. ${ }^{{ }^{2 x}}$ Once more, the Rukundo victim certainly faced this fear of being raped, not just from the more removed but real fact that rape was rampant during the Rwandan genocide, but also that the accused himself had directly manhandled her in an actual attempt at raping her.

Next, in his analysis of the enduring harm that the terror of hate can inflict on the mind of victims, Grossman draws on the studies of the survivors of Nazi concentration camps. ${ }^{22}$ Such studies readily reveal that the survivors 'did suffer from great, lifelong, psychological damage as a result of their experiences in concentration camps .... ${ }^{23}$ Part of the enduring trauma resulted from the fact that the victims had to look their killers in the face and know that another human being denied their humanity and hated them enough to personally slaughter them, their

20 Grossman, supra, p 76.

2I Loc cit.

22 See for instance, Viktor Frankl, Man's Search for Meaning [Boston: Beacon Press, I959]; Bruno Bettleheim, The Uses of Enchantment [New York: Penguin Books, 1991], and S Davidson, 'A clinical classification of psychiatric disturbances of Holocaust survivors and their treatment' (1967) The Israel Annals of Psychiatry and Related Disciplines, pp 5, 96-98.

Grossman, supra, $\mathrm{p} 78$. 
families, and their race as though they were nothing more than animals. ${ }^{24}$ As Grossman put it: '[I]n the death camps it was starkly, horribly personal. Victims of this horror had to look the darkest, most loathsome depths of human hatred in the eye. There was no room for denial, and the only escape was more madness. ${ }^{25}$ Again, there is little doubt that $\mathrm{CCH}$ in the Rukundo case readily fits the description of the victim described by Grossman in this thesis. The difference is only one of degree. Like the concentration camp survivors, she, too, was a survivor of a genocide in which the reality was starkly clear to her that her fellow citizens denied her humanity and that of her family and her ethnic group and hated them enough to slaughter them personally. And she, too, was subjected to a variant of the concentration camp experience: her place of refuge became a concentration camp surrounded by the forces of genocide who wanted to kill them; and soldiers allied to those forces would come in from time to time and abduct refugees and take them away to be killed. Given the foregoing, there is little doubt that the Trial Chamber majority in the Rukundo case were correct to infer serious mental harm on the part of the victim. Their recognition of the 'highly charged, oppressive and other circumstances surrounding the sexual assault on Witness $\mathrm{CCH}^{26}$ is a judicial expression of the phenomenon that Grossman was describing in his own way as serious mental harm.

The conclusion that sexual assault_-including rape-can be an act of genocide has, however, a potential to engage a number of more controversial issues along the way. Some of those issues include the following: whether that conclusion is encumbered by the debate on whether the intent to destroy a group in part requires the intent to destroy a substantial part; and, the value of the jurisprudence of joint criminal enterprise as a method of attribution of criminal responsibility for rape as a genocide. It is with these issues that the current chapter is concerned.

\section{Rape as Genocide in Light of the Debate regarding Intent to Destroy the Group in Whole or in (Substantial) Part}

In the jurisprudence of international criminal law, the destruction or the intended destruction of a group in whole usually generates no dispute as to the proper application of the 'genocide' label. What generates debate is the idea of destruction of a group in part. The usual question here is whether a minimum number of the group must be destroyed or intended for destruction for there to be a proper application of the label of genocide. On this question, a school of thought from the United States insists that the required intent must be to destroy a 'substantial' part of the targeted group. ${ }^{27}$ This point of view is even clearly reflected in US federal law of genocide. For instance, in §rogI of the United States Genocide Convention

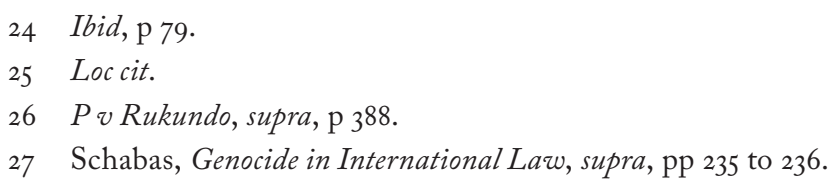


Implementation Act 1987 (the Proxmire Act), genocide is redefined in the following way:

(a) Basic Offense. Whoever, whether in time of peace or in time of war, in circumstances described in subsection (d) and with the specific intent to destroy, in whole or in substantial part, a national, ethnic, racial or religious group as such:$\ldots{ }^{28}$.

Regrettably, this view of genocide has metastasised into the jurisprudence of the ad hoc international criminal tribunals. The first traces of this run of jurisprudence are found in the ICTR Trial Chamber II judgment in the Kayishema and Ruzindana case. It was held there that, "in part" requires the intention to destroy a considerable number of individuals who are part of the group. ${ }^{29}$ Citing Kayishema and Ruzindana, the theme was echoed by the ICTR Trial Chamber that decided Baglishema..$^{\circ}$ It was next repeated by the Chamber that decided Semanza ${ }^{31}$ who cited Baglishema. And then it got picked up by the Appeals Chamber of ICTY in Krstić, citing Kayishema and Ruzindana, Baglishema and Semanza. According to the ICTY Appeals Chamber:

The intent requirement of genocide under Article 4 of the Statute is therefore satisfied where evidence shows that the alleged perpetrator intended to destroy at least a substantial part of the protected group. ${ }^{32}$

Interestingly enough, in the Kajelijeli and the Kamubanda cases, the same Chamber that decided Kayishema and Ruzindana appeared more cautious than they had been in the earlier case, by replacing 'considerable number' with the more tentative expression: 'more than an imperceptible number'. The entire treatment of the 'in part' debate in Kajelijeli appears as follows:

Under Article 2, an accused may be liable if he intends to destroy in whole or in part a [...] group.' As has been explained in judgments of this Tribunal, in order to establish an intent to destroy 'in whole or in part', it is not necessary to show that the perpetrator intended to achieve the complete annihilation of a group from every corner of the globe. Nevertheless, the perpetrator must have intended

28 See i8 USC § го9г. Emphasis added.

29 Prosecutor v Kayishema and Ruzindana (Judgment) dated 2I May 1999, Case No ICTR-95-I-T [ICTR Trial Chamber] para 97. It is possible to speculate that this American influence might have resulted from the presence of an American lawyer in the prosecution team.

30 Prosecutor v Bagilishema (Judgment) dated 7 June 200I, Case No ICTR-95-IA-T [ICTR Trial Chamber] para 64 ("the intention to destroy must target at least a substantial part of the group').

3I Prosecutor v Semanza, supra, [ICTR Trial Chamber] para 3I6 ('the intention to destroy must be, at least, to destroy a substantial part of the group').

32 Prosecutor v Krstić (Judgment) dated 19 April 2004, Case No IT-98-33-A, [ICTY Appeals Chamber] para I2. 
to destroy more than an imperceptible number of the targeted group. [Footnote omitted] In effect, the Semanza Trial Chamber was correct in observing that while the Prosecution must establish, beyond reasonable doubt, the intent of the perpetrator to destroy the target group in whole or in part, there is no numeric threshold of victims necessary to establish genocide. [Footnote omitted] ${ }^{33}$

There are a number of reasons to reject the view that 'in part' means in substantial part. First, one difficulty with the 'substantial' part theory is its relevance only to the purpose of punishment, while ill-serving the purpose of prevention of genocide. The preventive purpose is as vital as - if not more so than-the punitive purpose expressed in the Genocide Convention. The hazard of the 'substantial' part theory relates directly to the moral and the legal compulsion on the international community to take immediate action to stop an ongoing genocide in its tracks. ${ }^{34}$ Such a purpose is evident particularly in articles $\mathrm{I}^{35}$ and $\mathrm{VIII}^{36}$ of the Genocide Convention.

In order fully to appreciate the hazardous effect of the 'substantial part' theory to the purpose of prevention of genocide, it is useful to invoke the interpretative assistance of article 3I(I) of the Vienna Convention on the Law of Treaties which provides as follows:

A treaty shall be interpreted in good faith in accordance with the ordinary meaning to be given to the terms of the treaty in their context and in the light of its object and purpose. [Emphasis added.]

Article 3I(I) of the Vienna Convention necessarily compels the following questions: What are the relevant terms of the Genocide Convention? What is the ordinary meaning of those terms? And what are the purposes of the Genocide Convention that must be kept in view?

Question One. What are the relevant terms of the Genocide Convention? The relevant terms appear in the phrase 'destroy ... in part' contained in the statement of the dolus specialis of genocide, regarding the intent to destroy a protected

33 Prosecutor v Kajelijeli, supra, para 809. See also Prosecutor v Kamuhanda, supra, para 628.

34 United Nations, Letter dated I5 December 1999 from the Secretary-General addressed to the President of the Security Council, enclosing Report of the Independent Inquiry into the actions of the United Nations during the 1994 Genocide in Rwanda, Doc No S/1999/I257 of I6 December 1999, p 38.

35 According to article I, 'The Contracting Parties confirm that genocide, whether committed in time of peace or in time of war, is a crime under international law which they undertake to prevent and to punish.' [Emphasis added.]

36 Article VIII of the Genocide Convention provides: 'Any Contracting Party may call upon the competent organs of the United Nations to take such action under the Charter of the United Nations as they consider appropriate for the prevention and suppression of acts of genocide or any of the other acts enumerated in article III.' 
group. Question Two. What is the ordinary meaning of those terms? For one thing, their ordinary meaning does not contain any adjectival qualifier to the phrase 'in part'. In other words, there is an appreciable distinction in meaning between the phrases 'in part' and 'in substantial part'. The ordinary meaning, then, of the former is that there is no language in the provision which indicates that a minimum aliquot was intended to constitute a 'part'. That makes one person a part of the group to which (s)he belongs. It is important to recall, in this connection, that it has been settled that the point of genocide is that it is a crime against a group and not merely a crime against a plurality or several of its part. ${ }^{37}$ This feature underscores what makes genocide so unique as to distinguish it from an ordinary case of murder or mass murder, regardless of the mass of the part of a group that was targeted for destruction. That unique feature involves the absence of personalization of the act, so that any member of the targeted group is a potential victim. Approached in this way, the view that intending to destroy less than substantial part of a protected group would properly attract the sanctions of the Genocide Convention is a view that enhances the punitive purpose. This is so since the violation of the international criminal norm against commission of genocide is given zero tolerance in application.

Question Three. What are the purposes of the Genocide Convention that the Vienna Convention on the Law of Treaties requires to be kept in mind at all times? Here, it need not be asserted that the preventive purpose of the Genocide Convention is more important than the punitive purpose upon which the 'substantial' part theory is solely focused. It is sufficient to consider those purposes at least at the level of their lowest common factor. At that level, the preventive purpose will be seen as vital as the punitive purpose. Even then, the purpose of punishment is enhanced, rather than ill-served, by insisting that the term 'in part' as expressed in the Genocide Convention be given its ordinary meaning.

More importantly, the ordinary meaning of 'in part', as discussed above, serves properly the preventive purpose of genocide. This is so given that one does not need to wait too long to form a view that a genocide is apparently underway, if, for instance, there is a certain pattern to a widespread killing of members of a group.

Conversely, the theory of reading in the word 'substantial' to the phrase 'in part' is clearly hazardous to the preventive purpose of genocide (as will be seen below), while arguably not enhancing the punitive purpose of the Genocide Convention. It does not enhance the punitive purpose, since it will be harder to convict any

37 While holding in Akayesu that the commission of one of the five acts of genocide qualifies as genocide, an ICTR Trial Chamber said as follows: 'In concrete terms, for any of the acts charged under Article 2 (2) of the Statute to be a constitutive element of genocide, the act must have been committed against one or several individuals, because such individual or individuals were members of a specific group, and specifically because they belonged to this group. Thus, the victim is chosen not because of his individual identity, but rather on account of his membership of a national, ethnical, racial or religious group. The victim of the act is therefore a member of a group, chosen as such, which, hence, means that the victim of the crime of genocide is the group itself and not only the individual:' Akayesu (Judgment), supra, para 52I [ICTR Trial Chamber]. 
single accused of the crime of genocide. This is so, not only because it will be more difficult to show that the accused intended to destroy a substantial part of the group in question, but also because it arguably requires demonstration that the accused was at all material times in a position to destroy the substantial part of a protected group. The element of being in a position to destroy a substantial part of a group has to be at the heart of the 'substantial' part theory if that theory is to have practical significance; otherwise, the theory will result in the penalization of mere intention, if the accused is not in a position factually to achieve the intent. Yet, the practical effect of this requirement is that no accused will be convicted of genocide if that accused is only in a position to destroy less than a substantial part of a protected group, but not in a position to destroy a substantial part. This outcome does not enhance the punitive purpose of the genocide convention, for it potentially allows many killings of members of a group protected under the Genocide Convention before the Convention itself is seen as engaged.

While not enhancing the punitive purpose of the Genocide Convention, the 'substantial' part theory is, worse still, clearly hazardous to the preventive purpose. For in the throes of an unfolding apparent genocide, it will, in most cases, be difficult to ascertain the state of mind of the perpetrators and planners in order to establish whether or not they harbour joint or several intent to destroy a 'substantial' part of the targeted group. The longer the delay in establishing whether or not the perpetrators and planners harboured that intent, the longer it will take for the international community to react and intervene with the level of urgency and action required. This mischief was especially evident during the Rwandan Genocide, when the US Government refused to acknowledge that genocide was in progress, for fear of being impelled into an expenditure of effort..$^{8}$ This predisposition on the part of the US was a major explanation for the inaction of the United Nations. ${ }^{39}$ The absurdity of this definitional subterfuge is epitomised in an exchange between Ms Christine Shelly (a US State Department spokesperson) and Mr Alan Elsner of Reuters, in a press conference on ro June 1994. The State Department spokesperson had refused to acknowledge that genocide was occurring, even after she had admitted that 'acts of genocide' were being committed:

Elsner: How would you describe the events taking place in Rwanda?

Shelly: Based on the evidence we have seen from observations on the ground, we have every reason to believe that acts of genocide have occurred in Rwanda.

38 Samantha Power, 'Bystanders to Genocide' in The Atlantic Monthly, September 2oor: available at <http://www.theatlantic.com/doc/20oIog/power-genocide/6> (accessed Io December 2006).

39 United Nations, Letter dated ${ }_{5}$ December 1999 from the Secretary-General addressed to the President of the Security Council, enclosing Report of the Independent Inquiry into the actions of the United Nations during the 1994 Genocide in Rwanda, supra, p 38 . 
Elsner: What's the difference between "acts of genocide" and "genocide"?

Shelly: Well, I think the-as you know, there's a legal definition of this ... clearly not all of the killings that have taken place in Rwanda are killings to which you might apply that label ... But as to the distinctions between the words, we're trying to call what we have seen so far as best as we can; and based, again, on the evidence, we have every reason to believe that acts of genocide have occurred.

Elsner: How many acts of genocide does it take to make genocide?

Shelly: Alan, that's just not a question that I'm in a position to answer. ${ }^{40}$

It is entirely possible that even without the American understanding of the genocidal definition as requiring intent to destroy a 'substantial' part of the group, a definitional ruse could still be engaged in to avoid preventive intervention. However, the ability to indulge in such a ruse is greater with an understanding of the definition as requiring the intent to destroy a substantial part of a protected group. But this is obviously less likely, if it is understood that the mass of the part of the group intended for destruction is considered immaterial.

Second, the insistence upon a reading in of the qualifier 'substantial' part poses another problem of a practical nature. At what point is the line to be drawn between non-substantial and substantial destruction? This would surely throw the adjudication into the old dilemma of how many hairs qualify a man as bearded. It is certainly part of this dilemma that has driven some of the judges of international criminal tribunals to say that 'there is no numeric threshold of victims necessary to establish genocide'. ${ }^{41}$ The dilemma, however, is not avoided-but possibly accentuated-by declaring that there is no numeric threshold, while insisting that a substantial part must be intended for destruction. This is so, as the notion of genocide is thus made extremely nebulous.

Third, as a matter of plain language construction of a legal provision, article II of the Genocide Convention itself, as noted earlier, does not contain any qualifier to the phrase 'in part'. To then qualify that phrase in the Genocide Convention by adding 'substantial' in front of the phrase is nothing short of rewriting the Convention. In the nature of things this will be a substantial rewriting indeed. This point is perhaps more easily understood if it is considered to be just as wrong, in the context of an American domestic case, to delete that extra word in the construction of the Proxmire Act, as it is if that absent word is read into the Genocide Convention in the context of an international case.

Finally, it is perhaps notable that in Kayishema and Ruzindana, the common judges of the Appeals Chambers of the ICTY and ICTR quarrelled with the characterisation of genocide as 'the crime of crimes'. The Appeals Chamber remarked

40 Loc cit.

4I Kajelijeli (Judgment), supra, [ICTR Trial Chamber] para 809. See also Prosecutor v Kamuhanda (Judgment), supra, [ICTR Trial Chamber] para 628. 
that 'there is no hierarchy of crimes under the Statute, and that all of the crimes specified therein are "serious violations of international humanitarian law", capable of attracting the same sentence'. ${ }^{42}$ The Appeals Chamber's disagreement with the Trial Chamber is certainly curious, not the least because of the absence of any elaboration in the reasoning in this regard, but also for the implicit view that pillaging of an institution dedicated to works of art-being a war crime provided for in article ${ }_{3}(\mathrm{~d})$ of the ICTY Statute-ranks as equal to the crime of genocide defined by its requirement of intent to destroy a group in whole or in part. Be that as it may, the Appeals Chamber's pronouncement that genocide ought not be viewed as 'the crime of crimes' effectively undermines the idea that nothing less than intent to destroy a 'substantial' part of a group is sufficient to ground a conviction for genocide. This is so for the simple reason that it is hard to see the point of insisting on the element of intent to destroy a 'substantial part', if genocide is seen as no more serious than any other international crime which does not require the intent to destroy a substantial part of any population.

In this debate, however, there are some notable commentators who disagree with the theory of intent to destroy 'substantial' part. One of them is Bill Schabas. According to him, the killing of one member of the protected group would support a count of genocide, provided the killing was done with the genocidal intent. ${ }^{43}$ I concur with Professor Schabas.

While the drafters of the ICC Elements of Crimes ${ }^{44}$ have not entirely put this debate to rest, although they do settle it more closely on the side of those who disagree with intent to destroy a 'substantial' part. In the Elements of Crime of genocide the following elements are indicated in respect of killing:

I. The perpetrator killed one or more persons.

2. Such person or persons belonged to a particular national, ethnical, racial or religious group.

3. The perpetrator intended to destroy, in whole or in part, that national, ethnical, racial or religious group, as such.

4. The conduct took place in the context of a manifest pattern of similar conduct directed against that group or was conduct that could itself effect such destruction.

Elements 2 to 4 are identical in respect of each of the five acts of genocide. While Element I clearly indicates that the commission of a proscribed genocidal actus reus against one person is sufficient to ground a crime of genocide from the perspective of one perpetrator, Element 4 quickly compounds that legal equation by indicating that the act of the perpetrator needs to take place in the context of a manifest pattern of similar conduct directed against the group'. In this connection, Element 4 is of doubtful validity, as it is a veritable amendment to the terms

42 Prosecutor v Kayishema and Ruzindana, supra, [ICTR Appeals Chamber] para 367.

43 Schabas, Genocide in International Law, supra, p 234.

44

Doc No ICC-ASP/I/3. 
of article II of the Genocide Convention as re-enacted in article 6 of the ICC Statute, and is arguably inconsistent with the relevant provision of the Statute. 45 Nevertheless, the requirements of Element 4 do not come close to endorsing the theory of destruction of a substantial part. This is because the phrase in the context of' is explained to 'include the initial acts in an emerging pattern.' In the context of genocide, this is certainly less than a substantial part. ${ }^{46}$

Perhaps the push to read the Genocide Convention as requiring destruction or intended destruction of a 'substantial' part comes from concerns about diluting the experiences of people who have actually suffered the destruction of a substantial part of their group, such as happened to Jewish people in Nazi occupied Europe during WWII and to Tutsis in Rwanda in 1994. This is entirely understandable. But there are two alternative arguments to be made in favour of still recognizing that genocide has occurred, although the destruction or intended destruction has not been of a substantial part. First, it would seem that the enormity of the numbers of human destruction suffered by Jewish people in Europe during WWII and Tutsis in Rwanda would be enhanced rather than diminished when compared to instances of genocide involving far lesser destruction of lives. But, perhaps, more importantly, any plan of genocide is a plan that must directly galvanize the international community into immediate preventive action, as a matter of extreme urgency. It is dangerous then to hold at bay the poignant devise of the genocide label that would trigger this rapid global response to stop a genocide in progress, until the destruction has become of a substantial part or until there is clear evidence of a plan to destroy a substantial part. In the end, it should be at least equally important to prevent a possible future genocide-or to arrest one as it occurred - though the evidence be unclear, as it is to preserve the memory of the fate of victims of a past, undeniable genocide.

\section{The Effect of the Debate on the Concept of Rape as Genocide}

Whatever the merits of the arguments for or against reading in 'substantial' part to the definition of genocide, the debate ought not perturb the conception of rape as genocide. This is because the debate has its greatest significance in the sphere of the question of what constitutes the proper degree of genocidal intent. The debate does not really engage the 'acts of genocide' themselves, such as rape is. In other words, the concerns of those urging a need to read in 'substantial' part to the genocidal intent would be addressed if the accused possessed the intent to destroy a substantial part of the group to which the victim of rape belonged, though less than a substantial part of the group is actually destroyed. Neither does the debate raise an issue regarding the particular act to be employed to execute the intended destruction of the group or part thereof. That is to say, once there is the required level of genocidal intent, the manner of the intended destruction becomes irrel-

45 It is to be noted that article 9(3) of the ICC Statute requires that 'The Elements of Crimes and amendments thereto shall be consistent with this Statute.'

46 See the Introduction to Article 6 (Genocide) in the ICC Elements of Crimes. 
evant. Thus, the same genocide could be perpetrated by a combination of actskillings, rapes and other acts. There is no requirement that it be shown that the accused intended to destroy the targeted group in part by raping a substantial part of the group. ${ }^{47}$

\section{Joint Criminal Enterprise and Rape as Genocide}

Responsibility for rape as an act of genocide is more directly established where the accused is found to have perpetrated the rape, or ordered or instigated its commission. Often enough in genocide cases, however, the decision maker is faced with clear evidence of perpetration, ordering or instigation of killing as an act of genocide, without any evidence tending to show that the accused had perpetrated, ordered or instigated rape.

As seen earlier in Chapter 2, one instance of this dilemma is the Akayesu case itself..$^{8}$ Although the accused was convicted of rape, that conviction was based on the fact that he had been heard clearly encouraging and ordering assailants to rape Tutsi women. ${ }^{49}$ In the instances where there had been no clear words from the accused suggesting the grant of licence to his subordinates, the Chamber had been reluctant to find him criminally responsible for any ensuing rape. For purposes of the present discussion, it might assist to recall the following pronouncement illustrative of this reluctance:

In considering the role of the Accused in the sexual violence which took place and the extent of his direct knowledge of incidents of sexual violence, the Chamber has taken into account only evidence which is direct and unequivocal. Witness $\mathrm{H}$ testified that the Accused was present during the rape of Tutsi women outside the compound of the bureau communal, but as she could not confirm that he was aware that the rapes were taking place, the Chamber discounts this testimony in its assessment of the evidence. Witness PP recalled the Accused directing the Interahamwe to take Alexia and her two nieces to Kinihira, saying "Don't you know where killings take place, where the others have been killed?" The three women were raped before they were killed, but the statement of the Accused does not refer to sexual violence and there is no evidence that the Accused was present at Kinihira. For this reason, the Chamber also discounts this testimony in its assessment of the evidence..$^{\circ}$

47 Notably, in Prosecutor v Krstic, supra, at para 32, the ICTY Appeals Chamber wrote that 'the offence of genocide does not require proof that the accused chose the most efficient method to accomplish his objective of destroying the targeted part.'

48 Prosecutor v Akayesu, supra, paras 422, 452, 706 and 731-733.

49 He had been heard saying to the assailants, 'Never ask me again what a Tutsi woman tastes like;' and 'you should first of all make sure that you sleep with this girl' referring to a Tutsi woman whom he had ordered his subordinates to kill. Akayesu, supra, paras 422 and 452 . 
We had also seen in Chapter 2 the similar reluctance of another ICTR Chamber in Kajelijeli, which had declined to find the accused guilty of the rapes of Tutsi women committed as part of that order to exterminate, notwithstanding that the Trial Chamber found that the accused had ordered assailants to exterminate Tutsis..$^{5}$ As already noted elsewhere, ${ }^{52}$ this was because the accused had not ordered the assailants to commit the collateral crime of rape. As was noted earlier, the Chamber had concluded as follows:

[...] After careful consideration of the evidence presented at trial the Chamber is convinced that Witness GDT was raped by members of the Interahamwe on 7 April 1994 in Susa secteur, Kinigi Commune. It is not in contention that the Accused was not present at the scene of the rape of GDT. The Chamber finds, by a majority, Judge Ramaroson dissenting, that the Prosecution did not prove that the Accused issued a specific order to rape or sexually assault Tutsi women in Susa secteur, Kinigi Commune on that day. ${ }^{53}$

One theory of criminal responsibility which becomes relevant in these instances is the theory of joint criminal enterprise. At the ICTR and ICTY, that theory has been construed into the jurisprudence as part of the notion of commission, as provided for under article 6(I) of the ICTR Statute and article 7(I) of the ICTY Statute. ${ }^{54}$ The doctrine has been pronounced upon in a number of cases reaching the Appeals Chamber of the ICTY. ${ }^{55}$ The notion was originally discussed by that Chamber in Prosecutor v Tadić (Judgment)..$^{6}$

The development of the law of joint criminal enterprise and its manner of application have already been discussed in Chapter 2 above and need not be repeated. It suffices only to say here that the concept of joint criminal enterprise is a useful method in the prosecution of rape as an act of genocide, where the evidence is clear that the accused planned, ordered or instigated other acts of genocide, although there is no apparent evidence that he ordered rape as an act of

5I Prosecutor v Kajelijeli, supra, para 907; see also paras 823, 825, 833, 836, 842, 856, 897, $899,904,905$.

52 See pp 102-103, supra.

53 Ibid, para 68I. See also paras 682, 683, 920, 923, 924, 936-938.

54 Article 6(I) and article 7(I) respectively of the ICTR and the ICTY Statutes commonly provided as follows: 'A person who planned, instigated, ordered, committed or otherwise aided and abetted in the planning, preparation or execution of a crime referred to in articles 2 to 5 of the present Statute, shall be individually responsible for the crime.'

55 See Prosecutor v Tadić (Judgment) I5 July i999 [ICTY Appeals Chamber], paras I85 et seq; Prosecutor v Furundžija, supra, paras II5-I20; Prosecutor v Delalic E̋ Ors, supra, [ICTY Appeals Chamber], paras 343, 365-366; and Prosecutor v Milutinovic,, Śainović \& Ojdanić (Decision on Dragoljub Ojdanić's Motion Challenging JurisdictionJoint Criminal Enterprise), supra, [ICTY Appeals Chamber].

Prosecutorv Tadic (Judgment), supra. 
genocide. This is the case, notwithstanding that it might be harder to employ that device under the ICC Statute than it might be under the ICTR/ICTY models.

\section{Conclusion}

The jurisprudence of the International Criminal Tribunal for Rwanda which determined rape as an act of genocide has been widely received into the annals of international criminal law with little debate. The absence of controversy with the proposition itself belies the difficulty surrounding the question in other respects. Among them is the question relating to the debate on whether it must be shown that the accused possessed the intent to destroy at least a substantial part of a protected group. While this debate is often thought to engage the question of the mass of the victims against whom acts of genocide had been actually committed, the debate really only engages the element of intent to commit genocide and not the actus reus of genocide. That being the case, the conception of rape as an act of genocide is largely spared the implications of this debate. Consequently, rape may continue to be conceived as an act of genocide, even though it has not been shown that a substantial part of a given group had been victims of acts of genocide-including rape itself.

In the next Chapter, we will consider the question of sexual violence as the war crime of terrorism, particularly viewed from the perspective of the mental element for the crime of terrorism. 
Chile Eboe-0suji - 978-90-04-22722-4 Downloaded from Brill.com $04 / 26 / 2023$ 12:45:46PM via free access 


\section{Chapter 5}

\section{Armed Conflicts, Sexual Violence and the Mens Rea of the War Crime of Terrorism}

\section{Introduction}

We saw, in Chapter I, during our review of the explanations for the evil of sexual violence, that the infliction of terror on a civilian population partly explains why some warring parties commit sexual assault during armed conflicts. We saw how it was that some fighting forces would deliberately rape women belonging to the enemy side, with the aim of demoralising - and instilling paralysing fear withinthe enemy population. There is a universal agreement, even by military die-hards who acknowledge such behaviour as 'effective military tactics', that these conducts amount to evil during armed conflicts. Regrettably, this is an area of international criminal law that has not received much attention. The aim of this chapter is to review developments in international criminal law, with the view to assessing the adequacy of the responses which international law has thus far made in relevant respects.

\section{The Conventional Source of the War Crime of Terrorism}

Terrorism enjoys unique stature as one of the most angst-ridden concepts in the annals of contemporary public international law. Controversy has persistently prevented the settling of a generally-accepted definition of the concept. ${ }^{57}$ This is notwithstanding credible efforts on the part of the international community. ${ }^{5}$

57 See, for instance, Antonio Cassese, International Criminal Law [Oxford: OUP, 2003] pp I2O-I25; and Kriangsak Kittichaisaree, International Criminal Law [Oxford: OUP, 200I] pp 227-228.

58 In 1937, the League of Nations adopted the Convention for the Prevention and Punishment of Terrorism. Article $\mathrm{r}(2)$ defined terrorism as 'criminal acts directed against a State and intended to or calculated to create a state of terror in the minds of particular persons, or a group of persons or the general public.' But the 1937 Convention never came into force. Notably, it was adopted at a period when wars of liberation-and the attendant question of self-determination-of colonised territories and peoples had not exercised international law with the fervour seen in later years: see Malcolm Shaw, International Law [Cambridge: CUP, 1997] p I77I78. In subsequent instruments of the United Nations, it was recognized that '[a] 11 peoples have the right to self-determination': UN General Assembly Resolution 
The best that has been achieved are definitions in specific international conventions with discrete fields of application. ${ }^{99}$ Happily for students and practitioners of international criminal law, the law of international law of armed conflicts is one of those specific fields. That 'definition' is achieved through the roundabout way of forbidding conducts of a certain character whose primary purpose is to spread terror.

${ }_{\text {I5I }} 4(\mathrm{XV})$-the Declaration on the Granting of Independence to Colonial Countries and Peoples (I960). And further still, it was accepted by the UN (a) that 'the continuation of colonialism ... is a crime and that colonial peoples have the inherent right to struggle by all necessary means at their disposal against colonial Powers and alien domination in exercise of their right of self-determination' [emphasis added]; and (b) that the 'struggle of peoples under colonial and alien domination and racist regimes for the implementation of their right to self-determination and independence is legitimate and in full accordance with the principles of international law': see UN General Assembly Resolution 3IO3 on the Basic Principles of the Legal Status of the Combatants Struggling against Colonial and Alien Domination and Racist Regimes (1973); and UN General Assembly Resolution 33I4(XXIX) on the Definition of Aggression (1974), art 7 to the annexed Definition of Aggression. See also and K Kittichaisaree, loc cit. It is this polarity of norms, animated by the street philosophy that 'one man's terrorist is another one's freedom fighter', that stymied agreement on a universal definition of terrorism. There is no evidence that this disagreement has abated even as the UN has adopted new universal international instruments on terrorism such as the International Convention for the Suppression of Terrorist Bombings (adopted by the General Assembly in 1997) and International Convention for the Suppression of the Financing of Terrorism (adopted by the General Assembly) 1999. Notably, a proposal in the late I990s to include terrorism within the regime of the Rome Statute of the International Criminal Court failed as a result of this enduring controversy: see Kittichaisaree, supra, p 227.

59 Convention on Offences and Certain Other Acts Committed on Board Aircraft (the 'Tokyo Convention'), adopted in Tokyo I963; Convention for the Suppression of Unlawful Seizure of Aircraft (the 'Hague Convention'), adopted at The Hague I970; Convention for the Suppression of Unlawful Acts against the Safety of Civil Aviation (the 'Montreal Convention'), adopted in Montreal in 197r; Protocol on the Suppression of Unlawful Acts of Violence at Airports Serving International Civil Aviation (the 'Montreal Protocol'), adopted in Montreal, in I988; Convention on the Prevention and Punishment of Crimes against Internationally Protected Persons including Diplomatic Agents, adopted by the UN General Assembly in 1973 [in force and has I66 States Parties]; International Convention against the Taking of Hostages (the 'Hostages Convention'), adopted by the General Assembly 1979 [in force, has ${ }_{64}$ States Parties]; Convention on the Physical Protection of Nuclear Material (the 'Vienna Convention'), adopted in Vienna 1980; Convention for the Suppression of Unlawful Acts against the Safety of Maritime Navigation (the Rome Convention'), adopted in Rome in I988; Protocol for the Suppression of Unlawful Acts against the Safety of Fixed Platforms Located on the Continental Shelf (the 'Rome Protocol'), adopted in Rome in I988; Convention on the Marking of Plastic Explosives for the Purpose of Detection, adopted in Montreal in I99I; International Convention for the Suppression of Acts of Nuclear Terrorism, adopted by the UN General Assembly in 2005 . 
The impetus for that definition may be found in the First Protocol of 1977 Additional to the Geneva Conventions of 1949 ['Additional Protocol I'] having international armed conflict as its field of application. In article $5 \mathrm{I}$ of that instrument, terrorism is given the following treatment:

I. The civilian population and individual civilians shall enjoy general protection against dangers arising from military operations. To give effect to this protection, the following rules, which are additional to other applicable rules of international law, shall be observed in circumstances.

2. The civilian population as such, as well as individual civilians, shall not be the object of attack. Acts or threats of violence the primary purpose of which is to spread terror among the civilian population are prohibited.

$[\ldots]$

A similar provision appears in article 13 of the Second Protocol of 1977 Additional to the Geneva Conventions of 1949 ['Additional Protocol II'], applying in armed conflicts not of an international character.

The concepts engaged in these provisions make it unavoidable to address the incidence of attacks against civilian women, in the manner of sexual violence, during armed conflicts, as incidents of terrorism during armed conflicts. This is the case, given the central nature of terrorism as the conduct of making civilians the object of attack, by virtue of acts or threats of violence the primary purpose of which is to spread terror among the civilian population.

\section{The Origins of the Jurisprudence of Specific Intent}

There has been a dearth of opportunities at the international criminal tribunals to adjudicate the crime of terrorism, even on the basis of the provisions of Additional Protocols I and II. Given the lack of jurisprudential activity at the International Criminal Court at the time of writing, its case law lends no assistance. The International Criminal Tribunal for Rwanda is preoccupied with cases of genocide: hence it has not had much scope to develop thought in the sphere of war crimes, including terrorism as a war crime. With a lesser focus on the crime of genocide at the International Criminal Tribunal for the former Yugoslavia, and with no jurisdiction at all in the Special Court for Sierra Leone over the crime of genocide, these two courts have had more scope to consider the finer points of war crimes. Within their jurisprudential compass has come the occasional charge of terrorism as a war crime. Their analyses, however, are not free from lingering questions of correctness or adequacy.

Of particular interest in this regard is the current view that the war crime of terrorism is a crime of specific intent. It is important to stress, perhaps, that this view is 'current' not because it is a settled view as such; but because it is the only one followed in the two or three cases in which the definition of the war crime 
of terrorism has been broached. The view was pioneered by the ICTY Appeals Chamber in Prosecutor v Galic. ${ }^{60}$ According to the Appeals Chamber:

The nature of the acts or threat of violence directed against the civilian population can vary; the primary concern ... is that those acts or threats of violence be committed with the specific intent to spread terror among the civilian population. Further, the crime of acts or threats of violence the primary purpose of which is to spread terror among the civilian population is not a case in which an explosive device was planted outside of an ongoing military attack but rather a case of "extensive trauma and psychological damage" being caused by "attacks [which] were designed to keep the inhabitants in a constant state of terror." ${ }^{61}$

This analysis is rather hazardous. Some of the hazards were quickly - and unwittingly-brought home in the judgment of a Trial Chamber of the Special Court for Sierra Leone in Brima E 2 ors (colloquially known as the AFRC Case), in relation to rape and sexual slavery of civilians, among other conducts proscribed by norms of international criminal law. ${ }^{62}$ The facts of the AFRC Case are these. The accused had been indicted in Count I with the crime of terrorism. They were also indicted in Count 2 with the crime of collective punishment. The factual bases for terrorism and collective punishment comprised the allegations pleaded in support of Counts 3 through I $_{4}$ of the Indictment, ${ }^{6}$ involving the following crimes:

6o Prosecutorv Galić (Judgment) 30 November 2006 [ICTY Appeals Chamber].

6I Ibid, para Io2. See also para I04 where the Chamber said inter alia: 'The mens rea of the crime of acts or threats of violence the primary purpose of which is to spread terror among the civilian population is composed of the specific intent to spread terror among the civilian population. Further, the Appeals Chamber finds that a plain reading of Article ${ }^{\mathrm{I}}(2)$ suggests that the purpose of the unlawful acts or threats to commit such unlawful acts need not be the only purpose of the acts or threats of violence. The fact that other purposes may have coexisted simultaneously with the purpose of spreading terror among the civilian population was principal among the aims.'

62 Prosecutor v Brima \& Ors, supra, [SCSL Trial Chamber].

63 The concise statements of facts of which are pleaded in paragraphs 42 through 79 of the Indictment. See Prosecutor v Brima E Ors (Further Amended Consolidated Indictment) dated I8 February 2005, para 4r. See also Prosecutor v Brima E Ors (Final Trial Brief) dated I December 2006, paras 543, 560, I373, I288, I488, I517 and 1562; Prosecutor v Brima E Ors (Prosecution Supplemental Pre-Trial Briefpursuant to Order to the Prosecution to File a Supplemental Pre-Trial Brief of I April 2004) dated 2I April 2004, para I4. 
- Unlawful Killings (Counts 3-5 $)^{64}$

- Sexual Violence (Counts 6-9) 65 $^{6}$

- Physical Violence involving mutilations (Counts IO-II) ${ }^{66}$

- Use of Children as Soldiers (Count I2 $)^{67}$

- Abductions and Forced Labour (Count 13); ${ }^{68}$ and

- Looting and Burning (Count I4). ${ }^{69}$

The Prosecution's case for terrorism, as pleaded in Count I (as with collective punishment as pleaded in Count 2), rested on the theory that, in addition to their own eponymous crimes, sexual violence (with particular reference to sexual slavery), among other crimes, also amounted to acts of terrorism (as well as of collective punishment). This is in the same way that mutilation of civilians, their unlawful killings, and the burning and looting of their property amounted to acts of terrorism and of collective punishment..$^{\circ}$

In their Judgment, the Trial Chamber did convict the accused of terrorism and collective punishment, as respectively charged in Count I and Count 2. But for purposes of these convictions, the Chamber took into account only the acts comprising unlawful killings, ${ }^{75}$ mutilations, ${ }^{72}$ and looting and burning. ${ }^{73}$ [Given that the focus of this Chapter is the crime of terrorism, discussion will henceforth be limited to terrorism to the general exclusion of collective punishment. It is also

64 Count 3: Extermination as a Crime against Humanity; Count 4: Murder as a Crime against Humanity; Count 5: Murder as the War Crime of Violence to Life, Health and Physical or Mental Well-Being of Persons, in violation of Article ${ }_{3}$ Common to the Geneva Conventions and of Additional Protocol II.

65 Count 6: Rape as a Crime against Humanity; Count 7: Sexual Slavery and any Other Form of Sexual Violence as a Crime against Humanity; Count 8: Other Inhumane Act as a Crime against Humanity; Count 9: the War Crime of Outrage upon Personal Dignity, in violation of Article 3 Common to the Geneva Conventions and of Additional Protocol II.

66 Count Io: Mutilation as the War Crime of Violence to Life, Health and Physical or Mental Well-Being of Persons, in violation of Article 3 Common to the Geneva Conventions and of Additional Protocol II; Count II: Mutilation as Other Inhumane Act as a Crime against Humanity.

67 Count 12: War Crime of Conscripting or Enlisting Children under the Age of I5 years into Armed Forces or Groups, or Using them to Participate Actively in Hostilities, as Other Serious Violation of International Humanitarian Law.

68 Count 13: Enslavement as a Crime against Humanity.

69 Count 14: War Crime of Pillage in violation of Article 3 Common to the Geneva Conventions and of Additional Protocol II.

$70 \quad$ Ibid, paras I43I and I 432 .

7I See, eg, Prosecutor v Brima \& Ors, supra, [SCSL Trial Chamber II] (hereafter 'Trial Judgment'), paras 1495, I525, and 1539 .

72 See, eg, Trial Judgment, paras I462, I463, I464, I475, I525 and I538.

73 See, eg, Trial Judgment, paras I482, I5IO, I525 and I53I. 
worth noting that the analysis of the Chamber took its overall bearing from the crime of terrorism, while making no analytical distinction between terrorism and collective punishment.]

Upon the reasoning - evidently inspired by Galic - that they did not amount to acts whose 'primary purpose was to terrorise the civilian population', the Trial Chamber discounted from the crimes of terrorism the acts comprising sexual violence (with particular reference to sexual slavery). According to the Trial Chamber, it was not the primary purpose of spreading terror that actuated the commission of the sexual crimes. Rather, it was the urge to 'take advantage of the spoils of war, by treating women as property and using them to satisfy [the perpetrators'] sexual desires and to fulfil other conjugal needs. ${ }^{74}$

Notably, the Trial Chamber did not 'discount that abduction and detention of persons from their homes and their subjection to forced labour under conditions of violence [did] spread terror among the civilian population.' But these, held the Chamber, were mere "side effects" of terror', which are insufficient to establish 'the specific intent element of the crime' of terror. ${ }^{75}$

In the view of the Chamber, the foregoing conclusions remain undisturbed by the fact that the abduction of civilians and their use as slaves, including as sexual slaves, may have been committed simultaneously with other acts of violence accepted by the Chamber as acts of terrorism. ${ }^{76}$ As the Chamber put it:

[T] he primary purpose behind commission of sexual slavery was not to spread terror among the civilian population, but rather was committed by the AFRC troops to take advantage of the spoils of war, by treating women as property and using them to satisfy their sexual desires and to fulfil other conjugal needs. As with evidence of the other enslavement crimes, namely the abduction and use of child soldiers and forced labour therefore, even where sexual slavery occurred simultaneously with other acts of violence examined by this Chamber with regards to the crime of terror, the Trial Chamber is of the opinion that such acts cannot be considered to have been committed with the primary purpose to terrorise the civilian population. ${ }^{77}$

The Prosecution appealed the Trial Chamber's reasoning and the resultant acquittal on the count of terrorism. But the Appeals Chamber dismissed the appeal. The dismissal, however, was not on the merit of the issues engaged; but rather on grounds that the prosecution appeal was unduly pedantic. In an apparent rebuke, the Appeals Chamber held that the Prosecution was being too officious in appealing for purposes of securing a conviction for terrorism, when conviction had already been entered on the underlying crimes of sexual violence, abduction and

\footnotetext{
74 See Trial Judgment, paras I455 and I459.

75 See Trial Judgment, para 1453.

76 See Trial Judgment, para I450, I 452 and I 459.

77 Ibid, para $\mathbf{1} 459$.
} 
enslavement of civilians, and as well as conscription of children and their active use in combat. Hence, the Appeals Chamber exercised what it described as 'discretion not to entertain' the Prosecution's appeal ground of terrorism..$^{8}$

The dismissal of the Prosecution appeal necessarily leaves undisturbed the reasoning of the Trial Chamber in the AFRC Case. As already indicated, that reasoning was the direct bi-product of the view, taken by the ICTY Appeals Chamber in Galic, that terrorism is a crime of specific intent-a professed interpretation and application of the texts of Additional Protocols I and II which contain the phrase 'acts or threats of violence the primary purpose of which is to spread terror'.

For the reasons that follow, it is submitted that the analysis of the Trial Chamber in the AFRC Case and its inspiring conclusion appearing in Galic are flawed. The criticism attends both the Trial Chamber's appreciation of the significance of the facts in the particular circumstances of the case before the Trial Chamber-being the particular facts of the Sierra Leone civil war-as well as a matter of general principles of international humanitarian law portended in the Galić judgment.

\section{Terrorism and the Mens Rea of Sexual Slavery}

Based strictly on the facts of the crimes as committed during the Sierra Leone civil war, the SCSL Trial Chamber's reasoning is vulnerable in light of, at least, the following failures attributable to the Trial Chamber: (a) the failure to infer the mens rea of war crime of terrorism from the nature and circumstances of the crimes of sexual slavery and other enslavement crimes; (b) the failure to adopt the multiple-purpose approach to the assessment of the intent for the war crime of terrorism; and (c) the failure to take a total view of the conducts of the perpetrators, in the assessment of the intent for the war crime of terrorism.

\section{(a) The Primary Purpose of Spreading Terror and the Nature and Circumstances of the Acts}

It was open to the Trial Chamber to infer the primary purpose of spreading terror from the nature and circumstances of the crimes of sexual slavery and other enslavement crimes committed during the Sierra Leone civil war. The Trial Chamber's failure to draw that inference was an error. In the Galic case itself,

78 Prosecutor v Brima E Ors, supra, [SCSL Appeals Chamber], paras I72 and I73. The Appeals Chamber's dismissal of the ground of appeal on the basis of 'discretion not to entertain' the ground of appeal is a little awkward, especially given that the source of the jurisdiction for the exercise of such discretion is not obvious from the reasoning or from the Court's Statute. A sounder basis might have been that the prosecution ground of appeal disclosed no error of fact occasioning miscarriage of justice, as required under article $20(\mathrm{I})(\mathrm{c})$ of the Special Court's statute. Such a reasoning would have been justified by the facts-driven nature of the Prosecution appeal, seen especially in light of the Prosecution reliance on 'the particular factual context of the case:' see para I72. 
the ICTY Appeals Chamber stated that the primary purpose of spreading terror among a civilian population 'can be inferred from the circumstances of the acts or threats, that is from their nature, manner, timing and duration.'79

It is to be recalled that the crimes at issue are sexual slavery; abduction of civilians and their subjection to forced labour; and, conscription of children and their use as soldiers. The timing and duration of those crimes in the circumstances of the Sierra Leone civil war could be easily stated as follows: these crimes were committed during the Sierra Leone civil war and for the duration of that war.

Nor is it too complicated to see that the nature of those crimes and the manner of their commission also make them susceptible of appreciation as terrorism. Those crimes were necessarily accomplished through the use or threat of use of repressive violence. The factual findings made by the Chamber revealed that the victims were held against their will; they dreaded their fate if they tried to escape; they were threatened with death if they tried to escape; orders were issued to kill any victim who tried to escape; and some of the victims who tried to escape were indeed killed or beaten or otherwise mistreated. In particular, the Trial Chamber made the following factual findings, among others, in ways that were relevant to sexual slavery and the other enslavement crimes.

In relation to sexual slavery, in particular, the Trial Chamber noted, among other things, evidence of one witness who had testified that she was abducted by an 'STF from Liberia.' Although there was no evidence to suggest with which of the warring sides, if any, the abductors were affiliated, the Trial Chamber was satisfied that the abductors were members of the AFRC/RUF faction-the faction to which the accused belonged. ${ }^{80}$ The Trial Chamber further accepted testimony that women were captured; that captured civilians who tried to escape were executed; that captured women were placed under the 'full control' of commanders and became their 'wives'; and, that these women cooked for the commanders and other soldiers is indicative of the deprivation of the captured women's liberty and the exercise of ownership over them by members of the AFRC. ${ }^{8 \mathrm{I}}$

In relation to the conscription of children and their use as soldiers, the Trial Chamber emphasized the fact that expert witnesses for both the Prosecution and the Defence agreed that persons under the age of 15 were used for military purposes by all factions, including the AFRC, during the conflict. ${ }^{82}$ Hence, the Trial Chamber found that the AFRC fighting forces conscripted children under the age of 15 years old and/or used them to participate actively in hostilities during the period covered by the Indictment. In particular, the Trial Chamber found the

79 Prosecutorv Galić (Appeal Judgment), para Io4.

80 The Trial Chamber's finding in this regard was partly based on the witness's description of her abductors as 'rebels'; and the route taken by the persons who captured the witness, namely from Wellington to Allen Town to Waterloo to Masiaka, Port Loko District where she was held for several months, was consistent with the known route taken by AFRC/RUF forces on the retreat from Freetown: ibid, para Io98.

8I Ibid, para IIO5.

82 Ibid, para I25I 
evidence to be conclusive that most, if not all, of the children in question were forcibly abducted from their families or legal guardians. In addition to having been kidnapped, former child soldiers described having been forced into hard labour and military training, and sent into battle, often on the frontlines. They were also beaten; forced to watch the commission of crimes against family members; injected with narcotics to make them fearless; compelled to commit crimes including rape, murder, amputation and abduction; used as human shields; and threatened with death if they tried to escape or refused to obey orders. ${ }^{83}$

And as regards abduction and enslavement in general, the Chamber heard evidence to the effect that during the 1999 invasion of Freetown, 'Gullit' (the first defendant was known by that sobriquet) ordered the capture of civilians, saying that it would attract the attention of the international community. Notably, in a similar attack in Karina, the hometown of President Kabbah (against whom the accused and their fellow rebels were fighting), the same accused was heard saying that he had intended 'to shock the whole country and the international community'. ${ }^{84}$ In the Freetown attack, approximately 300 abducted civilians were taken by the fighters from Freetown to Benguema. ${ }^{85}$ The Chamber heard evidence that at a certain diamond mine called 'Cyborg Pit', civilians would not refuse to work on 'government days' out of fear that such refusal would attract disciplinary measures from the AFRC/RUF. ${ }^{86}$ The AFRC/RUF began capturing civilians on the order of the notorious Johnny Paul Koroma, especially the strong men and the young women, from Tombodu, Yamadu and other surrounding villages in Kono District. 'Civilians who tried to escape were executed.'The AFRC/RUF used the civilians to carry their food, and trained some of them as soldiers for the movement. ${ }^{87}$ One witness testified that 'while under their command, he felt that he had to accept anything they did to him or otherwise they would kill him. ${ }^{88}$ There was evidence that at some point 'almost everybody had civilians,' including the commanders. It was the responsibility of the abducting commander to ensure that the civilians were 'well-secured', which the witness explained meant that they could not escape. ${ }^{89}$

83 Ibid, para 1275 .

84 Trial Judgment, para 1553 .

85 Ibid, para I272. Among those captured were 'many' small boys, including some as young as nine or ten years old.

86 Ibid, para I292. One witness stated, as an example, that one of his workers hid in an attempt to avoid work, but was found and beaten: ibid, para I293. "The supervising soldiers at Cyborg Pit were armed with guns, such as RPGs, LMGs, G-3s, and AK-47s, and would watch the civilian miners to ensure that all diamonds found were surrendered. Civilians who attempted to keep diamonds found during a government mining day would be flogged almost to death: ibid.

87 Ibid, para I3I3.

88 Ibid, para I3I

89 Ibid, para 1380. 
From the foregoing review of the Trial Chamber's findings, it is clear that the systematic use of violence to capture and keep the civilian victims did not escape the Trial Chamber. What is surprising is that the jural significance of such systematic use of violence would escape the Trial Chamber.

This systematic violence is necessarily the primary instrument of capturing the victims and subjugating them to sexual slavery and/or other conditions of enslavement. Such use of violence or the threat of it to accomplish the enslavement crimes here at issue necessarily spreads terror among the civilian population - and the individual civilians - made victims to such acts of violence. In other words, the use of violence in the maintenance of this system of repression is a classic expression of the notion of the 'reign of terror.'

To the extent that terrifying violence was both needed and used to sustain the system, it is reasonable to say that the victims were subjected to a reign of terror. The primary purpose of spreading terror was thus clearly established, as a matter of first principles. Consequently, it becomes immaterial that there might have been other purposes also bound up in the crimes. Indeed, it does not stretch reason to contend that the systematic use of violence to capture and press the victims into sexual slavery and other conditions of enslavement would have been the first and foremost instance of use of terror, before deducing the other or ultimate motive behind the enslavement. All this is to say that once the primary purpose of spreading terror is present for one reason, such as to capture the captives and subdue them in the first place into a state of sexual slavery, such a purpose is never displaced by the presence of other ulterior motives for the conduct, such as to use the victims for sexual gratification. And this is quite apart from the nature of the evil of sexual violence seen earlier in Chapter I, according to which sexual violence itself is but one tactical weapon used by warring parties to terrify the spirit of resistance out of enemy communities.

The consideration here goes beyond the general proposition, noted by the ICTY Appeals Chamber, ${ }^{\circ \circ}$ that the violence of war necessarily spreads terror among the civilian population. But more specifically, the evidential findings sampled above do clearly establish a deliberate use of terror to sustain a system of criminal conduct in the nature of sexual slavery and the other enslavement crimes committed in the particular circumstances of the Sierra Leone civil war.

The remaining question becomes this: Are sexual slavery and the other enslavement crimes and their circumstances saved by any theory of lawfulness or legitimacy, such as could anchor an alternative primary purpose in a manner that

90 In Galic, the ICTY Appeals Chamber said as follows: 'As noted by the representative of France [during the negotiation of the Additional Protocol I to the Geneva Conventions], the waging of war would almost automatically lead to the spreading of terror among the civilian population and the intent to spread terror is that had to be prohibited': ibid, para Io3. And at footnote 326, the Appeals Chamber quoted the representative of France as follows: 'in traditional war, attacks could not fail to spread terror among the civilian population: what would be prohibited [...] was the intention to do so.' 
would override the purpose of terror that the very nature of these crimes compels one to infer? In the circumstances of the Sierra Leone civil war, there is no theory known to international law, which could convert the sexual slavery and the other enslavement crimes into lawful and legitimate uses of war with a primary purpose that overrode the terror attendant upon those crimes. And the Trial Chamber did not indicate that there was.

In view of the foregoing reasoning, it was an error on the part of the SCSL Trial Chamber to not have inferred the primary purpose of spreading terror from the nature and circumstances of the crimes of sexual slavery and other enslavement crimes committed during the Sierra Leone civil war.

\section{(b) The Multi-Purpose Approach}

It was also open to the Trial Chamber to have adopted the multi-purpose approach, as articulated in earlier jurisprudence, as to the meaning of 'primary purpose.' ${ }^{9}$ Under this rule, the existence of other purposes for the conduct does not discount the purpose of spreading terror. Hence, it would not be acceptable for a terrorist group to blow up an aeroplane with a new type of bomb, and then hope to escape culpability for terrorism merely by saying: 'Terrorising the civilian population was not really the primary purpose of our act. Our primary intent was merely to test a new type of bomb: never mind that we also intended to terrorise civilians in the process.'

The Trial Chamber's failure to reflect the jurisprudence of the multi-purpose analysis is specifically evident in relation to the evidence of Witness TFI334. According to this witness, during the 1999 invasion of Freetown, the accused Brima (a.k.a. 'Gullit') ordered the abduction of civilians, saying, as noted earlier, that it would attract the attention of the international community. Although it was not specifically clear in the evidence, it is reasonable to presume that some of the abductees were women and that they would have been subjected to the system of sexual slavery that was widely practiced by the accused Brima and his colleagues in the AFRC and RUF. The declaration of the accused ${ }^{22}$ Brima that the capture would attract the attention of the international community clearly reveals a primary purpose of spreading terror among a civilian population. For, the attention of an international community remotely situated could not be attracted without attracting the attention of the immediate local civilian population who were the victims of the conduct. And the attention of the immediate local civilian population, in the circumstances, would necessarily have taken the shape of terror. This was surely the case in relation to a similar attack on Karina in relation to which Brima was heard saying that he wanted 'to shock the whole country and the international community.'

9I See especially Prosecutor v Galić (Judgment) 30 November 2006, Case No IT-9829-A, [ICTY Appeals Chamber] para ro4.

Trial Judgment, para I449. 
The Chamber attempted to discount the jural significance of this incident by analysing the conduct from the perspective of the presence of children among the abductees and military use of children. The Chamber was wrong to have discounted this consideration from its analysis, upon the reasoning that this 'non-military purpose [that] also drove the AFRC to abduct children ... was subordinate given the overwhelming evidence of the conscription and use of child soldiers for military purposes.' ${ }^{93}$ What the Chamber did in this reasoning was to treat the actus reus and mens rea differently. This occurred when the Chamber began the reasoning process, perhaps unwittingly, with recognising the abduction of adult civilians and children as discrete factual events; and then considered them together as a related group of acts. But when it came to the assessment of the mental element for these crimes, the Chamber abandoned its initial approach of looking at abduction of adult civilians and children as discrete events. Rather, the Chamber adopted a composite view of all the different acts of abduction, such that the mens rea for the abduction meant to attract the attention of - or shockthe international community lost its uniqueness in the mélange of mentes reae for all the other abductions.

One trouble with this reasoning process is that it was not applied consistently by the Trial Chamber. Indeed, as is argued presently below, such a global view of the acts of violence is desirable. Applied consistently, this approach would have resulted in the finding of a primary purpose of spreading terror among the civilian population, as has been argued below.

If, on the other hand, the global view of the attack is not to be taken, then the abduction of civilians, including women, to attract international attention or shock ought to have been treated separately and considered on its own individual merit. Had that been done, it would then have become clear that the particular incident in question (abducting civilians for the purpose of attracting international attention or shock) did, at least, engage the primary purpose of spreading terror. Hence any crime of sexual slavery or other crime of enslavement traceable to the abduction would qualify as a war crime of terror.

\section{(c) A Holistic Vierw of Attack: A Campaign of Terror}

If, on the other hand, sexual slavery, abductions and forced labour are to be considered as a whole, then the whole to be considered should not be limited to a whole made up only of sexual slavery and the other enslavement crimes, to which the test of 'primary purpose of spreading terror' is then applied in isolation. Rather, the better view of the whole is a whole that includes all the atrocities committed by the perpetrators as part of the general mayhem of crimes which the perpetrators intentionally inflicted upon the civilian population. In addition to sexual slavery and the other enslavement crimes, that whole would include the unlawful killings, the mutilations, and the lootings and burnings (which the Chamber found to have amounted to terrorism). That whole will indeed portray a picture of 'campaign of 
terror'. To that campaign sensibly belong the rampant crimes of sexual violence against women.

Much legal authority recommends such a holistic view of the concept of attack. For instance, in discussing the notion of 'attack' for purposes of the general elements of crimes against humanity, and ICTR Trial Chamber in Kayishema and Ruzindana observed as follows:

The attack is the event in which the enumerated crimes must form part. Indeed, within a single attack, there may exist a combination of the enumerated crimes, for example murder, rape and deportation. ${ }^{94}$

In Akayesu, an ICTR Trial Chamber held an attack to comprise 'an unlawful act, event or series of events. '95 In Tadic, an ICTY Trial Chamber held in a pre-trial decision that an attack must involve 'a course of conduct'. ${ }^{6}$ And in article $7(2)(\mathrm{a})$ of the Rome Statute, it is provided that an attack against a civilian population is 'a course of conduct involving the multiple commission of acts referred to in paragraph I against any civilian population, pursuant to or in furtherance of a State or organizational policy to commit such attack.' ${ }^{97}$ Notably, the offences listed in paragraph I of article 7 of the Rome Statute include the following: rape, sexual slavery, any other form of sexual violence, enslavement, imprisonment or other severe deprivation of physical liberty in violation of fundamental rules of international law. Clearly, these offences are the same or tantamount to the offences of sexual slavery and the enslavement crimes with which the accused had been charged. For purposes of article $7(\mathrm{I})$ of the Rome Statute, in particular, either or both of the offences of 'enslavement' or 'imprisonment or other severe deprivation of physical liberty in violation of fundamental rules of international law', as there indicated, ought amply to cover the offences of abductions, forced labour and conscription and militarisation of children which the Prosecution submitted as also amounting to acts of terrorism in the context of the Sierra Leone conflict.

The foregoing analysis and the authorities cited in support afford an ample legal basis for the view that an examination of what amounts to an act of violence that spreads terror among the civilian population, as is pleaded in paragraphs 38 and 39 of the Indictment in the AFRC case, must take a total account of all the acts committed against the civilian population as part of the same campaign of violations against the civilian population.

To take the totality of the circumstances of the acts of violence into account in the assessment of terrorism in the context of the Sierra Leone conflict would have required the Trial Chamber to take sexual slavery, abductions, forced labour and militarisation of children committed by the accused and their junta follow-

\footnotetext{
94 Prosecutor v Kayishema and Ruzindana, supra, [ICTR Trial Chamber] para I22.

95 Prosecutor $v$ Akayesu, supra, para 581.

96 Prosecutor $v$ Tadic (Decision on the Form of the Indictment) I4 November 1995, Case No IT-94-I-T [ICTY Trial Chamber] para II.

ICC Statute art 7(2)(a).
} 
ers, together with amputations, ${ }^{98}$ killings, burnings, ${ }^{99}$ etc, which the Chamber had recognised as acts of terror. All those conducts comprised the acts of violence-or attack, so to speak-against the civilian population.

Certainly, there is authority in international law for such treatment of the war crime of terrorism. In the Motomura case ${ }^{\text {100 }}$ the charge of terrorism included the 'seizing of men and women on grounds of wild rumours ... which led to or at least contributed to the death, severe physical and mental suffering. 'ror The Motomura court-martial convicted I3 of the 15 accused of 'systematic terrorism practiced against civilians' for acts including unlawful mass arrests. The court found that those arrests had the effect of terrorising the population, 'for nobody, even the most innocent, was any longer certain of his liberty, and a person once arrested, even if absolutely innocent, could no longer be sure of health and life.' ${ }^{\text {roz }}$ There is little doubt that the sorts of fears here recognised as amounting to terror in the minds of victim population do amply apply to a victim population who have been forced to live under an incubus of a systematic pattern of sexual violence.

A compelling authority for the view that sexual violence can form part of a campaign of terror, unleashed as part of an armed conflict, is the acceptance of such a view by the UN Sub-Commission on Prevention of Discrimination and Protection of Minorities. In its resolution I998/18 it endorsed an 'accepted view' that included the recognition that sexual violence in armed conflicts may occur 'on an apparently sporadic basis or as part of a comprehensive plan to attack and terrorise a targeted population'. In the words of the Sub-Commission:

The Sub-Commission on Prevention of Discrimination and Protection of Minorities,

\section{$[\ldots]$}

Endorses the accepted view that regardless of whether sexual violence in armed conflict occurs on an apparently sporadic basis or as part of a comprehensive plan to attack and terrorize a targeted population, all acts of sexual violence, in particular during armed conflict, including all acts of rape and sexual slavery, must be condemned and prosecuted; ${ }^{\text {ro3 }}$...

98 Trial Judgment, paras I462, I475, I493, I495.

99 Trial Judgment, paras I482, I485, I495, I496, I5IO, I57I.

Ioo The Motomura case was recognised in the Galic case as the first War Crimes trial for the crime of terrorism.

IoI Trial of Shigeki Motomura \& Ors, I3 Law R Trials War Crim I38, cited in Galić (Trial Judgment) paras II4, II5 and I32.

I02 See Galić (Trial Judgment) para II5. See also para I32.

I03 UN Economic and Social Council, Sub-Commission on Prevention of Discrimination and Protection of Minorities, Resolution 1998/18 (Systematic rape, sexual slavery and slavery-like practices during armed conflict, including internal armed conflict) dated 21 August 1998, para 2. 
If sexual violence could be recognised as a part of a comprehensive campaign of terror against a civilian population, a correspondence of reasoning will recommend a similar treatment for abduction of adults and children. In this connection, it is recalled that the Trial Chamber had accepted the testimony of TFI-334 regarding the division of troops at the Sierra Leonean town of Kamagbengbeh in June 1998. ${ }^{\text {104 }}$ One section of troops was sent to Karina, hometown of President Kabbah, on Brima's orders to demonstrate the junta's powers, burn down Karina, capture strong male civilians, and to amputate civilians. ${ }^{105}$ The Chamber accepted evidence that accused Brima had stated that the 'he wanted the attack on Karina to shock the whole country and the international community.' ${ }^{\text {ro6 }}$

In view of the foregoing, it is reasonable to conclude that the sexual slavery and other enslavement crimes, committed during the Sierra Leone civil war, did amount to acts of terrorism, considering especially that they had been committed 'simultaneously' with other acts of violence accepted by the Special Court's Trial Chamber as acts of terrorism. ${ }^{\text {I07 }}$

\section{Terrorism and Specific Intent: a Matter of General Principle}

Besides the weaknesses of the reasoning of the SCSL Trial Chamber, in light of the peculiar facts at play in that $A F R C$ case, the judgment is also questionable inasmuch as it advances the theory, first articulated in Galic, that terrorism is a crime of specific intent. In this part of the discussion, it is contended that this theory is neither necessary nor desirable as a matter of general principles of international humanitarian law.

\section{A Purposive Analysis of Terrorism as War Crime}

From first principles, in the interpretation of the meaning of 'primary purpose' of an attack, for purposes of the war crime of terrorism, it is crucial to keep in view at all times the object and purpose of the mischief proscribed, as well as the context of the provision in which the expression appears. These values do become readily apparent upon a close examination of the provisions of the entire article $5 \mathrm{I}$ of Additional Protocol I and article I3 of Additional Protocol II-beyond the narrow phrase: '[a]cts or threats of violence the primary purpose of which is to spread terror among the civilian population are prohibited'.

The net objectives of article $5 \mathrm{I}$ of Additional Protocol $\mathrm{I}$ - and article $\mathrm{I} 3$ of Additional Protocol II-are these. First, it involves a reiteration of the principle of distinction. According to this principle, only military objects may be the targets of military attacks, and civilians must be protected from military operations.

I04 Trial Judgment, para I553.

I05 Loc cit.

Io6 Loc cit.

Io7 See Trial Judgment, para I450, I452 and I459. 
And the second net objective is to except, from the scope of culpability for war crimes, collateral civilian damages resulting from attacks on legitimate military targets; for, the doctrine of military necessity 'permits the destruction of life or armed enemies and other persons whose destruction is incidentally unavoidable by the armed conflicts of war.' ${ }^{\text {'08 }}$ These two objectives, it is submitted, are the basic considerations that must guide the interpretation of the notion of 'primary purpose' of spreading terror, as well as give it context, for purposes of the war crime of terrorism.

The notion of 'primary purpose' of spreading terror as it appears in article ${ }_{5} \mathrm{I}(2)$ of Additional Protocol I-and in article $\mathrm{I}_{3}(2)$ of Additional Protocol IIcould not upon any reasonable view ever be seen as possibly intended to legitimise direct and deliberate attacks against civilians. Sadly, this was, surely unwittingly, the result to be deduced in the AFRC trial judgment, upon the view that such attacks were somehow intended by the perpetrators as attacks against 'military targets in the sense that [some] discernible strategic advantage [may be] gained from the attacks. 'rog Such a view would rest upon a jural foundation that is just as tenuous as the related-but now widely rejected-view that a commander is permitted to ignore the laws of war if to do so is perceived as necessary to avoid defeat, to escape from extreme danger, or for the realisation of the purpose of the war.'ro Such ideas of necessity are no longer current. The better view is that ' $[\mathrm{t}] \mathrm{he}$ means to achieve military victory are not unlimited. ${ }^{\prime \prime I}$ If that is the case, what then is the discernible strategic advantage which the sexual violence against women would legitimately produce to the perpetrators? The answer to this question takes us back to the discussion in Chapter I, where we reviewed sexual violence as actuated by policy. There, we saw that sexual violence often gets used as policy during armed conflicts, in the manner of an instrument of terror. One such use is to frighten the enemy away from where they are not wanted, or to terrorise them into surrender. We recall one US officer describing it as an 'effective tactic.' According to him, 'If you scare people enough they will keep away from you'. ${ }^{\text {I2 } 2} \mathrm{We}$ also recall that during the conflict in the former Yugoslavia, Serbian forces did use this tactic

Io8 UK Ministry of Defence, The Manual of the Law of Armed Conflict [Oxford: Oxford University Press, 2004] p 22. The exemption of collateral civilian damages from the purview of war crimes is particularly underscored in article $5 \mathrm{I}(7)$ of Additional Protocol I which provides as follows: 'The presence or movements of the civilian population or individual civilians shall not be used to render certain points or areas immune from military operations, in particular in attempts to shield military objectives from attacks or to shield, favour or impede military operations. The Parties to the conflict shall not direct the movement of the civilian population or individual civilians in order to attempt to shield military objectives from attacks or to shield military operations.'

Io9 Prosecutorv Brima EO Ors (Trial Judgment), supra, para 1568.

IIo UK Ministry of Defence, The Manual of the Law of Armed Conflict, supra, p 23.

III Ibid.

II2 Bourke, supra, p 362. 
as a method of ethnic cleansing. ${ }^{\mathrm{Ir}}$ In I746, King George's troops led by the Duke of Cumberland used various methods of terror, including sexual violence against women, in an effort to force Scottish Highlanders into a surrender following the Battle of Culloden. ${ }^{\text {II }}$ But all that was terrorism without a doubt.

\section{Subjective and Objective Examination of Primary Purpose of Attack}

In view of these considerations, it is submitted that the question of what is the 'primary purpose' of an attack in terms of the war crime of terrorism is better assessed from both the subjective and the objective perspectives. In the subjective assessment, the perpetrator's dominant intention in conducting the attack ought to be examined. If the dominant intention was found to be nothing more than to spread terror among the civilian population, then the inquiry ends there. It may then be held that the war crime of terrorism had been established. If, however, the evidence does not readily reveal such a dominant intention, then the inquiry will need to shift into the objective mode.

In the objective analysis, the crucial question ought to be whether the 'primary purpose' of the impugned attack could reasonably be viewed as an attack against a legitimate military target, though it regrettably resulted in collateral civilian damages within the permissible scope of military necessity as generally understood. If the attack was against a legitimate military target which resulted in unavoidable incidental or collateral civilian damages, then the primary purpose of the attack may be seen as having a military objective. Hence, the attack may not rightly be viewed as embarked upon for the 'primary purpose' of spreading terror among the civilian population. But if the attack could not be seen as an attack against a legitimate military target, but rather a direct and deliberate attack against civilians, the inquiry then needs to turn to whether such an attack had the effect of terrorising the civilian population. If the attack had that effect, it will then become harder to avoid characterising it as having a primary purpose of terrorising the civilian population. This may be described as the 'effects theory' of primary purpose of spreading terror. It is consistent with both the usages of language as well as the objective theory of mens rea which hinges upon the reasonable foresight of the given harm, as explained below.

Indeed, this focus on effect or outcome is adequately accommodated within the large and liberal usage of the word 'purpose'. In The Oxford Thesaurus, for instance, the noun 'purpose' also includes the following meanings, in addition to 'intent':

II3 See Vetlesen, supra, pp I97-I98.

II4 Brownmiller, supra, p 38. 
use, practicality, avail, effect, utility, usefulness, outcome, result, advantage, profit, gain, good, benefit; ... I cannot see the purpose in pursuing this line of questioning ... ${ }^{\mathrm{II}}$. [Bold emphasis added.]

The point is this. An attack that has no military purpose must be given the full legal significance that it can bear, if it resulted in foreseeable civilian casualties. It thus becomes reasonable to say that a naked act of violence against a civilian population - and not a military target-is an act of violence whose primary purpose is the spreading of terror, if it in fact spreads terror. Indeed, the ICTY Trial Chamber recognized this in the case of Prosecutor v Dragomir Milošević. There, the Trial Chamber considered that 'long term and persistent attacks against civilians, as well as indiscriminate attacks, may be taken as indicia of the intent to spread terror.'The Trial Chamber considered that 'the specific intent may also be inferred from the site of the attack.' According to the Trial Chamber, the fact that during the siege, 'civilians were targeted and attacked at sites, well-known to be frequented by them during their daily activities, such as market places, water distribution points, on public transport, and so on, may provide strong indicia of the intent to spread terror.' ${ }^{116}$ The Trial Chamber's analysis of intent to spread terror fully bears out the 'effects theory'. In concentrating their attacks against civilian population — and not on military targets—in a manner that foreseeably resulted in terror in the minds of the targeted civilian population, the perpetrators must be taken to have intended the resultant terror in the minds of the civilian population.

This construction of 'primary purpose' is not a mere linguistic contrivance. Indeed, it also rests on two important legal foundations. First, as already adumbrated, it is consistent with the objective theory of mens rea, which encompasses reasonable foresight of a given harm. This is generally viewed as the essence of the principle of mens rea. For it is accepted that the intent to commit a crime involves not only a deliberate desire to occasion the criminal outcome, but also the perpetration of a course of conduct with reasonable foresight of a certain criminal outcome. Ashworth explained the principle in the following way:

The essence of the principle of mens rea is that criminal liability should be imposed only on persons who are sufficiently aware of what they are doing, and of the consequences it might have, that they can fairly be said to have chosen the behaviour and its consequences. This approach is grounded in the principle of autonomy ...: individuals are regarded as autonomous persons with a general capacity to choose among alternative courses of behaviour, and respect for their autonomy means holding them liable only on the basis of their choices. ${ }^{\mathrm{II} 7}$ [Emphasis added.]

II5 Laurence Urdang, The Oxford Thesaurus [Oxford: Clarendon Press, I991] p 366.

II6 Prosecutor v Dragomir Milošević (Judgment) I2 December 2007 [ICTY Trial Chamber] para 88I.

II7 Andrew Ashworth, Principles of Criminal Law, 3rd edn [Oxford: Oxford University Press, 1999] pp i60-16r. 
The essence of the principle of mens rea thus explained has now been woven into the fabric of the jurisprudence of international criminal law. It is discernible within the doctrine of dolus eventualis as explained in the following statement made by an ICTY Trial Chamber in Prosecutor $v$ Stakic in the context of murder as a war crime:

Turning to the mens rea element of the crime, the Trial Chamber finds that both a dolus directus and a dolus eventualis are sufficient to establish the crime of murder under Article 3. In French and German law, the standard form of criminal homicide (meurtre, Totschlag) is defined simply as intentionally killing another human being. German law takes dolus eventualis as sufficient to constitute intentional killing. The technical definition of dolus eventualis is the following: if the actor engages in life-endangering behaviour, his killing becomes intentional if he "reconciles himself" or "makes peace" with the likelihood of death. Thus, if the killing is committed with "manifest indifference to the value of human life", even conduct of minimal risk can qualify as intentional homicide. Large scale killings that would be classified as reckless murder in the United States would meet the continental criteria of dolus eventualis. The Trial Chamber emphasises that the concept of dolus eventualis does not include a standard of negligence or gross negligence. ${ }^{\mathrm{II} 8}$

The essence of the objective theory of mens rea is also clearly evident in the settled jurisprudence of international criminal law that the mens rea for murder as a crime against humanity is not limited to premeditated killing. ${ }^{\text {II9 }}$

In these circumstances, the offence of terrorism proscribed under article $5 \mathrm{I}(2)$ of Additional Protocol I-and article I3(2) of Additional Protocol II-is much more clearly appreciated from the prism of its mischief-i.e. as the conduct of causing terror among the civilian population by attacking civilian targets instead of legitimate military targets. Upon the doctrine of mens rea commonly found in the principle of autonomy (explained by Professor Ashworth as seen above) as well as in the doctrine of dolus eventualis (enunciated by ICTY Judges in Stakic), where combatants in an armed conflict choose to attack civilian targets and not legitimate military targets, the objective analysis will make it neither necessary nor desirable to look for any other purpose (on the mind of the perpetrator) beyond the direct incidence of the attack upon the civilian population in question. To do so will be to confuse motive or desire with mens rea as an element of crime. Here, one may readily call into service the definition of intent which I suggested in Chapter I: 'intent, for purposes of criminal law may be defined as the existence of consciousness of the mind in correlative proximity to the foreseeable results of one's action.' If in attacking the civilian population there existed in the perpetra-

iI8 Prosecutor v Stakić (Judgment), supra, [ICTY Trial Chamber] para 587.

II9 See generally, C Eboe-Osuji, 'Murder as a Crime against Humanity at the Ad Hoc Tribunals: Reconciling Differing Languages', Canadian Yearbook of International Law (2005) p I45. 
tors' consciousness of the mind in correlative proximity to foreseeable terror in the minds of the targeted population as a result of the attacks, then the requirement of intent to spread terror would have been satisfied.

That is to say, the incidence of attacks during armed conflicts will necessarily spread terror among the civilian population. Legitimate military objectives, however, afford a saving grace for such attacks; thus insulating them from the quality of sheer terrorism. In the absence, however, of a reasonable claim to legitimate military operations, deliberate attacks against a civilian population will not be saved from the charge of terrorism committed under the cover of armed conflict. Upon this reasoning, rape, sexual slavery, and other sexual violence, at least, forming part of a direct attack against the civilian population, could not reasonably be claimed as legitimate military operations. They would necessarily have the effect of terrorising the civilian population against whom they were committed. Therefore, the conducts may properly be viewed as acts of terrorism.

The foregoing reasoning sufficiently weakens the idea of terrorism as crime of specific intent: thus making it unnecessary also to consider fully whether the reasoning applies as easily to the offences of militarisation of children and forced labour. ${ }^{\mathrm{I} 20}$

Furthermore, the effects theory of 'primary purpose of spreading terror', as articulated above, is also consistent with the meaning of terroristic act as clearly indicated in the International Convention for the Suppression of the Financing of Terrorism (2000). This Convention affords a useful guide to the interpretation of primary purpose of spreading terror, especially given its relevance to armed conflicts. Of interest in this regard is article 2(I) which provides as follows:

Any person commits an offence within the meaning of this Convention if that person by any means, directly or indirectly, unlawfully and wilfully, provides or collects funds with the intention that they should be used or in the knowledge that they are to be used, in full or in part, in order to carry out:

(a) An act which constitutes an offence within the scope of and as defined in one of the treaties listed in the annex; or

(b) Any other act intended to cause death or serious bodily injury to a civilian, or to any other person not taking an active part in the hostilities in a situation of armed conflict, when the purpose of such act, by its nature or context, is to intimidate a population, or to compel a government or an international organization to do or to abstain from doing any act. [Emphasis added.]

In making clear that the 'purpose' of an act, in terms of the crime of terrorism, is not limited to the declared intents of the perpetrators, but encompasses the 'nature

I20 Admittedly, this reasoning does not apply with as much force to the offences of militarisation of children and forced labour, also involved in the $A F R C$ case, without the aid of the rule that combatants are not unrestrained in their choice of means of warfare. Hence, requiring them to obey the dictates against militarisation of children and forced labour. 
and context' of the acts of the perpetrator, the Convention is to be seen as providing a concrete legal support for the effects theory of the conception of intent to spread terror.

Once more, it must be stressed that the foregoing analysis gives full scope to the anxious result sought to be avoided in article I3(2) of Additional Protocol II and article $5 \mathrm{I}(2)$ of Additional Protocol $\mathrm{I}$ - i.e. the criminalisation of collateral civilian damages resulting from attacks on legitimate military targets is to be avoided.

\section{The Statute of Rome on the War Crime of Terrorism}

In the era of international criminal law after the adoption of the Rome Statute, it is compelling to consider just how the debate as to the meaning of terrorism is influenced or shaped by the provisions of that instrument. Regrettably, the picture is not straightforward, in the sense of the Rome Statute providing a definitive answer either way. Interestingly, the Rome Statute makes no mention at all of the term 'terror' or 'terrorism', nor does it indicate that any crime akin to terror must be committed with the specific intent to alarm the civilian population. But the silence of the Rome Statute puts no end to the inquiry on the significance of that instrument to the debate on the definition of terrorism as a war crime within the meaning of Additional Protocols I and II.

Quite the contrary, it is arguable that the silence of the Rome Statute has the curious result of tilting the scale in favour of the case against the view that terrorism is a crime of specific intent. This conclusion is borne out by the fact that while silent on both the concept of terror and on the notion of specific intent to spread alarm in the mind of the civilian population, the Rome Statute does proceed to make repeated and elaborate provisions — and justifiably so-against the crime of subjecting the civilian population and objects to attacks. In particular, it is a war crime under the Rome Statute to do any of the following:

- intentionally direct attacks against the civilian population as such or against individual civilians not directly participating in the hostilities; ${ }^{\text {I2I }}$

- intentionally direct attacks against civilian objects; ${ }^{\mathrm{i22}}$

- intentionally direct attacks against personnel, installations, units, etc, involved in humanitarian assistance or such UN-authorised peacekeeping missions as are entitled to the protection given to civilians and civilian objects; ${ }^{\mathrm{I} 23}$

- intentionally launching an attack knowing that civilians will suffer incidental loss of life or injury, or that incidental damage will be occasioned to civilian objects, or that widespread, long-term and severe damage will result to the

I2I See Rome Statute, article $8(2)($ b)(i) as regards international armed conflicts, and article $8(2)(\mathrm{e})(\mathrm{i})$ for non-international armed conflicts.

I22 Ibid, article $8(2)($ b)(ii).

I23 Ibid, article 8(2)(b)(iii) as regards international armed conflicts, and article 8(2)(e)(iii) for non-international armed conflicts. 
natural environment, in excessive levels in comparison to the concrete and direct overall anticipated military advantages; ${ }^{\mathrm{I} 24}$

- attacking or bombarding undefended towns, villages, dwellings or buildings which are not military objectives; ${ }^{125}$

- intentionally directing attacks against buildings dedicated to religion, education, art, science, charity, and historic monuments, hospitals and health care centres, which are not military objectives; ${ }^{\mathrm{I2} 6}$

- $\quad$ pillaging a town or place; $;^{127}$

- employing weapons, projectiles, materiel and methods of warfare which are inherently indiscriminate and which have been prohibited by the international community: ${ }^{128}$

- intentionally directing attacks against buildings, material, medical units and transport, and personnel using the distinctive emblems of the Geneva Conventions; ${ }^{\text {:29 }}$

- intentionally using starvation of civilians as a method of warfare by depriving civilians of necessaries of life, including deliberately impeding relief supplies; ${ }^{130}$

- militarization of children under 15 years of age; ${ }^{\text {I3I }}$ and

- ordering the displacement of the civilian population for reasons related to the conflict in circumstances not dictated by their security or military necessity. ${ }^{132}$

Amidst this over-arching concern for the welfare of civilians during armed conflicts, the silence of the Rome Statute as regards both the concept of terrorism and the notion of specific intent to alarm the civilian population arguably suggests that the chief concern of humanitarian law in this sphere is the prevention of deliberate attacks against civilian populations, rather than the technical descriptions and modalities of such attacks.

The net result is this. At the ICC, a case revealing an unlawful attack against a civilian population will be adjudged without the distraction of the added inquiry as to whether such a conduct had been perpetrated for the primary purpose of

\footnotetext{
I24 Ibid, article $8(2)($ b)(iv).

I25 Ibid, article $8(2)(\mathrm{b})(\mathrm{v})$.

I26 Ibid, article 8(2)(b)(ix) as regards international armed conflicts, and article 8(2)(e)(iv) for non-international armed conflicts.

I27 Ibid, article 8(2)(b)(xvi) as regards international armed conflicts, and article $8(2)(\mathrm{e})(\mathrm{v})$ for non-international armed conflicts.

I28 Ibid, article $8(2)(\mathrm{b})(\mathrm{xx})$.

I29 Ibid, article 8(2)(b)(xxiv) as regards international armed conflicts, and article 8(2)(e) (ii) for non-international armed conflicts.

I30 Ibid, article $8(2)(\mathrm{b})(\mathrm{xxv})$.

I3I Ibid, article $8(2)(\mathrm{b})(\mathrm{xxvi})$ as regards international armed conflicts, and article $8(2)(\mathrm{e})$ (vii) for non-international armed conflicts.

I32 Ibid, article 8(2)(e)(viii) for non-international armed conflicts.
} 
spreading terror. Hence, while counsel and Judges at the Special Court for Sierra Leone may exercise their minds with that added inquiry in the face of sexual slavery and other enslavement crimes, the provisions of the Rome Statute leave little room for such a debate.

\section{Conclusion}

In an apparent effort to interpret and apply the provisions of the Additional Protocols I and II which forbid '[a]cts or threats of violence the primary purpose of which is to spread terror among the civilian population', a Trial Chamber of the SCSL and the Appeals Chamber of the ICTY have concluded that the war crime of terrorism is a crime of specific intent. This interpretation is not necessary, since it does not strictly follow from the language of the provisions being interpreted. Nor is the interpretation desirable, as it is fraught with the danger of legitimising conducts that are clearly criminal in international law, simply because those conducts may have the ultimate result of advancing the objectives of the perpetrators in the context of a given armed conflict. The latter danger was evident in the result of the $A F R C$ case before the SCSL where the Chamber held that sexual slavery and other enslavement crimes served some ultimate military objectives, hence were not acts of terror. Among other things, that reasoning failed to consider that a systematic use of violence was employed to capture and subjugate the victims, as a primary event, while the realisation of the ultimate utilitarian objective in each case was only achieved after that primary act of violence. There is a flaw in the reasoning that wholly ignores the jural significance of that primary event, while concentrating on the secondary event. That flaw sets back rather than advances the objectives of international humanitarian law.

Having reviewed the evil of sexual violence from the perspective of the war crime of terrorism, we will consider in the next chapter the question of perception of the enormity of evil of sexual violence from the perspective of typology of the armed conflict as either or not of an international character, as is engaged in the notion of 'grave breaches.' 
Chile Eboe-0suji - 978-90-04-22722-4 Downloaded from Brill.com $04 / 26 / 2023$ 12:45:46PM via free access 


\section{Chapter 6}

\section{Internal Armed Conflicts, Sexual Violence and 'Grave Breaches'}

\section{Introduction}

From the perspective of sexual violence in internal armed conflicts, this chapter examines the question of perception of the full scope of the evil of sexual violence. For this purpose, the central focus will be the consideration of the notions of 'grave breaches' and 'serious violations', two phrases often encountered in discussions on war crimes.

We have seen from both our discussions in Chapter I (review of the explanations for the evil of sexual violence) and in Chapter 2 (on superior responsibility), that sexual violence is a chronic feature of armed conflicts. In Chapter I, we saw that the explanations for the high frequency of sexual violence during armed conflicts lie both in the domain of policy and opportunism. And as we have also seen in Chapter 5 on sexual violence and terrorism, focusing on the Sierra Leone civil war as the case study, sexual violence committed in a civil war is every bit as horrendous to its victim as it is to the victim of sexual violence during international armed conflict.

As will be seen presently, there is a school of thought in international criminal law that tends to view crimes committed in international armed conflict as more 'grave'-jurally speaking - than those committed in internal armed conflict. The evil of sexual violence serves as a good reference point for the (f)utility of the debate whether the notion of 'grave breaches' is properly the exclusive preserve of international armed conflicts. As a matter of adequate responses to the evil of sexual violence, the concern is that women violated sexually in internal armed conflicts might not be viewed as in as great or urgent a need for legal protection if their fate is regarded as less 'grave' than the fate of their sisters elsewhere subjected to precisely the same violation in international armed conflicts.

Purely from the perspective of imagery and 'optics' of sound, 'grave breaches' is arguably larger than 'serious violations'. 'Grave breaches' has an ominously rumbling feel about it. It evokes the imagery of a big, bad, g-g-r-r-r-owling b-r-rute rolling by and bringing certain death and interment to its victims. 'Serious violations', on the other hand, does not sound and feel quite as bad. It arguably has a cleaner, more sophisticated, mellifluous, feel about it - much like a fine French phrase: 'serious violations'. 
But do these phonological notes about the two phrases also resonate in their intellection? International lawyers with greater familiarity with the two notions will likely, at first, think not. And, most assuredly, there is nothing clean, fine or sophisticated about 'serious violations'. The etymology of its words is not even French.

The answer, alas, may not be as certain regarding the intendment of a difference in meaning between the two phrases. Those liable to say, at first, that there is no intended difference in meaning may likely pause in their tracks to wonder why then it was that the drafter would employ the formulation 'grave breach ... or other serious violation' in article 9o(2)(c)(i) of the 1977 Additional Protocol I to the Geneva Conventions of 1949 . $^{\mathrm{I}}$

There are, however, those who might find themselves constrained to discover a difference in meaning between the two phrases. They are presumably those who subscribe to the doctrine that the two phrases operate in different spheres of armed conflicts. Therefore, there must be some purpose to the difference. But the members of this school of thought will also likely pause in their tracks when asked why precisely it could be that exactly the same act will be described differently if committed in different spheres of armed conflicts. That is to say, why would rape amount to a 'grave breach' when a soldier commits it in an international armed conflict, but a rape committed by a soldier fighting a civil war will not amount to a 'grave breach'? The aim of this Chapter is to explore these seemingly difficult questions, against the particular backdrop of the evil of sexual violence during armed conflicts.

\section{Defining 'War Crimes'}

The current accepted definition of 'war crimes' as a generic concept is serious violations of the laws or customs of international or internal armed conflicts, committed in the course of an armed conflict in circumstances that require punishment of the culprit in terms of criminal law. Although the modifier 'serious' often accompanies the modern description of the violations that are considered war crimes, ${ }^{2}$ that modifier in itself must not be viewed as a magic beacon that

I Protocol Additional to the Geneva Conventions of 12 August 1949, and Relating to the Protection of Victims of International Armed Conflicts (Protocol I). It should perhaps be noted that this is the only place in the entire GC 1949 system where such a formulation occurs. In fact, 'serious violations' never appears in the main Geneva Conventions, although, as will be seen later, 'grave breaches' does appear there.

2 See article 8 of the ICC Statute, article 2 of the ICTY Statute, article 4 of the ICTR Statute, article 3 of the SCSL Statute and s 6.I of Regulation 2000/15 on the Establishment of Panels with Exclusive Jurisdiction over Serious Criminal Offences (in East Timor), Doc No UNTAET/REG/2000/15 of 6 June 2000. Although article 3 of the ICTY Statute does not employ the term 'serious violation' or 'grave breaches' (as in article 2) to describe the violations therein listed, the Appeal Chamber of that Tribunal has, nevertheless, interpreted the provision as requiring the element of seriousness. As the ICTY Appeals Chamber observed, to steal a loaf of bread in an 
illumines a particular conduct as fit to be described as a war crime. It is rather the very characterisation of a violation as 'serious' that is the objective to be discovered in the process of identifying a war crime. At the end of that process, any violation which is identified is said to be 'serious', thus qualifying as a war crime; provided that the conduct is also intended to be punished by the sanctions of criminal law. The question thus arises: What is it that makes conduct a serious violation so that it is a war crime? The answer has been provided in the jurisprudence in the following way. Violations of the laws and customs of war are considered serious if (a) they endanger protected persons or objects or they breach important values; 3 and (b) they are committed wilfully ${ }^{4}$-in the sense of intentionally or in reckless disregard of their outcome as endangering protected persons or objects or their breach of important values. ${ }^{5}$ The former is the actus reus of the crime and latter is the mens rea.

The decision maker is, of course, largely spared this voyage of discovery if an international instrument has already identified a given conduct as a war crime. The prosecutors and judges of the International Criminal Court enjoy this benefit of a ready-made solution to the problem, because their Statute provides, in article 8(2), an apparently closed and lengthy catalogue of all the imaginable conducts fit to be described as war crimes.

Not all decision makers, however, enjoy the luxury—or hamstring, depending on one's perspective - of a ready-made solution. The prosecutors and judges of the International Criminal Tribunals for Rwanda and for the former Yugoslavia, as well as of the Special Court for Sierra Leone, are among those who may, from time to time, embark upon the voyage of discovery of what is a serious violation of the laws and customs of war. This is because their statutes provide the lists of war

occupied territory does not make a war criminal out of a member of the occupying force: in Tadic (Decision on the Defence Motion for Interlocutory Appeal on Jurisdiction) dated 2 October 1995, Case No IT-94-I-AR/72 [ICTY Appeals Chamber] para 94.

See Tadic (Decision on Interlocutory Appeal on Jurisdiction) dated 2 October 1995 [ICTY Appeals Chamber] para 94 ("the violation must be "serious", that is to say, it must constitute a breach of a rule protecting important values, and the breach must involve grave consequences for the victim.') See also See International Committee of the Red Cross, Customary International Humanitarian Law, vol I: Rules [Cambridge: Cambridge University Press, 2005] p 569.

4 Article II(4) of the 1977 Additional Protocol I of the Geneva Conventions provides as follows: 'Any wilful act or omission which seriously endangers the physical or mental health or integrity of any person who is in the power of a Party other than the one on which he depends and which either violates any of the prohibitions in paragraphs I and 2 or fails to comply with the requirements of paragraph 3 shall be a grave breach of this Protocol.' The same notion of wilfulness of the violation is repeated in article $85(3)$ and $85(4)$ of the same protocol; articles I2 and 50 of the Ist Geneva Convention 1949; articles 12 and 5 I of the 2nd Geneva Convention 1949; article I3O of 3 rd Geneva Convention I949; article I47 of the 4 th Geneva Convention I949.

5 See ICRC, Customary International Humanitarian Law, vol I: Rules, supra, p 574. 
crimes in the non-exhaustive formulation of 'these violations shall include, but shall not be limited to .... ${ }^{6}$ The provisions thus permit the lists to be augmented from other sources of international humanitarian law. The notion of seriousness in relation to the violations qualifying as war crimes thus assumes particular significance, given the general view that international humanitarian law also exists in general international law beyond the written codes of international humanitarian law. ${ }^{7}$

\section{'Serious Violations’ and 'Grave Breaches'}

An occasional by-product of the analysis of war crimes is the controversy surrounding an understanding and application of the term 'grave breaches' of the Geneva Conventions of 1949 on the laws and customs of war. The notion of 'grave breaches' was introduced into the Geneva Conventions of 1949 under the heading 'Repression of Abuses and Infractions' (of the Conventions). It began with article 49 of the First Convention which provides as follows:

The High Contracting Parties undertake to enact any legislation necessary to provide effective penal sanctions for persons committing, or ordering to be committed, any of the grave breaches of the present Convention defined in the following Article.

Each High Contracting Party shall be under the obligation to search for persons alleged to have committed, or to have ordered to be committed, such grave breaches, and shall bring such persons, regardless of their nationality, before its own courts. It may also, if it prefers, and in accordance with the provisions of its own legislation, hand such persons over for trial to another High Contracting Party concerned, provided such High Contracting Party has made out a prima facie case.

Each High Contracting Party shall take measures necessary for the suppression of all acts contrary to the provisions of the present Convention other than the grave breaches defined in the following Article.

6 See article 4 of the ICTR Statute, article 3 of the ICTY Statute, article 3 of the SCSL Statute.

7 See Case Concerning Military and Paramilitary Activities in and against Nicaragua (Nicaragua v United States of America) [1986] ICJ Rep I4 [ICJ] para 218; Legality of the Threat or Use of Nuclear Weapons (Advisory Opinion) [1996] I ICJ Rep 226 [paras 79-82]; Tadic (Decision on Interlocutory Appeal on Jurisdiction), supra, [ICTY Appeals Chamber] para 94; Prosecutor v Delalic (Judgment), dated i6 November 1998, Case No IT-96-2I-T [ICTY Trial Chamber] para 303; Report of the Secretary-General Pursuant to Paragraph 2 of Security Council Resolution 808 (3 May I993), UN Doc S/25704 para 35; Ethiopia v Eritrea (Prisoners of War-Ethiopia's Claim 4) Partial Award, I July 2003 [Eritrea-Ethiopia Claims Commission] para 3r. See also ICRC, Customary International Humanitarian Law, vol I: Rules, supra, p 572; and Cassese, International Criminal Law, supra, p 47. 
In all circumstances, the accused persons shall benefit by safeguards of proper trial and defence, which shall not be less favourable than those provided by Article I05 and those following the Geneva Convention relative to the Treatment of Prisoners of War of August I2, I949.

The same provision appears in identical terms in article 50 of the Second Convention, article I29 of the Third Convention and article 146 of the Fourth Convention. The stated aim of this common provision was to suppress 'abuses and infractions' of the Geneva Conventions. The two primary methods employed to achieve this aim were: (a) requiring States Parties, through their undertakings, to proscribe such abuses and infractions in their domestic criminal codes; and (b) obligating States Parties, within their territories, to search for and prosecute culprits found therein, under a regime of conditional universal jurisdiction, or to extradite the culprits to other States Parties with sufficient jurisdictional links to the violations.

Having required States to do these things in order to suppress 'abuses or infractions' of the Geneva Conventions, it became necessary to define the sort of 'abuses or infractions' intended to be suppressed. That was done in the next provisions. The typical provision is article 50 of the First Convention that states as follows:

Grave breaches to which the preceding Article relates shall be those involving any of the following acts, if committed against persons or property protected by the Convention: wilful killing, torture or inhuman treatment, including biological experiments, wilfully causing great suffering or serious injury to body or health, and extensive destruction and appropriation of property, not justified by military necessity and carried out unlawfully and wantonly.

The same provision appears in the same terms in all the four Geneva Conventions of 1949 , with necessary variation made after the sentence 'wilfully causing great suffering or serious injury to body or health', so as to meet the special aims of each particular Convention. ${ }^{8}$

These specific catalogues of grave breaches were further collated from the Geneva Conventions and restated in article 2 of the Statute of the International Criminal Tribunal for the former Yugoslavia, for purposes of defining the juris-

8 Article $5 \mathrm{I}$ of the Second Convention is identical to article 50 of the First Convention. But article 130 of the Third Convention ends with 'compelling a prisoner of war to serve in the forces of the hostile Power, or wilfully depriving a prisoner of war of the rights of fair and regular trial prescribed in this Convention'; and article 147 of the Fourth Convention ends with 'unlawful deportation or transfer or unlawful confinement of a protected person, compelling a protected person to serve in the forces of a hostile Power, or wilfully depriving a protected person of the rights of fair and regular trial prescribed in the present Convention, taking of hostages and extensive destruction and appropriation of property, not justified by military necessity and carried out unlawfully and wantonly.' 
diction of that Tribunal. One notes the specific reference to 'grave breaches' in the provision which reads as follow:

The International Tribunal shall have the power to prosecute persons committing or ordering to be committed grave breaches of the Geneva Conventions of I2 August 1949, namely the following acts against persons or property protected under the provisions of the relevant Geneva Convention:

(a) wilful killing;

(b) torture or inhuman treatment, including biological experiments;

(c) wilfully causing great suffering or serious injury to body or health;

(d) extensive destruction and appropriation of property, not justified by military necessity and carried out unlawfully and wantonly;

(e) compelling a prisoner of war or a civilian to serve in the forces of a hostile power;

(f) wilfully depriving a prisoner of war or a civilian of the rights of fair and regular trial;

(g) unlawful deportation or transfer or unlawful confinement of a civilian;

(h) taking civilians as hostages. [Emphasis added.]

Another war crimes provision is made in article 3 of the ICTY Statute. But this refers not to 'grave breaches' but merely to 'violating the laws or customs of war.' Although article 3 does not say 'serious', ${ }^{9}$ the Appeals Chamber of the ICTY has, by the reasoning process of necessary implication, interpreted article 3 as importing the concept of 'serious violations', since the notion of war crimes has been judicially interpreted in the Tadic case as relating only to serious violations. ${ }^{\text {io }}$

As the general tenor of this chapter will reveal, it is submitted that the failure of the drafters of article 3 of the ICTY Statute to employ the modifier 'serious' might not have been an accidental omission. To the contrary, this might have been a deliberate omission, in order to distinguish article 2 (which refers to 'grave breaches') from article 3 (which does not refer to 'grave breaches'). This proposition is particularly borne out by the submission (made below) that the word 'grave' is a synonym of the word 'serious'. Therefore, any intended distinction might have appeared contrived, had the drafters employed the words 'grave' (as they did in

9 Article 3 provides as follows: 'The International Tribunal shall have the power to prosecute persons violating the laws or customs of war. Such violations shall include, but not be limited to: (a) employment of poisonous weapons or other weapons calculated to cause unnecessary suffering; (b) wanton destruction of cities, towns or villages, or devastation not justified by military necessity; (c) attack, or bombardment, by whatever means, of undefended towns, villages, dwellings, or buildings; (d) seizure of, destruction or wilful damage done to institutions dedicated to religion, charity and education, the arts and sciences, historic monuments and works of art and science; (e) plunder of public or private property.'

Io See Tadic (Decision on Interlocutory Appeal on Jurisdiction), supra, [ICTY Appeals Chamber] para 94 . 
article 2) and 'serious' (as the judges in Tadić would have preferred) in relation to article 3. This might explain the decision not to employ the word 'serious' in the latter provision. It is arguable indeed that the drafters might have been wrong in their assumptions, if they had deliberately chosen not to employ the modifier 'serious' in article 3 . But such an argument may, as will be seen later, not easily warrant a judicial supply of a casus omissus by reading the word 'serious' into article 3, in order to justify treating the phrase 'grave breaches' as a concept different from 'serious violations.'

For its part, the Statute of the International Criminal Tribunal for Rwanda limited the jurisdiction of the ICTR to 'serious violations' of common article 3 of the Geneva Conventions. This is seen in article 4 of the ICTR Statute which is the only war crimes provision in the ICTR Statute. Notably, the ICTR Statute makes no reference to the phrase 'grave breaches'. Article 4 of the ICTR Statute provides as follows:

The International Tribunal for Rwanda shall have the power to prosecute persons committing or ordering to be committed serious violations of Article 3 common to the Geneva Conventions of I2 August 1949 for the Protection of War Victims, and of Additional Protocol II thereto of 8 June 1977. These violations shall include, but shall not be limited to:

(a) violence to life, health and physical or mental well-being of persons, in particular murder as well as cruel treatment such as torture, mutilation or any form of corporal punishment;

(b) collective punishments;

(c) taking of hostages;

(d) acts of terrorism;

(e) outrages upon personal dignity, in particular humiliating and degrading treatment, rape, enforced prostitution and any form of indecent assault;

(f) pillage;

(g) the passing of sentences and the carrying out of executions without previous judgement pronounced by a regularly constituted court, affording all the judicial guarantees which are recognized as indispensable by civilised peoples;

(h) threats to commit any of the foregoing acts.

Article 4 of the ICTR Statute is a collation of the provisions of common article 3 of the Geneva Conventions of 1949 and article 4 of the 1977 Additional Protocol II to the Geneva Conventions. Common article 3 of the Geneva Conventions is a special provision introduced in 1949 in a rather different effort to regulate internal armed conflicts, at a time when the view was particularly strong that international law must proceed with great caution in matters considered the internal affairs of nation States. $\mathrm{R}_{2} \mathrm{P}^{\text {Ir }}$ had not become a fashionable acronym in those days. With the evolution of international law and with confidence increasingly gained that

II Responsibility to Protect. 
international law could indeed regulate internal armed conflicts, ${ }^{12}$ an effort was made in 1977 to expand that regime of regulation for armed conflicts not of an international character. Hence, the introduction of Additional Protocol II.

In view of the dichotomy between international armed conflicts and internal armed conflicts, some commentators have imbued the term 'grave breaches' with a particularly sombrous aura of a special genre of war crimes that even transcends the idea of war crimes as 'serious violations' of the law and customs of war. In the British Manual of the Law of Armed Conflict, for instance, one observes the following commentaries:

The Geneva Conventions 1949 introduced a new concept, that of 'grave breaches'. These are war crimes of such seriousness as to invoke universal jurisdiction. ${ }^{13}$

Serious violations of the law of armed conflict, other than those listed as grave breaches in the Conventions or Protocol, remain war crimes and punishable as

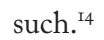

This manner of treating the concept of grave breaches has led even another commentator to assert as follows:

$[G]$ rave breaches only apply to armed conflicts of an international character (or to a state of occupation) and not to internal armed conflicts. A grave breach of the Geneva Conventions may not, therefore, be committed in the context of an internal armed conflict. Because the subject-matter jurisdiction of the ICTR is limited to war crimes committed in an internal armed conflict, grave breaches do not fall within its jurisdiction and the relevancy of the grave breaches regime is therefore limited, as far as the $a d$ hoc Tribunals are concerned, to the ICTY. ${ }^{\text {I5 }}$

More significant, however, is the fact that the drafters of the Elements of Crimes of the Statute of the International Criminal Court have subscribed to this view. They

I2 A notable milestone in this evolution was the declaration of the International Court of Justice in 1970 that 'all States can be held to have a legal interest' in the protection of certain rights, given their importance; thus making them obligations erga omnes. Rights qualifying as such include those deriving from the prohibition of genocide, as well as the principles and rules concerning the basic rights of the human person, including protection from slavery and racial discrimination: Case Concerning the Barcelona Traction, Light and Power Co Ltd (Belgium v Spain) 1970 ICJ $3, \mathrm{p} 32$.

I3 UK Ministry of Defence, The Manual of the Law of Armed Conflict, supra, p 424.

I4 Ibid, p 427 .

I5 Guénaël Mettraux, International Crimes and the Ad Hoc Tribunals [Oxford: OUP, 2005] p 54. See also Cassese, International Criminal Law, supra, pp 55-56. 
have inserted international armed conflict as an element of the grave breaches provision of article $8(2)$ (a) of the ICC Statute. This was done notwithstanding that article 8(2)(a) of the ICC Statute itself contains no such words of limitation; unlike article 8(2)(b) and article 8(2)(c) which, respectively, express themselves as operating in international armed conflicts and internal armed conflicts. Surely, the drafters were quite capable of limiting article $8(2)$ (a) to international armed conflicts, in the same manner that they had done as regards article $8(2)(\mathrm{b})$. That they had not so limited article $8(2)$ (a) surely makes it a questionable exercise for the drafters of the Elements of Crimes to undertake such an exercise in limitation. As will be argued presently, the description of a crime as a 'grave breach' is a doubtful basis upon which to confine its import exclusively to international armed conflicts. It is submitted that this is one instance in which the ICC Elements of Crimes ought to be disregarded as a non-binding instrument. ${ }^{16}$

The current view of 'grave breaches' as something special and different was given judicial impetus by a majority of the judges of the ICTY Appeals Chamber in Tadić (Decision on Interlocutory Appeal on Jurisdiction), with Judge Abi-Saab dissenting. ${ }^{17}$ In that decision, the majority of the ICTY Appeals Chamber reasoned that the notion of 'grave breaches' is limited to international armed conflicts and does not apply to internal armed conflicts. Their conclusion appears primarily based on the fact that the Geneva Conventions provided for universal jurisdiction for purposes of 'grave breaches.' As the Appeals Chamber put it:

The international armed conflict element generally attributed to the grave breaches provisions of the Geneva Conventions is merely a function of the system of universal mandatory jurisdiction that those provisions create. The international armed conflict requirement was a necessary limitation on the grave breaches system in light of the intrusion on State sovereignty that such mandatory universal jurisdiction represents. State parties to the 1949 Geneva Conventions did not want to give other States jurisdiction over serious violations of international

I6 In Prosecutor v Krstic, the Appeals Chamber of the ICTY held that '[t]he Trial Chamber's reliance on the definition of genocide given in the ICC's Elements of Crimes is inapposite,' to the extent that the ICC Elements of Crimes indicates that genocide requires that the impugned conduct 'took place in the context of a manifest pattern of similar conduct': Prosecutor v Krstić, supra, [ICTY Appeals Chamber], para 224. In this regard the Appeals Chamber reiterated that the Elements of Crimes "are intended only to "assist the Court in the interpretation and application" of the substantive definitions of crimes given in the Statute itself. ... Unlike the definitions present in the Statute, the definitions given in the Elements of Crimes are not binding rules, but only auxiliary means of interpretation': ibid, footnote 366 . See also article 9(I) and (3) of the ICC Statute; and Elements of Crimes, General Introduction, para I.

I7 Tadic (Decision on Defence Motion for Interlocutory Appeal on Jurisdiction) dated 2 October 1995 [ICTY Appeals Chamber] paras 79-84. 
humanitarian law committed in their internal armed conflicts—at least not the mandatory universal jurisdiction involved in the grave breaches system. ${ }^{18}$

Having identified universal jurisdiction as the defining attribute of the grave breaches' regime of the Geneva Conventions, the Appeals Chamber then concluded that it is for that reason that the term must be understood to apply exclusively to international armed conflicts. ${ }^{19}$

One can readily accept the Appeals Chamber's identification of universal jurisdiction as actuating the notion of 'grave breaches'-but only to the limited extent of conceiving 'grave breaches' as war crimes without more. The Appeals Chamber's analysis and conclusion would be both apparently and substantively wobbly, if it leads deliberately or unwittingly to the result of isolating 'grave breaches' as a special breed of war crimes only exigible in international armed conflicts. Its apparent weaknesses in the latter regard include the following considerations: first, that the Appeals Chamber itself did acknowledge that developments in international law may negate its conclusion, particularly those developments that contradict the original regulatory premises for the divergent treatment of international and internal armed conflicts. ${ }^{20}$ Second, there are no legal authorities cited by the Appeals Chamber in support of its analysis and conclusion that the concept of 'grave breaches' applies only to international armed conflicts. ${ }^{2 \mathrm{I}}$ Third, the Chamber cited state practices of the United States and Germany, according to which grave breaches may be committed both in international and internal conflicts alike. ${ }^{22}$ Fourth, the three judges of the Trial Chamber had taken the view

\section{I8 Ibid, para 80 .}

I9 The Appeals Chamber of the ICTY followed this precedent without further discussion in its subsequent judgment in the Čelebici Case: Prosecutor v Delalic \& Ors, supra, [ICTY Appeals Chamber] para I34.

20 According to the Chamber: 'However, we are aware that this conclusion may appear not to be consonant with recent trends of both State practice and the whole doctrine of human rights - which, as pointed out below (see paras 97-I27), tend to blur in many respects the traditional dichotomy between international wars and civil strife': para 83 .

2I The only attempt at citing an authority is the particularly weak reference to the opinion of the UN Secretary-General: 'The above interpretation is borne out by what could be considered as part of the preparatory works of the Statute of the International Tribunal, namely the Report of the Secretary-General. There, in introducing and explaining the meaning and purport of Article 2 and having regard to the "grave breaches" system of the Geneva Conventions, reference is made to "international armed conflicts" (Report of the Secretary-General at para. 37)': para 82.

22 Ibid, para 83. In their amicus curiae brief filed in the case, the United States asserted as follows: "the "grave breaches" provisions of Article 2 of the International Tribunal Statute apply to armed conflicts of a non-international character as well as those of an international character.' While the majority of the Appeals Chamber denied the correctness of this view as a legal proposition, they nevertheless accepted the 
that 'grave breaches' may be committed in both international and non-international armed conflicts. ${ }^{23}$ Similarly, Judge Abi-Saab, also of the Appeals Chamber, disagreed with his remaining four colleagues that the concept of 'grave breaches' applies only to international armed conflicts and not to internal conflicts. ${ }^{24}$ And, finally, and perhaps more importantly, the Appeals Chamber did not identify any juridical or policy advantage to be gained by limiting the application of the notion of grave breaches to international armed conflicts. That is to say, there is no real mischief addressed in the view taken by the Appeals Chamber.

Besides the foregoing outward weaknesses, the following substantive difficulties also undermine the persuasiveness of the Appeals Chamber's conclusion. First, the feature of universal jurisdiction cannot be seen as something exclusive to international crimes with factual international elements. Such a view is consistent only with the outmoded view of the plight of citizens in the hands of their governments as matters within the exclusive preserve of their State of nationality. It is now accepted without contention that genocide and other crimes against humanity committed within the domestic realm are matters of obligatio erga omnes, engaging universal jurisdiction. ${ }^{25}$ Similarly, it is accepted that war crimes

statement as 'articulat[ing] the legal views of one of the permanent members of the Security Council on a delicate legal issue; on this score it provides the first indication of a possible change in opinio juris of States. Were other States and international bodies to come to share this view, a change in customary law concerning the scope of the "grave breaches" system might gradually materialize.' In the same vein, it was accepted in the 1992 edition of the German Military Manual that grave breaches of international humanitarian law include some violations of common Article 3: Humanitäres Völkerrecht in bewaffneten Konflikten - Handbuch, August 1992, DSK $\mathrm{AV}_{2073200065}$, at para 1209 .

23 In this connection, it may be pointed out that there is no hierarchy or superiority among the judges of the ICTY, according to which judges of the Appeals Chamber enjoy a presumption of greater wisdom or knowledge of the law. The judges of the ICTY individually enjoy equal stature, and are under an equal obligation of regular rotation in and out of the Appeals Chamber. As rule $27(\mathrm{a})$ of the ICTY Rules provides: 'Permanent Judges shall rotate on a regular basis between the Trial Chambers and the Appeals Chamber. Rotation shall take into account the efficient disposal of cases.' In the circumstances, one may take the view that the eight judges who considered the question came out equally divided on the matter-i.e. the three judges of the Trial Chamber plus Judge Abi-Saab of the Appeals Chamber versus the four judges of the Appeals Chamber who formed the majority against Judge Abi-Saab.

24 See Separate Opinion of Judge Abi-Saab.

25 Paragraph 6 of the preamble to the Statute of the International Criminal Court; Ian Brownlie, Principles of Public International Law, 6th edn [Oxford: Oxford University Press, 2003] pp 303-304; Shaw, supra, pp 471-472; Vaughan Lowe, 'Jurisdiction' in Malcolm D Evans, International Law [Oxford: OUP, 2003] at p 343, and United Nations, Report of the Secretary-General pursuant to Paragraph 2 of Security Council Resolution 808 (1993) presented on 3 May 1993, paras 64 and 65; Principle 2(I) of the Princeton Principles on Universal Jurisdiction; Amnesty International, 'Universal Jurisdiction: I4 Fundamental Principles on the Effective Exercise of Universal 
committed within the jurisdiction of a State does attract universal jurisdiction. ${ }^{26}$ Notably, also, the ICTY Appeals Chamber itself and in the same Tadic (Decision on Interlocutory Appeal on Jurisdiction) paradoxically found out-of-date and 'gradually [losing] its weight' the traditional dichotomy between international and internal armed conflicts as a result of which different rules applied. ${ }^{27}$ According to the Appeals Chamber, "[ $\mathrm{t}$ ]his dichotomy was clearly sovereignty-oriented and reflected the traditional configuration of the international community, based on the coexistence of sovereign States more inclined to look after their own interests than community concerns or humanitarian demands. ${ }^{28}$ It is therefore submitted that, to the extent that there is no word of limitation in the Geneva Conventions, and there is none in fact, excluding the notion of grave breaches from application in internal conflicts, judges are not at liberty to introduce such words of limitation.

Second, admittedly, there are genuine questions regarding who qualifies as 'persons or property protected by the Convention' given the following provision of article 50 of the First Geneva Convention:

Grave breaches to which the preceding Article relates shall be those involving any of the following acts, if committed against persons or property protected by the Convention: wilful killing, torture or inhuman treatment, including biological experiments, wilfully causing great suffering or serious injury to body or health, and extensive destruction and appropriation of property, not justified by military necessity and carried out unlawfully and wantonly. ${ }^{29}$

Although it is tempting to note that the provision does not exclude common article 3 of the Geneva Conventions (dealing with internal conflicts) from the reference to 'if committed against persons or property protected by the Convention,' that argument is by no means straightforward either way. It is possible to take that view as regards the first three Geneva Conventions. But article 4 of the Fourth Geneva Convention might reasonably be seen as removing victims of internal armed conflicts from the class of 'persons protected by the Convention.' Notably, article 4 of the Fourth Geneva Convention provides as follows:

Jurisdiction' (1999) AI Index: IOR 53/or/99, p 2; Prosecutor v Furundžija, supra, para I56; In addition to customary international law, see also articles III and IV of the Convention for the Suppression and Punishment of the Crime of Apartheid (1973), GA Res 3068 (XXVIII).

26 See Jugement en la cause Fulgence Niyonteze, Tribunal de Division 2, Armée Suisse Justice Militaire, Lausanne, 30 April 1999 ('Niyonteze Appeals Judgment'). In that case, a Swiss military tribunal, exercising universal jurisdiction, tried and convicted a Rwandan national in Switzerland for, among other things, war crimes committed in Rwanda in 1994, in what is regarded as an internal armed conflict.

27 Tadić (Decision on Defence Motion for Interlocutory Appeal on Jurisdiction), supra, paras 96-98.

28 Ibid, paras 96.

29 Emphasis added. 
Persons protected by the Convention are those who, at a given moment and in any manner whatsoever, find themselves, in case of a conflict or occupation, in the hands of a Party to the conflict or Occupying Power of which they are not nationals.

It will not be canvassed now whether it is possible to construe the concept of nationality in that provision in a way that brings victims of civil wars within the protection of the Convention, in a war of partition or one that pits different ethnic groups (within a State) against each other. It is sufficient to allow, for now, that article 4 of the Fourth Convention is reasonably capable of a construction that removes victims of internal armed conflicts from the protection of the Convention. Notably, though, the ICTY Appeals Chamber did not appear to have considered the effect of article 4 of the Fourth Convention, since it limited itself saying that it is universal jurisdiction that warranted confining the notion of 'grave breaches' to the sphere of international armed conflicts.

It is possible, however, to take a certain view of 'grave breaches' that rescues it from the proprietary clutches of international armed conflicts. This can be achieved by strictly limiting article 50 of the First Geneva Convention and similar provisions in its sibling Conventions to their aim in 1949. That aim was not to define the notion of 'grave breaches' for all purposes and for all time. The aim was not even to create a regime of individual criminal responsibility for purposes of trials before international tribunals. Of note in this regard is the following Red Cross commentary:

The idea of including a definition of "grave breaches" in the actual text of the Convention came from the experts called in by the International Committee of the Red Cross in 1948. It was thought necessary to establish what these grave breaches were, in order to be able to ensure universality of treatment in their repression. Violations of certain of the detailed provisions of the Geneva Conventions might quite obviously be no more than offences of a minor or purely disciplinary nature, and there could be no question of providing for universal measures of repression in their case..$^{30}$

The aim was therefore simply to encourage states to know precisely what they had to codify as 'grave breaches' in their penal statutes. Once that aim was served, 'grave breaches' should remain free, as a notion, to service international law for purposes of proscribing atrocities committed in international and internal armed conflicts.

Perhaps, an elementary point might be made here. The term 'grave breaches' refers, in context, to a breach of the Geneva Conventions and its Additional Protocols. The idea of 'grave breaches' was not to create a distinction, as such, among war crimes; such as to make 'grave breaches' a special or graver breed of

30 ICRC Commentary to article 50 of the ist Geneva Convention <http://www.icrc. org/ihl.nsf/COM/365-570061?OpenDocument> (accessed on i9 November 2006). 
war crimes. The point rather was to automatically qualify as war crimes $^{3^{\mathrm{I}}}$ certain breaches of the Geneva Conventions, recognised by the agreement of nations as 'grave' or serious, without needing to subject them to any special inquiry as to whether they amount to war crimes. The provisions of the Geneva Conventions in question are those that guarantee a set of peremptory minimum international humanitarian standards forbidding any wilful act or omission which seriously endangers the physical or mental health or integrity of any person who is in the power of an adverse party to an armed conflict. The aim of these standards is to protect persons and such property as are essential to livelihood and cultural identity. And States Parties to the Geneva Conventions are required to subject their violation to criminal prosecution as war crimes. In other words, if a conduct comes within the purview of 'grave breaches' of the Geneva Conventions, then it is automatically a war crime. This is easily enough understood, if one considers that there are many obligations within the Geneva Conventions, the violation of any of which does not qualify as a war crime. ${ }^{32}$

Third, the matter of plain language remains to be considered. Did the 'grave breaches' provision of article 49 of the First Geneva Convention 1949 mean to do more, at the higher level of abstraction, than to repress 'serious violations' of the Convention? As a matter of a plain understanding of the English language, 'grave' is a synonym of 'serious' and 'breaches' is coterminous with 'violations' ${ }^{33}$ Hence, it

3I Notably, article 85(5) of Additional Protocol I provides: 'Without prejudice to the application of the Conventions and of this Protocol, grave breaches of these instruments shall be regarded as war crimes.'

32 See, for instance, article 8 of the First Geneva Convention (prescribing the rights and obligations of Parties to armed conflicts and Protecting Powers, in their relations with one another); article I7 of the First Geneva Convention (prescribing the obligations of Parties to armed conflicts in relation to burial or cremation of the dead); article 26 of the First Geneva Convention (prescribing an obligation on Parties to armed conflict to exchange names of the societies which they have authorized to render assistance to the regular medical service of their armed forces, as well as when to do so); etc. Violations of any of these obligations will be in breach of the Geneva Conventions. But those violations will not amount to 'grave breaches', therefore not war crimes.

33 Indeed, the view of 'grave breaches' as synonymous with 'serious violations' is given credence in the work of the International Law Commission. In its 1989 Yearbook, the following observations appear: 'In analysing the relevant provisions of the 1949 Geneva Conventions and the Additional Protocols thereto, it was stressed that the concept of a "war crime" was broader than that of a "grave breach". However, the distinction between "grave breaches" and "serious violations" was not clear. The Conventions and the Protocols seemed to use those two concepts synonymously, except in article 90, paragraph 2 (c) (i) of Protocol I, in which a distinction might have been made, although the text did not fully dispel doubts': United Nations, 'Draft Code of Crimes against the Peace and Security of Mankind,' para IoI, Chapter III to the 'Report of the International Law Commission on the work of its forty-first session (2 May-2I July 1989)' Yearbook of the International Law Commission, I989, vol II, Part Two, p 53, Doc No A/CN.4/SER.A/r989/Add.I (Part 2). 
becomes inescapable to conclude that 'grave breaches' simply means 'serious violations'. This view is assisted by the fact that the French version of 'grave breaches' is les infractions graves, ${ }^{34}$ while 'serious violations' translates into les violations graves. ${ }^{35}$ Both French phrases share the identical adjective 'graves' which translates into 'serious' in English. This is why the view might be taken, as suggested earlier, that the drafters of the ICTY Statute deliberately refrained, even if wrongly, from employing the term 'serious violations' again in article 3 of that Statute, having employed the term 'grave breaches' in article 2 of that Statute; thereby indicating a difference between the two provisions.

In construing 'grave breaches' according to its plain meaning, one is reminded of the exhortation of article 3I(I) of the Vienna Convention on the Law of Treaties which requires that a treaty be interpreted in good faith in accordance with the ordinary meaning to be given to the terms of the treaty in their context and in the light of its object and purpose.' The meaning of 'grave breaches' is 'serious violations' and the object and purpose of international humanitarian law is protection of humanity as the victim of armed conflict-international or internal.

Finally, it must be said that the definition and substance of 'grave breaches' indicate no difference as regards its sphere of application. This point relates to the preceding one. The definition of grave breaches hinges on wilful violation of the relevant rules of armed conflict which seriously endangers the physical or mental health or integrity of any protected person..$^{36}$ This element of endangerment of protected persons is a constant feature of article 2 of the ICTY Statute which employs the term 'grave breaches of the Geneva Conventions' and article 4 of the ICTR Statute which employs the term 'serious violations of article 3 common to the Geneva Conventions'. As the ICRC correctly observed:

It should be pointed out that, although some of the wording is not the same as the equivalent crimes in the grave breaches applicable to international armed conflicts, there is no difference in practice as far as the elements of these crimes [are] concerned. ${ }^{37}$

Ultimately, the conclusion becomes irresistible that the decision of the majority in the Tadic decision might have amounted in this particular instance, to an expenditure of important judicial effort on mere logomachy. Agreement is thus compelled toward the dissent of Judge Abi-Saab when he described as 'artificial' ${ }^{38}$

34 See the French version of article 2 of the ICTY Statute which translates 'grave breaches' into les infractions graves.

35 See the French version of article 4 of the ICTR Statute which translates 'serious violations' as les violations graves.

36 See Additional Protocol I to the Geneva Conventions of I949, articles II(4) and 85(2), $85(3)$ and $85(4)$.

37 ICRC, Customary International Humanitarian Law, vol I: Rules, supra, 591.

${ }_{3} 8$ Tadić (Decision on Interlocutory Appeal on Jurisdiction), supra, [ICTY Appeals Chamber], Separate Opinion of Judge Abi-Saab. 
the decision of the majority of the ICTY Appeals Chamber in Tadic (Decision on Interlocutory Appeal on Jurisdiction), which created 'a division of labour' whereby 'grave breaches' is confined exclusively to international armed conflicts, while similar violations committed in internal armed conflicts is treated as 'other serious violations'. More regrettable is the fact that such an artificial decision influenced the drafting of the elements of grave breaches in the Elements of Crimes of the ICC Statute.

The better approach is to accept that the concept of 'grave breaches' might have originated in the thought-mode of international armed conflicts, but does not exclude modern application to internal armed conflicts. This view is recommended by the realistic proposition that in 1949 when the language of 'grave breaches'was introduced into the Geneva Conventions, there might have remained some doubt, or State Parties' resistance, about the conception of the individual as a proper subject of international law. This might explain the trepidation, if not reluctance, that the drafters felt about providing a direct regime of individual criminal responsibility in the grave breaches provisions of the Geneva Conventions. Hence, the preference for the indirect approach of requiring states to undertake to proscribe, in their domestic criminal codes, grave breaches of the Conventions. This same concern would no doubt have plagued the confidence of the drafters about direct imposition of obligations from the international plane upon parties engaged in internal armed conflicts, especially where half of such parties to internal armed conflicts might not be seen as 'High Contracting Parties' to the Geneva Conventions. The drafters' tentativeness might reasonably have been made worse by the fact that the half of the parties to internal armed conflicts who would not be considered as 'High Contracting Parties' to the Geneva Conventions might have been considered by States, in 1949, as mere 'criminals', 'terrorists' or 'bandits' operating within the internal domain of the 'High Contracting Parties'.

Many of these concerns, however, are no longer valid in the new order of international law. For it is now axiomatic that international law does impose rights and obligations directly upon individuals, especially in matters of protection of the corporal integrity of the individual; a thing considered in the past as the internal affair of States. This is the ethos of humanity and is the fabric with which international humanitarian law is woven. And since one of the objects of international criminal law is to banish impunity from the minds of those in the position of violating the international norms that protect the corporal integrity of the individual, there is little real justification in allowing those engaged in internal armed conflicts to perceive that their own breaches of international humanitarian legal norms are less 'grave' than identical, and sometimes less severe, violations that may be committed during international armed conflicts. Yet that is what is achieved when it is said that 'grave breaches' may be committed only in international armed conflicts and not in internal ones. 
This is particularly the case with the evil of sexual violence during armed conflicts. Is international criminal law to be taken to say that it is 'grave breaches' if rapes were committed in the Ethiopia-Eritrea war ${ }^{39}$ : but it is not 'grave breaches' if government troops and their surrogates raped civilian women in Darfur ${ }^{40}$ in their prosecution of Sudan's civil war? Why is it a 'grave breach' for Japanese soldiers to sexually enslave Chinese and Korean women as 'comfort women' during World War II, while it is not a 'grave breach' for rebels to sexually enslave Sierra Leonean women, as 'bush wives' during the Sierra Leone civil war? A rational basis for such propositions has not been found. Nor is it warranted by the apposite observation made by the ICRC to the effect that 'the horrors of [internal armed conflicts] are sometimes even more terrible than those of international wars because of the fratricidal hatred they engender.' ${ }^{\prime 4}$ One recent instance of such fratricidal hatred which generated the apogee of horror possible in any war-international or internal-was seen in the Rwandan civil war, which began in 1990 and culminated in the 1994 Genocide. As it was committed under the guise of civil war, the Rwandan genocide, upon any view, will qualify for the term 'grave breaches.'

\section{Conclusion}

It is possible to take the view that the debate about the sphere of application of the notion of 'grave breaches' does not lend itself to a straightforward resolution. But this is so when one is unsurprisingly lost in the legal thicket and complexities of the Four Geneva Conventions of 1949 and their Additional Protocols of 1977. There are grounds in those instruments to contend that 'grave breaches' are war crimes which may only be committed in international armed conflicts. As we have seen above, there are reasons to quarrel with that proposition, especially from the particular point of view of sexual violence during armed conflicts.

In the final analysis, however, it is a pointless debate, for there are more powerful reasons to conclude that to say that 'grave breaches' is limited to international armed conflicts is to miss the whole point of international humanitarian law. It is about protecting the core values of humanity. And humanity remains the same, regardless of where it is found - on the fields of a high-tech war involving major Western powers against each other or against other nations, as well as in the jungles of an African or Asian country embroiled in a civil war fought with cudgels, machetes, and knobkerries. A serious violation of international humanitarian law

39 Eritrea v Ethiopia (Central Front-Eritrea's Claims 2, 4, 6, 7, 8 and 22) Partial Award, 28 April 2004 [Eritrea-Ethiopia Claims Commission] paras 42, 80 and 8I.

40 United Nations, Report of the International Commission of Inquiry on Darfur to the Secretary-General, dated 25 January 2005, Annex to Letter dated 3I January 2005 from the Secretary-General addressed to the President of the Security Council, Doc No S/2005/60, paras I04, 186, 221, 273, 337, 338 and 340.

4I ICRC, Commentary to Common Article 3 to the Geneva Conventions of I949: <http://www.icrc.org/ihl.nsf/COM/38o-60ooo6? OpenDocument> (accessed on 22 November 2006). 
is a 'grave breach' on either occasion. That is easy to see if the protection of humanity -including the protection of women from sexual violence-is the aim of international humanitarian law, as it ought to be.

The triumph of humanity in that debate is aided particularly by the usual requirement that a treaty shall be interpreted in good faith in accordance with the ordinary meaning to be given to the terms of the treaty in their context and in the light of its object and purpose. The plain meaning here and the object and purpose ideal must not be negated by the mystifying draftsmanship that is the hallmark of the Geneva Conventions. For ' $\mathrm{t}]$ he circumstances in which treaties are drafted are ... often such as to lead to lack of consistency in drafting and care must be taken in attributing significance to variations in terminology: "an interpreter is likely to find himself distorting passages if he imagines that their drafting is stamped with infallibility": Pertulosa Claim, ILR, I8, I8 (I95I), No I29, p 4I8.'42

Sexual violence against women is as much a 'serious violation' as it is a 'greave breach' of the laws and customs of war, whether committed in international or internal armed conflict. The nature of the evil of sexual violence must not tolerate a diminishment of the scope of its evil by accepting that it is not a 'grave breach' simply because of the typology of the armed conflict at issue as non-international in character. This consideration becomes ever more compelling given that internal armed conflicts account for as much, if not more, for the plurality of armed conflicts that result in the perennial tally of incidents of sexual violence committed against women during armed conflicts.

It is for this reason, in particular, that one must accept as the correct view the position expressed by the United States and Judge Abi-Saab in Tadic that 'grave breaches' may be committed in both internal and international armed conflicts. The majority in Tadić were wrong.

In the next chapter, we will review the significance of the emerging idea of forced marriage as an international crime.

42 Robert Jennings and Arthur Watts, Oppenheim's International Law, vol I, 9th edn [London \& New York: Longman, 1996] Parts 2 to 4, p I273, fn I2. 


\section{Chapter 7}

\section{Forced Marriage—an International Crime?}

\section{Introduction}

In Chapter I, we saw that the evil of sexual violence in armed conflicts has all through the years - ancient and modern-been expressed through an apparent martial policy of serving women up as prizes or incentives to fighting men. The Book of Deuteronomy apparently permitted men to keep female war captives as slaves and concubines. ${ }^{\mathrm{I}}$ We saw that modern day soldiers have carried over these practices across the gulf of time, by perpetrating it themselves or by condoning it on the part of their comrades. We noted that Soviet soldiers attacking Germany were reportedly told that German women were theirs by right. This resulted in millions of rapes, resulting in turn in an estimate of a hundred thousand births in Berlin alone, after World War II. We noted that the idea of women as the prize of victory was employed to encourage young men into volunteering to fight in Vietnam. We also saw that the most notorious recent example of this practice was the system of 'bush wives' that was a hallmark of the Sierra Leone civil war of the I990s. In this chapter, we will review the adequacy of international law's response in this regard, as well as the best way to remedy any available gaps in a manner that is sustainable in the long run.

It has been correctly observed that throughout the history of thought there has been a complex relationship between idealism and realism, between the way things ought to be and the way things are, and the debate as to whether legal philosophy should incorporate ethical standards or confine itself to an analysis of the law as it stands is a vital one that continues today. ${ }^{2}$ To students, scholars and practitioners of international law, a classic battle ground of this perennial tension between the law as it ought to be (lex ferenda) and the law as it is (lex lata) is the field of identification of the sources of international law, ${ }^{3}$ with especial regard to custom. But, in spite of this tension-perhaps, in view of it-there appears to be

I See Deuteronomy 20:I4; 2I:IO-I4, supra. See also Brownmiller, supra, p 33.

2 Malcom N Shaw, International Law, 4th edn [Cambridge: Cambridge University Press, 1997] p 40.

3 See Peter Malanczuk, Akehurst's Modern Introduction to International Law, 7 th edn [London and New York: Routledge, 1997] p 35. See also Jennings and Watts, supra, p 23. 
little dispute as to what is meant by 'sources' of international law. It means 'those provisions operating within the legal system on a technical level'; and in the process of identifying them such ultimate stimuli as reason or morality are set aside. ${ }^{4}$

It is not surprising, therefore, that the debate as to whether forced marriage is an international crime re-enacts the tension-or, perhaps, confusion-between international law as it ought to be and international law as it is. A main part of this Chapter is devoted to the exploration of this tension or confusion from the perspective of developments in legal thought on the subject of 'forced marriage' as an international crime. It is important to stress that it is never proposed that forced marriage should not be an international crime: the question, rather, is whether it has reached the point of recognition as such, or whether there is a yearning gap for a more generally accepted method of correction, other than the articulation of the norm in a single instance of controverted judge-made law.

\section{The Judgment of the Special Court for Sierra Leone}

The catalyst for the current discussion is to be found in the judgments of both the Trial Chamber and the Appeals Chamber of the Special Court for Sierra Leone in the case of Prosecutor $v$ Brima E Ors (the AFRC Case). ${ }^{5}$

As noted earlier, the vice of forced marriage was a particular feature of the Sierra Leone armed conflict of the I990s. In Sierra Leone, the victims of the experience were colloquially referred to as 'bush wives.'The uncontroverted expert evidence of Prosecution witness Zainab Hawa Bangura was particularly telling as to the pervasiveness of the incident of forced marriage during the Sierra Leonean conflict. According to her report tendered as an expert witness:

The conflict in Sierra Leone affected women directly in diverse ways. In addition to being displaced, raped or used as secondary combatants, women and girls were also used as spies, sex slaves, carriers of looted goods and smuggled weapons. Women suffered multiple traumas during the war. They were physically and psychologically abused. However, the most devastating effect on women of the war was the phenomenon called 'bush wife', rebel wife or jungle wife. This was a phenomenon adopted by rebels whereby young girls or women were captured or abducted and forcibly taken as wives [.... The use of the term 'wife' by the perpetrator was deliberate and strategic. The word 'wife' demonstrated a rebel's control over a woman. His psychological manipulations of her feelings rendered her unable to deny him his wishes. 'Wife' showed that the woman belonged to a man and could not be touched by another. By calling a woman 'wife', the man or 'husband' openly staked his claim and she was not allowed to have sex with any other person. If she did, she would be deemed unfaithful and the penalty was

4 Shaw, supra, p 55. See also Malanczuk, supra, p 35; and Jennings and Watts, supra, p 23.

5 Prosecutor v Brima E Ors, supra, [SCSL Trial Chamber]; and Prosecutor v Brima E Ors, supra, [SCSL Appeals Chamber]. 
severe beating or death. Similarly if the 'wife' were raped by another rebel, his act was punishable by death. ${ }^{6}$

In the context of the Sierra Leone conflict, the 'bush wife' endured a particular life of hardship and sexual abuse. According to Ms Bangura:

\begin{abstract}
'Bush wives' were expected to carry out all the functions of a wife and more. A 'bush wife' carried her 'husband's' possessions on her head and trekked across the countryside with him; she was expected to gratify her 'husband's' sexual wishes whenever he so desired without question; she cooked for him when food was available, did his laundry and generally protected his possessions in his absence; she was expected to show undying loyalty to her husband for his protection and reward him with 'love and affection'; she was not expected to attempt to escape as this was deemed disloyal. Punishment for disloyalty was always severe and so, women were led to believe, in most cases would be met with death. ${ }^{7}$
\end{abstract}

Continuing her exposition of how sexual abuse was a constant feature of the experience of the Sierra Leonean 'bush wife', Ms Bangura stated:

\begin{abstract}
'Bush wives' were constantly sexually abused, physically battered during and after pregnancies, and psychologically terrorised by their husbands, who thereby demonstrated their control over their wives. Physically, most of these girls experienced miscarriages, and received no medical attention at the time. They bled excessively because they lived in some of the remotest parts of the country with little or no access to medical services. Some now experience diverse medical problems such as severe stomach pains which they are reluctant to discuss; some have had their uterus removed; menstrual cycles are irregular; some were infected with sexually transmitted diseases and others tested HIV positive. ${ }^{8}$
\end{abstract}

It was against this background that the Prosecution indicted the accused with a number of gender related infractions. Among them was 'forced marriage', charged as 'other inhumane acts' of crimes against humanity.

In the judgment at first instance, the majority of the Trial Chamber (comprising Judge Julia Sebutinde and Judge Richard Lussick) declined to convict the accused on the charge of forced marriage as 'other inhumane acts.'They reasoned that, as a question of law, there is no crime known to international law as 'forced marriage.' According to the majority of the Trial Chamber, what the Prosecution had charged as forced marriage was already subsumed within other gender-oriented crimes against humanity, such as sexual slavery, which the Prosecution had also charged in the indictment. Notably, Judge Sebutinde (Presiding) expressed

6 Brima \& Ors, Trial Chamber Judgment, supra, Partly Dissenting Opinion of Judge Doherty, para I3.

$7 \quad$ Ibid, para I4.

$8 \quad$ Ibid, para 15. 
'the firm view that the phenomenon of forced "marriage" during the Sierra Leone conflict bears all the hallmarks or characteristics of the crime against humanity of sexual slavery. The general and specific elements of the crime against humanity of sexual slavery are satisfied in that forced "marriage" invariably occurred as part of a widespread or systematic attack on the civilian population in Sierra Leone.'9 In the result, the majority held that it was superfluous for the Prosecution to charge under the separate head of forced marriage, especially when there is no crime known to international law as such. ${ }^{\text {IO }}$

Judge Teresa Doherty disagreed. In a dissenting opinion on this point, she reasoned, among other things, that forced marriage is as a matter of law, (a) a recognised international crime under the rubric of 'other inhumane acts' of crimes against humanity; ${ }^{\mathrm{II}}$ and (b) a distinct international crime not completely subsumed in other gender-oriented crimes against humanity such as sexual slavery. ${ }^{\mathrm{I}}$

On appeal, the Appeals Chamber agreed with Judge Doherty. Regrettably, their reasoning could have benefitted from more sustained analysis on this controversial question upon which the Majority of the Trial Chamber had disagreed.

It is submitted that the judgment of the SCSL Appeals Chamber in the $A F R C$ case did not persuasively resolve the fundamental questions raised in that case. This lack of persuasion resulted not only from the rather brief and desultory manner ${ }^{13}$ in which the Appeals Chamber made its analysis, but also, as will be seen presently, in the content of their reasoning.

Consequently, the questions remained whether forced marriage is a recognised crime under international law; and whether other gender-oriented crimes against humanity subsume the infraction of forced marriage. These questions are important in that not only do they stand in the way of acceptance of the $A F R C$ case as a persuasive judicial precedent in the relevant respect, but also whether that judicial precedent may be accepted as adequate response to the evil of sexual violence in the relevant respect.

\section{A Proper Subject of International Criminal Law}

Before addressing these questions, however, it would be important to address the preliminary question whether forced marriage is a proper subject of international criminal law, in the first pace.

9 Brima E Ors, Trial Chamber Judgment, supra, Separate Concurring Opinion of Judge Sebutinde, para I6.

Io See Brima E Ors, Trial Chamber Judgment, supra, paras 697, 703, 710 and 712.

II Brima \& Ors, Trial Chamber Judgment, supra, Partly Dissenting Opinion of Judge Doherty, paras 21, 58 to 67 .

I2 Brima $\&$ Ors, Trial Chamber Judgment, supra, Partly Dissenting Opinion of Judge Doherty, paras $47,48,50,52$ to 57 .

I3 For a useful discussion on the values of exhaustive judicial reasoning, see Hersch Lauterpacht, The Development of International Law by the International Court [Cambridge: Cambridge University Press, 1996] pp 37 et seq. 
There is a certain anxiety surrounding this question. It clearly comes through in the judgment of the SCSL Appeals Chamber in the $A F R C$ case, ${ }^{14}$ as well as in the Partly Dissenting Opinion of Judge Doherty and the Separate Concurring Opinion of Judge Sebutinde in the Trial Chamber. ${ }^{15}$ That anxiety relates to the desire to exclude the practice of arranged marriages from the purview of international criminal law, noting, of course, that arranged marriages remain a sustained institution in much of the non-European world. Notably, the expert witnesses called by both sides in the case were extremely anxious to avoid drawing parallels between forced marriages during armed conflicts and arranged marriages in times of peace. ${ }^{16}$ Remarkably, this anxiety nearly drove the Defence expert witness to the point of virtual irrelevance in the case. She simply refused to answer the question whether the custom of arranged marriage in the West African region had any bearing on the phenomenon of 'forced marriage' prevalently seen during the Sierra Leone armed conflict. ${ }^{17}$ For her part, the Prosecution expert witness, Ms Bangura, sought to explain the differences by awkwardly limiting the institution of arranged marriages to 'early' marriages and then dwelled, for their validity, on the presence of the kinsfolk ceremonies that formalise these marriages, which ceremonies are absent in forced marriages during wars. ${ }^{18}$ It may well be that these sociological distinctions identified above are sufficient to insulate arranged marriages from the reaches of international criminal law. There may be some doubt about that.

It is submitted that the distinctions between arranged marriages and forced marriages are more safely anchored on the legal principles that differentiate international crimes from other legal norms. Those principles are found in the basic elements of the classic international crimes: genocide, crimes against humanity and war crimes. Necessarily, the cultural institution of arranged marriage is simply not encumbered by these elements. For genocide, it is recalled that there must be

I4 Brima Eं Ors, Appeal Judgment, supra, para I94.

I5 See Brima छ Ors, Trial Judgment, supra, Partly Dissenting Opinion of Judge Doherty, para 36; and Separate Concurring Opinion of Judge Sebutinde, paras 9-I2.

I6 See ibid, Separate Concurring Opinion of Judge Sebutinde, para II.

I7 See ibid, para 9. At footnote 3454 of the Trial Judgment, Judge Sebutinde noted as follows: '[Defence Expert Witness] stated that she was requested to "carry out a research on the concept of forced marriage in the West African region, the purpose of which was to outline the history and practice of forced marriage in the region and possibly also the way in which this practice is embedded in local culture and practice". She explains in the introduction to her report that she declined to carry out the research in that form because she was "concerned with the long-term consequences of making straightforward links between complex social practices of arranging marriages between kin groups, international conceptualisations of 'forced marriages' and the coercion of women into being bush wives during the civil war in Sierra Leone."' See also Partly Dissenting Opinion of Judge Doherty, para 25.

I8 See ibid, Separate Concurring Opinion of Judge Sebutinde, para II. 
intent to destroy a group in whole or in part. ${ }^{19}$ For crimes against humanity, there must be a widespread or systematic attack against a civilian population, ${ }^{20}$ with the conduct in question constituting part of the attack. ${ }^{2 \mathrm{I}}$ War crimes, for their part, must feature a nexus between the conduct under consideration and an armed conflict, in the sense that the conduct is seen as part of the armed conflict. ${ }^{22}$

The ethno-cultural institution of arranged marriage is not typically perturbed by these elements. It is then easy to say without hesitation that 'forced marriage' can be, and should be, an international crime whenever the conduct in question is attended by the unique elements of international crimes indicated above. Unhappily, however, this might not have been enough to satisfy the proponents of the 'forced marriage' issue in the case before the Appeals Chamber of the Special Court for Sierra Leone. ${ }^{23}$ There, the interest was more on the question whether there was in one form or another a distinct crime known to international law as 'forced marriage'. That question will be examined next.

\section{A Recognised Crime in International law?}

Some commentators have suggested that the crime of forced marriage as charged by the SCSL Prosecutor was a 'new' crime ${ }^{24}$ with its elements unknown as at the

I9 See art II of the Genocide Convention I948; art 2(2) of the Statute of the International Criminal Tribunal for Rwanda, art 4(2) of the Statute of the International Criminal Tribunal for the former Yugoslavia, art 6 of the Statute of the International Criminal Court. See also art I7 of the 1996 ILC Draft Code of Crimes against Peace and Security of Mankind.

20 See article 3 of the ICTR Statute, article 5 of the ICTY Statute, art 7 of the ICC Statute, article 2 of the Statute of the Special Court for Sierra Leone and article I8 of the International Law Commission's Draft Code of Crimes against the Peace and Security of Mankind (1996).

2I Prosecutor v Blaškić (Judgment), supra, [ICTY Appeals Chamber] para I26.

22 Prosecutor $v$ Tadic (Decision on the Defence Motion for Interlocutory Appeal on Jurisdiction) 2 October 1995 [ICTY Appeals Chamber], para 70. See also Prosecutor v Kunarac, supra, [ICTY Appeals Chamber], para 58.

23 Ironically, I happen to have been part of the Prosecution Appeal Team that argued the matter before the Appeals Chamber of the SCSL. I had to go along as part of the team, but I always harboured a different view.

24 See Neha Jain, 'Forced Marriage as a Crime against Humanity: Problems of Definition and Prosecution' (2008) 6 Journal of International Criminal Justice IOI3 at Iorg (describing forced marriage as 'novel'). In this regard, one notes the dilemma that Micaela Frulli confronted in her effort to argue that forced marriage is not a new international crime, while at the same time insisting that it was a crime different from other crimes against humanity. Her difficulty was that she needed to rely on the incidence of the other crimes against humanity, such as sexual slavery, to assert her proposition that forced marriage was not a new crime created at the Special Court for Sierra Leone. To do this, she had to say that those other crimes some how reflected the crime of forced marriage. Having said that, she now found it difficult 
time of confirmation of the indictment in which the crime was charged. One such commentator, Binaifer Nowrojee, a renowned advocate of legal protection of women during armed conflicts, ${ }^{25}$ has written as follows:

\begin{abstract}
Additionally, Prosecutor Crane has attempted to expand international jurisprudence by bringing a new charge of "forced marriage" as a crime against humanity. During the Sierra Leone war, it was widespread practice by combatants to abduct women as "wives," forcing them to have sex and bear children. Arguing the case before the Court, Crane emphasized that this was not just rape because the women, often known as "bush wives," were held for so long under the threat of harm or death and were forced to clean, cook, and porter for their combatant "husbands." The Prosecutor has creatively used the section of "other inhumane acts" under crimes against humanity — a catch-all category meant to encompass acts that are of similar gravity and seriousness to the enumerated crimes- to expand legal recognition for the types of sexual violence that women endure in conflict. ${ }^{26}$ [Emphasis added.]
\end{abstract}

Commenting on the Trial Chamber's confirmation of the crime of 'forced marriage' as charged in the indictment, Nowrojee observed that the elements of that crime were unknown as at the time of the confirmation of the indictment. According to her:

In May 2004, the Trial Chamber of the Special Court approved the addition of "forced marriage" to the counts contained in an indictment against six defendants accused of heading the former rebel AFRC and RUF. The Trial Chamber's decision marks the first time that an international court will recognize "forced marriage" as a

to appear convincing when she continued to assert that forced marriage was distinct from those other crimes. Her refuge in the dilemma became her assertion that the 'above conclusion on non-retroactivity should not undermine the importance of prosecuting forced marriage as a separate crime, since its most typical feature, precisely the imposition of forced conjugality, distinguishes it from other conducts that are 'only' sexual crimes.' Micaela Frulli, 'Advancing International Criminal Law: The Special Court for Sierra Leone Recognizes Forced Marriage as a "New" Crime against Humanity' (2008) 6 Journal of International Criminal Justice 1033 at I040. The trouble, of course, is that what necessarily makes the crime a new crime would be that element of 'imposition of forced conjugality' that was not present in the other crimes that are only sexual crimes. And, as will be seen later, it is this element of imposition of forced conjugality that has prevented a general acceptance of the idea of criminalisation of forced marriage, out of anxiety for arranged marriages in the cultures that practice them.

25 Her work in this regard includes the very important study published by Human Rights Watch under the title Shattered Lives: Sexual Violence during the Rwandan Genocide and its Aftermath, supra.

26 Binaifer Nowrojee, 'Making the Invisible War Crime Visible: Post-Conflict Justice for Sierra Leone's Rape Victims' I8 Harv Hum Rts J (Spring 2005) 85 at IoI. 
possible category of "other inhumane acts" within the legal category of crimes against bumanity. Whether this new charge will ultimately further the jurisprudence on gender crimes remains to be seen. How "forced marriage" will be distinguished from "sexual slavery" has yet to be argued in the courtroom..$^{27}$ [Emphasis added.]

But in an obvious sleight of hand intended to circumvent the questions whether 'forced marriage' was a new crime with unknown elements, the Prosecution deftly managed to hide forced marriage under the nebulous phrase 'other inhumane acts'. Having done so, the Prosecution moved on to address the question whether 'other inhumane acts' was a recognised 'crime' under international law. ${ }^{28}$ The trouble with this sort of tactic is that it attracts attention away from the existence of a problem in need of correction, with intellectual energy focused on whether sophistry had been employed momentarily to resolve a problem. In the end, the problem at issue is left fundamentally unresolved.

The Prosecution's approach as indicated above must of course be seen as a tacit admission of the fact that there is no offence in international law known as forced marriage. Had the offence existed, the Prosecution would surely have submitted so. Indeed, Judge Doherty even considered that there was no offence known as forced marriage in international law. As she correctly observed, "[f] orced marriage as a crime against humanity has not been specified in any treaty provision nor recognised as a separate crime by the other International Tribunals. ${ }^{29} \mathrm{In}$ fact, there is no evidence that forced marriage has been recognised under customary international law as a crime or in any of the other sources of international law identified in article 38(I) of the Statute of the International Court of Justice.

To the contrary, there is evidence that the international community has decided against the recognition of 'forced marriage' as a crime in international law. For instance, during the UN General Assembly's 23rd special session from 5June 2000 at the UN Headquarters in New York, entitled Women 2000: Gender Equality, Development And Peace for the 2Ist Century, 'references to harmful traditional practices, including ... forced marriage were deleted' from the section of the outcome document dealing with women and armed conflict..$^{30}$ No doubt this negative attitude from the international community stems from the anxiety, discussed earlier, in relation to the desire to exclude the practice of arranged marriages from the purview of international criminal law, since arranged marriages remain a sustained institution in much of the non-European world. But the net effect of this negative attitude essentially nullifies any suggestion that there exists among the international community a history of intent to create international legal criminal norm requiring criminal sanctions against the conduct.

27 Ibid, at Io2.

28 See Brima E Ors, Trial Judgment, supra, para 7or.

29 Ibid, Partly Dissenting Opinion of Justice Doherty, para 58.

30 See United Nations Non-Governmental Liaison Service, 'Women 2000: GA Special Session' in NGLS Roundup, No 56, July 2000, p 2. Available at <http:// www.un-ngls.org/documents/text/roundup/56wom200o.txt> 
In the circumstances, to bring forced marriage in through the rubric of 'other inhumane acts' may be criticised as smuggling in through the back door something which one could not bring in through the front door. Surely, any solution obtained in that way cannot be sustained in the long run. And the evil of sexual violence requires all candour in the identification of the problem and the search for appropriate and lasting solution.

Aside from the non-recognition of 'forced marriage' in international law, the approach of capturing 'forced marriage' through the route of 'other inhumane acts', as was done by the SCSL Appeals Chamber, is fraught with certain evidential and doctrinal difficulties.

\section{Evidential Problems of the SCSL Appeal's Chamber's Reasoning}

One such difficulty is apparent from the reasoning of the majority of the Trial Chamber. They were not impressed by the Prosecution's tactic of diverting the thrust of the inquiry in the direction of 'other inhumane acts' as the crime to consider as accepted in international law. According to the majority of the Trial Chamber, 'other inhumane acts' must necessarily be applied in the case in the function of a residual receptacle for similar conducts that have not already been listed as crimes against humanity. The Chamber considered that in view of the constant feature of the sexual abuse that was the experience of the Sierra Leonean 'bush wives', coupled with the fact that the victims were deprived of their liberty, the experience of the Sierra Leonean 'bush wives' could otherwise be described as 'sexual slavery.' Since 'sexual slavery' was already listed in the Statute of the SCSL as a crime against humanity, the same conduct could then not be charged again as 'forced marriage' without more. In a bid to pre-empt this reasoning, the Prosecution had argued that forced marriage did not require a sexual element. And it was therefore valid to convict the accused of forced marriage as 'other inhumane act.' In view of that rebuttal, the Chamber found that upon a review of the evidence led by the Prosecution, there was no single instance in which the Prosecution produced evidence of 'forced marriage' that did not involve the sexual factor. ${ }^{3 \mathrm{I}}$

It is submitted that the reasoning of the majority of the Trial Chamber is more consistent with generally accepted methods of judicial reasoning-assuming that the concept of ratio decidendi is an accepted one in international law. ${ }^{32}$ For however desirable it is to crystallise the notion of 'forced marriage' in the annals of international criminal law, and it is certainly most desirable to do so, judicial decisions must still be based on the evidence led in the case under adjudication. It is strange indeed to render a judgment of a court that is disconnected from the

3I See Brima E' Ors, Trial Judgment, supra, paras 703-714.

32 The preponderance of opinions and practice appear to accept that it is. See Mohamed Shahabuddeen, Precedent in the World Court [Cambridge: Cambridge University Press, 1997] pp I53-I60. 
evidence. Regrettably, the judgement of the Appeals Chamber is open to criticism on that score. There was evidence of sexual abuse of women coupled with deprivation of their liberty.

The majority of the Trial Chamber, underscored by the Separate Concurring Opinion of Judge Sebutinde, held that the facts of the case did not go beyond what was covered by sexual slavery as a crime against humanity. Notable in this regard is the testimony of the expert witness called by the Prosecution. According to her:

The conflict in Sierra Leone affected women directly in diverse ways. In addition to being displaced, raped or used as secondary combatants, women and girls were also used as spies, sex slaves, carriers of looted goods and smuggled weapons..$^{33}$

\section{$[\ldots]$}

A 'bush wife' ... was expected to gratify her 'busband's' sexual wishes whenever he so desired without question ... ${ }^{34}$

'Bush wives' were constantly sexually abused, physically battered during and after pregnancies, and psychologically terrorised by their husbands, who thereby demonstrated their control over their wives. Physically, most of these girls experienced miscarriages, and received no medical attention at the time. They bled excessively because they lived in some of the remotest parts of the country with little or no access to medical services. Some now experience diverse medical problems such as severe stomach pains which they are reluctant to discuss; some have had their uterus removed; menstrual cycles are irregular; some were infected with sexually transmitted diseases and others tested HIV positive..$^{35}$

Given then the constancy of sexual violation in the life of the Sierra Leonean 'bush wife', as appeared in the evidence of the expert witness for the Prosecution, it would seem unreasonable to disagree with the majority of the Trial Chamber that the evidence in the case revealed that the conduct which the Prosecution charged as forced marriage had a constant feature of unlawful sexual conduct towards the victims under conditions in which they were not at liberty to opt out. ${ }^{36}$ To the extent that these conducts would constitute sufficient cause for the prosecution of the accused, it was neither necessary nor desirable to punish the accused for anything more, let alone for a crime not recognised as such in international law. According to the majority of the Trial Chamber, the circumstances were those of sexual slavery.

33 Brima \& Ors, Trial Chamber Judgment, supra, Partly Dissenting Opinion of Judge Doherty, para I3.

34 Ibid, para I4.

35 Ibid, para 15.

36 See Brima E Ors, Trial Judgment, supra, paras 708-7II. 
The Appeals Chamber disagreed with this finding, insisting that the 'record contains ample evidence ... that forced marriage is not predominantly a sexual crime. ${ }^{37}$ There are a number of problems with this finding. First, it necessarily involved a false question. The issue was not the abstract question whether 'forced marriage is predominantly a sexual crime.' The issue in the case must turn on what the evidence in the case revealed. Second, the Appeals Chamber did not point to a single instance in which the evidence revealed an incident of 'forced marriage' without sexual violation of the victim. Third, the Prosecution itself had in the Indictment classified 'forced marriage' under the heading of 'sexual violence'. Interestingly, the Appeals Chamber noted so; but proceeded to diminish the significance of that prosecutorial choice as an unfortunate minor matter that might have misled the Trial Chamber in their reasoning, without excusing the Trial Chamber in their reasoning. ${ }^{38} \mathrm{~W}$ ith respect to the Appeals Chamber, it is submitted that the matter has deeper significance than was acknowledged by the Appeals Chamber. The significance of the Prosecution's classification of 'forced marriage' as 'sexual violence' in the Indictment is mostly one of consistency with the fact that the evidence led by the Prosecution also indicated that the crime they had in mind was always underlain by 'sexual violence'. It is not to be forgotten that Prosecution indictments at the international criminal tribunals are not casually drawn up, introduced and confirmed by the judges. They are drawn up by the Prosecution, following their review of the evidence in support of the counts in the indictment. At the ICTR and ICTY, an indictment presented for confirmation before a confirming judge is required to be accompanied by a document known as the 'supporting material. ${ }^{39}$ At the Special Court for Sierra Leone the equivalent document is called 'case summary'. The 'supporting material' or the 'case summary' is simply a synopsis of the facts upon which the charges in the indictment are based. Notably, at the SCSL, the case summary is required to state the 'allegations [the Prosecutor] proposes to prove in making his case.' ${ }^{\circ}$ Following the preparation of the indictment, the indictment and the 'supporting material' or the 'case summary' are next presented to a judge for review and confirmation of the indictment. The judge is required to ensure that the evidence in the dossier supported the charges as framed. Given these thorough and intensive systems of indictment preparation and confirmation, especially given the requirement of verification (prior to confirmation) that the indictment as framed must be borne out by the evidence, it has to be concluded that the Prosecution's classification of forced marriage as 'sexual violence' must be taken to have been a conclusion supported by the evidence reviewed by the Prosecution at the time of preparing the indictment. It was not surprising then that the evidence led by the Prosecution in the case

37 Brima Eं Ors, Appeal Judgment, supra, para 190.

$38 \quad$ Ibid, para I8I.

39 See $\mathrm{r}_{47}(\mathrm{~b})$ in the Rules of Procedure and Evidence of both the ICTR and ICTY.

40 See ${ }_{47}(c)$ in the Rules of Procedure and Evidence of the SCSL. 
under consideration was also consistent with the proposition that 'forced marriage' in the case for the Prosecution also comprised of sexual conduct.

In view of all the foregoing problems with the Appeals Chamber's reasoning, it is hard to resist the conclusion that its judgment on forced marriage is necessarily obiter dictum, since it had not been faithful to the facts revealed in the case. Furthermore, the reasoning exposes the Appeals Chamber to the worry that their desire to 'enrich the jurisprudence of international criminal law' ${ }^{4 I}$ might have led them upon 'the hazardous course of judicial legislation.' ${ }^{42}$ It is perhaps important always to bear in mind that 'courts have to apply the law and that they have to apply the law in force. They have to apply - and no more than that - the law. It is not within their province to speculate on the law or to explore the possibilities of its development.' ${ }^{43}$ Such manner of judicial legislation has often been a matter of concern in the work of judges, with some of the more colourful commentators suggesting on the part of judges a tendency to make up new law and lie about having done so. ${ }^{44}$ Indeed, it will be hard to defend the Prosecutors and judges of the SCSL Appeals Chamber against the criticism of having made up the law on forced marriage. This is certainly the case as regards the very definition of forced marriage. The definition of 'forced marriage' was first framed by the Prosecutors in the Closing Brief they had submitted at the end of the trial. In that brief, 'forced marriage' was defined in terms of 'words or conduct intended to confer a status of marriage by force or threat of force or coercion, such as that caused by fear of violence, duress, detention, psychological oppression or abuse of power against the victim, or by taking advantage of a coercive environment, with the intention of conferring the status of marriage.' Not a single legal authority was cited by the Prosecution as the source of this definition. This suggests an obvious gap in the law that ought to have been candidly acknowledged, in order that an appropriate and lasting remedy may be sought. In her Partially Dissenting Opinion in the Trial Chamber, Judge Doherty accepted the definition offered by the Prosecution and re-issued it as follows: "The crucial element of "forced marriage" is the imposition, by threat or physical force arising from the perpetrator's words or other conduct, of a forced conjugal association by the perpetrator over the victim.' ${ }^{45}$ And in their own judgment, the Appeals Chamber accepted this ideation of forced marriage without question, as the basis of their own assessment of what constituted forced

4I Brima \& Ors, Appeal Judgment, supra, para I8I.

42 See Lauterpacht, supra, p I9.

43 Ibid, p 75.

44 See Martin Shapiro, 'Judges as Liars' (1994) I7 Harvard Journal of Law and Public Policy 155 and Pintip Dunn, 'How Judges Overrule: Speech Act Theory and the Doctrine of Stare Decisis' (2003) In3 Yale Law Journal pp 493. See also Laura Little, 'Hiding with Words: Obfuscation, Avoidance, and Federal Jurisdiction Opinions' (1998) 46 UCLA Law Review 75 at 85 and Lauterpacht, supra, pp 155-156.

45 Brima \& Ors, Trial Chamber Judgment, supra, Partly Dissenting Opinion of Judge Doherty, para 53 . 
marriage. ${ }^{46}$ Specifically, the Appeals Chamber held that 'forced marriage involves a perpetrator compelling a person by force or threat of force, through the words or conduct of the perpetrator or those associated with him, into a forced conjugal association with another person resulting in great suffering, or serious physical or mental injury on the part of the victim. ${ }^{47}$ As was the case in the definition offered by the Prosecution, not once did either Judge Doherty in the Trial Chamber or the Appeals Chamber refer to any source outside of their own authority for this definition of forced marriage.

It would then not be wrong to suggest that the Prosecution and the judges had quite literally 'made up' the definition of 'forced marriage' as offered in the $A F R C$ case. In a manner of speaking that is nothing short of judicial legislation. What was done in that regard clearly went beyond the proper remit of interpreting and applying existing law-even creatively. It is one thing to interpret existing law and apply it creatively to unusual facts: it is quite another matter to create a brand new legal norm and apply it to a set of perhaps familiar facts.

International judges have always been known to safely engage in creative interpretation and application of existing norms for purposes of correcting problems which may be so creatively corrected. In Akayesu, for instance, the ICTR judges applied existing law of genocide creatively to the conduct of rape. In that case, international law had already recognised the legal norm of genocide, together with its comprehension of the crime as including the infliction of serious physical or mental harm on members of a group with intent to destroy the group in whole or in part. Also already recognised as a crime in international law was rape committed in certain contexts. All that Akayesu did was link the two norms together. It did so by holding that rape as rape is clearly an infliction of physical or mental harm upon the victim; and it can be an act of genocide when committed as part of an effort to destroy a group in whole or in part. While the proposition was novel and creative at the time of its postulation, there was nothing controversial at all about it, from the perspective of the power of the judges to interpret and apply in that way the norms of international law concerning both genocide and rape.

The $A F R C$ case went beyond that. This is especially seen in the fact that there was no previous legal authority in international criminal law for the norm or the definition of forced marriage offered by the Prosecution.

\section{Doctrinal Problems of the SCSL Appeal's Chamber's Reasoning}

Besides the difficulties discussed above, the idea of convicting the accused of 'forced marriage' through the route of 'other inhumane acts' runs into additional problems of a doctrinal sort.

In the judgment of the Trial Chamber, Justice Doherty correctly noted in her Partially Dissenting Opinion that ' $\mathrm{f}$ ] orced marriage as a crime against humanity

46 See Brima \& Ors, Appeal Judgment, supra, paras I89-195.

47

Ibid, para 195 . 
has not been specified in any treaty provision nor recognised as a separate crime by the other International Tribunals. ${ }^{48}$ Nevertheless, the purpose that motivated the creation of the residual category of 'other inhumane acts' of crimes against humanity should, where the conditions are right, amply justify the recognition of forced marriage within that residual category. And the essence of that residual category is to underscore the fact that the list of crimes against humanity is not closed. ${ }^{49}$ The essence and purpose of the residual category of 'other inhumane acts' had been stated as follows by the ICTY Appeals Chamber in Prosecutor v Kordic and $\check{C}$ erkez:

The Appeals Chamber notes that inhumane acts as crimes against humanity were 'deliberately designed as a residual category, as it was felt undesirable for this category to be exhaustively enumerated. An exhaustive categorization would merely create opportunities for evasion or the letter of the prohibition. ${ }^{50}$

It would then appear that what needed to be done are first to identify the legal yardsticks of the category of 'other inhumane acts' as they have been laid down in the jurisprudence of international criminal law; and, then to measure forced marriage against those yardsticks. For those yardsticks, the case law of the ICTY provides a useful guide. In Kordic and Čerkez, the ICTY Appeals Chamber indicated the following elements as legal properties of 'other inhumane acts':

Inhumane acts as a crime against humanity is $[\mathrm{sic}]$ comprised of acts which fulfill the following conditions:

- $\quad$ the victim must have suffered serious bodily or mental harm; the degree of severity must be assessed on a case-by-case basis with due regard for the individual circumstances;

48 Dissenting Opinion of Justice Doherty, para 58.

49 See Prosecutorv Stakić (Judgment) dated 22 March 2006, Case No IT-97-24-A [ICTY Appeals Chamber] paras 315 and 316; Prosecutor v Kordic and Čerkez, supra, [ICTY Appeals Chamber] para II7; Prosecutor v Galić (Judgment) dated 5 December 2003, Case No IT-98-29-T [ICTY Trial Chamber]; Prosecutor v Naletilic and Martinović (Judgment) dated 3I March 2003, Case No IT-98-34-T [ICTY Trial Chamber] para 247; Prosecutor v Vasiljević (Judgment) dated 29 November 2002, Case No IT-9832-T [ICTY Trial Chamber], para I30; Prosecutor v Kvocka E Ors (Judgment) dated 2 November 200I, Case No IT-98-30/I-T [ICTY Trial Chamber] para 206; Prosecutor $v$ Kordić and Čerkez, supra, [ICTY Trial Chamber] para 269; Prosecutor v Kupreškić (Judgment) dated I4 January 2000, Case No IT-95-I6-T, [ICTY Trial Chamber] para 563; Prosecutor v Jelesić (Judgment) dated I4 December 1999, Case No IT-95-10-T, [ICTY Trial Chamber] para 52; and Prosecutor v Kayishema and Ruzindana, supra, [ICTR Trial Chamber] para I5o.

50 Prosecutor v Kordić and Čerkez, supra, [ICTY Appeals Chamber] para II7, quoting with approval a passage in Prosecutor v Kupreškić, supra, [ICTY Trial Chamber] para 563. To the same effect, see Prosecutor v Stakic, supra, [ICTY Appeals Chamber] paras 315 and 316 . 
- $\quad$ the suffering must be the result of an act or omission of the accused or his subordinate; and

- when the offence was committed, the accused or his subordinate must have been motivated by the intent to inflict serious bodily or mental harm upon the victim..$^{5}$

The actus reus component of the foregoing statement was restated by the same Appeals Chamber in the subsequent case of Prosecutor $v$ Stakic, in virtue of the following pronouncement:

The crime of other inhumane acts requires proof of an act or omission causing serious mental or physical suffering or injury or constituting a serious attack on human dignity..$^{52}$

Before proceeding further, it is perhaps helpful to address the matter of mens rea, adumbrated by the ICTY Appeals Chamber in the third condition indicated in the Kordic and Čerkez quotation seen earlier. In terms of that condition, the ICTY Appeals Chamber stated that the accused or his subordinate must have been motivated by the intent to inflict serious bodily or mental harm upon the victim. It is submitted that it should not be lightly assumed that the ICTY Appeals Chamber intended by that remark to postulate a doctrine of specific intent for 'other inhumane acts'. That such an assumption is not lightly to be made follows from a subsequent statement of the Appeals Chamber in the same judgment; such as is capable of interpretation as suggesting that only the causation of serious bodily or mental harm to the victim is required for 'other inhumane acts', regardless of the actual intent of the perpetrator. As already indicated, this is merely an interpretation of a statement of the Appeals Chamber. The actual statement of the Appeals Chamber was made in the context of distinguishing persecution from other inhumane acts, as separate categories of crimes against humanity. As the Appeals Chamber put it:

The Appeals Chamber finds that the definition of persecutions contains materially distinct elements not present in the definition of other inhumane acts under Article 5 of the Statute: the requirement of proof that an act or omission discriminates in fact and proof that the act or omission was committed with specific intent to discriminate. Other inhumane acts, by contrast, require proof that the accused caused serious bodily or mental harm to the victim(s), regardless of whether the act or omission causing the harm discriminates in fact or was specifically intended as discriminatory, which is not required by persecutions. ${ }^{53}$ [Emphasis added.]

5I Kordic and Čerkez (Appeal Judgment), supra, para II7.

$52 \quad$ Stakić (Appeal Judgment), supra, para 366.

53 Kordic and Čerkez (Appeal Judgment), supra, para Io42. 
At first blush, it is tempting to suppose that the Appeals Chamber's remarks as set out above are of limited application, only to the question of discrimination. But that assumption is negated when it is recalled that the essence of other inhumane acts is the infliction of bodily or mental harm. Mental harm can be inflicted by the perpetration of discrimination (the distinguishing feature of persecution), as can be physical harm, depending on the circumstances. Seen in that way, the Appeals Chamber's remarks then become a statement of general principle saying, as the words of the Appeals Chamber themselves suggest, that an accused need not have specifically intended to cause the bodily or mental harm that the victim suffered.

The logic of the foregoing submission is precisely parallel to the state of the law on the mens rea for murder as a crime against humanity, bearing in mind that it is now settled that murder as a crime against humanity is not a crime of specific intent. ${ }^{54}$ It is instructive to note then that in Kordic and $\check{C}_{\text {erkez, the Appeals }}$ Chamber made a strikingly similar statement in respect of murder as a crime against humanity as that quoted above (in relation to other inhumane acts). And this is what they said in respect of murder:

The Appeals Chamber finds that the definition of persecutions contains materially distinct elements not present in the definition of murder under Article 5 of the Statute: the requirement of proof that an act or omission discriminates in fact and proof that the act or omission was committed with specific intent to discriminate. Murder, by contrast, requires proof that the accused caused the death of one or more persons, regardless of whether the act or omission causing the death discriminates in fact or was specifically intended as discriminatory, which is not required by persecutions.5 [Emphasis added.]

Here, the Appeals Chamber is saying that murder is proved against an accused who caused the death of another person, notwithstanding that the accused might not have specifically intended to discriminate against the victim. In the previous quote we saw the Appeals Chamber saying that other inhumane acts is proved against an accused who caused serious bodily or mental harm to another, notwithstanding that the Accused might not have specifically intended to discriminate against the victim. Given the striking similarity between the two statements, it is compelling as a matter of general principle to view other inhumane acts as

54 See Prosecutor v Akayesu, supra, paras 588 and 589. See also Prosecutor v Jelesić, supra, paras 35 and $5 \mathrm{I}$; Prosecutor v Kupreškić, supra, paras 560 and 56r; Prosecutor v Blaškić (Judgment) 3 March 2000 [Trial Chamber] paras 216 and 217; Prosecutor v Kordić (Judgment) 28 February 200I [Trial Chamber] paras 235 and 236; Prosecutor v Krstić (Judgment) 2 August 2oor [Trial Chamber] para 485; Prosecutorv Kvoćka (Judgment) 2 November 200I [Trial Chamber] paras 132 and I36; Prosecutor v Vasiljević (Judgment) 28 November 2002 [Trial Chamber] para 205; Prosecutor v Naletilic E Anor, supra, [Trial Chamber] paras 248 and 249; Prosecutor v Stakic, supra, [Trial Chamber] paras $584-587$ and 63r.

Kordic and Čerkez (Appeal Judgment), supra, para Io42. 
not requiring specific intent, since murder, for instance, does not require a specific intent.

The point may be differently stated as follows: to require specific intent for other inhumane acts is incongruous in the neighbourhood of the other crimes against humanity, some prominent among which do not require specific intent. Notably, as indicated earlier, murder as a crime against humanity does not require specific intent..$^{6}$ The state of the law on the matter is as stated by the ICTY Trial Chamber in Kordic and Čerkez:

Although there has been some controversy in the International Tribunal's jurisprudence as to the meaning to be attached to the discrepancy between the use of the word "murder" in the English text of the Statute and the use of the word "assassinat" in the French text, it is now settled that premeditation is not required. Most recently, the Blaškic Trial Chamber held that "it is murder ("meurtre") and not premeditated murder ("assassinat") which must be the underlying offence of a crime against humanity." 57

In terms of what murder requires as its elements, for purposes of crimes against humanity, the Appeals Chamber said as follows:

The constituent elements of a murder do not appear to be controversial. In order for an accused to be found guilty of murder, the following elements need to be proved:

- the death of the victim;

- that the death resulted from an act or omission of the accused or his subordinate;

- that the accused or his subordinate intended to kill the victim, or to cause grievous bodily harm or inflict serious injury in the reasonable knowledge that the attack was likely to result in death.

These elements are similar to those required in connection to wilful killing under Article 2 and murder under Article 3 of the Statute, with the exception that in order to be characterised as a crime against humanity a "murder" must have been committed as part of a widespread or systematic attack against a civilian population..$^{8}$

${ }_{56} 6$ Akayesu, supra, [ICTR Trial Chamber], paras 588 and 589. See also Prosecutor v Jelesic, supra, paras 35 and $5 \mathrm{I}$; Prosecutor v Kupreškić, supra, [Trial Chamber] paras 560 and 56r; Prosecutor v Blaškić (Judgment), supra, paras 216 and 217; Prosecutor v Kordić (Judgment) 28 February 200I [Trial Chamber] paras 235 and 236; Prosecutor v Krstić, supra, [Trial Chamber] para 485; Prosecutor v Kvoćka, supra, [Trial Chamber] paras 132 and 136; Prosecutor v Vasiljević (Judgment) 28 November 2002 [Trial Chamber] para 205; Prosecutor v Naletilic \& Anor, supra, [Trial Chamber] paras 248 and 249; Prosecutor v Stakic, supra, [Trial Chamber] paras 584-587 and 631.

Prosecutor v Kordić (Judgment), supra, para 235.

$5^{8} \quad$ Ibid, para 235 . 
The fact then that murder as a crime against humanity does not require specific intent makes it incongruous to require such a specific intent in every case of other inhumane acts of crimes against humanity to be developed in the future.

Furthermore, it will be imprudent at this stage to impose such a requirement for other inhumane acts given that it is a residual category intended for future development of international criminal law, so as to punish unenumerated conducts of equal gravity and similar character. It is best then to leave the development of the regime of mens rea of the conduct in question according to the similar or associated conducts, and on a case-by-case basis.

In the circumstances, it is suggested that the mens rea of other inhumane acts has been correctly formulated in the following terms in some judgments of the Trial Chambers of the ICTY, along the lines of the objective analysis. In Blagojevic and Jokic, for instance, an ICTY Trial Chamber stated as follows:

It is required that the perpetrator, at the time of the act or omission, had the intention to inflict serious physical or mental suffering or to commit a serious attack on the human dignity of the victim(s), or that the perpetrator knew that his act or omission was likely to cause such suffering to, or amount to a serious attack on, the human dignity of the victim(s) and, with that knowledge, acted or failed to act..$^{59}$

It is therefore submitted that in the circumstances where forced marriage is seen as an international crime properly comprised within the rubric of other inhumane acts, Trial Judge Doherty's analysis would have implied the correct mens rea of the crime. As she put it in the relevant respect:

When presented with pleadings which suggest that certain conduct falls within [the category of Other Inhumane Acts], the fundamental question which falls to the Trial Chamber is whether such conduct inflicts great suffering, or serious injury to body or to mental or physical health, and is of a gravity similar to the acts referred to in Article 2(a) to (b) of the Statute. ${ }^{6}$ [Emphasis added.]

The point, of course, is not that Judge Doherty is correct in suggesting that the central test for the determination of forced marriage as an international crime is

59 Prosecutor $v$ Blagojević and Jokić (Judgment) dated I7 January 2005 [ICTY Trial Chamber] para 628. See also Prosecutor v Galić (Judgment) dated 5 December 2003 [ICTY Trial Chamber] para I54; and, Prosecutor v Krnojelac (Judgment) dated 15 March 2002 [ICTY Trial Chamber] para 132.

6o Dissenting Opinion of Justice Doherty, para 54. In the same vein, she wrote as follows: '[T] he conduct contemplated as 'forced marriage' does not necessarily involve elements of physical violence such as abduction, enslavement or rape, although the presence of these elements may go to prove the lack of consent of the victim. The crime is concerned primarily with the mental and moral suffering of the victim': ibid para 70. [Emphasis added.] 
simply the question whether the conduct under consideration 'inflicts great suffering, or serious injury to body or to mental or physical health, and is of a gravity similar' to other enumerated crimes against humanity. She is wrong on that score. As has been suggested elsewhere, there is a need to consider whether such a conduct has been recognised as a crime in international law. But she would be right if she also meant to say that the criminality of the conduct of the accused does not depend on his or her own subjective or specific intent.

In sum, the mischief of forced marriage is the use of the violent auspices of war to lord upon a woman a conjugal union against her will. In the nature of things, forced marriage is capable of causing the victim 'serious mental or physical suffering or injury or constituting a serious attack on human dignity', as the Appeals Chamber of the ICTY aptly described other inhumane acts of crimes against humanity in Stakic. ${ }^{6 \mathrm{r}}$ But the capacity of forced marriage to cause this manner of harm certainly makes it an international crime de lege ferenda, but it does not make the conduct an international crime in terms of lex lata. And the inquiry as to whether it is an international crime is not avoided by diverting the thrust of the inquiry in the direction of whether 'other inhumane acts' is a crime recognised in international law. To the extent that forced marriage is not covered or subsumed by other crimes against humanity, there remains work to be done in order to convert what is now de lege ferenda into a crime de lege lata. That is not correctly achieved by employing the route of 'other inhumane acts' to address forced marriage.

The main difficulty with employing the route of 'other inhumane acts' lies with the divination of the proper purpose of that residual category of crimes against humanity. Relying on the jurisprudence of the ICTY and ICTR, the SCSL Appeals Chamber posited that "the crime of "Other Inhumane Acts" is intended to be a residual provision so as to punish criminal acts not specifically recognised as crimes against humanity, but which, in context, are of comparable gravity to the listed crimes against humanity. ${ }^{\prime 62}$ It is submitted that this proposition is too slim to accommodate comfortably the entire purpose of 'other inhumane acts' as a concept in the instruments of international criminal law providing for it. Left as the Appeals Chamber stated it, 'other inhumane acts' might effectively become a nebulous magic mantra which prosecutors and judges would chant whenever they liked, in order to justify prosecution of whatever conduct catches their creative imagination, with little regard to the views of the international community as to whether the conduct at issue has been accepted as a norm of international criminal law; hence leaving unaddressed in a candid way the need for the international community to cover an existing gap. An example of this danger is evi-

6I Stakić (Appeal Judgment), supra, para 366.

62 Ibid, para I83. See also Prosecutor v Stakić, supra, [ICTY Appeals Chamber] para 315; Prosecutor v Rutaganda (Judgment) 6 December 1999 [ICTR Trial Chamber] para 77; Prosecutor v Kayishema and Ruzindana, supra, [ICTR Trial Chamber] para I49; Prosecutorv Kupreškić, supra, para 563; and Prosecutorv Blagojević and Jokić (Judgment), supra, para 625 . 
dent from the Appeals Chamber's apparent inability to offer guidance as to the conceptual boundaries of 'other inhumane acts.' On the one hand, the Appeals Chamber disagreed with the Trial Chamber's view that 'other inhumane acts' must be restrictively interpreted; in the same breath, the Appeals Chamber held without any elaboration or guidance that care must be taken not 'to render the crime nebulous and incapable of concrete ascertainment', as an 'over-broad interpretation will certainly infringe the rule requiring specificity of criminal prohibitions.' ${ }^{6}$ The Appeals Chamber's reasoning would have been greatly assisted by an indication of when 'other inhumane acts' as a concept might be seen as having become nebulous and incapable of concrete ascertainment.

One is of course mindful of an apparent rebuttal to the effect that the Appeals Chamber's restatement of the purpose of 'other inhumane acts' already contains within it some of the limits of the concept. In particular, the Appeals Chamber did say that the purpose of the category was 'to punish criminal acts not specifically recognised as crimes against humanity, but which, in context, are of comparable gravity to the listed crimes against humanity.' And therein lie the limits of 'other inhumane acts.' If that is so, the proposition will necessarily raise a slew of questions which have the effect of negating the Prosecution's and the Appeals Chamber's avoidance of the question whether forced marriage per se is a crime recognised in international law. In particular, the Appeals Chamber recognised that the purpose of the category of 'other inhumane acts' is to 'punish criminal acts' not specifically listed already as crimes against humanity.

The second limiting property alluded to by the Appeals Chamber-i.e. the 'comparable gravity' of the act-may also be seen as engaging the question of criminality. This is so given the fuller expression of that limitation in the Statute of the International Criminal Court and its Elements of Crimes. According to article $7(\mathrm{I})(\mathrm{k})$ of the Rome Statute, 'other inhumane acts' must be of a 'similar character' as the other listed crimes against humanity. And in the ICC's Elements of Crimes, the understanding is expressed that 'similar character' refers to similarity of both nature and gravity. The nature of a thing includes all its properties. Criminality is part of the nature or character of each listed crime against humanity. It is therefore the case that there cannot be similarity in character if what is held out as 'other inhumane act' is not of proven criminality, when the other listed crimes against humanity are clearly criminal in international law-hence, their appellation as crimes against humanity.

But one need not try that hard to show that the SCSL Appeals Chamber's articulation of the purpose of the category of 'other inhumane acts' recognises that the act in question must have a 'criminal' character. The Appeals Chamber did explicitly say that much. The questions thus arise: Whose province is it to recognise these acts as criminal? Is it the province of international prosecutors and judges or is it the province of the traditional norm creators in international law? And what is the process by which an act is to be recognised as criminal for purposes of prosecuting it as an 'other inhumane act'? Is it through the traditional

63 Brima \& Ors, Appeal Judgment, supra, para 185. 
primary methods of conventions, custom as evidence of the practice of states, or general principles of law? Or is it through the subsidiary means of judicial decisions, as indicated in article $38(\mathrm{I})(\mathrm{d})$ of ICJ Statute, ranking no higher than the opinions of highly qualified academics? Finally, if the purpose of 'other inhumane acts' as a category is to capture 'criminal acts' not already captured as crimes against humanity, is it then a valid method of legal reasoning to avoid the very exercise of examining whether the 'act' in question is 'criminal' in international law, but rather divert the question to whether 'other inhumane acts' is a recognised crime in international law? Clearly, the reasoning process is unbecomingly circular.

In the circumstances, the better statement of the purpose of 'other inhumane acts' is one that fully reconciles that purpose with the doctrine of nullum crimen sine lege. The ICTY Appeals Chamber effectively recognised this in Kordic and Cerkez, when it 'consider[ed] that the potentially broad range of the crime of inhumane acts may raise concerns as to a possible violation of the nullum crimen principle. $^{64}$

The hazards of the nullum crimen principle to the category of 'other inhumane acts'was brought into sharp focus in Prosecutor $v$ Stakic in which some ICTY Trial Judges viewed with 'serious concerns' the use of the 'other inhumane acts' category. In that case, the relevant charge against the accused was 'forcible transfer' of persons as an 'other inhumane act', contrary to article 5 (i) of the ICTY Statute. Recalling its decision on the Rule 98 bis motion for acquittal, the Trial Chamber observed as follows:

The Trial Chamber recalls that " $(t)$ he use of 'other inhumane acts' as a crime against humanity under Article 5 (i) of the Statute to attach criminal liability to forcible transfers, which are not otherwise punishable as deportations, raises serious concerns." While noting that "(n)ot every law can be defined with ultimate precision and that it is for the jurisprudence to interpret and apply legal provisions which need, in part, to be formulated in the abstract”, the Trial Chamber declared that the description of a criminal offence extends beyond the permissible when the specific form of conduct prohibited cannot be identified."The Trial Chamber therefore held that as "( $t$ )he crime of 'other inhumane acts' subsumes a potentially broad range of criminal behaviour and may well be considered to lack sufficient clarity, precision and definiteness" it might violate the fundamental criminal law principle nullum crimen sine lege certa. ${ }^{65}$

Having said that, the Trial Chamber next took issue with another Trial Chamber's reliance on human rights instruments in an effort to resolve an issue involving nullum crimen sine lege. According to the Stakić Trial Chamber:

[...] After referring to several international human rights instruments such as the Universal Declaration of Human Rights of 1948 and the two United Nations

64 Prosecutorv Kordic and Čerkez, supra, para II7.

65 Prosecutor v Stakic, supra, [ICTY Trial Chamber] para 7I9. 
Covenants of 1966, the Kupreskic Trial Chamber concluded that by referring to such instruments one would be able to identify "less broad parameters for the interpretation of 'other inhumane acts" and "identify a set of basic rights appertaining to human beings, the infringement of which may amount, depending on the accompanying circumstances, to a crime against humanity." ${ }^{\prime 6}$

This Trial Chamber disagrees with that approach and notes that the international human rights instruments referred to by the Kupreskić Trial Chamber provide somewhat different formulations and definitions of human rights. However, regardless of the status of the enumerated instruments under customary international law, the rights contained therein do not necessarily amount to norms recognised by international criminal law. The Trial Chamber recalls the report of the Secretary-General according to which "the application of the principle nullum crime sine lege requires that the international tribunal should apply rules of international humanitarian law which are beyond doubt part of customary law." Accordingly, this Trial Chamber hesitates to use such human rights instruments automatically as a basis for a norm of criminal law, such as the one set out in Article 5 (i) of the Statute. Its hesitation is even more pronounced when, as in the present case, there is no need to undertake such an exercise. A norm of criminal law must always provide a Trial Chamber with an appropriate yardstick to gauge alleged criminal conduct for the purposes of Article $5(\mathrm{i})$ so that individuals will know what is permissible behaviour and what is not. ${ }^{67}$

Consequently, the Trial Chamber dismissed the charge of forcible transfer as an 'other inhumane act'. ${ }^{68}$ On appeal, however, the Appeals Chamber considered both the notion of 'other inhumane acts' and forcible transfer against the hazard of nullum crimen sine lege and found as follows. First, the 'notion of "other inhumane acts" contained in Article 5(i) of the Statute cannot be regarded as a violation of the principle of nullum crimen sine lege as it forms part of customary international law. ${ }^{69}$ In this connection, the Appeals Chamber recalled the repeated occurrence of the notion of 'other inhumane acts' in the instruments of international criminal law going back to the Nuremberg Charter. ${ }^{70}$ And, second, as regards the notion of forcible transfer, the Appeals Chamber held that the crime had been defined in the jurisprudence of the Tribunal, following its inclusion in the ICTY Statute and proscription in the other international humanitarian law instruments that inform the work of that Tribunal. In the words of the Appeals Chamber:

In the instant case, the Prosecution charged forcible transfer (in Count 8 of the Indictment) as the act underlying Article 5(i). Forcible transfer has been defined

\footnotetext{
66 Ibid, para 720.

67 Ibid, para $72 \mathrm{I}$.

68 Ibid, para 724 .

69 Prosecutor v Stakic, supra, [ICTY Appeals Chamber] para 315.

70 Prosecutor v Stakić (Appeal Judgment) footnote 649.
} 
in the jurisprudence of the Tribunal as the forcible displacement of persons which may take place within national boundaries. The mens rea does not require the intent to transfer permanently. The Appeals Chamber notes that Article 2(g) of the Statute, Articles 49 and 147 of Geneva Convention IV, Article 85(4)(a) of Additional Protocol I, and Article I8 of the I996 ILC Draft Code all condemn forcible transfer. The notion of forcible transfer had therefore clearly been accepted as conduct criminalised at the time relevant to this case, such that it does not violate the principle of nullum crimen sine lege. Furthermore, acts of forcible transfer have been accepted in other cases before the Tribunal as specifically substantiating the notion of other inhumane acts pursuant to Article 5 (i). In view of the foregoing, the Appeals Chamber finds that acts of forcible transfer may be sufficiently serious as to amount to other inhumane acts. ${ }^{7 \mathrm{I}}$

Indeed the judicial definition of forcible transfer to which the ICTY Appeals Chamber refers in the foregoing quotation, following earlier proscription is quite consistent with the development of the law in other areas of international criminal law. Rape, for instance, was always proscribed but never defined in the instruments of international criminal law. It was later to be defined by judicial efforts in such cases as Akayesu, ${ }^{72}$ Furundžija ${ }^{73}$ and Kunarac. ${ }^{74}$ The same was true of murder. ${ }^{75}$

The doctrine of nullum crimen sine lege is fully reconcilable with the residual category of 'other inhumane acts' in the following understanding of the purpose of the category. That residual category is intended as an avenue through which to receive into international criminal law new norms of international criminal law progressively recognised by the international community through the usual process by which norms of international criminal law are created; without a need to amend instruments of international criminal law piece-by-piece upon the emergence of such new norms. This then involves a two-stage process. First, the new norm of international criminal law has to be recognised as such by the international community, in the usual manner indicated in article 38(I) of the Statute of the International Court of Justice. Once such a norm is recognised, prosecutors and judges would then apply the new norm in the administration of international criminal justice, by trying the culprits of the new norm as 'other inhumane act'.

\footnotetext{
7I Ibid, para $3 \mathrm{I} 7$.

72 Prosecutor v Akayesu, supra.

73 Prosecutor v Furundžija, supra, [ICTY Trial Chamber].

74 Prosecutor v Kunarac, supra, [ICTY Trial Chamber].

75 Prosecutor v Akayesu (Trial Judgment), paras 588 and 589. See also Prosecutor v Jelesic, supra, [Trial Chamber] paras 35 and $5 \mathrm{I}$; Prosecutor v Kupreškic, supra, paras 560 and 56r; Prosecutor v Blaškić, supra, [Trial Chamber] paras 216 and 217; Prosecutor v Kordić, supra, [Trial Chamber] paras 235 and 236; Prosecutor v Krstic, supra, [Trial Chamber] para 485; Prosecutor v Kvoćka, supra, [Trial Chamber] paras I32 and 136; Prosecutor v Vasiljević (Judgment) 28 November 2002 [Trial Chamber] para 205; Prosecutor v Naletilić \& Anor, supra, [Trial Chamber] paras 248 and 249; Prosecutor v Stakić, supra, [Trial Chamber] paras $584-587$ and 631.
} 


\section{Forced Marriage and other Gender-oriented Crimes against Humanity}

As indicated earlier, another question which arose in the $A F R C$ case, but which was not convincingly resolved by the SCSL Appeals Chamber was whether forced marriage is a superfluous notion, given that the mischief sought to be proscribed had already been captured in the other conducts listed as 'crimes against humanity'.

From the outset, it might be helpful to resolve the distraction of the paradox of contending on the one hand that forced marriage is a crime similar in character as those enumerated in the list of crimes against humanity, while insisting, on the other hand, that it is a distinct crime. This matter is highlighted from the outset of the discussion in this part, in order quickly to put it to one side as a trifle that is capable of distracting attention from more important thinking.

To say that a candidate for the rank of crime against humanity shares a similarity of character as the enumerated crimes is a proposition that simply deals with the classification of crimes. That is to say an orderly grouping of crimes according to a common thread that binds them. The common thread generally accepted as binding crimes recognised in international law as crimes against humanity is their ability to inflict 'serious mental or physical suffering or injury or constituting a serious attack on human dignity. ${ }^{76}$ This exercise to discern the common thread that binds crimes against humanity does not detract from the uniqueness of the individual crimes according to their distinct elements.

It should aid analysis to review in this segment of the discussion the elements of sexual slavery and trafficking in persons, being two crimes against humanity most often associated with the notion of forced marriage. In this exercise, reference will be made to the Elements of Crimes of the International Criminal Court as a useful guide,, 7 although it is a non-binding document and may be departed from when not consistent with a statutory text or with customary international law. $^{78}$

76 Stakić(Appeal Judgment), supra, para 366.

77 Available at <http://www.amicc.org/docs/Elements_of_Crimes_I20704EN.pdf>. International criminal tribunals have usually cited with approval the Elements of Crimes of the ICC, for purposes of similar crimes provided for in their own statutes. See for instance, Prosecutor v Brima $\Xi$ Ors (Decision on Defence Motion for Judgement of Acquittal Pursuant to Rule 98) dated 31 March 2006, Case No SCSL-04-16-T [SCSL Trial Chamber]; Prosecutor v Brima E Ors, supra, [Trial Chamber], para 708 juncto footnote 1378 , para 716 juncto footnote 1399 , para 729 juncto footnote I4I6.

78 As noted earlier, in Prosecutor v Krstic, the Appeals Chamber of the ICTY held that ' $[t]$ he Trial Chamber's reliance on the definition of genocide given in the ICC's Elements of Crimes is inapposite,' to the extent that the ICC Elements of Crimes indicates that genocide requires that the impugned conduct 'took place in the context of a manifest pattern of similar conduct': Prosecutor v Krstic, supra, [ICTY Appeals Chamber], para 224. In this regard the Appeals Chamber reiterated that the Elements of Crimes 'are intended only to "assist the Court in the interpretation and applica- 


\section{Forced Marriage versus Sexual Slavery}

The comparison will begin with sexual slavery, since the majority of the Trial Chamber (Judge Doherty dissenting) had equiparated forced marriage and sexual slavery. ${ }^{79}$ The Appeals Chamber disagreed with the Trial Chamber majority and held, agreeing with Judge Doherty, that forced marriage was not subsumed in sexual slavery or indeed in any of the other enumerated crimes against humanity. ${ }^{80}$

In the $A F R C$ case, the majority of the Trial Chamber considered that the essence of the offence charged as forced marriage was subsumed in sexual slavery as a crime against humanity. As noted already, the majority of Trial Chamber's point of departure in the analysis was to recall that 'other inhumane acts', the statutory category under which the Prosecution brought the charge of forced marriage, exists as 'a residual category' of crimes against humanity. That being the case, reasoned the majority of the Trial Chamber, forced marriage must not involve conduct not otherwise subsumed under any other conduct enumerated under the statute as a crime against humanity. Having considered the evidence presented in the case, the Chamber majority was not satisfied that the crime charged as forced marriage engaged a conduct not subsumed under the crime of sexual slavery. ${ }^{{ }^{8}} \mathrm{In}$ particular, the Chamber found that 'the totality of the evidence adduced by the Prosecution as proof of "forced marriage" goes to proof of elements subsumed by the crime of sexual slavery' ${ }^{82}$ And, for good measure, the Chamber held that there was no lacuna in the law which would necessitate a separate crime of forced marriage as an 'other inhumane act'. ${ }^{83}$

The Prosecution had aimed to separate 'forced marriage' from sexual slavery, by emphasising an angle of conjugal association and disemphasising the factor of sexual violence. The Prosecution had urged the Chamber to find that forced marriage, unlike sexual slavery, has, as a distinguishing element in the perpetrator's claim or declaration of conjugal association with the victim, such that the culprit's claim or declaration amounts to a crime against humanity. [As an aside, it is submitted that this should be no more than a normative statement on the part of the Prosecution, given that there was no prior authoritative reference for both the legal definition and the elements of 'forced marriage' offered in the case by the Prosecution. It was an original idea from the Prosecution.] The majority of the Trial Chamber rejected the Prosecution's submission on this point. According

tion" of the substantive definitions of crimes given in the Statute itself. ... Unlike the definitions present in the Statute, the definitions given in the Elements of Crimes are not binding rules, but only auxiliary means of interpretation': ibid, footnote 366 . See also article 9(I) and (3) of the ICC Statute; and Elements of Crimes, General Introduction, para I.

Brima $\mathcal{E}^{2}$ Ors, Trial Judgment, supra, in particular para $7 \mathrm{I} 3$.

80 Brima E Ors, Appeal Judgment, supra, para 195.

8I Brima EO Ors, Trial Chamber Judgment, supra, paras 703 to $7 \mathrm{I} 4$.

82 Ibid, para 7 II.

83 Ibid, para $7 \mathrm{I} 3$. 
to the Chamber, the Prosecution evidence does not point to even one instance of 'forced marriage' that did not amount to sexual slavery. And not a single victim had testified that the mere fact of a perpetrator declaring her as a 'wife' had caused her any particular trauma of any sort, whether physical or psychological. Nor, the Chamber held, would such evidence have been sufficient to make a crime against humanity, as it would not have been of gravity similar to the enumerated crimes against humanity. ${ }^{84}$

Judge Doherty disagreed with the findings and analysis of the majority on this point. She held that forced marriage constitutes a crime against humanity. ${ }^{85}$ She did not hesitate in conceding, first, that forced marriage as a crime against humanity 'has not been specified in any treaty provision nor recognised as a separate crime by the other international tribunals'. However, in search of a source of an international criminal norm against forced marriage, she resorted to a review of 'non-criminal instruments' of international law and general principles of law. In terms of general principles of law recognised by states in their own realms, Judge Doherty noted that national legal systems in both the common law and the civil law traditions have criminalised 'abduction of any person or any female person with intent to have that person marry.' As an example, she cited the Criminal Code of Nigeria which provides: 'Any person who, with the intent to marry or carnally know a female of any age, or to cause her to be married, or carnally known by any other person, takes her away, or detains her, against her will, is guilty of a felony, and is liable to imprisonment for seven years. ${ }^{86}$ And she noted that similar penal laws have been enacted in Bulgaria, Papua New Guinea, India, Singapore, Indonesia, Venezuela and Brazil. ${ }^{87}$

As for the non-criminal international instruments, Judge Doherty considered the following instruments all of which required marriage to be entered into with free and full consent of the intending spouses: the Universal Declaration of Human Rights, ${ }^{88}$ the International Covenant on Civil and Political Rights, ${ }^{89}$ the Convention on the Elimination of all Forms of Discrimination against Women, ${ }^{90}$ the Convention on Consent to Marriage, Minimum Age for Marriage and Registration of Marriage. ${ }^{9 \mathrm{r}}$ To the same effect, Judge Doherty also considered the provisions of the African Charter on Human and People's Rights ${ }^{92}$ and the Protocol to African Charter on the Rights of Women in Africa. ${ }^{93}$

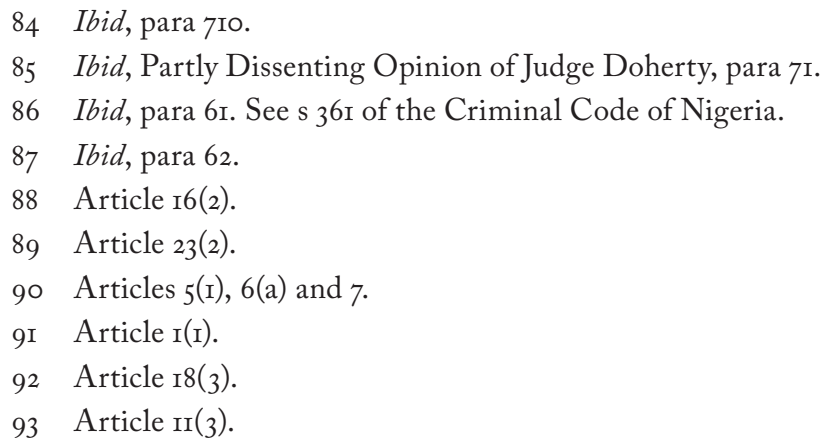


At the end of the exercise she considered that forced marriage violated the rule of consent to marriage, as required by both these international instruments and the national criminal provisions against abduction which she had reviewed. According to her, the victim, '[i]n the absence of such consent ... is forced into a relationship of a conjugal nature with the perpetrator thereby subsuming the victim's will and undermining the victim's exercise of their right to self-determination.'94 In her view, forced marriage need not involve sexual violence; 95 the main concern of the crime is 'the mental and moral suffering of the victim'. ${ }^{96}$ Concluding, she held that '[b]y vitiating the will of one party and forcing him or her to enter into and remain in a marital union the victim is subjected to physical and mental suffering. The phenomenon of forced marriage transgresses the internationally accepted conventions that both parties must consent to a marriage. ${ }^{97}$

On appeal, as already noted, the Appeals Chamber sided with Judge Doherty. They concluded that the Trial Chamber had erred in holding that the evidence of forced marriage is subsumed in the elements of sexual slavery. They agreed that forced marriage shares certain elements with sexual slavery: nevertheless, there are some distinguishing elements. The Appeals Judges pointed to two factors which made forced marriage a crime not predominantly of a sexual nature. First, they considered that 'forced marriage involves a perpetrator compelling a person by force or threat of force, through the words or conduct of the perpetrator or those associated with him, into a forced conjugal association with a another person resulting in great suffering, or serious physical or mental injury on the part of the victim.'The second distinguishing factor considered as such by the Appeals Chamber was that "unlike sexual slavery, forced marriage implies a relationship of exclusivity between the "husband" and "wife," which could lead to disciplinary consequences for breach of this exclusive arrangement. '98 Therefore, they concluded that in the context of the Sierra Leone conflict, forced marriage describes a situation in which the perpetrator is responsible for the employment of words or other conduct to compel a person by force, threat of force, or coercion to serve as a conjugal partner in a manner that results in severe physical or psychological injury to the victim. ${ }^{99}$

It is submitted that the reasoning of the majority of the Trial Chamber is the most convincing. Indeed, the Trial Chamber's Majority Opinion that forced marriage is subsumed within the crime of sexual slavery finds support in a majority of the literature on the subject.

94 Brima Eं Ors, Trial Chamber Judgment, supra, Partly Dissenting Opinion of Judge Doherty, para 69.

95 Ibid, para 70.

96 Ibid.

97 Ibid, para 7 I.

98 Brima $\Xi$ Ors, Appeal Judgment, supra, para 195.

99 Ibid, para 196. 
In their recommendations and commentary to the Preparatory Committee on the establishment of the International Criminal Court, the Women's Caucus for Gender Justice in the International Criminal Court made it abundantly clear that 'forced marriage' is an aspect of enslavement or sexual slavery. Notably, both of these conducts are enumerated acts of crimes against humanity. According to the Women's Caucus, '[g]ender violence is the most extreme form of gender discrimination.' And in their lexicon, '[g]ender violence also includes ... the enslavement of women through forced marriage or otherwise for domestic as well as sexual service.' ${ }^{\text {roo }}$ They considered that 'in Rwanda, Algeria and other parts of the world, the practice of taking women as "temporary wives" or in forced "temporary marriage" is also sexual enslavement.' ${ }^{\text {'or }}$ Similarly, they considered that 'enslavement is also gendered when it exploits women's or men's traditional roles. When, as discussed above, women are impressed into maternity, this is a form of gender enslavement. The same is true when women are impressed into providing domestic services whether on a large-scale or individualized (forced temporary marriage) basis.' ${ }^{\text {'02 }}$

In order to ensure that all forms of enslavement and slavery-like practices are captured as crimes against humanity within the jurisdiction of the International Criminal Court, the Women's Caucus recommended adding the phrase 'including by sale, deception, coercion or threat' to the relevant text of the Statute. This, as they saw it, would ensure, for example, that 'women and girls are not only sold into forced marriage, but also kidnapped, coerced, threatened or deceived into "accepting" it. ${ }^{{ }_{103}}$ To this end, they favoured a formulation of the crime against humanity of enslavement along the following lines: 'All forms of enslavement, including sexual or domestic enslavement and forced marriage, by sale, deception, coercion or threat.' ${ }^{\text {'o4 }}$

In the report entitled Abolishing Slavery and its Contemporary Forms, the Office of the United Nations High Commissioner for Human Rights included 'Forced Marriage and Sale of Wives' in the section dealing with 'Forms of Slavery', under a general introductory paragraph saying, 'In this section the review will summarize briefly the various forms of slavery and slavery-like practices.' ${ }^{\circ o 5}$ And under the sub-heading of 'Forced Marriage and Sale of Wives', the following observation is made:

Ioo Women's Caucus for Gender Justice in the International Criminal Court, 'Recommendations and Commentary for December 1997 PrepCom on the Establishment of An International Criminal Court United Nations Headquarters, December I-I2, I997', WC 4.4, pp 9-Iо.

IoI Ibid, WC 5.6-7, p 27. Emphasis added.

IO2 Ibid, WC 5.6-I3, p 30.

I03 Ibid, WC 8.2, p 35 .

I04 Ibid, Annex I, (a)bis.

I05 United Nations Office of the High Commissioner for Human Rights, 'Abolishing Slavery and its Contemporary Forms' [New York and Geneva: United Nations, 2002] para 30, Doc No HR/PUB/o2/4. 
The Supplementary Convention [on the Abolition of Slavery, the Slave Trade and Institutions and Practices Similar to Slavery] of 1956 identifies three types of institutions or practices akin to slavery to which women can be subjected in the context of marriage. The Supplementary Convention first prohibits any institution or practice whereby "a woman, without the right to refuse, is promised or given in marriage on payment of a consideration in money or in kind to her parents, guardian, family, or any other person or group". It is not the payment which is an abuse but its occurrence in a forced or non-consensual marriage. ${ }^{\mathrm{IO}}$ [Emphasis added.]

In her updated report (of 6 June 2006) to the UN Sub-Commission on Prevention of Discrimination and Protection of Minorities, Ms Gay J McDougall, Special Rapporteur for Systematic Rape, Sexual Slavery and Slavery-Like Practices during Armed Conflict, wrote as follows:

The repeated rape and sexual abuse of women and girls under the guise of "marriage" constitutes slavery, as the victims do not have the freedom to leave, to refuse the sham "marriage" or to decide whether and on what terms to engage in sexual activity. ${ }^{\text {107 }}$

The foregoing observation restates the conclusion reached by the Special Rapporteur in her final report (of 22 June 1998) to the same Sub-Commission. In that earlier report, she had written as follows:

The term "sexual" is used in this report as an adjective to describe a form of slavery, not to denote a separate crime. In all respects and in all circumstances, sexual slavery is slavery and its prohibition is a jus cogens norm. The "comfort stations" that were maintained by the Japanese military during the Second World War (see appendix) and the "rape camps" that have been well documented in the former Yugoslavia are particularly egregious examples of sexual slavery. Sexual slavery also encompasses situations where women and girls are forced into "marriage", domestic servitude or other forced labour that ultimately involves forced sexual activity, including rape by their captors. For instance, in addition to the cases documented in Rwanda and the former Yugoslavia, there are reports from Myanmar of women and girls who have been raped and otherwise sexually abused after being forced into "marriages" or forced to work as porters or minefield sweepers for the military. In Liberia, there are similar reports of women and girls who have been

Io6 Ibid, para II2.

I07 United Nations, Contemporary Forms of Slavery: Systematic Rape, Sexual Slavery and Slavery-Like Practices during Armed Conflict (Update to the Final Report submitted by Ms Gay J McDougall, Special Rapporteur) E/CN.4/Sub.2/200o/2I of 6 June 2000 , para I3. 
forced by combatants into working as cooks and who are also held as sexual

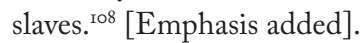

In the context of sexual slavery as a crime against humanity listed in the Statute of the International Criminal Court, Amnesty International specifically recaptured the definition of sexual slavery that includes forced marriage, pursuant to the report of the Special Rapporteur for Systematic Rape, Sexual Slavery and SlaveryLike Practices during Armed Conflict. ${ }^{\text {I09 }}$ To the same effect and in approval, the Sierra Leone Truth and Reconciliation Commission observed as follows:

Forced "marriage" is a form of sexual slavery as is the detention of women in "rape camps" or any circumstances under which women are subjected repeatedly to rape or the threat of rape or any other sexual violence. In Sierra Leone, as well as in many other conflicts, women and girls were given as "wives" to commanders and combatants. These sexual slaves are widely referred to as "bush wives". When "forced marriage" involves forced sex or the inability to control sexual access or exercise sexual autonomy, which, by definition, forced marriage almost always does, it constitutes sexual slavery, as recognised by the Special Rapporteur for Systematic Rape, Sexual Slavery and Slavery-Like Practices during Armed Conflict. ${ }^{\text {IIo }}$

Other scholarly works also support the notion that sexual slavery also comprises forced marriage. ${ }^{\text {III }}$

Prior to the SCSL judgments in the $A F R C$ case, there was not much else in the way of other judicial authority on the subject of whether forced marriage is subsumed in the crime of sexual slavery. However, it is notable that in a footnote

Io8 United Nations, 'Contemporary Forms of Slavery: Systematic Rape, Sexual Slavery and Slavery-Like Practices during Armed Conflict': Final Report submitted by Ms Gay J McDougall, Special Rapporteur, supra, para 30.

Io9 See Amnesty International, 'International Criminal Court: Preliminary comments concerning the elements of war crimes other than grave breaches of the Geneva Conventions-Part I [AI Index: IOR 40/rI/99] p 7. Found at: <http://www.amnesty. org/en/library/asset/IOR4o/oII/r999/en/dom-IOR40oIII999en.pdf>

Iıo Sierra Leone Truth \& Reconciliation Commission, Witness To Truth (Final Report of the Sierra Leone Truth \& Reconciliation Commission) (2004), vol 3b, at para I84: available at <http:// www.trcsierraleone.org> (last visited on Io August 2007). It is perhaps notable that Professor William Schabas was a member of this Commission.

III Otto Triffterer (ed), Commentary on the Rome Statute of the International Criminal Court-Observers Notes, Article by Article [The Hague: Kluwer, I999] page I42: 'The word "sexual" in the current paragraph denotes the result of this particular crime of enslavement: limitations on one's autonomy, freedom of movement and power to decide matters relating to one's sexual activity... Sexual slavery thus also encompasses situations where women and girls are forced into "marriage", domestic servitude or other forced labour that ultimately involves forced sexual activity, including rape by captors.' [Emphasis added.] 
in Prosecutor v Kvocka and Ors, an ICTY Trial Chamber appears to say so when it wrote as follows:

Sexual violence would also include such crimes as sexual mutilation, forced marriage, and forced abortion as well as the gender related crimes explicitly listed in the ICC Statute as war crimes and crimes against humanity, namely "rape, sexual slavery, enforced prostitution, forced pregnancy, enforced sterilization" and other similar forms of violence. ${ }^{\mathrm{II} 2}$

This authority was cited by Judge Doherty in her Partly Dissenting Opinion in the $A F R C$ case, en route to her conclusion that forced marriage is not a predominantly sexual crime. ${ }^{\mathrm{II}}$ The problem of course is that the authority stands precisely for the opposite conclusion, as the ICTY Trial Chamber was clearly saying that 'sexual violence would also include ... forced marriage.' Similarly, Judge Doherty's conclusion was not really aided by her reliance on the provisions of the Nigerian Criminal Code as part of her analysis that forced marriage is not subsumed in the other enumerated crimes against humanity.

Section 36r of the Criminal Code of Nigeria appears under Chapter 30 entitled: 'Assaults on Females: Abduction'. That provision and the other national laws-especially those from the common law countries-cited by Judge Doherty trace their lineage to section 54 of the Offences against the Person Act 186I of England. ${ }^{\mathrm{II}}$ The offence in question is usually referred to in the common law jurisdictions as 'abduction' ${ }^{115}$ — more specifically, 'abduction of a woman with intent to marry or carnally know her.'Ir6 That these laws are anti-abduction laws is very significant given that abduction should comfortably fit into the sexual slavery in virtue of the element of deprivation of liberty in the manner outlined in the Elements of Crimes of the Rome Statute. ${ }^{\mathrm{II} 7}$ And that surely advances the matter no

II2 Prosecutor v Kvocka E Ors, supra, [ICTY Trial Chamber] footnote 343.

II3 Brima \& Ors, Trial Chamber Judgment, supra, Partly Dissenting Opinion of Judge Doherty, para 68.

II4 Repealed by the Sexual Offences Act 1956 (c 69), Sch 4 <www.cirp.org/library/ legal/UKlaw/oapr86r/> For an unofficial version of the original statute, see $<$ http:// www.swarb.co.uk/acts/186IOffencesAgainstThePersonAct.shtml $>$.

II5 For s 36I of the Criminal Code of Nigeria, see <http://www.nigeria-law.org/ Criminal\%2oCode\%2oAct-PartV.htm\#Chapter\%2030>. See also s I42 of Kenya's Sexual Offences Act 2006 <http://mzalendo.com/Bills.Details.php?ID=I>.

II6 See the title to s 54 of Offences Against the Person Act, r86r: 'Forcible abduction of any woman with intent to marry or carnally know her, \&c'. This is contrasted with 'abduction of a woman for the motives of lucre': See title to s 5I of Dominica's Offences against the Person Act <http://www.interpol.int/Public/Children/ SexualAbuse/NationalLaws/csaDominica.pdf> or 'abduction of a girl under age against the will of her father': See the title to s 53 of Offences against the Person Act, I86I.

II7 See ICC Elements of Crimes: note II (Enslavement as a Crime against Humanity), 
further away from the proposition that forced marriage is subsumed within the other enumerated crimes against humanity.

In view of these considerations, it is submitted that the reasoning of the majority of the Trial Chamber was more consistent with the prevailing law and authorities. The views of Judge Doherty and the Appeals Chamber, on the other hand, were not apparently based on any prevailing authority in international law, other than their own.

\section{Forced Marriage versus Trafficking in Persons}

Trafficking in persons is another slavery-like crime that tends to be frequently associated with forced marriage and sexual slavery. Article 3(a) of the Protocol to Prevent, Suppress and Punish Trafficking in Persons, Especially Women and Children, supplementing the United Nations Convention against Transnational Organized Crime $^{\mathrm{Ir} 8}$ (the 'Protocol on Trafficking in Persons') defines 'Trafficking in Persons' as follows:

[T] he recruitment, transportation, transfer, harbouring or receipt of persons, by means of the threat or use of force or other forms of coercion, of abduction, of fraud, of deception, of the abuse of power or of a position of vulnerability or of the giving or receiving of payments or benefits to achieve the consent of a person having control over another person, for the purpose of exploitation. Exploitation shall include, at a minimum, the exploitation of the prostitution of others or other forms of sexual exploitation, forced labour or services, slavery or practices similar to slavery, servitude or the removal of organs.

As one commentator has observed, "[a] striking feature of the definition is that it includes trafficking for purposes other than prostitution, such as for forced labour, forced marriage, and other slavery-like practices. 'II9

UNIFEM's Independent Experts on the Assessment of the Impact of Armed Conflict on Women and Women's Role in Peace-building have also made a linkage among trafficking in persons, sexual slavery and forced marriage. As they wrote:

Trafficking and sexual slavery are inextricably linked to conflict. Women are trafficked out of one country into another to be used in forced labour schemes that

note 18 (Sexual Slavery as a Crime against Humanity), note 53 (Sexual Slavery as a War Crime in international armed conflicts), and note 65 (Sexual Slavery as a War Crime in non-international armed conflicts). See <http://www.amicc.org/docs/ Elements_of_Crimes_I20704EN.pdf>.

II8 It entered into force on 25 December 2003: see <http://www.unodc.org/unodc/en/ crime_cicp_convention.html> (accessed on 30 July 2007).

II9 Ratna Kapur, 'Travel Plans: Border Crossings and the Rights Of Transnational Migrants' (Spring 2005) I8 Harv Hum Rts J, I07 at II6. 
often include forced prostitution. They are pushed into marriage with members of opposing groups either directly, through abduction, or in order to protect their families. They are abducted by armed groups and forced to accompany them on raids and to provide everything from food to sexual services. Many sexual slaves are also used for dangerous work like demining contested areas, forced to risk their lives to make a field or a hillside safe for soldiers.

In East Timor, Kirsty Gusmao, the wife of East Timor President Xanana Gusmao, told us the story of Juliana dos Santos, who had been kidnapped by an Indonesian army officer when she was about I4 years old. She was taken to a camp in West Timor controlled by militia groups and the Indonesian Army. Eventually she married an Indonesian in the camp and bore a child. Kirsty Gusmao campaigned vigorously to have dos Santos and her child returned to her home and her family and, in the process, the girl became a symbol in East Timor of the terrible price women had paid for their country's independence. Gusmao's efforts ultimately failed. Arrangements were made for dos Santos to be turned over to the East Timorese, but on the appointed day she arrived surrounded by a group of armed men and said she did not want to go home. ${ }^{\text {I20 }}$

The UN Office of the High Commissioner for Human Rights has been known to make a linkage between trafficking in persons and slavery. In one report, they wrote as follows:

The trafficking of persons today can be viewed as the modern equivalent of the slave trade of the nineteenth century. The Covenant of the League of Nations adopted on 28 April r9r9 not only called on Member States to ensure fair and humane conditions of employment for all but also to work towards the suppression of traffic in women and children, in particular for the purpose of sexual exploitation. Prior to the existence of the League of Nations, certain efforts had been made by the international community to prohibit the slave trade. ${ }^{\mathrm{I} 2 \mathrm{I}}$

In her own report, Radhika Coomaraswamy, formerly Special Rapporteur on Violence against Women, its Causes and Consequences, had found a linkage between trafficking in persons, forced marriage and slavery-like practices. According to her:

Documentation and research shows that trafficking occurs for a myriad of exploitative purposes to which trafficked victims have not consented, including

I20 UNIFEM, Women, War, Peace: The Independent Experts' Assessment on the Impact of Armed Conflict on Women and Women's Role in Peace-Building,' p I2; see $<$ http://www.unifem.org/filesconfirmed/I49/2I3_chapteror.pdf>.

I2I United Nations Office of the High Commissioner for Human Rights, 'Abolishing Slavery and its Contemporary Forms,' supra. 
but not limited to forced and/or bonded labour, including within the sex trade, forced marriage and other slavery-like practices. ${ }^{\text {I22 }}$

In Resolution 53/ri6 of February 1999 (Traffic in Women and Girls), the UN General Assembly appears to confirm this union of notions among trafficking in persons, forced marriage and sexual slavery. In that resolution, the General Assembly:

Call[ed] upon Governments to take appropriate measures to address the root factors, including external factors, that encourage trafficking in women and girls for prostitution and other forms of commercialized sex, forced marriages and forced labour, so as to eliminate trafficking in women, including by strengthening existing legislation with a view to providing better protection of the rights of women and girls and to punishing perpetrators, through both criminal and civil measures; ... ${ }^{23}$ [Emphasis added.]

Similarly, the Elements of Crimes of the ICC contains the following common note in relation to deprivation of liberty as an element of the crimes of enslavement and sexual slavery:

It is understood that such deprivation of liberty may, in some circumstances, include exacting forced labour or otherwise reducing a person to a servile status as defined in the Supplementary Convention on the Abolition of Slavery, the Slave Trade, and Institutions and Practices Similar to Slavery of 1956. It is also understood that the conduct described in this element includes trafficking in persons, in particular women and children. ${ }^{\mathrm{I} 24}$ [Emphasis added.]

I22 United Nations Economic and Social Council, 'Integration of the Human Rights of Women and the Gender Perspective': Report of the Special Rapporteur on violence against women, its causes and consequences, Ms Radhika Coomaraswamy, on trafficking in women, women's migration and violence against women, submitted in accordance with Commission on Human Rights resolution 1997/44,' Doc No E/ CN.4/2000/68 (2000), para I3.

I23 UN GA res A/RES/53/II6 of I February 1999, para 7. See also United Nations General Assembly resolution 49/166 of 23 December 1994 which condemned the 'illicit and clandestine movement of persons across national and international borders, largely from developing countries and some countries with economies in transition, with the end goal of forcing women and girl children into sexually or economically oppressive and exploitative situations for the profit of recruiters, traffickers and crime syndicates, as well as other illegal activities related to trafficking, such as forced domestic labour, false marriages, clandestine employment and false adoption.'

I24 See ICC Elements of Crimes: note II (Enslavement as a Crime against Humanity), note 18 (Sexual Slavery as a Crime against Humanity), note 53 (Sexual Slavery as a War Crime in international armed conflicts), and note 65 (Sexual Slavery as a War Crime in non-international armed conflicts). See <http://www.amicc.org/docs/ Elements_of_Crimes_I20704EN.pdf> 
Before concluding the discussion on this part, it is perhaps useful to address Judge Doherty's reliance on non-penal international instruments for support of her reasoning that forced marriage is a crime against humanity. First, one must note the hesitation on the part of some international judges to rely on human rights instruments for purposes of constructing elements of crimes against humanity, as the rights embodied in those instruments do not necessarily amount to international criminal law norms. ${ }^{25}$ One ICTY Trial Chamber sounded this hesitation in the following way:

This Trial Chamber disagrees with that approach and notes that the international human rights instruments ... provide somewhat different formulations and definitions of human rights. However, regardless of the status of the enumerated instruments under customary international law, the rights contained therein do not necessarily amount to norms recognised by international criminal law. The Trial Chamber recalls the report of the Secretary-General according to which "the application of the principle nullum crime sine lege requires that the international tribunal should apply rules of international humanitarian law which are beyond doubt part of customary law." Accordingly, this Trial Chamber hesitates to use such human rights instruments automatically as a basis for a norm of criminal law, such as the one set out in Article 5 (i) of the Statute. Its hesitation is even more pronounced when, as in the present case, there is no need to undertake such an exercise. A norm of criminal law must always provide a Trial Chamber with an appropriate yardstick to gauge alleged criminal conduct for the purposes of Article $5(\mathrm{i})$ so that individuals will know what is permissible behaviour and what is not. ${ }^{\mathrm{I} 26}$

Indeed, on the subject of forced marriage, human rights instruments' requirement of full and free consent to marriage has other uses short of constituting a criminal norm. One such use is the vitiation of marriage contracted without full and free consent. Hence, it need not be seen as laying down a criminal norm.

Finally, international human rights instruments contain numerous statements of international legal norms the violations of which have never been viewed as criminal in nature. In the circumstances, more is required to deduce a criminal norm from an international human rights instrument. What is so required has been sufficiently stated by the Secretary-General in his report when he observed that 'the international tribunal should apply rules of international humanitarian law which are beyond doubt part of customary law,' as recalled in the dictum of the ICTY Trial Chamber quoted above. Forced marriage simply does not belong among the rules of international humanitarian law which are beyond doubt part of customary international law.

I25 See Prosecutor v Stakic, supra, [ICTY Trial Chamber] paras 720 and 72 I.

I26 Prosecutor v Stakić (Trial Judgment) para 72I. 


\section{Conclusion}

In conclusion, to use the auspices of war to lord a conjugal relationship with a woman against her will is a highly immoral conduct that international law ought to punish as a crime against humanity or war crime. But this statement de lege ferenda is sadly insufficient to make this highly opprobrious conduct an international crime accepted by states as such.

To qualify as an international crime, there needs to be evidence of acceptance of the legal norm in question as crime, coupled with the requisite opinio juris. In the absence of such evidence it does not assist matters for prosecutors and judges of an international criminal court to prosecute and convict anyone of the 'offence' of forced marriage, by conjuring up stilted theories of legality. To do so would be akin to applying a weak band-aid to a deep gash. That gash is the failure of the creators of norms of international law, alluded to at the outset of this study, to provide a range of norms sufficient to address the enduring problem of the special brand of male-inflicted sufferings to which women are perennially subjected during armed conflicts. One such special brand of sufferings is forced marriage.

There is a credible view that the offence of forced marriage is sufficiently addressed by sexual slavery and other enslavement crimes already provided for in international criminal law as crimes against humanity. If that view is correct, it may then be said that there is no gap in international law in relation to protection of women from the evil of forced marriage. But if that view is incorrect and a gap is truly seen to exist in relation to legal protection against forced marriage during armed conflicts, that gap is not sufficiently covered by a denial of its existence, because it is possible to conjure up a judge-made construction that avoids inquiring into the existence of the gap.

In the absence of an international criminal norm forbidding forced marriage, the better course would be for prosecutors and judges of international criminal courts to make a strong recommendation to the international community to create such a norm. Such a recommendation should specifically address the concerns, founded on misapprehensions, that may have prevented the international community from establishing such a norm in the first place. In particular, it is important to make clear that the international criminal norm against forced marriage is wholly capable of limitation to criminal deprivations of liberty directed at women during armed conflicts. Limited as such, there will be no need to fear that parents and communities who give their daughters' hands in arranged marriages will be viewed as outlaws of international criminal law. 


\section{Chapter 8}

\section{Prosecution of Sexual Violence against Women in Post-Conflict Societies}

\section{Introductory: A Question of Choices?}

Two of the main challenges facing conflict-inspired prosecution programmes in (or for) post-conflict societies are invariably these: (a) large numbers of crimes and suspects deserving of prosecution, in the face of limited resources and time to try them all in a regular court of law; and (b) other social reconstruction, rehabilitation and reconciliation needs and projects of ostensibly equally high priority, which necessarily compete with the justice priority for the limited resources and time. ${ }^{\mathrm{I}}$

One consequence of all of this has been the need to have a particularly focused approach to conflict-inspired prosecution programmes in post-conflict societies. This immediately boils down to the question: How is the choice to be made as to who to prosecute?

The evolution of the concern underlying this question now appears to suggest, as an emergent consensus, that the focus of prosecution should rest on 'persons who bear the greatest responsibility' for the crimes committed. It was through the Statute of the Special Court for Sierra Leone (SCSL), ${ }^{2}$ and the Security Council resolution fostering it, ${ }^{3}$ that this notion was first introduced into the lexicon of international criminal law. The next appearance of the concept-or a variant of it - was in the context of the establishment of the Extraordinary Chambers in the Courts of Cambodia for the prosecution of crimes committed during the period of Kampuchea. In the law establishing it, the ECCC was empowered 'to bring to trial senior leaders of Democratic Kampuchea and those who were most responsible for the crimes and serious violations of Cambodian laws related to crimes, international humanitarian law and custom, and international conventions recog-

I See, for instance, an address by Ms Navanethem Pillay, United Nations High Commissioner for Human Rights at the UN Approach to Transitional Justice: Dialogue with Member States on rule of law at the international level organized by the Rule of Law Unit on 2 December 2009.

2 See article I of the Statute of the Special Court for Sierra Leone.

3 See UN Security Council Resolution I3I5 (2000) of I4 August 2000, Doc No S/ $\mathrm{RES} / \mathrm{I}_{315}$ (2000). 
nized by Cambodia, that were committed during the period from I7 April 1975 to 6 January 1979.' ${ }^{4}$

Although not originally part of the language of the constitutive instruments either of the International Criminal Tribunal for the former Yugoslavia in 1993 or of the International Criminal Tribunal for Rwanda in 1994, by the year 2003, however, the idea had crystallised that, for those Tribunals, prosecution strategy was required or encouraged to concentrate only on persons 'who bear the greatest responsibility', or those 'most responsible', for widespread or systematic crimes committed during the relevant periods of armed conflict. In subsequent UN Security Council resolutions relating to the prosecution strategy of the ICTR or ICTY or both, there is a consistent reference to that theme. For instance, in resolution 1503 (2003) initiating the completion strategies of both ICTY and ICTR, the Security Council called upon both Tribunals thenceforth to concentrate 'on the prosecution and trial of the most senior leaders suspected of being most responsible for crimes' within the respective jurisdictions of the two Tribunals. ${ }^{5} \mathrm{~A}$ similar call, also in respect of ICTR and ICTY, is contained in Security Council resolution 1534 (2004). ${ }^{6}$

Notable in the language of Security Council resolutions 1503 (2003) and 1534 (2004) is the shift to the even narrower focus of 'most senior leaders suspected of being most responsible for crimes'. This greatly narrowed focussing is arguably excusable at that point in the lives of ICTY and ICTR, as both Tribunals had been in existence since 1993 and 1994, respectively; hence justifying a 2003 completion strategy that emphasised such a narrow focus. On the other hand, it is notable that in his report on the establishment of the SCSL, the UN SecretaryGeneral correctly suggested that these formulations indicate an orientation (of the choice of accused) towards those in a 'political or military leadership' or 'others in command authority' down a chain of command. 7 That this understanding is suggested in relation to the prosecutorial strategy of the SCSL, may indeed suggest, in turn, that the completion strategy modes of the ICTY and ICTR may be irrelevant to the clear expression of that understanding in the Security Council resolutions 1503 (2003) and 1534 (2004). In other words, the Security Council was, as a matter of first principles, retrofitting an emergent appreciation into the work of the ICTR and ICTY at every opportunity.

In any event, coming in the wake of the requirement upon the SCSL and ECCC to concentrate, from their inception, upon 'persons who bear the great-

4 See article 2 of Law on the Establishment of the Extraordinary Chambers, with inclusion of amendments as promulgated on 27 October 2004 (NS/RKM/roo4/oo6).

5 UN Security Council Resolution $\mathrm{I}_{503}$ (2003) of 28 August 2003, Doc No S/RES/1503 (2003).

6 UN Security Council Resolution 1534 (2004) of 26 March 2004, Doc No S/RES/1534 (2004).

7 UN Security Council, Report of the Secretary General on the Establishment of the Special Court for Sierra Leone, 4 October 2000, Doc No S/2000/915, paras 29-3I, especially at para 30 . 
est responsibility' or those 'most responsible' for crimes committed in the context of armed conflicts, the conclusion appears inescapable that evolving thoughts on conflict-inspired prosecution programmes need to concentrate on persons 'bearing the greatest responsibility' or 'most responsible' for the crimes under consideration.

As indicated earlier, such a narrowing of focus is entirely understandable, in view of the challenges of scope of criminality (demanding prosecutorial attention) amidst the competition for resources and time, engaged by other needs of a society recently emerged from an armed conflict.

When focus is placed on persons 'who bear the greatest responsibility' or those 'most responsible' for conflict-inspired crimes, particularly when such a focus suggests an orientation towards persons in leadership or command positions, the logic of that inquiry tends, in turn, to produce a related focus on certain types of crimes, as commanding greater priority in the prosecution strategy. Here the focus tends to rest on system crimes intrinsically connected to the armed conflicts. Generally, those system crimes are genocide, crimes against humanity and war crimes. Hence, the prosecution strategy tends to rest on prosecuting persons in leadership or chain of command in criminal enterprises involving the commission of genocide, crimes against humanity and war crimes. This may be consciously or subconsciously justified by the fact that the intervention of the United Nations Security Council usually under Chapter VII of the UN Charter, and notably in the case of the creation of ICTR and ICTY, proceeded out of the need to maintain or restore international peace and security. And the system crimes of genocide, crimes against humanity and war crimes, are more readily seen as threats to international peace and security, given expression either in international or internal armed conflicts.

These are system crimes in the sense of certain prerequisite elements that must link them to an armed conflict - involving violent attacks against an aggregation of people. For genocide, the crime in question must have proceeded from the intent to destroy a racial, ethnic, religious or national group in whole or in part ${ }^{8}$ (the focus thus is upon the destruction of a group); for crimes against humanity, the specific criminal conduct must be seen as part of a widespread or systematic attack against $a$ civilian population ${ }^{9}$ (the focus is on attack against a group); and for

8 See article 2(2) of the Statute of the International Criminal Tribunal for Rwanda; article $4(2)$ of the Statute of the International Criminal Tribunal for the former Yugoslavia; article 6 of the Statute of the International Criminal Court. See also article 17 of the 1996 International Law Commission's Draft Code of Crimes against Peace and Security of Mankind. In the Akayesu case, the ICTR held that sexual violence can be an act of genocide, as it fits into the act of 'causing serious bodily or mental harm' to members of a group protected by the Genocide Convention of I948: Prosecutor v Akayesu (Judgment) dated 2 September 1998 [ICTR Trial Chamber] paras, $73 \mathrm{I}^{-} 734$.

9 See article 3 of the ICTR Statute; article 5 of the ICTY Statute; article 7 of the ICC Statute; article 2 of the Statute of the Special Court for Sierra Leone and article I8 of the International Law Commission's Draft Code of Crimes against the Peace and 
war crimes, the specific crime must be seen as bearing a close connection to the armed conflict, in the sense of the 'perpetrator's ability to commit it, his decision to commit it, the manner in which it was committed or the purpose for which it was committed' (as well the focus is on attack against a group). ${ }^{\text {I }}$

Thus understood, any committed crime that fits such a focus would ordinarily be captured within the purview of the post-conflict prosecution programme in question.

\section{The Importance of Sexual Violence Prosecution}

The foregoing considerations notwithstanding, one crime that must command especial attention when committed in the context of an armed conflict is the crime of sexual violence against women. That is to say, sexual violence against women (in peace-time or war) is a truly exceptional evil, by reason of its social, historical and even cultural tenacity and dimensions: as such, efforts aimed at its eradication as an evil must not be constrained by the logic of nexus to armed conflicts. The reasons for this proposition will become readily apparent in the following analysis.

Sexual violence against women is a particular scourge on humanity and is recognised as such by numerous contemporary international documents, including numerous UN resolutions, declarations and reports. ${ }^{\text {II }} 25$ November is dedicated by the UN as International Day for the Elimination of Violence against Women. In February 2008, the UN Secretary-General launched the campaign 'UNiTE to End Violence against Women'. ${ }^{12}$ The campaign to end violence against women has been a foremost thematic issue on the list of priorities of successive UN High Commissioners for Human Rights. This is especially the case with High Commissioner Navi Pillay, who as a judge at the ICTR was widely credited with the Akayesu locus classicus of rape as an act of genocide. There is rarely a public address in which she does not stress the theme of halting violence against women. ${ }^{\mathrm{I3}}$

\section{Security of Mankind.}

Io Prosecutor v Kunarac $\mathcal{F}^{2}$ ors (Judgment) dated I2 June 2002 [ICTY Appeals Chamber] para 58. See also Prosecutor v Tadic (Decision on the Defence Motion for Interlocutory Appeal on Jurisdiction) dated 2 October 1995 [ICTY Appeals Chamber] para 70.

II See generally the discussion in Chapter I under the subheading 'A Legislative Fact Amply Proved.'

I2 See <http://www.un.org/en/women/endviolence/>.

I3 See for instance, UNHCHR Press Statement (I8 December 2009): 'Stop treating Migrants as Second-class Human Beings-Statement by the UN High Commissioner for Human Rights, Navi Pillay, on International Migrants' Day <http://www.huffingtonpost.com/navi-pillay/stop-treating-migrants-as_b_400825. html>; Keynote address by the High Commissioner for Human Rights, Navi Pillay, Human Rights Day, ro December 2009 <http:/www.unhchr.ch/huricane/huricane.nsf/viewor/6E $4844 \mathrm{D}_{43} \mathrm{~B}_{70}{ }_{9} \mathrm{~B}_{5} \mathrm{BC}_{1257688005} \mathrm{FB}_{22} \mathrm{~B}$ ?opendocum ent>; UNHCHR Press Release (8 March 2008): 'Women still face discrimination 
Indeed, often enough misogynistic sexual crimes committed in the context of an armed conflict would satisfy the linkage elements—or fit within the juridical focal range - of the system crimes of genocide, crimes against humanity or war crimes. In many cases, therefore, the prosecution of sexual crimes against women will fit naturally within the general conceptual scheme of a post-conflict prosecution project that is aimed at addressing crimes committed during an armed conflict. There is, however, a chance that a sexual crime may have been committed during an armed conflict, without it fitting neatly within the system crimes indicated above.

This possibility is apparent from the explanation of nexus requirement for war crimes, offered by the Appeals Chamber of the ICTR (populated by the same judges that sit on the Appeals Chamber of ICTY). In view of a point of jurisprudence that any crime committed 'under the guise' of the armed conflict would normally be seen as closely connected to the armed conflict, ${ }^{14}$ the ICTR Appeals Chamber sought in Rutaganda to explain the point. And their explanation is "under the guise of the armed conflict" does not mean simply "at the same time as an armed conflict" and/or "in any circumstances created in part by the armed conflict". For example, if a non-combatant takes advantage of the lessened effectiveness of the police in conditions of disorder created by an armed conflict to murder a neighbour he has hated for years, that would not, without more, constitute a war crime .... ${ }^{15}$ By contrast, the crime is a war crime where combatants took advantage of their military positions of authority to rape individuals whose displacement was an express goal of a military campaign in which they participated. ${ }^{16} \mathrm{But}$ the exclusion articulated by the Appeals Chamber would equally remove from consideration the prosecution of a man who, taking advantage of the diverted attention of the police during an armed conflict, raped a female neighbour he had coveted for years. The question is this: is it right to exclude this case of sexual violence from a post-conflict prosecution programme?

The danger with the Rutaganda explanation is that it may lead to a limitation of the conception of nexus to only positive or direct nexus. It is particularly insightful that the Appeals Chamber alluded to murder and sexual violence, as examples with which to illustrate the limitation at issue. Such limitation may be permissible for murder. Murder is always perceived as the ultimate crime which equally terrorises every member of society, hence its uniform abhorrence by every-

worldwide' <http://www.un.org/apps/news/story.asp?NewsID=25893>, UNHCHR Press Release (23 November 2008): 'Real Equality and End to Impunity Needed to Stop Violence against Women' at <http://www.unhchr.ch/huricane/huricane.nsf/o $/ 76 \mathrm{CIFC}_{\mathrm{I}} 85920 \mathrm{DEB} \mathrm{C}_{125739} \mathrm{Coo}_{34} \mathrm{~A}_{5} \mathrm{AF}$ ?opendocument>, Editorial Opinion by Louise Arbour: 'Impunity for War Crimes against Women' in the Daily Nerws of Egypt (8 March 2008) <http://www.dailystaregypt.com/article.aspx?ArticleID=6025 >.

I4 Prosecutorv Kunarac, supra, para 58.

15 Prosecutor v Rutaganda (Judgment) dated 26 May 2003 [ICTR Appeals Chamber], para 570. 
one who is not an accomplice or sympathiser to the perpetration of the particular murder. The general plague of the terror of murder and the resulting implication of self-interest (or even the corporal fatality of its consequence) have traditionally ensured that policy-makers regard it as a primary evil that must be kept in check at all times. This undoubtedly assists in ensuring that murder remains an aberration, especially in pre- or post-conflict peacetime. As it always has been regarded as a primary evil exercising the anxieties and efforts of every man and woman and policy maker, there may be no great urgency in fearing that society would be so used to it as to permit a post-conflict toleration of it as a new social habit resulting from war.

Such a perpetually aberrant quality of murder gives it a distinguishing quality that may excuse - in respect of it - the theory of positive or direct nexus adumbrated by the ICTR Appeals Chamber in Rutaganda.

In contrast, the theory of positive or direct nexus affords an inadequate formula as regards the crime of sexual violence against women during armed conflicts. The reason is that the high frequency of sexual violence during armed conflicts and in peacetime has made the crime a particular scourge that has plagued humanity through the ages - and continues to plague the international community in modern times. Such high frequency of sexual violence against women resulted, no doubt, from failure of men traditionally to relate to the conduct as an act of terror or of abhorrence-to them-unlike the crime of murder. As recently as 2008, for instance, Ms Louise Arbour, the High Commissioner for Human Rights as she then was, lamented the fact that discrimination against women persists in all countries. According to her: 'Perhaps the most pernicious and dangerous discrimination involves sexual abuse that is not recognized as such under a country's laws, or is in effect tolerated by legislation that is either vague or not enforced. "Rape is recognized as a crime in most legal systems," said Arbour. "But, even when it is, inadequate legislation or local traditions often mean laws are not properly enforced. In addition, at least 53 states still do not outlaw rape within marriage, and men frequently enjoy total impunity for physical as well as sexual violence against their wives." ${ }^{17}$

Quite contrary to the existence in men of a natural impulse for the eradication of sexual violence against women, the high frequency of sexual violence against women has been explained by some Darwinian scholars as an evolutionary tactic that portends advantages to men. ${ }^{18}$ At the barest minimum, it is eminently reasonable to accept that the frequency of sexual violence against women results from a 'general disregard for the bodily integrity of women.' General Ban Ki-Moon correctly observed, 'Most societies prohibit such vio-

I7 See <http://www.un.org/apps/news/story.asp?NewsID=25893>.

I8 R Thornhill and C T Palmer, A Natural History of Rape: Biological Bases of Sexual Coersion [Cambridge, Mass: MIT Press, 200o].

I9 S Brownmiller, Against Our Will: Men, Women and Rape [New York: Simon \& Schuster, 1975] p 37 . 
lence-yet the reality is that too often, it is covered up or tacitly condoned. ${ }^{20}$ An undoubted explanation for such cover-ups or tacit condonation is the fact that sexual violence against women was never seriously considered by the traditionally male policy-makers as a conduct whose elimination is of utmost priority-or even desirable - certainly never at the same degree as murder.

An affective combat against sexual violence against women as an evil requires a composite strategy that necessarily involves a policy of zero-tolerance against the conduct. The policy of zero-tolerance ought to warrant all efforts made to prevent any accretion to the gnarled culture of peacetime or conflict-inspired sexual violence against women. Such accretion may result from failure to prosecute sexual crimes committed against women during armed conflicts, on grounds that they were opportunistic acts of sexual violence not committed by those closely connected to the armed conflicts. The resulting impunity gap naturally fuels the fear of wartime sexual violence becoming peacetime reality for women. ${ }^{2 \mathrm{~T}}$

To prevent this, a circumstantial or indirect theory of nexus must be permitted to allow prosecution of sexual violence against women committed during an armed conflict. Hence, a proper policy of zero tolerance against misogynistic sexual violence ought to bring within the scheme (of post-conflict prosecution of conflict-inspired crimes) sexual violence against women committed by anyone who took advantage of lawlessness resulting from war- or diversion of the attention of the security forces - to commit acts of sexual violence against women during an armed conflict. Hence, it is wholly necessary to accommodate within the post-conflict prosecution strategy the case of the man who, taking advantage of the diverted attention of the police during an armed conflict, raped a woman he had coveted for years.

As indicated earlier, the need for this approach is to close the impunity gap that might result where post-conflict prosecution efforts are limited to sexual violence with clear links to the armed conflicts, notwithstanding that in many instances such crimes would have such links, and may thus be prosecuted without much difficulty. Such an impunity gap becomes particularly odious in view, as will be explained presently, of the potential for the deformation of post-conflict social mores, such as might allow tolerance for sexual violence against women, in a society that had grown so used to such crimes during an armed conflict.

\section{Post-Conflict Social $(\mathrm{Re})$ Engineering as an Objective of the Prosecution Strategy}

In the nature of things, armed conflicts are fiery social upheavals that afford potential and opportunity for undesirable social conducts, such as rape and other

20 UN, Violence against Women Fact Sheet <http://www.un.org/en/women/endviolence/pdf/VAW.pdf>

2I This was the theme of a high-level experts meeting held from 22 to 24 June 2009, under the auspices of UNIFEM. See < http://www.unifem.org/news_events/story_ detail.php?StoryID=894> 
manner of sexual violation of women. This is the case, however brief the period of the armed conflict. And the longer a particular conflict lasts the greater the chances that such undesirable social conducts may solidify into new social norms. Perpetrators, victims and society may become so used to the bad behaviours that such behaviours lose some of their quality of social infamy, with altered perceptions of tolerable normalism. The social process by which armed conflicts generate such ignominious cultural habits very much brings to mind the physical process of formation of igneous rock from molten magma following a volcanic eruption.

With particular reference to sexual violence, the risk of such maladjustment (an incidence of armed conflict) grows larger in societies-and there are many around the world-in which discrimination and violence against women have enjoyed a pre-existent or long history.

From available research literature, the Colombian armed conflict is a case study in this sort of maladjustment of cultural paradigms. There is a general consensus, in published literature, that violence against women has been an endemic feature of the Colombian armed conflict, often perceived as a strategic instrument of war employed by both sides. ${ }^{22}$

In a 2004 report, Amnesty International observed that in the Colombian armed conflict, '[women's] bodies have become a battleground in which the most brutal violence is committed. This has sometimes reached horrific proportions, such as the tearing open of the bellies of pregnant women in order to rip out the foetus. "Don't leave even the seed behind" ("No dejar ni la semilla")—an expression that dates back to the atrocities perpetrated during La Violencia in the I950s but still used today - is a reflection of the extreme cruelty involved. Many men have also been castrated for similar reasons in the context of massacres and selective killings committed during the armed conflict. ${ }^{23}$ Following her $200 \mathrm{I}$ visit to Columbia to investigate and evaluate the impact of the armed conflict on the protection of women's rights, the UN Rapporteur on violence against women and its causes and consequences reported that the conflict 'reproduces and deepens discrimination between the different groups and women suffer intersectional discrimination on the basis of their gender, and their ethnic and cultural origin. Although men are most frequently the victims of summary executions and massacres, violence against women, particularly sexual violence by armed groups, has become a common practice in the context of a slowly degrading conflict and lack of respect for international humanitarian law. ${ }^{24}$

22 See generally, Amnesty International, Colombia: Scarred bodies, hidden crimes-Sexual Violence against Women in the Armed Conflict, Doc No AI Index: AMR 23/040/2004, I3 October 2004. See also Oxfam International, 'Sexual Violence in Colombia: Instrument of War' 9 September 2009.

23 Amnesty International, Colombia: Scarred bodies, hidden crimes-Sexual Violence against Women in the Armed Conflict, supra, p II-I2.

24 United Nations, Report submitted by Ms Radbika Coomaraswamy, Special Rapporteur on violence against women, its causes and consequences: Mission to Colombia ( $\mathrm{I}^{-} 7$ November 200I), E/CN.4/2002/83/Add.3, dated II March 2002, para 42. 
Spanning over half a century, the Colombian armed conflict is one of the longest running armed conflicts in the modern world. By some accounts, the current Colombian civil war is a violent culmination of historical rivalry between forces of conservative and liberal politics in the country. The rivalry dates back to the Igth and 2oth centuries, with flashes of violence along the way. But the genesis of the current violence is traceable to 9 April 1948, with the assassination in Bogota of Jorge Eliécer Gaitán, the dissident Liberal politician and a leading presidential candidate. The assassination 'triggered the Bogotazo, a popular uprising by the Liberal lower classes that resulted in massive destruction and looting' in Bogota that spread throughout the country, pitting Liberal militants against their Conservative opponents and others caught in between. Afraid that the violence might metamorphose into a class-based, Bolshevik-style revolution, the Liberal elites reportedly supported the uncompromising methods employed by the Conservative government to suppress the uprising. ${ }^{25}$ All of this triggered La Violencia of the I950s-a period characterised by a cycle of political violence that ebbed and flowed; with political alliances between Conservative and Liberal elites forged and broken, increasing suspicion and distrust between political factions and social classes. These events eventually snowballed into guerrilla warfare between government forces and variegated bands of armed guerrilla movements operating in rural areas and from deep in the jungles of Colombia. ${ }^{26}$

In 1966, many of these guerrilla movements merged into the Fuerzas Armadas Revolucionarias de Colombia (FARC), which became the main guerrilla movement, alongside lesser known ones such as the Ejército de Liberación Nacional (ELN). In an effort to counter the sustained insurgency of these guerrilla movements, paramilitary forces, mainly organised under the umbrella of the Autodefensas Unidas de Colombia (AUC), were formed in the I970s and I980s to support the government forces. ${ }^{27}$ According to Amnesty International and the Inter-American Commission of Human Rights, these paramilitary forces have continued in existence, although they were, in I989, technically stripped of legitimacy. ${ }^{28}$ Following the breakdown of peace negotiations in February 2002, fighting continued. 'The armed conflict entered a new critical phase with serious consequences for human rights. ${ }^{29}$

25 See Gary Leech, '5o Years of Violence', Colombia Journal (200o) <http://colombiajournal.org/special-reports/fiftyyearsofviolence>

26 See Leech, generally.

27 Amnesty International, Colombia: Scarred bodies, hidden crimes-Sexual Violence against Women in the Armed Conflict, supra, p 7 .

28 Ibid, p 7. See also Organisation of American States, Inter-American Commission of Human Rights, 'Violence and Discrimination against Women in the Armed Conflict in Colombia' Doc No OEA/Ser.L/V/II Doc 67 of i8 October 2006, para 35 .

29 Amnesty International, Colombia: Scarred bodies, hidden crimes-Sexual Violence against Women in the Armed Conflict, supra, p 7 . 
One notable feature of this armed conflict-and the resulting violation of human rights-has been the prevalence of sexual violence against women. According to Oxfam International, 'During the half century of Colombian conflict all armed groups-State military forces, paramilitaries and guerrilla groupshave sexually abused or exploited women, both civilians and women within their own ranks. Women can be direct or collateral victims of different forms of violence as a result of their caring relationships as daughters, mothers, spouses, sisters or friends. ${ }^{\prime \circ}$ The violence is systematic. According to Oxfam, 'Far from being a sporadic occurrence, the use of sexual violence is normal practice that has become an integral part of the armed conflict. ${ }^{3}{ }^{\mathrm{I}}$

As in many parts of the world, the incidence of discrimination and violence against women enjoys a long history in Colombia. ${ }^{32}$ It is this wider historical context of discrimination and sexual violence against women that has made even more invidious the presence of these evils in the Colombian armed conflict. As observed by Amnesty International:

Women and girls in Colombia not only suffer the danger, hardship and suffering inherent in any armed conflict, but have to endure the gender discrimination which is prevalent in many societies around the world, including Colombia. It is this continuum-from domestic- to conflict-related sexual violence-that is particularly corrosive. ${ }^{33}$

30 Oxfam International, 'Sexual Violence in Colombia: Instrument of War' 9 September 2009, p II.

3I Ibid, p I2.

32 As observed by Amnesty International, 'Sexual and gender-based violence is not a new phenomenon in Colombia; it has been a constant in the country's history, and a defining part of the conflict. The conflict has pitted the security forces and armybacked paramilitaries against several guerrilla groups, with each group vying for control of territory and economic resources. Rape, used as a method of torture or a means of injuring the "enemy's honour", has been a common feature of the conflict': Amnesty International, Colombia: Scarred bodies, bidden crimes-Sexual Violence against Women in the Armed Conflict, supra, p 8. Also, recall the observations of the UN Special Rapporteur on violence against women who noted that the conflict 'reproduces and deepens discrimination between the different groups and women suffer intersectional discrimination on the basis of their gender, and their ethnic and cultural origin:' United Nations, Report submitted by Ms Radhika Coomaraswamy, Special Rapporteur on violence against women, its causes and consequences: Mission to Colombia, supra, para 42. See also Organisation of American States, Inter-American Commission of Human Rights, 'Violence and Discrimination against Women in the Armed Conflict in Colombia', supra, paras 3 and $42-46$.

33 Amnesty International, Colombia: Scarred bodies, hidden crimes-Sexual Violence against Women in the Armed Conflict, supra, p io. 
The point was even more elaborately made by the Inter-American Commission of Human Rights (IACHR) of the Organisation of American States in the following compelling way:

The IACHR has repeatedly stated that both civilian men and women in Colombia have their rights violated during the Colombian armed conflict and suffer the worst consequences. However, although both suffer human rights violations and bear the burdens of this conflict, the effects are different for each. The source of this difference is that Colombian women have suffered situations of discrimination and violence because they are women since they were born, and the armed conflict has worsened and perpetuated this history. The violence and discrimination against women is not solely the product of the armed conflictthey are fixtures in the lives of women during times of peace that worsen and degenerate during the internal strife.

Within the armed conflict, all the circumstances that have historically exposed women to discrimination and to receive an inferior treatment, above all their bodily differences and their reproductive capacity, as well as the civil, political, economic and social consequences of this situation of disadvantage, are exploited and manipulated by the actors of the armed conflict in their struggle to control territory and economic resources. A variety of sources, including the United Nations, Amnesty International and civil society organizations in Colombia, have identified, described and documented multiple forms in which the rights of women are infringed upon in the context of the armed conflict, because of their condition as women. ${ }^{34}$

An unfortunate outcome of all of this is the danger of apparent acceptance of these wrongs as part of life in Colombia. In a briefing note late in 2009, Oxfam International observed a tendency within Colombian society to 'accept' sexual violence 'as "normal" ... and many women do not consider themselves victims because they do not know that sexual violence is a crime.' ${ }^{35}$

The length of the Colombian armed conflict, which undoubtedly is partly responsible for this misshapen attitude, compels a certain need for elevated, conscious effort by way of determined social (re)engineering, aimed at correcting any cultural malformation in the manner of diminution of the opprobrium normally associated with sexual violence against women. One way of achieving that would be to accept without equivocation the idea of zero tolerance for sexual violence within the Colombian society. And one concrete way of communicating that message in practice will be to prosecute - as a matter of course-all instances of sexual violence against women committed during that armed conflict. This should cer-

34 Organisation of American States, Inter-American Commission of Human Rights, 'Violence and Discrimination against Women in the Armed Conflict in Colombia', supra, paras 44 and 46 .

35 Oxfam International, 'Sexual Violence in Colombia: Instrument of War', supra, p 2. 
tainly be the case wherever the nexus of the crime to the armed conflict is either direct or indirect.

\section{The Need to Avoid Double Victimisation of Women}

It is not unusual that good intentions turn out quite badly in execution. Prosecution of sexual violence is fraught with such a risk, in the shape of the possibility of double victimisation of the victims through prosecution of the perpetrators. The risk is particularly inherent in how rape is conceived and its prosecution executed, from the perspective of its definition.

A traditional conception of rape in many national jurisdictions hinges upon a view of rape as an act of sex without the consent of the (usually female) victim. A classic example of such a definition was that found in Sexual Offences Act 1956, as amended by the Sexual Offences (Amendment) Act 1976, of the England. Section I(I) of the 1956 Act proscribed rape by the simple provision: 'It is an offence for a man to rape a woman.' But rape was not defined until the 1976 Act which provided:

For the purposes of section I of the Sexual Offences Act 1956 (which relates to rape) a man commits rape if-

(a) he has unlawful sexual intercourse with a woman who at the time of the intercourse does not consent to it; and

(b) at that time he knows that she does not consent to the intercourse or he is reckless as to whether she consents to it;

\section{$[\ldots] \cdot .^{6}[$ Emphasis added. $]$}

That rape was viewed as 'sexual intercourse with a woman who at the time of the intercourse does not consent to it', in due course sparked genuine consent debate regarding whether the legal opprobrium regarding the law of rape should focus on the sex or the violence of the occasion. The relevant discussion in this respect has generally been done in Chapter 3 and need not be repeated. It warrants reiterat-

36 See <http://www.opsi.gov.uk/RevisedStatutes/Acts/ukpga/I976/cukpga_I9760082_ en_I>. This definition of rape was fundamentally altered in 1994, by the Criminal Justice and Public Order Act, section ${ }_{4} 2$ of which now provides the new definition in the following words:

(I) It is an offence for a man to rape a woman or another man.

(2) A man commits rape if-

(a) he has sexual intercourse with a person (whether vaginal or anal) who at the time of the intercourse does not consent to it; and

(b) at the time he knows that the person does not consent to the intercourse or is reckless as to whether that person consents to it.

(3) A man also commits rape if he induces a married woman to have sexual intercourse with him by impersonating her husband.

See <http://www.opsi.gov.uk/acts/actsi994/ukpga_I9940033_en_I6\#ptiI-pbi-ligI42>. 
ing, however, that there are practical consequences in the choice of focus upon the violent circumstances in which rapes are normally committed during armed conflicts, rather than on consent of the victims. To focus the inquiry on the consent of the victim will risk preoccupation with the conduct of the victim. Many victims will find such a forensic spotlight on them so uncomfortable that they may justly feel doubly victimised. This may result in the victims' refusal to cooperate with the prosecution, to the extent of resulting in a failed prosecution. This truly is a recipe for impunity for the perpetrator.

\section{Conclusion}

The need to stamp out both the historical legacy of sexual violence against women and the distorted culture of its acceptance or toleration, induced or encouraged by war, compels a special place for sexual violence as a necessary component of the justice and social reconstruction programme in post-conflict societies. The need for this is accentuated by the constant complaint of inaction levelled against legitimate authorities in the societies involved, with traditionally sexist attitudes, that it behoves them to make determined efforts to prosecute sexual crimes committed.

The sexual crimes to be prosecuted must include those that were committed as an integral part of the armed conflicts, such as where a particular offence was employed as a weapon of the armed conflict or was committed by persons who abused their military positions. Also to be included are crimes committed by persons who took the advantage of the conflict-created lapses in public safety, such as the diverted attention of the security forces, to commit sexual crimes. 
Chile Eboe-0suji - 978-90-04-22722-4 Downloaded from Brill.com $04 / 26 / 2023$ 12:45:46PM via free access 


\section{Chapter 9}

\section{Reparation for Female Victims of Sexual Violence in Armed Conflicts}

'For the innocent victims of such crimes we all feel sympathy, but we feel that sympathy alone is not enough.'

—Lord Dilhorne LC ${ }^{\mathrm{I}}$

\section{Introduction}

The epigraph appearing above comes from a speech made by Lord Chancellor Dilhorne on 7 May 1964, during debates in the UK House of Lords. His reference to 'such crimes' was to crimes of violence, which were the subject of the debates that introduced into that jurisdiction the scheme of compensation for criminal injuries.

What he said then for crimes of violence in general commands even today a heavy weight of persuasion in the matter of the specific crime of sexual violence that women and girls have continued to endure in a rampant way during armed conflicts. Resolutions, reports and other documents ${ }^{2}$ of international bodies abound, saying moving words of sympathy. On their account, one is tempted to the view that a conversion of their sentimental value into money might make

I United Kingdom, 'Compensation for Victims of Crimes of Violence', Parliament, House of Lords, House of Lords Debates (Hansard), HL Deb o7 May ig64 vol 257 CCI35I-I4I9 at I352.

2 A very sampling of such resolutions would include the following among many: UN General Assembly resolution 5I/II5 dated 7 March 1997, Doc No A/RES/5I/II5 (1997); UN General Assembly Resolution 64/I37 dated ir February 2010, Doc No A/ RES/64/137 (2010); UN General Assembly resolution 63/155 dated 30 January 2009, Doc No A/RES/63/I55 (2009); UN General Assembly Resolution 63/159 dated 4 February 2009, Doc No A/RES/63/159 (2009); UN Security Council resolution I325 dated 3I October 2000 Doc No S/RES/r325 (2000); UN Security Council resolution I820 dated I9 June 2008, Doc No S/RES/I820 (2008); UN Security Council resolution I888 dated 30 September 2009, Doc No S/RES/I888 (2009); UN Security Council resolution 1889 dated 5 October 2009, Doc No UN S/RES/r889 (2009); UN Security Council resolution I960 dated I6 December 20I0, Doc No S/RES/ı96o (20Iо); UN General Assembly Third Committee resolution A/C.3/65/L.I7/Rev.2 (20I0) dated 2 November 20Io; African Union, Protocol to the African Charter on Human and Peoples' Rights on the Rights of Women in Africa (2003); African Union, Assembly of Heads of State and Government, Solemn Declaration on Gender Equality in Africa (2004); African Union, African Union Gender Policy (2008); Council of Europe, 'Comprehensive approach to the EU implementation of the United Nations Security Council Resolutions 1325 and 1820 on women, peace and security' dated i December 2008, Doc No 15671/1/08 Rev I. 
the victims almost whole-at least in the sense that the world truly cares. But then, Lord Dilhorne's words remind us that 'sympathy alone is not enough'. And the implication of that reality on the international communal plane is especially sobering, given the virtual absence of conversion of such sympathy into tangible emollients for the tragic experiences of the victims here under consideration.

In terms of popular usage, the word 'reparation' as a legal concept can simply mean compensation - ie payments of money to a victim in consequence of the injury suffered, with the aim of redressing in economic terms the loss occasioned the victim by a crime. That usage of the term appears even in legal documents such as the American Bar Association's Standards for Criminal Justice, ${ }^{3}$ as well as in the US Uniform Victims of Crimes Act ${ }^{4}$ (formerly known as the Uniform Crime Victims Reparation Act).

In the world of international law and policy, however, the word 'reparation' is a generic term with a broader meaning. ${ }^{5}$ This is consistent with the general usage of the word in the Concise Oxford Dictionary predominantly as an action noun meaning: 'I. the act or instance of making amends. 2. (a) compensation. (b) (esp. in $p l$.) compensation for war damage paid by the defeated state. 3. the act or instance of repairing or being repaired.'The universality of its meaning in international law and policy is illustrated by the usage appearing in the International Law Association's Declaration of International Law Principles on Reparation for Victims of Armed Conflict (Substantive Issues) (2010). ${ }^{6}$ In the first paragraph of article I of the Declaration, the root definition of 'reparation' is stated as cov-

3 American Bar Association, Standards for Criminal Justice, 3rd edn (1993), standard I8-3.I5 generally. In standard I8-3.I5(c)(i), for instance, the following pecuniary-oriented meaning appears: 'The sanction [for restitution or reparation] should be limited to the greater of the benefit to an offender or actual loss to identified persons or entities. Claimants seeking general, exemplary, or punitive damages, or asserting losses that require estimation of consequential damages, such as pain and suffering or lost profits, should be limited to their civil remedies.'

4 See generally article 4 appearing under the subtitle of 'reparation'. Notably, article 3 of the same document addresses the matter of 'compensation'. These two provisions are similar in substance, with the difference being that section 305 (under article 3) deals with loss directly linked to personal injury - that is to say, pecuniary redress for 'economic loss directly caused by death or physical, emotional, or psychological injury or impairment'. Section 40I, on the other hand, (under article 4) accommodates a more extended meaning, in the terms of 'economic loss caused to a person by the crime', including loss of property [emphases added.]

5 See, for instance, Federico Ortino, 'Reparation and other remedies in international law, in Peter Cane and Joanne Conaghan, The New Oxford Companion to Law [Oxford: Oxford University Press Inc, Oxford Reference Online] accessed 3 January 2oII: www.oxfordreference.com/views/ENTRY.html?subview=Main\&entry=t287. eI868

6 International Law Association, Resolution 2/2010 adopted at the 74th Conference of the International Law Association, held at The Hague, The Netherlands, 15-20 August 20Io. 
ering 'measures that seek to eliminate all the harmful consequences of a violation of rules of international law applicable in armed conflict and to re-establish the situation that would have existed if the violation had not occurred.' 7 And, in the second paragraph of article I, the particular measures serviced by the term 'reparation' are specified as 'restitution, compensation, satisfaction and guarantees and assurances of non-repetition, either singly or in combination. ${ }^{8}$ Restitution is indicated as consisting of measures that restore the status quo existing prior to the injury ${ }^{9}$; compensation deals with pecuniary payments; ${ }^{\text {:0 }}$ satisfaction entails acknowledging responsibility, expressing sincere regrets and formally tendering meaningful apology $\mathrm{y}^{\mathrm{II}}$; and offering guarantees and assurances of non-repetition is an expression of obvious meaning. ${ }^{\mathrm{I}}{ }^{2}$

The ILA definition is a synthesis of meanings of reparation appearing in earlier international documents from UN sources, such as the General Assembly, the Economic and Social Council, the Commission on Human Rights, and the International Law Commission. The earliest of these instruments, the International Law Commission's draft articles on the Responsibility of States for Internationally Wrongful Acts (200I), provides as follows: 'Full reparation for the injury caused by the internationally wrongful act shall take the form of restitution, compensation and satisfaction, either singly or in combination ...'. ${ }^{13}$ Similarly, in the Basic Principles and Guidelines on the Right to a Remedy and Reparation for Victims of Gross Violations of International Human Rights Law and Serious Violations of International Humanitarian Law (2005) - as adopted in identical terms by the UN General Assembly, ${ }^{14}$ the UN Economic and Social Council, ${ }^{15}$ and the Commission on Human Rights, ${ }^{16}$ - included within the notion of 'full

$7 \quad$ See article $\mathrm{I}(\mathrm{I})$.

8 See $\operatorname{article} \mathrm{I}(2)$.

9 According to article 7: 'Restitution consists of measures that re-establish the situation which existed before the violation of rules of international law applicable in armed conflict occurred.'

Io According to article 8: 'Compensation covers any financially assessable damage.'

II In the words of article 9: 'I. Satisfaction may consist in an acknowledgement of the breach, an expression of regret, a formal apology or another appropriate modality. 2. Satisfaction shall not be out of proportion to the harm.'

I2 According to article ro: 'The responsible party is under an obligation to offer appropriate assurances and guarantees of non-repetition, if circumstances so require.'

I3 See article 34 of the ILC Draft Articles on the Responsibility of States for Internationally Wrongful Acts. See annex to General Assembly resolution 56/83 of I2 December 200I, Doc No A/RES/56/83 (200I) and corrected by document A/56/49(Vol. I)/Corr. 4 .

I4 See General Assembly resolution General Assembly resolution 60/I47 of 16 December 2005, Doc No A/RES/60/247 (2005).

I5 See UN ECOSOC resolution 2005/30 adopted on 25 July 2005 .

I6 See UN Commission on Human Rights resolution 2005/35 adopted on I9 April 2005 . 
and effective reparation' are 'restitution, compensation, rehabilitation, satisfaction and guarantees of non-repetition. ${ }^{\mathrm{T}} \mathrm{T}$

The UN Basic Principles and Guidelines is more expansive in the meanings it ascribes to restitution, ${ }^{18}$ compensation, ${ }^{19}$ satisfaction, ${ }^{20}$ and guarantees of nonrepetition. ${ }^{21}$ Additionally, it very usefully recognises 'rehabilitation' as a distinct

I7 See common paragraph i8.

I8 Paragraph i9 provides: 'Restitution should, whenever possible, restore the victim to the original situation before the gross violations of international human rights law or serious violations of international humanitarian law occurred. Restitution includes, as appropriate: restoration of liberty, enjoyment of human rights, identity, family life and citizenship, return to one's place of residence, restoration of employment and return of property.'

I9 Paragraph 20 provides: 'Compensation should be provided for any economically assessable damage, as appropriate and proportional to the gravity of the violation and the circumstances of each case, resulting from gross violations of international human rights law and serious violations of international humanitarian law, such as: (a) Physical or mental harm; (b) Lost opportunities, including employment, education and social benefits; $(c)$ Material damages and loss of earnings, including loss of earning potential; $(d)$ Moral damage; $(e)$ Costs required for legal or expert assistance, medicine and medical services, and psychological and social services.'

20 Paragraph 22 provides: 'Satisfaction should include, where applicable, any or all of the following: (a) Effective measures aimed at the cessation of continuing violations; (b) Verification of the facts and full and public disclosure of the truth to the extent that such disclosure does not cause further harm or threaten the safety and interests of the victim, the victim's relatives, witnesses, or persons who have intervened to assist the victim or prevent the occurrence of further violations; $(c)$ The search for the whereabouts of the disappeared, for the identities of the children abducted, and for the bodies of those killed, and assistance in the recovery, identification and reburial of the bodies in accordance with the expressed or presumed wish of the victims, or the cultural practices of the families and communities; $(d)$ An official declaration or a judicial decision restoring the dignity, the reputation and the rights of the victim and of persons closely connected with the victim; (e) Public apology, including acknowledgement of the facts and acceptance of responsibility; $(f)$ Judicial and administrative sanctions against persons liable for the violations; $(g)$ Commemorations and tributes to the victims; ( $h$ ) Inclusion of an accurate account of the violations that occurred in international human rights law and international humanitarian law training and in educational material at all levels.'

2I Paragraph 23 provides: 'Guarantees of non-repetition should include, where applicable, any or all of the following measures, which will also contribute to prevention: (a) Ensuring effective civilian control of military and security forces; (b) Ensuring that all civilian and military proceedings abide by international standards of due process, fairness and impartiality; $(c)$ Strengthening the independence of the judiciary; $(d)$ Protecting persons in the legal, medical and health-care professions, the media and other related professions, and human rights defenders; (e) Providing, on a priority and continued basis, human rights and international humanitarian law education to all sectors of society and training for law enforcement officials as well as military and security forces; $(f)$ Promoting the observance of codes of conduct and ethical norms, 
and specific form of reparation. This is defined as including 'medical and psychological care as well as legal and social services. ${ }^{22}$

From the days of Nuremberg trials to the modern era of international law, currently symbolised by the International Criminal Court, international law and policy have been chiefly preoccupied with punitive justice, focusing on the individual criminal responsibility of the perpetrators. That preoccupation was understandably inspired by a long-standing reality of impunity enjoyed all along by violators of humanitarian norms. With the ascendancy of a new norm of accountability for violation of humanitarian norms - in the era of International Criminal Tribunal for the former Yugoslavia, International Criminal Tribunal for Rwanda, Special Court for Sierra Leon, Extraordinary Chamber in the Courts of Cambodia, etc, and, of course, the International Criminal Court—-there is now a particular need for attention shift towards restorative justice, focusing on the victims of those violations.

As has been noted elsewhere in this study, a perpetual class of victims of these violations is comprised by women and girls; in virtue of the sexual violations that they almost always suffer in any armed conflicts. The purpose of the discussion in the following pages is to examine the normative bases for reparation in their behalf.

\section{The Theoretical Bases for Reparation}

The plight of women and girl victims of sexual violence in the armed conflicts that have blighted the Democratic Republic of the Congo in its recent history provides a case study in the lethargy endured by the idea of reparation for victims of armed conflict as an emerging norm in international law and policy. Despite a generally acknowledged need for a reparation programme, movement towards its realization has been firmly stuck on the launch pad, despite the spirited and good faith

in particular international standards, by public servants, including law enforcement, correctional, media, medical, psychological, social service and military personnel, as well as by economic enterprises; $(g)$ Promoting mechanisms for preventing and monitoring social conflicts and their resolution; $(b)$ Reviewing and reforming laws contributing to or allowing gross violations of international human rights law and serious violations of international humanitarian law.' 
efforts of concerned UN entities and NGOs. ${ }^{23}$ Similar inertia has been reported as regards post-conflict reparation programme in Sierra Leone. ${ }^{24}$

The difficulty that these reparation initiatives have encountered is perhaps explained, at least in part, by the confusion resulting from the absence of a rational, clear and coherent articulation of the theoretical basis for the desired norm. Illustrative of the confusion is the query from a former President of the Special Court for Sierra Leone. During the course of the oral hearings in the appeal in the case of Brima, Sesay and Kanu v Prosecutor, Judge King found occasion to note that certain NGOs had been reported in the press that morning as demanding that the Government of Sierra Leone should make reparation to female victims of sexual violence during the Sierra Leone civil war. Judge King wondered aloud about the basis upon which the Government should be held responsible to make the urged reparation. ${ }^{25}$ Without a doubt, this visceral reaction has a discernible basis in the law regarding the principle of fault. An old case of note in this connection is The Jamaica Case arbitrated by the Mixed Claim Commission established under the Jay Treaty of $1794 .{ }^{26}$ The United States was a neutral party in in the war between

23 See, for instance, United Nations, Office of the High Commissioner for Human Rights, 'Report of the Panel on Remedies and Reparations for Victims of Sexual Violence in the Democratic Republic of Congo to the High Commissioner for Human Rights' (March 20II), generally. See also the interview of Ms Kyung-wha Kang, the Deputy High Commissioner for Human Rights, as part of the efforts of a high level panel convened by the UN High Commissioner for Human Rights to explore the question of reparation for victims of sexual violence in the Democratic Republic of Congo. As she observed: 'There is indeed a tremendous need and a clear call from the victims themselves for more assistance and reparation. Some things are being provided but it is very ad hoc the more you go into the remote rural areas there is almost absolutely nothing. Their lives have been largely destroyed, they suffer greatly, physically, mentally, materially, and this victimization is compounded by the stigma that they have to suffer not just in families but in communities.' Available at www.unmultimedia.org/tv/unifeed/d/r6i88.html. See also www.youtube.com/ watch? $=\mathrm{UbGwFWiiFeM}$.

24 See Jamesina King, 'Gender and Reparations in Sierra Leone: The Wounds of War Remain Open' in Ruth Rubio-Marín (ed), What Happened to Women? Gender and Reparations for Human Rights Violations [New York: Social Science Research Council, 2006], pp 246 et seq. The lack of implementation of the post-conflict reparation programme in Sierra, generally reported by Ms King in her 2006 assessment, was an observation more recently made by Ms Brenda Hollis in her capacity as the Prosecutor of the Special Court for Sierra Leone, when she was reported to have 'deplor[ed] lack of assistance to victims', in a lecture at The Hague on I7 November 20I0: see <www.haguejusticeportal.net/smartsite.html?id=I2284>.

25 The present author was one of prosecution appeals counsel appearing before the SCSL Appeals Chamber during the proceedings of I2 to I4 November 2007, when Judge King made the interjection in question.

26 The Jamaica Case (1798) 4 Int Arb MS 489 [Jay Treaty Mixed Claim Commission]. See Bin Cheng, General Principles of Law: as Applied by International Courts and Tribunals [Cambridge: Cambridge University Press, 1994] 218. See also J H W 
England and France. But a French privateer, who had been originally armed and equipped in the United States, burnt The Jamaica, a British vessel, on the high seas. In a claim brought by England against the United States under the Jay Treaty, the two American Commissioners, as the majority, found that the case did not fall for determination under the terms of the Treaty. They were thus left to consider it under customary international law. In that regard, the concluded that responsibility depended on fault on the part of the United States. In dismissing the claim on this ground, they wrote as follows:

According to principles of justice, on which is founded the law of nations, no government can be liable to compensate for an injury which they did not commit, or for not preventing a loss when out of their power to prevent it, or for not using means in their power to restore property wrongfully taken, when such property never came within the reach of those means ....

Indeed nothing could be more incongruous with the principles of justice, as well as with the laws of nations, than to render an individual or government under an obligation to restore that which was never in his power to restore, or under such circumstances to compensate for not restoring it, when the loss arose without the smallest fault imputable to such government or individual....

Where there is no fault, no omission of duty, there can be nothing whereupon to support a charge of responsibility or justify a complaint. ${ }^{27}$

Evidently, then, Judge King's angst about the basis upon which the Government of Sierra Leone might have been required to compensate women victims of sexual violence during the Sierra Leone armed conflict does engage a legitimate legal question. It is, nevertheless, symptomatic of what Ms Rashida Manjoo, UN Special Rapporteur on Violence against Women, Its Causes and Consequences, observed as the lack of 'a coherent theory' of reparation in international law $^{28}$ and lack of clarity as to the 'content of the obligation to provide reparations, ${ }^{29}$ despite increasing recognition of the right to remedy. ${ }^{30}$ That question affords a good point of departure for the discussion here.

Verzijl, International Law in Historical Perspective, vol X [Sijthoff \& Noordhoff: Alphen Aan Den Reijn, 1979] at pp 56-57 and 148.

Ibid.

28 United Nations, Human Rights Council, 'Report of the Special Rapporteur on Violence against Women, Its Causes and Consequences, Rashida Manjoo' dated I9 April 2oro, Doc No A/HRC/I4/22, para I3. See also Frederic Megret, 'Justifying Compensation for the International Criminal Court's Trust Fund for Victims: Lessons from Domestic Compensation Schemes' (2010) 36 Brooklyn Journal of International Law I23.

29 United Nations, Human Rights Council, 'Report of the Special Rapporteur on Violence against Women, Its Causes and Consequences, Rahida Manjoo', supra, para I4.

Ibid, para $\mathrm{I} 3$. 
In international law and policy, there are, broadly speaking, two trains of theoretical analysis by which one can travel to the desired reparation destination. One is a fault-based analysis; the other entails a no-fault analysis. It is possible to say from the outset that, as a practical matter, a full and effective reparation norm must depend on the readiness of the party insisting upon a rational basis for reparation to accept that both sets of analysis can simultaneously sustain the reparation norm. In other words, the fault-based analysis and the no-fault analysis are not mutually exclusive in particular cases. As will be seen later, it is easy enough to conceptualise the no-fault rationale as the default basis for reparation. It is, however, not advisable to discard the fault-based rationale in the proper case. The fault-based analysis is eminently sensible and entirely salutary-nay, necessary - in some instances. For one thing, it helps in the realization of the right to the truth enjoyed by the victim and the community. Hence, in the cases in which it is appropriate to invoke the fault-based analysis, there will be a high juristic and social value for insisting that the dictum of that analysis be brought to bear.

There are, however, instances in which the fault-based theory may leave the victim bereft of reparation. This is particularly so in those cases in which fault for the impugned harm lies with a party out of reach or out of pocket to make reparation. The overriding concern may then be the need to ensure that the victim benefits from reparation, regardless of fault. It is for that reason that both the fault-based and the no-fault rationales must remain simultaneously in play as serviceable bases for reparation in every case. We will next take a closer look at the rationales.

\section{(i) The Fault Basis for Reparation}

The fault-based theory of reparation begins with the proposition that victims of human rights violations have a right to full and effective remedy. This is a proposition that has received increasing acceptance in international law and policy. ${ }^{3 \mathrm{~T}}$ A renowned scholar in this area of international law and policy is Professor Theo van Boven. He had observed as follows: 'As the result of an international normative process the legal basis for a right to a remedy and reparation became firmly anchored in the elaborate corpus of international human rights instruments, now widely ratified by States.' ${ }^{2}$

3I See United Nations, Human Rights Council, 'Report of the Special Rapporteur on Violence against Women, Its Causes and Consequences, Rashida Manjoo', supra, para I3.

32 Theo van Boven, 'Victims' Rights to a Remedy and Reparation: The New United Nations Principles and Guidelines' in Carla Ferstman et al (ed), Reparations for Victims of Genocide, War Crimes and Crimes Against Humanity: Systems in Place and Systems in the Making [Leiden: Brill, 2009] p 2I. 


\section{Regarding Chorzórw Case as a Reference for Reparation}

In the legal discourse on reparation (for human rights and international humanitarian law violations) one often encounters an invocation of the Case Concerning the Factory at Chorzów $w^{33}$ as the classic international judicial authority for the right to reparation. This, it is submitted, requires some caution: for a closer look would suggest that the emphasis on Chorzórw Factory might indeed be misplaced as regards the evolution of the right to reparation for violations of international human rights and humanitarian norms. The case concerned a claim of diplomatic protection for expropriation of the interests of the corporate citizen of a foreign State, at a time when States alone were the generally accepted subjects of international law. Concomitantly, at the time, respect for human rights had not been declared as a fundamental international norm. ${ }^{34}$

The Chorzów Factory Case was decided by the Permanent Court of International Justice in September 1928 - twenty years before the adoption of the Universal Declaration of Human Rights in December 1948. It arose out of events connected to the terms of the Peace Treaty signed in Versailles in I9I9 to end World War I. According to that treaty, certain territories were to be transferred from Germany to the Allied and Associated Powers. The statuses of certain other erstwhile German territories were to be settled by plebiscites. Poland was an Associated Allied Power that famously benefited from this new order of European topography. The region of Chorzów was ceded to it.

The Government of Poland had, by a 1922 decree, expropriated the land and other interests belonging to the German companies, Oberschlesische Stickstoffwerke AG and Bayerische Stickstoffwerke AG, which respectively owned and operated a nitrates manufactory at Chorzów.

[Of interest in the narrative, perhaps, was how the factory ended up in the ownership of the companies. It happened as follows. In March 1915, the German Government contracted the Bavarian company Bayerische Stickstoffwerke AG to build and manage the nitrates factory at Chorzów, on behalf of the Government. In December I9I9, a new company, Oberschlesische Stickstoffwerke AG, was formed in Berlin and the German Government sold its interest in the Chorzów factory to this new company. But the management of the factory remained with Bayerische Stickstoffwerke AG, who had intellectual proprietary interests in the resulting management know-how.]

33 Case Concerning the Factory at Chorzów (Claim for Indemnity) (Merits) (Germany v Poland), 1928, Judgment No I8, PCIJ, Series A, No I7.

34 The late Sir Ian Brownlie has observed that the first appearance of the terminology 'human rights' in an international instrument was in the Charter of the United Nations (1945): see Ian Brownlie, Principles of Public International Law, 7 th edn [Oxford: Oxford University Press, 2008] p 555. 
Exercising its right of diplomatic protection in respect of the company, Germany protested the 1922 Polish expropriation as inconsistent with the terms of the Treaty of Versailles. A key issue therefore was whether the factory and the management know-how belonged to Germany or were the private property of the companies.

The lis must be appreciated against the background of the construction of two provisions of the Treaty of Versailles relating to the right of expropriation granted Allied and Associated Powers. That right was granted under article 297, which, in part, provided as follows:

(b) Subject to any contrary stipulations which may be provided for in the present Treaty, the Allied and Associated Powers reserve the right to retain and liquidate all property, rights and interests belonging at the date of the coming into force of the present Treaty to German nationals, or companies controlled by them, within their territories, colonies, possessions and protectorates including territories ceded to them by the present Treaty....

But the proviso indicated in the opening phrases of article $297(\mathrm{~b})$ brought into play the provisions of article 92, which appeared to make certain exceptions in respect of Poland as regards private property of German nationals. In the relevant part, article 92 provided as follows:

... In all the German territory transferred in accordance with the present Treaty and recognised as forming definitively part of Poland, the property, rights, and interests of German nationals shall not be liquidated under Article 297 by the Polish Government except in accordance with the following provisions:

(I) The proceeds of the liquidation shall be paid direct to the owner;

(2) If on his application the Mixed Arbitral Tribunal provided for by Section VI of Part X (Economic Clauses) of the present Treaty, or an arbitrator appointed by that Tribunal, is satisfied that the conditions of the sale or measures taken by the Polish Government outside its general legislation were unfairly prejudicial to the price obtained, they shall have discretion to award to the owner equitable compensation to be paid by the Polish Government.....

Thus, it appeared, the expropriation right granted to Allied and Associated Powers did not extend, in respect of Poland, to the right to expropriate private property of German nationals and those of companies controlled by them. And under the Convention concerning Upper Silesia, signed in Geneva in May 1922, implementing the Treaty of Versailles in respect of Poland and Germany, Poland was entitled to appropriate German interests, with the view to offsetting Germany's reparation obligations to the victorious Allies. [As noted earlier in the OED definition of the word 'reparation' especially in the plural usage, in classical international law, a vanquished State was required to pay reparations (meaning compensation) to the victorious State(s).] However, as also provided for in article 92 of the Treaty of Versailles, excepted from Poland's expropriation rights in Upper Silesia were 
proprietary interests of German nationals or those of companies controlled by them. Notably, article 6 of the Geneva Convention of 1922 provided that 'Poland may expropriate in Upper Silesia major industrial takings, conformably to the provisions of Articles 7 to 23 of the Convention; but that, with this exception, the property, rights and interests of German nationals, or of companies controlled by them, cannot be liquidated. ${ }^{35}$

In their judgment, the PCIJ held that the proprietary interests in question were those of the companies; and that Poland's expropriation was thus in violation of international law and inconsistent with the applicable treaties. Notably, the Court had observed in a related case ${ }^{36}$ that expropriation is 'a derogation from the rules generally applied in regard to the treatment of foreigners and the principle of respect for vested rights.'It is in the context of this finding that the PCIJ famously made the following statement (now frequently quoted in humanitarian law and human rights reparation literature): 'it is a principle of international law, and even a general conception of law, that the breach of an engagement involves an obligation to make reparation in an adequate form. ${ }^{37}$ This dictum is, of course, a classic support in international law for the proposition that there can be no expropriation without full compensation.

Also notable, and equally of interest to the discourse of reparation in the context of human rights and humanitarian law, is the Court's view of the extent of reparation that may be considered 'reparation in adequate form'. According to the Court: 'The essential principle contained in the actual notion of an illegal act-a principle which seems to be established by international practice and in particular by the decisions of arbitral tribunals - is that reparation must, as far as possible, wipe out all the consequences of an illegal act and reestablish the situation which would, in all probability, have existed if that act had not been committed. ${ }^{38}$

Thus, on a large and liberal view, particular on an isolated reading of the passages quoted above, it is tempting to associate the Chorzów Factory Case with the evolution of the right to reparation for violations of human rights and humanitarian norms. However, the circumstances of the case, the cause in it, and the very pronouncements of the Court itself combine into a ratio decidendi that would make that association a rather tenuous one. The reason is not only, as pointed out earlier, that the case was decided in an era when international law held no selfpropelling value to human beings as subjects of international law. But perhaps, more importantly, the Court's own several observations virtually emasculate the case of any valuable application to the human rights field. This resulted from a sort of preliminary question that the Court was called upon to decide. The question involved the nature of the dispute as regards the very question of reparation.

35 Case Concerning the Factory at Chorzów (Claim for Indemnity) (Jurisdiction) (Germany v Poland), 1927, Judgment No 8, PCIJ, Series A, No 9, at p I3.

36 Case Concerning Certain German Interests in Upper Silesia (Merits), I926, Judgment No 7, PCIJ, Series A, No 7, at p 22.

37 Chorzów Factory (Merits), ibid, p 29.

$3^{8} \quad$ Ibid, p 47. 
At some point in the oral arguments, the parties got into a tangle as to whether Germany had brought the claim in her own right as a State, or whether she was acting merely as an agent for the two companies, given that the damage they suffered in the expropriation was being used as the measure of reparation. In her submission, Germany contended that the dispute was 'a dispute between governments and nothing but a dispute between governments. ${ }^{3} 9$ The Court agreed. In particular, the Court observed that the matter before it was 'exclusively a dispute between States as to the interpretation and application of a convention in force between them.'40 And it is quite normal in this sort of interstate litigation to measure the reparation to the aggrieved State by reference to the damage suffered by her citizens..$^{41}$ Making sure that the Court's assumption of jurisdiction to decide the question of reparation upon which the parties had joined issues was to be understood in the particular context of an interstate litigation, the Court made a series of very interesting pronouncements. Among them were the following:

The Court in fact declared itself competent to pass upon the claim for reparation because it regarded reparation as the corollary of the violation of the obligations resulting from an engagement between States. ${ }^{42}$ [Emphasis added.]

\section{$[\ldots]$}

It was on the basis, among other things, of the purely interstate character of the dispute ... that the Court reserved the case for judgment, notwithstanding that the actions brought by the two Companies were pending before one of the arbitral tribunals [for private claims]. ${ }^{43}$ [Emphases added.]

And, as if it was issuing a disclaimer against future use of the judgment in the context of violation of vested rights of human beings, the Court said as follows:

The rules of law governing the reparation are the rules of international law in force between the two States concerned, and not the law governing relations between the State which has committed a wrongful act and the individual who has suffered damage. Rights or interests of an individual the violation of which rights causes damage are always in a different plane to rights belonging to a State, which rights may also be infringed by the same act. The damage suffered by an individual is never therefore identical in kind with that which will be suffered by a State; it can only afford a convenient scale for the calculation of the reparation due to the State.

\footnotetext{
39 Ibid, p 26.

$40 \quad$ Ibid, $\mathrm{p} 27$.

4I Ibid, pp 27-28.

42 Ibid, p 27.

43 Ibid.
} 
International law does not prevent one State from granting to another the right to have recourse to international arbitral tribunals in order to obtain the direct award to nationals of the latter State of compensation for damage suffered by them as a result of infractions of international law by the first State. But there is nothing-either in the terms of Article 23 or in the relation between this provision and certain others of a jurisdictional character included in the Geneva Conventionwhich tends to show that the jurisdiction established by Article 23 extends to reparation other than that due to one of the contracting Parties to the other in consequence of an infraction of Articles 6 to 22, duly recognised as such by the Court. ${ }^{44}$ [Emphasis added.]

In view of the foregoing, the idea of reparation for violation of human rights and humanitarian law norms is clearly attributed an improbable provenance in the ratio decidendi of the Chorzów Factory Case.

\section{Other Juristic Anchors for Reparation for Human Rights Violations}

The point in the foregoing discussion is not, of course, to be understood as questioning the otherwise correct view that the right to reparation for violation of human rights and humanitarian norms is now firmly anchored in international law. That firm anchor is not to be seen in the Chorzów Factory Case. It is to be seen rather in what Professor Van Boven correctly described as 'the elaborate corpus of international human rights instruments, now widely ratified by States'. The elaborate corpus of instruments in question includes the following international and regional instruments: the Universal Declaration of Human Rights, ${ }^{45}$ the International Covenant on Civil and Political Rights, ${ }^{46}$ the International Convention on the Elimination of All Forms of Racial Discrimination, ${ }^{47}$ the Convention on the Elimination of All Forms of Discrimination against Women, ${ }^{48}$

44 Ibid, p 28.

45 Article 8: 'Everyone has the right to an effective remedy by the competent national tribunals for acts violating the fundamental rights granted him by the constitution or by law.'

46 Article 2(3): 'Where not already provided for by existing legislative or other measures, each State Party to the present Covenant undertakes to take the necessary steps, in accordance with its constitutional processes and with the provisions of the present Covenant, to adopt such other measures as may be necessary to give effect to the rights recognized in the present Covenant.'

47 Article 6: 'States Parties shall assure to everyone within their jurisdiction effective protection and remedies, through the competent national tribunals and other State institutions, against any acts of racial discrimination which violate his human rights and fundamental freedoms contrary to this Convention, as well as the right to seek from such tribunals just and adequate reparation or satisfaction for any damage suffered as a result of such discrimination.'

48 Article 2(c): 'States Parties condemn discrimination against women in all its forms, agree to pursue by all appropriate means and without delay a policy of eliminating 
the Convention against Torture and other Cruel, Inhuman or Degrading Treatment or Punishment, ${ }^{49}$ and the Convention on the Rights of the Child, ${ }^{50}$ the Statute of the International Criminal Court, ${ }^{5 \mathrm{I}}$ the International Convention for the Protection of All Persons from Enforced Disappearance, ${ }^{52}$ the International Convention on the Protection of the Rights of All Migrant Workers and Members

discrimination against women and, to this end, undertake: ... To establish legal protection of the rights of women on an equal basis with men and to ensure through competent national tribunals and other public institutions the effective protection of women against any act of discrimination; .....

49 Article I4: '(I) Each State Party shall ensure in its legal system that the victim of an act of torture obtains redress and has an enforceable right to fair and adequate compensation including the means for as full rehabilitation as possible. In the event of the death of the victim as a result of an act of torture, his dependents shall be entitled to compensation. (2) Nothing in this article shall affect any right of the victim or other person to compensation which may exist under national law.'

50 Article 39: 'States Parties shall take all appropriate measures to promote physical and psychological recovery and social reintegration of a child victim of: any form of neglect, exploitation, or abuse; torture or any other form of cruel, inhuman or degrading treatment or punishment; or armed conflicts. Such recovery and reintegration shall take place in an environment which fosters the health, self-respect and dignity of the child.'

5I Article 75: '(I) The Court shall establish principles relating to reparations to, or in respect of, victims, including restitution, compensation and rehabilitation. On this basis, in its decision the Court may, either upon request or on its own motion in exceptional circumstances, determine the scope and extent of any damage, loss and injury to, or in respect of, victims and will state the principles on which it is acting. (2) The Court may make an order directly against a convicted person specifying appropriate reparations to, or in respect of, victims, including restitution, compensation and rehabilitation. Where appropriate, the Court may order that the award for reparations be made through the Trust Fund provided for in article 79 ...'

52 Article 24: '(I) For the purposes of this Convention, "victim" means the disappeared person and any individual who has suffered harm as the direct result of an enforced disappearance. (2) Each victim has the right to know the truth regarding the circumstances of the enforced disappearance, the progress and results of the investigation and the fate of the disappeared person. Each State Party shall take appropriate measures in this regard. (3) Each State Party shall take all appropriate measures to search for, locate and release disappeared persons and, in the event of death, to locate, respect and return their remains. (4) Each State Party shall ensure in its legal system that the victims of enforced disappearance have the right to obtain reparation and prompt, fair and adequate compensation. (5) The right to obtain reparation referred to in paragraph 4 of this article covers material and moral damages and, where appropriate, other forms of reparation such as: (a) Restitution; (b) Rehabilitation; (c) Satisfaction, including restoration of dignity and reputation; (d) Guarantees of non-repetition.' See also articles 8(2) and $20(2)$. 
of Their Families, ${ }^{53}$ the European Convention on Human Rights, ${ }^{54}$ the American Convention on Human Rights, ${ }^{55}$ and the Protocol to the African Charter on Human and Peoples' Rights on the Rights of Women in Africa. ${ }^{56}$

It is also notable that in interpreting article 2(3) of the ICCPR (which requires States Parties to 'to give effect to the rights recognized in the present Covenant', the Human Rights Committee has held that article 2(3) 'requires that States Parties make reparation to individuals whose Covenant rights have been violated. Without reparation to individuals whose Covenant rights have been violated, the obligation to provide an effective remedy, which is central to the efficacy of Article 2, paragraph 3, is not discharged'. ${ }^{57}$

As it has become customary to see provisions on the right to effective remedy or reparation in these instruments, it is easy to accept that the right to reparation is now something of customary norm in international law.

53 Article 83: 'Each State Party to the present Convention undertakes: (a) To ensure that any person whose rights or freedoms as herein recognized are violated shall have an effective remedy, notwithstanding that the violation has been committed by persons acting in an official capacity; (b) To ensure that any persons seeking such a remedy shall have his or her claim reviewed and decided by competent judicial, administrative or legislative authorities, or by any other competent authority provided for by the legal system of the State, and to develop the possibilities of judicial remedy; (c) To ensure that the competent authorities shall enforce such remedies when granted.'

54 Article 13: 'Everyone whose rights and freedoms as set forth in this Convention are violated shall have an effective remedy before a national authority notwithstanding that the violation has been committed by persons acting in an official capacity.'

55 Article 25: '(I) Everyone has the right to simple and prompt recourse, or any other effective recourse, to a competent court or tribunal for protection against acts that violate his fundamental rights recognized by the constitution or laws of the state concerned or by this Convention, even though such violation may have been committed by persons acting in the course of their official duties. (2) The States Parties undertake: (a) to ensure that any person claiming such remedy shall have his rights determined by the competent authority provided for by the legal system of the state; (b) to develop the possibilities of judicial remedy; and (c) to ensure that the competent authorities shall enforce such remedies when granted.' See also article 63(I): 'If the Court finds that there has been a violation of a right or freedom protected by this Convention, the Court shall rule that the injured party be ensured the enjoyment of his right or freedom that was violated. It shall also rule, if appropriate, that the consequences of the measure or situation that constituted the breach of such right or freedom be remedied and that fair compensation be paid to the injured party.'

56 Article 25: 'States Parties shall undertake to: (a) provide for appropriate remedies to any woman whose rights or freedoms, as herein recognised, have been violated; (b) ensure that such remedies are determined by competent judicial, administrative or legislative authorities, or by any other competent authority provided for by law.'

United Nations Human Rights Committee, General Comment No 3I, Doc No CCPR/C/2I/Rev.I/Add.I3 (2004), para I6. 
It may well be that the origins of the opinio juris that inspired this new custom are indeed in the flicker of a principle encased in a parenthetical sevenword obiter dictum that the PCIJ almost never made in the Chorzów Factory Case, when the Court observed that 'it is a principle of international law, and even a general conception of law, that the breach of an engagement involves an obligation to make reparation in an adequate form.' [Emphasis added.] The innocuous nature of that parenthetical obiter is seen in the regularity with which it is elided in contemporary iterations of the Chorzów Factory Case in discussions of reparation in the context of violations of human rights and humanitarian norms..$^{8}$ Yet, it is submitted that perhaps the strongest link between the contemporary notion of right to remedy or reparation for human rights violation and the Chorzów Factory Case lies in that innocuous obiter. But, it is doubtful that the strength of that link, formulated most relevantly on the generic premise of 'a general conception of law', is strong enough to bear the weight of authority often imposed on the Chorzów Factory Case for reparation in human rights cases. The better view may be that such 'general conception of law' is just that: a general conception of law, not uniquely stated in the Chorzów Factory Case. Rather, the general conception of law clearly invokes the principle ordinarily expressed in the Latin maxim ubi jus ibi remedium ${ }^{59}$ (where there is a right, there is a remedy ${ }^{60}$ ) anchored both in the equitable maxim 'equity shall not suffer a wrong without a remedy', and in the classic judgment of Lord Justice Holt in Ashby $v$ White, rendered at the close of the I7th century. ${ }^{61}$ The Lusitania Cases (United States v Germany) (1923) afforded an early instance of the recognition in the international law of this principle, in cases involving injury to human beings. The cases arose out of the sinking of The

$5^{8}$ For instance, in their write up entitled 'What is Reparation?', REDRESS renders the passage as follows: 'it is a principle of international law that the breach of an engagement involves an obligation to make reparation in an adequate form': see www.redress.org/smartweb/what-is-reparation/what-is-reparation\#II [accessed on 2 January 20II]. The passage is iterated with similar elision in Professor van Boven's contribution in Ferstman, et al, supra, p 2I. See also by Carla Ferstman, Mariana Goetz and Alan Stephens, 'Introduction' in Ferstman, et al, p 8; Heike Niebergall, 'Overcoming Evidentiary Weaknesses in Reparation Claims Programmes' in Ferstman, et al, supra, p I45; Dinah Shelton, 'United Nations Principles and Guidelines on Reparations: Context and Content' in K. Feyter, S. Parmentier, M. Bossuyt and P Lemmens, Out of the Ashes: Reparation for Victims of Gross and Systematic Human Rights Violations [Antwerpen-Oxford: Intersentia, 2005] p I2, footnote 6.

59 Cheng, supra, footnote I at p 233.

6o See Ellery Stowell, Intervention in International Law [Washington DC: John Byrne \& Co, I92I] p I.

6I Ashby v White (I703) I4 St $\operatorname{Tr} 695,92$ ER I26. So powerful is the legal impulsion for remedy for a violated right that common law jurisdictions recognize a little known residual cause of action called 'action on the case' to ensure that remedies are afforded for violations of rights whose causes of action may not neatly fit into the more traditional causes of action. 
Lusitania, a British ocean liner, which was torpedoed off the coast of Ireland, on 7 May 1915, by a German submarine. At the time of the incident, the United States was a neutral party in World War I. There were 197 American citizens onboard the vessel at the time of the attack. I2 8 of them lost their lives. Germany accepted liability. The remaining issue was the determination of the measure of damages. In that connection, the Commissioners invoked the principle of ubi jus ibi remedium. They did so in the following words:

It is a general rule of both the civil and the common law that every invasion of private right imports an injury and that for every such injury the law gives a remedy. Speaking generally, that remedy must be commensurate with the injury received. It is variously expressed as "compensation", "reparation", "indemnity", "recompense", and is measured by pecuniary standards, because, says Grotius, "money is the common measure of valuable things". ${ }^{62}$

This notion of ubi jus ibi remedium, so clearly and relevantly articulated so long ago in the Lusitania Cases, is a discernible golden thread that runs through much of the present day 'elaborate corpus of international human rights instruments,' in the manner of the idea of the right to effective remedy.

Stated as a right in the victim, reparation must then involve an obligation upon another party to deliver the actual dividends of the claim. ${ }^{63}$ But, before examining the potential parties who may be looked upon as bearing the obligation to make reparation, it is perhaps helpful, at this stage, to clarify a certain matter of terminology.

For present purposes, the term 'fault' is intended to encompass a cross-spectral view of responsibilities, from both the vertical and horizontal axes. The vertical axis entails a view of the actions and omissions of a range of potential respondents. It captures, at its sharpest and most obvious edge, the conduct of the party occa-

62 The Lusitania Cases (1923) VII RIAA 32 at p 35. Grotius had expressed himself on the matter in the following way: 'But, as we have said, damage is also done to honour and reputation, as by blows, insults, abuse, calumny, derision, and other similar means. In these acts, no less than in theft and other crimes, the criminality of the act must be distinguished from its effects. For to the former punishment corresponds, and reparation for the loss to the latter; and reparation is made by confession of the fault, by manifestation of honour, by witness of innocence, and through the other means which are similar to these. Nevertheless, such a damage may be made good with money, if the injured party so desires, because money is the common measure of useful things': Grotius, supra, Bk II, Ch XVII, p 437.

63 See Manfred Nowak, UN Covenant on Civil and Political Rights: CCPR Commentary, 2nd revised edn [Kehl: NP Engel, 2005], Introduction, para 4; H Victor Condé, A Handbook of International Human Rights Terminology [Lincoln: University of Nebraska Press, 2004] p 73. See also Joel Feinberg, Social Philosophy [Englewood Cliffs, NJ: Prentice Hall, I973] p 58; Welsely Newcomb Hohfeld, 'Some Fundamental Legal Conceptions as Applied in Judicial Reasoning,' 23 Yale Law Journal (I9I3) I6, at pp 3I-32. 
sioning the initial harm; and, at its softest edge, the failures and inactions of the stranger to the initial harm who, for some reason, is now looked upon to ameliorate what Jeremy Bentham described as the 'evil condition' ${ }^{6}$ into which the victim has been placed in consequence of the initial harm. From the horizontal axis, one looks at the range of responsibility attributable to each person or aggregation. They range from immediately actionable legal causes to (perhaps non-justiciable) questions of moral responsibility that, left unaddressed, still leave victims feeling cold lumps of injustice in their hearts. Non-justiceabilty in this sense may result from issues of exhaustion of local remedies, immunity of the local or foreign sovereign, lack of a cause of action known to domestic or international law, and so on.

The potential parties whose conducts could come within these spectrums of responsibilities would include the State of the victim's nationality, a non-State actor, a foreign State, or the international community. We will look at those next.

\section{(ii) Fault resulting from Actions}

Fault may result from actions or omissions. Fault stemming from actions is fairly obvious and requires no elaborate discussion. The spectrum of respondents that may be looked upon for reparation as regards injurious actions, depending on the circumstances, might include:

- State of Nationality whose agents might have been perpetrators or accomplices in the actions that directly or indirectly caused the initial harm, and/or the agents themselves;

- Non-State Actor (such as an armed group, a corporation or their affiliates) whose agents might have been perpetrators or accomplices in the actions that directly or indirectly caused the initial harm, and/or the agents themselves;

- Foreign State whose agents might have been perpetrators or accomplices in the actions that directly or indirectly caused the initial harm, and/or the agents themselves; and

- The International Community (acting severally or jointly through a multilateral organisation) whose agents might have been perpetrators or accomplices in the actions that directly or indirectly caused the initial harm, and/or the agents themselves.

That the aggregation or individual to whom such actions are attributable should be proceeded against for reparation would generally attract little controversy. That is to say, when an act of sexual violence or other form of serious human rights violation is committed by a soldier, an insurgent, an employee of a private military firm or of an international organization, he and his Government, company or organization, as the case may be, may be proceeded against for reparation, with little reasonable controversy. Questions regarding the capacity in which he acted

64 Jeremy Bentham, The Works of Jeremy Bentham, published under the Superintendence of his Executor, John Bowring (Edinburgh: William Tait, I838-I843). II vols. Vol. I, p 579 . 
at the material time will not detract from the general proposition as to the liability of the employer for reparation in the appropriate case.

\section{(iii) Fault resulting from Omission}

The greater difficulty arises from attribution of fault as a result of omission. The spectrum of respondents in this regard might include the following:

- State of nationality (a) whose agents might have been implicated in the violations through omissions that directly or indirectly caused the initial harm; (b) who might have failed to pursue non-state actors or foreign States for violations committed against its nationals in the territory, such as are attributable to the foreign State or non-state actor;

- Non-State actor (such as an armed group, a corporation or their affiliates) whose agents might have been perpetrators or accomplices in the omissions that directly or indirectly caused the initial harm;

- $\quad$ Foreign State whose agents might have been implicated in the violations through omissions that directly or indirectly caused the initial harm;

- The international community (a) (acting severally ${ }^{65}$ or jointly through a multilateral organisation) whose agents might have been implicated in the omissions that directly or indirectly caused the initial harm; and (b) for failing to take available steps to make or occasion the required reparation even when they are jural strangers to the initial harm.

The next segment of the discussion will review some of the legal issues thus engaged.

\section{(a) Fault resulting from Omissions of State of Nationality in respect of State Agents}

The victim of sexual violence in armed conflict or other human rights violation is now a subject of international law in her own right. ${ }^{66}$ The implication of this is a recognition in her the standing in international law to make claims against her State of nationality for acts of state amounting to an internationally wrongful act. ${ }^{67}$ The relevant principles have now been succinctly captured by the

65 For instance, Belgium's admission of fault for its failure to help prevent the Rwandan Genocide of 1994, as part of the UN Mission in Rwanda: see http://news.bbc. co.uk/2/hi/africa/705402.stm.

66 See United Nations, Report of the International Law Commission on the work of its fifty-eighth session, Doc No A/6I/Io, Commentary to draft article I on Diplomatic Protection, pp 25-26, para 4. See also Prosecutor v Tadic (Decision on the Defence Motion for Interlocutory Appeal on Jurisdiction) 2 October 1995 [ICTY Appeals Chamber], para 97; and Malcolm Shaw, International Law, 6th edn [Cambridge: Cambridge University Press, 2008], p 258.

67 It is noted in this regard that the International Law Commission has stated that the 
International Law Commission in the draft articles on Responsibility of States for Internationally Wrongful Acts (200I). ${ }^{68}$ The question of fault attendant upon her claims to reparation would engage the state responsibility of her State of nationality; considering that such responsibility arises whenever there has been a 'refusal to fulfil a treaty obligation' ${ }^{69}$ or whenever there has been 'any violation by a State of any obligation, of whatever origin'..$^{\circ}$ Therefore, any action attributable to the State of nationality as an act of state that violates international human rights or humanitarian norm, deriving from an international convention or custom, would readily engage the question of fault, for which the State of nationality would owe reparation to its own nationals who are victims of such violations. The responsibility of the State would be engaged even where a State agent or responsible organ acts in excess of authority or contrary to instructions, as long as the agent or organ acted in the capacity of an agent or organ of State. ${ }^{7 \mathrm{~T}}$

The question of fault is thus straightforward as regards the reparation obligations of the State of nationality whose agents might, acting in official capacity, have been perpetrators or accomplices in the actions that directly or indirectly caused the initial harm to the victim.

\section{(b) Responsibility to Protect and National State's Omissions Regarding Rogue Agents of State and Non-State Actors}

Less straightforward is the issue of state agents acting in purely private capacity when they violated the international human rights or humanitarian norms that protected their citizens. It is beyond the scope of the present discussion to review the details of the theory of attribution of a wrongful act to the State, which is one of the two basic elements of state responsibility codified in the ILC draft articles on Responsibility of States for Internationally Wrongful Acts [the second element being the determination of the act as constituting 'a breach of an inter-

'term "international responsibility" ... covers the relations which arise under international law from the internationally wrongful act of a State, whether such relations are limited to the wrongdoing State and one injured State or whether they extend also to other States or indeed to other subjects of international law ...' [emphasis added]: see United Nations, Report of the International Law Commission on the work of its fifty-third session, Doc No A/56/10, in the Yearbook of the International Law Commission (200I), vol II part 2, Commentary to draft article I on Responsibility of States for Internationally Wrongful Acts, p 33, para 5. See also James Crawford, The International Law Commission's Articles on State Responsibility: Introduction, Text and Commentaries [Cambridge: Cambridge University Press, 2002], p 79, para 5.

68 See United Nations, Report of the International Law Commission on the work of its fifty-third session, supra, pp 32-33. See also Crawford, supra, p 78.

69 See Interpretation of Peace Treaties with Bulgaria, Hungary and Romania, Second Phase, (1950) ICJ Reports 22I at 228.

70 See Rainbow Warrior (New Zealand/France) (1990) RIAA vol xx 217 at p 25I, para 75.

7I See article 7 of the draft articles on Responsibility of States for Internationally Wrongful Acts. 
national obligation of the State'. ${ }^{2}$ ] A very useful discussion of the law in this regard may be found in both the ILC's and Professor James Crawford's sets of commentaries on the draft articles on Responsibility of States for Internationally Wrongful Acts. ${ }^{73}$

What is perhaps important to keep in mind for present purposes-i.e. in the specific context of reparation for violation of international human rights and humanitarian norms-is the availability of complementary theories that should still obligate States to, at the barest minimum, facilitate reparation for violations committed by state agents whose acts are not easily attributable to the State. Such complementary theories of duty may derive from the doctrine of responsibility to protect, which encumbers the national State as the primary obligor.

The doctrine of responsibility to protect $\left(\mathrm{R}_{2} \mathrm{P}\right)$ enjoys currency in our time by virtue of the UN General Assembly's 2005 World Summit Outcome resolution,74 presaged by A More Secure World: Our Shared Responsibility (the 2004 report of the Secretary-General's High Level Panel on Threats, Challenges and Change). ${ }^{75}$ With a two-part statement deep inside the World Summit Outcome resolution, the General Assembly adjusted the international norms concerning sovereignty of States in relation to their treatment of their own citizens. That adjustment came in the manner of a normative formula in two parts: (i) an acknowledgment that the each State bears the primary responsibility to prevent the gross violation of the human rights of its citizens in the manner of genocide, crimes against humanity, ethnic cleansing, or war crimes $^{7}$; and (ii) an acceptance of a complementary responsibility on the part of the international community, acting under the coor-

72 See article 2 of ILC draft articles on Responsibility of States for Internationally Wrongful Acts.

73 See United Nations, Report of the International Law Commission on the work of its fifty-third session, supra, pp 34-36. See also Crawford, supra, pp 8I-85.

74 United Nations, General Assembly resolution 60/I (2005) of 24 October 2005, '2005 World Summit Outcome', paras I38 and I39.

75 United Nations, General Assembly, A more secure world: our shared responsibilityReport of the High-level Panel on Threats, Challenges and Change' Doc No A/ $159 / 565$ of 2 December 2004. See also the 200I report of the Canadian Government established International Commission on Intervention and State Sovereignty: ICISS, 'The Responsibility to Protect-Report of the International Commission on Intervention and State Sovereignty' [Ottawa: International Development Research Centre, 200I].

76 In the relevant part, the full text of the resolution appears as follows: 'Each individual State has the responsibility to protect its populations from genocide, war crimes, ethnic cleansing and crimes against humanity. This responsibility entails the prevention of such crimes, including their incitement, through appropriate and necessary means. We accept that responsibility and will act in accordance with it. The international community should, as appropriate, encourage and help States to exercise this responsibility and support the United Nations in establishing an early warning capability': United Nations, General Assembly resolution 60/I (2005), supra, para $\mathrm{I} 38$. 
dination of the UN, to undertake peaceful—and, as a last resort, Security Council sanctioned military-humanitarian intervention aimed at preventing violations of that kind, when the Government with the sovereign jurisdiction appears unable to prevent the violations, or is implicated in their commission..$^{77}$

The first part of the formula-i.e. that it is the primary responsibility of the State to protect its citizens - is certainly, at best, a modern restatement ${ }^{78}$ of a very old principle. One finds it in the writings of classical publicists such as Pufendorf,79 Wolff ${ }^{8 \circ}$

77 As the resolution states: 'The international community, through the United Nations, also has the responsibility to use appropriate diplomatic, humanitarian and other peaceful means, in accordance with Chapters VI and VIII of the Charter, to help to protect populations from genocide, war crimes, ethnic cleansing and crimes against humanity. In this context, we are prepared to take collective action, in a timely and decisive manner, through the Security Council, in accordance with the Charter, including Chapter VII, on a case-by-case basis and in cooperation with relevant regional organizations as appropriate, should peaceful means be inadequate and national authorities are manifestly failing to protect their populations from genocide, war crimes, ethnic cleansing and crimes against humanity. We stress the need for the General Assembly to continue consideration of the responsibility to protect populations from genocide, war crimes, ethnic cleansing and crimes against humanity and its implications, bearing in mind the principles of the Charter and international law. We also intend to commit ourselves, as necessary and appropriate, to helping States build capacity to protect their populations from genocide, war crimes, ethnic cleansing and crimes against humanity and to assisting those which are under stress before crises and conflicts break out': United Nations, General Assembly resolution 60/I (2005), supra, para 139.

78 See United Nations, General Assembly, A more secure world: our shared responsibility-Report of the High-level Panel on Threats, Challenges and Change', supra, para I99.

79 In his discussions 'On the Duty of Supreme Sovereigns', Pufendorf stated '[t]he general rule for the conduct of supreme sovereigns' in the following way: 'Let the safety of the people be the supreme law': Samuel Pufendorf, De Jure Naturae et Gentium Libri Octo (I688) (C A and W A Oldfather translation) [Oxford: Clarendon Press, 1934] Vol 2, Bk VII, p III8. This naturally follows from his earlier observation that safety is the primary reason for the existence of the State: ibid, pp 956 and 959.

80 According to Wolff: 'Every nation is bound to preserve itself. For the men who make a nation, when they have united into a state, are as individuals bound to the whole for promoting the common good, and the whole is bound to the individuals to provide for them those things which are required as a competency for life, for peace and security. Furthermore it is self-evident that this obligation cannot be satisfied, either on the part of the individuals or of the whole, unless the union in a state should persist, consequently, since the preservation of the nation depends on this union, unless the nation should be preserved. Therefore every nation is bound to preserve itself': Christian Wolff, Jus Gentium Methodo Scientifica Pertractatum (I764) (Joseph H Drake translation) [Oxford: Clarendon Press, 1934] p 22. 
and Vattel ${ }^{8}$ - even Hobbes $^{82}$ - whose views of the legal order had directly or indirectly obligated the State to protect its citizens, as a crucial part of the social contract.

Even as regards the second part of the $\mathrm{R}_{2} \mathrm{P}$ declaration, it is possible to take the view that it develops international law and policy only by way of settling the old debate ${ }^{8_{3}}$ concerning whether the idea of sovereignty of States is an absolute

8I As he wrote: '[...] Whoever wrongs the State, violates, its rights, disturbs its peace, or injures it in any manner whatever becomes its declared enemy and is in a position to be justly punished. Whoever ill-treats a citizen indirectly injures the State, which must protect that citizen. The sovereign of the injured citizen must avenge the deed and, if possible, force the aggressor to give full satisfaction or punish him, since otherwise the citizen will not obtain the chief end of society, which is protection': Emmerich de Vattel, The Law of Nations or the Principles of Natural Law Applied to the Conduct and to the Affairs of Nations and Sovereigns (I758) (Charles G Fenwick translation) [Washington: Gibson Bros, I9I6], Bk II, Ch VI, § 7I. Although Vattel made that specific comment in the context of interstate relations, and the right of the national State to protect its citizens from external harm, it is submitted that the theme of the national State's duty to protect the citizen-as the citizen's chief benefice from the social contract (in order that he may enjoy a peaceful and happy life)-is a constant refrain in Vattel's work. One sees that resonance in other parts of his work dealing strictly with the relationship between the citizen and his sovereign. See, for instance, Bk I, Ch II (on 'General Principles of the Duties of a Nation towards Itself'), Bk I, Ch III (on 'The Constitution of the State, and the Duties and Rights of the Nation in this Respect'), and Bk I, Ch IV (on 'The Sovereign; His Obligations and His Rights').

82 Even Thomas Hobbes, who was less inclined to limiting the absoluteness of his philosopher king with any duties so to speak, began his thesis of the social contract largely from the citizen's duty of obedience to an absolute ruler. Yet, he ended up with the proposition that such civic duty of obedience was 'understood to last as long, and no longer than' the sovereign was able to protect the citizen-for 'the end of obedience is protection'. In his words: 'The obligation of subjects to the sovereign is understood to last as long, and no longer, than the power lasteth by which he is able to protect them. For the right men have by nature to protect themselves, when none else can protect them, can by no covenant be relinquished. The sovereignty is the soul of the Commonwealth; which, once departed from the body, the members do no more receive their motion from it. The end of obedience is protection ....: Thomas Hobbes, Leviathan or The Matter, Forme \& Power of a Commonwealth Ecclesiasticall and Civill [sic][London: Andrew Crooke, 165I) Ch XXI, p I36 (in the edition Prepared for the McMaster University Archive of the History of Economic Thought, by Rod Hay). See also Sharon Lloyd and Susanne Sreedhar, 'Hobbes's Moral and Political Philosophy', The Stanford Encyclopedia of Philosophy (Spring 2009 Edition), Edward N. Zalta (ed), <www.plato.stanford.edu/archives/ spr2oog/entries/hobbes-moral/>.

83 See, for instance, Theodore Woolsey, Introduction to the Study of International Law, 4th edn [New York: Scribner, Armstrong, 1874] pp 57-58. See also United Nations, General Assembly, A more secure world: our shared responsibility-Report of the Highlevel Panel on Threats, Challenges and Change', supra, para 199. The debate predates the era of international lawyers of the vintage of Woolsey. Grotius, notably, 
concept which permits no derogation, even in the face of a genocide of a people or their subjection to crimes against humanity at the hands of their sovereign.

At the 2005 World Summit, the General Assembly built upon the idea that respect for human rights is obligation erga omnes ${ }^{8}$ — an obligation owed the whole world - and accepted by a general affirmation that sovereignty of States must yield to the need to protect citizens whose governments have proven unable to protect from gross human rights violations of the worst kind; that humanitarian interventions are legally permissible under international law; but that such intervention efforts must be undertaken under the coordination of the UN. Again, it is notable that humanitarian interventions in aid of foreign populations in extremis were a frequent occurrence on the international scene in the past. ${ }^{85}$ The $\mathrm{R}_{2} \mathrm{P}$ declaration

wrote approvingly about Hercules who had a reputation for 'travers[ing] the world chastising the unjust', for 'punish[ing] wicked men and overthrew the power of the haughty or transferred it to others', and for 'slaying lawless men and arrogant despots [and making] the cities happy'; and thus 'deserved to be elevated among the gods because of his espousal of the common interest of the human race.' See Hugo Grotius, De Jure Belli ac Pacis (I646) (Francis Kelsey translation) [Oxford: Clarendon Press, I925] vol II, Bk II, Ch XX, p 505. By our own modern sensibilities, some of these Herculean laudations may be far too worrisome. They do, nevertheless, amply support the view that in the era of Grotius there was a lively debate about a version of $\mathrm{R}_{2} \mathrm{P}$ - the second part-which Grotius had argued as follows: 'The fact must also be recognized that kings, and those who possess rights equal to those kings, have the right of demanding punishments not only on account of injuries committed against themselves or their subjects, but also on account of injuries which do not directly affect them but excessively violate the law of nature or of nations in regard to any persons whatsoever ...': ibid, p 504. For his part, Vattel wrote with considerable rapture in favour of a duty of humanity which 'consist in doing all in our power for the welfare and happiness of others, as far as is consistent with our duties towards ourselves': Vattel, supra, Bk II, Ch I, § 3 . And, it follows from this duty of humanity 'that whatever we owe to ourselves we owe also to others, as far as they are really in need of our help and we can give it to them without neglecting ourselves': ibid. But he was less enthusiastic about Grotius's more bellicose rendition of this duty, in terms of authorizing humanitarian military intervention undertaken unilaterally by States when their own interests are not directly at stake. In this connection, Vattel quite appropriately asked: 'Did not Grotius perceive that ... his view opens the door to all the passions of zealots and fanatics, and gives to ambitious men pretexts without number?' Ibid, § 7. Since Vattel's chief reservations against unilateral, humanitarian military intervention were zealotry, fanaticism and territorial ambition, one wonders whether he might have truly opposed a multilateral military humanitarian intervention pursuant to the 2005 World Summit Outcome resolution.

84 See the Case Concerning Barcelona Traction, Light and Power Co (1970) ICJ Reports p 32. See also Cheriff Bassiouni, 'International Crimes, Jus Cogens and Obligatio Erga Omnes' 59 Law and Contemporary Problems (1996) 63.

85 See also William Edward Hall, A Treatise on International Law, 8th edn (edited by Pearce Higgins) [Oxford: Clarendon Press, 1924] 64; James Kent, Commentaries on American Law, I2th edn (by O W Holmes Jr) [Boston: Little, Brown and Company, I873] Vol I, pp 24-25. 
is simply a realization of the hopes expressed by Hyde in 1922 for 'united efforts to intervene' when a particular State definitely abuses the right of sovereignty, with such intervention involving the 'mode of collective interference, through an established agency, as well as the recognition of circumstances when such [intervention] is excusable. ${ }^{86}$

Returning now to the obligation on the national State, there is little doubt that the doctrine of responsibility to protect ought to encompass an obligation of the State to deploy its powers and resources in pursuit of those who violate the human rights of its citizens. It is now established as a matter of customary international law, requiring no extended discussion, that this obligation of pursuit entails an obligation to bring the full weight of criminal justice to bear on nationals implicated in punishable violation of international human rights. This obligation is stressed not only in the Statute of the International Criminal Court, ${ }^{87}$ and its famous doctrine of complementarity, ${ }^{88}$ but also in numerous resolutions of the United Nations Security Council. ${ }^{89}$ The same norm was also chronicled by Pufendorf ${ }^{\circ}$ and Vattel $^{9 \mathrm{I}}$ in their own ways.

What is less frequently emphasized in UN General Assembly and Security Council resolutions is the obligation of States to pursue the culprits for the specific purposes of facilitating the victim's rights to reparation when the breach involves gross violations of human rights. Yet, this obligation is no less compelling in terms of the objective of the battle against impunity, as with the usual stress on criminal prosecution. To the extent that this normative duty (i.e. as regards reparation) is broached, it is usually expressed in the oblique manner of permitting or encour-

86 See Charles Cheney Hyde, International Law: Chiefly as Interpreted and Applied by the United States [Boston: Little, Brown and Company, 1922] Vol I, p II8.

87 See paragraph 6 in the preamble of the ICC Statute.

88 See article I of the ICC Statute.

89 See, for instance, United Nations Security Council, resolution I820 (2008) of I9 June 2008, preambular paragraph I2; United Nations Security Council, resolution I888(2009) preambular paragraph 7; United Nations Security Council, resolution I960 (2010) of I6 December 20I0, preambular paragraph 6;

90 He expressed the same principle in the following injunction: '[S]ince men have come together into a state to the end that they might gain security against the injuries of others, it is the task of supreme sovereigns to prevent citizens from offering injury to one another, and this with a severity proportionate to the greater ease with which their constant proximity gives them opportunity for doing mischief. Nor should differences in ranks and dignities be so influential that the more powerful can insult the less fortunate at their pleasure. Isocrates, To Nicocles [I6]: 'You will be a good popular leader if you neither permit the multitude to commit outrages nor allow them to suffer them, but contrive that, while the best men take the honours, the rest shall suffer no wrong': Pufendorf, supra, p iा22.

9I According to Vattel: 'The care of securing justice to all will therefore be one of the principal duties of the Prince, and nothing is more worthy of his sovereign rank': Vattel, supra, p 68. 
aging judges to make restitution orders at the end of a criminal case-mostly in terms of return of property. ${ }^{92}$

But, it is now generally accepted that the normative duty of States to fight impunity for human rights violations ought to be more robustly articulated as going beyond the duty to do justice according to criminal law; and that this robust articulation ought to give a pride of place to the duty of the State to exact the full measure of reparation from the culprits. It is submitted, as many would no doubt agree, that this duty ought to be unshackled from the criminal process, in view, among other considerations, of the different standards of proof that guide criminal proceedings and the process under which reparation proceedings must come as a distinct subject matter. It is submitted that such an alternative track for the pursuit of violators of the human rights of citizens is fully consistent with the repeated recognition that 'States bear primary responsibility to respect and ensure the human rights of their citizens, as well as all individuals within their territory as provided for by relevant international law.' ${ }^{93}$

This complementary theory of state responsibility is an obvious avenue through which States ought to be required to pursue the State agent whose serious violation of human rights of nationals is not easily attributed to the State under the traditional conceptions of state responsibility for an internationally wrongful act that is not of a human rights character. This is so, for the rogue State agent acting in purely private capacity may not enjoy greater immunity than the free agent whom the State is ordinarily obligated under international law to pursue for punishable human rights violation.

In the circumstances, it is a legitimate matter of fault on the part of the national State if it fails to exact reparation from State agents who violate rights in situations in which their acts may not amount to acts of state.

\section{(c) National State's Omissions Regarding Non-State Actors}

The same consideration of fault on the part of the national State (as discussed immediately above) would apply in respect of violations attributed to non-State actors, such as rebel groups and corporations over whom the national State may

92 See, for instance, article $24(3)$ of the Statute of the International Criminal Tribunal for the former Yugoslavia, together with rules I05 and 106 of the ICTY Rules of Procedure and Evidence; article 23(3) of the Statute of the International Criminal Tribunal for Rwanda, together with rules Io5 and Io6 of the ICTR Rules of Procedure and Evidence; article I9(3) of the Statute of the Special Court for Sierra Leone, together with rules Io5 and 106 of the SCSL Rules of Procedure and Evidence; and, article $75(2)$ of the ICC Statute.

93 See, for instance, United Nations Security Council, resolutions I265 (1999) of I7 September 1999, preambular paragraph I0; 1820 (2008) of I9 June 2008, preambular paragraph I2; I888(2009) preambular paragraph 20; 1960 (2010) of I6 December 2010, preambular paragraph 8; I962 (2010) of 20 December 2010, preambular paragraph 5. See also the General Assembly resolution 60/I (2005) of 24 October 2005, '2005 World Summit Outcome', para 138 . 
have present or future ability to bring to justice. The national State should, as part of its responsibility to protect its citizens, pursue such non-State actors, with the view to obtaining reparation for violations attributed to them. In this regard, there is a need also to emphasise, as has already been done in respect of criminal prosecutions, that reparation for violations cannot be overtaken by the event of peace agreements to end armed conflicts.

\section{(d) Diplomatic Protection and National State's Omissions Regarding Foreign States}

\section{Armed Conflicts and Diplomatic Protection}

The traditional theories of state responsibility, with particular reference to the terms of the draft articles on Responsibility of States for Internationally Wrongful Acts of States, will govern the responsibility of foreign States for violation of the human rights of citizens of another State in their own territory.

Beyond the dictates of the doctrine of state responsibility encumbering the foreign State, its conduct would, in certain circumstances, also give rise to questions of fault on the part of the State of nationality of the victim. In particular, a question of fault for the national State would arise from its failure to pursue reparation through diplomatic protection claims against foreign States for internationally wrongful acts of state that grossly violated the human rights of citizens of the national State.

Although the concept of diplomatic protection often evokes the image of 'treatment of aliens'94_ as the notion of 'aliens' ordinary entail foreigners to a territory-its scope does not exclude claims arising from internationally wrongful acts of foreign States committed against nationals of other States in their own home territory. Notably, the ILC's general definition of diplomatic protection does not suggest any such exclusion. According to that definition, 'diplomatic protection consists of the invocation by a State, through diplomatic action or other means of peaceful settlement, of the responsibility of another State for an injury

94 United Nations, Report of the International Law Commission on the work of its fifty-eighth session, supra, pp 22 and 26. For instance, Belgium's claim against Spain for Spain's expropriation of the interests of Belgian shareholders in the Spanish operations of a Canadian company: see Barcelona Traction, Light and Power Company, Limited (Judgment) (1970) ICJ Reports 3; Germany's claim against the US for denial of right of consular assistance to two German nationals tried in the US for capital punishment offences committed in the US: LaGrand (Germany v United States of America)(Judgment) (200I) IC J Reports 466; and a similar case by Mexico against the US for denial of consular assistance to Mexican nationals tried in the US: Avena and Other Mexican Nationals (Mexico v United States) (2004) ICJ Reports I2; and a claim by Guinea against the Democratic Republic of the Congo for wrongful detention, expulsion and expropriation committed by DRC against a Guinean national formerly resident in the DRC: Ahmadou Sadio Diallo (Guinea v DRC) (Judgment) (2010) 30 November 2010 General List io3. 
caused by an internationally wrongful act of that State to a natural or legal person that is a national of the former State with a view to the implementation of such responsibility'. ${ }^{95}$ Thus, the concept of diplomatic protection generally describes 'the procedure employed by the State of nationality of the injured persons to secure protection of that person and to obtain reparation for the internationally wrongful act inflicted.' ${ }^{\prime 6}$

Such internationally wrongful acts of State often arise from acts or omissions of the foreign State in the course of an armed conflict affecting the national State. Examples of such acts or omissions of foreign States occasioning gross violation of human rights include the findings of the ICJ in the Armed Activities on the Territory of The Congo (Congo v Uganda) ${ }^{97}$ and the Application of the Convention on the Prevention and Punishment of the Crime of Genocide (Bosnia-Herzegovina v Serbia and Montenegro)..$^{98}$ In Armed Activities on the Territory of The Congo, the ICJ found that Uganda was responsible for gross human rights violations committed by its troops against Congolese people in the course of armed conflicts occurring in the territory of Congo in which Uganda was a party. And in the Application of the Convention on the Prevention and Punishment of the Crime of Genocide, the Court found that the deep-seated hatred between Bosnian Serbs and Muslims ought to have kept Serbian authorities alive to the possibility of the Srebrenica genocidal massacre. Therefore, Serbia should have brought its influence to bear on Bosnian Serb forces to prevent the massacre. Having failed to show that it brought such influence to bear, the Court held that Serbia failed in its duty to prevent the genocide.

Armed conflicts in their potential to occasion gross violation of human rights could come in the way of conflicts in which the respondent State is guilty of act(s) of aggression (which in itself is an internationally wrongful act ${ }^{99}$ ) or conflicts in which the respondent State itself is the victim of act(s) of aggression. An act of aggression has been defined as 'the use of armed force by a State against the sovereignty, territorial integrity or political independence of another State, or in any other manner inconsistent with the Charter of the United Nations. ${ }^{\text {Ioo }}$ An act of aggression is now an international crime when the act 'constitutes a manifest

95 Article I of the draft articles on Diplomatic Protection.

96 United Nations, Report of the International Law Commission on the work of its fifty-eighth session, supra, $\mathrm{p} 24$.

97 Armed Activities on the Territory of the Congo (Democratic Republic of the Congo v Uganda) (Judgment) (2005) ICJ Reports 168.

98 Application of the Convention on the Prevention and Punishment of the Crime of Genocide (Bosnia and Herzegovina v Serbia and Montenegro) (Judgment) (2007) 26 February 2007, General List No 9I.

99 See article 5(2) of the United Nations General Assembly resolution $33{ }^{4}$ (XXIX) of I4 December 1974, on the Definition of Aggression.

Ioo See article $8 b i s(2)$ of the ICC Statute, as amended by Assembly of States Parties resolution RC Res/6 of ir June 20Io. See also article I of General Assembly resolution 3314 (XXIX), supra. 
violation of the Charter of the United Nations', in view of the 'character, gravity and scale' of the act in question. ${ }^{\text {ror }}$ There is a prima facie case of aggression against the State that strikes first with an armed force in contravention of the Charter; although the Security Council may, taking other relevant factors into account, determine otherwise. What the Security Council may take into account in this regard may include the non-grave character of the act and its consequences. ${ }^{102}$

Traditionally, regard to the nature of an armed conflict (jus ad bellum) viewed from the lens of aggression has not been permitted in the calculation of what would amount to violation of international humanitarian law (jus in bello). ${ }^{103}$ But things have changed since the summer of 2010 in view of the adoption of the amendment to the ICC Statute, now making aggression a crime in international law, for which the directing minds of State action may be held individually responsible. ${ }^{104}$

This change in the law ought also to be reflected in the analysis of fault for purposes of reparation to victims of armed conflict. It is, thus, submitted that in cases of aggression, there ought to be a presumption, at least a rebuttable one, that all resulting casualties and injuries are a gross violation of the human rights of the victims. This presumption operates alongside the ordinary norms of humanitarian law that govern armed conflicts (jus in bello). This is a logical, practical significance of branding it an international crime to use, against another State, an armed force of such 'character, gravity and scale' as to amount to a manifest violation of the Charter of the United Nations. There is, therefore, a direct causal connection between such an act of aggression and injuries and casualties suffered by nationals of the target of the act of aggression. ${ }^{105}$ The reverse side of this analysis is

IOI See art 8bis(I) of the ICC Statute, supra.

IO2 See article 2 of General Assembly resolution 3314 (XXIX), supra.

Io3 See Christopher Greenwood, 'Historical Development and Legal Basis' in Dieter Fleck (ed), Handbook of Humanitarian Law in Armed Conflicts [Oxford: OUP, 1999] p 8.

I04 See articles 8bis(I) and 25(3)bis of the ICC Statute, supra.

IO5 Indeed, it is this principle of causal connection that animated article 23I of the Treaty of Versailles when it provided as follows: 'The Allied and Associated Governments affirm and Germany accepts the responsibility of Germany and her allies for causing all the loss and damage to which the Allied and Associated Governments and their nationals have been subjected as a consequence of the war imposed upon them by the aggression of Germany and her allies.' It was on that basis that Germany and her allies were required to make reparation to the Allied and Associated Governments after the World War I. It must be noted at once that the reparation provisions of the Treaty of Versailles have, through the ages, elicited controversy among historians and other scholars. It is submitted, however, that the controversy relates more to the application of the principle of reparation in the particular case of World War $\mathrm{I}$, rather than with the very principle considered by itself that those who launch a war of aggression ought to repair the natural consequences of the war. J M Roberts, for instance, observed that 'most of the harshest terms' of the Treaty of Versailles resulted not from the attribution (to Germany and her allies) of the 'moral guilt' of 
not, of course, that the State victim of aggression is absolved from scrutiny of its own conducts during the armed conflict. It will remain burdened by the ordinary norms of humanitarian law that regulate the conduct of armed conflicts.

Thus, armed conflicts, whether or not in the nature of aggression have a potential to engage claims of diplomatic protection on behalf of human victims of the war.

\section{Diplomatic Protection as a Question of Duty on the National State}

The victims of sexual violence and other serious human rights violations committed in armed conflicts must, however, confront the old question whether there is a duty on their national State to pursue claims of diplomatic protection on their behalf. In other words, is diplomatic protection a matter of duty for the State, such that omission to pursue it could result in a determination of fault on the part of the national State? In international law, diplomatic protection is clearly accepted - and often considered - as a matter of right for the State in relation to other States. ${ }^{106}$ What is less clear is the extent to which it is also a matter of duty on the State as regards the citizen whose human right has been grossly violated by an act of a foreign State.

Under the domestic laws of many States, diplomatic protection is a matter of prerogative on the part of the State, since it necessarily falls under the rubric of international relations, over which the State has prerogative. ${ }^{107}$ The ICJ in the Barcelona Traction Case stated this State prerogative over diplomatic protection with crystal clarity. ${ }^{\text {I08 }}$

the war, but from a punitive, deterrent motive: 'so to tie Germany down that any third German war was inconceivable': see J M Roberts, The New Penguin History of the World [London: Penguin Books, 2004] 9or. See also Chambers Dictionary of World History [Edinburgh: Chambers Harrap Publishers, 1993] 94I.

Io6 United Nations, Report of the International Law Commission on the work of its fifty-eighth session, supra, p 25. See also John Dugard, International Law: a South African Perspective 3rd edn [Cape Town: Juta \& Co Ltd, 2008] 290; Enrico Milano, 'Diplomatic protection and human rights before the International Court of Justice' (2004) Netherlands Yearbook of International Law 85 at pp 94-95; Noura Karazivan, 'Diplomatic Protection: Taking Human Rights Extraterritorially' (2006) XLIV Canadian Yearbook of International Law 299, at p 300; Gerhard Erasmus and Lyle Davidson, 'Do South Africans Have a Right to Diplomatic Protection?' (2000) 25 South African Yearbook of International Law II3 at I27; F V García-Amador, Louis Sohn, Richard Baxter, Recent Codification of the Law of State Responsibility for Injuries to Aliens [Dobbs Ferry, New York: Oceania Publications, 1974] p 4.

I07 For an overview of some national practice in this connection, see Milano, supra, $\mathrm{p}$ 95 , fn 33 .

Io8 As the Court put the matter: 'The Court would here observe that, within the limits prescribed by international law, a State may exercise diplomatic protection by whatever means and to whatever extent it thinks fit, for it is its own right that the State is asserting. Should the natural or legal persons on whose behalf it is acting consider that their rights are not adequately protected, they have no remedy in international 
This theory of State prerogative is possibly explained by the old view that human beings had no status on the plains of international law, and thus any injury to the individual was an injury to the State. ${ }^{\text {Iog }}$ This foreign policy prerogative is a legal fiction upon which States have clung like a last seawall of protection against the relentless tide of an ever-expanding corpus of human rights norms. The resulting obstacle on the path of a diplomatic protection norm entailing duty largely appears in the manner of peremptory rejection of the idea by States. One frequently finds observations to that effect in commentaries such as this: 'Neither national nor international practice has recognised it as a duty. It is purely and simply a right which the State may exercise, or choose not to exercise, in its absolute discretion. ${ }^{\text {IIO }}$ When the obstacle is more diplomatically presented, it appears in the phrasing of 'time was not ripe yet' ${ }^{\text {'II }}$ for such a norm on the scene. But this rejection appears driven more by an apprehension of inconvenience than by superior philosophical conviction.

What is then to be borne in mind in considering the legitimacy of the idea of duty of diplomatic protection in respect of human rights violations is the conflict of interests evidently at play in States' refusal to develop such a norm through state practice or permit or tolerate its formation through other sources of international law. Notable here is the observation by García-Amador, Sohn and Baxter that smaller or less powerful State 'not infrequently choose not to exercise this right for fear of creating a difficult situation in their relations with the powerful State against which the claim is being made. ${ }^{{ }^{12} 2}$ Surely, those smaller or less powerful States will not readily consent to the development of a norm that would compel them to lock diplomatic or legal horns against the more powerful States, nor will the more powerful States permit the development of norms that could encour-

law. All they can do is to resort to municipal law, if means are available, with a view to furthering their cause or obtaining redress. The municipal legislator may lay upon the State an obligation to protect its citizens abroad, and may not also confer upon the national a right to demand the performance of that obligation, and clothe the right with corresponding sanctions. However, all these questions remain within the province of municipal law and do not affect the position internationally. [Paragraph] The State must be viewed as the sole judge to decide whether its protection will be granted, to what extent it is granted, and when it will cease. It retains in this respect a discretionary power the exercise of which may be determined by considerations of a political or other nature, unrelated to the particular case. Since the claim of the State is not identical with that of the individual or corporate person whose cause is espoused, the State enjoys complete freedom of action. ...': Case Concerning Barcelona Traction, Light and Power Co, supra, paras 78 and 79 .

Io9 See Mavrommatis Palestine Concessions (Judgment No 2) (I924) PCIJ, Series A, No 2; Panevezys-Saldutiskis Railway Judgment (1939) PCIJ, Series A/B, No 76, p. 4; Nottebohm, Second Phase, (Judgment) (1955) ICJ Reports.

iı García-Amador, Sohn and Baxter, supra, p 4.

III See Milano, supra, p 95, reporting on the rejection of the notion of duty by the ILC in the context of its work on the draft articles on Diplomatic Protection.

II2 García-Amador, Sohn and Baxter, supra, p 4. 
age awkward situations for themselves. And, in the nature of things, the medium powers would also not readily encourage a norm that would fetter their choice of action. In view of this conflict of interests, the proper course of action would be to consider whether there are cogent rationales for the development of the norm of duty of diplomatic protection for purposes of reparation for human rights violations, such as in the case of sexual violence committed in armed conflicts.

Indeed, there are compelling reasons to consider that a national State's right of diplomatic protection is also a matter of duty at the instance of the citizen. First, as has already been noted, the human being is now a subject of international law. ${ }^{\mathrm{Ir}}$ As a subject of international law, her rights can co-exist alongside those of her national State in relation to the same subject matter-her wellbeing. ${ }^{\text {II }}$ Secondly, if it is accepted —as it has been - as a settled principle of international law that there is no right without a remedy, then surely that settled principle cannot permit a foreign State to escape reparation for violations of the rights of citizens of other States, especially in their own territory. The circumstances of such violations are such that place on the national State the duty to engage the foreign State for purposes of obtaining reparation for the national State's injured national. Factors to consider would include the following: (a) the national State is generally better placed and better resourced to proceed against the foreign State for reparation due to the nationals; for ' $[\mathrm{a}] \mathrm{s}$ long as the State remained the dominant actor in international relations, the espousal of claims by States for violation of the rights of their nationals remained the most effective remedy for human rights protection' ${ }^{\text {III }}$; (b) that smaller or weaker States would 'often' find it difficult to tangle with more powerful States in diplomatic protection claims would suggest an exponentially harder ordeal for the average national in her quest for reparation from foreign States; (c) it was the duty of the national State to defend her territorial integrity against the foreign incursion and protect the national against the resulting violation by the foreign State; this is a practical question of duty of national defence. This duty of national defence is, of course, directly connected to the theory of social compact, in virtue of which the national State is generally obligated to protect the citizen from harm-both internal and external. In this connection, one must recall Vattel's dictum to the effect that whoever injures a citizen becomes an enemy of her State. Consequently, "[t]he sovereign of the injured citizen must avenge the deed and, if possible, force the aggressor to give full satisfaction or punish him, since otherwise the citizen will not obtain the chief end of society, which is protection. ${ }^{{ } \mathrm{II} 6}$ [Emphasis added.] Vattel was clear that this protection which the citizen expects from the State is part of the social compact, as a result of

II3 See Karazivan, supra, generally; Erasmus and Davidson, supra, generally.

II4 See LaGrand, supra, paras 76 and 77. See also Avena, supra, para 40.

II5 United Nations, International Law Commission, Summary Record of the $26 \mathrm{I} 7 \mathrm{th}$ Meeting (Diplomatic Protection), Doc No A/CN.4/SR.26r7, Yearbook of the International Law Commission (2000), vol I, para I6, summarizing the views of John Dugard, the ILC Special Rapporteur on Diplomatic Protection.

II6 Vattel, supra, Bk II, Ch VI, §7I. 
which the citizen gave up the right to make war against foreign interests. It is for this reason that '[i]t is the sovereign power alone, therefore, which has the right to make war.' ${ }^{\text {II7 }}$ As part of this trade-off, the protection due to the national from her State directly translates into a duty in the State in the nature of diplomatic protection. As Vattel put it: 'If an individual wishes to prosecute his right against the subject of a foreign power, he may apply to the sovereign of that subject, or to the officers who exercise the public authority; and if he does not obtain justice, he should turn to his own sovereign, who is bound to protect him. ${ }^{\mathrm{II} 8}$ [Emphasis added.] The dictates of peace among nations afford further support for this duty of diplomatic protection on the national State, for ' $i \mathrm{i}] \mathrm{t}$ would be too dangerous to leave to each citizen the right to obtain justice from foreigners by force; there would not be a single citizen who might not draw his nation into war. And how could nations preserve peace among themselves if each individual had the power to disturb it?'rr9 While this theory of protection of the citizen may not go so far as to obligate a national State to make war ${ }^{\mathrm{r} 20}$ on another State bearing the responsibility for violation of human rights of the citizens of the national State, the principle behind remains applicable in the modern context of pacific pursuit of reparation for the wronged citizen, through diplomatic, political or judicial procedures on the international plain.

It should be possible to allow the national State the freedom to elect, in its wisdom or intelligence, to forego a claim of diplomatic protect against another State for violation of human rights, as a matter of sovereign 'prerogative. ${ }^{\mathrm{I} 2 \mathrm{~T}}$ But this would not be a fault-free choice for the national State who has failed in its duty to protect a national in the given instance-beginning with its inability to prevent the initial harm, and continuing into a failure to pursue reparation on behalf of the victimised national by way of diplomatic protection procedures. This feature of fault is cognizable even by the standards of some adamant opponents of the idea of duty of diplomatic protection. Notably, in dismissing the idea of a legal duty back in 1915, Edwin Borchard argued that any such duty would be 'only

\footnotetext{
II7 Ibid.

II8 Vattel, supra, Bk III, Ch I, §4.

II9 Ibid.
}

I2O It is noted here that diplomatic protection can 'embrace consular action, negotiation, mediation, judicial and arbitral proceedings, reprisals, retortion, severance of diplomatic relations, economic pressure and, in the final resort, the use of force': see United Nations, International Law Commission, Report of the International Law Commission on the work of its fifty-second session (Diplomatic Protection), Doc No A/55/ıo, Yearbook of the International Law Commission (2000), vol II(2), para 420. See also Barcelona Traction, supra, para 82.

I2I Although Vattel was writing in the context of power to make war, when he described as 'prerogative of kinship' or 'royal prerogative'-and a right of the utmost importance- the 'right to decide whether a nation has just subject of complaint' (ibid), it can be readily accepted that the right to pursue pacific reparation claims against foreign States is a matter of legitimate exercise of foreign policy. 
a moral duty and not a legal duty', as it was not capable of enforcement by 'legal methods'. ${ }^{22}$ Surely, such a 'moral duty' raises questions of fault. And the consequences of the attendant fault is that the national State may now be legitimately looked upon to assume the obligation of reparation, in lieu of the foreign State against whom the diplomatic protection proceedings could have been-but was not-brought.

\section{(e) The International Community and Fault resulting from Omissions}

The international community is increasingly looked upon for reparation for violations of human rights in the context of armed conflicts. Such questions of reparation arise in connection with actions, such as where personnel of international organizations and associated persons are accused of sexual violation and sexual exploitation. The question of fault in such circumstances does not usually attract controversy.

The more involved questions of fault relate to omissions-such as UN's failure to prevent the Rwandan Genocide, ${ }^{123}$ the Srebrenica massacres ${ }^{124}$ or the Walikale mass rapes in the DRC. ${ }^{125}$ And even more complicated are questions of fault connected to failure of the international community to take available steps to make, occasion or facilitate the required reparation even when the initial harm had no link to them. A major obstacle to overcome for victims hoping for reparation from the international community is whether it could be said that the gravamen of their complaint is amenable to characterization as an internationally wrongful act' on the part of the international community, such as might entail international responsibility to make reparation. As the embodiment of the international com-

I22 Edwin Montefiore Borchard, The Diplomatic Protection of Citizens Abroad, or, The Law of International Claims [New York: Banks Law Publication Co, 1915] p 29-30.

I23 See United Nations, Report of the Independent Inquiry into the Actions of the United Nations during the 1994 Genocide in Rwanda. Doc No S/1999/1257 of 15 December 1999. Notably, the UN Security admitted to this failure in the case of Rwanda: see http://news.bbc.co.uk/2/hi/africa/714025.stm.

I24 As with Rwanda, the UN also admitted its failure to protect Moslems in the UN established 'safe area' of Srebrenica. See United Nations, The Fall of Srebrenica: Report of the Secretary-General pursuant to General Assembly resolution 53/35 dated 15 November 1999, Doc No A/54/549.

I25 In a widely publicised statement before the Security Council in early September 2oro, Mr Atul Khare, the UN Assistant Secretary-General for Peacekeeping admitted as follows: 'While the primary responsibility for protection of civilians lies with the state, its national army and police force, clearly we have also failed. Our actions were not adequate, resulting in unacceptable brutalization of the population of villages in the area': see http:/www.chinadaily.com.cn/world/201o-o9/o8/content_II270459.htm. See also Amnesty International, 'Mass Rapes in Walikale: Still a Need for Protection and Justice in Eastern Congo, dated December 20Io, Index: AFR 62/oII/20Io. 
munity are the international multilateral organizations through which the will of the international community is expressed and its actions coordinated, it may be helpful to briefly review some of the emerging norms relating to the responsibility of international organizations for internationally wrongful acts.

In this regard, it must be noted that, as at the time of writing (in April 20II) the International Law Commission is engaged in work on draft articles on Responsibility of International Organisations. It is uncertain that the draft articles will be adopted by the General Assembly as treaty, rather than remain only as a 'soft law instrument'. ${ }^{226}$ But even as soft law, the draft articles are expected to afford a useful tool in the assessment of fault on the part of the international community, in the matter of reparation. It is particularly notable that the draft articles themselves deal with the specific question of reparation. ${ }^{127}$

On the question of fault, it is notable that the responsibility of an international organization is founded upon the attribution of an 'internationally wrongful act' to the organization. Draft article 3 lays down the basic principle of responsibility by providing that '[e]very internationally wrongful act of an international organization entails the international responsibility of the international organization.' Draft article 4 engages the question of when it may be said that an internationally wrongful act has occurred on the part of an international organization. The answer is provided as follows: 'There is an internationally wrongful act of an international organization when conduct consisting of an action or omission: (a) is attributable to the international organization under international law; and (b) constitutes a breach of an international obligation of that international organization. ${ }^{{ }_{228}}$ Draft articles 5 through 8 deal with the rules of attribution of internationally wrongful act to the international organization. And draft articles 9 to I2 deal with rules to assist in the determination of a breach of an international obligation of the international organization.

Ultimately, then, the question of fault will depend on whether the international organization may be said to have breached an international obligation that encumbers the organization. Such a breach is said to have occurred when an act of that international organization-in terms of conduct consisting of an action or omission-is not in conformity with what is required of it in terms of that obligation. ${ }^{\mathrm{I} 29}$ The origin and character of the obligation is irrelevant. ${ }^{130}$ Breach of

I26 See J E Alvarez, Memo (on Draft Articles on International Organisation) to the Advisory Committee, Meeting of 2I June 2010 (distributed as public document), p I; available at <http://www.law.nyu.edu/ecm_dlv3/groups/public/@ nyu_law_website_ffaculty__faculty_profiles__jalvarez/documents/documents/ ecm_pro_o6690o.pdf>

I27 See draft article 33 and following.

I28 Draft article 4.

I29 See draft article 9(I).

I30 Ibid. 
an international obligation may even arise under the rules of the organization in question. ${ }^{\mathrm{ir}}$

In the consideration of what is an international obligation on the part of the international community — or of an organization representing it - it is important to distinguish an obligation truly speaking, as the correlative of right or claim, from humanitarian benevolences to which the recipient is not entitled as of right. For, as Grotius observed, "if one is under obligation according to the rule of love, by omission he will sin indeed, but he will not be held to make reparation; for the source of the obligation to make good is the true right, properly speaking .... . ${ }^{\mathrm{r}_{32}}$

These considerations must be kept firmly in mind when grappling with the question of fault on the part of the international community, in relation to its failure vel non to take available steps to make, occasion or facilitate the required reparation when the initial harm had no link to it. It is important at all times to avoid confusing the humanitarian undertakings of a Good Samaritan, in the service of humanity, with her (or his) legal obligation to the beneficiaries of such undertakings; for it is charity and not obligation properly so called that impels the Good Samaritan. Any confusion in this regard may result in a counter-productive chill on the spirit of philanthropy, leaving the world a much poorer place and victims of injustice the worse for it. ${ }^{\mathrm{I} 33}$

One classic instance in which this confusion reared its head was in the area of criminal injuries compensation schemes that exist in some domestic jurisdictions. We shall review that scheme next, for what lessons it may hold for reparation for victims of sexual violence in armed conflicts.

\section{(iv) A No-Fault Basis for Reparation}

Wherever there is discernible fault, the ethos of accountability, entirely necessary in the fight against impunity for gross violations of human rights or serious violations of international humanitarian law, fully warrants, nay, recommends, the fault-based analysis to reparation. ${ }^{\mathrm{I} 4}$ There are, however, those instances where the fault-based analysis may prove insufficient to afford reparation to victims. This may be the case where, for instance, the party at fault is either unable or unavailable to make reparation, particularly where reparation has an economic quotient. Such is the case where the victim is genuinely unable to identify her rapist or she is too afraid to do so due to fear of further violence or the perpetrator is simply

I3I See draft article $9(2)$.

I32 Grotius, supra, Ch XVII, p 433.

I33 This realisation has led some of the more litigious societies of North America to adopt laws that now seek to protect Good Samaritans from law suits: see for instance, the Good Samaritan Act (1996) of British Columbia, Canada and the Good Samaritan Act (200I) of Ontario, Canada. See also the US Federal Law known as the Emerson Good Samaritan Food Donation Act (1996).

I34 See also Andrew Ashworth, 'Punishment and Compensation: Victims, Offenders and the State' (I986) 6 Oxford Journal of Legal Studies 86 at p 99. 
unable to pay any compensation ordered by the Court or other reparation awarding authority. ${ }^{135}$ In these instances, the fault-based analysis may be of no use to the victim. It is in these situations that the no-fault basis should be employed-as the default position.

The model for the no-fault reparation scheme may be found in the criminal injuries compensation schemes that are found in much of the economically advanced societies of the world. ${ }^{\mathrm{r} 36}$ They exist for purposes of compensating victims who suffered personal injuries, from violent crimes.

Although the legislative impetus for national compensation for victims of violent crimes started in New Zealand with the adoption of its Criminal Injuries Compensation Act in $1963,{ }^{137}$ the philosophical battleground for the national schemes gained the highest profile in England between 1954 (when the proposal was first made to the British public) and 1964 (when the scheme was put in place in England). Soon after its formation in $\mathrm{I} 957$, JUSTICE, the British legal thinktank and section of the International Commission of Jurists, urged upon the British Government the adoption of the scheme of criminal injuries compensation proposed by Margery Fry in 1954. It was a scheme wholly at home in the Welfare State. ${ }^{13^{8}}$ The Home Secretary reluctantly set up a Working Party in 1959 to study the acceptability and workability of the proposal. The report of the Working Party was published in June 196r. ${ }^{\mathrm{I} 9}$

The report of the Working Party highlighted certain theoretical objections to be resolved. Notable among them was the question whether there was any duty on the State to provide compensation for citizens who are victims of violent

I35 See the Explanatory Report to the European Convention on the Compensation of Victims of Violent Crimes, para I, available at < http://conventions.coe.int/ treaty/en/Reports/Html/Ir6.htm>.See also JUSTICE, 'A Report by JUSTICE: Compensation for Victims of Crimes of Violence' (1962) paras 2 and 76; Robert E Scott, 'Compensation for Victims of Violent Crimes: An Analysis', (I967) 8 William \& Mary Law Review 277 at 278; Jo Goodey, 'Compensating Victims of Violent Crime in the European Union With a Special Focus on Victims of Terrorism' [a discussion paper for National Center for Victims of Crime, May 2003] p I <www.ncvc.org/ncvc/ AGP.Net/Components/documentViewer/Download.aspxnz?DocumentID=32594>

I36 See, Goodey, supra, p 5. See also the European Convention on Compensation of Victims of Violent Crimes (1983); Council of Europe Directive 2004/80/EC of 29 April 2004; Hans-Joerg Albrecht and Michael Kilchling, 'Victims of TerrorismPolicies and Legislation in Europe: An Overview on Victim Related Assistance and Support' [expert paper presented to Council of Europe, European Committee on Crime Problems, Group of Specialists on Assistance to Victims and Prevention of Victimisation, Second Meeting, Strasbourg, I8-20 May 2005; Frederic Megret, supra, at pp $130-\mathrm{I} 33$.

I37 See Criminal Injuries Compensation Act I963, I New Zealand Statute No I34 (1963).

I38 JUSTICE, supra, $\mathrm{p} 2$.

I39 Ibid, p 2. See also United Kingdom, Report of the Working Party on Compensation for Victims of Crimes of Violence (Cmnd I406). 
crimes. ${ }^{\mathrm{I} 40}$ To this query, JUSTICE responded as follows: 'Although it is difficult to point to any absolute obligation on the part of the State to provide compensation for its citizens who are injured by the commission of a crime of violence, we think that there are sound reasons why the State should accept some responsibility for the victim's injuries. ' ${ }^{\text {I4I }}$ Among those reasons were the following. First, compensation in the nature of victimization from violent crimes is similar to other types of harm for which the State (in Britain) had already accepted liability, in the circumstances of the State's failure to maintain peace and order in society, even when such harms could not have been prevented by the State. This was particularly the case as regards compensation for victims who suffer injury in consequence of enemy action and civil riots. Second, citizens are discouraged from carrying weapons to defend themselves against violent attacks. Third, citizens are saddled with certain obligations the fulfillment of which may leave them exposed to immediate or eventual injuries to their persons. These duties included lending assistance to the State in the prevention or detection of crimes and enforcement of the law. Fourth, neglect of interest of victims of crimes might stimulate in the public a desire for vigilante justice. Fifth, it is desirable to have in place an effective injuries compensation scheme to counterbalance the State's dissuasion of citizens from taking the law into their own hands. And, finally, the State, by its own direct intervention, gets in the way of the effectiveness of the victims civil remedy, by imposing heavy penalties, by way of fines or periods of incarceration, on the offender. ${ }^{\mathrm{It}}$

It is noteworthy, perhaps, that some of these philosophical rationales-rooted in notions of a right in the victim to reparation correlative to a duty on the State to provide it-continued to motivate the impetus for reparation for victims of violent crimes, even beyond the arena of the pre-r964 debate in the UK. ${ }^{143}$

An epic debate on the matter occurred in the British House of Lords on 5 December 1962, during which Lord Denning vehemently opposed the theory of right in the victim to receive, and obligation on the State to pay, compensation. As he summed up the matter, 'this is not a matter for lawyers and for legal entitlement. What should happen is that the Government themselves should provide a

\footnotetext{
I40 JUSTICE, supra, para 5 .

I4I Ibid, para 6.

I42 Ibid.
}

I43 See for instance, Paul Rothstein, 'How the Uniform Crime Victims Reparations Act Works' 6o American Bar Association Journal (December 1974) I531; Michael Gahan and Rose Lennon, 'Compensating Crime Victims: a Legislative and Program Analysis' (1977) 4 Journal of Legislation $7 \mathrm{I}$ at pp 72-73; Paul Hudson, 'The Crime Victim and the Criminal Justice System: Time for a Change' (1983-I984) in Pepperdine Law Review 23 at pp 29-33; LeRoy Lamborn, 'The Propriety of Governmental Compensation for Victims of Crime' (1972-1973) 4I George Washington Law Review 446 at pp 462-463; Peter Duff, 'The Measure of Criminal Injuries Compensation: Political Pragmatism or Dog's Dinner' (1998) i8 Oxford Journal of Legal Studies 105 at p 106; Ashworth, 'Punishment and Compensation: Victims, Offenders and the State', supra, p Io2 et seq. 
fund, maybe supported by charitable bodies, too, which can be allotted ex gratia for those deserving cases by sympathetic administrators, without all the paraphernalia to entitlement, rights at law and tribunals'. ${ }^{\text {I4 }}$ This view, as it were, eventually carried the day in the adoption in 1964 of a criminal injuries compensation scheme in England. ${ }^{145}$ This ex gratia rationale appears in the Home Office's White Paper on the Criminal Injuries Compensation Scheme proposing its adoption in I964. The focus of concern was stated to be: 'the common good and the idea that in the person of the victim a harm is done to society which he or she has no duty to bear alone. Accordingly compensation is a means by which the loss is distributed across society as a whole, so recognizing the reality of social existence and deepening a sense of community. ${ }^{{ }^{146}}$ One also notes the following observation appearing as part of the background information in a 2005 UK Government Command Paper:

Ever since the scheme started in 1964, successive Governments have made clear their view that the state is not liable for injuries caused to people by the criminal acts of others. The guilty party is the offender and, in an ideal world, it should be the offender who compensates the victim. But the reality is that offenders are not always caught or even identified, and may lack the means to pay compensation to the victim. Successive Governments have recognised that the public feel a sense of responsibility for, and sympathy with, the innocent victim of a crime of violence. They have taken the view that it is right for those feelings to be given practical expression by the provision of a monetary award on behalf of the community. ${ }^{\mathrm{I} 47}$

It is also notable that in the European Convention on Compensation of Victims of Violent Crimes (1983), 'reasons of equity and social solidarity'-not reasons of rights and obligations of the victims and the State respectively-were advanced as necessitating the national compensation scheme prescribed in the Convention..$^{148}$ For those reasons, it was deemed 'necessary to introduce or develop schemes for the compensation of these victims by the State in whose territory such crimes

I44 United Kingdom, 'Crimes of Violence, Compensation for Victims', Parliament, House of Lords, House of Lords Debates (Hansard), HL Deb o5 December 1962 vol 245 cc245-319, at 274 .

I45 United Kingdom, Home Office, Scottish Home and Health Department, 'Compensation for Victims of Crimes of Violence', I964, Cmnd 2323. See also United Kingdom, 'Compensation for Victims of Crimes of Violence', Parliament, House of Lords, House of Lords Debates (Hansard), HL Deb o7 May I964 vol 257 ccr35I-I4I9 at 1352 .

I46 United Kingdom, Home Office, Scottish Home and Health Department, 'Compensation for Victims of Crimes of Violence', r964, Cmnd 2323, p 8.

I47 United Kingdom, Criminal Justice System, 'Rebuilding Lives-Supporting Victims of Crime', Cmnd 6705 (December 2005) p I4.

I48 See preamble to the European Convention on Compensation of Victims of Violent Crimes. 
were committed, in particular when the offender has not been identified or is without resources. ${ }^{\mathrm{I} 49}$ To that end, article 2 of the Convention provides as follows:

I. When compensation is not fully available from other sources the State shall contribute to compensate:

(a) those who have sustained serious bodily injury or impairment of health directly attributable to an intentional crime of violence;

(b) the dependants of persons who have died as a result of such crime.

2. Compensation shall be awarded in the above cases even if the offender cannot be prosecuted or punished.

It is also notable that in the Declaration of Basic Principles of Justice for Victims of Crime and Abuse of Power (1985), the UN General Assembly urged States to endeavour to provide financial compensation to victims of serious crime, when compensation is not fully available from the offender or other sources. ${ }^{150}$ To that end, the General Assembly urged the establishment, strengthening and expansion of national funds for compensation to victims. ${ }^{151}$ 'Where appropriate,' urged the General Assembly additionally, 'other funds may also be established for this purpose, including those cases where the State of which the victim is a national is not in a position to compensate the victim for the harm. ${ }^{{ }_{\mathrm{I} 52}}$ There is no hint in the Declaration that the urge on States to endeavour to provide such compensation rested upon any theory of duty, occasioned by fault, upon the State or the international community, as the case may be, to provide it.

As seen earlier in the debates in England in the early i96os, one recurring strain of argument in the theory of duty was the argument of social contract, as part of which the victim had surrendered his or her right to bear arms to defend self. Such a theory would be difficult to sustain as a reason to look to the international community for purposes of reparation to victims of sexual violence in international armed conflicts. As one commentator persuasively observed:

Social contract theory provides a broad and elegant rationalization for compensation, but its transposition to the international plane is a conceptual stretch. The international community is certainly taking on more responsibilities in terms of guaranteeing a certain level of security, but it is difficult to say the failure to protect populations against certain international crimes now creates a political obligation to provide reparations and assistance..$^{153}$

\footnotetext{
I49 Ibid.

I50 See para I2.

I5I See para I3.

I52 Ibid.

I53 Megrets, supra, p 203.
} 
It may well be that the most promising theory of duty on the part of the international community to make reparation to victims of international crimes may be founded on the doctrine of responsibility to protect so clearly articulated in the 2005 World Summit Outcome resolution. According to that doctrine, States and the international community bear complementary responsibility-with States bearing the primary responsibility — to protect those within their territories from such serious human rights violations as genocide, crimes against humanity and war crimes. Surely, this complementarity of the responsibility to protect was primarily motivated by a humanitarian need to limit the doctrine of sovereignty of States that had hitherto inhibited foreign intervention to prevent imminent violations or those in progress. Nevertheless, the incidence of the norm could possibly engage a question of fault on the part of the international community, in the event of its failure to discharge its own part of the responsibility to protect. It is, however, quite uncertain that the growing norm of responsibility to protect is strong enough to sustain such a theory of duty at this stage of its development. This observation is not diminished by the role of humanitarian aid contemplated in the discussion of responsibility to protect seen in A More Secure World. There, the following observation appears:

\begin{abstract}
Humanitarian aid is a vital tool for helping Governments to fulfil this responsibility. Its core purpose is to protect civilian victims, minimize their suffering and keep them alive during the conflict so that when war ends they have the opportunity to rebuild shattered lives. The provision of assistance is a necessary part of this effort. Donors must fully and equitably fund humanitarian protection and assistance operations. ${ }^{154}$
\end{abstract}

The observation clearly relates to what the international community needs to do to assist Governments fulfil their own responsibility to protect. Regardless of the imperative statement that 'donors must fully and equitably fund humanitarian protection and assistance operations', the focus of the general observation has less to do with the international aspect of the doctrine of responsibility to protect.

In the circumstances, one clear path to articulating the basis upon which the international community may intervene in aid of female victims of sexual violence during armed conflicts lies with the ex gratia rationale of domestic criminal injuries compensation schemes. While it may not afford a perfect explanation, and will not satisfy everyone, it has assisted many victims of crimes in domestic jurisdictions beyond what has so far been available for the women victims of sexual violence in armed conflicts in the Democratic Republic of Congo and elsewhere around the world.

I54 United Nations, A More Secure World: Our Shared Responsibility (Report of the Highlevel Panel on Threats, Challenges and Change) (2004) para 234. 


\section{The Special Focus on Female Victims}

The theories and models of reparation reviewed above are, of course, of general applicability to all victims of human rights violations during armed conflictsregardless of gender. As a practical matter, however, women victims of sexual violence during armed conflicts have a legitimate claim to priority in the application of these theories. This priority of claim arises simply from the fact that women tend to bear the heavier burden of armed conflicts. Although the case exists for caution in the assertion of the proposition, ${ }^{55}$ it is submitted that the UN SecretaryGeneral provided a convincing résumé of how the burdens of armed conflicts tend to weigh heavier on women than on men. ${ }^{156}$ It notably begins with the burden of inequality that women generally bear in all societies in peacetime. They are generally poorer, suffer greater deprivation of education, and are less occupationally mobile, than men. Their disability in this regard includes limited participation in decisions regarding peace and armed conflicts. Armed conflicts generally compound these disadvantages. ${ }^{157}$

And, of course, armed conflict itself has its own set of unique burdens on women. They include the following. Although modern armed conflicts have seen increasing number of women among combatants, the fact remains that women are more likely than men to experience conflict as civilians. ${ }^{15^{8}}$ This is a formula that systematically tilts against women the scale of burdens of armed conflicts that civilians bear. A logical and indeed empirical consequence of this is that a great deal of such burden involves the hardship that results to women when the armed conflict separates them from the men who provide them with economic support. ${ }^{59}$ 'Women and children also constitute the majority of the world's refugees and internally displaced persons. ${ }^{\text {' }}$ '00

As shown clearly elsewhere in this study, a particular burden of armed conflicts that women experience at a disproportionate rate is the burden of sexual violence and exploitation during armed conflicts which women experience at a far higher proportion than men, 'in particular ... torture, rape, mass rape, forced pregnancy, sexual slavery, enforced prostitution and trafficking. ${ }^{16 r}$ A recent snap shot of this disproportionate burden of sexual violence appears in the account of

I55 See generally, Charlotte Lindsey, 'Women Facing War: ICRC Study on the Impact of Armed Conflict on Women' (2003).

I56 United Nations, 'Report of the Secretary-General on women, peace and security', Doc No S/ /2002/1r54 of I6 October 2002. See also Judith Gardam and Hillary Charlesworth, 'Protection of Women in Armed Conflict' (2000) 22 Human Rights Quarterly $\mathrm{I} 48$.

I57 See, United Nations, 'Report of the Secretary-General on women, peace and security', supra, para 5 .

158 Ibid, para 6.

I59 Ibid, para 9 .

I6o Ibid, para 6.

I6I Ibid, para 7 . 
four American journalists - three men and one woman-who were seized by proGaddafi forces during the $201 \mathrm{I}$ Libyan armed conflict. ${ }^{\mathrm{I} 2}$ Upon their capture, the primary concern of the woman journalist was thus expressed: 'God, I just don't want to be raped.' None of the men expressed a similar concern. And, indeed, the experience of the four journalists included accounts of sexual groping of only the woman. Although the published story does not make clear whether or not she was raped, it was clear from the story that the potent concern about her own sexual safety was a concern not shared by her male colleagues in their own regards.

As noted earlier, a broader effect of a culture of sexual violence against women during armed conflicts could be a trend towards maladjustment of social norms, in virtue of which sexual violence could be tolerated as 'normal' within the particular society. ${ }^{\mathrm{I} 3}$ Proliferation of small arms is another relevant byproduct of armed conflicts on women. It 'increases the risk of interpersonal violence, including domestic violence, which often continues after the conflict. ${ }^{164}$

The Prologue to this study also contains a summary of other precise manner in which armed conflicts negatively affect women especially in terms of their physical and mental health, as well as their economic well-being in society.

One particular significance of keeping the differential impact of armed conflicts on women victims of sexual violence in the reparation discourse pertains to the phenomenon of scarcity of funds in the face of 'the sheer number of victims and perpetrators [that] may overwhelm the best efforts to provide full redress to victims' without regard to gender. ${ }^{165}$ Given the fundamentally different effect that armed conflicts tend to have on women, it will be inequitable to hold up the matter of reparation of women victims of sexual violence in armed conflicts, in circumstances in which resources are scarce for the many other victims of armed conflicts.

I62 Anthony Shadid, Lindsey Addario, Stephen Farrell and Tyler Hicks, '4 Times Journalists Held Captive in Libya Faced Days of Brutality' New York Times, 22 March 2oII, at <http://www.nytimes.com/20II/o3/23/world/africa/23times.html>

I63 See Prologue. See also UN General Assembly Third Committee resolution A/C.3/65/L.I7/Rev.2 (2010), supra, para 1o; United Nations, Report of the SecretaryGeneral pursuant to Security Council resolution 1820 (2008), supra, para 7; Oxfam International, 'Sexual Violence in Colombia: Instrument of War', supra, 2; Harvard Humanitarian Initiative (with support from Oxfam of America), 'Now, the World is Without Me,' supra, pp 2 and 38-40.

I64 See, United Nations, 'Report of the Secretary-General on women, peace and security', supra, para 7 .

I65 Dinah Shelton and Thordis Ingadottir, 'The International Criminal Court Reparations to Victims of Crimes (Article 75 of the Rome Statute) and the Trust Fund (Article 79)' available at < www.pict-pcti.org/publications/PICT_articles/ REPARATIONS.PDF> 


\section{Conclusion}

In a welcome development, international law has experienced a shift in focus to restorative justice in the manner of reparation for the victims of gross violations of human rights. This shift in focus has been mostly aspirational. Efforts to translate that aspiration to tangible, effective reparation programmes have been slowed down partly by the absence of coherent theoretical bases-especially palatable ones-for reparation in particular cases.

It is submitted, however, that in canvassing the theories of reparation, the driving consideration must always remain the interest of victims and not the intellectual gratification of experts engaged in the exercise. A fine-grained rationalization of the idea of reparation will be of no consequence if it does not assist in improving the lives of the victims in practical terms. In this connection, it is important always to keep in view the fault-based theories of reparation. However, it is also advisable to consider whether and when it is more useful to employ the no-fault-based rationale for achieving the aim of reparation when the party at fault is either unavailable or unable to make reparation at all or in full. In those instances, guidance might be had to the gratis model of reparation that has been employed in many domestic jurisdictions to make some compensation to victims of violent crimes. 


\section{Epilogue}

\section{Summary of the Study}

The foregoing exercise has been an exploration of ways in which international law could be improved with a view to adapting it better for the protection of women from sexual violence during armed conflicts. The chief aim, of course, is to deny impunity to those who commit such crimes. The present study began with an attempt, made in chapter $\mathrm{I}$, at understanding the prevalence of evil during armed conflicts. Although the main focus of the study is evil in the nature of sexual violence during armed conflicts, the exercise began with a review of some plausible explanations for evil-doing in armed conflicts, as a general phenomenon. From there, we zeroed in on the reasons for the particular brand of evil that women are made to endure during armed conflicts-i.e. sexual violence. That manner of proceeding was inspired by the belief that a general and wider inquiry into evil-doing during armed conflicts affords a useful starting point for the study of sexual violence as a particular brand of evil.

In exploring the nature and causes of evil, much reliance was placed on the theories propounded in fields of humanities cognate to law, such as philosophy, sociology and psychology, in hopes that a multi-disciplinary appreciation of the nature of evil offers a sounder understanding of the phenomenon of evil-doing.

In the general review of the causes of evil-doing, we explored whether evildoing results from situational circumstances of the perpetrators or their predisposition to do evil, or both. In this regard, we explored the works of renowned thinkers like Hannah Arendt, Zygmunt Bauman, Stanley Milgram, Jean-Paul Sartre, Philip Zimbardo and others, for what insights they may offer to international law in its efforts to contain evil-doing during armed conflicts.

In the review of the explanations for sexual violence during armed conflicts, we explored the more familiar theories, such as the theory of opportunism and theory of sexual violence as a deliberate weapon of war. We also reviewed the less familiar theories such as sexual violence as an evolutionary tactic, as well as the theory of connivance and condonation of sexual violence during armed conflicts.

In chapter 2, we began to see in earnest how these theories might assist in improving the international law, so as to make it better able to protect women during armed conflicts. We examined the shortcomings of international law as 
regards the responsibility of a superior occasioned by crimes committed by his subordinates. As it is, international law imposes upon superiors a responsibility to prevent and to punish the commission of crimes. Regrettably, the responsibility of a superior to prevent the commission of crimes-including the crime of sexual violence during armed conflict-is not engaged unless it is shown that the superior knew or ought to have known that the subordinate in question was committing or was about to commit the crime.

It is submitted that in view of the prevalence of sexual violence against women during armed conflicts, the responsibility to prevent must require more from the superior. It must require the superior to put in place reasonable measures aimed at preventing the commission of sexual violence during armed conflicts. Such an obligation will assist in denying impunity to superiors who may have an inclination or tendency to connive at or condone the commission of sexual violence by subordinates.

Also explored are ways in which the duty to punish could be improved through interpretation of the underling norm. Here, it is noted that the law is not clear as regards whether a superior is under an obligation to punish a subordinate who committed a crime prior to the superior's assumption of command. It is suggested that if the purpose of international law is to prevent impunity, then there is an obligation on a superior to punish a subordinate who committed a crime prior to the superior's assumption of command.

In chapter 3 , it is argued that in the effort to achieve a legal framework which will contain the evil of sexual violence during armed conflicts, there is a need to devise a proper definition of rape in international criminal law. The part envisaged for such a definition in the calculus of criminal responsibility will include legal developments, in terms of procedure, which will prevent perpetrators of sexual violence during armed conflicts from enjoying impunity. This objective of criminal responsibility may be defeated if victims of sexual violence during armed conflicts are induced to refrain from participating in rape trials due to an unhealthy focus on their own conducts at the time of the crime. This may result from a definition of rape that unwittingly puts the victims on trial, by routinely focusing on whether or not they gave consent to the sexual acts. The focus of the definition should rather be on the coercive circumstances of the occasion, rather than whether the conduct of the victim could have amounted to consent or objection to the sexual act. A definition of rape which concentrates on the coercive circumstances of the occasion is more likely to achieve the ends of containment of sexual violence than one which routinely requires the Prosecution to prove that the victim did not give consent to the sexual act.

In chapter 4 , we examined a certain debate regarding the definition of genocide. That debate relates to whether conviction for genocide requires the prosecution to prove that an accused possessed specific intent to destroy at least a substantial part of a protected group. While this debate is often thought to engage the question of the mass of the victims against whom acts of genocide had been actually committed, the debate really only engages the element of intent to commit genocide and not the actus reus of genocide. That is to say, the debate 
does not require that the acts amounting to crime be committed against a substantial part of the protected group; it is rather that the perpetrator be seen to have intended the destruction of a substantial part. Consequently, the conception of rape as an act of genocide must largely remain unperturbed by the implications of this debate, as long as the requisite intent is established on the part of the perpetrator. Hence, rape may continue to be conceived as an act of genocide, whether or not it had been shown that a substantial part of a given group had been victims of acts of genocide-including rape itself.

Still on specific intent, in international criminal law, one crime for which a specific intent is required is the crime of genocide. This is the intent to destroy in whole or in part a protected group as such. Recently, however, some judges have also attempted to interpret specific intent into the provisions relating to the war crime of terrorism. This approach comes from a certain construction of the definition of terrorism as '[a]cts or threats of violence the primary purpose of which is to spread terror among the civilian population'. Chapter 5 examines this attempt and its correctness. The concern here is that international law may be compromised in its effort to protect women better against sexual violence, if the veritable terror of sexual violence during armed conflict is denied legal recognition as terrorism, simply because at the fore of the perpetrator's state of mind is libidinal indulgence, rather than to spread terror among a civilian population. The question is examined whether it is reasonable to examine the purpose of the perpetrator's act from the perspective of its effects as inducing terror in the mind of the victim.

Chapter 6 examines the utility of special characterisation of certain war crimes as 'grave breaches', according to whether those crimes were committed during international armed conflicts rather than in internal armed conflicts. Again, this is a discussion with serious implications for the war crime of sexual violence. Issue is taken with an outcome which would recognise the characterisation of sexual violence against women as 'grave' if they are committed in international armed conflicts, whereas the same offences are denied such a characterisation if they are committed in internal armed conflicts.

Chapter 7 deals with a situation in which well-intentioned enthusiasm by international judges and prosecutors to advance international law outside the boundaries of legislation may mask stark and serious lacunae in the law, or casus omissus, the correction of which is better done through legislation. Such is the case with forced marriage. To use the guise of war to impose a conjugal relationship upon a woman against her will is a highly immoral conduct that international law ought rightly to punish as a crime against humanity or war crime. This, however, is only a statement of legal aspiration-lex ferenda. It is insufficient to make the conduct an international crime accepted by states as such.

According to some view, there is no lacuna relating to forced to marriage, since the offence of forced marriage is sufficiently addressed by the prohibition against sexual slavery and other enslavement crimes already provided in international criminal law as crimes against humanity. In that case, it may then be said that there is no gap in international law in relation to protection of women from the evil of forced marriage. But if that view is incorrect and a gap is truly 
seen to exist in relation to legal protection against forced marriage during armed conflicts, that gap is not sufficiently covered by a denial of its existence, because it is possible to conjure up a judge-made construction that avoids inquiring into the existence of the gap. In chapter 8 , it is urged that prosecution of sexual violence committed during armed conflicts ought to form a central plank in all transitional justice initiatives in post-conflict societies. Such efforts must target not only sexual crimes which directly form part of the system crimes typically associated with armed conflicts, such as genocide, crimes against humanity and war crimes; but also sexual crimes indirectly associated with the armed conflict, in the sense that the perpetrators took advantage of the war-inspired diversion of the security forces to commit the crimes. Finally, in chapter 9, the normative basis of reparation is explored. In doing so, the traditional fault-basis of reparation is not rejected. Quite the contrary, its importance is stressed in the deserving cases. It is nevertheless urged, in the end, that inspiration be derived from domestic jurisdictions, where the no-fault scheme has largely evolved as a government-sponsored back-up mechanism that ensures that the victim of violent crime will receive some compensation, rather than go wholly without, in those instances in which the offender is either unable or unavailable to make reparation.

\section{A Note of Optimism}

In the final analysis, we have seen the pervasive presence of the evil of sexual violence during armed conflicts over the years, since time immemorial. There is as yet no evidence tending to show any abatement to the trend. The question thus arises as to the prospect of eradication or containment of the problem in the future.

Certainly, the long history of the problem of the pervasive presence of the evil of sexual violence during armed conflicts, its perennial nature and its variegated aetiology sadly combine to dampen optimism in any prognosis for future abatement. We have already seen in this combination of factors a few considerations that help to explain the pervasiveness and longevity of this problem. Not to be excluded from these factors is the initial view expressed long ago by Cicero that 'silent enim leges inter arma' [law is silent in war]. 'This alone should sufficiently explain the culture of savagery of the ancient wars during the era of Cicero. A regular feature of such savagery was sexual violence against women during armed conflicts of the age. We recall the observations of Tacitus regarding the mayhem, the plunder and the rapes of women during the siege of Cremona: 'Composed as the army was of citizens, allies, and foreign troops, differing widely in language and customs, the objects of the soldiers' greed differed also. But while their views of what was right might vary, they all agreed in thinking nothing wrong.' Eventually, the international community embarked upon a course away from the views of war and law according to Cicero. The need was seen to regulate wars. Prominent

I Marcus Tullius Cicero, Pro Milone I6 (N H Watts translation) 5th edn [New Haven: Harvard University Press], IV:Ir. See also <www.thelatinlibrary.com/cicero/milo. shtml>. 
among the early efforts in this regard were those of Henri Dunant, inspired by the battle of Solferino, and his partly inspired International Committee of the Red Cross. ${ }^{2}$ These efforts resulted in early regulatory efforts on the international stage, albeit, tentative at the early stages. Notable among these were the Geneva Convention 1864; the Hague Regulations Respecting the Laws and Customs of War on Land (annexed to the Hague Convention r907 Respecting the Laws and Customs of War on Land); and the Geneva Conventions I949.

Regrettably, however, there were little or no internationally standardised enforcement mechanisms to make readily and uniformly realisable the ambitions of these instruments. Not even the prosecutions of war criminals of World War II in Germany and the Far East were directly founded on jurisdiction located in any of these instruments. One notes, for instance, the still lingering debate on whether even the humanitarian norms of the Geneva Conventions 1949 created criminal offences such as satisfied the rule of legality. ${ }^{3}$ And, as old habits die hard, the culture of martial violence against women continued unabated.

Enforcement of the norms created in these international instruments was left wholly within the domestic enforcement domain of States. Enforcement thus depended upon the volition and ability of each State to recognise the civilised merits of these norms and legislate them into domestic law. Particularly notable is the obligation on States to incorporate only part of the range of the norms created in the instruments adopted at the international level. For instance, the Geneva Conventions Act (1960) of Nigeria gave Nigerian courts jurisdiction to prosecute only the 'grave breaches' provisions of the Geneva Conventions of I949-being articles 50, 5I, 130 and 147 respectively of the First, the Second, the Third and the Fourth Conventions. This limited incorporation leaves out all other norms prescribed in the Geneva Conventions i949. Notably left out are the norms recognised in article 3 common to the Geneva Conventions: and they are the only provisions of the Geneva Conventions that apply as such to armed conflicts not of an international character. The significance of the exclusion of common article 3 from the scheme of domestic incorporation is immediately obvious as regards the pervasiveness of sexual violence against women in armed conflicts. This is considering that armed conflicts not of an international character account as much, if not more, for the sexual violence against women in armed conflicts. Yet this limited incorporation is precisely what the Geneva Conventions themselves require. ${ }^{4}$

2 See Chile Eboe-Osuji, 'Genocide, Justice and the Forensic Sensibilities of the International Committee of the Red Cross' Chinese Journal of International Law (2006) Vol 5, No I, p I49.

3 See Cassese, International Criminal Law, supra, pp 50-53; and Mettraux, supra, p 52.

4 For instance, article 49 of the First Geneva Convention provides as follows: 'The High Contracting Parties undertake to enact any legislation necessary to provide effective penal sanctions for persons committing, or ordering to be committed, any of the grave breaches of the present Convention defined in the following Article.' See also similar provisions in articles 50, 129 and 146 respectively of the Second, Third and Fourth Geneva Conventions. 
Certain deleterious attitudes towards women were compounded by the impetus towards violations such as was fostered by the absence of standardised international enforcement mechanisms in the international instruments of yesteryears. Prominent among these attitudes was, as we saw in Chapter I, that women, alongside other chattels, were viewed as prizes and booties to be won willy-nilly by victorious warriors.

All of these would undoubtedly have helped sow an early seed of a free-forall attitude towards sexual violence against women during armed conflicts. It thus explains its pervasiveness in the early periods. And such pervasiveness in the early periods would no doubt have assisted in the entrenchment of an enduring culture of the violations in the later years that has endured until the contemporary time.

Nevertheless, it is entirely possible to contain the evil of sexual violence in future armed conflicts. In this regard, it helps to recall that there was a time when the evil of slavery of Africans and disenfranchisement of women also looked insurmountable. But with a strong resolve from the international community, aided by the unrelenting encouragement of committed individuals with passion or expertise or both in the subject matter, it has been possible to contain slavery and largely pave the way for women's suffrage in most places around the world.

Useful foundations of hope have been laid in the plains of international criminal law, such as ought to assist the development of international criminal law in a manner that should bring greater sensitivity to the need to contain sexual violence against women. Such foundations include the following: consistent proscription of acts of sexual violence in every modern instrument of international criminal law from the Statutes of ad hoc international criminal tribunals to the Statute of Rome; the efforts of pressure groups who constantly remind international prosecutors to ensure prosecution of these crimes; the need to ensure 'a fair representation of female and male judges' on the Bench of the International Criminal Court; 5 and the need to ensure that there is expertise on the Bench of the ICC on the subject of violence against women, by requiring States Parties to take such expertise into account when electing judges. ${ }^{6}$

It is also a positive development that there now appears a significant scholarly interest in the subject of international law and sexual violence against women during armed conflict. Such interest includes the present one, the aims of which encompasses the articulation of the aetiology of sexual violence against women during armed conflict, as a matter to be thoroughly understood in all its emanations (including from the perspective of the policy of connivance or condonation) as part of the attempt to fashion adequate legal responses to the problem.

With these efforts, among many existing and yet to be conceived ones, there is optimism about the prospects of containing the evil of sexual violence against women during armed conflicts.

5 See article $36(8)$ (a)(iii) of the ICC Statute.

6 See article $36(8)(b)$ of the ICC Statute. 


\section{Bibliography}

Alford, C Fred, What Evil Means to Us [Ithaca, NY: Cornell University Press, 1997].

Albrecht, Hans-Joerg and Kilchling, Michael, 'Victims of Terrorism-Policies and Legislation in Europe: An Overview on Victim Related Assistance and Support' [expert paper presented to Council of Europe, European Committee on Crime Problems, Group of Specialists on Assistance to Victims and Prevention of Victimisation, Second Meeting, Strasbourg, 18-20 May 2005.

Alvarez, J E, Memo (on Draft Articles on International Organisation) to the Advisory Committee, Meeting of 21 June 2010 (distributed as public document); available at <http://www.law.nyu.edu/ecm_dlv3/groups/public/@nyu_law_website_ffaculty__ faculty_profiles__jalvarez/documents/documents/ecm_pro_066900.pdf>.

Ambos, Kai, 'Superior Responsibility' in Cassese et al (eds), The Rome Statute of the International Criminal Court: A Commentary [London: Oxford University Press, 2002] Vol I.

—— 'Joint Criminal Enterprise and Command Responsibility' (2007) 5 Journal of International Criminal Justice 159.

American Bar Association, Standards for Criminal Justice, $3^{\text {rd }}$ edn (1993).

Amnesty International, 'International Criminal Court: Preliminary comments concerning the elements of war crimes other than grave breaches of the Geneva Conventions-Part I [AI Index: IOR 40/11/99], at <http://www.amnesty.org/en/library/ asset/IOR40/011/1999/en/dom-IOR400111999en.pdf>

'The State of the World's Human Rights (2008).

'Universal Jurisdiction: 14 Fundamental Principles on the Effective Exercise of Universal Jurisdiction' (1999) AI Index: IOR 53/01/99.

- - 'Mass Rapes in Walikale: Still a Need for Protection and Justice in Eastern Congo, dated December 2010, Index: AFR 62/011/2010.

'Colombia: Scarred bodies, hidden crimes-Sexual Violence against Women in the Armed Conflict', Doc No AI Index: AMR 23/040/2004, 13 October 2004.

Arcel, Libby Tata, and Simunkovic, Gorana Tocilj, (eds), War Violence, Trauma and the Coping Process: Armed Conflict in Europe and the Survivor Response [Copenhagen: International Rehabilitation Council for Torture Victims, Denmark, 1998].

Arendt, Hannah, Eichmann in Jerusalem: A Report on the Banality of Evil [New York: Viking Press, 1963].

Aristophanes, Lysistrata (410 BC), [anonymous translator]; <http://drama.eserver.org/ plays/classical/aristophanes/lysistrata.txt> 
Ashworth, Andrew, Principles of Criminal Law, 3rd edn [Oxford: Oxford University Press, 1999].

_- 'Punishment and Compensation: Victims, Offenders and the State' (1986) 6 Oxford Journal of Legal Studies 86.

Atsma, Aaron J, Theoi Project: Greek Mythologies, 'Aphrodite Loves 1', <www.theoi. com/Olympios/AphroditeLoves.html>

—— 'Aphrodite Loves 2', <www.theoi.com/Olympios/AphroditeLoves2.html>.

Bachman, Ronet, and Paternoster, Raymond, 'A Contemporary Look at the Effects of Rape Law Reform: How Far Have We Really Come? (1993) 84 Journal of Criminal Law and Criminology.

Baker, Brenda M, 'Understanding Consent in Sexual Assault' in Burgess-Jackson (ed), A Most Detestable Crime: New Philosophical Essays on Rape [New York: Oxford University Press, 1999].

Bakhtin, Mikhail, Rabelais and His World (translated by Helen Iswolsky) [Bloomington: Indian University Press, 1985].

Bantekas, Ilias, 'The Contemporary Law of Superior Responsibility' (1999) 93 American Journal of International Law p 573.

Barber, Laurie, 'Yamashita Trial Revisited' (1998) 1 WaiMilHist (available at www. waikato.ac.nz/wfass/subjects/history/waimilhist/1998/yamashita.htm).

Bassiouni, Cherif, 'From Versailles to Rwanda in Seventy-Five Years: The Need to Establish a Permanent International Criminal Court,' (1997) 10 Harvard Human Rights Journal 11.

_- 'International Crimes, Jus Cogens and Obligatio Erga Omnes' (1996) 59 Law and Contemporary Problems.

Bauman, Zygmunt, Modernity and the Holocaust [Ithaca, NY: Cornell University Press, 1989].

Bentham, Jeremy, The Works of Jeremy Bentham, published under the Superintendence of his Executor, John Bowring (Edinburgh: William Tait, 1838-1843). (11 vols) Vol 1.

Berger, Vivian, 'Rape Law Reform at the Millennium: Remarks on Professor Bryden's Non-Millennial Approach' (2000) Buffalo Criminal Law Review.

Berkeley, Bill, The Graves Are Not Yet Full: Race, Tribe and Power in the Heart of Africa [New York: Perseus Publishing, 2001].

Bettleheim, Bruno, The Uses of Enchantment [New York: Penguin Books, 1991].

Bhasin, K, and Menon R, Borders and Boundaries: Women in India's Partition [New Brunswick, N J: Rutgers University Press, 1998].

Blackstone, Sir William, Commentaries on the Laws of England, vol 4 [Oxford: Clarendon Press, 1765-69].

Blass, Thomas, (ed), Obedience to Authority: Current Perspectives on the Milgram Paradigm [Mahwah, NJ: Lawrence Erlbaum Associates, 2000].

Bonafé, Beatrice, 'Finding a Proper Role for Command Responsibility', (2007) 5 Journal of International Criminal Justice 599.

Bonger, Willem Adriaan, Criminality and Economic Conditions translated by Henry P Horton [Boston: 1916].

Borchard, Edwin Montefiore, The Diplomatic Protection of Citizens Abroad, or, The 
Law of International Claims [New York: Banks Law Publication Co, 1915].

Bourke, Joanna, Rape: Sex, Violence, History [Berkeley, CA: Shoemaker \& Hoard, 2007].

Brauman, Rony, and Sivan, Eyal, The Specialist-Portrait of a Modern Criminal (1999) (a movie).

British Broadcasting Corporation, 'People "still willing to torture”, BBC News, 19 December 2008. See <www.news.bbc.co.uk/2/hi/health/7791278.stm>

Browning, Christopher, Ordinary Men: Reserve Police Battalion 101 and the Final Solution in Poland [New York: Harper Perennial, 1993]

- Christopher, 'Introduction' in Leonard S Newman (ed), Understanding Genocide: The Social Psychology of the Holocaust [Oxford: Oxford University Press, 2002].

Brownlie, Ian, Principles of Public International Law, 7th edn [Oxford: Oxford University Press, 2008].

Brownmiller, Susan, Against Our Will: Men, Women and Rape [New York: Simon \& Schuster, 1975].

Bryden, David P, and Lengnick, Sonja, 'Rape in the Criminal Justice System' (1997) 87 Journal of Criminal Law and Criminology.

Burgess-Jackson, Keith, 'A History of Rape Law' in Burgess-Jackson (ed), A Most Detestable Crime: New Philosophical Essays on Rape.

_- 'Introduction' in K Burgess-Jackson (ed), A Most Detestable Crime: Nerw Philosophical Essays on Rape [New York: Oxford University Press, 1999].

Burns, Robert, 'Man Was Made to Mourn' (A Dirge) (1784).

Canada, International Commission on Intervention and State Sovereignty: ICISS, 'The Responsibility to Protect-Report of the International Commission on Intervention and State Sovereignty' [Ottawa: International Development Research Centre, 2001].

Cassese, Antonio, International Criminal Law [Oxford: OUP, 2003] and the Board of Editors of the Journal of International Criminal Justice, Amicus Curiae Brief filed before the Extraordinary Chamber in the Courts of Cambodia in Case No 001/18-07-2007-ECCC/OCIJ (PTC 02) dated 27 October 2008.

Chambers Dictionary of World History [Edinburgh: Chambers Harrap Publishers, 1993].

Cheng, Bin, General Principles of Law: as Applied by International Courts and Tribunals [Cambridge: Cambridge University Press, 1994].

Chinkin, Christine, 'Rape and Sexual Abuse of Women in International Law' (1994) 5 European Journal of International Law.

Chuter, David, War Crimes: Confronting Atrocity in the Modern World [Boulder, Colorado: Lynne Rienner, 2003].

Cicero, Marcus Tullius, Pro Milone 16 (N H Watts translation) $5^{\text {th }}$ edn [New Haven: Harvard University Press], IV:11. See also <www.thelatinlibrary.com/cicero/milo. shtml>

Clark, Roger S, 'The Mental Element in International Criminal Law: the Rome Statute of the International Criminal Court and the Elements of Offences,' (2001) 12 Criminal Law Forum 291.

CNN, 'Sexual Assault in Military “jaw dropping”, at <www.edition.cnn.com/2008/ US/07/31/military.sexabuse/> 
'Obama: U S to withdraw most Iraq troops by August 2010' at <www.cnn. com/2009/POLITICS/02/27/obama.troops/index.html>

Condé, H Victor, A Handbook of International Human Rights Terminology [Lincoln: University of Nebraska Press, 2004].

Coomaraswamy, Radhika, 'A Question of Honour: Women, Ethnicity and Armed Conflict' (1999) mimeograph. Available at <http://www.sacw.net/Wmov/RCoomaraswamyOnHonour.html>

Council of Europe (Parliamentary Assembly), Resolution 1212 (2000): Rape in Armed Conflict, para 7.

- 'Rape of women, including marital rape: Report of the Committee on Equal Opportunities for Women and Men' dated 14 September 2009, Doc No 12013.

- Committee on Equal Opportunities, 'Report on Sexual Violence against Women in Armed Conflict, dated 15 May 2009, Doc No 11916.

Crawford, James, The International Law Commission's Articles on State Responsibility: Introduction, Text and Commentaries [Cambridge: Cambridge University Press, 2002].

Daley, Susanne, 'Torturer's Testimony Gives South Africa a New Lesson in the Banality of Evil', New York Times, 9 November 1997, <http://www.hartford-hwp.com/ archives/37a/041.html>

Damaška, Mirjan, 'The Shadow Side of Command Responsibility' (2001) 49 American Journal of Comparative Law 455.

Danner, Allison, 'Joint Criminal Enterprise' in Cherif Bassiouni, International Criminal Law $3^{\text {rd }}$ edn [Leyden: Martinus Nijhoff, 2008] vol III, p 483.

—— and Jenny S Martinez, 'Guilty Associations: Joint Criminal Enterprise, Command Responsibility, and the Development of International Criminal Law (2005) 93 California Law Review 75.

Darrow, Clarence Seward, Crime: Its Cause and Treatment New York: Kaplan Publishing, 2009; originally published: New York: Thomas Y Crowell, 1922].

Davidson, S, 'A clinical classification of psychiatric disturbances of Holocaust survivors and their treatment' (1967) The Israel Annals of Psychiatry and Related Disciplines.

Denike, Margaret, 'Sexual Violence and "Fundamental Justice": On the Failure of Equality Reforms to Criminal Proceedings' (2000) 20 Canadian Woman Studies.

Dobzhansky, Theodosius, et al, Evolution [San Francisco: W H Freeman, 1977].

Duff, Peter, 'The Measure of Criminal Injuries Compensation: Political Pragmatism or Dog's Dinner' (1998) 18 Oxford Journal of Legal Studies 105.

Dugard, John, International Law: a South African Perspective 3rd edn [Cape Town: Juta \& Co Ltd, 2008].

Dunn, Pintip, 'How Judges Overrule: Speech Act Theory and the Doctrine of Stare Decisis' (2003) 113 Yale Law Journal.

Dyer, Gwynne, War: the Lethal Custom, revised edition [New York: Carroll \& Graf, 2004].

Eboe-Osuji, Chile, (ed), Protecting Humanity [Leyden: Martinus Nijhoff: 2010].

" Complicity in Genocide" versus "Aiding and Abetting Genocide: Construing the Difference in the Statutes of the ICTY and ICTR' (2005) 3 Journal of International 
Criminal Justice.

'Genocide, Justice and the Forensic Sensibilities of the International Committee of the Red Cross' Chinese Journal of International Law (2006) Vol 5, No 1.

- - 'Murder as a Crime against Humanity at the Ad Hoc Tribunals: Reconciling Differing Languages', Canadian Yearbook of International Law (2005).

- - and Nworgu, Angela, 'Nigeria's Jurisdiction to Prosecute Johnny Paul Koroma for War Crimes Committed in Sierra Leone' in C Eboe-Osuji (ed), Protecting Humanity [Leyden: Martinus Nijhoff: 2010] 839

Elon, Amos, 'Introduction', in Arendt, Hannah, Eichmann in Jerusalem: A Report on the Banality of Evil [New York: Viking Press,1963].

Erasmus, Gerhard and Davidson, Lyle, 'Do South Africans Have a Right to Diplomatic Protection?' (2000) 25 South African Yearbook of International Law 113.

Milano, Enrico, 'Diplomatic protection and human rights before the International Court of Justice' (2004) Netherlands Yearbook of International Law 85.

Everhart, Amy Jo, 'Predicting the Effect of Italy's Long-Awaited Rape Law Reform in "The Land of Machismo" (1998) 31 Vanderbilt Journal of Transnational Law.

Falk, Richard, et al (ed), Crimes of War: A Legal, Political-Documentary, and Psychological Inquiry into the Responsibility of Leaders, Citizens, and Soldiers for Criminal Acts in Wars [New York: Random House, 1971].

Fein, Helen, Accounting for Genocide: National Response and Jerwish Victimisation during the Holocaust [New York: Free Press, 1979].

Feinberg, Joel, Social Philosophy [Englewood Cliffs, NJ: Prentice Hall, 1973].

Ferstman, Carla; Goetz, Mariana; and Stephens, Alan (eds), Reparations for Victims of Genocide, War Crimes and Crimes Against Humanity: Systems in Place and Systems in the Making [Leiden: Brill, 2009].

Finkelstein, Norman, 'Daniel Jonah Goldhagen's “Crazy” Thesis: A Critique of Hitler's Willing Executioners', (1997) New Left Review vol a Issue 224.

Forster, Steve, 'Joint Enterprise Liability', Criminal Law and Justice Weekly (8 August 2009)<www.criminallawandjustice.co.uk/index.php?/Analysis/joint-enterpriseliability.html>.

Frankl, Viktor, Man's Search for Meaning [Boston: Beacon Press, 1959].

Freud, Sigmund, (rev Peter Gay), The Freud Reader [New York: W W Norton, 1989].

Frulli, Micaela, 'Advancing International Criminal Law: The Special Court for Sierra Leone Recognizes Forced Marriage as a 'New' Crime against Humanity' (2008) 6 Journal of International Criminal Justice 1033.

Gahan, Michael and Lennon, Rose, 'Compensating Crime Victims: a Legislative and Program Analysis' (1977) 4 Journal of Legislation 71.

García-Amador, F V; Sohn, Louis; and Baxter, Richard, Recent Codification of the Law of State Responsibility for Injuries to Aliens [Dobbs Ferry, New York: Oceania Publications, 1974].

Gardam, Judith and Charlesworth, Hillary, 'Protection of Women in Armed Conflict' (2000) 22 Human Rights Quarterly 148.

Gauthier, Jeffery, A., 'Consent, Coercion and Sexual Autonomy' in Burgess-Jackson (ed), A Most Detestable Crime: New Philosophical Essays on Rape. 
Germany. Humanitäres Völkerrecht in berwaffneten Konflikten - Handbuch, August 1992, DSK AV2073200065.

Giles, Wenona, et al, (eds), Sites of Violence: Gender and Conflict Zones [Berkeley, California: University of California Press, 2004].

Goldhagen, Daniel Jonah, 'A Reply to My Critics', The New Republic 23 December 1996.

- - Daniel Jonah, Hitler's Willing Executioners: Ordinary Germans and the Holocaust [New York: Vintage Books, 1997].

Goodey, Jo, 'Compensating Victims of Violent Crime in the European Union With a Special Focus on Victims of Terrorism' [a discussion paper for National Center for Victims of Crime, May 2003] available at <www.ncvc.org/ncvc/AGP.Net/Components/documentViewer/Download.aspxnz?DocumentID=32594>.

Gray, J Glenn, The Warriors: Reflections on Men in Battle [New York: Harcourt, Brace, 1959].

Green, Leslie, 'War Crimes, Crimes against Humanity and Command Responsibility' (1997) 50 Naval War College Review 26.

Greenwood, Christopher, 'Historical Development and Legal Basis' in Dieter Fleck (ed), Handbook of Humanitarian Law in Armed Conflicts [Oxford: OUP, 1999].

Greer, Edward, 'The Truth Behind Legal Dominance Feminism's "Two Percent False Rape Claim” Figure' (2000) 33 Loyola of Los Angeles Law Review.

Grossman, Dave, On Killing: The Psychological Cost of Learning to Kill in War and Society [New York: Little, Brown and Company, 1995].

Grotius, Hugo, De Jure Belli ac Pacis (1646) (Francis Kelsey translation) [Oxford: Clarendon Press, 1925] vol II.

Grubin, Don, 'Sexual Offending: A Cross-Cultural Comparison', (1992) iii Annual Review of Sex Research.

Hale, Sir Matthew, Pleas of the Crown, or, a methodical summary of the principal matters relating to that subject, vol 1, [London: W. Shrewsbury, 1694].

Hall, William Edward, $A$ Treatise on International Law, $8^{\text {th }}$ edn (edited by Pearce Higgins) [Oxford: Clarendon Press, 1924].

Harmon, Mark and Gaynor, Fergal, 'Ordinary Sentences for Extraordinary Crimes' (2007) 5 Journal of International Criminal Justice 683.

Harvard Humanitarian Initiative (with support from Oxfam of America), 'Now, the World is Without Me: an Investigation of Sexual Violence in Eastern Democratic Republic of Congo' dated April 2010.

Hilberg, Raul, The Destruction of the European Jerws (revised and definitive edition) [New York: Holmes and Meier, 1985].

Hillard, Gloria, 'Scars of War Run Deep for Female Vets', National Public Radio at <www.npr.org/templates/story/story.php?storyId=15005484\#14921214>.

Hillis, Newell Dwight, German Atrocities: Their Nature and Philosophy [New York: Fleming H Revell, 1918].

Hobbes, Thomas, Leviathan or The Matter, Forme \& Power of a Common-wealth Ecclesiasticall and Civill [sic][London: Andrew Crooke, 1651) Ch XXI, p 136 (in the edition Prepared for the McMaster University Archive of the History of Economic Thought, by Rod Hay). 
Hochschild, Adam, King Leopold's Ghost: A Story of Greed, Terror and Heroism in Colonial Africa [New York: Houghton Mifflin, 1999].

Hohfeld, Welsely Newcomb, 'Some Fundamental Legal Conceptions as Applied in Judicial Reasoning,' 23 Yale Law Journal (1913) 16.

Horder, Jeremy, 'Criminal Culpability: the Possibility of a General Theory', (May 1993) 12 Law and Philosophy.

Hudson, Paul, 'The Crime Victim and the Criminal Justice System: Time for a Change' (1983-1984) 11 Pepperdine Law Review 23.

Hyde, Charles Cheney, International Law: Chiefly as Interpreted and Applied by the United States [Boston: Little, Brown and Company, 1922].

Human Rights Watch, Shattered Lives: Sexual Violence during the Rwandan Genocide and its Aftermath [New York: Human Rights Watch, 1997].

Ignatieff, Michael, 'The Seductiveness of Moral Disgust' (1995) 62 Social Research 77.

International Committee of the Red Cross, Commentary to Common Article 3 to the Geneva Conventions of 1949: <http://www.icrc.org/ihl.nsf/COM/380600006?OpenDocument>.

- Customary International Humanitarian Law, vol I: Rules [Cambridge: Cambridge University Press, 2005].

International Law Association, Resolution 2/2010 adopted at the 74th Conference of the International Law Association, held at The Hague, The Netherlands, 15-20 August 2010.

Jain, Neha, 'Forced Marriage as a Crime against Humanity: Problems of Definition and Prosecution' (2008) 6 Journal of International Criminal Justice 1013.

Jennings, Robert, and Watts, Arthur, Oppenheim's International Law, vol 1, $9^{\text {th }}$ edn [London \& New York: Longman, 1996] Parts 2 to 4.

Jia, Bing Bing, 'The Doctrine of Command Responsibility: Current Problems' (2000) 3 Yearbook of International Humanitarian Law 131.

- - 'Doctrine of Command Responsibility Revisited' (2004) 3 Chinese Journal of International Law 1.

JUSTICE, 'A Report by JUSTICE: Compensation for Victims of Crimes of Violence' (1962).

Kanazawa, Satoshi and Still, Mary C, 'Why Men Commit Crimes (And Why They Desist)', Sociological Theory 18.3 (November 2000).

Kapur, Ratna, 'Travel Plans: Border Crossings and the Rights Of Transnational Migrants' (Spring 2005) 18 Harv Hum Rts J.

Karazivan, Noura, 'Diplomatic Protection: Taking Human Rights Extraterritorially' (2006) XLIV Canadian Yearbook of International Law 299.

Kelman, H C and Hamilton, V L, Crimes of obedience: Toward a social psychology of authority and responsibility [New Haven, CT: Yale University Press, 1989]

Kelman, Herbert, 'Violence without Moral Restraint', (1973) 29 Journal of Social Issues pp 29-61.

Kent, James, Commentaries on American Law, 12 $2^{\text {th }}$ edn (by O W Holmes Jr) [Boston: Little, Brown and Company, 1873] Vol 1.

Kimmel, Michael, 'An Unnatural History of Rape,' in Cheryl B Travis (ed), Evolution, 
Gender and Rape [Cambridge, Mass: MIT Press, 2003].

King, Jamesina, 'Gender and Reparations in Sierra Leone: The Wounds of War Remain Open' in Ruth Rubio-Marín (ed), What Happened to Women? Gender and Reparations for Human Rights Violations [New York: Social Science Research Council, 2006].

Kittichaisaree, Kriangsak, International Criminal Law [Oxford: OUP, 2001].

Lachs, John, Responsibility of the Individual in Modern Society [Brighton: Harvester, 1981].

Lamborn, LeRoy, 'The Propriety of Governmental Compensation for Victims of Crime' (1972-1973) 41 George Washington Law Review 446.

Laughland, John, 'Conspiracy, joint criminal enterprise and command responsibility in international criminal law' available at <www.heritagetpirdefense.org/papers/John_ laughland_Conspiracy_joint_criminal_enterprise_and_command_responsibility. pdf >

Lauterpacht, Hersch, The Development of International Law by the International Court [Cambridge: Cambridge University Press, 1996].

Laviolette, Nicole, 'Commanding Rape: Sexual Violence, Command Responsibility, and the Prosecution of Superiors by the International Criminal Tribunals for the Former Yugoslavia and Rwanda' (1998) 36 Canadian Yearbook of International Law 93.

Lee, R S (ed), The International Criminal Court, The Making of the Rome Statute [The Hague: Kluwer Law International, 1999].

Leech, Gary, '50 Years of Violence', Colombia Journal (2000) <http://colombiajournal. org/special-reports/fiftyyearsofviolence>

Lindqvist, Sven, "Exterminate All the Brutes": One Man's Odyssey into the Heart of Darkness and the Origins of European Genocide [New York: New Press, 1996].

Little, Laura, 'Hiding with Words: Obfuscation, Avoidance, and Federal Jurisdiction Opinions' (1998) 46 UCLA Law Review.

Lloyd, Sharon, and Sreedhar, Susanne, 'Hobbes's Moral and Political Philosophy', The Stanford Encyclopedia of Philosophy (Spring 2009 Edition), Edward N. Zalta (ed), <www.plato.stanford.edu/archives/spr2009/entries/hobbes-moral/>.

Lowe, Vaughan, 'Jurisdiction' in M Evans, International Law [Oxford: OUP, 2003].

Lindsey, Charlotte, 'Women Facing War: ICRC Study on the Impact of Armed Conflict on Women' (2003).

Malanczuk, Peter, Akehurst's Modern Introduction to International Law, $7^{\text {th }}$ edn [London and New York: Routledge, 1997].

Marsh, Jeanne, Geist, Alison and Caplan, Nathan, Rape and the Limits of Law Reform [Boston: Auburn House Publishing, 1982].

Marshall, S L A, Men Against Fire: The Problem of Battle Command in Future Wars [New York: William Morrow, 1947].

Martinez, Jenny, 'Understanding Mens Rea in Command Responsibility: From Yamashita to Blaškic and Beyond' (2007) 5 Journal of International Criminal Justice 628.

May, Richard, Criminal Evidence, $3^{\text {rd }}$ edn [London: Sweet \& Maxwell, 1995].

McDonald, Gabrielle Kirk, and Swaak-Goldman, Olivia (eds), Substantive and Procedural Aspects of International Criminal Law: The Experience of International and National Courts, vol II part 2 [The Hague: Kluwer, 2000]

McIntyre, Sheila, et al, 'Tracking and Resisting Backlash against Equality Gains in 
Sexual Offence Law' (2000) 20 Canadian Woman Studies.

McNamara, Robert S, and Blight, James G, Wilson's Ghost: Reducing the Risk of Conflict, Killing, and Catastrophe in the 21st Century [New York: Public Affairs, 2001].

Megret, Frederic, 'Justifying Compensation for the International Criminal Court's Trust Fund for Victims: Lessons from Domestic Compensation Schemes' (2010) 36 Brooklyn Journal of International Law 123.

Meron, Theodor, 'Rape as a Crime under International Humanitarian Law' (1993) 87 American Journal of International Law 424.

Meloni, Chantal, 'Command Responsibility: Mode of Liability for the Crimes of Subordinates or Separate Offence of the Superior?' (2007) 5 Journal of International Criminal Justice 619.

Mettraux, Guénaël, International Crimes and the Ad Hoc Tribunals [Oxford: OUP, 2005].

- The Law of Command Responsibility [Oxford: Oxford University Press, 2009].

Milgram, Stanley, 'Behavioral Study of Obedience', (1961) 67 Journal of Abnormal Social Psychology;

__ 'Some Conditions of Obedience and Disobedience to Authority', (1965) 18(1) Human Relations.

- - 'The Perils of Obedience', Harper's Magazine [1974], <http://home.swebell.net/ revscat/perilsOfObedience.html>

- Obedience to Authority [New York: Harper \& Row, 1974].

Morris, Madeline, 'By Force of Arms: Rape, War, and Military Culture' (1996) 45 Duke Law Journal 651.

Moses, A Dirk, and Stone, Dan (eds), Colonialism and Genocide [New York: Routledge, 2006].

- - (ed), Empire, Colony, Genocide: Conquest, Occupation and Subaltern Resistance in World History [New York: Bergham Books, 2008].

Mosher, Donald, and Anderson, Ronald, 'Macho Personality, Sexual Aggression, and Reactions to Guided Imagery of Realistic Rape,' (1986) 20 Journal of Research in Personality 77.

Mueller, John, The Remnants of War [Ithaca: Cornell University Press, 2004].

Nerlich, Volker, Superior Responsibility under Article 28 ICC Statute: For What Exactly is the Superior Held Responsible?'(2007) 5 Journal of International Criminal Justice 665.

Newman, Leonard, 'What is Social-Psychological Account of Perpetrator Behaviour? The Person versus the Situation in Goldhage's Hitler's Willing Executioners' in Leonard Newman and Ralph Erber (ed), Understanding Genocide: The Social Psychology of the Holocaust [New York: Oxford University Press, 2002].

Niebergall, Heike, 'Overcoming Evidentiary Weaknesses in Reparation Claims Programmes' in Ferstman, Carla; Goetz, Mariana; and Stephens, Alan (eds) Reparations for Victims of Genocide, War Crimes and Crimes Against Humanity: Systems in Place and Systems in the Making [Leiden: Brill, 2009].

Norris, Michele, 'Reported Cases of Sexual Assault in Military Rise', National Public Radio at <www.npr.org/templates/story/story.php?storyId=15005484>.

Notar, Susan, 'Peacekeepers as Perpetrators: Sexual Exploitation and Abuse of Women 
and Children in the Democratic Republic of the Congo' (2006) 14:2 Journal of Gender, Social Policy and Law.

Nowak, Manfred, UN Covenant on Civil and Political Rights: CCPR Commentary, $2^{\text {nd }}$ revised edn [Kehl: NP Engel, 2005].

Nowrojee, Binaifer, 'Making the Invisible War Crime Visible: Post-Conflict Justice for Sierra Leone's Rape Victims' 18 Harv Hum Rts J (Spring 2005).

Ohlin, Jens, 'Three Conceptual Problems with the Doctrine of Joint Criminal Enterprise' (2007) 5 Journal of International Criminal Justice 69.

O'Reilly, Arthur, 'Command Responsibility: A Call to Realign the Doctrine with Principles' (2004-2005) 20 American University International Law Review 71.

Organisation of African Unity, 'The Preventable Genocide', the report of the International Panel of Eminent Persons to Investigate the 1994 Genocide in Rwanda, dated 7 July 2000.

Ortino, Federico, 'Reparation and other remedies in international law, in Peter Cane and Joanne Conaghan, The New Oxford Companion to Law [Oxford: Oxford University Press Inc, Oxford Reference Online].

Osiel, Mark, 'The Banality of Good: Aligning Incentives against Mass Atrocity', (2005) 105 Columbia Law Review 1751.

Osofsky, Michael J; Bandura, Albert; and, Zimdardo, Philip G, 'The Role of Disengagement in the Execution Process' (2005) 29 Law and Human Behavior.

Oxfam International, 'Sexual Violence in Colombia: Instrument of War' dated 9 September 2009.

Parker, Geoffrey, 'Dynastic War: 1494-1660' in Geoffrey Parker (ed), Cambridge Illustrated History of Warfare [Cambridge: Cambridge University Press, 1995].

Parks, William, 'Command Responsibility for War Crimes' (1973) 62 Military Law Review 1.

Patton, George S, Jr, War as I Knew It (with an Introduction by Rick Atkinson) [Boston \& New York: Houghton Mifflin Company, 1995].

Phipson on Evidence [London: Sweet \& Maxwell, 1990].

Power, Samantha, 'Bystanders to Genocide' in The Atlantic Monthly, September 2001, <http://www.theatlantic.com/doc/200109/power-genocide/6>.

Princeton University Program on Law and Public Affairs, Princeton Principles on Universal Jurisdiction (2001).

Pufendorf, Samuel, De Jure Naturae et Gentium Libri Octo (1688) (C A and W A Oldfather translation) [Oxford: Clarendon Press, 1934] Vol 2, Bk VII.

Pym, T W, and Gordon, Godfrey, Papers from Picardy by Two Chaplains [London: Constable, 1917].

Rank, Otto, Will Therapy and Truth and Reality [New York: Knopf, 1945].

Reed, Alan, 'Joint Participation in Criminal Activity' (1996) 60 Journal of Criminal Law 310.

Roberts, J M, The New Penguin History of the World [London: Penguin Books, 2004].

Röling, Bernard V A and C F Rüter (eds), The Tokyo Judgment [Amsterdam: APA-University Press Amsterdam BV, 1977].

Ronen, Yaël, 'Superior Responsibility of Civilians for International Crimes Committed 
in Civilian Settings' (2010) 43 Vanderbilt Journal of Transnational Law 313.

Rothstein, Paul, 'How the Uniform Crime Victims Reparations Act Works' 60 American Bar Association Journal (December 1974) 1531.

SáCouto, Susana, 'Advances and Missed Opportunities in the International Prosecution of Gender-based Crimes' (2007) 15 Michigan State Journal of International Law 137 at 139.

Saland, Per in R S Lee (ed), The International Criminal Court, The Making of the Rome Statute [The Hague: Kluwer Law International, 1999]

Salhany, Roger, The Practical Guide to Evidence in Criminal Cases, $5^{\text {th }}$ edn [Toronto: Carswell, 1997].

Sartre, Jean-Paul, 'On Genocide', in Richard Falk, et al (ed), Crimes of War: A Legal, Political-Documentary, and Psychological Inquiry into the Responsibility of Leaders, Citizens, and Soldiers for Criminal Acts in Wars [New York: Random House, 1971].

Schabas, William, Genocide in International Law [Cambridge: Cambridge University Press, 2000].

- - Introduction to the International Criminal Court, $2^{\text {nd }}$ edn [Cambridge, Cambridge University Press, 2004].

- - 'Mens Rea and the International Criminal Tribunal for the Former Yugoslavia', (2003) 37 New England Law Review 1015.

Schafran, Lynn Hecht, 'The Limits of Law Reform: What Really Happens in the Courtroom,' Shimon Shetreet (ed), Women in Law [London: Kluwer International, 1998].

Scott, Robert E, 'Compensation for Victims of Violent Crimes: An Analysis,' (1967) 8 William E Mary Law Review 277.

Shackelford, T K and G J LeBlanc, 'Courageous, Compassionate and Scholarly: An Evolutionary Analysis of Rape and Male Sexual Coercion' in The Journal of Sex Research vol 38 No 1 (2001), pp 81-83.

Shadid, Anthony; Addario, Lindsey; Farrell, Stephen; and Hicks, Tyler, '4 Times Journalists Held Captive in Libya Faced Days of Brutality' Nerw York Times, 22 March 2011, at <http://www.nytimes.com/2011/03/23/world/africa/23times.html>.

Shahabuddeen, Mohamed, Precedent in the World Court [Cambridge: Cambridge University Press, 1997].

Shakespeare, William, Henry $V$.

Shapiro, Martin, 'Judges as Liars' (1994) 17 Harvard Journal of Law and Public Policy.

Shaw, Malcolm, International Law, $6^{\text {th }}$ ed [Cambridge: CUP, 2008].

Sheehy, Elizabeth, 'Legal Responses to Violence against Women in Canada' (1999) 19 Canadian Woman Studies.

Shelton, Dinah, 'United Nations Principles and Guidelines on Reparations: Context and Content' in Feyter, K; Parmentier, S; Bossuyt, M and Lemmens, P (eds), Out of the Ashes: Reparation for Victims of Gross and Systematic Human Rights Violations [Antwerpen-Oxford: Intersentia, 2005].

- - and Thordis Ingadottir, 'The International Criminal Court Reparations to Victims of Crimes (Article 75 of the Rome Statute) and the Trust Fund (Article 79)' available at < www.pict-pcti.org/publications/PICT_articles/REPARATIONS.PDF .

Sierra Leone Truth \& Reconciliation Commission, 'Witness To Truth': Final Report of 
the Sierra Leone Truth \& Reconciliation Commission) (2004), vol 3b, at <http:// www.trcsierraleone.org> (last visited on 10 August 2007).

Simester, A P, 'The Mental Element in Complicity', (2006) 122 Law Quarterly Review 578.

Smith, Jeffrey, 'Sexual Assaults in Army on Rise', Washington Post at <www.washingtonpost.com/wp-dyn/articles/A10959-2004Jun2.html>.

Stowell, Ellery, Intervention in International Law [Washington DC: John Byrne \& Co, 1921].

Stuart, Don, Canadian Criminal Law, $3^{\text {rd }}$ edn [Toronto: Carswell, 1995].

Tacitus, Cornelius, The Histories vol 2, translated by W Hamilton Fyfe [Oxford: Clarendon Press, 1912].

The Bible, Deuteronomy 20:14; 21:10-14.

Thornhill, Randy, and Palmer, Craig T, A Natural History of Rape: Biological Bases of Sexual Coersion [Cambridge, Mass: MIT Press, 2000].

Tobach, E and R Reed, 'Understanding Rape', in Cheryl B Travis (ed), Evolution, Gender and Rape [Cambridge, Mass: MIT Press, 2003]105.

Travis, Cheryl Brown (ed), Evolution, Gender and Rape [Cambridge, Mass: MIT Press, 2003].

Triffterer, Otto (ed), Commentary on the Rome Statute of the International Criminal Court - Observers Notes, Article by Article [The Hague: Kluwer, 1999].

Tritle, Lawrence, From Melos to My Lai: War and Survival [London: Routledge, 2000].

Tsagourias, Nicholas, 'Command Responsibility and the Principle of Individual Criminal Responsibility: a Critical Analysis of International Jurisprudence' in C EboeOsuji, Protecting Humanity [Leyden: Martinus Nijhoff: 2010] 817.

UNICEF, 'Armed Conflict', <http://www.unicef.org/protection/index_armedconflict. html>.

UNIFEM, 'Women, War, Peace: The Independent Experts' Assessment on the Impact of Armed Conflict on Women and Women's Role in Peace-Building.' p 12; see <http://www.unifem.org/filesconfirmed/149/213_chapter01.pdf>

United Kingdom, Ministry of Defence, The Manual of the Law of Armed Conflict [Oxford: Oxford University Press, 2004].

- - Report of the Working Party on Compensation for Victims of Crimes of Violence (Cmnd 1406)

- - Home Office, Scottish Home and Health Department, 'Compensation for Victims of Crimes of Violence', 1964, Cmnd 2323

- - Home Office, Scottish Home and Health Department, 'Compensation for Victims of Crimes of Violence', 1964, Cmnd 2323.

'Crimes of Violence, Compensation for Victims', Parliament, House of Lords, House of Lords Debates (Hansard), HL Deb 05 December 1962 vol 245.

'Compensation for Victims of Crimes of Violence', Parliament, House of Lords, House of Lords Debates (Hansard), HL Deb 07 May 1964 vol 257.

- C Criminal Justice System, 'Rebuilding Lives-Supporting Victims of Crime', Cmnd 6705 (December 2005).

United Nations, General Assembly, A more secure world: our shared responsibility-Report 
of the High-level Panel on Threats, Challenges and Change' Doc No A/ /59/565 of 2 December 2004.

- Security Council, Report of the Secretary General on the Establishment of the Special Court for Sierra Leone, 4 October 2000, Doc No S/2000/915.

- Economic and Social Council, 'Integration of the Human Rights of Women and the Gender Perspective': Report of the Special Rapporteur on violence against women, its causes and consequences, Ms Radhika Coomaraswamy, on trafficking in women, women's migration and violence against women, submitted in accordance with Commission on Human Rights resolution 1997/44,' Doc No E/CN.4/2000/68 (2000).

- Human Rights Council, 'Report of the Special Rapporteur on Violence against Women, Its Causes and Consequences, Rahida Manjoo' dated 19 April 2010, Doc No A/HRC/14/22.

- - Non-Governmental Liaison Service, 'Women 2000: GA Special Session' in NGLS Roundup, No 56, July 2000, p 2. Available at <http://www.un-ngls.org/documents/ text/roundup/56wom2000.txt>

- - The Fall of Srebrenica: Report of the Secretary-General pursuant to General Assembly resolution 53/35 dated 15 November 1999, Doc No A/54/549

- - 'Report of the Secretary-General on women, peace and security', Doc No S/ /2002/1154 of 16 October 2002

- - Office of the High Commissioner for Human Rights, 'Abolishing Slavery and its Contemporary Forms' [New York and Geneva: United Nations, 2002], Doc No HR/PUB/02/4.

- - Office of the High Commissioner for Human Rights, 'Report of the Panel on Remedies and Reparations for Victims of Sexual Violence in the Democratic Republic of Congo to the High Commissioner for Human Rights' (March 2011).

- - 'Report of the International Commission of Inquiry on Darfur to the SecretaryGeneral of the United Nations', pursuant to Security Council Resolution 1564 of 18 September 2004, dated 25 January 2005 (transmitted to the Security Council under the cover of the Secretary-General's letter of 1 February 2005), Doc S/2005/60.

'Report of the Secretary-General to the Security Council on the Protection of Civilians in Armed Conflict,' Doc S/1999/957 of 8 September 1999.

- - 'Report of the Secretary-General to the Security Council on the Protection of Civilians in Armed Conflict,' Doc S/2002/1300 of 26 November 2002.

- - 'Report of the United Nations Development Fund for Women on the Elimination of Violence against Women': Note by the Secretary-General, Doc E/CN.6/2004/8E/CN.4/2004/117 of 19 January 2004.

- - 'Report on Mission to Indonesia and East Timor': Report of the Special Rapporteur for Violence against Women (1999) Doc No E/CN.4/1999/68/Add.3.

- - Review and Appraisal of the Implementation of the Beijing Platform for Action': Report of the Secretary General, Doc E/CN.6/2000/PC/2 of 19 January 2000.

- _ 'Review of Reports, Studies and Other Documentation for the Preparatory Committee and the World Conference' Doc A/CONF.189/PC.3/5 of 27 July 2001.

'Systematic Rape, Sexual Slavery and Slavery like Practices during Armed Conflict': Final report submitted by Ms Gay J McDougall, Special Rapporteur, Doc E/ 
CN.4/Sub.2/1998/13 of 22 June 1998, para 10.

'Systematic Rape, Sexual Slavery and Slavery like Practices during Armed Conflict': Report of the High Commissioner for Human Rights, Doc E/CN.4/Sub.2/2000/20 of 27 June 2000.

'Vienna Declaration and Programme of Action of 1993,' Doc No UNGA/ CONF.157/23 of 12 July 1993.

'Women's Equal Participation in Conflict Prevention, Management and Conflict Resolution and in Post-Conflict Peace-Building: Report of the Secretary-General, Doc E/CN.6/2004/10 of 22 December 2003.

Basic Security in the Field-Staff Safety, Health, and Welfare: a CD-ROM Course, <http://www.christie.ab.ca/htmlsite/webBSITF.htm>.

- - Report of the Independent Inquiry into the Actions of the United Nations during the 1994 Genocide in Rwanda, dated 16 December 1999, Doc No S/1999/1257.

- - Report of the International Law Commission on the work of its forty-first session (2 May-21 July 1989)' Yearbook of the International Law Commission, 1989, vol II, Part Two, Doc No A/CN.4/SER.A/1989/Add.1 (Part 2).

- - Report of the Secretary-General Pursuant to Paragraph 2 of Security Council Resolution 808 (3 May 1993), UN Doc S/25704.

- - Report of the Secretary-General pursuant to Security Council resolution 1820 (2008) dated 20 August 2009, Doc No S/2009/362 (Reissued).

- - Security Awareness: An Aide-Mémoire (1995).

International Law Commission, Yearbook of the International Law Commission (1996), Vol II, Part Two, Report of the Commission to the General Assembly on the Work of its Forty-eighth Session, Doc No (A/51/10).

- - International Law Commission, Report of the International Law Commission on the work of its fifty-eighth session, Doc No A/61/10, Commentary to draft article 1 on Diplomatic Protection.

- - International Law Commission, Report of the International Law Commission on the work of its fifty-third session, Doc No A/56/10, in the Yearbook of the International Law Commission (2001), vol II part 2.

- - International Law Commission, Draft Articles on the Responsibility of States for Internationally Wrongful Acts.

- - International Law Commission, Summary Record of the 2617th Meeting (Diplomatic Protection), Doc No A/CN.4/SR.2617, Yearbook of the International Law Commission (2000), vol 1

- Human Rights Committee, General Comment No 31, Doc No CCPR/C/21/ Rev.1/Add.13 (2004).

- - 'Report submitted by Ms Radhika Coomaraswamy, Special Rapporteur on violence against women, its causes and consequences: Mission to Colombia' (1-7 November 2001), E/CN.4/2002/83/Add.3, dated 11 March 2002.

United States Senate, Judiciary Committee, The Response to Rape: Detours on the Road to Equal Justice One Hundred Third Congress [Washington: US GPO, 1993].

Urdang, Laurence, The Oxford Thesaurus [Oxford: Clarendon Press, 1991].

Van Boven, Theo, 'Victims' Rights to a Remedy and Reparation: The New United Nations Principles and Guidelines' in Carla Ferstman et al (ed), Reparations for Victims of 
Genocide, War Crimes and Crimes Against Humanity: Systems in Place and Systems in the Making [Leiden: Brill, 2009].

Vattel, de, Emmerich, The Law of Nations or the Principles of Natural Law Applied to the Conduct and to the Affairs of Nations and Sovereigns (1758) (Charles G Fenwick translation) [Washington: Gibson Bros, 1916], Bk II.

Verzijl, J H W, International Law in Historical Perspective, vol X [Sijthoff \& Noordhoff: Alphen Aan Den Reijn, 1979].

Vetlesen, Arne Johan, Evil and Human Agency: Understanding Collective Evildoing [Cambridge: University Press, 2005].

Watson, Peter, War on the Mind: the Military Uses and Abuses of Psychology [London: Hutchinson, 1978].

Werle, Gerhard and Florian Jessberger, Principles of International Criminal Law [The Hague: T M C Asser Press, 2005]

Wigmore, John, (rev James Chadbourn), Evidence in Trials at Common Law [Boston: Little, Brown and Company, 1970].

Williams, Glanville, Textbook of Criminal Law [London: Stevens \& Sons, 1978].

Wilt, Harmen van der, 'Joint Criminal Enterprise: Possibilities and Limitations' (2007) 5 Journal of International Criminal Justice 91.

—_, 'The Continuous Quest for Proper Modes of Criminal Responsibility' (2009) 7 Journal of International Criminal Justice 307.

- - 'Joint Criminal enterprise and functional perpetration' in André Nollkaemper and Harmen van der Wilt, (eds), System Criminality in International Law [Cambridge: Cambridge University Press, 2009] 158.

Wolff, Christian, Jus Gentium Methodo Scientifica Pertractatum (1764) (Joseph H Drake translation) [Oxford: Clarendon Press, 1934].

Women's Caucus for Gender Justice in the International Criminal Court, 'Recommendations and Commentary for December 1997 PrepCom on the Establishment of An International Criminal Court United Nations Headquarters, December 1-12, 1997'.

Woodward, Bob, The Commanders [New York: Simon \& Schuster, 1991]

Woolsey, Theodore, Introduction to the Study of International Law, $4^{\text {th }}$ edn [New York: Scribner, Armstrong, 1874].

Wright, Ann (Lt Col, rtd), 'Sexual Assault in the Military: a DoD Cover-Up?', Common Dreams at <www.commondreams.org/archive/2008/08/04/10786/>.

Wu, Timothy and Kang, Yong-Sung (Johnathan), 'Criminal Liability for the Actions of Subordinates-the Doctrine of Command Responsibility and Its Analogues in United States Law' (1997) 38 Harvard International Law Journal 272.

Zimbardo, Phillip G, 'The psychology of evil: situationist perspective on recruiting good people to engage in anti-social acts', (1995) 11 Research in Social Psychology, 125-133.

- - 'Revisiting the Stanford Prison Experiment: a Lesson in the Power of Situation', Chronicle of Higher Education, 30 March 2007 available at <www.lucifereffect.org/ about_reviews_chronicle.htm>

'The Lucifer Effect', <http://www.lucifereffect.com 


\section{Cases Cited}

Application of the Convention on the Prevention and Punishment of the Crime of Genocide (Bosnia and Herzegovina v Serbia and Montenegro) (Judgment) (2007) 26 February 2007, General List No 91 [ICJ].

Armed Activities on the Territory of the Congo (Democratic Republic of the Congo $v$ Uganda) (Judgment) (2005) ICJ Reports [ICJ].

Ashby v White (1703) 14 St Tr 695, 92 ER 126 [UK, King's Bench].

Avena and Other Mexican Nationals (Mexico v United States) (2004) ICJ Reports [ICJ].

Barcelona Traction, Light and Power Co Ltd (Belgium v Spain) 1970 ICJ 3 [ICJ]

Brown E Isaac $v$ The State [2003] UKPC 10 [Privy Council]

Chan Wing-Siu v R [1985] AC 168 [Privy Council]

Chorzów Factory (Claim for Indemnity) (Merits) (Germany v Poland), 1928, Judgment No 18, PCIJ, Series A, No 17

Chorzów Factory (Claim for Indemnity) (Jurisdiction) (Germany v Poland), 1927, Judgment No 8, PCIJ, Series A, No 9

Clayton $v R$ [2006] HCA 58 [High Court of Australia]

Diallo, A hmadou Sadio (Guinea v DRC) (Judgment) (2010) 30 November 2010 General List [ICJ]

The Eichmann Case available at <www.nizkor.org/ftp.cgi/people/e/eichmann.adolf/transcripts/ftp.py?people/e/eichmann.adolf/transcripts/Judgment/Judgment-069>

Ethiopia v Eritrea (Prisoners of War-Ethiopia's Claim 4) Partial Award, 1 July 2003 [Eritrea-Ethiopia Claims Commission]

Eritrea v Ethiopia (Central Front-Eritrea's Claims 2, 4, 6, 7, 8 and 22) Partial Award, 28 April 2004 [Eritrea-Ethiopia Claims Commission]

German Interests in Upper Silesia (Merits), 1926, Judgment No 7, PCIJ, Series A, No 7 [PCIJ].

Gillard $v$ R (2003) 219 CLR 1 [High Court of Australia]

The Göring Case (Judgment) 1 October 1946, 1 Trial of Major War Criminals before the International Military Tribunal at Nuremberg [Nuremberg, 1947] 171

Hui Chi-Ming v R [1992] 94 Cr App R 236 [Privy Council]

International Status of South West Africa (1950) ICJ 128 [ICJ]

Interpretation of Peace Treaties with Bulgaria, Hungary and Romania (Second Phase) (1950) ICJ Reports 221 [ICJ].

The Jamaica Case (1798) 4 Int Arb MS 489; (RAI I 178) [Jay Treaty Mixed Claim Commission]

Johns v R (1980) 143 CLR 108 [High Court of Australia]

LaGrand (Germany $v$ United States of America)(Judgment) (2001) IC J Reports [ICJ].

Legality of the Threat or Use of Nuclear Weapons (Advisory Opinion) [1996] 1 ICJ Rep 226

Lusitania Cases (1923) VII RIAA 32 [US/Germany Mixed Claim Commission.]

Mavrommatis Palestine Concessions (Judgment No 2) (1924) PCIJ, Series A, No 2 [PCIJ].

McAuliffe $v R$ (1995) 130 ALR 26 [High Court of Australia] 
Military and Paramilitary Activities in and against Nicaragua (Nicaragua v United States of America) [1986] ICJ Rep 14

Motomura \& Ors, 13 Law R Trials War Crim 138

Jugement en la cause Fulgence Niyonteze, Tribunal de Division 2, Armée Suisse Justice Militaire, Lausanne, 30 April 1999 [Military Court of Switzerland.]

Nottebohm (Second Phase) (Judgment) (1955) ICJ Reports [ICJ].

Panevezys-Saldutiskis Railway (Judgment) (1939) PCIJ, Series A/B, No 76 [PCIJ].

Prosecutor v Akayesu (Judgment) 2 September 1998 [ICTR Trial Chamber]; 1 June 2001 [ICTR Appeals Chamber]

Prosecutor v Bagilishema (Judgment) 7 June 2001 [ICTR Trial Chamber]; 3 July 2002 [ICTR Appeals Chamber]

Prosecutor v Blagojević and Jokić (Judgment) 17 January 2005 [ICTY Trial Chamber]; 9 May 2007 [ICTY Appeals Chamber]

Prosecutor v Blaškić (Judgment) 3 March 2000 [ICTY Trial Chamber]; 29 July 2004 [ICTY Appeals Chamber]

Prosecutor v Brima \& Ors (Judgment) 20 June 2007 [SCSL Trial Chamber II]; 22 February 2008, reasons issued on 3 March 2008 [SCSL Appeals Chamber]

Prosecutor v Delalić (Judgment) 16 November 1998 [ICTY Trial Chamber]; 20 February 2001 [ICTY Appeals Chamber]

Prosecutor v Erdemović (Judgment) 29 November 1996 [ICTY Trial Chamber]; 7 October 1997 [ICTY Appeals Chamber]

Prosecutor v Fofana and Kondewa, 2 August 2007 [SCSL Trial Chamber]; 28 May 2008 [SCSL Trial Appeals Chamber]

Prosecutor v Furundžija (Judgment) 10 December 1998 [ICTY Trial Chamber]; 21 July 2000 (ICTY Appeals Chamber)

Prosecutor v Gacumbitsi (Judgment) 17 June 2004 [ICTR Trial Chamber]; 7 July 2006 [ICTR Appeals Chamber]

Prosecutor v Galić (Judgment) 5 December 2003 [ICTY Trial Chamber]; 30 November 2006 [ICTY Appeals Chamber]

Prosecutor v Hadžihasanović (Judgment) 15 March 2006 [ICTY Trial Chamber]; 28 April 2008 [ICTY Appeals Chamber]

Prosecutor v Jelesić (Judgment) 14 December 1999 [ICTY Trial Chamber]; 5 July 2001 [ICTY Appeals Chamber]

Prosecutor v Kajelijeli (Judgment) 1 December 2003 [ICTR Trial Chamber]; 23 May 2005 [ICTR Appeals Chamber]

Prosecutor v Kamuhanda (Judgment) 22 January 2004 [ICTR Trial Chamber]; 19 September 2005 [ICTR Appeals Chamber]

Prosecutor $v$ Kayishema and Ruzindana (Judgment) 21 May 1999 [ICTR Trial Chamber]; 1 June 2001 [ICTR Appeals Chamber]

Prosecutor v Kordic \& Čerkez (Judgment) 26 February 2001 [ICTY Trial Chamber]; 17 December 2004 [ICTY Appeals Chamber]

Prosecutor v Krnojelac (Judgment) 15 March 2002 [ICTR Trial Chamber]; 17 September 2003 [ICTY Appeals Chamber]

Prosecutor v Krstić (Judgment) 2 August 2001 [ICTY Trial Chamber]; 19 April 2004 
[ICTY Appeals Chamber]

Prosecutor v Kunarac (Judgment) 22 February 2001 [ICTY Tial Chamber]; 12 June 2002

[ICTY Appeals Chamber]

Prosecutor v Kupreškić (Judgment) 14 January 2000 [ICTY Trial Chamber]; 23 October 2001 [ICTY Appeals Chamber]

Prosecutor v Kvocka (Judgment) 2 November 2001 [ICTY Trial Chamber]; 28 February 2005 [ICTY Appeals Chamber]

Prosecutorv Milošević (Dragomir) (Judgment) 12 December 2007 [ICTY Trial Chamber]; 12 November 2009 [ICTY Appeals Chamber]

Prosecutor v Milutinović, Šainović E Ojdanić (Decision on Dragoljub Ojdanićs Motion Challenging Jurisdiction-Joint Criminal Enterprise) 21 May 2003 [ICTY Appeals Chamber]

Prosecutor v Milutinović \& Ors (Judgment) 26 February 2009 [ICTY Trial Chamber]

Prosecutor v Mubimana (Judgment) 28 April 2005 [ICTR Trial Chamber]; 21 May 2007 [ICTR Appeals Chamber]

Prosecutor v Musema (Judgment) 27 January 2000 [ICTR Trial Chamber]; 16 November 2001 [ICTR Appeals Chamber]

Prosecutor v Nabimana (Judgment) 3 December 2003 [ICTR Trial Chamber]; 28 November 2007 [ICTR Appeals Chamber]

Prosecutor v Naletilić and Martinović (Judgment) 31 March 2003 [ICTY Trial Chamber]; 3 May 2006 [ICTY Appeals Chamber]

Prosecutor v Niyitegeka (Judgment) 16 May 2003 [ICTR Trial Chamber]; 9 July 2004 [ICTR Appeals Chamber]

Prosecutor v Ntakirutimana (Judgment) 21 February 2003 [ICTR Trial Chamber]; 13 December 2004 [ICTR Appeals Chamber]

Prosecutor v Rukundo (Judgment) 29 February 2009 [ICTR Trial Chamber]; 20 October 2010 [ICTR Appeals Chamber]

Prosecutor v Rutaganda (Judgment) 6 December 1999 [ICTR Trial Chamber]; 66 May 2003 [ICTR Appeals Chamber]

Prosecutor v Rwamakuba (Judgment) 20 September 2006 [ICTR Trial Chamber]

Prosecutor v Semanza (Judgment) 15 May 2003 [ICTR Trial Chamber]; 20 May 2005 [ICTR Appeals Chamber]

Prosecutor v Sesay, Kallon and Gbao (Judgment) 25 February 2009 [SCSL Trial Chamber]; 26 October 2009 [SCSL Appeals Chamber]

Prosecutor v Stakić (Judgment) 31 July 2003 [ICTY Trial Chamber]; 22 March 2006 [ICTY Appeals Chamber]

Prosecutor v Tadic (Decision on the Defence Motion for Interlocutory Appeal on Jurisdiction) 2 October 1995[ICTY Appeals Chamber]

Prosecutor v Tadic (Decision on the Form of the Indictment) 14 November 1995 [ICTY Trial Chamber]

Prosecutor v Tadić (Judgment) 7 May 1997 [ICTY Trial Chamber]; July 1999 [ICTY Appeals Chamber]

Prosecutor v Vasiljević (Judgment) 29 November 2002 [ICTY Trial Chamber]; 25 February 2004 [ICTY Appeals Chamber] 
Prosecutor v Zigiranyirazo (Judgment) 18 December 2008 [ICTR Trial Chamber]; 16 November 2009 [ICTY Appeals Chamber]

Quayle and Others v R; Attorney-General's Reference (No 2 of 2004) [2005] EWCA Crim 1415 [Court of Appeal of England and Wales.]

$R$ v Carter (1982), 1982 CarswellNB 13 para 8; [1982] 1 SCR 938, 31 CR (3d) 97, 67

CCC (2d) 568, 137 DLR (3d) 387 [Supreme Court of Canada]

$R v$ Finta [1994] 1 SCR 701 [Supreme Court of Canada]

$R v$ Hyde [1991] 1 QB 134 [Court of Appeal of England and Wales]

$R v$ Powell and English [1999] AC 1, [1998] 1 Cr App R 261 [House of Lords]

$R v$ Rabman and Ors [2008] UKHL 45 [House of Lords]

$R v$ Tomkins [1985] 2 NZLR 253 [New Zealand Court of Appeal]

$R v$ Uddin [1999] 1 Cr App Rep 319 [Court of Appeal of England and Wales]

Rainbow Warrior (New Zealand v France) (1990) RIAA vol xx 217 [PCIA].

The Tokyo Judgment in Bernard V A Röling and C F Rüter (eds), The Tokyo Judgment

[Amsterdam: APA-University Press Amsterdam BV, 1977]

Yamashita, In re, 327 US 1 (1946) [United States Supreme Court]

\section{Conventional International Instruments}

Convention for the Prevention and Punishment of Terrorism, 19 League of Nations OJ 23 (1938), League of Nations Doc C 546(I) M 383(I) 1937 V (1938).

Convention for the Suppression of Acts of Nuclear Terrorism (2005), UN Doc A/ RES/59/290 (2005) / [2005] ATNIF 20

International Convention for the Suppression of Terrorist Bombings (1997), 2149 UNTS 256 / [2002] ATS 17 / UN Doc A/RES/52/164

Convention for the Suppression of the Financing of Terrorism (1999), UN Doc A/ RES/54/109 (1999), 2178 UNTS 197 / 39 ILM 270 (2000) / [2002] ATS 23

Convention for the Suppression of Unlawful Acts against the Safety of Civil Aviation (1971) (the 'Montreal Convention'), 974 UNTS 177 / [1973] ATS 24 / 10 ILM 1151 (1971)

Convention for the Suppression of Unlawful Acts against the Safety of Maritime Navigation (1988), 1678 UNTS 221

Convention for the Suppression of Unlawful Seizure of Aircraft (1970) (the 'Hague Convention'), adopted at The Hague 1970, 860 UNTS 105

Convention on Consent to Marriage, Minimum Age for Marriage and Registration of Marriage (1962), GA Res 1763 A (XVII) (1962)

Convention on the Elimination of all Forms of Discrimination against Women (1979), GA Res 34/180 (1979)

Convention on the Marking of Plastic Explosives for the Purpose of Detection (1991), ICAO Doc S/22393

Convention on the Physical Protection of Nuclear Material (1980), 1456 UNTS 246 / 18 
ILM 1419 (1980) / [1987] ATS 16

Convention on the Prevention and Punishment of Crimes against Internationally Protected Persons including Diplomatic Agents (1973), 1035 UNTS 167 / [1977] ATS 1

Geneva Convention for the Amelioration of the Condition of the Wounded in Armies in the Field Geneva (1864)

Geneva Convention (I) for the Amelioration of the Condition of the Wounded and Sick in Armed Forces in the Field (1949), 75 UNTS 31/ [1958] ATS No 21

Geneva Convention (II) for the Amelioration of the Condition of Wounded, Sick and Shipwrecked Members of Armed Forces at Sea (1949), 75 UNTS 85/ [1958] ATS No 21

Geneva Convention (III) Relative to the Treatment of Prisoners of War (1949), 75 UNTS 135/ [1958] ATS No 21

Geneva Convention (IV) Relative to the Protection of Civilian Persons in Time of War (1949), 75 UNTS 287/ 1958 ATS No 21

Protocol Additional to the Geneva Conventions of 12 August 1949, and relating to the Protection of Victims of International Armed Conflicts (Protocol I) (1977), 1125 UNTS 3/ 1991 ATS No 29/ 16 ILM 1391 (1977)

Protocol Additional to the Geneva Conventions of 12 August 1949, and relating to the Protection of Victims of Non-International Armed Conflicts (Protocol II) (1977), 1125 UNTS 609

Convention on the Prevention and Punishment of Genocide (1948), 78 UNTS 277/ [1951] ATS 2 / UN Doc A/RES/260

International Convention against the Taking of Hostages (1979), 1316 UNTS $205 /$ [1990] ATS 17 / 18 ILM 1456 (1979)

International Covenant on Civil and Political Rights (1966), 999 UNTS 171 and 1057 UNTS 407 / [1980] ATS 23 / 6 ILM 368 (1967)

Statute of the International Criminal Court (1998), 2187 UNTS 90 / 37 ILM 1002 (1998) / [2002] ATS 15

Protocol for the Suppression of Unlawful Acts against the Safety of Fixed Platforms Located on the Continental Shelf (2005), UNTS 1678, I-29004

Protocol on the Suppression of Unlawful Acts of Violence at Airports Serving International Civil Aviation (1988), UNTS 1990

Protocol to African Charter on the Rights of Women in Africa (2005), CAB/LEG/66.6; reprinted in 1 Afr Hum Rts LJ 40

Regulation 2000/15 on the Establishment of Panels with Exclusive Jurisdiction over Serious Criminal Offences (in East Timor), UNTAET/REG/2000/15

Statute of the International Court of Justice (1945), 3 Bevans 1179; 59 Stat. 1031; TS 993; 39 AJIL Supp. 215 (1945)

Statute of the International Criminal Tribunal for Rwanda (1994), SC Res 955, UN Doc S/RES/955 (1994), 33 ILM 1598, 1600 (1994)

Statute of the International Criminal Tribunal for the former Yugoslavia (1993), SC Res 827, UN SCOR, UN Doc S/RES/827 (1993), 32 ILM 1203 (1993)

Statute of the Special Court for Sierra Leone (2002) 
Supplementary Convention on the Abolition of Slavery, the Slave Trade and Institutions and Practices Similar to Slavery (1956), 226 UNTS 3

The Hague Convention (IV) respecting the Laws and Customs of War on Land (1907), 36 Stat 2295

The Hague Regulations Respecting the Laws and Customs of War on Land (annexed to the Hague Convention 1907 Respecting the Laws and Customs of War on Land) (1907), 36 Stat 2295

Vienna Convention on the Law of Treaties (1969), 1155 UNTS 331, 8 ILM 679 (1969)

African Charter on Human and Peoples' Rights (1981), OAU Doc CAB/LEG/67/3 rev 5, 21 ILM 58 (1982).

African Union, Protocol to the African Charter on Human and Peoples' Rights on the Rights of Women in Africa (2003).

European Convention on Compensation of Victims of Violent Crimes (1983).

\section{Other International and Domestic Legal and Policy Instruments}

United Nations, General Assembly, Basic Principles of the Legal Status of the Combatants Struggling against Colonial and Alien Domination and Racist Regimes (1973)

- - General Assembly resolution 51/115 dated 7 March 1997, Doc No A/RES/51/115 (1997).

- - General Assembly Resolution 64/137 dated 11 February 2010, Doc No A/ RES/64/137 (2010).

- - General Assembly resolution 63/155 dated 30 January 2009, Doc No A/ RES/63/155 (2009).

- - General Assembly Resolution 63/159 dated 4 February 2009, Doc No A/ RES/63/159 (2009).

—_ General Assembly Third Committee resolution A/C.3/65/L.17/Rev.2 (2010) dated 2 November 2010.

- - General Assembly resolution 56/83 of 12 December 2001, Doc No A/RES/56/83 (2001) and corrected by document A/56/49(Vol. I)/Corr. 4.

- - General Assembly resolution General Assembly resolution 60/147 of 16 December 2005, Doc No A/RES/60/247 (2005).

- - General Assembly resolution 60/1 (2005) of 24 October 2005, '2005 World Summit Outcome'.

- - General Assembly, Declaration on the Granting of Independence to Colonial Countries and Peoples (1960)

- - General Assembly, Vienna Declaration and Programme of Action (1993).

_- General Assembly Resolution 3314(XX1X) on the Definition of Aggression (1974).

- - General Assembly Resolution on the Safety and Security of Humanitarian Personnel and Protection of United Nations Personnel (2003).

- - General Assembly Resolution on the Safety and Security of Humanitarian Personnel and Protection of United Nations Personnel of 16 December 2003, Doc 
A/58/L.47.

—- Security Council resolution 1325 dated 31 October 2000 Doc No S/RES/1325 (2000).

- - Security Council resolution 1820 dated 19 June 2008, Doc No S/RES/1820 (2008).

—- Security Council resolution 1888 dated 30 September 2009, Doc No S/RES/1888 (2009).

—- Security Council resolution 1889 dated 5 October 2009, Doc No UN S/RES/1889 (2009).

—- Security Council resolution 1960 dated 16 December 2010, Doc No S/RES/1960 (2010).

—_ Security Council Resolution 1503 (2003) of 28 August 2003, Doc No S/RES/1503 (2003).

- - Security Council Resolution 1315 (2000) of 14 August 2000, Doc No S/RES/1315 (2000).

—- Security Council Resolution 1534 (2004) of 26 March 2004, Doc No S/RES/1534 (2004).

- _ Economic and Social Council, resolution 2005/30 adopted on 25 July 2005.

- _ Economic and Social Council, Sub-Commission on Prevention of Discrimination and Protection of Minorities, Resolution 1998/18 (Systematic rape, sexual slavery and slavery-like practices during armed conflict, including internal armed conflict) dated 21 August 1998.

_-Human Rights Commission, resolution 2005/35 adopted on 19 April 2005.

_- International Law Commission, Draft Code of Crimes against the Peace and Security of Mankind

International Criminal Court, Elements of Crimes.

African Union, Assembly of Heads of State and Government, Solemn Declaration on Gender Equality in Africa (2004).

_- African Union Gender Policy (2008).

Council of Europe, Parliamentary Assembly, Resolution 1212 (2000): Rape in Armed Conflict.

- - Directive 2004/80/EC of 29 April 2004.

- - 'Comprehensive approach to the EU implementation of the United Nations Security Council Resolutions 1325 and 1820 on women, peace and security' dated 1 December 2008, Doc No 15671/1/08 Rev 1.

Organisation of American States, Inter-American Commission of Human Rights, 'Violence and Discrimination against Women in the Armed Conflict in Colombia' Doc No OEA/Ser.L/V/II Doc 67 of 18 October 2006.

\section{Domestic Statutes and Model Codes}

Australia, Criminal Code of Queensland, Australia (1899).

Canada, The Good Samaritan Act (1996) of British Columbia. 
—— The Good Samaritan Act (2001) of Ontario.

Cambodia, Law on the Establishment of the Extraordinary Chambers, with inclusion of amendments as promulgated on 27 October 2004 (NS/RKM/1004/006).

New Zealand, Criminal Injuries Compensation Act (1963).

Nigeria, Geneva Conventions Act of Nigeria (1960).

_- Criminal Code of Nigeria, cap 77, (1990).

United Kingdom, Offences against the Person Act (1861) of England.

United States, Model Penal Code of (1981) of the American Law Institute.

- - Genocide Convention Implementation Act (1987) ['The Proxmire Act'] of the United States, 18 USC § 1091.

—— The Emerson Good Samaritan Food Donation Act (1996). 
Chile Eboe-0suji - 978-90-04-22722-4 Downloaded from Brill.com $04 / 26 / 2023$ 12:45:46PM via free access 


\section{Index}

A

Abduction

assaults on females, 251

international community, attracting attention of, 187

Alford, C Fred, 45-49

Arendt, Hannah

conclusions, 41

genocide research, 19, 54-55

Armed conflict

enemy's humanity, denial of, 37

evil-doing during. See Evil

grave crimes committed in, 203

peacemakers, women as, 11

soldiers, killing by, 35-37

women, crime against. See Sexual crime against women

Attack

holistic view of, 190-193

no military purpose, with, 196

notion of, 191

primary purpose, subjective and objec-

tive examination of, 195-199

terror, spreading, 198

\section{B}

Bagosora, Theoneste, 21

Bauman, Zygmunt, 33-35, 39-42, 55, 57-58

Berkeley, Bill, 59

Bezien, Jeffrey, 23

Browning, Christopher, 39, 57

Bureaucracy evil, hijacking for, 58

C

Children conscription of, 186-187

sexual crime against women, effect of, 5-6

victimisation through sexual violence, 6

Civilian populations

duties to, 133-134

Colombia

armed conflict in, 264-267

guerrilla movements, 265

human rights consequences, 265

sexual violence against women in,

266-267

Courts of Cambodia

Extraordinary Chamber, establishment of, 257

person bearing greatest responsibility, prosecution of, 258-259

Crimes against humanity

attack, notion of, 191

classification, 244

enslavement, 248

gender-oriented, character of, 244

forced marriage, and, 244-256

sexual slavery, 245-252

trafficking in persons, 252-255

murder as,

elements of, 237

law, state of, 237

mens rea, 236

persecution and inhumane acts, 235

rape as, 155

Criminal enterprise guilty participation in, test of, 28 joint. See Joint criminal enterprise

Criminal injuries compensation schemes no-fault basis, 307-308

Criminal responsibility 
aiding and abetting,

domestic criminal legislation, in, 127

military-type hierarchy, in, 127-129

planning, preparation or execution of offence, in, 126

strict liability analogy, 128

Yamashita judgment, 129-132

appellate adjudication, judicial deference to, 132

civilian leaders, of, 133-136

collective, 110

commission, 104-109

joint criminal enterprise. See Joint criminal enterprise

ordering,

collateral crime as possible consequence of crime ordered, for, 122-123

conceptual boundaries of, 123

ICC Statute art 30, value of, 123-125

superior, responsibility of, 121-125

planning and instigating, 125-126

superior responsibility for rape. See

Superior responsibility for rape vicarious, 140

\section{D}

Diplomatic protection

aliens, treatment of, 297

armed conflicts, in, 297-300

duty at instance of citizen, as, 302-303

duty of national State, as question of,

300-304

election to forgo claim, 303

prerogative, as matter of, 300-301

Discrimination

women, against, 262

\section{E}

Eichmann, Adolf

Arendt's view of, 20

Arendt's work on, 54-55

banal or ordinary, appearance as, 29

demeanour, 27

deportation of Jews by, 31-32

extermination of Jews, role in, 31-32

film on, 23-24

guilt, evidence of, 32 individual criminal responsibility, 28-29, 31

personal responsibility, not feeling, 40-41

qualms, sense of, 64

specialist, as, 29-30

studies of, 19-22

trial, 23-33

Wannsee Conference, at, 41

Enslavement

crime against humanity, as, 248

international community, attracting attention of, 187

Evil

aetiology,

intent as limiting theories of, 63-64

law, in context of, 60-65

armed conflict, during, scenarios, 16

authority figure commanding perpetration of, 39

banality of, 18, 20-22

commonsensical and minimalistic definition, 53

critique of theories, 54

dispositional theory of, 43-49

division of labour, role of, 39

eclectic theory of, 53-60, 63

Eichmann, of, 20

human capacity for, review of, 17-60

impersonality, 20-21

inherent personality traits, responsibility of, 42

justice and reconciliation, post-conflict quest for, 64-65

law's response to, 64-65

mass atrocities, of, 45

moral disgust, theory of, 51-53

narcissistic theory of, 50-53

nature and causes of, 315

Nazi Germany, in, 19

pain and suffering, infliction of, 53-54

perpetrators, nature of, 49

sadism, 45-49

sexual violence, of, human capacity for, 65-68

simplification of understanding, 47

situational theory of, 18-43

specific location, in, 47

war, during, international law, containment by, 17 
theories explaining, 16

theories of, 11-13

Executioners

job, doing, 34-35

\section{F}

Family home burning down, 5

Forced marriage arranged marriage, and, 225-226

bush wives, system of, 221-224

comparable gravity of, 240

consent to marriage, violation of rule, 247

crime against humanity, as, 233-234, 246, 255

crime, as, 14

criminal character, 240-241

definition, 233

elements of crime of, 227-228, 247

enslavement, as aspect of, 248-250

gender-oriented crimes against humanity, and, 244-256

immorality of, 256

inhumane act, as, 228-229, 234-242

international crime, whether, 222, 226229, 238-239, 317

international criminal law, as proper subject of, 224-226

international criminal norm forbidding, creation of, 256

mens rea, 235, 238

mischief of, 239

proof of, 245

sale of wives, 248

sexual crime, whether, 231

sexual slavery, as, 230

sexual slavery, versus, 245-252

slavery, as, 248-250

Special Court for Sierra Leone, judgment of, 222-224

doctrinal problems of, 233-243

reasoning, evidential problem of, 229-233

trafficking in persons, versus, 252-255

Forcible transfer

definition, 242-243

inhumane act, as, 241-243

\section{G}

Geneva Convention

abuses and infractions of, 207

civil war victims within protection of, 215

grave breaches,

application, sphere of, 217, 219

automatic qualification as war crimes, 216

categories of, 207

codification of, 215

construction of, 217

current view of, 211

international and internal armed conflicts, dichotomy between, 210-213

international armed conflict, in, 203

International Criminal Tribunal for the former Yugoslavia, Statute of, 208

introduction of, 206-207

serious violations, and, 203-204, 216-217

understanding and application of term, 206

universal jurisdiction, 212

persons or property protected by, determining, 214-215

serious violations,

grave breaches, and, 203-204, 216217

International Criminal Tribunal for Rwanda, Statute of, 209

jurisprudence, 205

repressing, 216

understanding and application of term, 206

universal jurisdiction, 212-213

Genocide

acti rei, 160, 173

Arendt, research by, 19

Convention, interpretation, 169-174

preventive purpose, 170

definition, 159-160, 168

debate, 316

Eichmann, study of, 19-22

elements of, 160

evil of, understanding, 45 
factors responsible for, 56

intent, assessment of, 164-165

international criminal law instruments, in, 160

one member of protected group, killing, 173

prerequisite elements of, 259

propaganda, role of, 56

rape as act of, 13, 155

agreement as to, 159

circumstances of, 161

context of, 166

extension of notion, 160-161

fear of, 166

hate, effect on victims, 166-167

ICTR, jurisprudence of, 177

intent to destroy group in whole

or in substantial part, in light of, 167-175

joint criminal enterprise, and, 175177

Rwanda, in, 160-167

systematic and repeated pattern of conduct, 165

Rwandan. See Rwandan Genocide

sexual violence, legal response to, 159

specific intent, 317

US federal law, 167-168

women, crime against, 159

Goldhagen, Daniel, 43-44

Gray, J Glenn 72-75, 80, 87

\section{H}

Holocaust

anti-Jewish propaganda, causal link with, 55-56

by-product of modern society, as, 33-34

Eichmann, role of. See Eichmann, Adolf

Milgram experiment, and, 39, 45

perpetrator, invisibility to, 36

Homicide

self-preservation, 79

Human rights violations

aggression, in case of, 299

diplomatic protection, legitimacy of, 301

massive, 69

normative duty of States to fight impunity, 296

reparation. See Reparations
Hussein, Saddam, 20-21

I

Igniatiff, Michael, 51-53

Intent

consciousness, dealing with, 63

theories of aetiology of evil, limiting, 63-64

International Criminal Court

Rome Statute,

elements of crime, 210-211

joint criminal enterprise, provision for, 107-109

ordering, boundaries of, 123-125

war crime of terrorism, provisions on, 199-201

terrorism, lack of jurisprudential activity, 181

International criminal law

criminal responsibility under, 61-63

evolutionary theory of rape, relevance of, 80

other inhumane acts, residual category of, 243

sexual violence, response to, 94

International Criminal Tribunal for

Rwanda

completion strategies, 258

propaganda, view of, 56

prosecution strategy, 258

rape as genocide, jurisprudence of. See

Genocide

sentences at, 114-115

Statute,

acting under orders, no excuse of, 61-62

criminal responsibility, definition of, 61

joint criminal enterprise, silent on, 107

serious violations of Geneva Convention, reference to, 209

superior responsibility for crimes under, 99-100

war crimes, nexus requirements, 261262

International Criminal Tribunal for the former Yugoslavia completion strategies, 258 
joint criminal enterprise, requiring substantial contribution to, 118

prosecution strategy, 258

sentences at, 114-115

Statute,

grave breaches, reference to, 208 joint criminal enterprise, silent on, 107

jurisdiction, defining, 207-208

superior responsibility for crimes under, 99-100

violation of laws of war, reference to, 208-209

war crimes, nexus requirements, 261-

262

International criminal tribunals sexual crimes, jurisprudence as to, 7

International humanitarian law serious violations of, $219-220$

International law evil-doing during war, containment of, 17

rights and obligations imposed by, 218

International Law Commission

Responsibility for International Organizations, draft articles on, 305

International Military Tribunal at Nuremberg

guilty participation in joint criminal enterprise, test of, 28

International organizations international obligation, breach of, 305-306

responsibility of, 305

J

Joint criminal enterprise

categories of, 104-105

commission, as, 105

common design, 105

common purpose, scope of, 112, 121

controversy as to, 109-121

doctrine of, 104-109

domestic critics of doctrine, 113

extended form, 106, 110-112

guilt by association, 110, 115

individual wrongdoing, and, 116

international criminal law, problems in, 109-121
International Criminal Tribunal Statutes, under, 107-109

international judges, application of rule by, 113-114

legitimate joint venture, and, 116, 120121

mental element requirement, 117

natural and foreseeable consequence, act being, 105, 111

notion of, 104

position of authority, one member with, 105

positive contribution, requirement of, 118

public policy principle, 117,119

punishment, imposing, 119-120

rape as genocide, and, 175-177

reform proposals, 112, 118, 120

sentencing, 114-115

Justice

post-conflict quest for, 64-65

L

Lex lata

routes round difficulties of, aiding and abetting, 126-136

arguable limits of, 136-137

joint criminal enterprise, 103-121

ordering, 121-125

planning and instigating, 125-126

M

Marriage

arranged, 225-226

forced. See Forced marriage

free and full consent, requirement of, 246,255

Marshall, S L A, 48

Milgram, Stanley, 33, 37-42, 54-55, 57

Milosevic, Slobodan, 21

Modernism

dangers of, $57-58$

Modernity

deleterious process of social separation, as 34

Holocaust as by-product of, 33-34

social separation, and, 34

Morality

intent, contrasted with, 63 
Murder

crime against humanity, as, elements of, 237

law, state of, 237

mens rea, 236

\section{$\mathbf{N}$}

Nazi Final Solution study of, 39

Nazi Germany anti-Jewish conditioning, 44 moral paradigm, perversion of, 19

Necessity defence of, 79

\section{$\mathbf{P}$}

\section{Palmer, Craig 75-81}

Persecution discrimination, 236 other inhumane acts, and, 235

Physiognomy fallacy of, 20

Prisoners of war duties to, 133-134

Punishment learning, effect on, 37-39

\section{$\mathbf{R}$}

Rape act of domination, as, 83-84 adaptation hypothesis, 77 American military personnel, by, 68 anger with authorities, showing, 81 appropriate punishment for, 79 by-product hypothesis, 77-78 Canadian law, 151-152 crime against humanity, as, 155 definition,

body parts, focus on, 146-149 coercive nature, focus on, 157 consent, focus on, 146-147 domestic jurisdictions, in, 146, 149151

extended scope of, 148-149 generally, 13 ICTY Trial Chamber, by, 146-147 international law, in, lack of, 145 international tribunals, jurisprudence of, 145

oral penetration, to include, 147,152 proper, need for, 316 urgent attention, need for, 145 violence, primary focus on, 145-146 demoralisation, for, 179 domestic jurisdictions, reform in, 149151

effective combat performance, required for, 90-92

evolutionary theory of, 75-81

fellatio as, 146

genocide, as act of, 13, 155, 159-177. See also Genocide

human society, explanation of phenomenon in, 77

international criminal law, development of, 152

military rape differential, 68-72

non-consent, removal of requirement to prove, $155-157$

overwhelming will to resist, 79-80

primary groups, associated with, 67

proof of force, 155

sex-consent-force inquiry, 153,155

sex hunger, hypothesis of, 78

sexual assault, replacement with, 151

superior responsibility for. See Superior responsibility for rape

systematic connivance or condonation, 86-94

torture during interrogation, as, 85-86

US Senate Judiciary Committee report, 3

victim, questioning, 154-156

war crime, as, 155

woman, conviction of, 97

Reconciliation

post-conflict quest for, 64-65

Reparations

breach of engagement, for, 286

complementary theories, availability of, 291

expropriation, for, 279-283

facilitating rights to, obligation of States to pursue victims, 295

fault, scope of, 287

female victims of sexual violence, for, requirement, 271

shift in focus, 314

special focus on, 312-313 
theoretical bases for. See theoretical bases for, below

human rights context, in, 281-283

juristic anchors for, 283-288

human rights violations, for, 14

initiatives, difficulty of, 276

international law and policy, in, 272, 275

International Law Association's Declaration of International Law Principles, 272-273

Lusitania Cases, 286-287

meaning, 272-273

no-fault basis for, criminal injuries compensation schemes as model for, 307-308

European Convention on Compensation of Victims of Violent Crime, 309-310

international community, duty of, 311 opposition to, 308-309

responsible party, inability to make reparation, 306

omissions, fault resulting from, diplomatic protection, 297-304 international community, responsibility of, 304-306

non-state actors, regarding, 296-297

respondents, spectrum of, 289

rogue state agents and non-state actors, relating to, 290-296

state agents, relating to, 289-290

right to victim, as, 287

theoretical bases for, actions, fault resulting from, 288 Chorzow Factory case, 279-283

fault-based, 278-288

general conception of law, 286

Government, responsibility of, 276

historical, 276-277

international law and policy, in, 278

lethargy, case study in, 275

no-fault, 306-311

omissions, fault resulting from, 289306

rational, clear and coherent articulation, absence of, 276

Special Court for Sierra Leone, case in, 276-277

UN sources, definitions in, 273-275
Responsibility

proximity, arising from, 34

Responsibility to protect doctrine of, 291-295

Rwandan Genocide brain-washing strategy, 36

Francois, participation of, 59

intent to destroy group in whole or in substantial part, in light of, 167-174

rape, $160-167$

Tutsi victims, 163-164

Vetlesen, observations of, 60

\section{S}

\section{Sadism}

definition, 45-46

evil, dispositional theory of, 45-49

Sartre, Jean-Paul, 50

Sexism

society, in, 66

Sexual crime during armed conflict act of domination, as, 83-84

American soldiers in Vietnam, by, 93

cataclysmic events, as part of, 70

children, effect on, 5-6

Colombia, in, 264-267

combating, 9

consequences of, 3-4

control of soldiers, 129

deliberate policy, theory of, act of domination, as, 83-84

humiliation, factor of, 83

impregnation, for, 84

instrument of terror, as, 85

systematic connivance or condonation, 86-94

theory of, 83

torture during interrogation, as, 85-86

violence traditional articulated as, 83-86

early recovery and peacebuilding, undermining, 6-7

evidence of, 1

explanations of, 83

fact of life, as, 71

family home, loss of, 5

forced marriage. See Forced marriage genocide, as. See Genocide

grave breaches, as, 219 
high frequency of, aetiology of, deliberate policy, theory of, 83-94 evolutionary theory of rape, 75-81 Gray, theory of, 72-75 inevitability, theory of, 72-75 male fighters, psyche of, 72 myth, in, 74-75

opportunism, 81-83 perpetrators, nature of, 73 history, in, 71 human capacity for, 65-68 humiliation, factor of, 83 impregnation, for, 84 inducement, as, 91 inevitability of, 129 instrument of domination, as, 78 instrument of terror, as, 85 intellectual reflex to, 2 international law, containment task of, 94

law reform, 7-10

linkage elements, 261

literature of, 95

machismo, predisposition to, 67

maladjustment, risk of, 264

men, sexual atavism of, 73

negative effects, 7

optimism as to problem of, $318-320$

other violence accompanying, 5

palpable effects of, 6

perennial problem of, 1

prevalence of, 316

prosecution of, 14

psychological toll of, 4

reparation. See Reparations

scope of, 65

searching, as, 86

Security Council actions, 7-9

social encumbrances, 4-5

social glue, as, 92-93

spousal abandonment following, 5

summary of study, 315-318

superior responsibility for. See Superior responsibility for rape

systematic connivance or condonation, 86-94

terrorism, as. See Terrorism

torture during interrogation, as, 85-86

unquestionable incidence of war, as, 70

victimisation, typology of, 82 violence, prosecution in post-conflict societies. See Sexual violence

\section{Sexual slavery}

campaign of terror, as part of, 190-193

crime against humanity, as, 248, 250

evidence of, 186

forced marriage, versus, 245-252

holistic view of attack, 190-193

lawfulness or legitimacy, theory of, 188-189

multi-purpose approach, 189-190

nature and circumstances of act, 185189

primary purpose, $189-190$

primary purpose, multi-purpose approach, 189-190

Special Court for Sierra Leone Trial

Chamber, reasoning of 182

terror, spreading, 185-189

trafficking in persons, and, 252-255

use of term, 249

violence, use or threat of, 188

Sexual violence

affective combat, 263

campaign to end, 260

Colombia, in, 266-267

examples of, 251

high frequency of, explanation of, 262

historical legacy, need to stamp out, 269

post-conflict societies, prosecution in, choices, question of, 257-260

circumstantial or indirect nexus, 263

double victimisation, need to avoid, 268-269

focus on, 318

focused approach to, 257

importance of, 260-263

integral part of armed conflict, crimes being, 269

international criminal tribunals, in, 258

person bearing greatest responsibility, of, 257-259

Security Council resolutions, 258

social engineering as objective of, 263-268

underlying concern, evolution of, 257

reparation. See Reparations

scourge on humanity, as, 260

Sierra Leone 
bush wives, system of, 91, 221-224

Soldiers

killing empowerment, 92

pathetic circumstances of, 89

resentment, 90

sex, obsession with, 87-89

South African Trust and Reconciliation

Commission

post-apartheid proceedings, testimony in, 22-23

Special Court for Sierra Leone

AFRC Case, 182-185

forced marriage, judgment on, 222-224

doctrinal problems of, 233-243

reasoning, evidential problem of, 229-233

person bearing greatest responsibility, prosecution of, 257-259

reparations, demand for, 276-277

State responsibility

citizens, protection of, 292

foreign State, dictates encumbering, 297

responsibility to protect doctrine, 291295

violation of human rights, to pursue culprits, 295

Superior responsibility for rape

civilian leaders, responsibility of, 133136

commission of offence, 104-109

control of soldiers, 129

current assessment of, 100

Draft Code of Crimes against Peace and Security of Mankind, Article 6, 100

due diligence, 143-144

legal duty of, 98

duty to prevent commission of crime, 127

duty to prevent violence, 100

duty to punish, 137-142

foreseeability, test of, 99

foundation of doctrine, 132

generally, 13

immediate connection with subordinate, 102

International Criminal Tribunal Statutes, 99-100

international law, standard of protection in, 98-99 joint criminal enterprise. See Joint criminal enterprise

knowledge, requirement of, 101-103

law on, as it is, $99-100$

as it should be, 98-99

lex lata, routes round difficulties of, aiding and abetting, 126-136

arguable limits of, 136-137

joint criminal enterprise, 103-121

ordering, 121-125

planning and instigating, 125-126

motive, 98

protection of women under international

law, 143

rogue subordinates, failure to control, 138

Rome Statute, 99-100

superior-subordinate hierarchy, absence of, 106-107

Tokyo judgment, 134-136

transactional relationship with subordinates, 106

vicarious criminal responsibility, as, 140

woman, conviction of, 97

Yamashita judgment, 129-132

T

Terrorism

all acts, taking account of, 191-192

definition, 180-182

generally-accepted definition, lack of, 179

jurisprudence, lack of, 181

mens rea, 197

primary purpose of spreading, 194

sexual assault, explaining, 179

sexual slavery, mens rea of,

evidence of, 186

holistic view of attack, 190-193

lawfulness or legitimacy, theory of, 188-189

multi-purpose approach, 189-190

nature and circumstances of act, 185-189

Special Court for Sierra Leone Trial

Chamber, reasoning of 182

terror, spreading, 185-189

violence, use or threat of, 188

sexual violence as part of, 192-193 
Special Court for Sierra Leone, AFRC Case, 182-185

specific intent, origins of jurisprudence of, 181-185 principle of, 193-195

systematic, 192

war crime of, conventional sources of, 179-181 generally, 13 purposive analysis of, 193-195 specific intent, crime of, 181-185, 201 Statute of Rome, provisions of, 199201

Thornhill, Randy, 75-81

Torture

rape as instrument of, 85-86 sexual organs, targeting, 86

Trafficking

forced marriage, versus, 252-255

nature of, 252

purposes of, 253-254

sexual slavery, and, 252-253

slave trade, as modern equivalent of, 253

Treaty

good faith, interpretation in, 220

V

Vetlesen, Arne Johan, 46, 53-60, 63

Victims

perpetrator, invisibility to, $35-36$

\section{W}

Wannsee Conference extermination plot made at, 41

War. See also Armed conflict episodes of mindless slaughter and wanton destruction, as, 15

killing, as business of, 15-16 misogynistic subtexts of, 66 profanity, as, 15

War crimes

definition, 204-206

genocide, as. See Genocide grave breaches, application, sphere of, 217, 219 automatic qualification as war crimes, 216

categories of, 207 codification of, 215

construction of, 217

current view of, 211

Geneva Convention, of. See Geneva Convention

international and internal armed conflicts, dichotomy between, 210-213

international armed conflict, in, 203

International Criminal Tribunal for the former Yugoslavia, Statute of, 208

introduction of, 206-207

notion of, 13

origin of concept, 218

serious violations, and, 203-204, 216-217

special characterisation as, 317

understanding and application of term, 206

universal jurisdiction, 212

jurisdiction of State, committed in, 214 nexus requirements, 261-262

prerequisite elements of, 260

rape as, 155

serious violations,

Geneva Convention, of. See Geneva Convention

grave breaches, and, 203-204, 216217

International Criminal Tribunal for Rwanda, Statute of, 209

jurisprudence, 205

understanding and application of term, 206

Statutes of international tribunals, lists in, 205-206

terrorism, as. See Terrorism

World War II

American GIs, low firing rate of, 48

\section{Z}

Zimbardo, Philip, 33, 42-43

Stanford Prison Experiment, 42-43 